\title{
a CONTRibuiçio da geografia aO planejamento educacional
}

- Tese de Doutoramento apresentada a discipl1 na de Geografia Humana da faculdade de filo sofla. Letras e ciēncias Humanas da Universidade de são paulo. 
Orientador da tese:

Professor Pasquale Petrone 


\section{A CONTRIBUIÇAO DA GEOGRAFIA AO PLANEJAMENTO EDUCACIONAL}

\section{$S \cup M A R I O$}

I - INTRODUÇÅO - Justificativa metodolög1ca - Informes sobre a tëcnica de trabalho - Trabalhos no Brasil na ărea do planejamento educaclonal apolado na Geografia - Objetivos da tese.

II - FUNDAMENTAÇÃO TEORICA: SINTESE DO PROCESSO EDUCACIONAL

Capitulo I - Visão da educação no Mundo, após 1945.

Capitulo 2 - Problemas educacionais na América do sul.

Capitulo 3 - A questão educacional no Brasil.

III - FUNDIMENTAÇOO TEORICA: PLANEJAMENTO; PLANEJAMENTO EDUCACTONAL Capitulo 1 - Planejamento: aspectos gerals;o caso brasileiro. Capitulo 2 - Os planos setoriais de educação.

iv - a geograeta atuante

Capitulo 1 - Mudanças de enfoques na aplicação dos conhecimen tos geogräficos.

CapItulo 2 - Geografia e Educação.

Capitulo 3 - Geografia e carta escolar.

Capitulo 4 - Geografia e curriculo.

Capitulo 5 - Geografia e comunidade.

Capitulo 6 - Geografia e mercado-de-trabalho.

V - A FORMAÇAO DO GEOGRAFO E DO PROFESSOR DE GEOGRAFIA

Capitulo 1 - Os cursos de graduação e de pōs-graduação.

Capitulo 2 - A formação do professor universitärio.

VI - CONCLUSŐES

VII - BIELIOGRAFIA 
I- IHTRODUGAO 
I - INTRODUÇAO

1 - EXPLICAÇ̃̃O PRELIMINAR

Desde algum tempo, observa-se que a preocupação com a Edú cação, dos pontos de vista quantitativo e qualitativo, vem ganhando uma importância básica en todos os paises. No Brasil, 1denticamente, ela passou a integrar-se no concelto global do planejamento para o desenvolvimento.

Todavia o planejamento educacional, especificamente, ain da se ressente das pesadas tradições de uma época em que a educação visava ao aprimoramento exclusivo das elites; quando os conceitos hoje mais ou menos correntes de planos, programas, projetos, investimentos, custo/beneficlo, crescimento econōmico e desenvolvimento soclal eram inexistentes.

A ultrapassagem desse periodo se fez mais ou menos aceleradamente, por força de um confunto de fatores soctais, econōmlcos e politicos, e a ciência Econômica assumiu a liderança no campo do planejamento, com sua tëcnica, seus modelos.

Se o concelto de planejamento envolve a conotaçāo de abrangência, esforço interdisciplinar, não hä porque deixar de lado a Geografia, que visa ao estudo da organização do espaço pelos grupos humanos.

Ma1s ainda, planejamento-educação-desenvolvimento são varlāvels que necessarlamente integram os objetivos permanentes da po litica nacional. Para a execução e implementação desses objetivos deve haver, como atitude preliminar, o diagnöstico dos recursos fisicos, humanos e econômicos, seja do pais, seja de "regiöes-plano: Não se imaginará que a contribuição da Geografia para esse diagnóstico seja a mals importante de todas, mas é compreensivel que seja tão importante como outras.

E fácll perceber que as contrıbuıções da Geografla para o planejamento educacional podem ser vallosissimas, preenchendo lacunas que muitas vezes têm conduzido a falhas lamentáveis. Nesse sentıđo, a Geografia - seja atravēs dos geögrafos, seja atravēs de pro fessores dos diferentes graus, 019,029 e 0 universitärı́ - tem stdo subutilizada.

Nesta fase de evolução dos conhectmentos geogräficos, de reformulação dos seus grandes objetivos, de aplıcação pragmátíca , nāo se poderla adintir que a Geografia permanecesse alienada do esfoxço para racionalızar a pesquisa e o planejamento educacionais.ES sa aplicabilidade adquire novo e mals importante significado no ca- 
so particular do Brasil que conscientizou a necessidade de "quelmar etapas" desenvolvendo um planejamento integral.

\section{2 - JUSTIFICATIVA :AETODOLOGICA}

De há muito tempo era evidente que as ligações mais estreltas e lnterfecundantes Geografia-Eđucação, mesmo öbvias, não eram levadas a termo de unidade de esforços.

Confirmação da necessidade de conjugar Geografia e planejamento educacional foi felta pelo autor a partix da análise de pro jetos especificos do Programa de Expansão e Melhoria do Enstno (PREMEN - örgão do Ministërio de Educação e cultura).

Posteriormente, foi constatada Igual lacuna na apreclação dos programas especificos do Governo Federal, tais como o PROTERRA, - PRODOESTE, O PROVALE. Nos decretos de criação dos organismos 1mplementadores e na definição de atribuições, flcou claro que a educação fol pouco contemplaca e que os quadros espaciais e humanos de viam ter stdo objeto de um levantamento completo, para coordenar as necessidades educacionais com os projetos de carăter econômico. (1)

\section{1- A motocioicyta para o estudo da situação.}

Inicialmente foram analisados livros que tratassem do macroplanejamento ${ }^{(2)}$. A seguir, outros que ligassem macroplanejamento aos estudos de prospectiva ${ }^{(3)}$. A medida que se configurou a estrutu ra geral do macroplanejamento integrado e de prospectiva, evidenciou-se a necessidade de entrosar às mesmas metodologias as tëcnicas de planejamento educacional (4).

En complementação a esses estudos foram analisados planos setorfals de educação a nivel de Ministēto e de Secretartas Estaduais $^{(5)}$.

Isto posto, buscaram-se em livros e artigos de Geografia Aplicada modelos ou referências sobre as ligações entre Geografia e planejamento educactonal ${ }^{(6)}$.

Por ültimo, o estudo se voltou para a pesquisa de anälise de sistemas, assim como de novas técnicas de trabalho geogräfico que pudessem ser validadas para a elaboração de metodologias para o planejamento educacional, en que a Geografia, ao lado de outras dis clplinas, puciesse melhorar os diagnösticos nacional e regional (7).

Essa fase de trabalhos teóricos, foi reforçada com duas atividades: entrevistas com técnicos em planejamento e visitas de 
observação aos Estados da Bahia, Espirito Santo, M1nas Gera1s, Rio Grande do Sul, Pernambuco, Paraná, Pará, Rło de Jane1ro e Guanabara.

\section{2- A metodologia do presente trabalho.}

Conforme se depreende da leltura do SUMARIO, o trabalho fol dividido ern très grandes segmentos:

18 - Slntese sobre o processo educacional; o planefamento; os planos setoriais de educação.

28 - A Geografla atuante.

38 - A formação do geógrafo e do professor de Geografia

Nas três partes combina-se a aplicaçāo dos métodos dedut vo e Indutivo, a partir da anälise das situaçōes.

Na primeira, busca-se descrever, anal1sar, comparar e crí ticar, com vistas ao estabelecimento de linhas de ação e/ou sugestöes alternativas.

Na segunda, intenta-se demonstrar a necessidade e as múltiplas possibilidades de a Geografia, tornando-se atuante, servir aos diversos tipos de planejamento educacional. A análise de cada s1tuação precede as sugestōes.

Na terceira, parte-se de un estudo h1stórico da formação de geógrafos e de professores de Geografia, focalizam-se as tendênclas atuals e as possibilidades de reformulação de parte dos cursos de Graduação e de pōs-Graduação, para atender aos objetivos propostos na segunda parte da tese.

\section{3 - INFORHES SOBRE A. TECNICA DE TRABALHO}

Evidentemente o tema sendo o estudo do subsistema educaclonal e de como ele pode beneficiar-se das contribuições da Geogra fía, a técnica básica adotada para elaboraçāo deste trabalho fol apolada na análise de sistemas. Isto porque torna-se necessário par t1r da visão do conjunto dos dados essenclals e caracterizadores do mesmo, como premissa para descer à anál1se dos subsistemas, de que são exemplos entre outros: a educação e o ensino de 28 Grau; a Geografia e o currículo; a formação do geógrafo colaborador no planeja mento educacional.

Outro elemento norteador da técnica de trabalho fol a anā 11se dos dados estatisticos que possib1l1tassem a quantificąão dos fenômenos observados e/ou estudados. 
Por ültimo, dada a formaçāo geogrāfica do autor,multas ve zes até intultivamente, o estudo de um fato ou fenōmeno fol enquadrado nos princlpios da Geografia.

4 - O QUE SE TEM FEITO No BRAsil Na KREA DO PLANEJAMENTo EDUCACIONAL APOIADO NA GEOGRAFIA.

A Ifigor, pode-se dizer: nada. As causas, que serão anal1sadas no capitulo referente ao "planejamento global e o planejamento educacional", podem ser esquematizadas como segue:

10- a consclentização da necessidacie de elaborar planos globals, no Brasil, é multo recente, não atingindo, a rigor, duas dëcadas;

28- o setor educactonal só multo lentamente começou a se beneficlar das técnicas de planejamento elaboradas pelos economistas. Alnda hoje, muitos órgāos de planejamento educacional, a nível de Estado, nāo definiram modelos ou metodologias para tal atividade;

38- a Geografta aplicada no Brasil è de vida recente, tendo-se desenvolvido mals no final da década de 1960 e, assim mes mo, alnda nāo sensibllizada pelos aspectos educacionals.

Todavia, parece que a ldëla de embasar o planejamento edú cacional em diagnósticos de carāter geográftco serā vitoriosa senão a curto prazo, a médlo prazo, podendo-se apontar como uma das causas o trabalho "Divisāo do Brasil em Micro-Regiöes Homoyêneas - 1968Fundação IBGE. Embora o propöstto do trabalho não fosse o de lançar bases para o planejamento educaclonal, fato è que nos setores volta dos para essa atividade, no HEC, nas Secretarlas de Educação e nos Conselhos Estaduais de Educação, fá se fala, jā se pensa em termos de regional1zação ou małs precisamente de microrreglöes. Isto porque começa-se a crer na importâncta da caracterização especifica de unidades espaciais para que o planejamento e a montagen de projetos estejam voltados para uma realidade diagnosticada e para o atend1mento de prioridades.

Identificam-se, contudo, obstäculos a vencer, pois hă un caminho mais ou menos longo entre o reconhecimento de uma necessida de e a sua concretização operacional. A aceleração desse processo deverả ter a participação dos geögrafos e dos professores de Geogra f1a. 
18- Caracterizar o subsistema educacional no Brast1 como parte de un sistema mais amplo que è o modelo brasileiro de desenvolvimento.

28- Comparar o subsistema educacional no Brasil com outros subsistemas, particularmente na América Latina.

38- Demonstrar a viabilidade de o planejamento educacional no Brasil se valer de un conjunto de especialistas de diversas disciplinas e, en particular, de Geografia.

49- Identificar as ligações entre planejamento educacional no Brastl e a Geografia.

58- Propor metodologlas que possam orientar o especialista em Geografla na sua tarefa de elaborar planejamento educa clonal, em una equipe multidisclplinar.

69- Sugerir novos enfoques nos cursos de Graduação e de pósGraduação que capacitem o especialista em Geografia para a tarefa de plonejamento educacional. 
NOTAS A PARTE I

(1) A análise dos textos dos Decretos que crlaram os programas men clonados - PROTERRA, PRODOESTE e PROVALE - não possibilita localizar os itens que se refiram especificamente à educação.

Sente-se, contudo, que atividades como as que se desenvol verão, à determinada altura do detalhamento da planificação, por certo irão programar o setor educacional.

(2) PERRouX, Françols - A economla do século XX. Tradução de José Lebre de Freitas - Lisboa - Portugal - Livraria Morals Editora - 1967.

A obra interessa ao estudioso da Geografla por mültiplas razōes, das quals duas ressaltam:

Ia - a visão globalizadora do processo econômico, quer em termos de ciência Econômica, que em termos de constatação de suas leis em diversas äreas e paises;

2a - as noçōes que são desenvolvidas sobre espaço econômico e a teoria dos polos de crescimento.

(3) FOURASTIE, Jean - As 40.000 horas. Tradução de Paulo Moreira da Silva - Rio de Janeiro - GB - Companhia Editora Forense 1967.

MASSE, Pierre - O plano, aventura calculada. Tradução de Alda Rosa e Alfredo de Souza - Lisboa - Portugal - Livraria Morats Editora - 1967.

(4) CURLE, Adam - L'ldentité professionnelle du planlficateur de l'éducation. Louvałn - Belgique - UNEsco - 1970.

MELo, Osvaldo Ferrelra de. Teorla e prática do planejamento educactonal. Porto Alegre - RS - Editora Globo S.A. 1969.

PFEIFFER, John - Uma visão nova da educação. Tradução de Leon das H.B. Hegenberg e Octanny Silveira da Mota, revista por AnI sio Teixeira. São Paulo - SP - Companhia Ed1tora Nacional - Editora da Universiajade de são Paulo - 1971.

A leitura dos três livros citados confirmou e abriu, para - autor, a visão dos problemas educacionais de forma ma1s abrangente e como subsistema de un sistema aberto, que é o sócło-politico-econômico.

(5) MINISTERIO DO PLANEJAMENTO E COORDENAÇÃO ECONOMICA - Plano Decenal de Desenvolvimento Econömico e Social - EDUCAÇ\% (I) (II) - Diagnóstico Preliminar - Rio de Janeiro - GB - EPEA - 1967. 
- autor se deteve na anālise de Planos Estaduals de Educa ção, em particular, os referentes aos seguintes Estados:Bahia, Espirito Santo, Minas Gerais, Pernambuco e R1o Grande do Sul. Para efeito de comprovação, comparou os planos elaborados em 1968 com os preparados para ter inficio em 1972.

PRESIDENCIA DA REPOBLICA - Metas e Bases para a ação do govêrno - Brasilia - DF - 1970.

MINISTERIO DA EDUCAÇÃo E CULTURA - Plano Setorial de Educacão e Cultura - 1972/74 - Secretaria Geral - Brasilia-DF- 1971.

(6) PHLIPPONNEAU, Michel - Geografia e Ação. Tradução de Judite Cordeiro Ferreira - Lisboa - Portugal - Edições Cosmos-1964.

MONBEIG, Pierre - Novos Estudos de Geografia Humana Brastleira Sāo Paulo - SP - Difusão Européía do Livro - 1957.

HARTSHORNE, Richard - Questões sobre a natureza da Geografia. Tradução de Thomaz Newlands Neto. Rio de Janeiro - GB- Textos Bāsıcos - 4 - Instituto Panamericano de Geografia e Histöria 1969 .

COMISION DE GEOGRAFIA - INSTITUTO PANAMERICANO DE GEOGRAFIA E HISTORIA - Regionalización - Rio de Janeiro - GB - Apec Editora - 1969 .

SANTOS, Milton - Le Mētiex de Géographe en pays sous-développé Paris - France - Editions OPHRYS - 1968.

AB'SABER, Aziz Nacib - Geografia e Planejamento, in Revista de H1störia. NQ 80 - Ano XX - São Paulo - SP - 1969.

(7) FAISSOL, Speridião - Mëtodos Quantitativos na Geografia, in Curso para professores de Geografia. R10 de Janeiro -GB- Fundação IBGE - N\& 16 - 1970 .

RACINE, Jean-Bernard - Nova Fronteira para a Pesquisa Geogräftca, in Boletim Geogrāfico. no 221 - Rio de Janelro-GB- Funda ção IBGE - 1971 .

GALVÃo, MarIlla Velloso - FAISSOL, Speridião - A revolução quantitativa na Geografia e seus reflexos no Brasil, in Revista Brasileira de Geografla, Ano 32-no 4- R1o de Janeiro - GB Funđação IBGE - 1970.

DINIZ, Alexandre F., et al1ii- Boletim de Geografia Teoréticano 2 - Rto Claro- SP - 1971.

BERRY, Brian J.L. - PYLE, Gerald - Grandes regiões e tipos de agricultura no Brasil, in Revista Brastle1ra de Geografia, Ano 32, no 4 - Rio de Janeiro-GB- Fundação IBGE - 1970. 
II - FUNDAMENTAÇAO TEÓRICA: SINTESE DO PROCESSO EDUCACIONAL 
C A P I T U L 0

VISAOO DA EDUCAÇO NO MUNDO, APOS 1945 
1 - VISÃO DA EDUCAÇAO NO MUNDO, APÓS 1945.

\section{$1.1-$ objetivos}

18- Assinalar as causas bāsicas que determinaram a acelerada evolução do processo educacional, no mundo, após 1945.

28- Estabelecer as diferenças fundamenta1s que se observam entre värlos grupos de países, assim como indicar as causas das mesmas.

39- Relacionar istemas globais com os subsistemas de educação, nos diferentes grupos de paises.

49- Identificar as perspectivas próximas e remotas, no campo da educação, relaclonando as possiveis soluções para a pro blemátıca esboçada.

59- Buscar a fundamentação geográfico-econōmico-polítıca para determinação dos modelos educaclonals, nos diferentes grupos de países.

\section{2- O marco determinado pelo ano de 1945}

A elelção de uma data como divisor de tendênctas históricas corre o perigo de ser 1rrealista, porquanto os processos sociais, politicos e econômicos, "latu sensu", nem sempre são alterados em sua essêncla e direçäo por um dia, um mês, um ano.

Outro risco é o referente à sincronla dos eventos, que, multas vezes sofre un retardamento se se comparam palses entre s1 e, mesmo, reg1ōes de um pais, unas com as outras.

A escolha de uma data, contudo, didaticamente, è um bom referencial e não se faz aleatoriamente. Ela deve ser carregada de significado que indique uma reversāo de expectativas.

o envolvimento direto ou ind1reto de todos os palses no conflito, fol seguido, mais próxima ou mais remotamente, de um rea justamento dos quadros espaciais, humanos, econömicos, tecnológlcos, 1deolögicos. (1)

Altexaçōes profundas, nas relaçōes internacionais,como na própria organização Interna de multos palses, teriam forçosamente que se refletir no setor educacional.

A tecnologia desenvolvida no perlodo de 1939/1945, fol pos ta a serviço da reconstrução de multos palses ou, em outros casos, procurou satisfazer demandas reprimidas. 
A noção alnda mal aceita de planejamento global pelos pai ses não-comunistas, aos poucos foi se tornando 1mperativa para mu1tos deles.

A fase do "latssez-faire" em economia cedeu, gradativa ou mals rapidamente, ao primado da Economia como ciēncia, a regular ou a acelerar o crescimento global e/ou setorlal.

Com isso, verifica-se uma transferência para outros campos dos principios metodolöglcos da Economia, com seus modelos de anālise e programação, variando apenas de intensidade ou, conforme os postulados politico-ideolögicos.

Evidentemente logo se faz sentir a penetração da ciência Econômica nos dominios da Educação e, mats particularmente, do ensi no formal.

As respostas que os setores educacionals davam ou podiam dar aos reclamos urgentes dos demais segmentos da vida de un pais, estavam em nitido descompasso com as necessidades diagnosticadas.

o perfodo, que separa os anos de 1945 a 1970, fol marcado por profundos impactos, que mostraram uma nova face dos problemas e dos fenōmenos mundiais. Entre eles, podern se assinalar:

10- o rāpldo crescimento quantitativo dos contingentes demogräficos;

28- a elevação da renda per capita em mułtos palses, em flagrante contraste com as baixas rendas per capita em outros;

38- a redução das distâncias virtuais entre povos, graças à melhoria dos transportes e evolução rápida dos sistemas de comunicação. O mecanismo do "efelto-demonstração", gerando novas necessidades de consumo se fez sentir em quase todos os grupamentos humanos, particularmente entre os jovens ${ }^{(4)}$;

48- as alteraçōes dos fulcros de influência politica, quer mun dial, quer regional, de que resultaram numa sequência rápida, Impiedosa e traumatizante: a guerra fria, os confli tos armados internacionais e naciona1s;

5\%- alteraçōes nos quadros politicos e econômicos, com a ener gêncla de novos palses independentes e a formação de blocos econônicos (MCE, ALALC, MCCA, COMECON, etc.); organizações polfticas (Comunidade das Nações, OEA, OUA, entre outras); organizaçōes militares (OTAN, OTASE,Pacto de var 
sóvia), além da ONU e seus organismos especializados, como por exemplo o que mals interessa ao caso, a UNESCO;

68- a divisão do mundo em dols estratos bem diferenclados: palses Industrlalizados e países subdesenvolvidos, estabelecendo-se a relaçāo "centro-periferta";

78- o surg1mento dos grandes complexos ou conglomerados econô micos, de Influência dilatada para alëm-frontelras da empresa-sede, gerando centros de dectsão que escapam ao con trole de multos governos;

88- o avanço clentifico e por via de consequência, tecnológico, multiplicando os Inventos de enome repercussão na ví da de multos palses, a ponto de quebrar, constantemente, as acomodaçöes ao "status quo". Assim como surgen novos campos de trabalho, outros se tornam absoletos, ocasionan do flutuaçōes no mercado-de-trabalho, multas vezes de carāter dramāttco;

98- os fenōmenos de urbantzação acelerada, que forçam a curto ou longo prazo, a adoçāo de medidas para räo permitir a desorgantzação concomitante no campo e na cidade;

108- os impactos gerados pelas 1deologias, muitas vezes confli tantes; novas concepçōes de vida; tentativas de reajustamento interno em vărias religiōes; novos på̉rões ët1cos não tèrn siquer tempo de se cristalizarem, sendo substituí dos por outros.

A todos esses fatos verificados en diferentes graus de in tensidade, comblnados de formas diferentes uns dos outros e tendo como substrato a formaçäo h1stórica de cada povo, corresponderam di ferentes reações, como serła previsivel.

Uma das reações fol a tomada de consciêncla a respeito dos conceltos de crescimento econômico e, por outro lado, de subdesenvolvimento.

A farta l1teratura a respe1to dos temas acabou por domons trar que a luta não era entre regimes politicos, entre oriente e Ocldente, mas una luta contra as distorções ocasionadas pelo progresso material e contra as imensas lacunas próprias dos subdesenvolvidos. (5) Essa luta tinha e tem que ser travada en cada pais, in dependentemente de seu regime politico.

Outro problema que se tornou claro fol o referente a importâncla da educação como um dos agenteg capazes de corrigir as distorçōes e de ser uma força na mudança social. 
Conforme assinala BEEBY ${ }^{(6)}$, em alguns países de ma1or cresclmento econômico, podia-se "...tolerar um grau de superprodução educacional, ou mesmo de desperdfcio, e concentrar o raciocinio educacional mais sobre as necessidades do individuo do que propriamente sobre as necessidades econômicas do pals". Mais adiante, escreve: "As teorias educacionals baseadas em tals práticas mostraram-se bastante insuficientes para solucionar o problema dos pafses emergentes que não tinham margem para o desperdicio em potenclal hu mano especializado ou bancos escolares".

Posto que a educação passou a ser considerada de importân cia capital, houve necessidade de introduzir e quantificar a noção de custo/beneficio, a fim de se alocar recursos orçamentārios e extra-orçamentárıs que apresentassem taxas de retorno condizentes com as necessidades sociais, politicas e econômtcas.

A partir dessa conscientização, jā não se fala proprłamente en "despesas com educação", mas em "Investimentos educacionais".

Essa nova valorização da eđucação resultou de anälises do comportamento de economias nacionals, tendo-se ao longo dos estudos, demonstrado que, em muitos casos, o crescimento econômico se apoiava cada vez mats na qualiftcação dos recursos humanos - desde os niveis ma1s baixos de preparação da mão-de-obra, até os mais altos, representados pela pesquisa clentifica e tecnológica, nas Universidades - que propriamente no investimento representado pelo capi$\operatorname{tal}(7)$.

A part1r dessas constatações, volumes crescentes de recur sos foram aplicados na educaçāo, seja no aumento quantitativo, seja na melhoria qualitativa ${ }^{(8)}$.

Evidentemente outros fatores pesaram fortemente para a ex pansão e melhorła do enstno, tais como:

- rápido aumento quantitativo da população, que em muitos casos, pressiona em direção đe una democratização do en sino;

- desenvolvimento dos meios de comunicação de massa:

- elevação dos padrões de vida ou aspiraçōes populares pa ra melhorá-10;

- urbanização e Industrialização que, em muitos casos, for çaram a denanda de empregos no setor terciärlo e reajug tamentos no setor primärio, nos palses ou regiōes de economia prë-industrial, industrial ou pös-industrial. 
Na década de 60 , pode-se dizer que politicos, administradores, economistas, sociólogos e educađores estavam conscientizados da importância da educação para o crescimento econômico e para o dẹ senvolvimento social.

Todavia, restavam limitaçōes de vārias ordens para enfatí zar, na medida das necessidades, a educação e, particularmente, o ensıno formal. Essas limıtaçōes não eram e não são genéricas, mas variam de pals para país, de regiāo para região. As metas propostas esbarram nas realidades especlficas, nas potenclalidades e nos recursos. Assim, não se pode falar em "uma politica educacional", mas em "muitas políticas educacionais", até mesmo nos limites de um pais.

A aceleração ou o retardamento educacional é função de muitas variāveis, refletindo o grau de desenvolvimento ou de subdesenvolvimento.

\section{3- A questão do subdesenvolvimento}

Os conceftos de subdesenvolvimento (termo aplicado a certas áreas e/ou grupos socials, é farto em sinonimia, como: "em desenvolvimento", "emergente", "em transição") variam amplamente, con forme o enfoque dos analistas do fenômeno: sociólogos, economistas, geōgrafos, pollticos, etc.

Os indicadores para a quantificação e a qualificação do fenômeno, variam igualmente. Torna-se necessärio trabalhar com o maior nümero possivel desses indicadores, combinados entre s1, para definir a tipologia do subdesenvolvimento em qualquer área estudada. Yves Lacoste ${ }^{(10)}$ relaciona os seguintes indicadores: 
Aspectos básicos

Subalimentação

e

Desperdicio

Handcaps

Econōmicos

Estruturas socials opressivas e parailsantes

Disparidade entre - crescimento demo gräfico e o cresci mento econômico.
Situações tIpicas
Insuflciência alimentar
Recursos negligenciados ou desperdiçados

Grande nümero de agricultores com baixa produtividade

Industrialização restrita e Incompleta

Hipertrofla e paras1t1smo do setor terciário

Situação de subordinação econônica.

Violentas desigualdades soclais

Subemprego crôn1co e trabalho das crłanças Graves defıciências da população: analfabe tismo e doenças de massas

Insuficiente integração nacional

Amplidão do crescimento demogrä́fico

Lento crescimento dos recursos de que a po pulação efetivamente dtspōe.

Tomada de conscièn cla e uma situaçāo en plena evolução.

Naturalmente, como fol assinalado, quanto malor o nümero de indicadores disponivels, devidamente quantificados, tanto ma1s preciso serà o delineamento do perfil socio-politico-econômico do pais ou regtão.

Os gráficos nos $1,2,3,4,5$ e 6 , retirados do livro ci tado de Yves Lacoste, se devidamente comparados, permitem começar a posicionar um determinado pais no conjunto dos demais.

Outros indicadores tornartam mais preciso esse posiclonamento. 


\section{Gräfico no i}

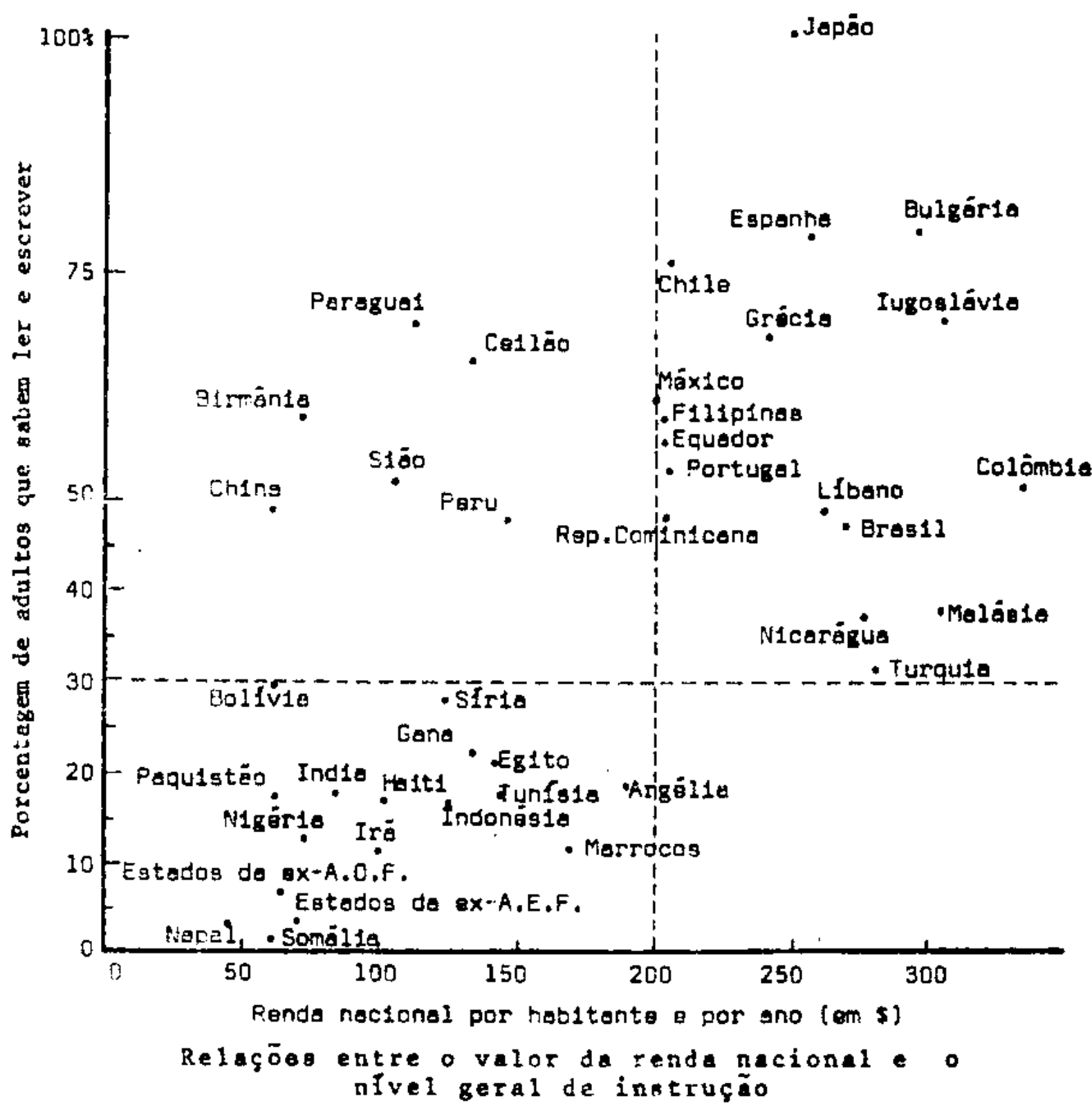


Gráfico nQ 2

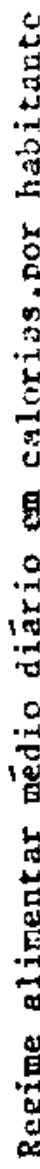

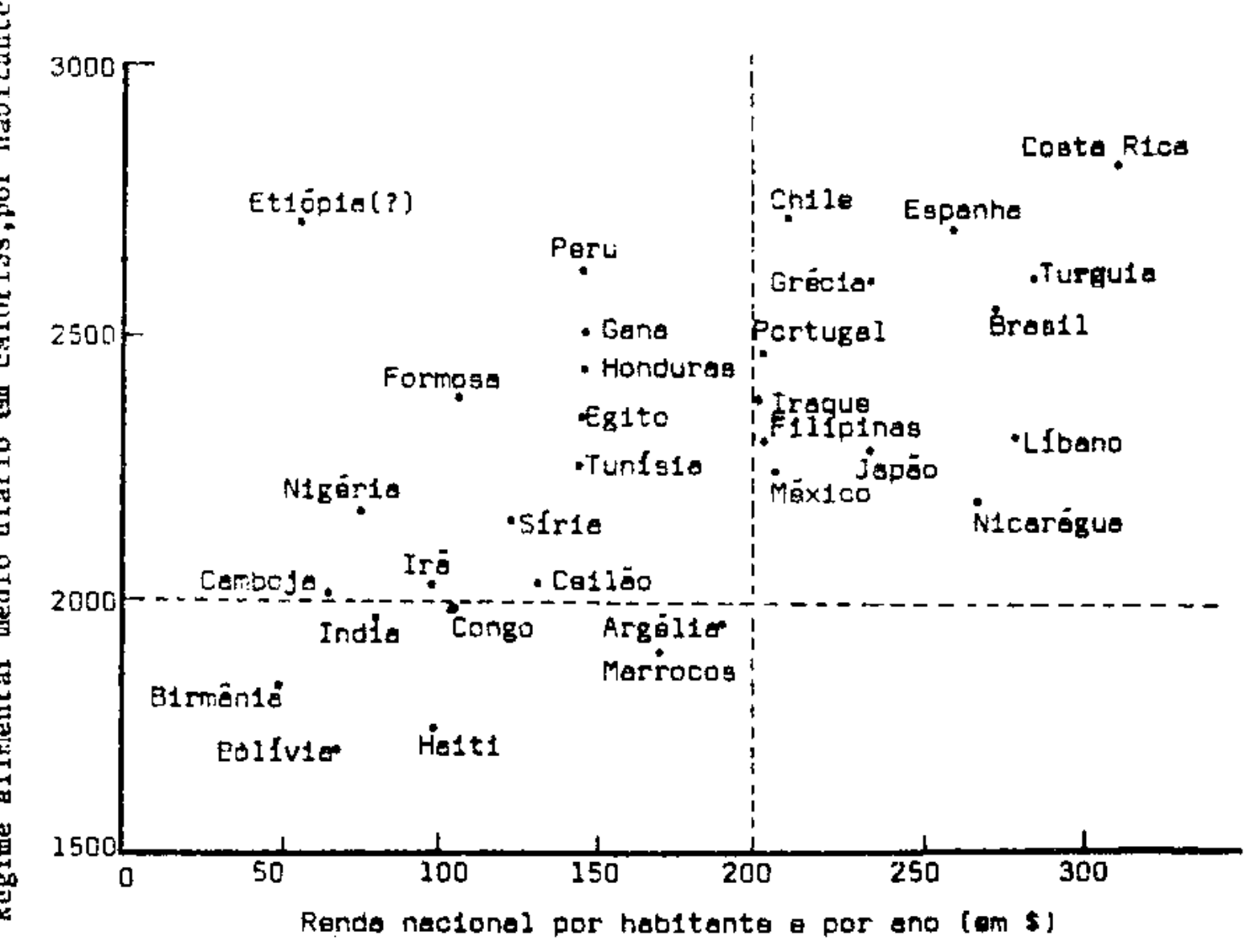

Relaçöes entre o valor da randa nactonal e importäncia do regime alimentar 
Gräfico ne 3

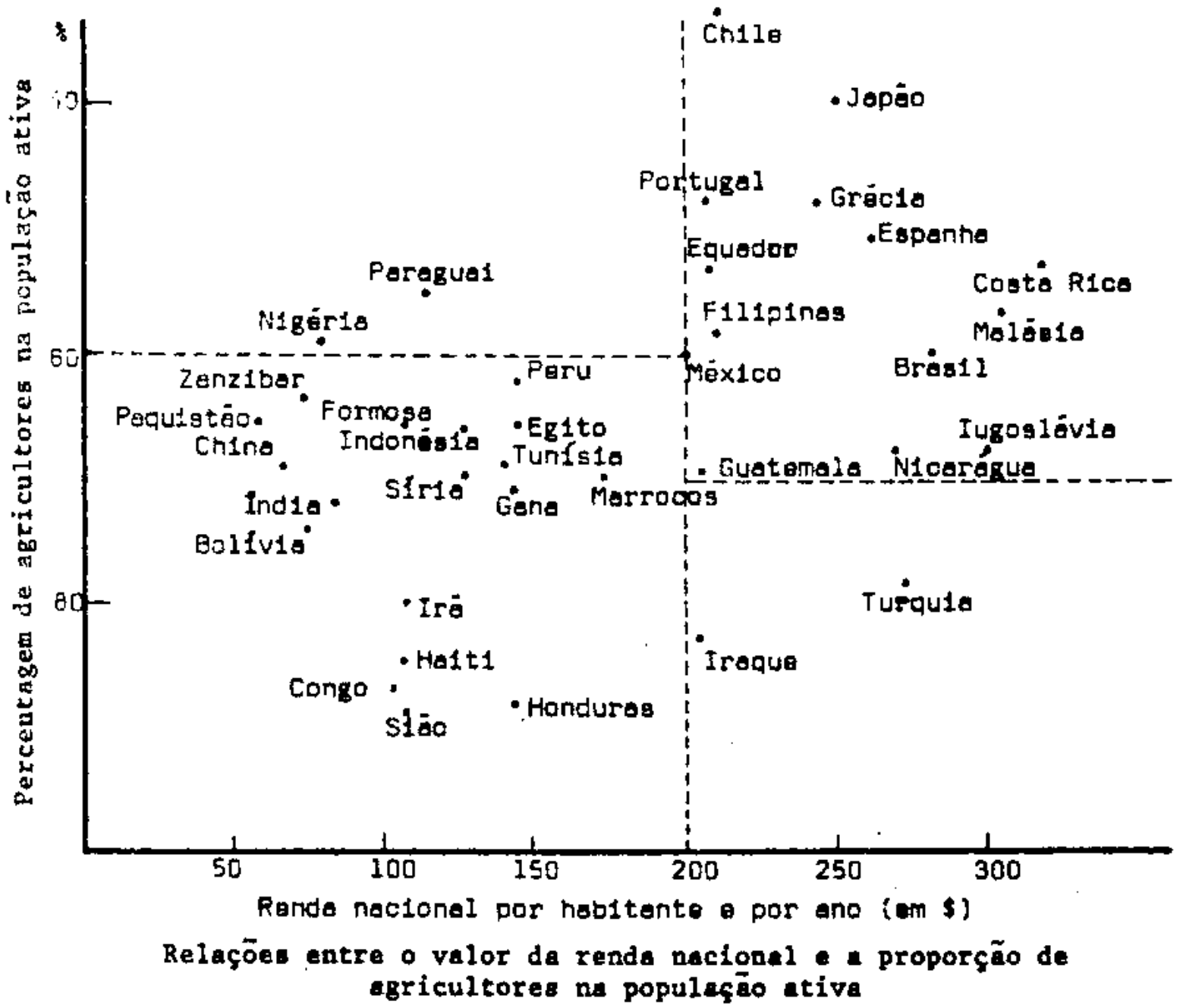


Gräfico ne 4

总

$7000-$
6000
5000
4000
3000

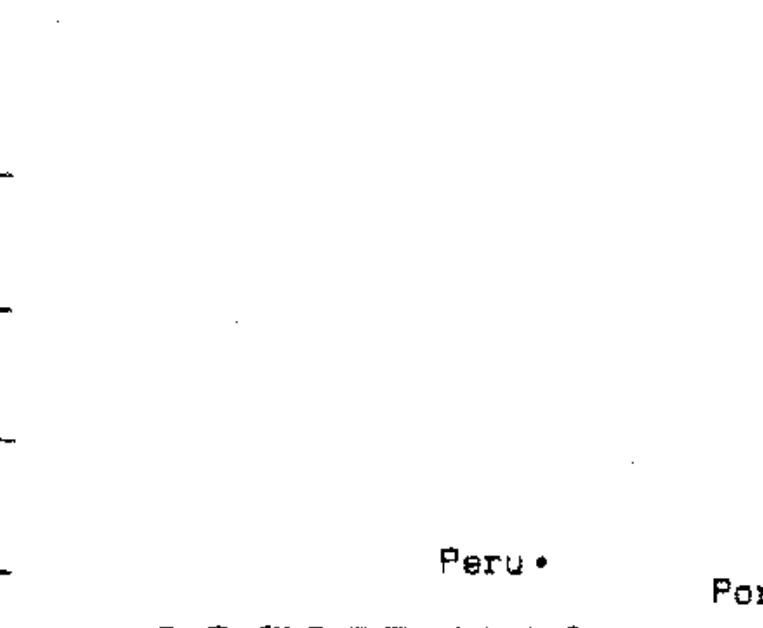

- Ch11日

1 - Jep̄̄o

1*México

- Esparta

Eras1I

- Molósia

Iugos lovia"

Portugal Grécla turquia

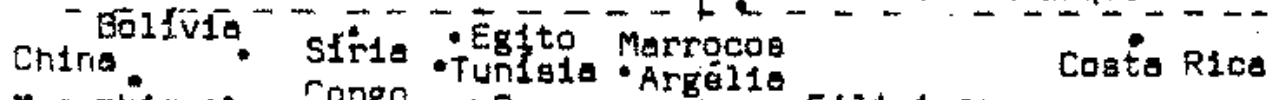

Chira. Elí. Efto Marroco

Costa Rica

Birménia.

Niqēriä

Fongo

- ira Gana

- Filipinas

- Stĩo ceslẽo

Heiti Indonéa

- Equador

- Iracue 


\section{Gräftco ne 5}

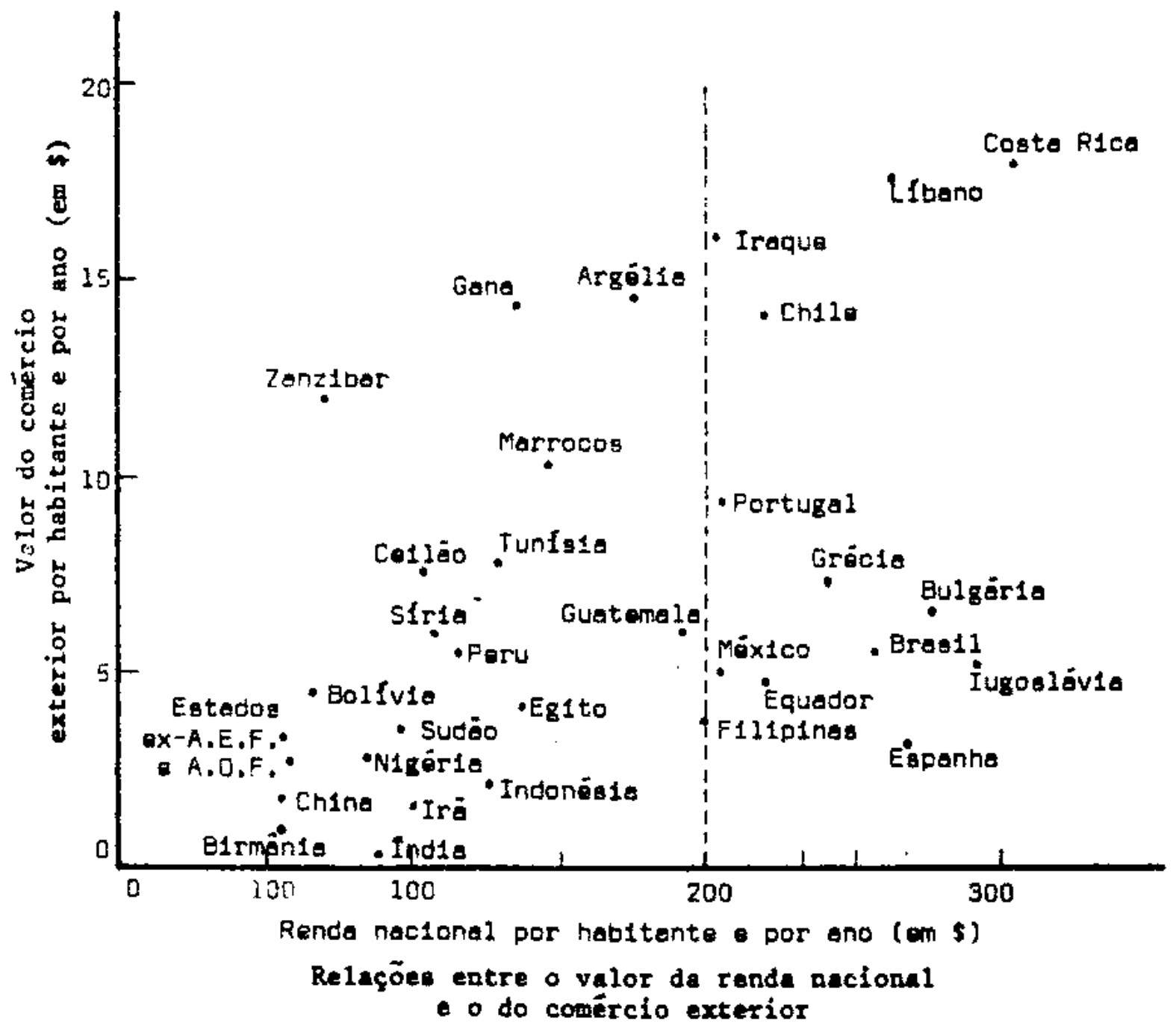


Gräfico nQ 6

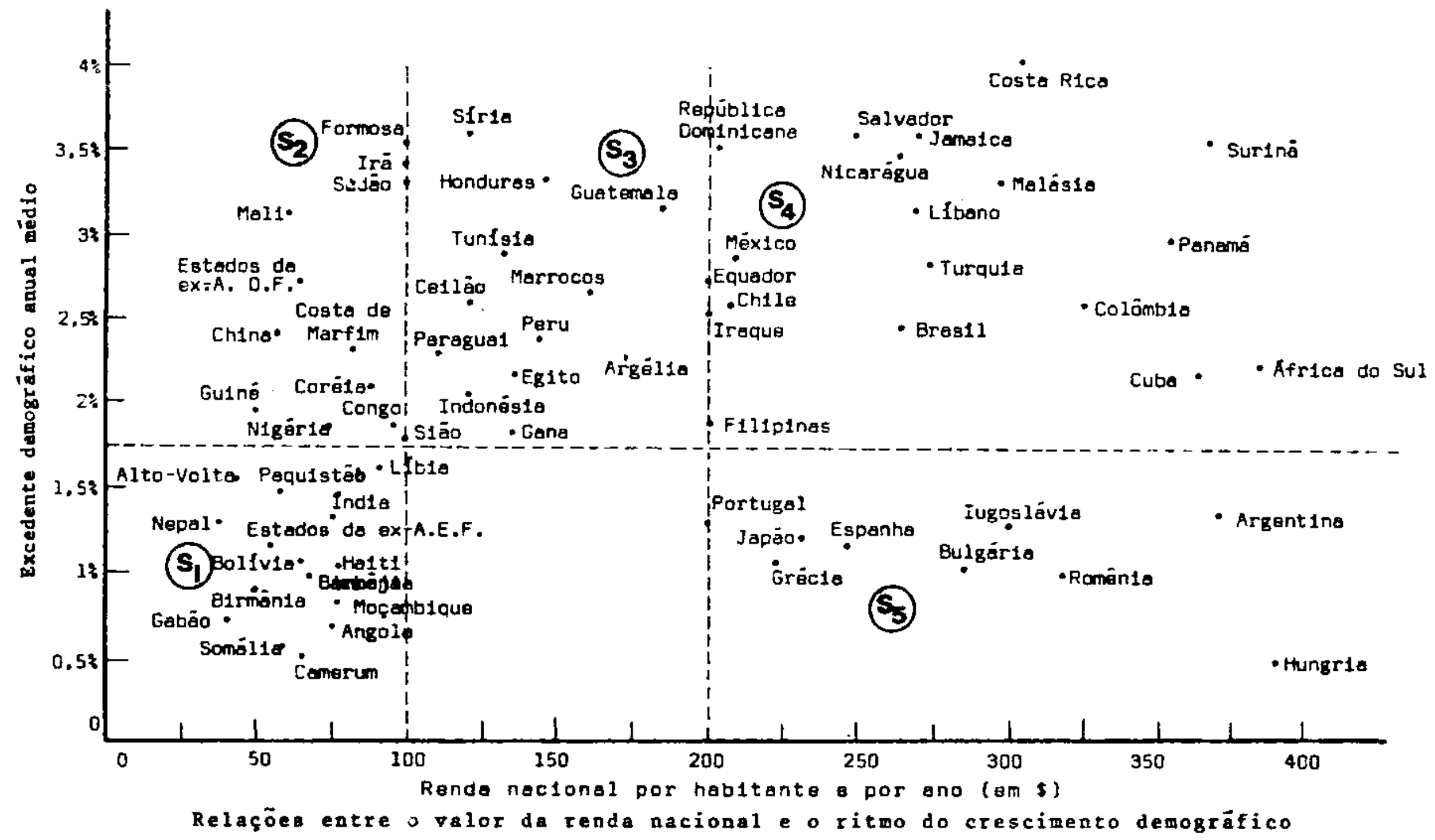


No quadro geral dos indicadores, torna-se necessärio descer a uma análise mais profunda do subsistema educacional, componen te de um sistema mals amplo que envolve todas as variáveis.

\section{4- Diagnöst1cos educacionais}

Os diagnösticos educacionais são muitas vezes entravados por falta de pessoal qualificado e de dados estatisticos, que possam ao fim revelar, em espaço de tempo hābll, sob pena de o trabatho tornar-se ultrapassado face a mudanças rápldas verificadas na região em causa, as lacunas e as potenclalidades.

Os elementos a Identificar säo variados e dependem, multas vezes, da politica de crescimento e de descnvolvimento e das riztodo logias empregadas para o dfagnóstico.

\# apuração dos dados quantitativos deve-se seguir a anäl1se de aspectos qualitativos, sem o que o perfil nacional e/ou regio nal apresenta sërlas distorções.

Em paỉses subdesenvolvidos, variando a claro ce um para outro, os dados a verificar são mals de natureza adjetiva do que substantiva, isto é,variam em grau, em intensidade, mas não em espëcie.

Alguns dentre eles são:

18- taxa de analfabetismo global e por faixas etărias;

2Q- caracteristicas e quantificação do ensino primārio, secundário e terciário, no que tange à população global - população escolarizável - população escolarizada:

38- questōes relativas a prëdios, equipamentos, pessoal docente e tecnologia do ensino, o que pesa fortemente na relação matricula inicial .- tërmino de curso;

4\% - taxas de evasão e repetèncla;

58- investimentos no setor do ensino:

68- atendimento às necessidades comunltärias, reglonais e nacionais, pelo sistsma formal e por outros agantes de educação.

Isso posto, é Indispensāvel compatibilizar o planejamento educactonal com os planos de crescimento e desenvolvimento gerais. o insucesso total ou parcial de projetos educaclonais resulta, não apenas das falhas no diagnöst1co, mas do seu desvinculamento com os planos globais, que envolvem outros setores obviamente ${ }^{\text {(11). }}$. 
Se este entrosamento è importante vara os paises mais adiantados, ele é indispensável para os que são carentes de recursos financeiros, tecnológicos e humanos. Os palses deste último grupo não podem se dar ao luxo de perdas ou má aplicação de recursos escassos.

Parece, então, evidente que se torna crioritāria a mohili

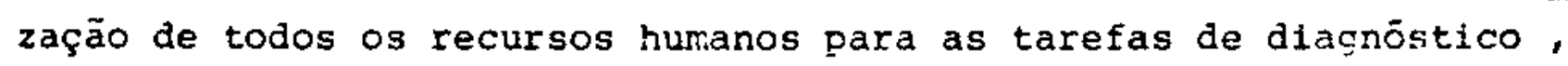
planejamento, programação, implementação e avaliação. A tarefa è global, não pode ser de responsabilidade apenas de economistas, ou de polfticos, ou de educadores, requerendo o concurso de outros especlalistas como os geögrafos, os soctölogos, os urbanistas, os engenheiros, os sanitaristas, etc., etc. O trabalio de equipes interdisciplinares è prē-requisto para a formulação das estratēglas glo bais e setorials.

E claro que os fenömenos educactonats e as relaçōes do subsistema com o sistema global, são de outra natureza nos países e/ou regtões industriais ou de economia pós-industrial.

o impacto da industrialização nas formas de organizeção do espaço, na reestruturaçāo dos quadros humanos, nas novas tendēnclas econômicas ë imensurăvel. Conforme as caracteristicas da $1 m-$ plantação industrial e as caracteristicas das regiōes que sofrem sua influência, o processo desencadeado pode ser de repercussão mui to ou pouco profunda $(12)$.

A industrialização acelerou as reformas educacionats, por gue se tratava de uma nova forma de organtzação econòmica que deman dava novos quadros, quer para atendè-la airetamente loperärios com qualificação especifica, engenheiros, administradores, economistas, pesquisadores de alto nivel), quer indiretamente, no setor primário (produção de matēria-prima), no setor terciārio (comercializaçāo,pu blicidade, etc). Configurou-se a necessidade de ampliar o mercado consumidor dos produtos industrializacos e isso, iqualmente, gerou os reclamos de um novo tipo de educação para o consumo.

A antiga ligação entre empresas e caoitalistas financiado res da implantação e/ou expansāo industrial, pouco a pouco fol sendo substituida pela nova acoplagem empresa-centros educaciona1s.

Esses centros educacionais, notadamente as Universidades, ganharam nova dimensäo, principalmente por se constituirem nos focos de pesquisa cientifica e ensaios de novas tecnologias. Ao mesmo tempo, de lá saem os engenheiros, os sesquisadores, os administrado res, os economistas, os técnicos em comunicação, os psicōlugos, etc., Indispensāveis para manter o ritmo acelerado das sociedades 
afluentes. Em contrapartida, as empresas e o governo mesmo, que são os actonadores e os guardiães dessa socledade afluente, alimentam o subsistema educacional, com dotações orçamentárias especificas e crescentes, estabelecendo prioridades para a expansão das matrículas e para a aplıcạ̃ão dos recursos ${ }^{(13)}$.

A tal ponto se interpenetram educação-1ndústria, que o conceito de indústria foi, a pouco e pouco, perdendo a conotação de estabelecimento fabril e se alargando, até fronteiras não suspeitadas. O próprio ensino já é entendido como indústrıa, sem que isso cause maior desprestigio às instituições e, mesmo, às suas finalıạ $\operatorname{des}^{(14)}$.

Os problemas colocados nas sociedades afluentes, no que se refere à educação, são novos e devem acompanhar as mudanças sociais que se fazem aceleradamente. Causa e efeito dessas mudanças, talvez por isso mesmo, sem tenpo suficiente para firmar-se doutrinariamente, a educação debate-se num torvelinho de contradiçōes. Educação de massa $x$ atendimento às diferenças individuais; padrontza ção $X$ criatividade; custos crescentes $x$ outras despesas urgentes $e$ Inadiāvels; conformismo $x$ contestação; preparação da mão-de-obra $x$ formação integral do individuo; aumento da produtividade $x$ desempre go. A listagem bipolar vai num crescenco, variando de intensidade conforme o pais ou região.

Nos paises subdesenvolviāos grande parte dos esforços se concentra na alfabetização de aduitos, a fim de qualificar a curto prazo uma mão-de-obra de balxa produtividade e, por via de consequênc1a, de reduzido poder aguisitivo e na extensão da escolarizaçāo para todo o universo etárı de 7 a 13 ou 14 anos.

Hos paises industrializados e nös-industriais os problemas são de outra ordem. A expansão do ensino de 18 grau apenas acom panha as baixas taxas de crescimento demográfico: os investimentos, as pesquisas e os cuidados se voltam mais para o ensino de 28 grau, para o universitār1o e o pōs-universitário, para a educação permanente. Esta è uma forma continua de educação, que visa não apenas à reciclagem, retreinamento da mão-de-obra em seus diversos niveis de qualificação, mas ao atendimento das aspirações de melhoria individual.

A automação dos serviços reduz as horas de trabalho, aumentando, consequentemente, os periodos de lazer. o setor quaternärio das atividades econômicas posstvelmente estară centrado nas for mas de produzir situações e meios que sirvam ao lazer. Tudo indica que, em muitos países e/ou regiões a duração do temo destinado ao 
trabalho, nos prōximos trinta anos, não ultrapassarā 68 ou 78 da v1da de uma pessoa ${ }^{(15)}$.

Ora, este fato condicionarã toda uma revolução nos subsíg temas educaciona1s. O "homo faber" que guarda estrelta vinculação com o "homo economicus", val aos poucos cedendo lugar ao "homo ludicus".

Deve ser levado também em consideração que as pesquisas cientificas e tecnológicas e a transformação da tecnologia de laboratörio em tecnologia aplicada, em sërie e em massa, Introduzırão,a cuxto ou médio prazo, mudanças radicals na vida das sociedades humanas.

Os estudos de prospectiva permitem antever, com razoāvel margem de segurança, as transformaçōes que ocorrerão nos próximos 20 ou 50 anos. (16)

\section{5- Propos1çōes de organismo Internacional}

As perspectivas no campo da educação delineiam-se com cer ta clareza.

Recente trabalho da UNESCO ${ }^{(17)}$ discute os grandes problemas que se evidenciarāo, assim como propõe determinadas soluçōes. o resumo é o que segue:

- Aumento da demanda social.

- Pressão econômica sobre os sistemas de educação.

- Sistemas educacionals desvinculados das necessidades co munttärias, notadamente no que se refere às exigèncias do mercado-de-trabalho.

- Desemprego atingindo pessoas com razoãvel nivel de instrų̧ão.

- Contestação da juventude em relą̧ão às estruturas, programas e métodos de educação.

As soluções, em grandes linhas, são:

- Pesquisa e inovaçōes.

- Aumento dos recursos financetros e da eficácia da educação.

- Melhoria na ajuda exterior.

- Modernização gerencial da educação.

- Planificação educactonal.

- Partıcıpação das comunidades no planejamento educacional. 


\section{6- Conclusões parcials}

10 - Os processos educacionais foram acelerados nos ültimosvin te e cinco anos, em todos os paises, mesmo naqueles que conquistaram recentemente a independência politica.

20 - As alterações verificadas não são estereotipadas, mas variam de acordo com o grau de cresclmento econômico e do substrato histórico dos paises.

38 - Novos conceitos sobre educação foram equacionados, princi palmente por influêncta da Economia.

40 - A corrida em direção da educação para todos envolve sērios problemas relacionados com a "explosão escolar",quer do ponto-de-vista quantitativo quer qualitativo. Esse pro blema gera o do financiamento da educą̧ão, com custos sem pre crescentes.

58 - A Industrialização e os meios de comunicação de massa alteraram os postulados educacionais.

68 - A educação não pode ser encarada isoladamente, mas no con texto mals amplo das demandas globais de crescimento eco. nômico e desenvolvimento social.

78 - As perspectivas pröximas e remotas do processo educacional requerem planejamentos integrados. Esses planejamentos serão mais adequados na medida em que sejam elaborados por equipes interdisciplinares. 
(1) CROUZET, Maurice - Histöria Geral da Civilizacão - Tomo VII A Época Contemporānea - 29 volume - o Mundo Dividido -Tradução de Paulo zingg e J. Guinsburg - São Paulo - Difusão Européia do Livro - 1958.

Nesta obra, interessam, de perto, para a anālise das profundas transformações porque passou o mundo, os l1vros segundo e Tercelro. Ambos enfocam em países da Europa, nos Estados Unt dos, no chamado mundo comunista, as novas tendências constatadas em värios aspectos da vida econômica, política, social, aqual incluidas referências sobre as manifestações culturais e religiosas.

(2) GENET, L., et allii - Le Monde Contemporain - Classes Terminales - Collection D'Histoire Hatier - Paris - Libraire Hatier 1962.

No capitulo 13 "Introduction a l'étude des clvilizations", os autores lançam bases para caracterizax as civilızações, notadamente face à aceleração da História.

(3) A rigor antes de 1939 o regime capitalista em diversos palses particularmente os que foram atingidos por crises economicas estruturais - passou a adotar mais rigidos controles econômicos.

Ver a respelto:

LAJUGIE, Joseph - Os Sistemas Econômicos - Tradução de Geraldo Gerson de Souza - 2a edição - Coleção Saber Atual - são PauloDifusão Europēia do Livro - 1965 - p. 72 - 95.

(4) FURTFR, Pierre - Juventude e Tempo Presente - Tradução de Luís Lourdes orlando - Rio de Janeiro - Editora Paz e Terra Ltda. 1967.

O Item "Juventude Planetária", p. 16 e 17, assinala a angüstia que se apodera da juventude, notadamente das äreas subdesenvolvidas. Nāo se trata apenas de consumir mais, na esteira de outros povos, mas de "uma possibilidade de mudança efetiva", a "impaciência demonstracaa, de maneira quase obsessiva, em particlpar efetiva, real e integralmente do processo histörico".

(5) Livros recentes ainda se prendem a essas questões que se vão tornando apenas histöricas. Ver, por exemplo:

BAADE, Fritz. A corrida para o ano 2000 - Tradução de Macédo Neto - Rio de Janeiro - Editora Nova Fronteira S/A. - 1966 capItulos III, IV e IX, particularmente. 
(6) BEEBY, C.E. - Educação e Desenvolvimento Econōmico - Traduçāo de Edmond Jorge - Rio de Janeiro - Zahar Editores - 1967 - p. 13 - 19.

(7) SCHREIBER, Jean Jacques Servan - O Desafio Americano - Tradução de Alvaro Cabral - Rio de Janeiro - Editora Expressão e Cultura $-1968-\mathrm{p} . \leqslant 7 \quad 74$.

Embora muitos manuais de Economia jä tratassem do assunto à farta, a divulgação dessa realidade, a nível popular, se deve a esse l1vro, cujos conceitos forçaram amplos debates. Fato è, porẻm, que ficou demonstracio que a distância entre os países em fase de pós-industrialização dos meramente industrial1zados, nara não descer a níveis inferiores de crescimento econômico, se deve mais ao "fosso tecnológico" e gerencial que propriamente aos investimentos de capital.

(8) KHOI, Lê Thănh - $\Lambda$ indústria do Ensino - Tradução de Maria Fer nanda Margarida Correia - Porto - Portugal - Livraria Civiliza ção Editora - 1970.

"Uma consequência desta evolução consiste na su bida constderável da empresa com o ensino, que aumen tou em todos os países mais depressa que o rendimento nacional. Hoje em dia atinge ou ultrapassa $6 \&$ des te rendimento, não só nas nações industrializadas co mo a União Soviética, os Estados Unidos, o Japão e os Países Baixos, mas tambëra nos países menos ricos como Israel, Porto Rico, Finlāndia, Tunisla e Libia. A gestão de tal despesas impõe a aplicação de métodos industriais". p. 12 .

(9) Eoje bastante vulgarizada a classificacão de W.W.Rostow, que grupa os paises nos seguintes escalöes: sociedade tradicional, os requisitos prévios para a decolagem, a decolagem, o impulso para a maturidade e a exa do elevado consumo das massas.

(10) IACOSTE, Yves - Geografia do Subdesenvolvimento - Tradução de T. Santos - São Paulo - Difusão Eurodēia do Livro - Editora da Universidade de São Paulo - 1966.

E interessante, como ponto de partida, ler o prefácio, on de o autor analisa a posição da Geografia nos estudos do subde senvolvimento.

Nos seis anos que medeian entre a publicação do livro e o ano de 1972, tem se verificado um esforço grande por parte dos geógrafos para recuperar o tempo perdido, nos estudos mais am- 
plos ou mais localizados, do fenömeno do subdesenvolvimento.Pa rece, todavia que tal esforço orecisa ser bastante aumentado, para que a contribuição da Geografia nesse setor seja ma1s ponderăvel e evidente.

(11) UNESCO - La planification de l'ëducation: Bilan, problèmes et perspectives - Felgisue - Imprimé par llaison d'tdition S.C. Mar cinelle - 1970 .

"Quelques-uns lies tous premiers efforts de planffication de l'éducation étaient dejá étroltement liês au développement socio-ëconomique. En règle générale, toutefois, la planification de l'éducation, au lendemain de la seconde guerre mundiale, const1tuait une opération à part, sans liaison rëelle avec les autres chapitres du plan général de développement. La liaison comença à s'établir sous l'angle financier, puisqu'il fallait harmoniser les dépenses d'éducation avec les dépenses des autres secteurs.

Sur les 98 pays nour lesquels nous possédons des renseignements, 86 ont un plan de développement économique et social, so ont un plan d'éducation et, dans 70 cas, le olan d'education actuel falt partie du plan de céveloppement économique et social". p. 55 e 56 .

(12) GEORGE, Plerre - Geografia Econômica - Tradução de Ruth Magnanini - Rio de Janeiro - Editôra Fundo de Cultura S.A. - la. edição - 1961 - ver. Terceira Parte - Capitulo Primeiro - p. $265-290$.

(13) GALBRAITH, John Kenneth - O Novo Estado Industrial - Tradução de Alvaro Cabral - Rio de Janeiro - Editora Civilização Brasileira S.I. - 1968 - Capitulos XXV e XXXIII.

(14) KHOI, Lè Thành, on. cit. ?. 1n.

Podemos considerar o ensino como a maior "indústria" de nossa época, tanto pelos "recursos" humanos e financeiros que absorve como pela imoortància da sua "produçāo": os quadros ad ministrativos, científicos e técnicos que desempenham un papel motor no desenvolvimento das sociedades actuais.

Podemos elaborar o quadro que se segue, com os factores constitutivos de sua função de produção e do seu produto: 
Factores

f.lunos

Professores

Estabelecimentos escolares

Apetrechamento

Móvels escolares

Bens e serviços diversos

(água, gās, eletricidade,

alugueres, seguros, etc.)
Produto

Alfabetizados

Pessoas com instrução

primária

Pessoas com instrução

secundária

ressoas com instruczo

superior.

(15) FOURASTIE, Jean. As 40000 horas - Tradução de Paulo Moreira da Silva - Rio de Janeiro - Coleção Prospectiva - Companhia Ed1tora Forense - 1967.

A proprós1to, ver especialmente o capitulo II, onde o autor se detem mais sobre os gêneros de vida e o lazer, em futuro pröximo.

(16) IIMA, Lauro de Oliveira. Treinamento em Dinâmica de Grupo, no Lar, na Emprêsa, na Escola - Petröpolis - RJ - Edytora Vozes Limitada - 1970 - 2a. Edição. D. 419 . Ver o quadro que segue.

\section{QUADRO DO FUTURO}

- Quadro que se segue não deve evidentemente ser tomado demasiado a sērto. E divertido e instrutivo extrapolar para o futuro a escala de tempo das realizações cientificas realizadas no passado. Se não valesse mais do que isso, o breve resumo do que aconteceu nos últimos 150 anos convenceria qualquer pessoa de que nenhuma imaginação atual pode esperar prever alëm do ano 2100. Eu nem sequer tentel fazer isso. 


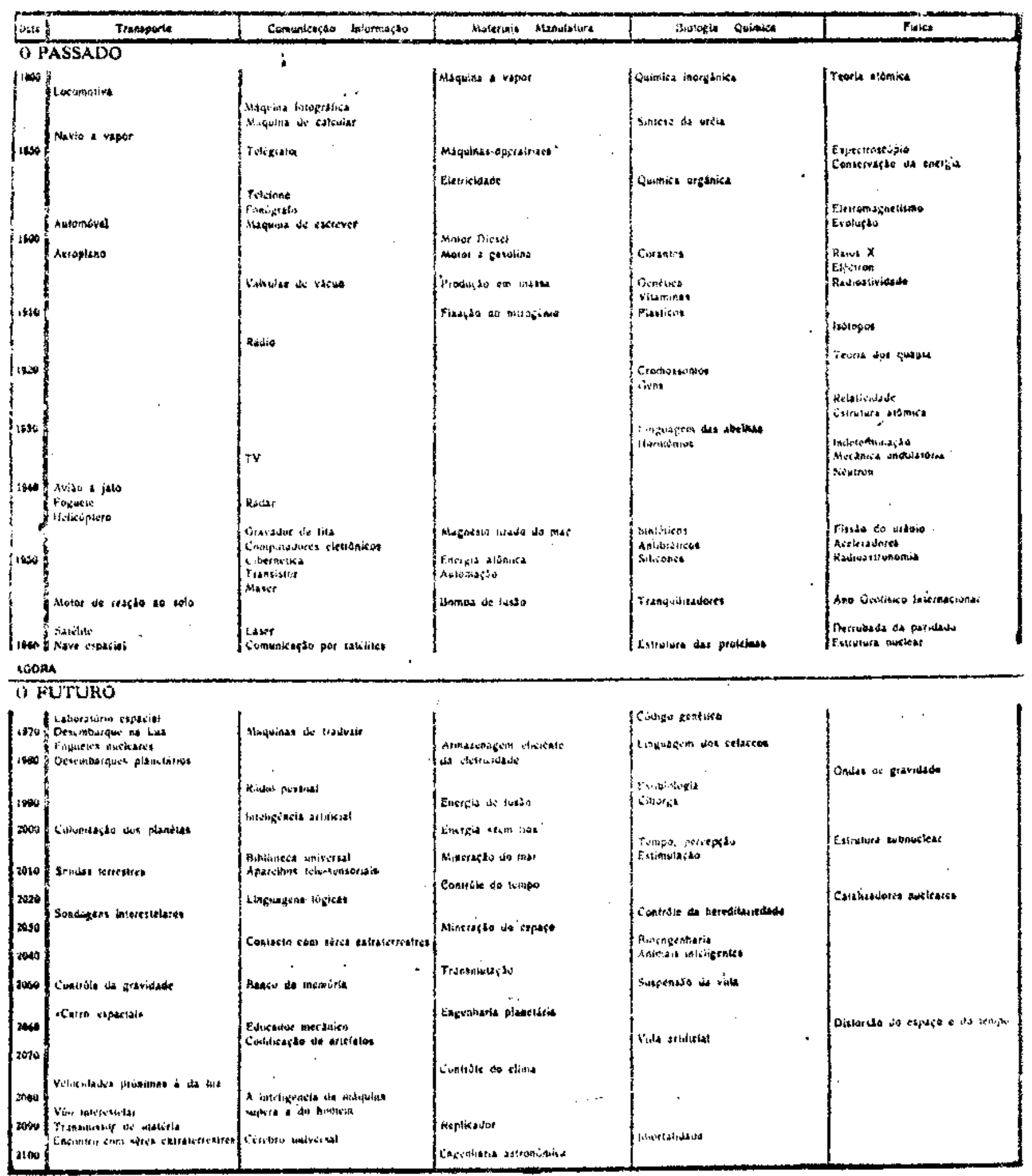

(17) UNESCO Ia Planification de l'education - op. cit. p. 18-27. 


\section{A P I T U L 0}

PROBLEMAS ENUCACIONAIS IAA AMERICA DO SUL 
2 - PROBLEMAS educacionaIS NA AMERICA DO SUL

\section{1 - objetivos}

19 Correlacionar a questão educacional com sistemas gerais, do ponto de vista das estruturas histöricas-demogräficas-soclais-econômicas-politicas.

28 Demonstrar que o subdesenvolvimento de muitas äreas sulamericanas age como causa-efeito do pauperismo educacional.

38 Estabelecer possiveis soluções para a questão educacional na Amërica do Sul.

\section{2 - América Latina?}

Já se tornou lugar comum designar-se os paises da Amërica - excluidos os de fala inglesa, notadamente, como mērica Latina. Nes sa denominação cabem os da Amërica do Sul.

A rigor essa generalização encobre falsamente una idẽia comum, que daria a todos os países caracteristicas básicas que os identificassem.

o termo "latina" carece de malor precisāo, porque a cultú ra latina se expressa hoje de formas diversas e aparece, de uma ou outra maneira, em países que não estiveram diretamente sob a influencla de Roma. Excluindo o Brasil, talvez fosse mals correto aplicar-se a essa região a designação "Amērlca Hispānlca", porque aí no tam-se marcas multo mals profundas e atuais da cultura espanhola nos nove palses da América do Sul que falam o castelhano.

0corre porëm, que a influência da Espanha não fol e não è integral, pois hä uma Amërica India, que fol submetida à força, mas que se manteve à parte e, ainda hoje, rejelta os padröes culturais de origem espanhola. Hä comunidades indigenas na reglão andina, tạn bén importantes no Paraguai, mas bastante expressivas (1), conforme se depreende dos quadros a seguir: 
Quadro 1 (*)

Estimação da populacão indiquena na Amērica Andina
Bolivia ..........
$2450 \quad 000$
Colômbia .......... 200000
Chile ........... 250000
Equador ..........
1838700
Peru .............
4753200
Venezuela
98700
(*) CunILl, Pedro. A Amërica Andina - op. cit.
Esses dados são mais significa- tivos se os compararmos como to tal da população dos países re- feridos, no ano de 1966:
57108000 habitantes. Fonte: op. cit.

Quadro 1-À

(*)

Estimativa da populacão total, em 1972, na Amëxica Andina.

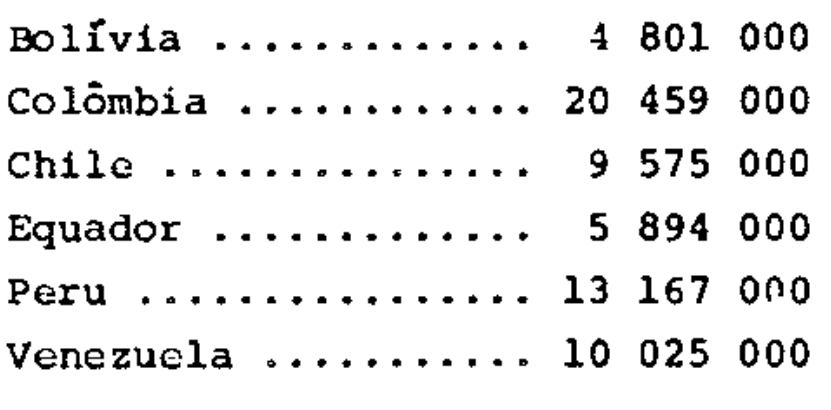

(*) Anuärio Delta Larousse-1972 0 total da população acıma estimada: 63921000 habitantes.

Essa população, a rigor não assimilada, constitui um traco marcante na parte andina da América e, do ponto de vista educa cional, un problema específico que não pode ser abordado de Igual me neira que o restante. LInqua, costumes, relações familiares e so ciais, concetto de propriedade, religião, präticas econômicas, etc., formam um conjunto cuja caracteristica cultural näo pode ser violen tada por modelos educacionais estereotipados.

De outro ângulo, a Amērica Hispântca, igualmente não è um bloco ünico. Fisicamente, ao menos, dois grandes conjuntos podem ser identificados: a América Andina e a Amërica Platina.

As desigualdades entre os paises que compöem os dois con juntos vão se aprofundando ã medida que a análise detalha as caracteristicas e as peculiaridades de cada pais: caracteristicas físi cas, ocupação dos espaços, estrutura da população, urbanızação, escolartzaçāo, renda "per-capita", regimes políticos, etc.

observem-se a respeito os quadros seguintes: 
QUADRO 2

CARACTERIZAÇÃO GERAL: NUERICA LATINA

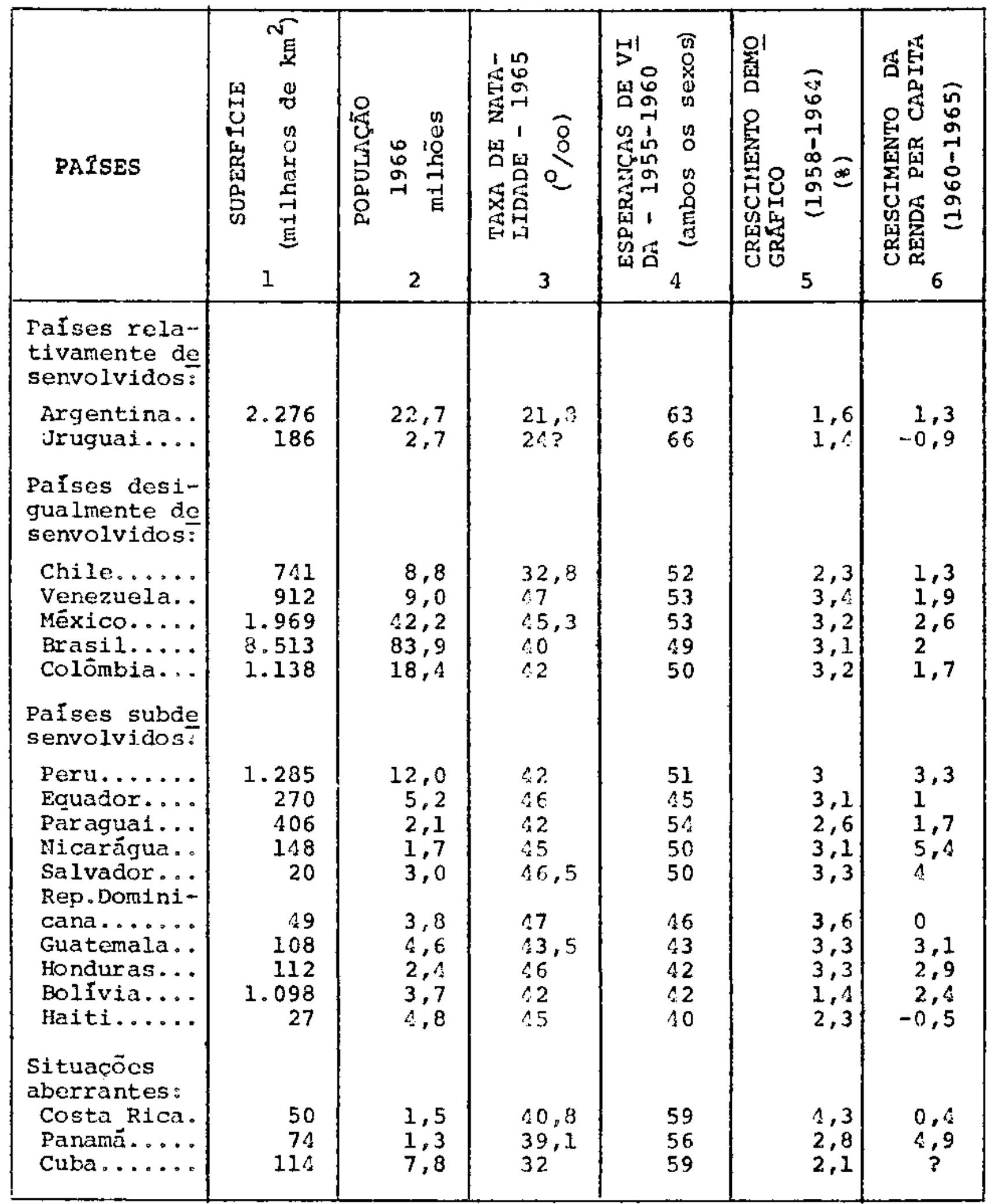

FONTES:

(continua)...

1, 2 e 3 - Anuärio demogräfico das Nações unidas e Population Index

4 - Carmen M1ro, "The population of Latin America", Demography, $1964(1), 5$.

5 - Population Reference Bureau, dezmbro de 1966.

6 - Statistical Abstracts of Latin Fmerica, 1966.

FONTE:

Amërica Latina - Jacques Lembert - p. 52-53. 
(continuação)

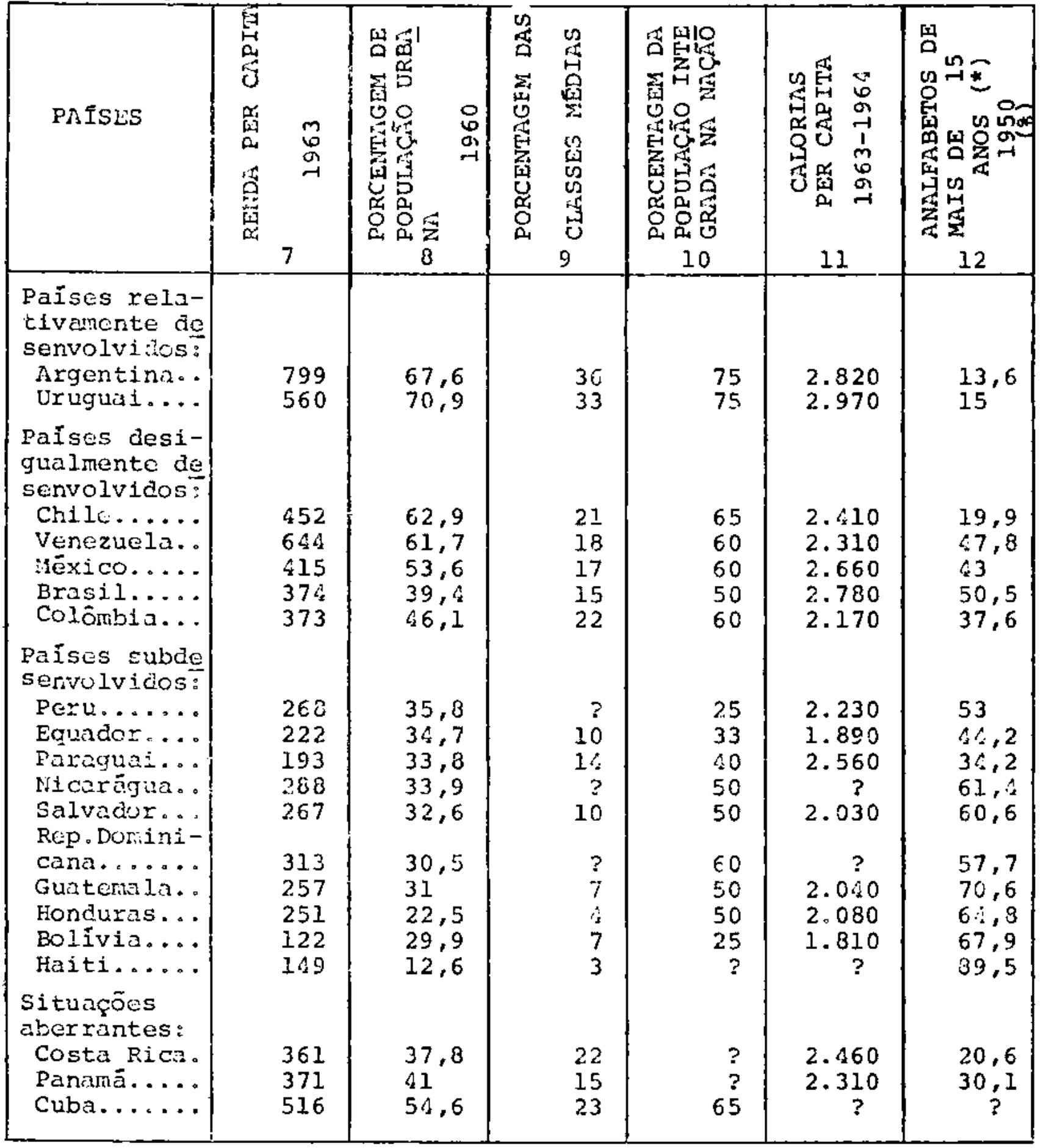

(*) N.B.: Essas porcentagens de analfabetos jā são antigas e os esforços feitos de quinzo anos reduziram-nas acentuadamente em certos países. A medida dos räpidos progressos na alfabetizaçäo é daca pelas cifras oferecidas pelo inuário demogrä́ico das Nações Unidas, 1963 , em relação a alguns paises, no recenseamento de 1960: Mexico, 34,68 de analfabetos; Peru, 39,48; Honduras, 55,48 ; Venezuela, 3*,28. n cifra relativa a Cuba, 1966, pela Conisión Nacional de nlfabetización, $4 \%, \bar{e}$ da mesma orden de gran deza que a da França.

7 - OErs, Sociaj irust Fund, Wash., 196\%。

8 - Nações Unidas, The Econornic Dovolopment of Latin Amorican in the Post Far Pertod, 1964, p.76.

9 - Tipologia socio-econónica de los países latino-americanos, Pan. Am. Union, 1964, segundo GINO GERMANI.

10 - IEPEL (Institut d'Etudes Politiques pour l'Amérique latinc), Etude d'actualitó, no 9, ALALC, 1964, p.3.

11 - OAA, La situation mondiale dans l'agriculture, 1966, p. 240.

12 - Nacões Unidas, The Economic Development of Latin Anerica,op. cit., p. EO. 


\section{Quadro 3}

RENDA NACIONAL PER CAPITA, A PREÇOS CORREITTES, EM DOLARES DOS ESTADOS UNIDOS -. 1960 - 1969

\begin{tabular}{|c|c|c|}
\hline PAIS & ANO & RENDA \\
\hline Argentina & $\begin{array}{r}1960 \\
65 \\
69\end{array}$ & $\begin{array}{l}507 \\
709 \\
730\end{array}$ \\
\hline Bolívia & $\begin{array}{l}60 \\
65 \\
69\end{array}$ & $\begin{array}{r}84 \\
121 \\
158\end{array}$ \\
\hline Brasil & $\begin{array}{l}60 \\
65 \\
68\end{array}$ & $\begin{array}{l}153 \\
162 \\
194\end{array}$ \\
\hline Colômbia & $\begin{array}{l}60 \\
65 \\
68\end{array}$ & $\begin{array}{l}211 \\
206 \\
230\end{array}$ \\
\hline Chile & $\begin{array}{l}60 \\
65 \\
68\end{array}$ & $\begin{array}{l}376 \\
162 \\
467\end{array}$ \\
\hline Equador & $\begin{array}{l}60 \\
65 \\
68\end{array}$ & $\begin{array}{l}174 \\
184 \\
216\end{array}$ \\
\hline Paraguai & $\begin{array}{l}60 \\
65 \\
69\end{array}$ & $\begin{array}{l}135 \\
187 \\
198\end{array}$ \\
\hline Peru & $\begin{array}{l}60 \\
65 \\
66\end{array}$ & $\begin{array}{l}177 \\
302 \\
345\end{array}$ \\
\hline Uruguai & $\begin{array}{l}60 \\
65 \\
69\end{array}$ & $\begin{array}{r}426 \\
284 \\
252\end{array}$ \\
\hline Venozuela & $\begin{array}{l}60 \\
65 \\
68\end{array}$ & $\begin{array}{l}770 \\
727 \\
788\end{array}$ \\
\hline
\end{tabular}

\section{FONTE:}

América en cifras - Situación Econömica: \$ - Balanza de pagos, pro ducto e ingreso Nacional Y Finanzas.

Secretaria Geral da OEA - Washington - D.C. EUA - 1971 - (p.39-10). 
Quadro 1

ESTADO DA POPULAC̆ÃO URBANA E RURAL - 1950 - 1966

PORCENTAGEM DA POPULAÇÃO URBANA

\begin{tabular}{|l|c|}
\hline \multicolumn{1}{|c|}{ PAIs } & PORCENTAGEM \\
\hline Argentina & 73,8 \\
Bolivia & $\ldots \ldots$ \\
Brasil & 46,3 \\
Colömbia & 52,8 \\
Chile & 68,2 \\
Equador & 36,0 \\
Paraguai & 35,8 \\
Peru & 27,4 \\
Uruguai & 80,3 \\
Venezuela & 67,4 \\
\hline
\end{tabular}

\section{FONTE:}

América en Cifras - 1970 - Situaciōn Demogräfica - Estado Y Mov1miento de la poblactón -

Secretaria Gexal da OEA - Washington - D.C. EUA - 1970 (p.43).

Quadro 5

AMERICA DO SUL (MENOS GUINNAS)

CARACTERISTICAS GERAIG

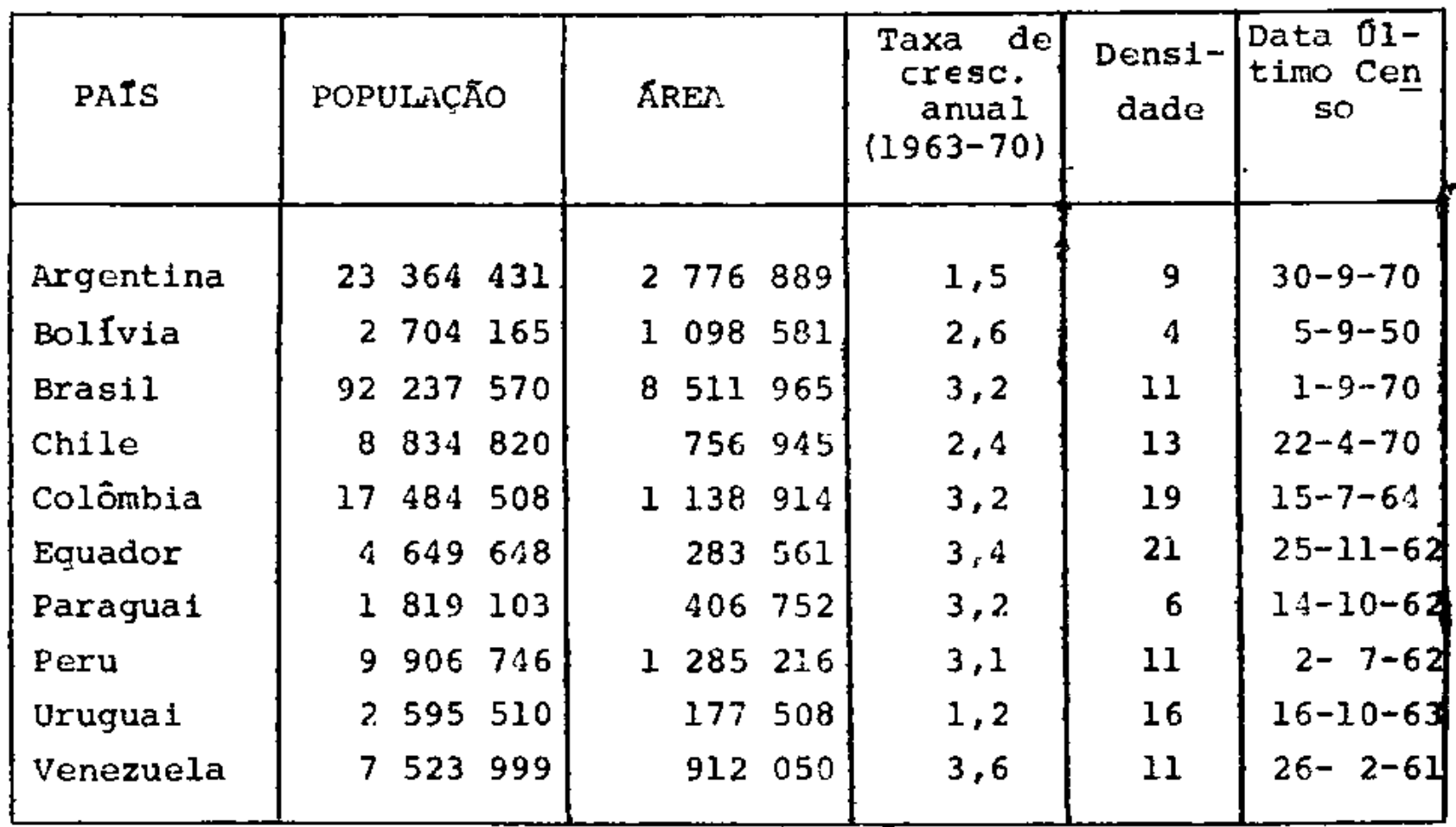

FONTE:

América en Cifras - 1970 - Situaciön Demográfica - Estado Y Movimiento de la población - Secretaria Geral da OEA - Washington D.C. EUA - 1970 (p. 108-109). 
A. obsorvação dos dados apresentados indica una razoāvel discrepäncia entre os fenômenos que atualmente serlam detectados por estatistica nais atualizada.

Cabo observar o fato notörio da carencia e certo grau de imprecisão que envolvem as pesquisas estatisticas en paises subdesen volvidos.

0 quadro geral de Lembert foi incluído no texto parque ser ve de referencial para um diagnöstico aproximativo da situação sócio-econômica dos países latino-americanos.

os quadros seguintes (3,4 e 5) são mais atualizados. Rẹ velam, contudo, quando comparados com o quadro 2 :

18 - publicaçōes oficiais recentes (1970-1971) apresentam dados de 4 ou mais anos anteriores;

28 - hã disparidades entre certas informações estatísti cas;

38 - a evolução dos fenômenos tem se processado com certa lentidão - o que é típico de ăreas subdesenvolvidas. Em certos casos, as estatísticas revelam, mesmo involução de quantitativos, como é o caso tipico da renda "per-capita" no Uruguai.

Feitas essas ressalvas em que se reconhece que cada país da Amërica do sul ë üntco quanto as suas realıdades, que se subdivi dem, ainda, regionalmente, pode-se passar à anālise do conjunto de fatores que explicam os quadros nactonais na atualidade.

\section{3 - Os fundamentos históricos}

Excetuando-se o Brasil, que será objeto de anälise particular, os denaís países da Amërica do sul (deixando-se de lado as Guianas), não podem ser enfocados do ponto-de-vista macro-educacional sem se levar em conta o peso ponderävel da História.

Nos anos iniciais do século xVx, os espanhöis haviam completado a conquista da América do sul, a ferro e fogo. 0 elemento indigena prë-existente, foi, de uma ou outra forma, dizimado e/ou posto em situação marginal de dependência. A escravização ostensiva ou disfarçada (as "encomiendas") estabeleceu uma profunda linha de clivagem na socjedade quo se formava: o estrato superior integra do pelos espanhóls e seus descendentes "criollos" e o estrato infe$r i o r$, integrado pelas populações indígenas $e$, muito secundariamente, pelos negros africanos. 
A classo média inexistia, ou era fracamente representada. Todavia o fenômeno da mestiçagen logo teve inicio, favorecido por um tipo de colonização en que as mulheres brancas eram quase ausentes.

Os mestļ̧os, aos poucos, pela mobilidade vertical foram ascendendo socialmente e constituindo, em muitas äreas, maioria. 0 processo continuou ao longo dos séculos e ainda hoje é bastante ex pressivo (3).

As diferenças constatadas entre mestiços e Indígenas são mais de caráter cultural que racial, depreendendo-se disso que há de pensar-se en tipos especiais de educação capazes de favorecer sua integrą̧ão harmonlcamente. Mas não seria desprovida de pesado onus una educąāo que refletisse apenas os padrões culturais dos estratos médio e superior da sociedade, sem levar en conta o peso mile nar da cultura Indígena. Essa realidade, muitas vezes, deve ser detectada a nivel regional e näo nacionai, o que esconderia a face do problema.

Outro dado significativo da Histöria è representado pelo tipo de exploração económıca, que gerou o latirúnaio, hoje ainda pre sente.

Suas conseqüencias são variadas, tais comos

1. - a Irregular ocupação dos territörios?

2. - a marginalização econômica de grande parte dos traballhadores rurais;

3. - o poder político e económico concertrado nas mãos de reduzida minoria, alienada dos interesses glo bais e muito mais voltada para os padröes culturais estrangeiros:

4. - a economia de subsisténcia ou direcionada para a ex portação de produtos primärios, de forte influência na estrutura econômica e no balanço de pagamentos.

São excmplos: o café, na Colômbia, a banana no Equador, a carne e a lã na Argentina e no Uruguai. Esse tipo de estrutura eco nómica ocasiona modestos ingressos de capital que, por seu turno, tornam reduzidos os investimentos educacionais.

5. - 0 èxodo rural, tendo como uma das conseqtèncias o congestionamento urbano e o desemprego ou subemprego;

6. - a ausência da classe mëdia rural:

7. - a dispersão e o isolamento de parcelas consideräveis da populaçāo rural, entravando a ação educacional. 
outro produto típico da colonização è a cidade, na Amér ca do sul.

Ela fol uma das formas de ocupação do solo e de domina ६ão. Era o centro que comandava extensas porçōes do território, mu "arrtère-pays", mas que exercia sob sua ärea de influēncta multo mais um processo de "drenagem" de recursos que de "irrigação" ou prestação de serviços. Essas características das funçōes urbanas, no passado, permanecem.

Assim, as cldades deixam de ser agentes propagadores do crescimento econômico e do desenvolvimento social, e deste àngulo, de irradiação educacional. Seu crescimento se faz, como outrora, às expensas de setores agrärios.

"A cldade foi um instrimento de conquista e é ainda hoje um instrumento de dominação". "... entre os mestiços que vivem na cidade nuclear da região e os índios que vivem no interior ru ral hä na realldade uma interdependéncia econômica e social ma1s estreita do que pode parecer a primeira vista". "Assim, as rela çōes metröpole-satëlite não se limitam ao nivel impertal ou internacional, mas penetram e estruturam a própria vida econômica, polí tica e social interna dos países c colönias da Amërica Latina"(5).

A Yistória se presentffica na caracterização do perfil social en muitos países da Arérica do Sul, como por exemplo:

18 - o nacionalismo que multas vezes è mais uma forma de auto-afirmação (a "argentinidade", a avcrsão mais ou menos latente contra o estrangetro) que propxiamente uma posição de defesa dos recursos naturałs (petróleo na Venezuela, estanho na Bolívia e, ate recentemente, o cobre no (hile); de valorização da cultura autócto ne; de mobilização do poder psicossocial para aceitação e participação efetiva nos projetos de modfficação de estruturas esclerosadas $(6)$;

29 - a resistência passiva à modernização de setores da estrutura soctal e de suas formas de comportamento. Exemplo tipico è a aversāo, consciente ou inconsciente, às tëcnicas de planejâ mento e programação; por outro lado, a ouase sacralização da burocracla retrögrada:

38 - a freqtência das agltações políticas, de efeitos va riáveis. Na década de 60 e no inicio da atual, a rigor todos os países sulamericanos registraran mais ou menos intensas, mals ou menos radicais, agitações políticas, seguidas ou não de transforma ఢ̧ão na estrutura do poder; 
48 - a atitude passiva e, até mesmo ocasionalmente subser viente, de amplas camadas da sociedade, en relação aos estratos superiores;

58 - a organização "de fato" centralizadora do governo, que dificulta ou impede a participaça comunitäria nos trabalhos de auto-crescimento. 0 patriarcalismo e paternalismo, através do cact quismo, do coronelismo, estão presentes en comunidades rura1s e,até mesmo, urbanas.

\title{
2.4 - Os problemas demogräficos
}

Educą̧̃o e demografia são duas questões intimamente ligadas.

A anälise do quadro demogräfico, seja a nivel nacional, se ja nos diagnósticos regionais que revelam mais claramente os dados quantitativos e qualitativos de uma população, deve constituir um dos prë-requisitos para o planejamonto integrado.

A guanttflicação dos guadros demogräficos não deve prescin dir da pesquisa local, não apenas para verłficar a exatıdão estatís $t 1 c a$, como para detectar outros aspectos que a anālise estatistica não revela.

A Amërica do sul como um todo, apresenta-se como uma ārea de apreciävel cresclmento demogräfico. Podemos observar a projeção do crescimento absoluto de população atravēs do quadro 6 .

\author{
Quadro 6 \\ POPULAÇÃO PROJETADA - 1970 - 2.000
}

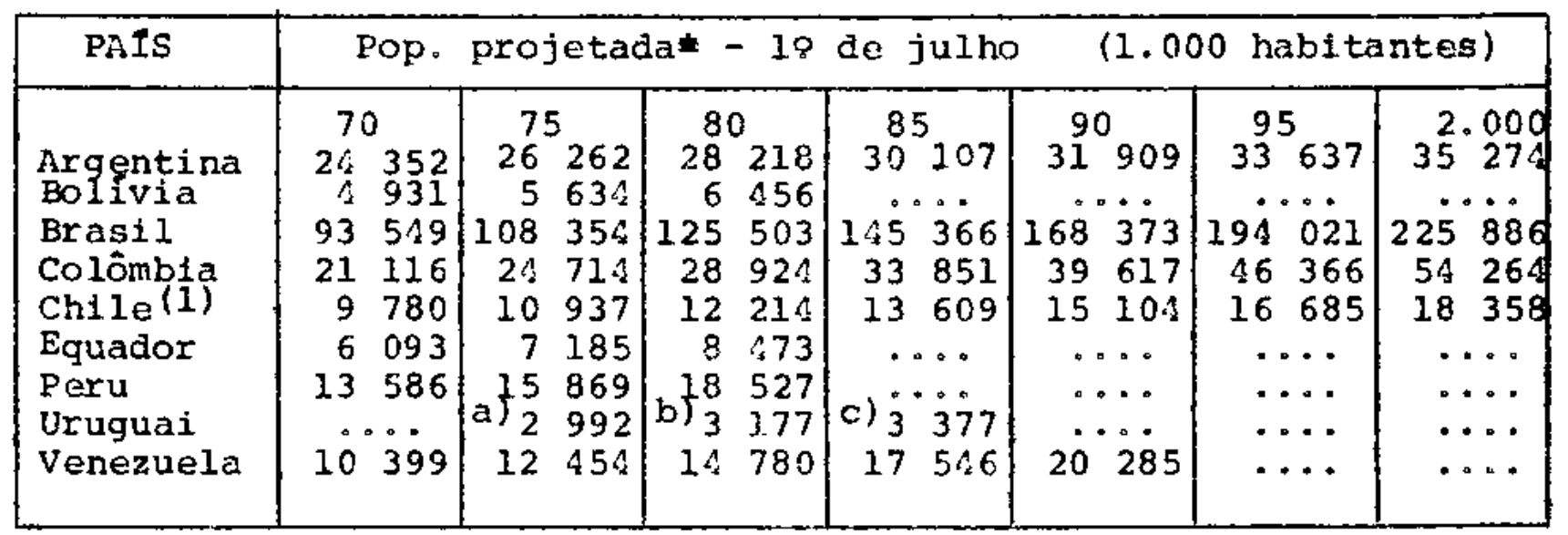

* As projeções de população foran calculadas pelas diferentes nações, a partir do censo da COTA -- 1960

1) Projeções calculadas pe10 CELADE
a) 1973
b) 1978
c) 1983

FONTE:

América en Cifras - 1970 - Situaciōn Demogräfica - Estado y Movimiento de la población. Secretaria Geral da OEA - Washington D.C. EUA - 1970 (p. 7 ) 
Igualmente as taxas de crescimento anual da população são elevadas, ultrapassando 2,58 ao ano, ficando a Argentina, o Uruguai e o Chile com taxas mais modestas en relação aos demals países.

Ao que tudo indica, essas taxas, oscilando em torno de 2,58 ao ano, tendem a manter-se com alteraçōes pequenas. Em certas äreas, onde o indice de natalidade não se modificará substancialmen te, o incremento anual poderá ser mais significativo na medida em que a expectativa de vida aumente graças ã difusão de medidas médico-sanitärias.

As tentativas de controle de natalidade, sob suas diversas formas são de resultado aleatörio. Mesmo que viessem a ser (hi pötese rumota) aplicadas em massa en determinada reg1ão, seus efeitos só seriam sentidos sobre a estrutura da população, no que tange aos efeitos escolares, oportunidades de emprego e população economi camente ativa, daqui a muitos anos. (7) Qualquer planejamento econô mico-social, e no contexto deste - o educacional - deve trabalhar com fatos, dados e não, meramente com hipöteses.

Um dos primeiros dados a considcrar para o planejamento $\underline{e}$ ducacional, è o que se refore à estrutura etária.

$c$ crescimento ajenográfico nos palses sulamericanos, mantendo-se em altos percentuais, nos ültimos vinte anos, reflete-se na grande proporção de jovens, na composição etāria de cada país.

A rigor, pode-se dizer que mais de 508 da população estão compreendidos entre 0 - 25 anos. 0 que interessa mais de perto, são contudo dois grupos etärios: o de 7 .. li anos, prioritariamente, e o de 15-19 anos.

o quadro 7, da obra da UNESCO (4), reproduzido integral mente, a seguir, para facilidade de observação, ten sublinhado os nomes e os dados dos países em causa no presente capítulo, ou seja, os da América do Sul. 
Quadro 7

AMERICA LÄTINA: POBLACION URBÄNA, RURAL Y TOTAL; INDICES DE CRECIMIENTO DE LA POBLACION TOTAL

Y POBLACION EN EDADES DE 7 a 14 Y DE 15 is 19 ANOS, EN LOS R̃NOS 1950, 1960 Y PROYECCION PART 1970

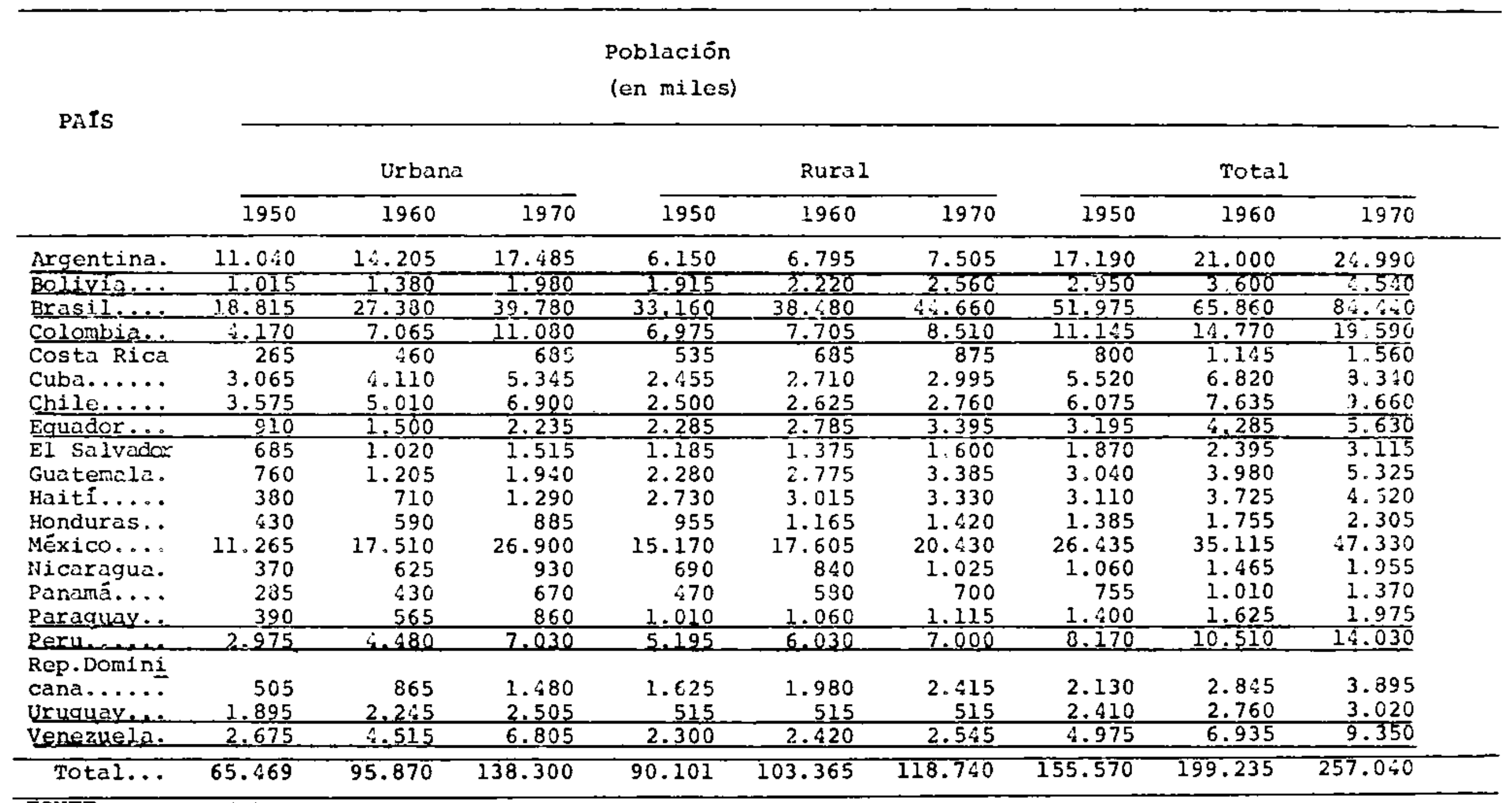

FONTE: UNESCO (4) 


\begin{tabular}{|c|c|c|c|c|c|c|c|c|c|}
\hline & \multirow{2}{*}{\multicolumn{3}{|c|}{$\begin{array}{l}\text { Indice de crecimiento } \\
\text { de la población total } \\
\text { (base } 1960=100 \text { ) }\end{array}$}} & \multicolumn{6}{|c|}{$\begin{array}{l}\text { Población por edades } \\
\text { (en miles) }\end{array}$} \\
\hline & & & & & a 14 & & 15 c & a $\quad 19$ & \\
\hline & 1950 & 1960 & 1970 & 1950 & 1960 & 1970 & 1950 & 1960 & 1970 \\
\hline Arqentina. & 82 & 100 & 119 & 2.630 & 3,250 & 3.735 & 1.605 & 1.800 & 2.170 \\
\hline Bolivia... & 81 & 100 & 126 & 585 & 700 & 900 & $\frac{.670}{310}$ & $\frac{375}{375}$ & 460 \\
\hline Brasil & 79 & 100 & 128 & 10.445 & 12.740 & 17.160 & 5,310 & 6.550 & 8.720 \\
\hline Colombia.. & 75 & 100 & 1.33 & 2.195 & 3.095 & 4.000 & 1.160 & 1.490 & $\frac{2.108}{2.100}$ \\
\hline Coste Rica & 70 & 100 & 136 & 165 & $\frac{2.025}{225}$ & 325 & 85 & 115 & 165 \\
\hline Cuba...... & 81 & 100 & 122 & 1.010 & 1.215 & 1.450 & 540 & 670 & 805 \\
\hline Chile..... & 80 & 100 & 127 & 1.135 & 1.420 & 1.780 & 590 & 755 & 965 \\
\hline Eguador. & 75 & $\frac{100}{100}$ & $\frac{146}{131}$ & 640 & $\frac{1.0720}{860}$ & 1.170 & 320 & 44.5 & 555 \\
\hline El Sulvador & 78 & 100 & 130 & 375 & 455 & 645 & 200 & 240 & 335 \\
\hline Guatemala. & 76 & 100 & 134 & 610 & 805 & 1.110 & 320 & 405 & 560 \\
\hline Haiti.... & 83 & 100 & 124 & 590 & 720 & 910 & 320 & 375 & 470 \\
\hline Honduras.. & 79 & 100 & 131 & 275 & 350 & 465 & 140 & 180 & 230 \\
\hline México.... & 75 & 100 & 135 & 5.280 & 7.130 & 9.745 & 2.650 & 3.560 & 4.925 \\
\hline Nicaragua. & 72 & 100 & 133 & 225 & 280 & 420 & 115 & 150 & 210 \\
\hline Panamá.... & 75 & 100 & 134 & 145 & 200 & 280 & 70 & 100 & 145 \\
\hline Paraguay... & 86 & 100 & 122 & 275 & 325 & 400 & 145 & 165 & 200 \\
\hline Peru...... & 78 & 100 & 133 & 1.615 & 2.085 & 2.855 & 835 & 1.070 & 1,430 \\
\hline Rep.Domin1 & & & & & & & & & \\
\hline cana..... & 75 & 100 & 137 & 450 & 595 & 820 & 225 & 290 & 410 \\
\hline Uruguay... & 87 & 100 & 109 & 330 & 375 & 400 & 215 & 210 & 240 \\
\hline Venezuela. & 72 & 100 & 135 & 960 & 1.355 & 1.870 & 500 & 685 & 960 \\
\hline Total... & 78 & 100 & 129 & 29.935 & 38.180 & 50.440 & 15.655 & 19.630 & 26.115 \\
\hline
\end{tabular}


0 aumento exprossivo da população na faixa etária de 7 a 14 anos, mostrando qué o rejuvenescimento populacional è um fato so cial e demogräfico, traz una série do impllações de ordem política -econômica e, particularmente, educacional.

Trata-se de urn segmento da populaçāo para a qual os 1 nves timentos de infraestrutura social tên que ser considerados com ux gência prioritäria. E o caso do investimento educacional.

0 adiamento das soluçōes en prazo curto, para dar atendimento quantitativo e qualitativo à demanda escolar, cada vez mais mais premente, transfere para o futuro o problema. E essa transferência não se faz sem graves prejuízos para o crescimento econônico e para o desenvolvimento social.

Jā não se trata de escolarizar tão somente para atender a inperativos de natureza democrätica, vez que todas as Constıtulçöes dos países sulamerlcanos garanter a educação de primeiro nível até 12 ou 14 anos de ldade.

0 problema ton outras faces, tais como:

- as tendēncias para a modirnização das estruturas agrá rias estarão scriamente comprometides se não puderen se apolar en recursos humanos com um minimo de qualificação;

- - fenòmeno observado em todos os paises da Amcrica do Sul, no qu: se refere à urbanização (ver quadro 7 anteriormente referido), só não se tornarā social e politicamente inviāvel e, quiçá explosivo, se a elasticidade da oferta de empregos encontrar a con trapartida do uma mão-de-obra qualificada minimamente;

- a própria modernizaçäo das estruturas polfticas, que re querem uma particlpação efetiva e consciente de parcelas cada vez mais considerăveis da população, só se viabiliza a mẻdio e longo prazos com elementos que tenham un minimo de escolaridade de qualida de não desprezível;

- a planetarização cultural ("aldeia", de que fala Marshal Mc Luhan), possibilitando o acesso do individuo ao consumo intell gente da cultura só é factível onde as cstruturas sociais não se en contram esclerosadas pelo analfabetismo dc fato ou virtual.

Levando-se o problema da escolarização às faixas etärias de 15 - 19 anos e, mesmo, dos 20 - 25 anos, ele assume outros aspec tos. Essas faixas correspondem aos niveis de instrução de 28 grau e univarsitärlo. \# medida em que aumentam as matriculas no ensino de 18 grau; à medida em que as taxas de repeténcia e evasão ainda ca taströficas (8) scjam contidas: à medida em que a pressão social pá mais e melhores escolas se acentue, o nocessärio dar-se a devida a tenção para o problema. 
A formação dos quadros de técnicos de nivel médio e de pro fissionais de nivel superior é un reclamo de todo processo de crescinento econômico c dc alteração das cstruturas socials.

A falta de olites dirigentes, nos setores profissionais, politicos, culturais impede ou retarda a demarragem nacional no sen tido da criação do bem estar público, da justiça social, da afirmação no contexto internacional, de busca de mais e melhores perspectivas de vida (9) (10).

Cabe acrescentar que nos paises da Amërica do Sul, o atendimento escolar no 28 grau e no nivel untversitärio, conquanto tenha apresentado sensivel evolução nos ültimos vinte anos, ainda $\bar{e}$ bastante precário.

Se o fenōmeno for generalizado, verifica-se que cerca de 808 da populaçāo escolarizada se enguadram no ensino de 18 grau. Dos 208 restantes, a maioria se reparte por um ensino de $28 \mathrm{grau}$ bastante diversificado (ensino tēcnico: industrial, agrícola, comer cłal o de formação de professores de $19 \mathrm{grau}$; ensino acadêmico).

ocorre, todavia, que a maior parte das matriculas se con centra no ensino acadêmico, que, de forma geral, $\vec{e}$ inöcuo do ponto de vista profissionalizante, constituindo-se mais num escalão 1lusō rio de acesso à Universidade. Essa, com suas deficiências estruturais, é ao mesmo tcmpo causa e efeito do subdesenvolvimento.

0 "numerus clausus" das instituições de ensino de $39 \mathrm{grau,}$ forçado aqui $c$ li por uma pressão cresconte e, não raro, explosiva, é o espelho da elitização das oportunidades educacionałs a nivel de graduação.

As perspectivas de ampliaça quantitativa das matriculas universitārias não são alentadoras (11)

Esta situação generalizada sofre, na análise da questão, em cada pais, diferenças acentuadas. A Argentina, o Chile e o uruguai apresentam problemas menos dramäticos, sendo mesmo de destacar -se a posiçäo privilegiada da Argentine no quo se refcre ao ensino de 38 grau.

\section{5 - 0 s investimentos um educaçäo $c$ as estruturas econòmicas}

Educar a mais pessoas, atendendo concomitantemento aos dois aspectos interligados da quantidade e da qualidade, depende de muitas variäveis, dentre elas destacando-se a questão dos 1nvesti mentos.

Hoje está supcrada a velhe questão em que so debatiam os teóricos do planejamento, se a educação ora um gasto, quo poderta 
ceder lugar a outras necessidades ou se ela importava tanto que não se poderia planejar sem tê-la na devida conta (12).

Investir representa, em termos mats simplistas, ter recur sos para investir. E aqui o problema se complexiflca, pois se pren de a uma estrutura mais ampla, qual seja a do sistema econômico na ctonal como um todo.

Destinar 4, ou 6, ou $10 \frac{3}{3}$ do PIB para a educação, pode re presentar uma decisão governamental que ponderou devidanente o mon tante de investimentos que deixam de ser destinados a certos setores para atender à educação.

Mas a economia dos países sulamericanos não é una Fônix, que renasce das prōprias cinzas. Ela sofre de "docnças" crōnicas, estruturais que, por seu turno, goram crises conjunturais quo agravam os deficits orçamentários e as disponibilidades de investimen tos de capital.

são problemas que podem ser destacados:

- o rápido crescimento populacional.

- o aumento da força-de-trabalho ociosa ou subempregada;

- a estrutura fundiăria e as técnicas de explotação agräria, de forma geral primitivas;

- a industrialização insuficiente:

- os baixos niveis sanitärios e alimentares;

- a Eraqueza dos investimentos em setoros infra-estrutu rais: energia, transportes, siderurgia;

- as urgentes prioridades de investimentos socia1s: habitação, saneamento, comunicação:

- a debilidado do comërcio externo, que acusa oscilações cíclicas, vez que se apola basicamente na exportação de produtos primärios e nã importação de bens de capital e de bens de consumo:

- o endividamento externo, que limita a capacidade de con seguir crëditos e/ou investimentos.

2.5.1 - O PIB e os totais domográficos em cada país origi nam rendas "per-capita" com duas caracteristicas bäsicas:

- säo pequenas;

- mascaram a realidade.

A primeira caracteristica: a renda "per-capita" pequena, sofre, $\vec{e}$ natural, variações, sendo, por exemplo de cerca de 1.000 dó lares na venezuela $e$ de menos de 100 dölares na Bolívia. 
A segunda característica: mascaram a realidade, se traduz na hiperconcentração de renda nos estratos sociais superiores. Em muitos países de 18 a $5 \%$ da população detêm mais de 508 da renda.

outro fenômeno a destacar é que a distribuição demogrä́ica urbano-rural ocaslona maior concentração da renda em segmentos p. pulacionais urbanos, ficando a população rural com niveis muito inferiores à médla nacional.

0ra, usses aspectos do problema geram una incapacidade pa ra a poupança popular, jä que grandes parcelas da população apenas sobrevivem.

Nesse particular, a estrutura agräria tom responsabilidade não desprezivel (13).

A baixa produtividade, assim mesmo, è que responde pela malor particlpação no comércio externo, salvo nos casos da venezuela (petróleo), Chile (cobre) e Bolivia (estanho).

2.5.2 - 0s processos adotados em värios países para a in dustrialização, particularmente nas dëcadas de 50 e 60 se limitaram à substituição das importações para atender a uma demanda pouco elās tica do mercado interno o às dificuldades de importaçäo (limitaçöes cambiats).

A industrialização substitutiva restringindo-se aos bens de consumo, chegou à fase da capacidade octosa pela inelasticidade do mercado internacional nas exportações.

E o que a torna mais grave é o pequeno crescimento do mer cado interno, possibilitando a instalaçäo de indüstrias de base.

Desta forma, continuam os países sulamericanos a assistir, ano após ano, à drenagem de capitais necessărios à importação de bens de capital, de minérios, de combustiveis e, em menor escala, de bens de consumo, inclusive os näo-duräveis (14),

2.5.3 - A dicotomia rural-urbana è reforçada pela mobilidade horizontal das populaçōes que se deslocam para as cidades que sofren o fenômeno da "inchação urbana" e não de crescimento.

os efeitos são de natureza vária, como por exemplo o dese quilibrto na repartição de empregos urbanos, dado que os setores se cundärio e terciärio näo se revelam capazes de gerar empregos no mes mo ritmo da demanda (15). outro efeito é sobre os investimentosem educação que se tornam mals necessärlos face ao processo acelerado de urban1zação. 
Como assinala FURžER, "...assistimos hoje, após o desen volviriento universal das atividades terciärias, sobrepondo-se às de mais, quando as cidades cresceram em ritmo desenfreado, ultrapassan do a possibllidades da industrialização integral, com extraordinā $r$ io avanço tecnolögico das indústrłas e das ciências modernas, assistımos, dizíamos nōs, à ascensão maciça da pequena e média burgue slas, arrastando com elas todos os elementos capazes das demais clas ses da população. A flm de atender às suas necessidades de ascen são, procurando os melhores processos para conseguir infłltrar-sena estrutura social e atingir os postos de comando, a burguesia - e os elementos das demais classes que a sustentam - precisa controlar o ensino secundärio, obrigando o Governo a dar facilidades de acesso a seus filhos e netos." (16)

Ora bem, chega-se após essa breve análise, ao impasse da causaçäo circular, em que o subdesenvolvimento nos países sulamericanos è, em grande parte, causado pela debilidade do subsistema edū cacional e, ao mesmo tempo, efeito dessa debilidade.

En algum ponto, de uma ou de outra forma, é imperioso rom per o circulo vicioso.

Näo se trata exclusivamente de dotar a educação de maiores recursos, è necessărto tē-los en quantidades suficientes e cres centes. E essa alocação de recursos não deve por de lado outros de importância vital para a economia do pais, seja ele a Argentina ou - Equador.

No estāgio atual dos sistemas econômicos dos paises sulamericanos, a solução (utōpica?) a altorar a estrutura interna do sis tema econômico que se baseia:

18 - numa agricultura primitiva de exportaçäo;

29 - em certos casos, no extrativismo mineral que apenas libera o minério bruto para exportação. E o caso do estanho boliviano, do cobre chileno, do petrólco venezuelano $e$, ao que tudo indica, dentro de pouco tem po, do petróleo do Equador;

38 - num sctor terciärio, que é a välvula de escape para a pressão da mão-de-obra que se ovade do campo ou da mão-de-obra não absorvida pela industrialização do tipo "capital intensivo". 0 setor terctärio acaba por constituir-se em panacêia, de produtividade muito pouco satisfatöria;

48 - numa 1ndustrialização inciplente, concentrada em ăreas rostritas, voltada para a produção de bens de 
consumo (exceçäo: a Argentina), sem "know-hown, mera extensão de empresas estrangeiras;

58 - numa carência de infra-estrutura física (energia, es tradas, portos, indüstria de base);

68 - numa poupança quase nula, saldos negativos no balanço de pagamentos, reservas cambials minguadas.

Não hã o impossivel em matéria de economia. Tambëm nảo hã milagres. 0 "milagre" alemão, o "milagre" japonês foram jā deví damente desmascarado como tals.

Há soluções värias, únicas para cada pals. Os exemplos do Peru e do Brasil são notäveis. Os diagnósticos dos diversos sistemas nacionais estão fettos e com terapêtica equacionada. Cabe aos comandos politicos as opções para preparar seus países para o "take -of $f^{n}$.

Essa decolagem não se fará contudo sem a valorização dos recursos humanos. Já não cabe mais a discussão estēril entre "educação para o desenvolvimento" e "o desenvolvimento como prë-requis 1 to para a educaçãon.

o planejamento global dos sistemas econômicos, respaldado pelos regimes politicos que busquem atingir as metas proposta é condição "sine qua non" para alterar positivamente o perfil econômi co-social dos países.

No que se rofere à educação, aos parcos recursos orçamentārios a ela destinados, podem ser adcionados recursos internacionais, sob a forma de empréstimos a longo prazo e assisténcla tẻcnica real, que venha cobrir lacunas no "know-how" de cada país. Epreciso cuidar quc assim o seja realmente, para impedir a transferen cla pura e simples de modelos estrangeiros que eliminam o substrato cultural do país e não removem os pontos de estrangulamento.

Quanto ao planejamento da educação, convēm que os proje tos prioritários, aqueles de efelto multiplicador, sejan selecionados cm função das realidades e das necessidades regionais. Cabe aqui valorizar os prłncípios da programação regional, que têm resultados mais objetivos c mais rápidos que os programas amplos, dilufidos, a barcando 1ndistintamente todo um país.

Essa programação regional da educação, devidamente ligada aos objetivos nacionals, não corre o risco de ser confundida com os estreitos limites do regionalismo, do ufanismo local.

"Los problcmas en Latino Amërica, en matéria de planifica clön para el desarrollo, se pueden classificar como problemas en el 
orden administrativo, conceptual y do ejecución. En todas estas tres esferas parecen haber serias fallas".

No es posible que pretendamos subsanar estos fenómenos con meros procedimientos de control".

En Amërica la planificación regional apenas comienza en estos momentos".

"Me parece quo solamente por razones de eficiencia, hay una necesidad imperiosa do decentralizar".

"Los pequeños recursos que tenemos tienen que emplearse en su mäxima capacidad. Esto significa que los procedimientos en pa ses sub-desarrollados tienen que ser mucho más sofisticados que los empleados en paĺscs desarrollados" (17).

\section{6 - Conclusōes parciais}

1. - A Amērica do sul apresenta estágios distintos quanto à es truturação do sistọna econômico de cada pais.

2. - Esses sistemas são fruto da história, da demografia, dos regimes politicos $\epsilon$, principalmentc da debilldade dos se tores econòmicos.

3. - A educação nos países sulamericanos se insere no quadro geral das deficiências sócio-econômicas.

4. - 0 räpido crescimento popillacional e os processos acelerados de urbanização revelaram o quadro real da educação nes ses países.

5. - A valorização dos recursos humanos è tarefa prioritáría pa ra o crescimento econômico e para o desenvolvimento so cial.

6. - E imperiosa a transformação do panorama econōmtco nos paî ses sulamericanos, para o que hã soluções alternatıvas jã levantadas.

7. - A melhoria do subsistema educactonal é perfeitamente viävel, desde que se apoie no planejamento integrado.

8. - A programação educacional terä efeitos multiplicadores se atentar para as prioridades e para a implementação a ní vel regional. 
NOTAS REFERENTES AO CAPITULO 2

(1) CunIL, Pedro - A Amëricz Anāina - Tradução de 0ctavio Mendes Cä jado - São Paulo - Difusão Européia do Livro - 1968.

Ver Capitulo Terceiro - p. $33-40$.

(2) LAMBERT, Jacques - Amērica Latine - Tradução de Lölio Lourenço de 0liveira - São paulo - Companhia Editōra Nacional - Editora da Universidade de Säo Paulo - 1969.

"Sucede, inevitavelmente, que qualquer tentativa de classificação dos vinte paises latino-aucicicanos em função de seu nfvel geral de desenvolvimento, social e politico, bem como eco nômico, implica amplamente ne intervenção de impressões pessoxis e comporta, assim, grande parcela de arbitrio. os diversos índices, que é preciso utilizar, frequentemente não coincidem $\epsilon$, sobretudo, a maloria desses indices não possuem senão escassa precisão na América Latinen. p. 47.

(3) Cuntl, Pedro - op. cit.

"No Pkru, assiste-se a erplo movimento de mestiçagem (Cho lización), que não é senão um movimento espontâneo, individual ou coletivo, da chitura indigona na direção da cultura nacional. dos modos de vida indigenas para os modos de vida da nação." p. 39 .

(4) UNESCO - Situación Demogräfica, Económica, Social y Educativa de América Latina - Buenos Aires - Argentine - Ediciones Solar $Y$ Libreria Hachette S.A. - 1966.

(5) FRANK, Andrew Gunder, et allii - Urbanização e Subdesenvolvimen to - Organłzação e Introđução de Luiz Pereira - Rio de JaneiroZahar Editores - 1969 - p. 28.

(6) PI:TO, L. A. Costa - Desenvolvimento Econômico e Transição Soclal - 2a. ediçāo - Rio de Janeiro - Editôra Civilização Brasileira S.A. - 1969 .

"Jä vimos, e isto cada vez se torna mais evidente, que o que caracteriza o desenvolvimento como processo histórico e so cial de mudança ē o fato dele ser promovido e não decorrer apenas de fatores espontancos, como ocorieu tantas vezes noutras $\underline{e}$ pocas e lugares". "...e que hoje intencionalmente, procuram a celerar o seu ritmo de transformação a fim de superar, em curto prazo, os seus indices de atraso." p. 38. 
(7) MYRDAL, Gunnar - Subdcsenvolvimento - Tradução e adaptação de Ro sinette Monteiro Soares - Brasilia-DF - Coordenadore - Editora e Brasilia Ltda. - 1970 .

"Isto deveria ser considerado em correlação ao fato de que por algum tempo, a força de trabalho em todos os países subde senvolvidos se elevara muito rapidamente, por mais de 28 ao ano, e em alguns paises muito mais.

A esse respeito deveria ser notado que um decrëscimo na ta xa de nascimentos, especialmente um decréscimo gradual, não tem efeito no tamanho da força de trabalho por 15 anos o sonente um efelto muito pequeno, por, pelo menos, três décadas". p. 16.

(8) UNESCO - Educación y Desarro110 en Amërica Latina - Bases para una politica cducativa - Buenos Ayres - Biblioteca "Dimensión A mericana" - Ediciones Solar S, A, Y Libreria Hachette S.A. la. ediciōn - 1967 .

"La importancia real del nürcro de alumos matriculados diminuye sensiblemente si se tiene en cuenta que la matriculaen enseñanza prināria representa el $80 \%$ de la poblaciön estudiantil lo que significa que la educación empartida por los sistemas edu cativos de la región siene el carácter predoninante de enseānza de primer grado - y se considera, por otra parte, el bajisimo promedio de retención escolar en todos los grados.

Esse bajo rendimiento del sistema educativo contribuye a que el problena del analfabetismo on la región siga teniendo ca racteristicas graves. A su vez, al inalfabetismo constituye un factor retardatärio del desarrollo como puedo apreciarse al exa minar la relación entre analfabetismo y renta per cápita en determtnados paises y zonas de la región". ‥ 123

(9) PINTO, L, A. Costa - op. cit.

"Ha medida cm que a educação cria um novo tipo de homem, exige - cono concomitante ou como conseatlerte - a produça do de novos bens, a circulação de novas idéias e valores, a participa ção em novas esferas de relaçōes e de decisões, a procura de no vas perspectivas, o cultivo e a satisfação, em suma, de novas necessidades. E essas aspiraçōes e necessłdades novas, una vez criadas mas não satisfeitas - diga-se de passagem - constituem, não raro, a mais inosperada e menos desejađa contribuição que a educação pode dar à accleração oxplosiva da transição social". p. 109 . 
(10) ECHEVARRIA, Josē Mudina, et alli1 - Desenvolvimento, Trabalho e Educação - Organização e Intrudução de Luiz Pereira - R1o de Jạ neiro - Zahar Editores - 1967.

"O desenvolvimento econömico implica que se possa contar, através de sucessivas ampliaçōes, com um sistema de postçōes tóc nicas sem as quáis se torna impossivel levar a cabo uma ativida do economica cada vez mais complexa e espectalizada.

E esses quadros de especialistas - desde os de mais modes ta significação ató us de mais complicado grau de formação inte lectual são os que se mostram sob a forma de uma demanda que a socledade reclama à educação, para que esta a atenda em prazo determinado. A educação vem a sor o instrumento de oferta ca paz de satisfazer à mencionada comanda". p. 21.

(1) RIBEIRo, Darcy - A Universidade Necessāria - Rio de Janciro-Edi tura Paz e Terra S.A. - 1969. p. 105.

Quadrs 8

PROJECÃO PROVÁVEL DO INCREMENTO DO SISTENA DE ENSINO SUPERIOR NA AMERICh LATINA Á PÄTIR DE 1965 ATE O ANO 2.000

\begin{tabular}{|c|c|c|c|c|}
\hline & \multirow{2}{*}{$\begin{array}{c}\text { Situação em } \\
1965 \\
\text { (mil) }\end{array}$} & \multicolumn{3}{|c|}{ Situaçāo no ano 2.000} \\
\hline & & $\underset{\text { (mil) }}{\operatorname{Hipótcse}} \pi$ & $\begin{array}{c}\text { Hipótese } \\
\text { (mil) }\end{array}$ & $\begin{array}{c}\text { Hipótese C } \\
\text { (mil) }\end{array}$ \\
\hline $\begin{array}{l}\text { População } \\
\text { total }\end{array}$ & 240.000 & 650.000 & 650.000 & 650.000 \\
\hline $\begin{array}{l}\text { Populaçäo } \\
19-22 \text { anos }\end{array}$ & 17.000 & 48.000 & 50.000 & 71.000 \\
\hline $\begin{array}{l}\text { Matrícula } \\
\text { Geral }\end{array}$ & 40.000 & 110.000 & 130.000 & 180.000 \\
\hline $\begin{array}{l}\text { Matricula } \\
39 \text { Nível }\end{array}$ & 800 & 2.100 & 6.500 & 13.500 \\
\hline $\begin{array}{l}\text { Profossorcs } \\
\text { Untersitarios }\end{array}$ & 80 & 210 & 500 & 900 \\
\hline
\end{tabular}

Hipōtese A: Projeçāo das proporções atuais sobre a populaçāo prevista para o ano 2.000 (ONU, 1958 e 1963).

Hipötese B: Projeção das proporcõcs atingidas pela Argentina em 1965 sobre a populaçāo total da Amërica Latina prevista para o anc 2.000 .

Hipōtese C: Projeção das proporções atingidas pelos Estados Unidos un 1965 sobrc a populaçăo total da Amërica la tina provista para o ano 2.000 . 
(12) MYINT, Hla, et alli1 - Desenvolvimento, Trabalho e Educacão - op cit.

"í experiēncia dos países desenvolvidos tem sugerido que a velocidade do crescimento econônlco do que estes têm gozado não pode ser explicada satisfatoriamente apenas em termos de au mentos quantitativos mensurávels cm capital físico e em tamenho da população trabalhadora. Isso conduziu à hipótese de que um "residuo" substancial do crescimento eccnónico deve ser explica do em termos de um aumento da produtividade dos recursos, devido a inovações técnicas e outros aperfeiçoamentos qualitativos dos métodos de produção e organização. Esses fatores "residuats" do crescimento econômica, segundo se crē, estão direta ou indiretamente relacionados com una educação melhor". p. 130.

(13) EChevarria, Josē Medina et allii - A igrlcultura Subdesenvolvida - Tradução de Dorothy Nebel - Petrópolis, RJ - Editora Vozes Limitada - 1968.

"Um aspecto tfplco co atraso rural da Amërica Latina são os baixos niveis da vida camponesa. Somente nos últimos anos $c$ principalmente, como conseqtència da mobilização politica de 1m portantes setores rurais, a atenção püblica pareceu captar os traços capitais dessa misēria.

Se levarmos en conta a participação relativamente baixa da agricultura no produte nacional, que caracterizou a grande maioria dos países durante o período de 1945-60, o alto número de pessoas que dependem dessa atividade produtiva, e a fraca ten dêncta da população rural a polarizar-se em grupos desiguats ao longo da escala de hierarquia social, não é dificil entender os baixos níveis de vida das massas camponesas". p. 33-34.

(14) FURTADo, Celso - Estagnação e Subdesenvolvimentc na Amër 1ca Latina - Rio de Janciro - Editora Civilização Brasileira - 1966.

(15) FRANK, Andrew Gunder, et allii - Urbanizacão e Subdesenvolvimen to - op. cit. p. 135-173.

(16) FURTER, Pierre - Juventude e Tempo Presente - Traduçäo de LuIs Lourdes de Orlandi - Rio de Janeirs - Editora Paz e Terra Ltda. 1967. p. 22-23.

(17) GARCES, Wilson - Resumen General de las Necessidades de Planifi cación en América Latina - Regionalización - Instituto Panamer cano de Geografla e Histöria - Comistón de Geografia - Rlo de $\underline{\underline{A}}$ neiro - APEC Editora S.A. - 1969. p. 245-248. 
C A P I T U L 0

A QUESTAO EDUCACIONAL NO BRASIL 


\section{1 - Objetivos}

1 - Assinalar a relação estreita entre sistema econōmi co, estrutura social, regime polftico e subsistema educacional no Brasil.

2 - Destacar as profundas alterações söclo-econômicas veriflcadas no Brasil, nos ultimos vinte anos e suas repercussões no panorama educacional.

3 - Analisar as perspectivas que se abrem para a educa ção, na presente dēcada, face ao modelo brasileiro de desenvolvimento.

4 - Mostrar a evolução do processo educacional no Brasil, através de "co.ates histöricon".

\section{2 - Introdução}

E conventente estabelecer, de infcio, uma diferença de conceitos entre educação como um todo e a educação normalmente dita formal.

A primeira ë inerente a todo grupo social, que a reali za atravës de um processo continuado, a angente, por intermë dio de todos os agentes, de una forma mais ou menos consciente. Encontramo-la nos grupos sociais mais primitivos como nas socle dades tecnologicamente ma1s avançadas. As variações são de con teúdo, de Intensidade, de meios, não, de propós'tos.

A educação formal, ao conträrio, è a que se realiza quase sempre nas escolas. Faz parte dos objetivos socials, to davia se caracteriza por pretender ser mais organizada, com periodos marcados - etapas ou ciclos. Quase sempre se processa nas escolas embora o conceito de escola - um ambiente físico onde se reunem alunos e professores para o trabalho educat1vo - tenha variado no tempo.

Hoje, mais que nunca, a educação formal vai liberandose da necessidade da "escola-prédio" típica. Os melos de comun 1 cação de massa (rädio, TV, cinema, toca-discos, cassetes, jor- 
nais e revistas, ensino por correspondência) - vèm atingindo parcelas considerāveis da população a escolarizar, de forma coe rente, planificada. O fenomeno pode ser observado em àreas ur banizadas dos Estados Unidos ou da Grä-Bretanha, como em grupa mentos rurais na Nigéria ou em fazendas isoladas na Austrälia (1). No Brasil, o Projeto Minerva atinge, pelo rädio, populações esparsas ao Iongo da Amazônia, a TV educativa amplia seu raio de ação e sua clientela.

Essa introdução visa a esclarecer que do fazer referência à educação, se enfocarả a educação formal.

\section{3 - Educacão no Brasil, ao longo dos sēculos.}

Observa-se que hả uma intima ligaçāo entre os estāgios econômicos, no Brasil, a formação da sociedade e sua movi mentação vertical e horizontal, sua caracterização politica e a educação. O conjunto forma um sistema coerente. Assim como uma organização pré-capitalista pode se dar ao luxo de prescidir de uma educação formal, o estágio atual que, baseado no ca pitalismo, enfatiza a industrialização e a reformúação agrária com vistas ao aumento da produtividade, fez fortes apelos à educação de massa. E esta tem qua atender ao duplo aspecto da conjugação de quantidade com qualidade.

o Brasil, como o restante da América sob o dominlo es panhol, teve seu destino marcado pelas caracteristicas do mer cantillsmo europeu, nos séculos XVI e XVII. Multo mais colónla de exploração que de povoamento, o qual se fazia em função do mercac s internacional a reclamar maior produção, o Brasil não teve implantado nesses sēculos nenhum "sistema educacional".

As fazendas de gado e de cana - imensos latifündos ra lamente povoados - viviam de forma quase autosuficiente. o plan tio da cana e da outros produtos secundărios, a criação exten siva do gado, prescindian de uma educaçāo formal. Quanto muito, no nücleo das fazendas, hä uma aprendizagem manual de ofícios necessáxios à pröpria movimentação do conjunto: serralhoiros, ferreiros, carpinteiros, oleiros, etc.. Aos poucos, esses oficios foram passando para os escravos e adqutrindo uma conota ção pejorativa até hoje não totalmente orradicada. 
As ordens religiosas cuidavam de ministrar a alfabet 1 zaçāo e rudimentos de latin, gramätica e retórtca a uns poucos que constituiam a camada dirigente, a aristocracia rural (2)

- início da mincração do ouro no Brasil, vai determi nar o deslocamento do eixo econômico, acompanhado de afluxo de mogräfico e de urbanização praticamente incipiente, à época.

Os trabalhos dacorrentes da mineração, de certa forma, ocasionam novo impulso à educação, não só para os "aprendizes" e "mestres-de-oficto", como para a aristocracia e a burguesia emergentes, centrađas nos núcleos urbanos, que buscavam mais e melhor educação.

Todavia o fenomeno, alëm de localizado em äreas restrí tas scm influenciar o restante do pais pela defictencia das co municaçōes, foi relativamente efêmero. Com o prenüncio do esgo tamento da mineração, já no século XVIII, murcha o dinamismo econômico-urbano, a lagislação torna-se mais opressiva atē desembocar nas proibições de atividades artasanais, como a peque na "indústria" gräfica $\odot$ outras.

A penetração de idêias europẽias, mais que Idēias, ideais, tinha que ser jugulada sob pena de ameaçar a precărla dominação portuguesa.

As rarissimas escolas existentes eram representadas pe los seminários. Do mais não necessitavam nem o sistema econôni co, nem a estratificação social. A casa grande e a senzala se autobastavam. Posteriormente, os sobrados e os mocambos refle tiam a divisão de riqueza ${ }^{(3)}$ e o parco consumo educacional,qua se restrito à minorla masculina das casas grandes e dos sobra dos.

o século XIX marcou-se logo na primeira década pela mudança da Corte Portuguesa para o Rio de Janeiro.

As mođificaçōes no panorama econômico, político, socí al, administrativo näo tardaram. A intensificação das correntes comerciais, a instalação de um aparelho administrativo que necessitava de infra-estrutura urbana e, por via de conseqtência, ao menos pré-industrial. E educacional, os movimentos de nature za ldeológica c politica vindos da Europa e dos Estados Unidos 
asabaram por refletir-se mais acentuadamente na demanda educacional no Brasil.

Essa demanda foi parcialmento satisfeita:aumentava o nüme ro de operários no Rio de Janeiro, instalavam-se nücleos de educação superior (militar e civil), mas o quadro refletia apenas os reclamos das classes dirigentes. A grande massa demográfica permane cia escrava ou sumi-escrava, à margem de quaisquer benefícios de uma educação formal.

liesmo o aparecimento de um novo produto - o café - näo determinou alteraçoes profundas no "status quo", so menos de inicio. Ao contrário, reforçou os quadros oilqärquicos e a marginali zação cultural dos trabalhadores, agora no vale do Paraíba encaminhando-se para são Paulo.

- fenōmeno continuava a se verificar em ärea restrita. o restante do pais permanecia pouquíssimo alterado.

A industrialização era apenas uma mancha diferente no qua dro predominantemente agrärio. Em 1889, não havia mais que 636 fábricas e 54.000 operârios. Fäbricas, muitas delas, pouco dígnas do nome e operários mais artesãos que propriamente operārios, como os da Europa industrializada.

o recenseamento de 1890 que registrou a existêncta de 17 milhões de habitantes no Brasil se descesse à anālise do panorama educacional assinalaria quase $17 \mathrm{milhöes} \mathrm{de} \mathrm{analfabetos} \mathrm{de} \mathrm{fato.}$

"O que então era considerado cultura aram apenas as cria ções culturais, o exercício da especulação intelectual, tanto mais alta a cultura quanto mais abstrata e menos prätica, o labor das classes sociais inferiores näo era mais do que o mero praticalismo das classes incultas, som qualquer chancela de prestígio social."(4)

Em 1900, a populaçāo de mais de 15 anos era de 9750000 habitantes, dos quais 3380000 eram considerados alfabetizados. Se hoje o conceito do alfabetizado è, ainda, täo elästlco, envolvendo muitas vezes 1 ou 2 anos de escolarização, è de imaginar-se a pouca fidedignidade desses dados censitärios. (5)

A letargia educacional do periodo monärquico vai legar à Repüblica um pais scm inframestrutura educacional. 
"Na realidade, ninguém dava crēdito aos educadores (nem sequer eles próprios) na sua pregaçāo de educaçāo para todos. Com efelto, os próprios educadores tinham sempre o culdado de dizer que näo era possivel, economicamente, a soluçāo do problema educacianal brasile1ro...

Quando mudanças de estrutura soctal, da ordem das que nos deviam trazer a república e com ela a democracia, se processam efe t1vamente no selo de um povo, o problema econômico não pode constí tuir obstāculo à sua real efetivação." (6)

Só na década de 1920 , com uma Industrialização menos déb11, com os processos de urbanlzação se conflgurando mais nitidamon te (7) com uma conscientização polftica que val desembocar na luta pela modiflcação dos processos eleftorals, é que se constatou a po breza e a mä distribulção da educação no Brasil.

O periodo de 1930-1950 é de transformações profundas, no Mundo e no Brasil. Em vinte anos, assiste-se à eclosão de guerras localizadas ou mals gerais (1939-45); à revolução de 1930 , co Bsta do Novo, à volta ao regime democrático em 1945, à sucessāo näo sem turbulênclas de governos federais; à crise econōmica mundial e seus reflexos no Bras1l; ao Inf́clo de nossa efetiva Industrializaçãos ao crescimento demogräfico acclerado; à urban1zação acompanhada de d1fusão dos melos de comunicação; o comërclo interregional, intra-re glonal e internacional se intensificou; as migraçöes lnternas se acentuaram.

Ora, todas as alteraçöes acima, apenas traçadas em linhas gerals, teriam que provocar conflitos e acomodaçōes sociats de caráter profundo. E 1850 não ocorreu sem refletir-se no quadro edü cacional: a escolaridade aumentou, foram criadas faculdades de f1losofia, multiplicaram-se as escolas normals.

Mas o ensino continuava marcado por profunda dicotomia: o ensino para as classes privilegiadas de uma ou de outra forma, era - humanistico; o ensino profissional "para as classes menos favore cldas", conforme se consagrava na constitulçäo de 1937.

Nas duas décadas seguintes, os fenōmenos antertormente as sinalados cresceram de intensidade: profundas alterações econômcas/ Instabllidades politicas; maior conscientização das necossida des Individuats e soclals; pressāo demográfica e escolar; planifica 
ção global de infclo timida e, posteriormente, considerada pré-requisito para a atuação governamental; 1mpacto dos "mass-media" ; equa clonamento dos problemas do desenvolvimento e do subdesenvolvimento.

As aspirações por uma melhor educaçāo, ainda não sat1sfeltas quantitativa e qualitativamente, são efeito de todas essas transformaçōes profundas e se colocam, no 1niclo da década de 70 , como prioridades bäsicas no quadro dos objetıvos nacionals.

\section{4 - O quadro atual da educacão no Brasil}

Durante multo tempo, no Brasil, o planejamento integral e integrado não entrava na cogitação dos responsávels pela condução polftica, de nfvel superior.

Cada setor culdava de programar atividades, que multas vezes não eram respaldadas por uma previsão de recursos, ○ que con duzia ao malogro das iniciativas. Outras variáveis interferiam no sucesso dessas programaçōes setoriais. Uma delas, de fäc1l ldentifí cação; é que os projetos setorials não estavam compatibilizados entre $s 1$ e os planos uns com os outros. (8)

Hoje, não se pode planejar a educação, seja do ponto-devista nacional, seja do ângulo estadual e/ou regional sem levar em conta as metas e bases globals estabelecidas pelo governo. A partir dai, devem ser estruturados os subsistemas educacionais, os modelos propostos, as previsões de natureza orçamentărıa e de recursos humanos, etc.

Ocorre que o Brasil se vincula a uma estrutura mals complexa, compondo un geo-sistema amplo, de ponto-de-vista polftico, econômico, social. Assim, também è tarefa preliminar estabelecerse quais sāo as metas gerais de integração no geo-sistema. (9)

Atualmente, hã uma preocupação nitida em buscar a integração do subsistema educacional com os dema1s subsistemas. E a edụ cação que se planeja, que se busca reformular, não se desvincula da valorızação integral do homem, considerado em si mesmo e como re curso para o desenvolvimento. Por isso, a questão educacional é enfocada desde o processo de alfabetização até os nivels mais altos, como os de pós-graduação. 
Considerando o aspecto particular da educação para o desenvolvimento, são nftidas duas preocupaçöes: a relativa ao pleno emprego e a que se volta para a 1mplementação de una tecnologia na cional.

Para a consecução das metas, torna-so necessāria a análí se da questão atravēs dos seguintes componentes:

- educação e individuo

- educação e desenvolvimento

- alfabet1zação - educação de base

- ensino de 18 grau

- ensino de 28 grau

- ensino universitárto e de pös-graduação

- ensino e trabalho

\section{4 .1 - Educaçāo e Indivíduo}

No Bras1l, como no Mundo, "a década dos 60 marcou a rea bilitação do homem como agente primordial do desenvolvimento; a dé cada de 70 enfatizará a posição do Homem como seu beneficiărio ex clusivo.

A frase é stmples e envolve o que se denomina uma rever são de expectativas. Mas, descendo-se ao fundo da proposição, vê-se que a complexidade do tema é ampla. De que formas, sob que aspectos, com que intensldade, com que grau de varlação, o Homem será o beneficiärı do desenvolvimento? Aqu1 o pröprio concelto de fell cldade entra em questão. O que vem a ser a felicidade individual ou, mesmo, a fellcidade social? htê que ponto ela pode, ou não deve, ser quantificada?

Do ponto-de-vista individual ela seră um estado de espir $\underline{1}$ to ou um complexo "condtçōes materials-estado de espirito", que só a cada um compete fruir e julgar, avallar? Neste sentido, entra-se no dominio da Etica, da Moral, da Religião, até da Metafísica.

Do ângulo dos grupos socials, o que vem a ser a felicida de? Sabe-se, por certo, o que não é, mais $18 s o$ nāo encaminha para a resposta ao que se deve ser.

Pode-se dizer que essa quase utopla alfere no tempo o no espaço. O 1deal grego hoje não poderia ser repetido e, mesmo, 
se nos afigura talvez absurdo, porque a Fellcldade Nacional Bruta era repartida entre os poucos que compunham os estratos superiores da socledade. Os grupamentos humanos a que convencionamos chamar de "primltivos", poden chegar ao estado de harmonia, de integração e de feltcidade soctal. Os trabalhos de $C$. Levy-Strauss e de Margareth Mead, de um grande nümero de antropologistas, ao menos nos mos tram que o nosso "modelo social" nāo è o úntco viável.

Sería o caso de uma auto-anālise: o modelo almejado,que é factivel, è o que conduz à felicidade soclal ? ou a nova santissima trindade: Industrlalização, tecnologia, consumo de massa jë ë contestada a partir do seu núcleo mesmo ? ou o sub-consctente soctai de que fala Jung está pesado de contradições ? Parece que a componente de criação está sendo suplantada pela de destrulção, auto e hetero.

Teremos todos que repetir os modelos que geraram a tecnologia avançada, ou poderemos conviver com a tecnologia nem os seus tnconvententes ? Cada nação, cada grupo soclal não terá mais que o direito, o dever, de buscar seu próprio perfil ?

Evidentemente vive-se una época de profundas contradiçōes e, por isso mesmo, a pré-histöria de um perlodo novo. Vive-se una época de transformações sociais apenas esboçadas, alto que se assemelha a periodos como o fim da Idade Mëdia, do Renascimento, da Revolução Industrial. Algo novo está en gestação, do ponto-de-vista social. E parece que é puro ensaio acadêmico testar modelos de labo ratoorio. Há varıáveis não quantificăveis.

"A grande regra de ouro - hoje abandonada - desta atitude é a da independência do pensamento humano".

"Não tenhanos medo de pensar, nem permitamos que alguëm nos ameace contra esse privilëgio de pensar independentemente e livremente." ...

"A promessa e as possibilidades do conhecimento humano abrem, com efeito, toda sorte de alternativas." (10) 
Parece mesmo, que quaisquer sejam os caminhos que as so ciedades venha a percorrer, $\circ$ "quid" de toda a sua bagagem flsica e mental ë a educação, cađa vez mals extensiva, cada vez mals inten siva. Educação que gere a liberdade e a vontade de pensar, requisi tos bãstcos para a solução de problemas de natureza väria.

\subsection{2 - Educaçāo e desenvolvimento}

Preliminarmente é interessante observar que os diversos conceitos en voga sobre "desenvolvimento" se identificam ao subl1 nharem a intercomplementaridade do fenômeno: o desenvolvimento não è tōplco, não ē setorial, mas abrangente do ponto-de-vista vertical e horizontal. Isso significa que ele não se refere apenas ao aspecto social, ou polftico, ou econômico. A conexão entre essas ya rianéis de ưn sistema é imprescindivel. Se o desenvolvimento se re laciona a una melhoria dos grupos soclais, è preciso identificar es sa melhorla do ângulo quantitativo e qualitativo.

o aumento da renda "per cap1ta", a điminuição da mortalı dade infant11, o aumento da expectativa de vida, o aumento da rela ção calorlas/habitante, o respeito às liberdades lndividuais e o respeito do individuo aos grupos socials e aos interesses nacionais, a ellminação do analfabetismo e a escolarizaçāo crescente da população, o lazer como parte integrante, necessária e planejada na vida de cada um, a eliminação do desemprego e do subemprego, 0 aces so às fontes de cultura, a mobilidade social acelerada, tudo isso, e multo mais, se entrelaça, numa interdecendência flagrante.

Por não haver - e nem sempre hă - sincronismo dos fenôme nos, alguns antecedendo outros, mas há correlação, a médio ou longo prazos. Porla não haver uma total conscientização e participação en gajada, ractonal, no processo, como assinala cosTA PINTO (11), mas que ele se desenrola é inegável. Os erros podem ser de aceleração ou de distribuição de resultados, que podem gerar uma forma antide mocrätica do desenvolvimento, ou seja a sua antitese, o axtidesenvolvimento que beneficia apenas a una parcela restrita da socieda de.

o desenvolvimento não deve ter valores hierarquizados, ou ele è total ou não è desenvolvimento. Pode haver, 1sso sim, uma es cala de prioridades que, por isso mesmo, constituem meios, antecedentes, para um fim. 


\subsection{3 - Desenvolvimento - economia - planejamento.}

Parece ultrapassado o conceito allenador de que "todas as sociedades tendem ao desenvolvimento". Ele seria quase una predes tinação, una espécle de utopia edênica viävel, vez que essa seria a "maxcha inexorāvel da h1stōrta dos povos". Os subdesenvolvidos apenas estariam atrasados historitamente: mas as etapas serian con cluidas. Algo assim como o "laissez-faire" que servia bem aos propósitos das classes sociais e do pequeno nümero de nações que usufruem quase integralmente o desenvolvimento.

Hoje acredita-se flrmemente que o "laissez-faire"está ter minado, que cada povo deve intervir no presente para alterar as perspectivas futuras. Os padröes referenciais não poden ser os de uma minoria, mas devem corresponder aos modelos que se traduzem por uma justiça social ampla.

Por 1sso, desenvolvimento-economia-planejamento constituem dados de uma equação e não angulações diferentes ou conflitan tes da problemätica social.

Os paises que se enquadram entre os de alto desenvolvimen to, reformulam, constantemente, seus objetivos, ou buscam fazê-1o.

Os subdesenvolvidos estão conscientes de que a estagnação, a miséria, o analfabetismo, a fome, o desemprego, não são 1mpo sições naturais ou extra-naturais. são removiveis.

o romplmento da "causação-circular" è possivel sem que se recorra a modelos alienfgenas, como se fosse fatalidade histórica todos terem que percorrer as mesmas etapas.

o desenvolvimento como estado de espirito coletıvo prepa ra camtnho para as realizaçōes pragmäticas.

o desenvolvimento è planejável e outra coisa não vêm fazendo todos os povos, varlando a orientação, o grau de esforço, a se leção de metas, as priorldades. 


\subsection{4 - Educação e desenvolvimento; desenvolvimento educaçāo}

Parece näo haver mals düvidas quanto ao valor da educação para o desenvolvimento. hä distorçōes nas tëcnicas de ajustar as duas variâveis, mas ambas não são desligadas, são intercomplemen tares.

Durante séculos a crença de que a educação era apenas um bem de consumo basicamente cultural, levou a eliminar a componente econômlca do processo.

"Em principlo, foi a vigência do puro dominio do concelto metafísico da educação, no seu reconhecimento como direlto humano universal. Uma colocação do problema situada na área exclusiva de sua fillaçāo a valores rorals, éticos, estéticos, civicos, fllosóficos, religiosos.

No fundo, una certa amblvalêncla de posição, entre a for mulacão democrática contida no reconhecimento ao direlto universal à educação e sua insplração motivadora, sutilmente ar1stocrātico-rẹ ligiosa". (12)

Os economistas deram partida aos estudos ma1s aprofundados das relaçōes entre educação e desenvolvimento, apös 1945, concluindo que os investimentos na educação sāo un dos fatores bás1cos para esse mesmo desenvolvimento.

Como diz o atual Ministro da Educaçāo: "Nos dias hodier nos, o jargão dos economistas deu novo colortdo à velha verdade $e$ d1z-se que sem a qualificação dos recursos humanos não hã possibilí dade de incremento do PIB até o limito do "take-off", para as naçös em desenvolvimento.

E sem dưvida, uma forma sedutora de expressar um conceito acactanon (13).

Mas o fato positivo das constatações è que se estabele ceu como verdade que a educação è investimento.

Estudos realizados por economistas, relativos a diversos palses e em diferentes perlodos, revelaram que o cresclmento do pro 
duto real não fol apenas funçäo do estoque de capital e da força de trabalho. Nem dependeu dos recursos econômicos flifcos, en esta do potencial. Em todas as anālises havia un "reslduo" apreciável na contab1lização do crescimento do produto real. Finalmente o "reslduo" fol 1dentificado: era produzido pela melhoria da educação e do progresso tēenico.

"Mais pormenorizados ainda foram os resultados obtidos por Denison a respelto do crescimento do produto real norte-america no entre 1929 e 1957, segundo os quals a taxa mëdıa do crescimento de 2,938 ao ano era atribuível aos seguintes elementos:

à acumulação flsica de capital ...............,538 a.a. ao aumento do estoque de māo-de-obra.............,808 a.a.

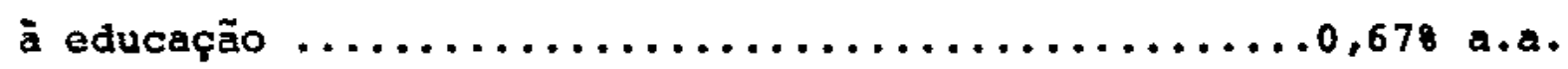

à melhorla da produtividade dos fatores $\ldots \ldots \ldots \ldots .0,938$ a.a.

Por esses ültimos resultados, o aumento flstco da quanti dade de fatores terla sldo a causa de apenas 458 do crescimento ve rlficado. O residuo era responsável por 558 do progresso, cabendo 238 à educação e 328 à melhoria da produtividade dos fatores". (14)

Assim, centra-se, cada vez mais, o esforço em destinar recursos para a educação. Esses, provêm de fontes diversas: federais, estaduais, municipals, particulares. O quadro no 9 , a soguir, dá ldèla da evolução dos recursos aplicados. 
BRASIL - RECURSOS APLICADOS EM EDUCAÇÃO E PRODUTO INTERNO BRUTO 1960/1970(*)

\begin{tabular}{|c|c|c|c|c|c|c|c|c|c|}
\hline \multirow{3}{*}{ ANO } & \multicolumn{4}{|c|}{ RECURSOS APLICADOS EM EDUCAÇÃO } & & & & \multirow{3}{*}{$\begin{array}{l}\text { P RODUTO } \\
\text { INTE RNO } \\
\text { BRUTO }\end{array}$} & \multirow{2}{*}{$\begin{array}{l}\text { RECURSOS } \\
\text { EM \& DO } \\
\text { P.I.B. }\end{array}$} \\
\hline & \multicolumn{4}{|c|}{ RECURSOS POBLICOS } & PRIVADOS & EXTEFNOS & TOTAL & & \\
\hline & FEDERAIS & ESTADUAIS & MUNICIP. & TOTAL & & & & & \\
\hline 1960 & 677.270 & 1.097 .301 & 147.320 & 1.921 .891 & 415.100 & 4.000 & 2.340 .991 & 95.604 .800 & 2,4 \\
\hline 1961 & 721.966 & 1.277 .448 & 149.066 & 2.148 .480 & 429.700 & 14.900 & 2.593 .080 & 102.587 .000 & 2,5 \\
\hline 1962 & 309.327 & 1.463 .298 & 135.430 & 2.471 .055 & 454.700 & 4.700 & 2.930 .355 & $110.203,800$ & 2,6 \\
\hline 1963 & 696.787 & 1.167 .626 & 86.880 & 1.951 .293 & 461.000 & 247.200 & 2.659 .493 & $113.560,300$ & 2,3 \\
\hline 1964 & 837.146 & 1.087 .428 & 136.154 & $2.060,728$ & 468.000 & 20.800 & 2.549 .528 & $115.205,800$ & 2,2 \\
\hline 1965 & 1.239 .212 & 1.839 .506 & 211.542 & 3.290 .260 & 477.100 & 19.800 & 3.787 .160 & 117.337 .700 & 3,2 \\
\hline 1966 & 1.292 .364 & 2.028 .876 & 268.316 & 3.589 .556 & 481.000 & 104.200 & 4.174 .756 & 124.156 .400 & 3,4 \\
\hline 1967 & 1.323 .921 & 2.406 .191 & 364.913 & 4.095 .025 & 507.800 & 214.300 & 4.717 .125 & $128.673,500$ & 3,7 \\
\hline 1968 & 1.202 .061 & 2.674 .652 & 479.706 & 4.356 .419 & 501.000 & 121.000 & 4.978 .419 & 143.842 .100 & 3,5 \\
\hline 1969 & 1.396 .200 & 3.322 .717 & 519.410 & 5.238 .327 & 560.500 & 180.000 & 5.978 .827 & 158.017 .800 & 3,8 \\
\hline 1970 & 1.490 .000 & 3.690 .000 & 610.200 & 5.780 .200 & 578.000 & 181.000 & 6.539 .200 & 172.239 .400 & 3,8 \\
\hline
\end{tabular}

FONTE - Centro Nacional de Recursos Humanos - IPEA - 1971

(*) Cr $\$ 1.000,00$ de 1970 . 
E nitida a evolução não apenas do PIB, como a porcentagem do mesmo que se destina à educação: ela è crescente $e$, no caso, refere-se tão somente a percentuals alocados à educação pelos setores menclonados.

Se, todavia, for considerado que outros Ministērios 1 gual mente destinam recursos à educação, o montante será mals significa tıvo. o caso, por exemplo, dos Ministērios que mantêm um subsistema paralelo ao do MEC, conquanto muito menos expressivo e mul to mais especifico. Tais são os casos do Ministērlo da Agricultura (Escolas Agricolas), do Ministërio do Exercito (Colëglos Milltares, Academla Militar das Agulhas Negras), do Ministērio da Marinha (EE colas Navals, Centros de Aprendizes, Colëgio Naval), Ministērio da Aeronáut1ca (Escolas de 19 e 29 graus, Escola superior), Polfcias Militares (Centro de Formação de oftclais), Ministério do Intorior (através de sub-sistemas mantidos pela SUDENE, SUDAM, SUDECO, suLesun etc. .

A esses, torna-se necessär1o, acrescentar que multas em presas particulares mantèm cursos para a preparação e qualificação da mão-de-obra especifica de que necessitan, como as empresas petrolfferas, automobilísticas, siderürglcas, de comunicação, etc.

Levando-se, todavia, em consideração o que demonstra, ape nas, o quadro anteriormente assinalado, observa-se que há atẻ 1970, um aumento da porcentagem do PIB em educação; 3,8\%. Mas, alnda, è pouco. Em situação ideal, deverfamos chegar a 58 e 68 do PIB deg tinados à educação. Outros empreendimentos, inclusive os de natụ reza soclal, näo permitem que a educação seja mais aquinhoada. E um problema típico de pals em desenvolvimento. Observe-se o quadro no 10, que assinala a posição do Bras1l no conjúnto de 22 países. Atente-se, contudo para: o periodo de referência não é 1dêntico Pa ra todos os pafses; as necessidades educacionais (1nvestimentos fí nancelros) variam igualmente conforme o estägio de desenvolvimento de cada pais. 
QUARFO NQ 10 - GASTOS POBLICOS EM EDUCACAO

(Como Porcentagem do Produto Nacional Bruto e Taxas de Cresc1mento em Alguns Países do Mundo)

\begin{tabular}{|c|c|c|c|c|}
\hline$P$ A I S E S & $\begin{array}{l}\text { GASTOS PU- } \\
\text { BICOS COMD } \\
\text { B DO P N B }\end{array}$ & $\begin{array}{l}\text { ANO DE } \\
\text { REFEREN } \\
\text { CIA }\end{array}$ & $\begin{array}{l}\text { TAXA REAL LE } \\
\text { CFASCIMENTO DAS } \\
\text { DFSPESYS PQETIS } \\
\text { E1 ELUCACAO }\end{array}$ & $\begin{array}{l}\text { PERtoD DS } \\
\text { FeriancIA }\end{array}$ \\
\hline AUSTRIA & 4,40 & 1967 & 9,3 & $1957-1966$ \\
\hline BELGICA & 5,57 & 1967 & 8,6 & $1958-1967$ \\
\hline BRASIL & 3,35 & 1970 & 18,8 & $1964-1970$ \\
\hline CANADA & 5,65 & 1965 & 13,5 & $1954-1965$ \\
\hline DINAMARCA & 6,12 & 1967 & 11,4 & $1955-1966$ \\
\hline FINLANDIA & 6,43 & 1967 & nd & - \\
\hline FRANCCA & 4,81 & 1967 & 11,0 & $1952-1967$ \\
\hline ALEMANHA OCIDENTAI & 2,96 & 1966 & 9,3 & $1950-1966$ \\
\hline GRECIA & 1,89 & 1964 & 12,2 & $1950-1966$ \\
\hline ISLANDIA & 4,80 & 1967 & nd & - \\
\hline I RLANDA & 4,23 & 1967 & 5,7 & $1950-1965$ \\
\hline ITALIA & 5,44 & 1967 & 13,7 & $1957-1965$ \\
\hline JAP AO & 4,54 & 1965 & 9,8 & $1950-1965$ \\
\hline HOLANDA & 6,71 & 1967 & 11,4 & $1950-1961$ \\
\hline NORUEGA & 5,81 & 1967 & 7,4 & $1950-1967$ \\
\hline PORTUGAL & 1,44 & 1965 & 6,5 & $1950-1965$ \\
\hline ESPANHA & 2,06 & 1967 & 10,4 & $1950-1966$ \\
\hline sUECIA & 7,40 & 1966 & 10,0 & $1957-1965$ \\
\hline SUIÇA & 3,62 & 1964 & 7,9 & 1955-1964 \\
\hline TUROUIA & 3,70 & 1967 & 9,5 & $1950-1967$ \\
\hline REINO UNIDO & 4,15 & 1965 & 7,8 & $1953-1965$ \\
\hline ESTADOS UNIDOS & 5,10 & 1967 & 8,2 & $1955-1967$ \\
\hline
\end{tabular}

Fonte: The OECD - Observer n9 44/February 1970 (Gastos públlcos como percentagem do PNB) .

The OECD - Observer no 47 August 1970 (Taxas de cresc1mento dos gastos).

Fonte brasile1ra: "Eđucação no Brasil" - MEC - 1971. 
Gasta-ge multo em aducação, mas gasta-re mal. Como diz Már10 Henrique simonsen (15) a produtividade do alotema é baixa. 0 insumos aducactonals podem ser elevados, mas o produto final, alén de quant1tativamente pequeno $\sigma$, multas vezes, de qualldade duvidosa.

A "pirânide do desperdicio" está representada no gräflco ne 7.

Gräfico no 7

SISTEMA EDUCACIONAL

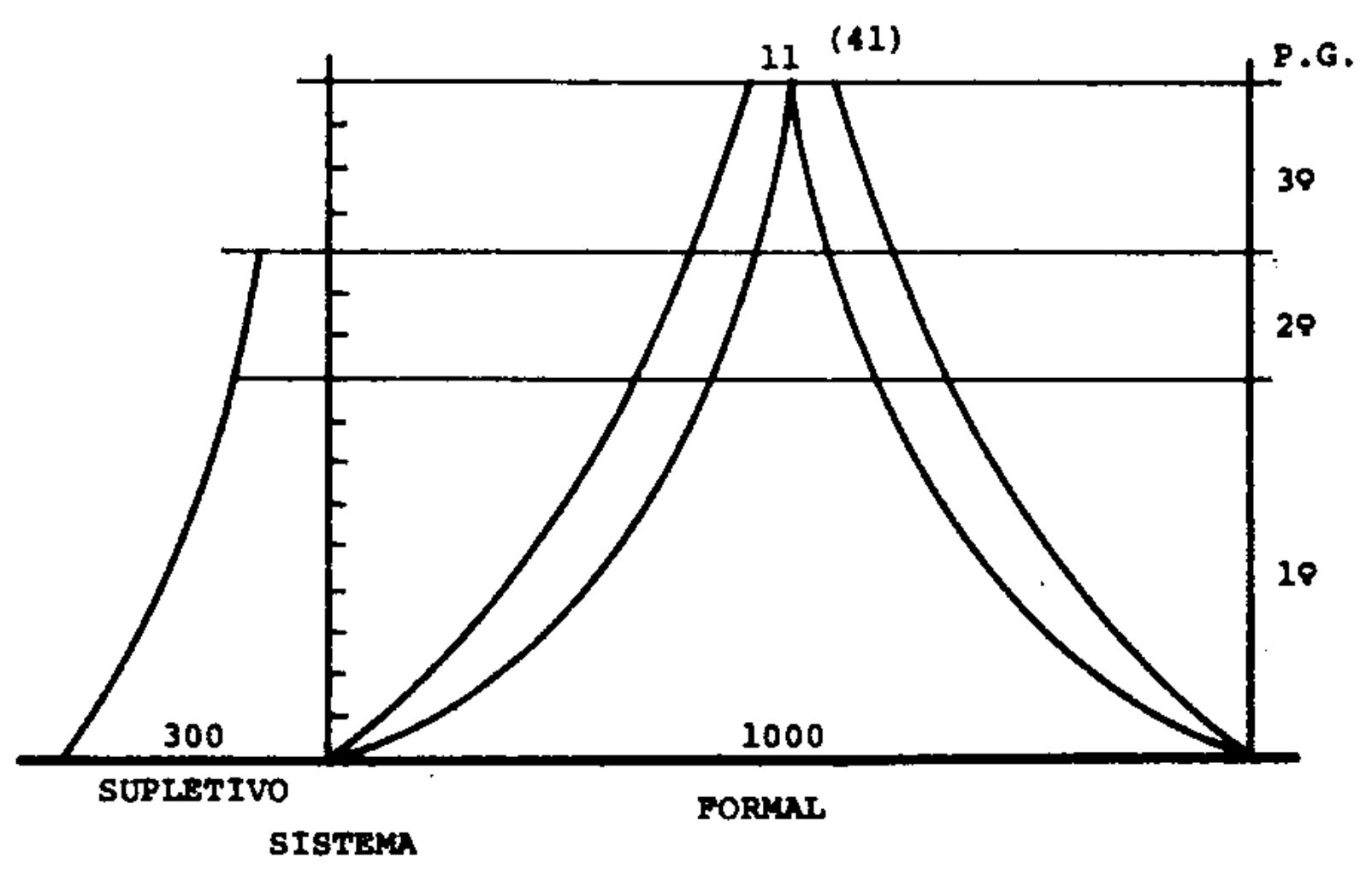

Fonte: "BDUCACXO PLANIFICADA" - MEC - 1971 
As perdas são incrivelmente absurdas, de tal forma que:

18 - a cada mil alunos que são matriculados na la. série do ensino de 18 grau, trezentas outras crianças f1cam fora do sistema formal, ou seja, a escolarização inicial estā aquén da demanda;

29 - ao longo do curso, as perdas väo se acentuando e, nụ ma consideração global, a partir do gráfico, de cada 1000 alunos referidos anteriormente, só 41 terminam o curso superior, isto è, 95,98 flcaram ao longo do caminho. Deve-se ainda considerar as perdas efetivas (e maciças) que se obscrvam no enstno de 19 grau, no tadamente na passagem da la. para a $2 \mathrm{a}$. sërie (repe tência e evasão).

o Investimento sem retorno, ou de retomo (custo/beneficio) multo pequeno, é função de inümeras variāveis, e só una anāl1 se regional revela as causas bäsicas. Todavia, de forma geral, podem ser apontadas as seguintes:

18 - matricula não total na la. série do ensino de 18grau;

28 - carências sōclo-econômicas de maloria esmagadora da população, que se reflate nos balxos Indices de aprendtzagem;

39 - professorado leigo (nos 4 primeiros anos de enstno, 49 das professoras são leigas) (16);

49 - escolas espacialmente mal distribuldas, agravando-se o problema nas zonas rurats;

59 - prēdios escolares:

- 708 das escolas que ministram os 4 primeiros anos, são de uma só sala, em que se misturam alunos com diferentes $\mathrm{n}$ Ivels de aprendizagem;

- paradoxalmente mal ocupados: são comuns as turmas de mals de 50 alunos, e a capacidade oclosa é gran de (fértas prolongadas, 180 dtas lativos apenas);

- mal equipados;

- raros os que são tẽcnlca e pedagoglcamente construI dos; 
69 - curriculos inadequados às realldades sociais, psicológlcas e lóglcas;

78 - falta de material escolar (livros, auxilios audioví suals, laboratórlos e oflclnas);

89 - mátodos didāticos ultrapassados;

98 - carínclas allmentares (vide papel da merenda escolar na retenção de alunos nas escolas), saúde precā rla do alunado das classes sociais mais balxas;

108 - falta de centros de preparação de professores, pre dominando o laicato no enstno de 28 grau $e$ no anti go ginásto (5a. a $8 \mathrm{a}$. séries do 18 grau);

118 - falta ou 1 rrealismo dos planejamentos educacionais;

129 - deficlência nos métodos de avallação da aprendizagem;

13? - burocracia administrativa esclerosada, que tem a con trapartida na falta de administradores do subsistema educacional com formação atualıada;

148 - deficlência de dados estatisticos, igualmente, difi culta ou torna irrealisticos os diagnósticos educa clonals.

Essas são, apenas, algumas das causas gerais que respondem pela defasagem custo/benefício na educação brasileira.

Anteriormento frisou-se que a educação é investimento e já se torna ultrapassado o debate girando em torno dos temas: "a educação è uma das causas do desenvolvimento $x$ o ritmo e o volume do cresclmento econômico predeterminam os investimentos educacionais".

Hoje é o ponto pacifico que mais e melhor educação marcham ao lado do crescimento econôntco, agem positivamente sobre o mesmo. (17)

Mas a moeda, como sempre, tem duas faces. Se, por un lado, a educação demanda investimentos, por outro ela é fator de con 
sumo. A medida que a educação abre novos horizontes ao Individuo, à medida em que ela o habilita profissionalmente, aumentando o seu poder aquisitivo, ele passa a ser um consumidor mals exigente. Näo apenas exigêncla de ma1s educaçäo - o que $\dot{\theta}$ um aspecto do proble ma -, mas exigênclas de outras ordens.

Algumas são de natureza material, física, tals como:

- aumenta a sua demanda de bens de consumo, duráve1s e näo durāvels;

- cresce a sua pressão no sentido de usufrulr de um equipamento terciärlo mais abundante e de melhor qua lidade.

Como se observa, essas exigências têm que ser satisfeltas por via de un crescimento econômico, nactonal e/ou regional. Além do crescimento que pode, na pior das hipóteses equilibrar o binô mio demanda-oferta, hä que incrementar os investimentos socla1s na Infra-estrutura: escolas, saneamento, hospitais, energia elêtrica, telefones, abastecimento de āgua, rede de esgoto, habttações, diversōes, etc., etc..

Se o crescimento econōmico possibilitar a alocação de recursos para investimento nessa infra-estrutura soc1al, sem prejuI zo dos investimentos na tnfra-estrutura econôntca, chega-se, confor me se assinalou anteriormente, ao equilibrio demanda-oferta. Mas, se ocorre o contrārio e, durante algum tempo a demanda $>$ oferta, as tensöes socla1s e os decorrentes problemas de natureza polftica sur gem fatalmente.

Outras exigênclas sāo de caräter polftico: referem-se a uma participaçāo nos processos politicos, sejam eles de carāter co munitário (fenômenos municipa1s), sejam de maior amplitude, a nIvol estadual e nacional. (18)

Como se vê, hã um fenômeno de dupla troca no que tante à "educação-desenvolvimento" $\rightleftarrows$ "desenvolvimento-educação".

A deflagração e a aceleração do fenōmeno, por 1580 mesmo, nāo podem ocorrer ao acaso, mas necessitam de amplo e abrangen te planejamento, a curto, mẻdio e longo prazos. Sem o conhecimen to da situação atual e suas projeçōes futuras, corre-se o sërio e inevitável risco de criar pontos de estrangulamento sócio-políticoeconônlcos de dificil soluçäo, 


\subsection{5 - Alfabetização; educação de base}

Em situaçōes normals, o subsistema formal de onsino, deverta ser o responsāvel pela escolarização de toda a sua população, ao menos na faixa etäria de 7 a 14 anos.

Tndavla isso não.ocorre siquer nos países que apresentan melhores perfomances economicas e educacionals, como os Estados uni dos, U.R.S.S., Alemanha Ocidental e Japão. Nesses, a escolarização intcial embora se aproximando de $100 \%$, ainda delxa um residuo não absorvido pelo subsistema educacional, variável de região para regiāo. Mas vale assinalar que a alfabetização não abrange a totalida de da população. No Brastl a situação nesse sentido, conquanto ve nha apresentando sensiveis melhorlas, ainda apresenta graves distor ções.

E o que se observa no quadro a segulr.

\section{QUADRO NQ 11}

ESTIMATIVA DAS POPULAÇZ̃ES ESCOLARIZSVEL E ESCOLARIZADA, DE 5 A 14 ANOS, COM BASE NAS TABULICCOES AVANCYIDAS DO CENSO DEMOGRAFICO - 1970

\begin{tabular}{|c|c|c|c|c|c|}
\hline DISCRIMINAC̆̃OO & $\begin{array}{l}\text { POPULAÇAO } \\
\text { ESCOLARI \& AVEL } \\
\text { (a) }\end{array}$ & $\begin{array}{c}\text { POPULAÇR̃ } \\
\text { ESCOLARIZADA } \\
\text { (b) }\end{array}$ & $\frac{(b)}{(a)}$ & $\mathrm{x}$ & 100 \\
\hline \multicolumn{6}{|l|}{ BRASIL } \\
\hline 5 e 6 anos & 5.579 .922 & 919.604 & & 16,5 & \\
\hline 7 a 10 anos & 10.326 .611 & 6.828 .454 & & 66,1 & \\
\hline 11 a 14 anos & 9.060 .996 & 6.140 .002 & & 67,8 & \\
\hline 5 a 14 anos & 24.967 .529 & 13.888 .060 & & 55,6 & \\
\hline 7 a 14 anos & 19.387 .607 & 12.968 .456 & & 66,9 & \\
\hline
\end{tabular}

Fonte: IBGE, Instituto Brasileiro de Informática. 
Cerca de 308 da população en ldade de se matricular nas escolas (aos 7 anos de idade), permanecem à margem do subsistema.

As causas do fenômeno são de natureza vária, tals como:

- forte contingente de população rural, o que é agravado pela dispersão demogrä́fica em multas äreas;

- baixos pađrões econônicos de parcela considerável da população, conduzindo ao trabalho do menor, antes mes mo de 10 anos de ldade;

- ausêncla de prédios escolares e de pessoal em vărios municiplos (casos típlcos são comuns na Amazônia e no Centro-Oeste);

- Ignorâncla das fanilias a respeito da importāncia da alfabetızação e da educą̧ão de base.

Essa população não escolarizada vai aos poucos aumentando o número de analfabetos de 15 anos e mals.

Quanto a esses, as estitisirzas são altamente contradi törias.

Escreve o Ministro da Educação: "Na verdade näo encontre1 un fundamento estatistico que me garantisse aquelas cifras, a não ser uma projeção dos três ülttimos recenseamentos: 40,50 \& 60 . Mas como de 40 para 50 calu a 0,58 a.a. O analfabettsmo no Brasil, e de 50 para 60 a queda era de 1,18 mais o dobro, procurei a razão que justiflcasse esse esforço. Não a encontrando, deram-se esta: a de que o recenseamento de 60 não merecia fé. Até o IBGE concorda com isso. De minha parte, l1a deseoperadamentc tudo o que me vinha às māos, mas não conseguia, à falta de informaçöes estatíticas fidedignas, chegar a uma conclusão. Creto que tenhamos cerca de $17 \mathrm{mi-}$ Ihöes de adult.ss analfabecos, em 1970"(20)

Hä duas formas de extlngulr-se gradativamente o analfá bet1smo, principalmente entre a faixa etäria de 15-35 anos:

la. - a universalização do ensino de 18 grau, que é obrt gatörio e gratulto (Le1 no 6.592), entre os 7 e 14 anos de 1dade;

2A. - através de movimentos continuos e crescentes de al fabetização, como o MOBRrL. 
Embora sejan metas governamentais estender a matricula re al, nos primeiros anos de ensino de 19 grau, a 808 da população eg colarizävel, nas äreas urbanas (21); ampliar a escolarização nas zonas rurais, de tal forma que atë 1980 haja atend1mento integral da população na falxa etāría de 7-14 anos, haverä necessidade de um esforço concentracio para que essas metas não flquem abalxo das prẹ visões.

Quanto à alfabetızação de adultos, o principal agente é - MOBRAL que vem ampliando sua esfera de atuação, através de convênios com os governos estaduals e municipals.

Os recursos financelros provêm de percentuals do Imposto ce kenda devido pelas empresas e de fundos da Loteria Esportiva.

A atuação do MOBRAL, quantitativamente é demonstrado no gräfico no 3 . 
Gräfico ne $B^{(*)}$

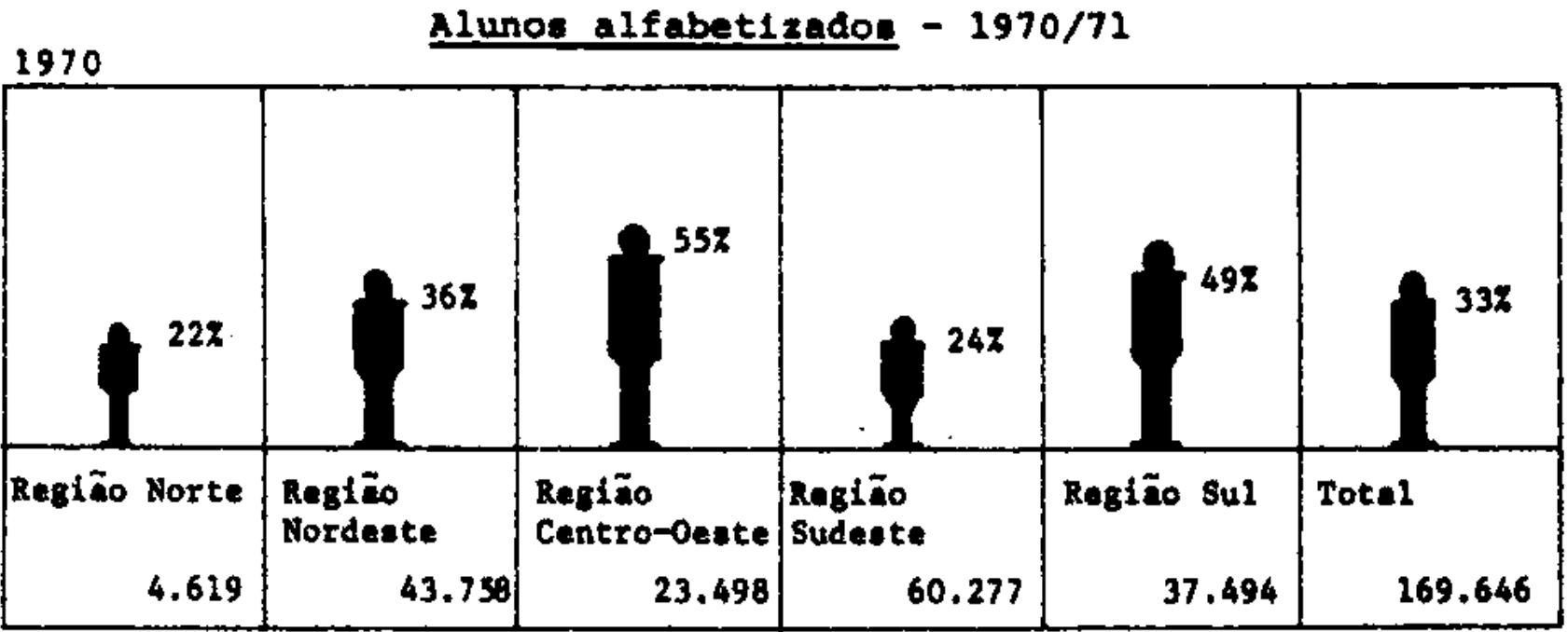

1971

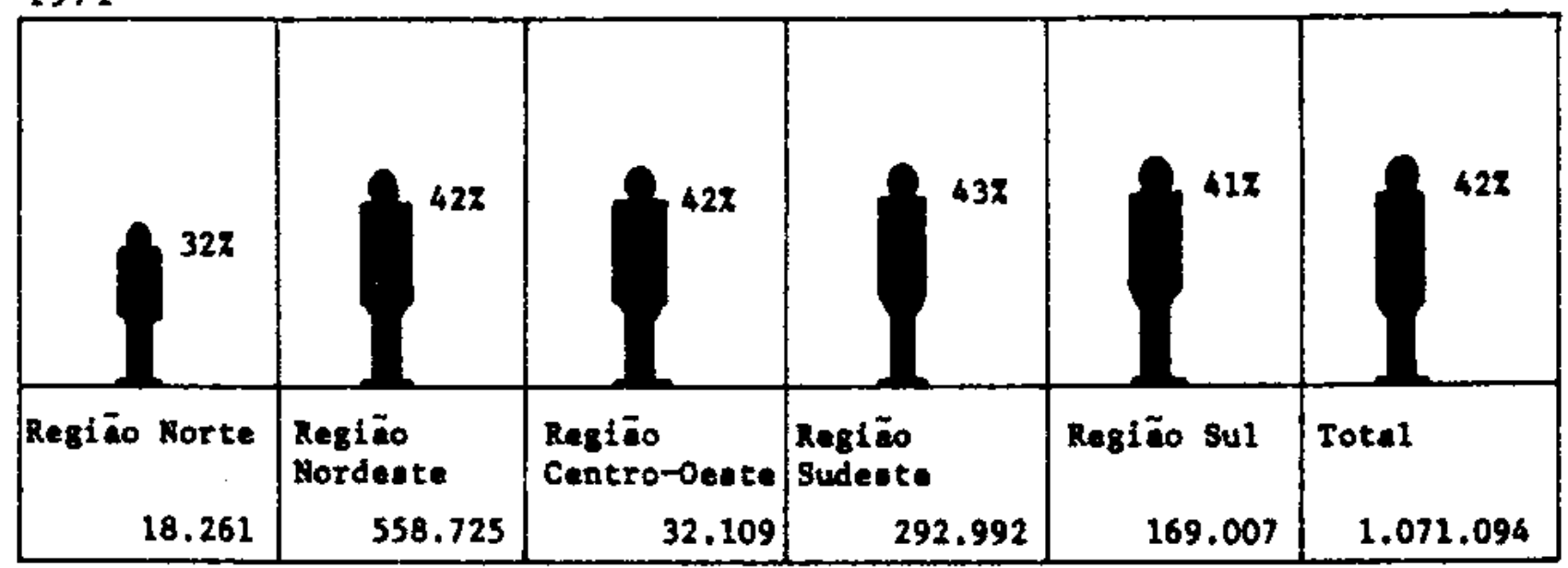

A meta de alfabetização de adultos ä a redução do nümaro de analfabetos na falxa etárła de 15-35 anos a 2 milhöes, an 1974. (22)

$$
\text { Graflco no } 9^{(*)}
$$

Porcentsgam de analfabetos na populacão de mals de 15 anos

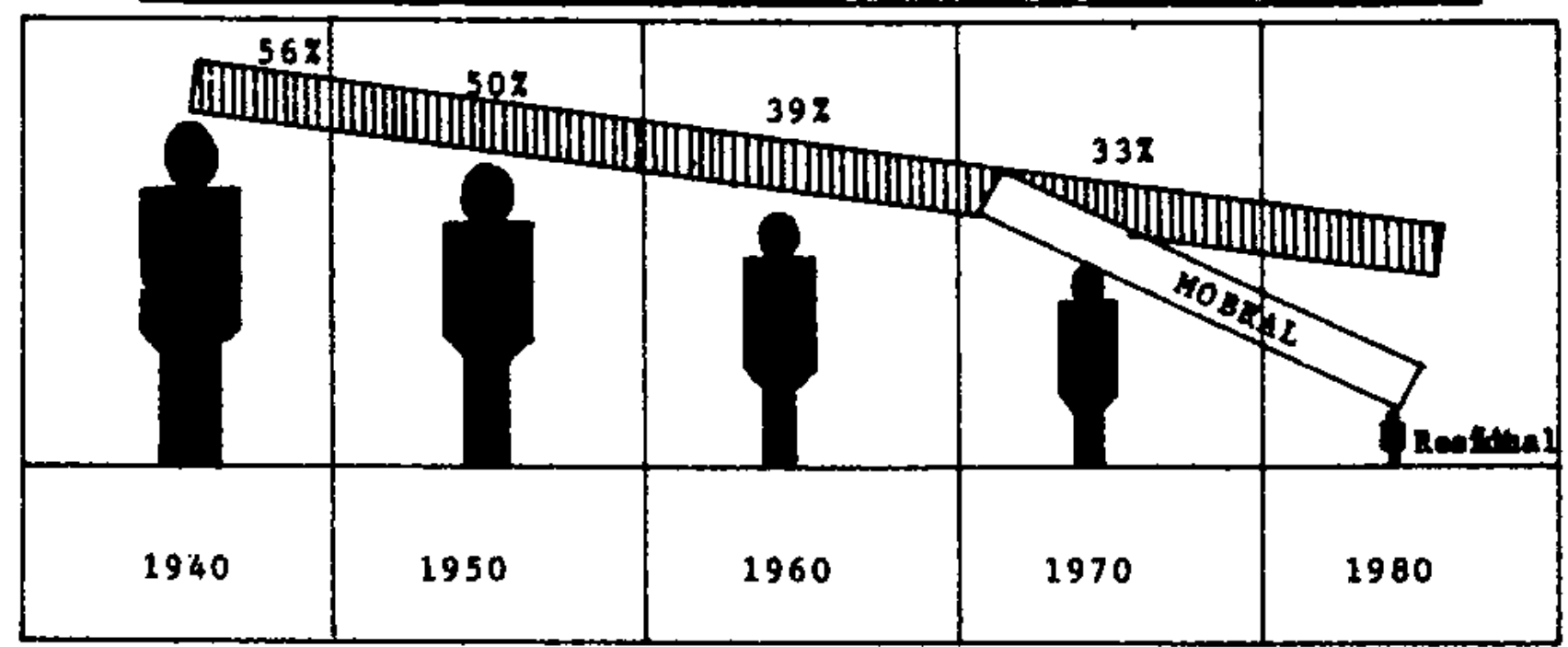

(*) FONTE: MOBRAL - Alfabetização: um projeto brastletro. 
Ambas as tarefas, a de aumentar a matricula efetiva no en sino de 18 grau e a de diminuir o quantitativo de analfabetos, Bão 1mperlosas. Não se poderā durante multo tempo manter a taxa de cres cimento econômico que, em 1971, fol'de 11,38, com parcela considerä vel da população analfabeta. (23)

Uma das vartâvels que condictonam o cresclmento econôntco é a escolar1zação de sua população, Essa escolarização, conforme se assinalou anteriormente, é hoje a responsãvel principal pelo incremento da renda bruta de un pais.

Em contrapartıda, a qualificaçāo profissional minima do homem torna mals clästıco o mercado consunidor interno, sem o que a economia nracłal começa a sofrer un processo de đesaceleração.

Do fcnto-de-vista polftico-social, o ninimo que se pode dizer a respeito do aumento das oportunidades $\epsilon:$ scaclona1s, nos pri meiros anos de vida escolar, é que ele constitul principio báaico de fustlça soc1a?. Como afłrma em dois livros de grande repercursão o professor Anisio Teixeira, "Educacāo nāo è privilégion" "Educacão è um dìreito".

A alfabet1zą̧̃̃̃o pela alfabetlzação, como um flm em $s 1$ mes ma, alêm de ser in Investimonto de quaso nulo retorno, é amadorismo educaclonal. Isso porque ele só, não hablilta profissionalmente 0 homen; quase certainente haverá a recorrêncla ao analfabetismo se nāo houver prossegutimento a da escolar1zação; pode tornar-se causa de frustração Individual.

o esforço em alfabetızar tornar-se-ã văl1do na madıda em que:

- seja məlo para a educação de base, aqul entend1da como aquela que altera padröes de conduta san1tärla, alimen tar, profissional, comunitäria, existencial;

- possa ter prossegulmento, através do ensino supletivo,

- qualisique profissionalmente o individuo.

Paralelizinnte as estruturas econômlcas têm que ser moder n1zadas, sem o que se gerarā un fosso entre nive1s de aspiraçāo e oferta de emprcgo e melhores padrões de vida.

Por 1 s3o mesmo, O MOBRAL tem dedicado parte de seu esfor go para o prosscguimento das atividades educaclonats, após o perío 
do de alfabetização.

$$
3.4 .6 \text { - } 0 \text { ensino da } 19 \text { grau }
$$

Em 11-8-1971 fol aprovada a Le1 np 5692, que te refere wo ensino de 18 e 28 graus.

A muitos pode ter parecido que se tratava de una lel a mals, destinada a flcar no limbo do faz-de-conta, como ocorreu com a Le1 de D1retrizes e Bases da Educação Nactonal, de 1961.

Mas tudo faz crer que 1880 não è verdade, porquanto a 101 nāo fol promulgada para gerar o fato, mas o fato pré-determinou a 1e1. O fato, no caso, é representado pelo slatana sóclo-polftico-oconömlco que demandava novo subsistema educacional, mals flexivel, mals cperativo, mals objetivo.

Já se assinalou anteriormente que um dos grandes obstácu los para o diagnóstico da educação no Brasil é o relativo às estatIsticas. (24)

Como ponto de partida, há a cansiderar o crescimento glo bal da população brasilelra, que é retratado no gráf1co no 10.

\section{GRAPICO NP 10}

\section{Cresclmento da Populacäo Bras1le1ra}

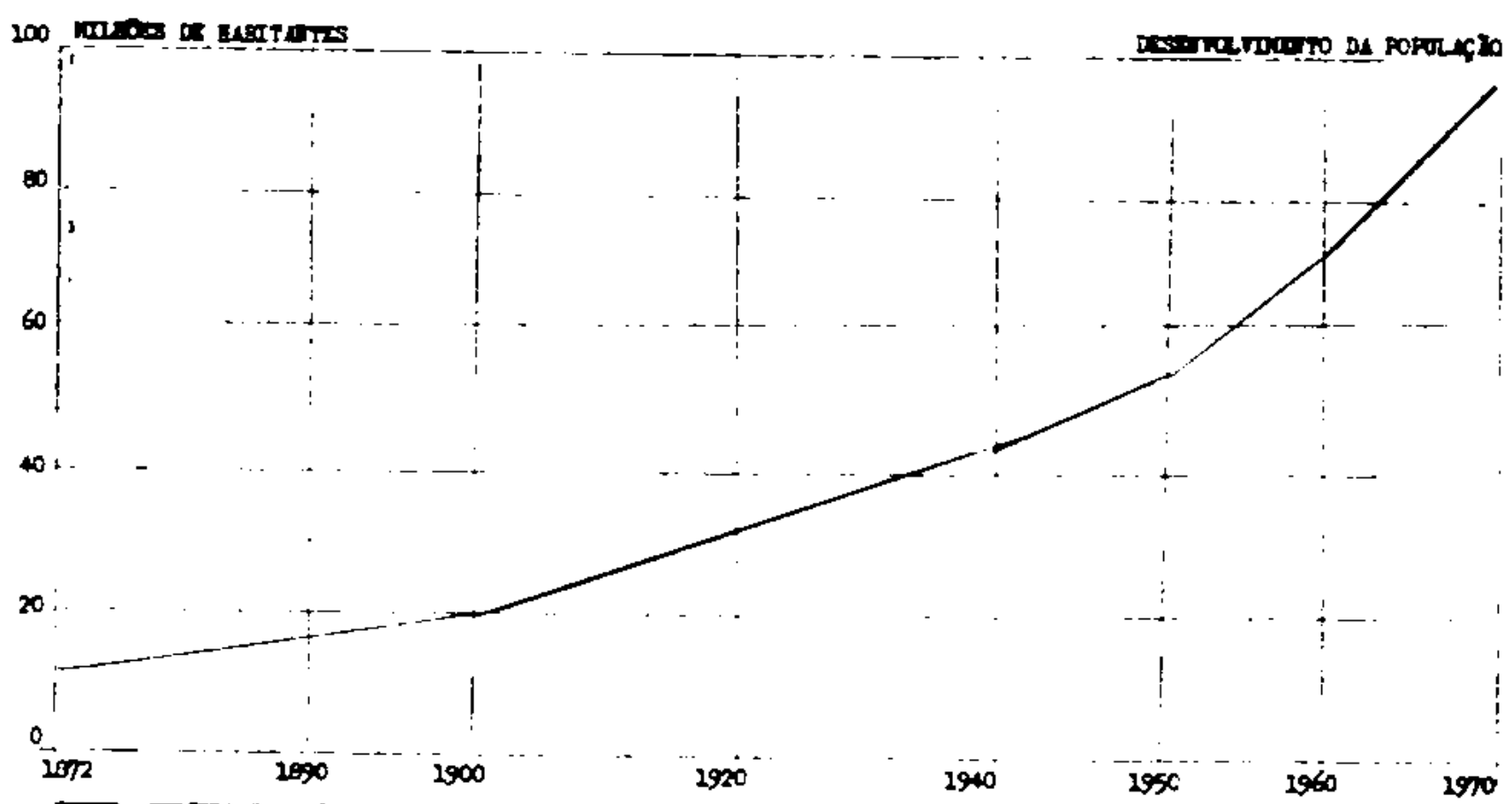

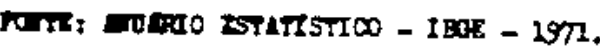


Outros dados a conslderar são os que se referem ao acelerado procesbo de urbanização no Brabil. O gráfico no 11 indica n1tidamente a evolução quantitativa da população urbana que, am 1970, Inlclava ascenção para $60 \mathrm{~m} 1$ hõos.

\title{
Gräf1co no 11
}

DISTRIBUIÇAO DA POPULAÇAO - 1970

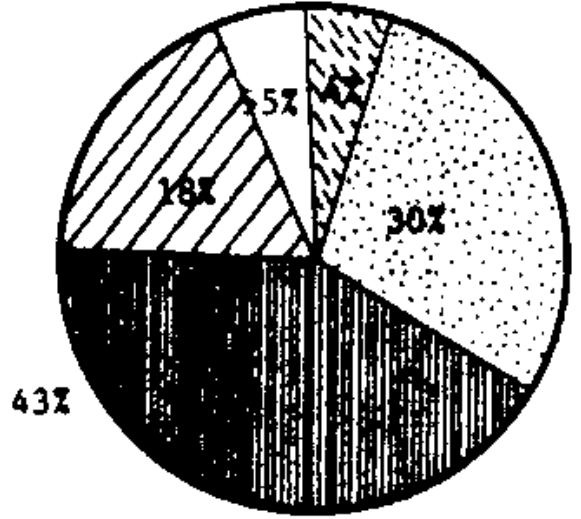

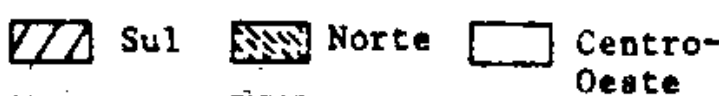
I.: Sudeste Nordente

FONTE: Anuärio Eatatiat1co - IBGE - 1971

- fenomeno reg1日trado globalmente adquire quantificaçö: diversas, do ponto de v1sta das macrorregiöes, conforme se depreende do gräfico no 12 .

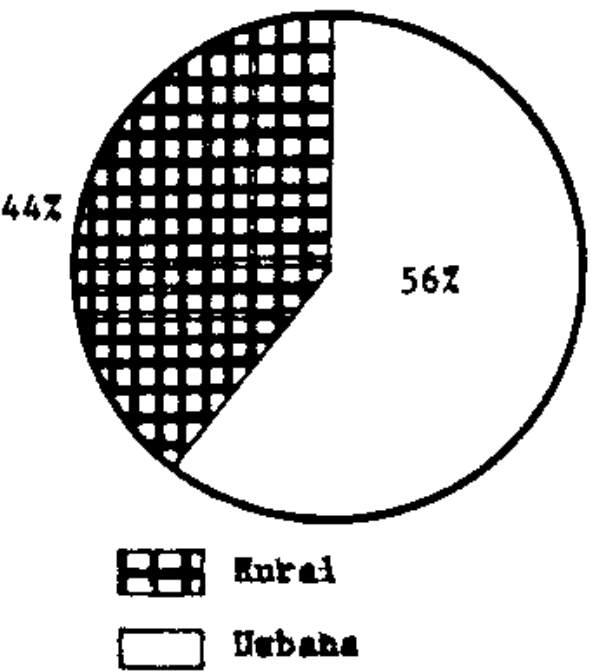

Itronten

\author{
Gräf 160 no 12 \\ POPULAÇAO URBANA E RURAL - REGIOES \\ Censo de 1950 . 1970
}

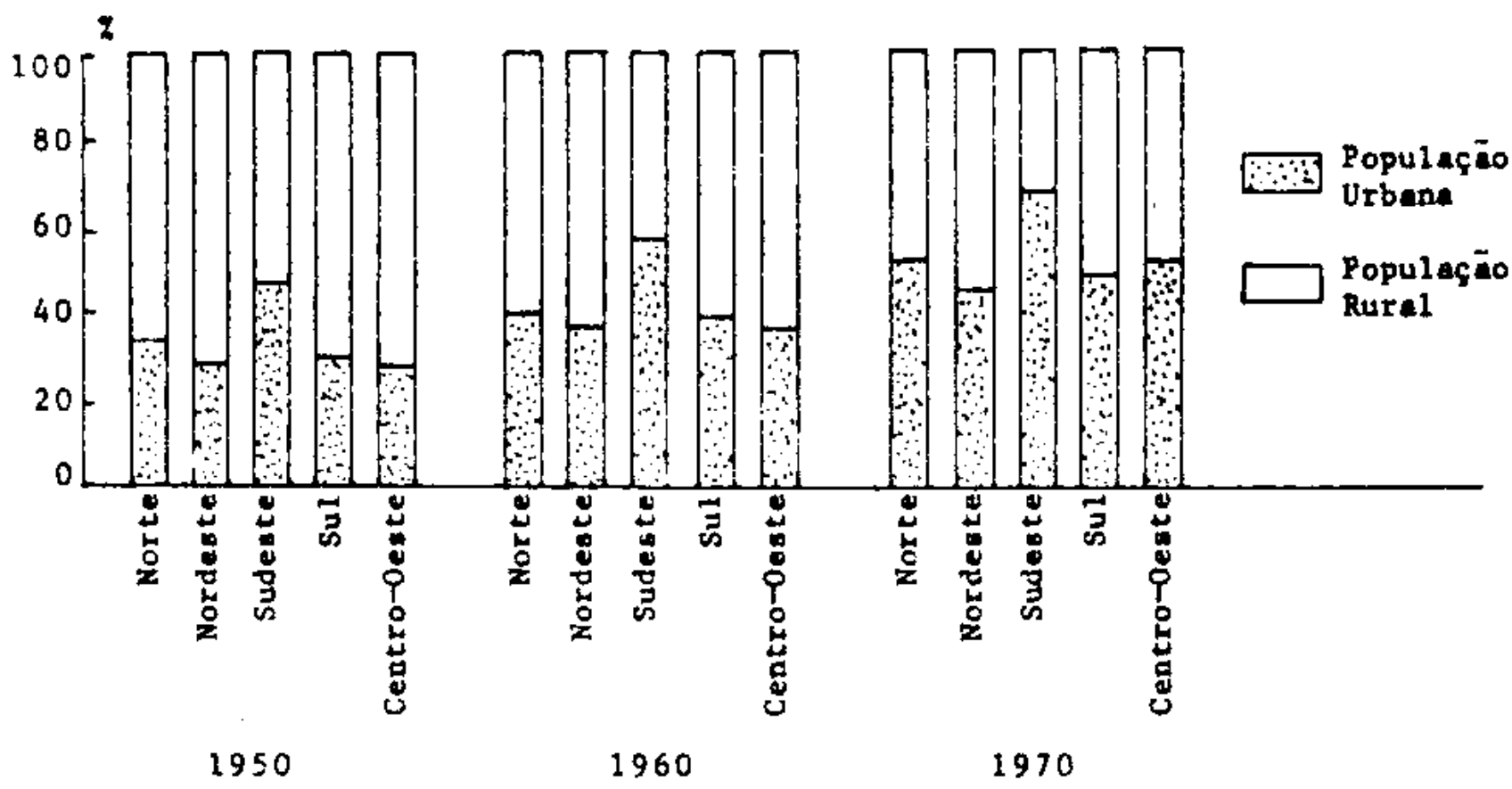

Fonte: Anuärio Eatatiot1co do Brasil - IBGE - 1971. 
Outros dados que auxiliarão a compreensão quantitativa da matrícula no ensino de 18 grau (que engloba os quatro anos do ant1 go "primário" e os quatro anos seguintes do antigo "10 clclo do ensino mëd1o") são transcritos nos quadros segulntes de nos 12 e 13 .

QUADRO NO 12

\begin{tabular}{|l|c|c|}
\hline \multirow{2}{*}{ Anos } & \multicolumn{2}{|c|}{ MATRICULA NO ENSINO PRIMARIO } \\
\cline { 2 - 3 } & NOME ROS ABSOLUTOS & NOME ROS RELATIVOS (1960=100) \\
\hline 1960 & 7.458002 & 100 \\
1962 & 8525823 & 114 \\
1964 & 10217324 & 137 \\
1966 & 10695391 & 143 \\
1968 & 11943506 & 160 \\
1970 & 13413763 & 180 \\
\hline
\end{tabular}

Fonte: IBGE - SEEC/MEC.

A matricula no antigo 19 clclo do ensino médio se cancen trava fortemente no chamado "secundärio", de cunho acadêmilco. As ma trículas nos cursos técnlcos eram bem menos representativas.De 1qual forma, o 18 ciclo - curso normal - para habilitação de professores primārios, pode ser considerado profissionalizante, mas corn matriculas quantitativamente pouco expressivas. Ressalte-se que, em alguns Estados, esse número não representava um total que se profis słonalizasse; estruturava-se como um ginásio do tipo "normal", que constitula pré-requlsito para o ingresso no "normal-29 c1clo", ou, mesmo, no secundário - 29 ciclo: clássico e cientifico.

- Gināsio Orlentadc para o Trabalho marca sua presença, na estatistica de 1969 , com apenas 0.678 do total.

Observe-se, a respeito, o quadro no 13. 
QUADRO NQ 13

Matricula no ensino méd1o, segundo os ramos de ens1no e os c1clos didät1cos 1960. 1965 e 1969 (Foram sublinhados os dados referentes ao $18 \mathrm{clclo}$

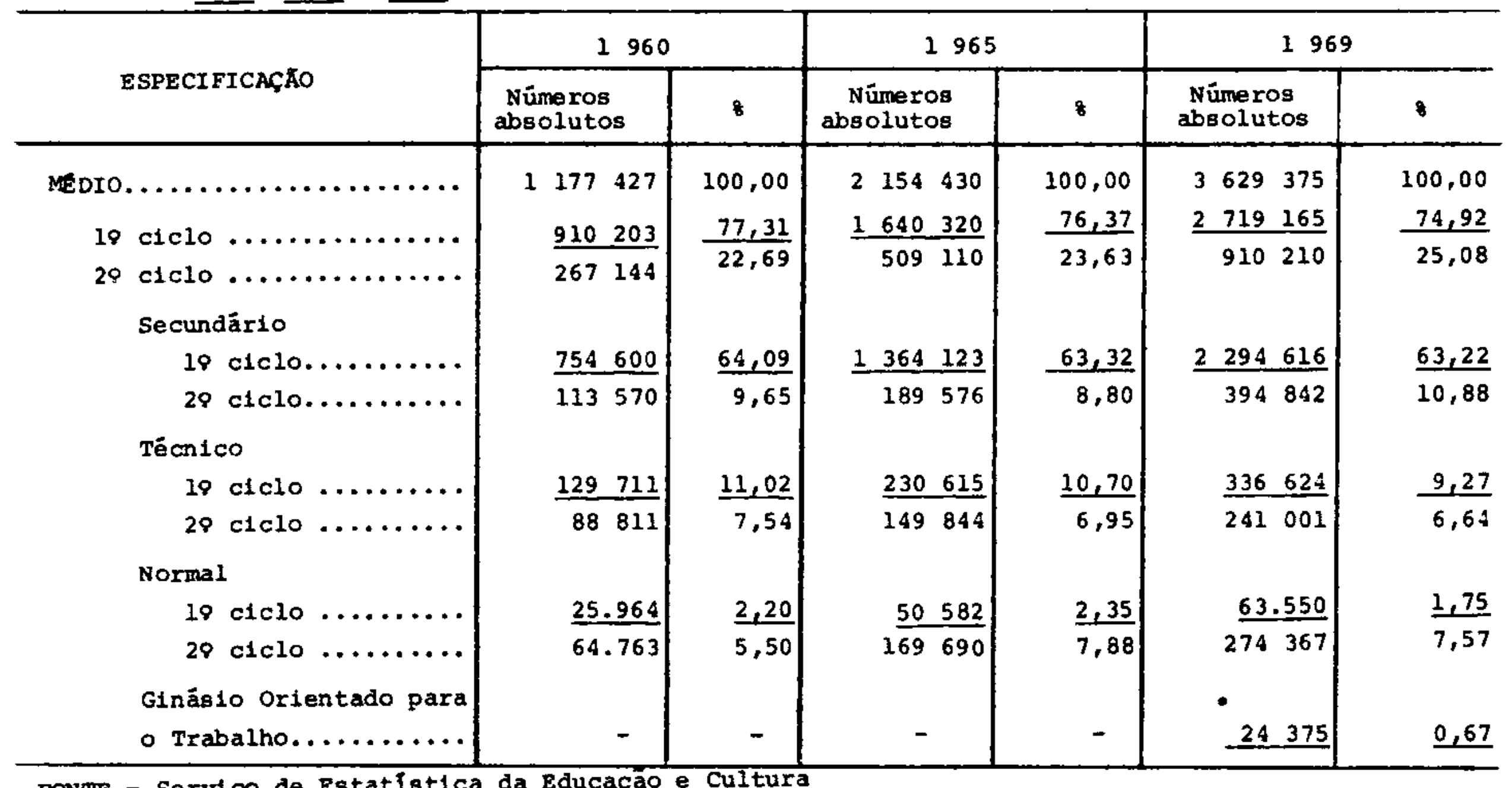

FONTE - Serviço de Estatistica da Educaçao e Cultura

NorA - A part1r de 1968 , Inclutram-se os rams: Artistico, Economia doméstica e Enfermagem em "Técon 1 co".

FONTE - Desenvolvimento da Educą̧ão no Brast1 - MEC - 1971 
A reforma do ensino, no que se refere ao 19 grau, iniclou sua implantação a partir do ano de 1972, variando de intensidade de Estado para Estado. Todos eles, porém, prepararam seus planos para a Implantação da Reforma, que se farā gradativamente. Atē 1976 as prı̂ melras turmas terão concluído a fase iniclal (quatro primeiros anos) da Reforma, enquanto outras terão terminado o seu perfodo de escolarização obrigatōría e gratuita (oltava sērie do ensino de 18 grau).

Destacam-se, na Lei 5692/71, aspectos posit1vos para o ensino de 19 grau. Para alcançar os objetivos propostos pela Lei oe rá necessărio o malor culdade para evitar os possiveis pontos de estrangulamento que poderlam levar à impraticabilidade a implantação efetiva do subsistema.

\section{Objetivos}

\section{- gratuidade}

- extinção do exame de admissão

- aumento do número de anos de escolarização minima para ofto

- Intercomplementaridade quanto à utilização dos prëdios e e quipamentos

- maior flexibilidade curricular

- sondagem vocacional

- maior assistència material ao aluno
Possiveis pontos de estrangulamento

$-$

- ampliação física da rede escolar; reduçäo da capacidade oct osa de prédios

- preparação do magistério e do pessoal têcnico e administrat 1 vo

- alocação de recursos

- dificuldade na prática quanto à utilização de prédlos c/ou mobiliārio por alunos de diferentes idades e entrosamento de diferentes administrações

- preparaçāo e treinamento de recursos humanos

- habilitação de pessoal, equtpamento escolar, adequação de prê dios

- alimentação escolar; assistēncla médico-sanitäria; material escolar 
Na anălise dos objetivos e dos pontos de estrangulamento, assinalados anteriormente, deve-se levar en conta, en regime de al ta prioridade, o problema da qualidade do ensino, a fim de se cor rigir un dos grandes focos de desperdiclo: a repetēncla e a evasão.

Observando-se o Gräfico no 13, tem-se ldéla do träglco perfil do ensino brasilelro, nas séries iniciais, em particular a perda entre $\circ 18$ e $\circ 29$ anos de escolarização.

\section{GRAFICO NQ I3}

Ensino Médio - 1958/1964

1958 MATRICULA. 297.904; PERDA.96,58

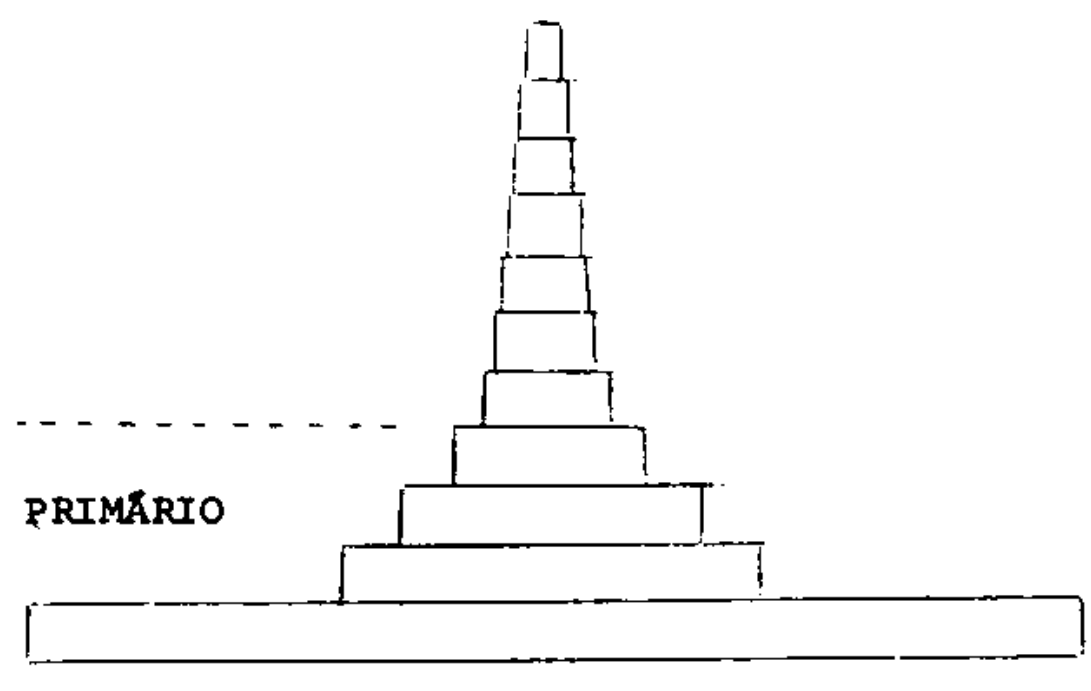

Fonte: SEEC

\subsection{7 - O ensino de 29 grau}

Corresponde ao antigo ensino médio - 28 ciclo,subdividido em ramos: secundärio, técnico (industrial, comercial, agricola) e normal.

A evolução das matrículas pode ser observada no quadro no 13. 
Ficam claras as segulntes observaçöes:

- Em 1969, o ensino de 28 ciclo englobava cerca de $1 / 4$ das matriculas do nivel médio;

- o secundārio e o normal abranglam a maior parte das matrlculas, restando para o técnico 6,648 dos 25,088 do trtal;

- percentualmerte, o ersino técnico vinha decrescendo : $1960-7,548 ; 1955-6,958 ; 1969-6,648$.

O grafico no is ilustra ega distribuição.

$$
\text { Gráflco no } 14
$$

\section{DISTRIBUICYKO DA MATRICULA POR RAMOS DE ENSINO}

RAMOS DE ENSINO - 1970
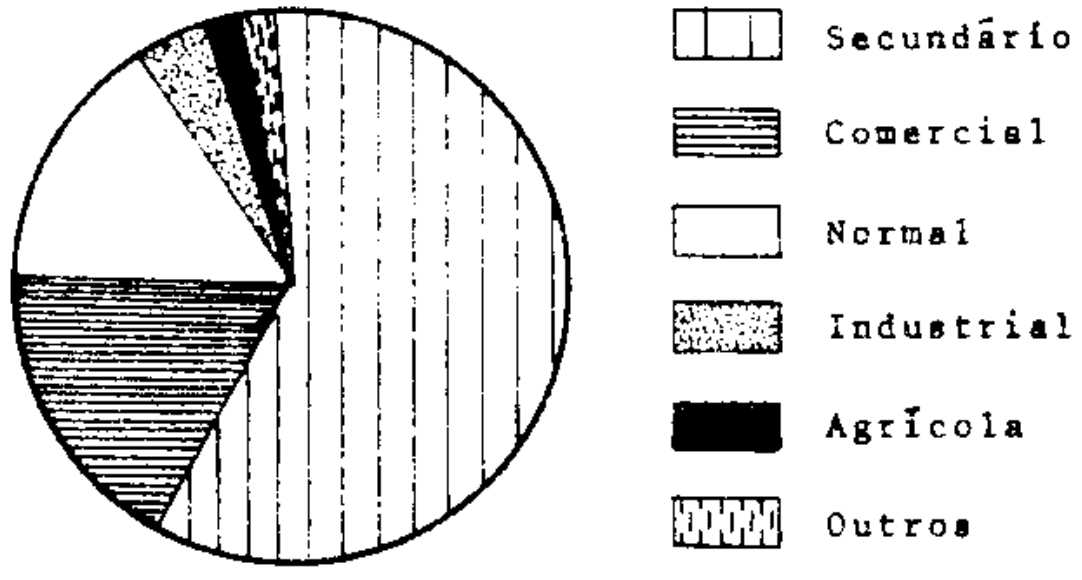

Fonte: Anuär10 Estatistico - IBGE - 1971

Essa divisão em ramos tem ralzes históricas profundas: o ensino secundárto e o normal de caráter "humanlata"; o ensino técnlco, de orlentaçõo "manual". Os dola primeiros, refúglo das chaoseg mals abastadas; o ültmo, destinado aos flihos das familias de estratos gociais mals balxos.

Tudo funcionava como se a meta de grande parte dos estudantes fosse o ensino universitärio; alguns seriam os técnicos de nivel mëd10, mas aspirando tambén a ingressar na escola superior, o que, aliās, era frequentemente tentado. 
As transformaçöes no sistema sóclo-econômico do país, todavia, demandam outra orlentação no ensino de 28 ciclo. A tecnifica ção das atividades nos setores primário, secundärto e terciárto, es tá a exigir cada vez mais mão-de-obra qualificađa, seja no escalão superior, seja no inferior, seja no intermediário. A carência de técnlcos de nivel médio chegou a um ponto altamente perigoso para a expansäo e a modernização das empresas. Toma-se necessärio, portanto, prever a formação de pessoal qualificacio de rivel mëđto.

A Le1 no 5692 veio ao encontro desss exigência, criando o ensino de 29 grau, de cunho profissionalizarte.

"... a lei abandona a estrutura de tipos de escola e ramos de ensino diferenclados, e visa a conferir predcrisantemente ter minalidade ao ensino de $28 \mathrm{grau}$, pela oferta, através de mecanismos de entrosagem e intercomplementaridade entre escolas, empresas e outras Institulçöes, bem como a crlação de centros intexescolares, de habllitaçõs 3 profissionals extgidas pelo mercado de trabalho. Abrax-se desse modo maiores possibllidades de formação regular de recursos humanos de nível intermedtário, segundo processos dinâmicos e flexíveis que acompanham a evoluçāo continua das necessida des e condições dos mercados de trabalho locais e reglcnats" (25)

A partir de 1972, iniciam os subsistemas estadua1s e o fe deral de ensino a 1 mplantação da nova modalidado de escola.

Evidentemente, hã una série de obstäculos a vencer, desde o arraigado preconceito popular contra a ezcola profissionalizante de nivel médio, até a dificuldade de estabelecer una rede de escolas fisicamente aparelhada e com pessoal docents qualificado.

Tudo faz crer que gradat1vamente os obstáculos serão ultrapassados, notadamente a partir dos majores núcleos urbanos, onde as empresas dos setores secundảrio e terciärto apresentan mator vitalidade e dinamismo.

o sistema empresarial e a criação de uina tecnologia nacio nal estarlam seriamente comprometidos se continuasse a ser registra do um enorme vazio na formação de técnicos de nivel médio. (26) 
Para se ter uma idëla do amplo lequo de oportunidades pro fissionais que se abre através do ensino de 28 grau, vale transcre ver a relação a seguir.

CURSOS TECNICOS DE ENSTNO MEDIO

AREA AGRICOLA

Agricultura

Economia Doméstica

Laticinios

Mecänico Agricola

Pecuäría

Viticultura e Enologia

\section{AREA COME RCIAL}

Aamintstração

Comércio e Propaganda

Contabilidade

Estatistica

Hotelaria

Secretariado

Turismo

AREA INDUSTRIAL

Aerofotogrametria

Agrimensura

Alimentação

Artes Grāficas

Cerânica

Curtume

Decoração

Edif1 cação

Eletromecânica

Eletrotēcnica

Eletrônica

Estradas

Estruturas Navais

Fabricação de cerveja e

Refrigerantes
PROFTSSŐES CORRESPONDENTES

Técnico Agr:-cola

Técnico em econonta rural

domés tica

Técnico Industrial em laticinios

Técnico em Mecânica Agri cola

Técnlco em zootecnia

V1ticultor ou Enologista

Assistente de Administração

Tëcnico en Comërcio e Pro paganda

Tẻcnico em contabilldade

Tëcnico em Estatistica

( nr)

Técn 1 co em Secretarlado

( $n r$ )

( $n x$ )

Tëcnico em Agrimensura

( $\mathrm{nr}$ )

Técnico em Artes Gräficas

Técnico em cerânica

Técnico em Curtume

Técntco em Decoração

Técnico em Edificação

Técnico em Eletronecânica

Técnico em Eletrotécnica

Técnico em Eletrônica

Téconico em Estradas

Técnico em Estruturas Na

vais

(nr) 
AKEA INDUSTRIAL

Prótese
Química
Refrigeração de Ar
Condicionado
Saneamento
Telecomunicaçöes
Tëxt1l
Geologia
Laticinios
Manutenção de Aeronaves
Mecänica
Matalurgia
Metcorologia
Mineração
Pesca

Técnico em Prötese

Técnico em Química

Técnlco em Refrigeração

de Ar Condicionado

( $\mathrm{nr}$ )

Técnico em Telecomunica-

çöes

Técnico em Indústria Téx t11

Técnico em Geologia

Técnico em Laticínios

Técnico em Manutenção de

Ae ronaves

Técnico em Mecânica

Técnico em Metalurgia

Técn1co em Meteorolog1a

Técnico em Mineração

Técnico em Peaca

\section{EM ESTUDO (*)}

$\begin{array}{lr}\text { Hidrografia } & (\mathrm{nr}) \\ \text { Cartografia } & (\mathrm{nr}) \\ \text { Energia Nuclear } & (\mathrm{nr}) \\ \text { Comunicação } & (\mathrm{nr}) \\ \text { Näutica e Mäquinas } & (\mathrm{nr}) \\ (\mathrm{nr}) \text { não regulamentada } & \\ \text { FONTE: Educaçäo no Brasıl - MEC - } 1971\end{array}$

(*) As possibilidades de criaçāo de novas habll1taçōes são imensas, e irão se configurando à medida em que se dtversiflcarem as attvidades nos setores primário., secundário e terciárıo. De mo mento, outras habilitações estão sendo pesquisaras e fá propostas aos słstemas de ensino. 
3.4 .8 - Ensino universitārio e de pós-graduação.

O ensino superior no Brasil data do século XIX, quando pré dominavam as escolas de Direito e de Kedicina, no Recife, em Salva dor, no Rto de Janeiro e em São Paulo. A formação militar compelta va o quadro restritissimo que refletia una socledade dual. No estrato mais elevado, a esmagadora minorla se formava ou apenas se "ilustrava" nas escolas superiores; a pouca expressiva classe média se contentava com a escolarização primária e, raramente, de nivel médio. O restants da população, era analfabeta ou l1geiramente alfabetizada o que representava quase o mesmo. A sociedade agrăria e escravocrata de mals não necessitava.

Conforme fol anteriormente assinalado, a partir de 1930 é que se registraram transformaçōes mais profundas no sistema söciopolitico-econômico e, en conseqüência, no subsistema educacional.

A Implantação industrial na década de 1940, a urbanizaçāo acelerando-se, começaram a alterar o panorama da educação.

- prōprio ensino superior viu multiplicar-se o número de escolas e sua diversificação se acentuou. Entretanto, as matrículas eram mais numerosas nos ramos de Filosofia e Direlto.

- quadro no 14, a seguir mostra essa hipertrofia.

A expansão das matriculas fol bastante sensivel na década de 1960, quando passou de 03.202 alunos para 425.479 alunos.

O quadro no 15 ilustra essa informação, assim como nostra o crescimento do corpo docente e uma melhoria na relaça aluno/ professor.

A partiz de 1968, com a 1mplantação da Reforma Universitä rla, è que começou a se delinear uma reorlentação do ensino super 1 or que atualmente $\vec{e}$ ministrado em 63 universidades ( 32 federals) e cerca de 550 estabelecimentos independentes.

Essa nova reformulação visa, em linhas gerais:

- a aumentar os investimentos nas āreas constderadas prio ritärias (Saúde, Ensino, Tecnologia), a fim de elastecer a ofexta de matrículas e. de melhorar os padrões qual 1 ficativos de ensino; 
- a melhorar os processos de exame vestibular (vestibular uniftcado);

- a incentivar a ampliação dos centros regionais de pósgraduação;

- a diminuir a evasão, que ultrapassa a 208 das matrículas intcials;

- a aumentar o nümero de professores em regime de tempo in tegral. (27) 
$\underline{B R S I L}$

Matrícula no ensino sperior, segundo os ranos de ensino - 1960, 1965 e 1970

\begin{tabular}{|c|c|c|c|c|c|c|c|c|c|}
\hline \multirow{2}{*}{ RAMDS ER ENSINO } & \multicolumn{2}{|l|}{1.960} & \multicolumn{2}{|l|}{1.965} & \multicolumn{2}{|l|}{1.970} & \multicolumn{2}{|c|}{ 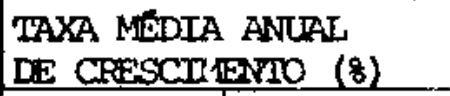 } & \multirow{2}{*}{$\begin{array}{l}\text { Indioe de } \\
\text { cressimento en } \\
1970 \\
(1960=100)\end{array}$} \\
\hline & & & & & & & & & \\
\hline Administrarão e econcmia. ...... & 8838 & 9,48 & 19751 & 12,68 & 63816 & 15,00 & 17,55 & 26,56 & 722 \\
\hline narricultura................ & 1936 & 2,08 & 4397 & 2,82 & 6855 & 1,61 & 17,91 & 9,31 & 354 \\
\hline smuitetura e Urbanismo........ & 1589 & 1,70 & 2601 & 1,67 & 4762 & 1,12 & 10,51 & 13,20 & 270 \\
\hline artistio $\ldots \ldots \ldots \ldots \ldots \ldots \ldots$ & 2813 & 3,02 & 2056 & 1,32 & 6338 & 1,49 & 5,23 & 22,25 & 225 \\
\hline Direito $\ldots \ldots \ldots \ldots \ldots \ldots \ldots$ & 23293 & 24,99 & 33603 & 21,57 & 71236 & 16,74 & 7,66 & 16,63 & 306 \\
\hline Enfermager $\ldots \ldots \ldots \ldots \ldots \ldots$ & 1624 & 1,74 & 1056 & 0,69 & 2713 & 0,64 & 9,54 & 20,82 & 167 \\
\hline Fncenharla ............... & 10821 & 11,61 & 21986 & 14,11 & 15 707 & 10,98 & 15,57 & 16,55 & 432 \\
\hline Fanmäcla $\ldots \ldots \ldots \ldots \ldots \ldots$ & 1.841 & 1,98 & 2350 & 1,51 & 4700 & 1,10 & 5,47 & 14,97 & 255 \\
\hline Filosofia, Ciências e Letras.. & 20418 & 21,91 & $36 \quad 314$ & 23,31 & 128402 & 30,18 & 12,25 & 29,09 & 629 \\
\hline redictina $\ldots \ldots \ldots \ldots \ldots \ldots \ldots$ & 10316 & 11,07 & 15574 & 10,00 & 32287 & 7,59 & 8,73 & 15,81 & 313 \\
\hline Medicina Veterinäria ........ & 802 & 0,56 & 1740 & 1,12 & 2830 & 0,66 & 17,27 & 10,34 & 353 \\
\hline dantologia $\ldots \ldots \ldots \ldots \ldots$ & 5591 & 6,00 & $6 \begin{array}{ll}644 \\
6\end{array}$ & 3,88 & 9254 & 2,17 & 1,59 & 8,91 & 165 \\
\hline Servico social ............. & 1289 & 1,38 & 3086 & 1,98 & 6201 & 1,46 & 19,66 & 15,27 & 481 \\
\hline 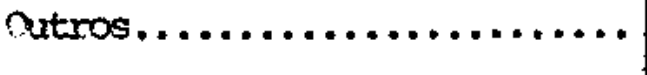 & 2031 & 2,018 & 5218 & 3,35 & 39377 & 9,26 & 31,54 & 52,13 & 194 \\
\hline TOTPL $\ldots \ldots \ldots \ldots \ldots \ldots \ldots$ & 93202 & 100,00 & 155781 & 100,00 & $425 \quad 478$ & 100,00 & 10,88 & 22,37 & 456 \\
\hline
\end{tabular}

FTNEE - Serviço de Estatística da Educação e oultura 


\section{QUADRO NQ 15 \\ BRASIL \\ ENSINO SUPERIOR}

Crescimento da Matrícula, do Corpo Docente e da Relação Aluno/Professor. nos períodos $\underline{1960 / 65 \text { e } 1.965 / 70}$

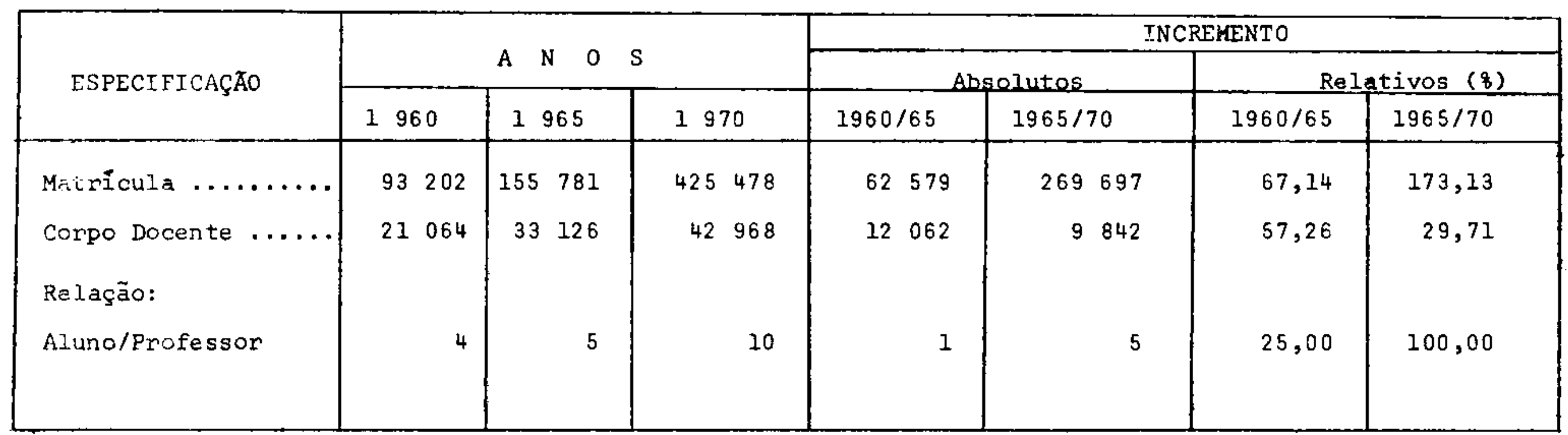

FONTE - Serviço de Estatística da Educaçäo e Cultura. 
A extensão universitária visa a integrar a universidade no contexto das realidades nacionals e reglonais. Para tanto, lança mão do PROJETO RONDON e do CRUTAC.

O primeiro se realiza através de contactos diretos dos alu nos com äreas remotas do pals e, numa etapa posterior, através da instalação de campl universitärios avançados.

o segundo, que é o Centro Rural Universitärio de Trelnamen to e Ação Comunttäria, representa um esforço no sentido de integrar os alunos na ärea de Influêncla pröxima da universidade, através de estägios na zona rural.

Cumpre assinalar uma outra modal1dade de entrosamento dos cursos universitärıos com a dinämica do sistema sōclo-econômico:tra ta-se do CIEE (Centro de Integração Escola-Empresa), que atuará, tambëm no nivel de ensino de 29 grau.

O ensino de pös-graduação é vital para a melhoria do ensi no universitärio, na medida em que qualifique o pessoal docente(mes trado e doutoramento).

Igualmente, possibllitarā o desenvolvimento da pesquisa de nivel superior, sem o que a politica cientifica e tecnológica não terã efetivação. A estratēgla montada, nesse sentido, prevê, em linhas gerals: (28)

- ordenar e acelerar a atuaçäo do Governo;

- desenvolver āreas tecnológicas prioritárias;

- fortalecer a infra-estrutura tecnológica e a capacidade de inovação da empresa nacional, privada e pública;

- acelerar a transferēncia de tecnologias, politica de patentes, interna e externa;

- integrar indústria-pesquisa-universidade.

Para tanto, a previsão de dispêndios é a seguinte: 
QUADRO NQ 16

DESENVOLVIMENTO CIENTIFICO E TECNOLOGICO

\begin{tabular}{|c|c|c|c|}
\hline Setores & $\begin{array}{c}\text { Situação em } \\
1970\end{array}$ & $\begin{array}{c}\text { Meta para } \\
1974\end{array}$ & $\begin{array}{c}\text { Aumento } \\
(8)\end{array}$ \\
\hline $\begin{array}{l}\text { Dispêndios em projetos } \\
\text { prioritärios (Plano Bä } \\
\text { sico) Cr\$ milhōes de } \\
1972 \ldots \ldots \ldots \ldots \ldots \ldots \ldots \\
\text { Dispêndios com pesqui- } \\
\text { sas de minerais atômi- } \\
\text { cos (Cr\$ milhöes de } \\
1972 \ldots \ldots \ldots \ldots \ldots \ldots\end{array}$ & 236 & 580 & $\begin{array}{l}146 \\
167\end{array}$ \\
\hline
\end{tabular}

Fonte: Projeto do I PLANO NACIONAL DE DESENVOLVIMENTO ECONOMICO E SOCIAL - Quadro III.

3.4.9 - Ensino e trabalho.

A perniciosa dicotomia entre o ensino e trabalho,"humanis mo $x$ tecnicismo", cujas origens datam dos anos iniciais da coloniza ção, só aos poucos foi sendo vencida $e$, ainda, não o foi completamente.

A profissionalização via ensino, sempre foi vista pelas classes "soi-disant" aristocrăticas e, por via de imitação, da bur guesia, como admissivel apenas ao fim do processo longo de escola rização, ou seja, ao fim do curso universitário.

Ora, jă se sabe à farta que:

- para cada mil alunos que se matriculam no 18 ano da es cola, outras trezentas crianças ficam fora do sistema;

- a perda real, por evasão é acentuada, a partir do 19 pa ra $\circ 28$ ano de vida-escolar;

- de cada mil alunos acima, pouco mais de quatro ingressam na universidade;

- onsino pseudo-humanista nāo habilita o aluno para as atividades profissionais;

- a Lei n\& 5.692 procura acabar de direito e de fato com 
a dicocomia e:ısino-trabalho. Isso não se fará de pron to, mas as cebo de um processo lento de conscientização por parte das familias e dos pröprios alunos.

Atē hoje a cducaçc̄o formal, no Eras1l, nāo habilita para o trabalho. Acrescenta-se a esse fato o räpido cresclmento de mogräflco do país, o qus se reflete numa plrāmlde etārla em que os jovens sāo cafa vez mals numerosos. (Ver gräfico no 15)

POPULAÇÃO

COMPOSIÇÃO POR IDADE

1940 - 1970 $\left[\begin{array}{r}70 \\ \text { e }\end{array}\right.$

Gräfico n? 15

MULHERES

HOMENS

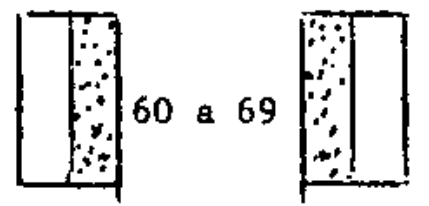

50 a 59

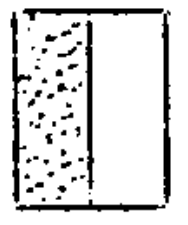

40 a 49

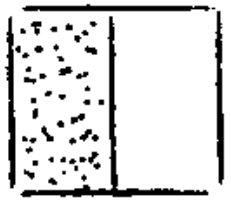

30 a 39

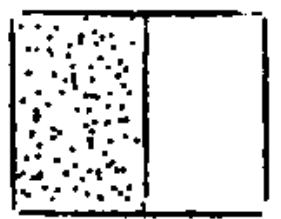

25 a 29
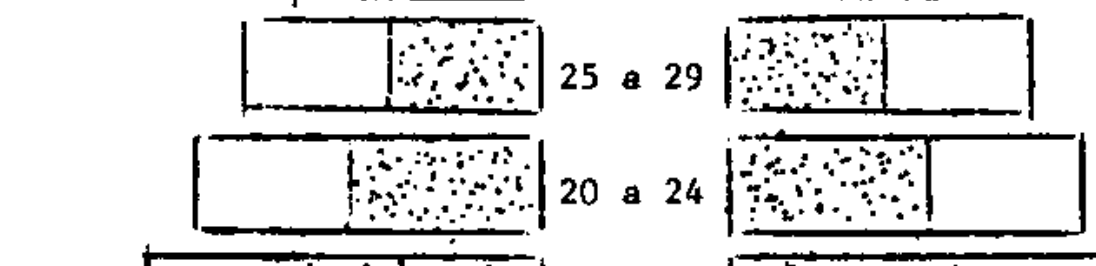

15 a 19

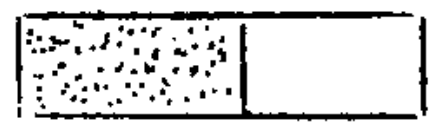

$\mid$

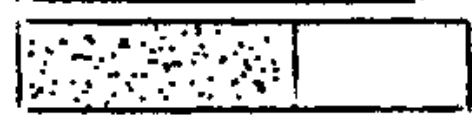

$\because \therefore \therefore ;$
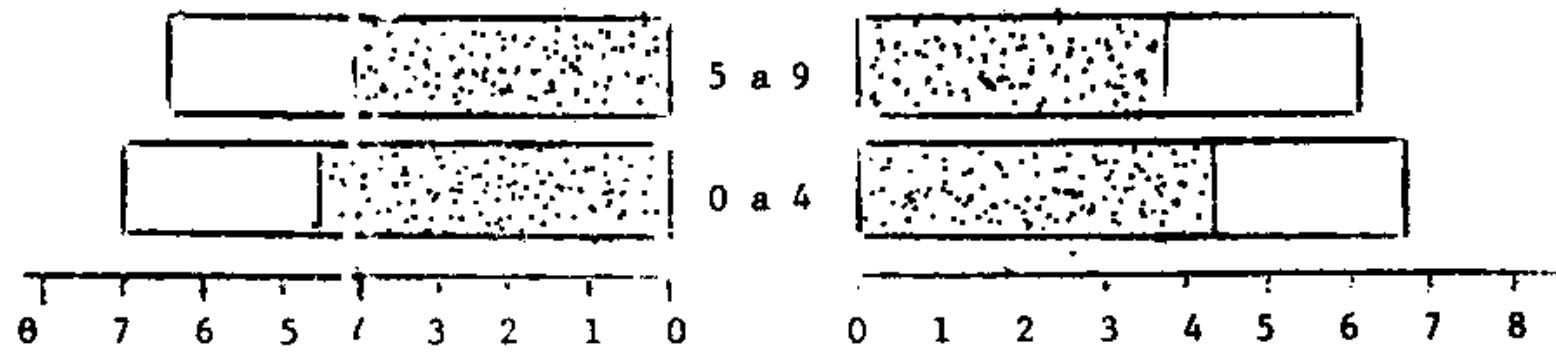

POPULAÇÃO EM MILHÕES

1040

Fonte: Rnuäri, Estat istico - IBGE - 1971 
Da análıse dos fatos resulta que:

- a força de trabalho no Brasil é pequena: 32,98. em

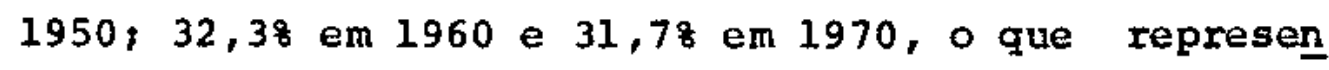
ta menos de 30 milhões ativamente econômicos. A taxa de atividade econōmica mundial é de 438,458 na Euro pa, 40 na Amërlca do Norte e 358 na Africa do Sul; (29)

- as elevadas taxas de analfabetismo real ou de analfabetismo de retomo (resultante de 1 ou 2 anos de escolarizaçio intcial, de qualidade duvidosa, ou de programas de mera alfabetização, sem prossegulmentoe sem modiflcação na estrutura econômica e social), ge ram uma mão-de-obra de baixisstma qualificaçāo prô fissional;

- a escolarização de 4 anos ou mals, medularmente acadêmica e desvinculada de sondagem de aptidöes ou de InIciação para o trabalho. Igualmente contribul mu1 to pouco para a habilitação profissional.

Assim, os trinta milhöes de individuos economicamente ativos, no Brosil, constituem uma mäo-de-obra de baixa produtivida de.

Criou-se um mito no Brasil a respetto da māo-de-obra: de que sendo ela pouco qualificada, é de baixa remuneração. Por seu turno os pequenos insumos com salários tornam mals barata a produção. Sendo mals baixos os custos de produção, principalmente por força dos balxos salärlos, maior è o poder de competlção inter na e externa dos produtos fabricados no Brasil.

Esse mito precisa ser analisado friamente à luz das es tatisticas, quando, possivelmente, se revelará uma faläcia.

Is to porque:

- a mão-de-obra de baixa qualıficação apresenta peque na produtividade;

- o trabalhador semt-qualificado tem reduzido poder aquisitivo, representando um ponto de estrangulamento na expansäo do mercado interno;

- os cronogramas de atividades a de custos são, constantemente, ultrapassados pela qualificação balxa da māo-de-obra, o que encarece a produção; 
- o desgaste de material e as perdas por deficiêncla do produto concorrem igualmente para onerar os custos de produção.

Atualmente, nos palses de produção e consumo de massa, os custos mais baixos não são computađos à mão-de-obra, são fruto do aumento da produtividade e da qualidade. Isto os torna mais capa citados para a concorrência nos mercados interno e externo. De igual maneira, a saúde do organismo econômico associada à qualificação da mão-de-obra, respondem pela pequena taxa de desemprego.

o desemprego e o subemprego estruturais, inversamente, geram mal estar social e a necessidade de o Estado intervir pater nalistamente para não criar focos de tensão. (30)

Em 1970, 850000 novos empregos deviam ser criados no Brasil, para atender à oferta . adicional de mão-de-obra. Em 1974, esse número passarā a cerca de 920000.

Evidentemente è preciso que essa força de trabalho seja qualitativamente expressiva.

As formas de quallficar essa mão-de-obra são:

- o ensino formal;

- o ensino supletivo que reincorpora ao sistema formal os não ingressados em ëpoca normal ou dele evadidos pre maturamente;

- os programas especificos de treinaunento da mäo-de-obra.

Os últimos são de diversas estruturações.

18 - O MOBRAL, através do curso de educação integrada, como se observa no quadro a seguir:

QUADRO NQ 17

*MATRICULA INICIAL NOS CURSOS DO MOBRAL - BRASIL 1970/1971

\begin{tabular}{|c|c|c|c|c|}
\hline \multirow{2}{*}{ ANO } & \multicolumn{2}{|c|}{ ALFABETIZACÃO FUNCIONAL } & \multicolumn{2}{|c|}{ EDUCACĨO INTEGRADA } \\
\cline { 2 - 5 } & MUNICIPIOS & ALUNOS & MUNICIPIOS & ALUNOS \\
\hline 1970 & 611 & 509014 & - & - \\
1971 & 2093 & 1632842 & 193 & 42000 \\
\hline
\end{tabular}

* FONTE: Assessoria Técnica do MOBRAL. 
Levando em conta, as deserçōes e as reprovaçöes, os resul tados esperados foram fortemente reduzidos - Ver Gräfico n\& 8 .

$2 \%$ - O Serviço Nacional de Aprendizagem Industrial (SENAI), a partir de 1942, vem treinando menores e adultos para o setor secundário. Esse trábalho é realizado no próprio serviço ou em esco las especificas.

39 - O Serviço Nacional de Aprendizagem Comercial(SENAC), a partir de 1966, promovendo cursos intensivos, na área do setor terciário (comércio) para menores e adultos.

48 - 0 Programa Intensivo de Preparação de Mão-de-Obra (PIPMO), originariamente PIPMOI, porquanto se dedicava a atender ao setor industrial (1964). A partir de 1970, anpliou suas atividades com vistas a atender, tambēm, os setores primärio e terciärio.

No gräfico no 16 tem-se una idéia da evolução do nünero de ireinados neste programa.

GRAFICO NO 16

\begin{tabular}{|l|r|r|}
\hline 1964 & \\
\hline 15.723 & & \\
\hline 1965 & 37.341 & \\
\hline 1966 & 47.922 & \\
\hline 1967 & 56.764 & \\
\hline 1968 & 54.756 & \\
\hline 1969 & & 72.336 \\
\hline 1970 & & \\
\hline
\end{tabular}

TOTAL 367.184 treinados

FONIE: EDUCACÃO - NOC - AnO I - nP 2. 
(*) Em 1971 as metas foram:

QLABRC NQ 19

\begin{tabular}{|c|c|}
\hline SETOR (Atividade Econômlca) & NOMERO A TREINAR \\
\hline Primärio & 33000 \\
\hline Secundārio (tradicional) & 60000 \\
\hline Terciärio & 25000 \\
\hline & 118000 \\
\hline
\end{tabular}

(*) Fonte: "EDUCAÇRo" - MEC - Ano I - no 2 - p.21-30

(*) Para 1972, os quatro projetos bäsicos são:

QUADRO NQ 19

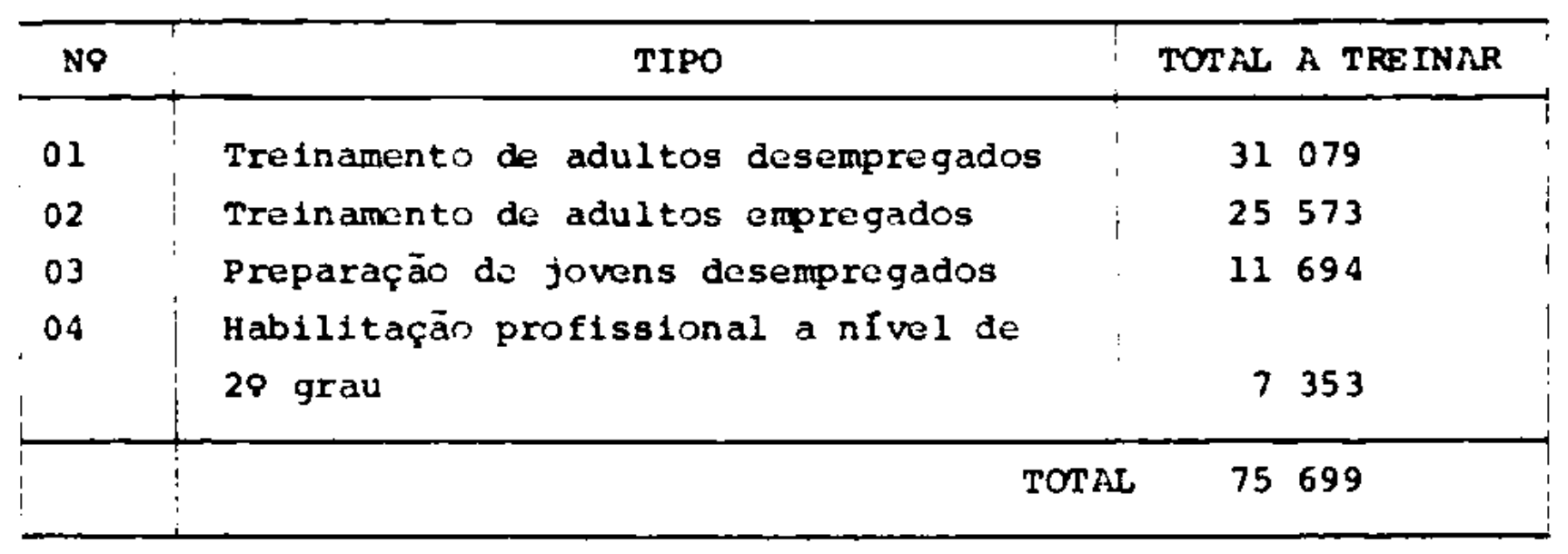

(*) Fonte: "EduCAÇO"-MEC - Ano I - ne 2 p.21-30

58 Nas zonas rurals diversos organismos vêm atuando no sentido de melhorar o padrão qualitativo dn trabalhador, cmo o atu al Instituto Nacional de Colonização e Feforma Agrária (INCRA) e ou tros que resultam do esforço conjunto de örgãos federais e/ou esta duais e organismos astrangeiros.

68 - Vărias empresas püblicas e privadas oferecem cursos para a qualificą̧ão de sua māo-de-obra.

\section{5 - V1säo Prospectiva}

A prospectiva não apenas estä em moda como se revelou una necessidade. Imaginar o que val ocorrer no futuro é tarefa da inteligência humana há multos séculos. Nos ültimos vinte anos, porém, adquiriu maior consistência graças ao emprego de modelos teo ricos, anălise de sistemas, apelo à matemática e à estatística. 
Pensar no futuro, a partir dos dados históricos e do pre sente è uma necessidade cada vez mais imperiosa. Correçōes agora em determinadas estruturas, podem alterar trajetörias dos fenômenos so clais, econônicos, politicos, projetando-se diferentemente no futu ro. (3i)

Hâ fenômenos de natureza física, dos quais se pode, com grau muito elevado de certeza, determinar as projeçōes.

Já os fenōmonos sociaís são menos sucestiveis de um con celto determinista. (32) E caso da educação. Num sistema qualquer, deve-se considerar que a alteraçāo de uma variável modiflca o seu relactoramento com as demais $e$, conseqtentemente, todo o modelo.

En educação, basta que haja, por exemplo, malor eflcãcia Interna para se modificar o quadro prospectivo, ou o crescimen to do PIB ser acompanhado de maiores recursos alocados à educação e mais eficientemente aplicados. Os exemplos, no campo restrito da educação, podem ser multiplicados.

De igual mancira, alterações futuras näo previsiveis, no sistema sōcio-econômico por certo modificaräo, mais ou menos inten samente, o subsistema educacional. E 1sto è mais verdadeiro nos países e/ou regiões em desenvolvimento, onde educação e comur.1caçäo representam dois fatores em profundo processo revolucionár1o. (33)

Desta forma prever-se a evolução educacional no Brasil nos pröximos 10 ou 15 anos è altamente temerário. Ficară mals próxima da realidade a prospectiva imediata, que não exceda 4 ou 5 anos.

Nesse sentido, prevê-se, atê 1974, o que a segulr se transcreve. (34) 
QUADRO NQ 20

PERSPECTIVAS DO CRESCIMENTO POR SETORES - 1970/1974

\begin{tabular}{|c|c|c|}
\hline$S E T O R E S$ & $\begin{array}{c}1966 / 1969 \\
\text { Taxa } \\
\text { Méd1a Anual } \\
(8)\end{array}$ & $\begin{array}{c}1970 / 1974 \\
\text { Taxa } \\
\text { Média Anual } \\
(8)\end{array}$ \\
\hline INFRA-ESTRUTURA $\ldots \ldots \ldots \ldots \ldots \ldots \ldots$ & 9,3 & $9 / 11$ \\
\hline 1 - Transportes - Comunicações .... & 9,4 & $9 / 10$ \\
\hline 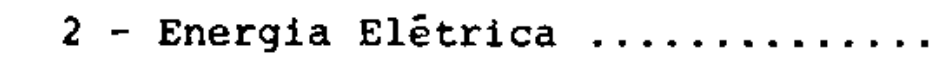 & 9,1 & $11 / 12$ \\
\hline PRIYAARIO & & \\
\hline (Vegetal - Animal) $\ldots \ldots \ldots \ldots \ldots$ & 4,4 & $7 / 8$ \\
\hline INDOSTRIA DE TRANSFORMAÇÃO E & & \\
\hline EXTRATIVA MINERAL $\ldots \ldots \ldots \ldots \ldots$ & 8,7 & $10 / 12$ \\
\hline CONSTRUÇAO $\ldots \ldots \ldots \ldots \ldots \ldots \ldots \ldots$ & 10,9 & $8 / 9$ \\
\hline OUTROS SERVIÇOS $\ldots \ldots \ldots \ldots \ldots \ldots \ldots$ & 7,5 & $7 / 9$ \\
\hline P I B & 7,4 & $8 / 10$ \\
\hline
\end{tabular}

Fonte: Projeto do I Plano de Desenvolvimento Econömico e Social - 
Quadro no 21

1974: DIMENSŐES DA ECONOMIA BRASILEIRA

\begin{tabular}{|l|l|l|l|}
\hline MAGNITUDES GLOBAIS & 1370 & 1974 & $\begin{array}{l}\text { Aumento no } \\
\text { Periodo }(\%)\end{array}$ \\
\hline
\end{tabular}

\begin{tabular}{|l|l|l|l|}
\hline $\begin{array}{l}\text { PROOUTO INTERHO BRUTO } \\
(\text { CrS MI B B B }\end{array}$ & 222.857 & 314.581 & 41 \\
\hline
\end{tabular}

\begin{tabular}{|l|l|l|l|}
\hline $\begin{array}{l}\text { POPULAÇAO } \\
(1000 \text { PESSOaS })\end{array}$ & 93.204 & 104.130 & 12 \\
\hline
\end{tabular}

\begin{tabular}{|l|l|l|l|}
\hline $\begin{array}{l}\text { PIB PER CAPITA } \\
\text { (CrS de 1972) (**) }\end{array}$ & 2.391 & 3.021 & 26 \\
\hline
\end{tabular}

PRODUTO INDUSTRIAL

(Cr\$ milhöes de 1972)

\begin{tabular}{|l|c|c|c|}
\hline $\begin{array}{l}\text { INVESTIMENTO BRUTO FIXO } \\
\text { (Cr\$milhöes de 1972) }\end{array}$ & 37.895 & 59.770 & 58 \\
\hline
\end{tabular}

TAXA DE INVESTIMENTO BRUTO FIXO

(\%)

\begin{tabular}{l|l|l|}
17 & 19 & - \\
\hline
\end{tabular}

\section{CONSUMO GLOBAL}

(Cr\$ milhóes de 1972)

\begin{tabular}{l|l|l}
185.015 & 251.224 & 36
\end{tabular}

\section{POPULAÇAO ECONOMICA ATIVA}

(1000 Pessoas)

(*) Não foram considerados os valores da nova revisão das Contas Nacionais que a F.G.V. acaba de realizar.

(**) Tomando-se simplesmente a taxa de câmblo corrente, o PIB, em 1974, estaria na ordem de US\$ 53,7 bilhões, e a renda per capi ta de US\$ 516 . Jä segundo a estimativa do IPEA, con métodos małs refinados e a partír de estudo anterior realizado pela ONU, os valores seriam: US $\$ 62,3$ bilhões para O P.I.B. e US $\$$ 598 para a renda per capita.

Fonte: Projeto do I Plano de Desenvolvimento Econômico e Social 
Quadro no 22

\begin{tabular}{|c|c|c|c|}
\hline$S E T O R E S$ & $\begin{array}{c}\text { S1 tuação } \\
\text { em } \\
1970\end{array}$ & $\begin{array}{l}\text { Meta } \\
\text { Dara } \\
1974\end{array}$ & $\begin{array}{c}\text { Aumento } \\
\text { (8) }\end{array}$ \\
\hline 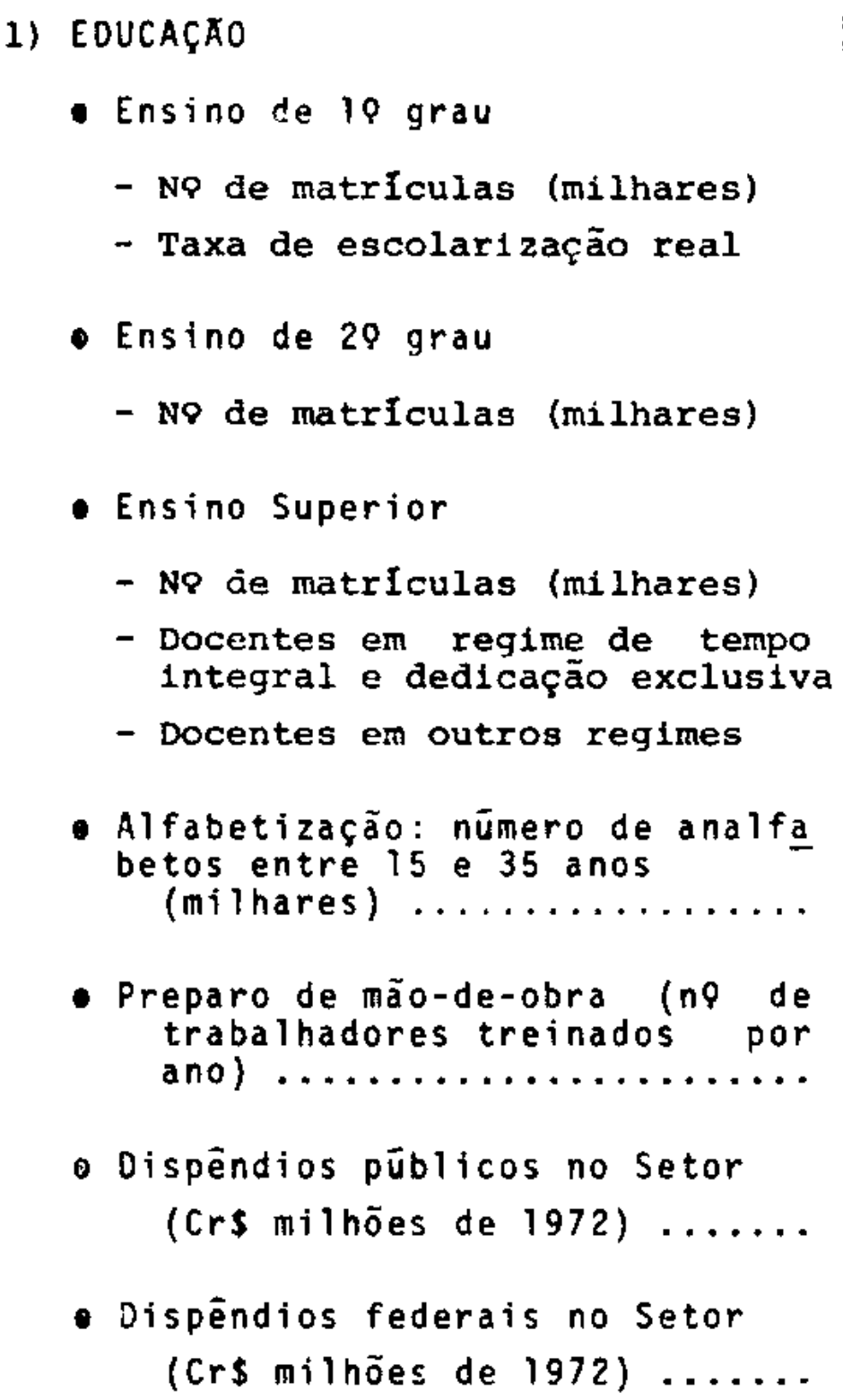 & $\begin{array}{r}16.39 ? \\
738 \\
1.100 \\
430 \\
2.800 \\
6.000\end{array}$ & $\begin{array}{r}217.000 \\
10.550 \\
3.060\end{array}$ & $\begin{array}{l}43 \\
33\end{array}$ \\
\hline
\end{tabular}

Fonte: Projeto do I Plano de Desenvolvimento Econômico e Social 


\section{6 - Conclusōes parciz1s}

1a. - o subsistema educacional brasileiro sempre fol determinado pelo sistema söcio-politico-econômico.

2a. - A democratização educacional é recente no país, tendo sido acelerada nos últimos vinte anos.

3a. - As modificações em curso buscam atender às novas estruturas söcio-econōmicas.

4a. - As disparidades regionals são muito acentuadas.

5a. - A Industrialização e a urban1zação tên agido como aceleradọ res do processo educacional.

6a. - As distorções educacionais ainda comprometem gravemente a eficăcia do subsistema, pulverizando recursos financeiros e humanos.

7a. - A extensão da escolarização, a retenção dos alunos no subsistema formal, a melhoria qualitativa do ensino são imperativos do crescimento econômico e do desenvolvimento social.

8a. - Todo esse processo se validarä na medida em que possibilite a auto-realização do ser humano, abrindo caminho para sua afirmação como Indivĩuo, com diretto ao usufruto da justiça soclal. 
NOTAS REFE RENTES AO CAP ITULO 3

(1) SCHRAMM, wilbur, et allii. Tëcnicas modernas y planeamiento de la educación - Amsterdam - Pafses Bajos-Unesno - ILPE- 1967 p. $19-77$.

(2) ABREU, Jayme - Educacão, sociedade e Desenvolvimento - Vojume 8 - 1968 - p. 105-138.

"Esse fato histórico de indios e escravos terem sido, como integrantes do estrato social inferior, dos primetros aprendizes de ofĺcios, para o qual teriam contribuldo vários fatores, entre os quais aquela mencionada superior. hierarquia atribufda as atividades ditas intelectuais ante 0 rudimentarismo rotineiro das "pesadas" tarefas manuais $e$, mais do que tudo isso, o prę̧o entāo vantajoso dessa força de trabalho com o qual não podia competir a dos raros trabalhadores livres emi grantes da Europa, concorreu para marcar com tenaz preconcelto de inferipridade söcio-cultural e estigma de servidão esse t1 po de atividade no Brasil" . p.106-107.

(3) FREYRE, Gilberto - Casa Grande \& Senzala - Rlo de Janeiro - $4 a$. edição, definitiva - Livraría Josē Olimplo Editora - 1943.

- Sobrados e Mocambos - São Paulo - Companhía Editora Nacional - 1936.

(4) ABREU, Jayme -op. cit. p. 113

(5) TEIXEIRA, AnIsio. Educação não é privilëgio. São Paulo - Compge nhía - Editora Nacional - 2 a. edıção - 1968 - p. 22.

(6) TEIXEIRA, AnIsio - op. cit. p. 60-68.

(7) Srlva, Geraldo Bastos. A educacão secundäria (Perspect1va histórica e teoria) - São Paulo - Companhia Editora Nacional 1969.

"Até 1933, os Indices antes estabelecidos evidenciam que as condições que serviam de suporte ao desenvolvimento do ensino se cundärto pouco se modificaram desde os ültimos vinte e cinco anos do Império e durante os primeiros trinta anos da Repüblica. Assentados sobre uma economia preponderantemente auricola e de exportação, fun 
dada até 1888 sobre o trabalho escravo, e caracterizadas pelo rudimentar desenvolvimento da classe mëdła e bałxo Indice de urbanização (entre 1972 e 1920 a população urbana se manteve em volta de 108 do total), aquelas condiçōes fazlam com que o enstno secundärio fosse acessivel a somente exígua parcela da população, àqueles que podiam aspirar ao ingresso nos cursos superlores. Tals condições dificulta vam o desenvolvimento do ensino primärio, enquanto o ensino profissional de nivel médio era praticamente inexistente". p. 301.

(8) CORREA, Arlindo Lopes. Reflexōes sobre uma politica de Recursos Humanos para o Bras1l - Rio de Janeiro- IPEA - CNRH - 1971.

"Tanto os recursos naturais como humanos exam abordados

fragmentarłamente, na medida de sua vinculação natural aos setores focalizados. Assim, havia referênclas dispersas aos recursos humanos, ao tratar-se das politicas de educação, emprego, etc., sem que se desse conta da necessidade de uma abordagem mais sistemática, abrangente e or gânica". p. 3 .

(9) PRESIDENCIA DA REPOBLICA. Metas e Bases para a ação do governo - Brasilia - Composto e tmpresso no Serviço Gráfico da Fundação IBGE - 1970 .

"A Pe-spectiva Mundial e os Problemas do Nosso Tempo".

Importa considerar a posição hrasileira na perspectiva mundial de nossa época. Na década de 70 , como se tem assinalado, ocorrerão grandes avanços cientificos e tecnolögicos na terra, no mar e no espaço; e, possivelmente, no mundo desenvol vido e no mundo subdesenvolvido, e assistir-se-à à exacerbação de tensões socials e politicas.

o Brasil, como so demais paises em desenvolvimento, Irä defrontar-se com importantes problemas, que reclamam solução sem delongas.

Em primeiro lugar, o problema econômico do subdesenvolvimento, pela necessidade de crescer acima de $7 \%$ ao ano, a fim de reduzir-se a distâncla em relação aos palses desenvolvidos e superar-se, de muito, o aumento da população, de modo a permitir a elevação considerável da renda per capita e dos padröes de bem-estar do povo.

Neste contexto de àspera preparaçāo interna para os ca- 
minhos do progresso, n Brasil nāo aspira apenas a crescer. Almeja, no final do século, ser parte integrante do mundo desenvolvido.

Ora, na sociedade mderna, o poder de competir entre as naçöes a de acelerar o crescimento depende cada vez mais da apllcação do conhecimento. Ou seja, do progresso tecnológico em sentido amplo - abrangendo a educação, a pesquisa, a Innvação, - pela sua crescente capacidade de transformar e tornar mals eficientes os demats fatores de produçãn, representados pela mão-de-obra, o capital, os recursos naturais. DaI estarem as disparidades de renda entro as nações cada vez mais condiclonadas pelo chamado hiato tecnológico,ou sejam, as disparidades crescentes de progresso na ärea cientifica e tecnolögica.

Em segundo lugar, estão os dols grandes problemas ëticos do nosso tempo.

De un lado, o da participação das massas nos frutos do progresso material, tornada exequivel pela revolução da tecnologia e pelos princípios da justiça social, que objetivam assegurar padröes minimos the bem-estar a todas as categorias sociais.

De outro lado, o da garantia de acesso ao mundo desen volvido do maior nümero de países em desenvolvimento, dotados de ví abilidade politica e económico-social, para que aquele mundo se converta efetivamente numa sociedade abcrta; $e$, concomitantemente,o do progressivo asseguramento de padrāo de vida mintmo satisfatório a tวdas as äreas subdesenvolvidas, inclusive pela aplicação dos mes mos princípios da justiça social - de não reciprocidade, de amparo ao menos forte, de oportunidade para os que emergem no cenärio mun dial - às relações entre povos desenvolvidos e subdesenvolvidos".

MINISTERIO DO PLANEJAMENTO E COORDENAÇRO GERAL - pmjeto dO I PLANO NAUTONAL DE DESENVOLVIMENTO ECONOMICO E SOCIAL. $1972 / 7 \mathrm{~A}$ Brasilia - 1971 - p. V - VIII.

"Sintese: As Realizaçöes Nacionais

o elenco das realizações nacionais para o periodo 19721974 oferece visão global do que a Nação ditou a s1 própría como tarefa bäsica.

Respeitante ao crescimento econômico, essas realizą̧ōes 
fundamentais peraitıão que 0 Brasıl:

- Alëm de se manter na lista dos 10 paises de maior nivel global do produto Interno Bruto (PIB), no mundo ocidental, passe também da posiçăo de nono colocado à de oitavo nessa categoria.

- Ultrapasse a barreira dos 500 dólares de renda per capita, em 1974.

Tais realizaçōes compreendem:

I - Consecução dos objetivos nacionals de desenvolvimen to e transformação social mediante processo de com petição capaz de assegurar niveis internacionals de efictência aos setores püblico e privado; e proces so de integração, com articulação harmônica entre Govèrno e setor privado, união e Estados, entre regí oes en desenvolvimento, entre empresa e trabalhadores

II - Implanteçäo de novos instrumentos para modernizar a empresa nacional, fortalecendo-lhe a capacidade com petitiva e eliminando as condiçōes de desigualdade em que opera, relativamente à estrangeira.

III - Atuação eficiente, do Governo, na administração direta, autarquias ou emresas governamentais, deftin do suas tarefas com clareza e preservando a viabi lidade o dinamismo no setor privado. O setor público procurará operar mediante estruturas simples e mo dernas, aperfeiçoando-se os sistemas de coordenação e acompanhamento da execução.

IV - Mobilização ainda mais intensa do sistema financeiro nacional e do mercado de canitais, para maior partí cipação no financiamento da formação real de capltal do setor prlvado e na criação de sôlldas estruturas das empresas; e ainda garantia de acesso da pequena e média ompresas a sistemas que permitam a melhoria de sua ostrutura flnancelra, bem cono utillzação dos instrumentos financeiros jä crialos, no BNDE e em outros orgaitsmos oficiais, para a grande empresa ou grandes empreendimsntos nacionzis. 
V - Implementação da Polftica Tecnológica Nacłonal, que permita a aceleração e ortentação da transferêncla tecnolögica, para o pals, assoctada à forte componente de elaboração tecnológica pröpria. o: Brasil ingressarä na era nuclear, com a construção da primeira Central-Nuclear, e com a realização do ciclo do combustivel atômico, para exploraçāo e processą mento de urânto em escala ampla. o programa de pesquisa de urânio nos colocará como o segundo ou tex ceiro país, no mundo, nesse campo.

Inolantar-se-ão sistemas de Centros de Tecnologia em äreas de Infraestrutura e Indūstrias Bástcas, como sejam: Energia Elētrica, Tecnologia Nuclear, Petrō leo, Telecomunicações, Siderúrgia, Pesquisa Mineral, Pesquisa Espacial, e se reformulará a carreira de pesquisador, para assegurar-lhe condições de traba1ho satisfatorias.

VI - Polftica de aproveitamento dos recursos humanos do pafs (que em 1973 ultrapassarão os 100 m1lhões de hâ bitantes), como fator de produção e de consumo.

No campo da Educação, o MO?RAL, realizará programa de alfabetização em massa, para reduzir a 2 milhões em 1974, O nümero de analfabetos na faixa de 15 a 35 anos, implantar-se-à também o sistema de Ensino de 18 Grau, integrando o primärio e o ginásio, com uni versalização progressiva desses dois nivels de ensí no; estabelecer-se-ã o sistema de centros regionals de pós-graduação, alēm de continuar-se a Reforma un 1 versităria.

Realizar-se-ā programa intenstvo de preparação de mão-de-obra, dentro da política de educação permanen te.

Ao mesmo tempo, a expansão das oportunidades de em prego deverä efetivar-se a taxas crescentes, superio res às do crescimento da cferta de inão-de-obra, em niveis de renda e produtividade acima das de economia de subsistência. Tais oportunidades serão abertas pelo crescimento aceizrado, com adequada polit 1 ca tecnológica e definição de prioridades setoriais 
e regionais, bem com pela mobilidade social e ausência de preconceltos, raclais ou de sutra ordem.

VII - Efetıvação de certo nümero do grandes programas de investimentos, cada um deles de valor superior ao equivalente a um bilhão de dōlares, em ctnco anos, em consonância com o propösito de consolidar a Infraestrutura cconômlca $e$ as indústrias bāsicas. Entre esses programas se encontram: o Programa de Expansão da S1derurgia; o Programa Petroquimico; a Implan tação dos Corredores de Transportes; o Programa de Construção Naval; o Programa Băsłco de Energła Elẹ trica, nos molies da Primelra central Nuclear e do conjunto de usinas hidrelétricas acima de $500000 \mathrm{KW}$ cada uma; O Programa de Comunicaçōes, com ênfase no PIano de 1000000 de telefones; o Programa de Mine ração, abrangendo, alēm do minério de ferro, um con junto de projetos de grande dimensão para lavra e industrialização.

VIII - Realização de Estratēgia Regional para efetivar a In tegração Nacional. M mesmo tempo em que se consoli da o núcleo desenvolvido do centro-sul, até com a criação de regiões metropolitanas, controle da polu1 ção e construção da estrutura integrada de Indüstria e Tecnologia, implantar-se-ão novos dolos regionals, notadamente o agro-industrial dn sul, o industrial-a grícola do Nordeste o o agropecuärio do Planal to Cen tral e da Amazônia.

o Brasil realizară, no perlođo, um dos maiores programas de desenvolvimento regional em todo 0 mundo. As transferênclas da União para $O$ Nordeste e a Mmazônta - por intermédio do PIN, do PROTERRA, dos incentivos fiscals, do Fundo de Participação, do Fundo Especial a dos Fundos Vinculados - deverão aproxi mar-se da mëdia anual de cr\$4.700 milhōes (preços de 1972), correspondendo a cerca de us $\$ 800$ milhöes montante superior ao total da assistêncla financeira líquida que o conjunto das instituıções financeiras internacionals proporcionou à América Latina, anual mente, no final dos anos 60 . 
IX - Abertura oocial, para assegurar a partıcipação de todas as categorias sociais nos resultados do desen volvimento, bem como a descentralização do poder econômico, com a formação do capitalismo do grande nū mero a a difusão de oportunidades. São instrumentos financeiros dessa polftica os programas de Integração Social, como o PIS, o PASEF; o PRO-RURAL e a abertura do capital das empresas.

X - Estratégła Econômica Externa para, no tocante as exportaçōes, assegurar o crescimento da receita ac1ma de 108 ao ano, a criação de duas categorias capa zes de competir com a posição do cafë (a de manufatụ rados e a de minério/produtos agrícolas não tradicio nais) e alnda a partıcipaçāo ativa do País no sistema de preferências gerais, estabelecido por certas $\underline{\mathbf{a}}$ reas desenvolvidas; e, quanto à nossa posição na comunidade internacional, armar o sistema cconömtco de instrumentos para evitar que as tendêncies neopro tecionistas de países desenvolvidos ou a situação mo netäria internacional possam prejudicar a realiza ção dos objetivos nacionals no campo externo".

(10) TEIXEIRA, Anísio. Educacão e o Mundo Moderno - säópaulä -. Companhia Editora Nacional -.1969 - p. 178.

(11) PINTO, I.A. Costa. Desenvolvimento Econömico e Transtcão Social. Rio de Jane1ro - 2a. edição - Editora Civilização Brasileira S.A. 1970 - p.9 - 30 .

(12) ABREU, Jayme - op. cit. p.82.

(13) PASSARINHo, Jarbas Gonçalves - A Educação no Brasil: esboco de uma politica nacional - Ric de Janeiro - 1970. p.7 -

(14) SIMONSEN, Mário Henrique .- Brastl 2001 - Rio de Janeiro -APEC Editora S.A. - 1969 - p.210.

(15) SIMONSEN, Märio Henrique - op. c1t. p.212.

(16) PASSARINHO, Jarbas Gonçalves - op. c1t. p. 17.

(17) TEIXEIRA, AnIsio - Educacão e o Mundo Modemo - op. cit. 
..."e a todos for dado o necessārto para a vida mate rial, as perspectivas que se abrem para o homem, serão não já as de culdar da morte, mas as de tornar a vida interessante e significativa.

A.té hoje o conseguimos, por mats paradoxal que is to possa ser, graças ao medo e a uma sombria econo mia da pobreza. Se conseguirmos a economia da abundâncla, que fă se anuncta nos países desenvolvidos, teremos perdido aquelas forças, truculentas mais ef $\underline{1}$ cazes, que não deixam ao homem outra saida senão a formação a a disciplina. As necessidades de educação consciente e formal passarão dal por diante a ser muito maiores". D. 123.

(18) UNESCO - Situaciōn Demogräfica, Econömica, Social y Educativa de Amërlca Latina - Buenos Aires - Argentina - Ediciones Solar y Libreria Hachette S.A. - 1966 - p. 41-48 e 61-66.

(19) BONILLA, Frank. A Educacão e o Desenvolvimento Politico no Brasil. A Evolução do Nacionalismo. Tradução de Amélla Maria Noronha - Rio de Janeiro - CBPE - 1962.

o trabalho do professor Bonilla, embora datado de 1962 , quando o quadro politico do país apresentava-se multo diferente do atual, não ẽ invalidado. Muitos dos seus prognósticos e de suas análises não são de natureza conjuntural, mas refletem uma estrutura mals complexa, de carăter histórico cultural.

(20) PASSARINHO, Jarbas Gonçalves - Ecucação Planificada. BrasilliaMinlstērio da Educação e Cultura - 1971 - p. 27.

(21) MINISTERIO DA EDUCAÇÃO E CULTURA - SECRETARIA GERAL. PLANO SETORIAL DE EDUCAÇÃO E CULTURA - 1972/1974- Brasilia. DF. 1971 p. 49.

(22) MINISTERIO DO PLANEJAMENTO E COORDENAÇR̃O GERAL - projeto do I Plano Nacional de Desenvolvimento Econömico e Social. op. cit. Quadro III.

(23) CONJUNTURA ECONOMICA - A economia bras1leira - 1971 - Retrospecto - Rio de Janeiro - GB - Fundação Getúllo Vargas. Vol. 26 1972 - p. 7-9.

(24) MINISTERIO DO PLNNEJAMENTO E COORDENAÇÃO ECONOMICA. ESCRITORIO DE PESQUISA ECONOMICA APLICADA - EPEA - Educacão (I) (II) Dlagnöstico prelimınar - Plano Decenal de Desenvolvimento Econômico e Soctal. Rio de Janeiro - Departamento de Imprensa Nacional - 1966 . 
Não abstante a carência do dados estatisticos, o que $\mathbf{s e}$ tornou mals grave em função dos resultados pouco fidedignos do censo de 1960, o trabalho referido representou sério esforço no sentido de colocar a problemática brasiletra em termos de análise e prognóg tico.

(25) MINISTERTO DA EDUCAÇÃo E CULTURA - Desenvolvimento da Educacão no Brasil - Brasilia - DF. 1971 - p.34

Este documento é uma boa fonte de referência sobre a edu cação no Brasil. Fol preparado para a Conferência de Ministros da Educação e Ministros responsāveis pelo Fomento da Ciência e da Tecno logla com relação ao desenvolvimento da América Latina e da Região do Caribe.

(26) MINISTERTo DO PLANEJAMENTO E COORDENAÇño GERAL - Projeto do I Plano Nacional de Descnvolvimento Económico e Social - op.cit. p. $43-45$.

(27) MINISTERIO DA EDUCAÇđ̆ E CULTURA - Educação no Brasıl (Subsíd1o para a Conferèncla Internacional de Educação) - Brasflia - DF 1971.

Vêm-se, a seguir, os pontos bäsicos que devem ser objẹ to de reformulação.

"1. Integração estru.ural e funcional da universidade tendo por base o princíplc le nāo duplicação dos metos para fins 1dêntí cos ou equivalen $3 s$, de modo a assegurar a plena ut1lizaçāo dos recursos empregados em sua manutenção e funcionamento.

2. Instituição do sistema departamental, eliminada a cätedra autônoma, concentrando-se, em cada jepartamento, todo o pessoal docente e recursos materials relativos à mesma ārea de conhecimentos, propiclando assim, as condiçōes para que as ativida des didáticas e de pesquisas se realizem no regime de cooperą ção.

3. Concentração dos estudos bäsicos, cientificos e humanisticos, num sistema integrado de unidades para servir a toda a untver sidade.

4. Institucionalização das atividades interescolares com a cria 
ção de órgãos de coordenação responsävels pelas atividades de cada curso ou projeto, compreendendo professores de diferentes departamentos e unidades que participam do curso.

5. Supervisāo dessas atividades ao nivel da administração superior da universidade por melo de órgãos de coordenação central com poderes deliberativos.

6. Organização de um primeiro clclo de estudos básıcos, comum a todos os cursos ou a grupos de cursos afins, com as seguintes funções: a) recuperação de insuftctências evidenciadas, pelo concurso vestibular, na formação dos alunos; b) orientação para a escolha da carreira; c) realização de estudos bāsicos pa ra ciclos ulteriores.

7. Criação de uma superestrutura de cursos de pós-graduação, conferindo os graus de mestre e doutor.

8. Maior flextbilidade dos estudos assegurando-se a matricula por disciplinas ou regime de créditos, com orientação pedagóglca dos alunos.

9. Instituir progressivamente o regime do tempo integral para o corpo docente, proporcionanüo-se remuneração cond1gna".

(28) MINISTERIO DO PLANEJAMENTO E COORDENAÇÃo GERAL - Projeto do I Plano Nacional de Desenvolvimento Econōmico e Social -op. cit. p. $44-47$.

(29) Idem, idem, op. cit.

(30) LEITE, Antonto Dias - Caminhos do Desenvolvimento, Contribuicão para um Projeto Brasileiro - Rio de Janeiro - Zahar Editores - 1966 .

"... país como o Brastl, caracterizado por baixo nivel de produtividade; tem, portanto: ampla margem pa ra acelerar o seu processo de crescimento se se concentrar em uma politica econômica voltada para o aumento da produtividade".

"O conhecimento de novos recursos naturais depende da disponibllidade de técnicos especialızados de nivel superior. A modernização da estrutura econô mica e soctal está intimamente relacionada com a evo lução cultural e polftica do povo e, portanto, com o 
nivel geral de educação. Deste mesmo nível geral de educação, depende, ainda, a melhoria da qualidade da força de trabalho." p. 71 .

"O desafio, de alcançar um ritmo de crescimento ma1s Intenso do que o já realizado, só poderá ser enfrentado mediante uma politica econômica que vise,precipuamente, melhor ut1lização dos recursos humanos e de cap1tal disponivels, e que coloque, portanto, a educą̧ão como problema econômico relevante".p.88-89.

(31) JUNGK, Robert - El futuro ha comenzado. Tiene porvenir la futurologia ? EL CORREO - UNESCO - Paris - France - Año XXIV 1971 .

"En la época de la revoluctón cientifico-tẻcnica el estudio sistemātico del mundo de mañana es una necesidad absoluta".

"Unos cuantos miles de especialistas trabajam ya en cast todos los paises de la tlerra con eses mëtodos de previsión a plazo corto, médio y largo que son in prescindibles para la supervivencia y el ulterior de sarrollo de la especie humana. Esos especialistas son consejeros de gobierno de ayuntamientos o de directores de industrias". p. 9 .

(32) LIONNAIS, François Le - Tiene porvenir la futurologia $?$ Los pros $y$ los contras.EL CORPEO-UNESCO-Paris-France-Año XXIV-1971.

"Llegamos asi, quemando en cierto modo etapas,al ter reno de lo humano. En la medida en que él actüa el ceterminismo, se trata de un terreno en que deberia aplicarse la prospectiva.

Ciertamente, los obstáculos que ésta ha de salvar son muy grandes, pero también es verdad que su carácter resulta menos radical.Esos obstáculos son, en forma resumlda,el nümero a veces degalentadoramente grande de factcres y la dificultad de medirlos correctamente $y$, a menudo, de medirlos lo bastante rapidamente para poder predecir los acontecimientos... antes de que ocurran". p. 6.

(33) JR, Datus C. Smith - Educacão e Comun1cação:duas verdades. S/d Artigo condensado de Forelgn Affairs - 1968

(34) MINISTERIO DO PLANEJAMENTO E COORDENAÇ̃̃ GERAL - PROJETO DO I PLANO NACIONAL DO DESENVOLVIMENTO ECONOMICO E SOCIAL. op. cit. Quadros I, II e III (parte relativa à educação). 
III - FUndamentaça teOrica: Planejamento; PLANEJAMENTO EDUCACIONAL 
C A P ITULO I

PLANEJAMENTO: aspectos geraIs;

O CASO BRASILEIRO 
1 - PLANEJAMENTO

1.1 - objetivos

- Traçar, em linhas gerals, a evolução dos conceltos de plạ noj amento.

- Assinalar a tendêncta crescente à consolidação das teorlas e da prätica do planejamento.

- Esquematizar o aparecimento do "fenòmeno planejamento" nos pafses subdesenvolvidos.

- Estabelecer as linhas gerais dos conceitos de planeja mento no Brastl.

- Relacionar planejamento global e profetos tópicos e setorials.

- Destacar a importância do planejamento educacional.

\section{2 - Economta capitalista e soclalista: a livre concorrêncta e a planificacão centralizada (estatal).}

Multo se tem falado e escrito a respeito do tema $\theta$, por $1 \underline{s}$ so, a btbliografia especifica é abundante. Mals ainda, como resultado do se falar e do escrever, o planejamento passou a ser una "idéla-força", discutida entre os teóricos, praticada con maior ou menor eflciêncla, popularizada como se fosse un mito ou una pana cëia para as "doenças" do progresso material e/ou do subdesenvolvimento. -

Qualquer intelectual, ou aspirante ao posto, considera, consciente ou inconscientemente, incompleta a sua formação se ela não tiver na sua bagagen, um certo peso resultante das noções de plạ nej amento.

Serã sempre interessante e não aleatór1o, que preliminarmente, sejam revistos os conceltos băsicos sobre o tema, o que en volve posicionar com correção as tdêlas substantivas que definem e diferenciam, na forma e na qualificação: sistema econōmico, regime, estrutura (1); planejamento, planificação, programação, projeto ${ }^{(2)}$, subdesenvolvimento ${ }^{(3)}$, etc.

Da simples leftura de definições ou de conceltuações, pode-se observar una forte predominâncla do substrato econômico, que termina por abranger todo o complexo. Tern-se como certo que a planificação, o planejamento, envolvem, apenas a grande variãvel econô mica. De resto, isto è uma distorção da realıdade, embor a tenha ex plicação, se não vālida, ao menos aceltăvel: é que os primeiros es- 
tudos mais sërios, amplos e programáticos a respeito do tema se devem aos economistas.

to tempo (4), o seu acervo de trabalhos sobre planiflcação, planejamento, etc., $\bar{\epsilon}$ bem menos significativo se o referenclal for a Econo mia.

De igual maneira, os trabalhos de Geografia, notadamente os voltados para o subdesenvolvimento e para a Geografia Aplicada ac Planejamento, são mais recentes e menos abundantes que os de Economia.

Todavia é forçoso convir que os conceltos atuals (e jă não tão modernos assim) de planejamento envolvem a noção de sistena,com posto de inüneras variãveis que guardam relação entre si. A modifí cação de uma variável, quantitativa ou qualitativamente, tem por e felto alterar as demais variäveis, dando outra configuração ao sistema.

Os "sistemas econômicos" capitalista e soclalista (tão di versificados hoje en dia, internamente, admitindo $n+1$ modelos), guar daram, de iniclo, um antagonismo conceitual e operactonal: a livre concorrência x o controle do mercado, através da planificação cen tralizada, estatal.

"Nos Palses Ocidentals, una das controvërsias menos escla recidas e menos inteligentes de nossa ëpoca tem sido aquela relacio nada com a questäo de devermos ter uma economia "livre" ou uma econom1a "planificada" (5).

Posto que a Ciência Econömica jä encerra em seus postulados o concelto de plano, isto è, ordenação, coerēncta, interligação, metas, etapas, "feed-back", etc., cabe apenas diferenctā-la em fun cão da ldeologia polftica a que serve.

Neste sentido, então, pode-se permitir falar en "economia capitalista" e "economla socialista".

A primeira, como è fartamente sabido, tinha como uma das suas caracteristicas básicas, o livre jogo da oferta e da procura, isto $\bar{e}$, a livre concorrência. Esta deu margen a uma das bandeiras ideologizantes do capitalismo, que era a infciativa pessoal, nao desvinculada dos princlplos do Humanismo, do livre-arbitr1o, do cil vinismo, etc.

o jogo do mercado, que parecia agir como equilibrador eco nômico, mostra-se ao conträrio, estático, num sistema que é sobrema neira, dinâmico. 0 "la1ssez-falre", a rigor, constitul un dos mi- 
tos da Histörta Econônica. De una forma ou de outra, ma1s ou menos veladamente, o Estado jamals esteve ausente ou alienado do caplta l1smo, mesmo quando este se encontrava em s1tuação embrionäria. A discreta intervenção estatal, que ë un prenüncio do planejamento es tatal, fol apenas amortecida nos primelros passos do capitalisma na Grä-Bretanha ou en outros países en que substituiu os velhos sistemas ${ }^{(6)}$.

As crises econômicas clclicas de un capttalismo que ainda não se autodominava, as asp1raçōes para o creacente bem-estar soalal, foram, a pouco e pouco, determinando uma presença mals atuante no Estado.

A estrutura das empresas, a organização da produção, as trocas internacionais, a evolução do regime de trabalho, a expansão colonial, as lutas externas, etc., acabam com o "interlüdio liberal"; de que fala Gunnar Myrdal (7).

o Estado organizativo acaba por se impor, a princlpio de bilmente (sēculo XIX), como por exemplo, atravēs da leg1slação prô tetora do trabalhador (a partir de 1848, na França), da liberdade sindical (a partir de 1824, na Inglaterra).

Durante a guerra de 1914/1918, a Intervenção estatal se fez presente graças às motivaçōes de caräter estratēg1co. Depois de 1918, o capitalismo ilberal se vê, cada vez mais, acompanhado de per to e, mesmo, orientado pelo Estado.

A crise de 1929 acelera esta orientaçäo, embora negada pẹ los teórtcos ou pelos defensores da livre-concorrência. São exemplos da atuação estatal na dēcada de 1930: O New Deal, nos Estados Unidos; o fascismo na Itálı; o nacional-socialımo na Alemanha; o corporativismo em Portugal; a revolução de 1930 e o Estado Novo, no Brasil; o estado militar-industrial no Japão, etc. ${ }^{(8)}$.

A guerra de 1939/1945 vai, novamente por motivaçöes militares e estratëgicas, reforçar a presença forte do Estado no sistema capitalista.

o sistema socialista, ou a economia coletivista como tambën se designa o todo pela parte, afora alguns ensalos malogrados e efêmeros no sēculo XIX, inlcla-se a rigor, em 1917, na Rússia (9).

0 estabelecimento do regime se fez rapidamente, entre fases de euforia e de sucesso seguidas de periodos conturbados a violentos ${ }^{(10)}$. Mesmo abrandando durante algur tempo os princípios rigidos que definem essa fllosofia econômica - eliminação da propriedade privada, surgindo o Estado como o grande planificador da socie dade, tomada en seu sentido, amplo e total - a sociallzação da eco nomia se fol impondo (11). 
Os planos quinqtenais, iniclados em 1928, após a fase da N.E.P. (Nova Polftica Econômica que possibilitava a coexistência da essência econömlca do socialismo com a propriedade privada) sucederam-se até a 2a. Guerra Mundial. De 1928 a 1941, a plantficaçāo cen tralizada através do Gosplan (Comissão do Plano do Estado), atingla todos os setores da URSs: o econöm1co, o cultural, o social.

\section{3 - Efeitos da querra de 1939-1945: afloramento da Economia e primado do planejamento}

A guerra de 39/45 fez alterar uma sérle Imensa de posiqües conceltos, equilibrios, cresclmentos, áreas de influêncla, teorias, técnlcas, etc. Não serla talvez despropositado afirmar que nova fase histörica surge após 1945.

os centros de decisão alteram-se, num confronto blpolar que tem os Estados Un1dos num dos extremos e a URSS, noutro.

Áreas tradiclonais de importäncia mundial encontram-se de sorganizadas, como a quase totalidade dos palses europeus e, na Ála, - Japão. Sucedem-se os programas assistencials para evitar a acele ração de colapsos aqui e all facllmente locallzados.

Em palses diretamente envolvidos na luta, problemas de reg tauraçāo das finanças, de desemprego, retomada de produçăo, novos enfoques politicos, reconstrução física, etc., estão na ordem do dia.

No outro contexto politico-ideolögico, duas grandes fren tes säo abertas: a criação das democraclas populares, girando em tor no da URSS e a descolonização, na Africa e Ásla, com a emergênciade novos paises, ao menos politicamente Independentes: India, Paquis tão, Fillpinas, Indonēsia, Gana e una sucessão rápida, com värios paises africanos, notadamonte na dëcada de 1960. A China, a partir de 1950, constitul um novo Estado, quanto ao seu raglme político e tendência à implantação do sistema econômico-socialista.

Ao mesmo tempo em que o mapa politico mundial val se alterando, as conferênctas internacionals se suceden e os acordos en globando vărios palses têm lugar: o plano Marshall, o pacto de varsōvia, a conferēncla de Bandung, a Comunidade Europēla do Carvāo e do Aço que se transforma no Mercado Comum Europeu, etc.

Na "América Latina", o pös-guerra è assinalado por revolu çöes no Carłbe, pelo esforço desenvolvimentista no México e no Bra sil, pelas alterações 1nstitucionais na Argentina, na Venezuela, etc. (12). 
Essa virada espetacular que acaba por agir em cadela sobre todas as grandes äreas, tem como cerne a discussão, a anāllse, o equaclonamento dos conceltos económicos, denogräficos, polfticos.

Uma nova conceltuação de "desenvolvimento" e de seus parâa metros, não se opōe, mas completa-se com uma nova concettuação do subdesenvolvimento. Subdesenvolvimento e suas causas ma1s profun das; as formas de romper com a causaçāo circular do atraso; a $1 \mathrm{~m}-$ plantação gradualista ou acelerada das diversas terapêticas visando a corrigir os males do subdesenvolvimento crôn1co (13) passam a preocupar amplas esferas do poder e as classes populares.

As 1 dëlas de planejamento entram en voga: aumentar o PIB fazer crescer a renda "per capita", controlar o consuno (caso multo especial da Grã-Bretanha), retomar os Indices de produção anterio res a 1939, corrigir as disparidades regiona1s, institulr planos de assistēncla social, atender às reinvindicaçōes dos sindicatos, agilizar a măquina burocrātica, etc., etc., são apenas exemplos seto rlais do esforço global que se realizava, a rigor, em quase todos os paises.

0 comando virtual do processo foi, então, entregue aos economistas. Se a dëcada de 1930 è partlcularmente a das grandes ma nobras polfticas, as de 1940 e 1950 , são, nos bastidores, manipuladas pelos economistas.

Nos palses soclalistas, os planos quinqthenals definem as metas a alcançar; nos pafses capitalistas, a intervenção estatal, ma1s ou menos ostensiva, val sucedendo à economia da livre-concor rèncla ${ }^{(14)}$.

"Acontecimento algum fol tão desprovido de planejamento quanto o aparecimento gradual e a importâncla crescente do planejamento, en todos os paises ocldentais" (15).

Na URSS após a época stalinista - firtemente centralizadora em termos de planejamento - sucederam-se fases de planejamento cen tral e execução-avaliação locais.

Hoje, a complexidsde da planificação val assurnindo formas cada vez mais sofisticadas, à medida en que se vão refinando as pró prias tẻcnicas de diagnose e proposição de objetivos (16).

0 Brasil mesmo nāo ficou incólume: depois de 1950, os pla nos governamentais foram se sucedendo e sofrendo um aperfelçoamento na sua sistemätica e implementação. A tal ponto chegou-se, que, a partir de 1964, foi crlado un organismo estatal especifico: o Minis tërlo do Planejamento e Coordenação Econômica. 
Fato que evidencla a importáncta da Economia e do Planejá mento (a nivel federal, estadual e nas empresas privadas) á a multi plicą̧̃o das Escolas Superiores de Economia e o aumento das matrícu las. Ver, a respetto, o gräfico no 17, que delxa nitica a evolução das matriculas nos cursos de Administração e Economia, no perfodo de 1964/1968. O quadro no 23, cobre as matrílulas nos anos de 1969 e 1970 .

\section{GRAFICO NQ 17}

MATRICULA NO ENSINO SUPERIOR - $1964 / 68$

Princlpais ramos de ensino
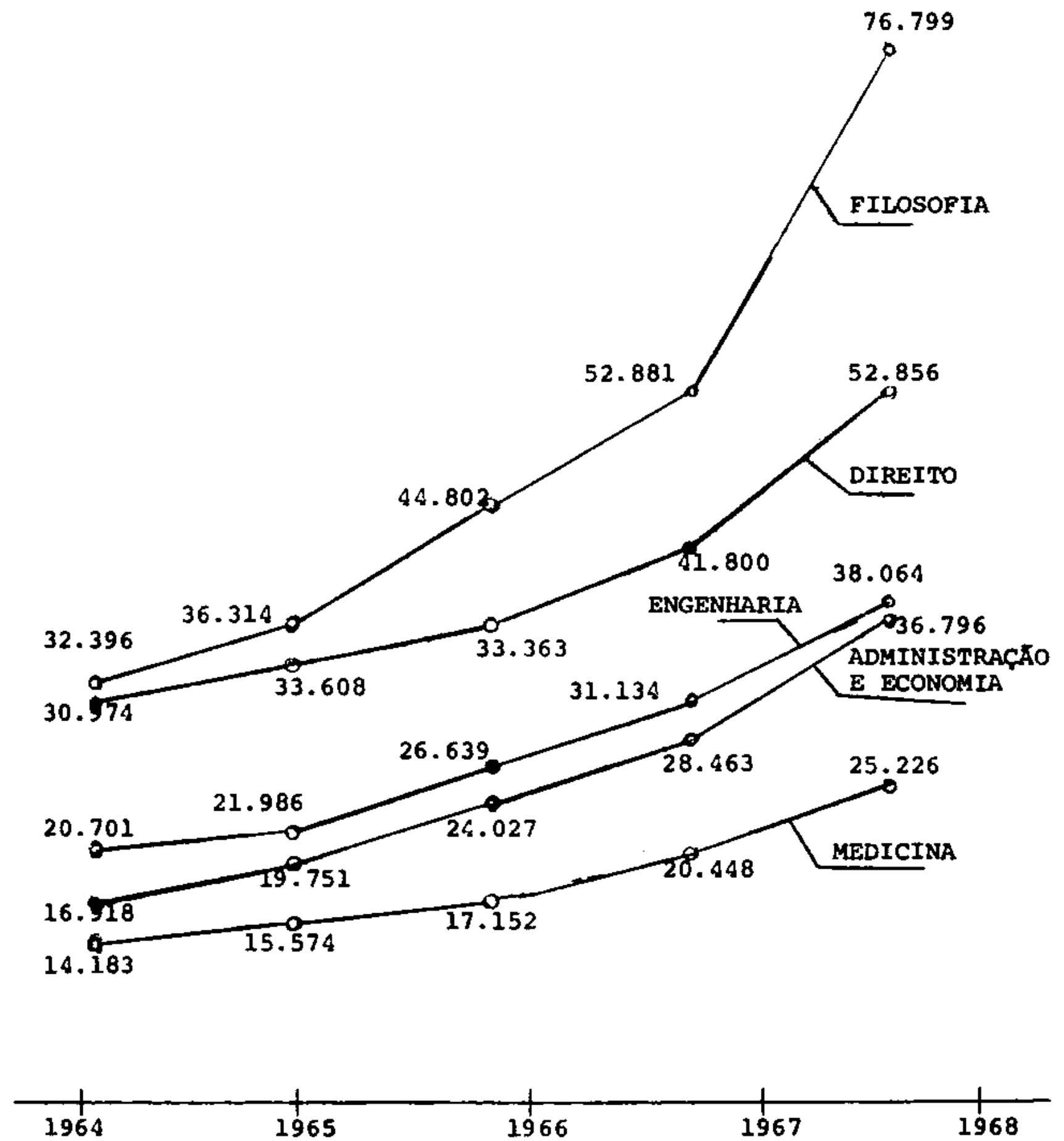

FONTE: Anuărio Estatistico do Bras1l - Fundaçāo IBGE - IBE - 1971. 
Quadro 23

ENSINO SUPERIOR

CURSOS EXISTENTES, MATRICULAS NO INICIO DO ANO, E CONCLUSÖES DE CURSO NO ANO ANTERIOR, SEGUNDO OS RAMOS DE ENSINO-1969/70

a) cursos de graduação

\begin{tabular}{|c|c|c|c|c|c|c|c|c|}
\hline \multirow{4}{*}{$\begin{array}{l}\text { RAMOS DE } \\
\text { ENSINO }\end{array}$} & \multicolumn{8}{|c|}{ PRINCIPAIS RESULTADOS } \\
\hline & \multicolumn{4}{|c|}{1969} & \multicolumn{4}{|c|}{1970} \\
\hline & \multirow{2}{*}{$\begin{array}{l}\text { CUR } \\
\text { SOS }\end{array}$} & \multicolumn{2}{|c|}{$\begin{array}{l}\text { Hatricula no } \\
\text { infolo do ano }\end{array}$} & \multirow[b]{2}{*}{$\begin{array}{l}\text { Concly } \\
\text { söes } \\
\text { do and } \\
\text { ante- } \\
\text { rior }\end{array}$} & \multirow{2}{*}{$\begin{array}{l}\text { CUR- } \\
\text { SOS }\end{array}$} & \multicolumn{2}{|c|}{$\begin{array}{l}\text { Matricula no } \\
\text { lniclo do ano }\end{array}$} & \multirow{2}{*}{$\begin{array}{l}\text { Con- } \\
\text { clu- } \\
\text { soos } \\
\text { do a } \\
\text { no an } \\
\text { te } \\
\text { rior }\end{array}$} \\
\hline & & Total & $\begin{array}{l}\text { Feni- } \\
\text { nino }\end{array}$ & & & Total & $\begin{array}{l}\text { Femi- } \\
\text { nino }\end{array}$ & \\
\hline \multicolumn{9}{|c|}{ BRASIL } \\
\hline $\begin{array}{l}\text { Adninistração e } \\
\text { Economia....... }\end{array}$ & 244 & 47.182 & 5.728 & 5.998 & 276 & 63.816 & 8.140 & 9.059 \\
\hline Bäsico........ & 48 & 16.540 & 2.906 & 1.239 & 63 & 23.363 & 3.032 & 3.356 \\
\hline Admin1stração.. & 12 & 888 & 128 & 31 & 20 & 1.920 & 329 & 10 \\
\hline $\begin{array}{l}\text { Administrą̧äo } \\
\text { Püblica........ }\end{array}$ & 10 & 1.259 & 254 & 161 & 12 & 1.595 & 341 & 136 \\
\hline $\begin{array}{l}\text { Administração } \\
\text { Privada....... }\end{array}$ & 35 & 6.486 & 461 & 629 & 42 & 11.844 & 932 & 21.031 \\
\hline Contador....... & 44 & 4.010 & 567 & 780 & 40 & 4.371 & 651 & 878 \\
\hline Economia...... & 82 & 16.943 & 1.869 & 3.020 & 86 & 19.790 & 2.362 & 23.413 \\
\hline Outros........ & 13 & 1.056 & 540 & 138 & 13 & 933 & 493 & 141 \\
\hline
\end{tabular}

Fonte: Anuário Estatfst1co do Brasil - Fundação IBGE - IBE - 1971

\section{4 - Subdesenvolvimento e necessidade da planificacão global pe lo Estado}

Em muitos palses, hoje, um dos problemas centrals do planejamento è reorientar a abundância; ao contrăr10, em outros - que correspondem à maior parte da população đo globo - a questão fundamental do planejamento é dirigir a penürı, visando a tornä-la menos incidente, menos cruel.

"A mudança mais 1mportante a ser realizada nas polfticas estatals dos países subdesenvolvidos é a compreensão geral da neces sidade de uma política nacional de desenvolvimento econöm1co"(17).

Isto se torna dfficll e, atē mesmo contraditório, pols o Estado vai assumindo o comando efetivo das suas atribulçõos na medi 
da en que se vai tornando mais effciente. Em situação oposta, o Estado não é mals que a coonestação do poder de uma ollgarquia típ ca das socledades subdesenvolvidas. E a essas ollgarquias interessa a manuterçäo do "status quo", a despeito de prcclamar, ou fazer proclamar, justamente o conträrio.

O Estado como agèncla de desenvolvimento soctal e de cres cimento econômico nos palses ubdesenvolvidos, resulta de una conscient1zação da problemát1ca do atraso, do fosso que separa os paIses desenvolvidos e de consumo de massa dos que ainda se preparampa ra a "decolagen".

Dada a fraqueza da Iniclativa privade en quase todos os paises subdesenvolvidos, a opção para o fortalectmento do Estado pla nejador e implementador dos planos è evidento. o Governo passa a exercer funções que, na histörla do capitalismo, sempre foram ärea pröpria da atividade privada.

"Qual a dose 1deal de interferêncla do Estado numa economla Interessada em extrair o máximo rendimento de seu esforço para se desenvolver?" ${ }^{(18)}$.

A resposta a essa pergunta, evidentemente, varia de pais para pais. Dependerä de muitas condicionantes e de multos propösitos.

Basicamente, nas sociedades subdesenvolvidas, compete ao Estado, assumindo o comando efetivo do processo histörico-social, romper o círculo vicioso do atraso. Isso, ele o fará ampliando a sua participação na produção de bens e serviços ou crlando cond1 ções para que se propicie a ação mals dinämica e de sentido soctal mais distributivo da iniciativa privada.

De qualquer forma, a intervenção do Estado como agente di retor do processo se torna evidente, mesmo que o controle se realize mais centradamente no ambito fiscal: redistribulção da renaa, cria çāo de dispênaios corrente, formação de capital.

0 que se vem observando é que o Estado não se limita ao controle da área financelra: abarca o campo psico-social, o estrutú ral, o politico, o educacional, etc. Os efeitos propulsores, a par tir de determinado focn, se multiplicam e envolvem outros setores, dado que a sociedade è um complexo integral e não-estanque.

Outra colsa è a capacidade efetiva da intervenção estatal no planejamento e no controle do processo induzido (19). Ela dependerá não apenas de mera declaração de propósttos, mas estará rela clonada a três fatores; 
"a) o grau de integração da soctedade.

b) A estrutura de poder e as funçōes que a sociedade atribui ao Estado e,

c) O grau de efictência do governo como instrumento operativo do Estado" $(20)$.

Esses fatores de ordem geral, quando dissecados an termos da realldade brasileira, se desdobram num formidävel elenco de pon tos de estrangulamento, que cabe diagnosticar, estabelecer graus de prlorldade, enquadrar no planejamento global e estabelecer estratêgias eflcazes para removè-1os.

Hëlio Jaguaribe ${ }^{(21)}$ desenvolve uma série de idëias, buscando conclusōes a respeito do desenvolvimento econömico e politico, como:

- "O desenvolvimento é urn processo social global, só por facilidade metodológlca, ou en sentido parclal, se podendo falar de desenvolvimento econômico, político, cultural e social" (p.13).

- "O desenvolvimento, como idêta, se distingue e de certo modo se opõe à idēia liustrada de progresso. 0 desenvolvimento, em termos conceituais, è a explicitação de virtualização preexistente no processo histörloo-social. Essas virtualidades säo os modos de exerclicio da racionalidade. 0 proccsso de desenvolvimento, em ter mos reais, é o processo histōrico-sncial mesmo enquanto se encaminhe para sua crescente racionalizaçãon (p,16).

- "O desenvolvimento, só em casos estatisticamente raros e historicamente quase irrepetiveis, como foi o da Grä-Bretanha e 0 de algumas de suas ex-colônias, se processa de modo totalmente es pontāneo..." (p.22).

- "A programação do desenvolvimento é uma técnica de racionallzação cuja validez depende da consistêncla com que se haja analisado a situação, eleitos objetivos compatfveis com a situação e compativels entre $s i$ e adotados, para realização desses objetivos os melos para tal apropriados. Sua vigêncla, como norma, depende, Intrinsicamente, da perduração das clrcunstâncias externas ao plano por ele assumidas como tal" (p.33).

- "... a possibilidade de a comunidade, como soctedade sub desenvolvida, superar a crise social, Induzida pelo efeito de demons traçāo das comuntades plenamente desenvolvidas;" (p.45)

- "o capitalismo de Estado - adequado aos palses en que ē dirıgente a classe mēdia tecnocrātlca - correspondendo esse modelo à transferência, para o Estado, da Iniciativa e do controle dos empreendimentos e acentuado nivelamento da capacidade de consumo de todos os estratos e individuos" (p.65). 


\section{5 - Planejamento e futurologia}

A Intervenção do Estado, seja como agente operacional de uma planiffcação, seja assuminco parte da execuçăo do seu plano e abrindo caminho para a inłciativa privada, atravēs de indicadores $€$ incentlvos, ē,cada vez mais, un fato incontestāvel nesse momento his tór1co.

Caberia, contuco, indagar, atè onde e até quando, en que grau de intensidade e frequência, a planificação estatal, ou não, sẹ ră dominante.

Pensar sobre o amanhã não ë nada de novo, e as expressões prospectiva, futurologia, planejamento a longo prazo, hoje tão em voga, são vocăbulos que expressam aponas un velho propósito do homem ou dos grupos sociafs. 0 temor do desconhecido, as 1ncertezas do amanhã, conduziram os grupos humanos, de forma mats ou menos pirica, a projetar o presente sobre o futuro. Toscamente outra colsa não faziam as socledades primitivas quando armazenavam grão ou carnes, utensillos sobressalentes ou melhoravam suas moradias. A as trologia, que buscava ligar o destino de cada ser a um astro; o ana lisar as vísceras de animais para predizer o futuro; "ler" as $11-$ nhas da mão antevendo a sucessão de fatos significantes; os "säbios" que acumulavan un conhecimento do passado e prediziam o bem ou omal a acontecer; "olhar o futuro", de una ou de outra forma, sempre fol uma preocupação do homen. Ele não se contentou jamals en sobrev1 ver, quis, mesmo, prolongar sua existência, delxar marcas para atestar sua presença, prolongar-se, como se suas obras, sua descendêncla, sua cultura devessem ser forças atuantes no futuro.

Construir o amanhä, mesmo de una maneira empirica, mero exercício da tmaginação ou fruto da criatividade que se realizava fora de sua época, podem ser exemplificados ao longo da histöria. 0s Leonardo da Vinc1, os Nostradamus, os Julio Verne são apenas algumas das figuras que se destacaram no seu tempo, porque o tornaram $e$ lästico, atē os limites da sua prōpria força criadora. As teorias do iluminismo não foram, apenas, un registro histörico, mas sempre, aqui e al1, estiveram presentes.

A medida em que as sociedades se lam tornando mals comple xas, as dificuldades de estabelecer prognósticos foram aumentando, mas isso não reduziu o desejo constante do homem em intervir no fu turo, mesmo que ele não fosse o benefictärio direto desse futuro.

As previsões econômicas, sociais, politicas eram mais que mero exercicio de lazer, traziam muitas vezes a marca da ciência. Exemplo mais popularizado encontra-se nos trabalhos de Karl Marx, no 
século passado, ao prever com os escassos dados que podia manipular, as transformações da sociedade capitalista por força mesmo do seu crescimento. E Marx não foi exemplo ünico do sēculo XIX; ao seu la do, alinham-se filösofos e soctölogos, politicos e economistas, le trados e iletrados, mais pessimistas ou mals otimistas, mals seguros ou menos dotados de certezas.

De Heräclito, conceltuando o "estado de ser" e de "vir a ser", ao Admirável Mundo Novo de Aldous Huxley; de Galileu a Arthur clark do código de Hamurabi ao 0 Ano 2000 , de Herman Kahn e Anthony $J$. Wiener, hä toda uma farta literatura, que val do imponderävel à c1 bernëtica, fazendo do passado e do presente o trampolim para pensar e modificar o futuro.

A futurolog ta como ciêncla se torna cada vez mats presente e atuante. Deixou de ser refügio de uns poucos, para se integrar a organismos estatats e a entidades particulares (22). A medida em que a ciência e a tecnologia avançam suas pesquisas, elas se projetam, se extrapolam, lançam metas a longo prazo.

Torna-se evidente que o tema - não obstante ser fascinante - não ẽ mais um simples exercício intelectual diletante.

A acumulação de uma massa de dados possibilita, atravēs de uma anălise matemătıca, conjugando as variáveis de um sistema, mon tar modelos e estudar o seu desenvolvimento. Isto ocorre em demo grafia, em economia, em sociologia, em biologia, em polftica, etc. Quanto mals dados, quanto mals impessoal ou dogmática a sua anăiise, quanto mais matematizadas as tëcnicas, tanto mais "possivel" mas não "provăvel" è a antevisão do futuro.

No Brasil, a futurologia como algo sërio, era, atê bem pou $\infty$ tempo, conhecida e estudada por uma minoria.

0 impacto do livro 0 Ano $2000{ }^{(23)}$ sobre parcela dos inte lectuais brasileiros foi violento, não pela obra em si mesmo, mas pelas previsões pouco alentadoras para a sociedade brasileira no ano 2 000. As extrapolações dos autores previam que estaríanos ao final do sēculo com uma renda "per capita" de 500 dölares, enquanto os Estados unidos ultrapassariam os 10.000 dólares, o Japão estaria en torno de 8.500 dōlares e a vizinha Argentina em posição bem mais favorăvel que a brasileira: 1.300 dölares.

Artigos e livros logo surgiram en resposta à obra citada, sempre procurando mostrax que a nossa colocação não serä, por certo, tão marginal. Hipöteses alternativas foram levantadas, buscando mos trar que a projeção econômico-financeira, afina:., não deixava lugar a um pessimismo altamente desalentador. 
A vulgarização do tema, que não é esotērico, mas que envolve uma alta dose de pesquisa, acabou por dar-nos a impressão, qua se corteza, de que o futuro não serä tão sombrio. A evolução do PNB passou a ser una mania fixa, ventilada por jornals e revistas. Cor re-se o risco de se imaginar a elasticidade orescente do PNB até atingir percentuais mais e mais próximos do absoluto.

Mas o PNB não pode ser o Eldorado, o Eden que muitos imaginam. Ele ë apenas um referencial que envolve mültiplas variäveis de natureza social e, mesmo, ideológ1ca.

A realidade presente $\vec{e}$, por certo, mutävel, a trajetória pode ser corrigida, sempre que ajustada à realidade.

"Na exploração do futuro, a "gināstica do possivel" conduz ao estreitamento da perspectiva, o que não significa tacanhez de espirito ou pobreza de golpe de vista, mas eliminação voluntária de uma superabundância de imagens. A coerência interna é a primeira virtude dos fins a prosseguir. 0 mundo em que dois e dois são cinco pertence à 1lusão e ao sonho. Ora, o problema não é sonhar, mas agir" (24).

Conforme assinalado anter 1ormente, a planificação é, nos tempos atuais, não un modismo, mas uma técnica de assegurar um futㅆ ro menos incerto.

As empresas privadas, em grau variável, planejan suas at $\underline{1}$ vidades para uma faixa de tempo que pode chegar aos cinco, dez anos.

Os Estados socialistas dispõen de serviços de previsão so cial (exemplo: Conité Estatal "Polōnia no ano 2 000"); outros, capi tal1stas, como a França têm seus organismos pröprios (Comissariado Geral do Plano); outros mais, lançam mão de institulções particulares que se especialtzaram nos estudos de prospectiva (Rand Corporation, nos Estados Unidos).

o fato Inegável é que hä uma preocupação generallzada em näo mals ver na "bola de cristal", mas ter à disposição linhas de ação, soluçōes-alternativas a partir das anălises matemäticas e do cälculo de probabilldades.

A Intervenção estatal nesse sentido é cada vez mais forte, ora mals impositiva, ora mais diretiva, Indicativa, mas nenhum Esta do abdica do dever de traçar os rumos para sua sociedade.

Nos paises subdesenvolvidos as variävels nāo são menos nụ merosas que nos desenvolvidos, a margem da imprevisibilidade è mator numa socledade e nun sistoma econômico que se acelera mais rapida mente, em função de seu atraso histörico-cultural. 
Parece arriscado ir alēm de planos globais de média duração, sob pena de planos mais longos, decenats por exemplo, caducerem antes do tempo, serem alterados pelo surgimento de variāvels imprevisive1s.

As grandes finalidades, as metas, os objetivos a longo pra zo devem ou poden permanecer cono referenciais, mas os planos devem reajustar-se, à medida em que os fatos evoluen, estabelecendo novos pontos de apoto, novos focos de impulso, novas tramas sociais e eco nômicas.

\section{6 - Histórico do planejamento no Bras1l}

o histórico do planejamento tal como tem sido descrito, no caso particular do Brasil, confunde-se com a própria histöria do pais.

Mas, a rigor, è possivel abreviar a exposição de "cortes histöricos", mesmo porque o planejamento sécio-econômico, como hoje se entende, $\bar{e}$ de passado multo recente no Brasil.

A economia e a socledade brasileiras, a partir da Repübl 1 ca, herdaram dos séculos anteriores uma estrutura nodal, en função dos "ciclos" econômicos, que tornara enquistadas no espaço organiza ções que pouco ou nada tinham a ver umas com as outras.

0 traço de ligação política era o regime nitidamente oligärquico, que se fazia representar principalmente pelos governantes paulistas e minelros (o conhecldo acordo "café-com-leiten).

o isolamento das āreas geo-econômicas, agravado por uma precariedade dos transportes que não constituiam uma rede funclonal a Interligar as regiōes, era completado por una economia de exporta ção.

As soluçöes aos problemas de caräter mais profundo e ma1s amplo, eram conjunturais $e$, no cerne da conjuntura, estava a ques tão do cafë, que contribuia con mats de 808 do valor das exporta çōes.

Os governos republicanos se sucediam sem una planifłcacão para o pals: apenas respondtam, com planos emergenciais, às questões que, de uma ou de outra mane1ra, exan geradas pela "produção-exportação-cotação internacional do cafén. Exemplos tfpicos foram - plano de recuperação flnanceira proposto por Joaquim Murtinho, Mi n1stro da Fazenda no governo Campos Salles (1898-1902); o plano de defesa e valorização do café (1906); os planos para 1mplantação de 
ferrovias e ampliação do porto exportador de café - Santos; os $f \underline{i}$ ranclamentos externos para atender à politica cafeeira.

De quando en quando, ao sabor das emergēncias, o Estado 으 ligärquico agta como Interventor: plano de obras contra as secas do Nordeste; questões mil1tares (Canudos, Contestado, o "tenentismo", ...); emergênclas afloradas pela guerra de 1914-1918; leg1slação tra balhista para controlar o surgente "problema operärio", etc. A r $\underline{\underline{1}}$ gor, nada com efe1to que tivesse a configuração de um planejamento orgânico.

No entanto, O Estado oligärquico nāo pōde impedir a cres cente urbanização; o crescimento quantitativo da burgues1a, que so mente em parte era absorvida nos serviços burocráticos do Estado e nas forças armadas; as modiflcações no plano Internacional que acabavam por se refletir na socledade brasilelra; o aumento demograf1co: 1900 - 17.000.000 habitante - 1920 - 30.000.000 habltantes, a nascente industrializaça no elxo Rio-são Paulo.

Os choques de interesses entre os dols grandes lifderes da politica nacional - são Paulo e Minas Gerals - abriram uma brecha no monolitismo que foi aproveltada pela composiçāo polftica gaúcha: a revolução de 1930 se valeu dessa oportunidade no campo interno, com - esforço da crtso internacional de 1929 de amplos reflexos na economia brasileira.

"As crises que haviam abalado a socledade brasiletra nas décadas anterlores à Revolucão, particularmente durante os anos da Depressão Econômica Mundial, tornaram explícitos tanto os pontos de estrangulamento como a complexidade crescente do sistema económico-financedro do Pais".

"Assim, nos anos de 1930-45, o governo federal crlou comissöes, con selhos, departamentos, institutos, companhlas, fundaçōes e formulou planos. Além disso, promulgou leis e decretos. E incentivou a rea l1zação de debates, em nfvel oflcial e oficioso, sobre os problemas econômicos, financelros, alnistrativos, educacionals, tecnológi $\cos$ e outros" (25).

A evoluçāo do quadro söcio-econônico, no Brasil, os pro blemas Intermacionais, determinaram, no parfodo de quinze anos do governo kargas, alterçöos substantivas no regime palitico glo acobou par desembocar no Estado Novo (1937).

As reformas adminlstrativas empreendidas foram confladas a Departamento Administrativo to Servifo Pübllco (DASP), que passa va a agir como um suparmintetério, corn poderes amplos do ponto-do- 
vista orçamentärto, de pessoal, planejamento, controle. Pode-se, a rıgor, assinalar que a crlação do DASP marcou o inflcto do controle do governo sobre as burocracias estadual e naclonal. Mas não chegou o DASP a produzir nenhum plano governamental integrado e dura douro.

"Siegel salienta que o DASP foi conscientemente empregado para absorver as crfticas contra a nova centralizaçāo do regime, per mitindo que vargas parecesse longe dos detalhes do controle" (26).

Em 1934, fol criado o Conselho Federal de Comérclo Exterlor, numa clara evidência de que as grandes preocupações governa mentais alnda estavam centradas na questão das exportações. Esse Con selho produzlu una sërie de estudos e indicações sobre "problemas da economia brasłleira: siderurgla, carvão mineral, combustiveis, If quidos, eletricidade, soda cáustica, vidro plano, crlstal de rocha (quartzo), sal, pinho, erva-mate, carnes, padronização dos produtos exportäveis, nacionalização dos bancos de depósito, cooperativismo, defesa da economia nacional e portos, alëm de todos os aspectos básicos do comércio exterior do Bras $11^{n}(27)$.

Mas tanto o DASP como o Conselho Federal de Comérc10 Exte rior, não obstante reunirem o que de mals signtficativo havia de re cursos humanos para o planejanento, näo produztram mais que proje tos tóplcos, setorlais, quase sempre desvinculados uns dos outros.

A guerra de 1939-1945 levou o Brasil à necessidade de ado tar medidas emergenclais, para fazer face à desarticulação dos mercados estrangetros. Em 1942, o governo criou a "Coordenação da Mobllização Econômica", com atribuições amplas nos setores econōmico e social. Tratava-se de mais um örgão de criação dłtada por una situação externa à problemätica brasileira. Neste espaço de clnco anos iniciais da década de 1940, dols grupos norte-americanos foram contratados pelo Governo Federal para realizar estudos e propor pla nos mals abrangentes para o Bras1l. A 1mplementaçäo dos planos ją mais saiu do nascedouro. Ao tempo en que isso ocorria, em que ou tros örgãos montavam projetos especificos, O DASP armou o "plano Odinquenal de Obras e Reaparelhamento da Defesa Nacional", mals uma carta de intenções não executadas e seguida em 1943 de novo plano quinqtenal de Obras e Equipamento" cuja vigència se previa de 19441948 .

En 1945, a deposição de Vargas iria tmprimir novos rumos ao regime politico.

Todavia é forçoso acrescentar que todos os trabalhos realizados pelos diversos örgãos de planejamento e de execução haviam 
deixado um lastro que mais tarde seria corporificado em planos esta duais e mesmo federa1s. Formava-se, em suma, un "know-how" bras1 leiro nas técnicas de planejamento. A implementação dos planos era outra face da moeda que esbarrava numa sërie de obstāculos, dentre os quais pode ser realçado o peso morto da maquina administrativa, emperrada por una burocracia impavidamente ineficiente.

A Constituição de 1945 não fazia referência ao planejamen to soc1o-econômico global, agenclado e executado pelo governo federal.

As disparidades reglonats crescentes levaram à criação de agências especificas para o planejamento e desenvolvimento da Amazô nia e do Nordeste, dotando-as de órgãos planejadores e do neçessã rio suprimento orçamentärio.

A filosofia governamental de então, dominada pelos ideais de liberalismo, reduziram a açāo governamental na ärea econômica e social. O Conselho Nacional de Economia crlado pela Constitulção de 1946, só fo1 realmente estruturado très anos depois.

A dicotomia entre os setores püblico e privado represen tou un hlato no sentido de coordenar as diferentes atividades cujo objetivo deveria ser o desenvolvimento menos desequilibrado do Pais A razoãvel dose de om1ssão estatal não correspondeu maior agressivi dade do setor privado, alnda dēbil para assumir funções bãsıcas no crescimento econômico e, mais fraca ainda, no que concerne ao desen volvimento social.

Os problemas que se evidenciavam, nos setores camblais, sa larials, de infra-estrutura econômica, foram equacionados no PLANo SALTE (Saūde, Alimentação, Transporte e Energ1a), que, enfocou aspec tos setorials como prioritärios, mas só teve recursos orçanentärtos próprios en 1949. Acabou por ser posto de lado em 1952.

A Superintendência do Plano de Valorização Econōmica da Amazônia (SPVEA) e a Comissão do Vale do são Francisco (CVSF), só tiveram seus planos aprovados, respectivamente, 1953 e 1950.

"A politica econômica do Governo Dutra inspirou-se no 1iberalismo (ideologicamente) e na empresa privada (na prătıca). Por isso, não se configurou como uma politica deliberada de desenvolvimento econōmico-nacional" ${ }^{(28)}$.

o período seguinte que correspondeu ao segundo governo var gas, caracterizou-se por nova orientação no tocante ao planejamento. A conjuntura internacional, em plena vigèncla da "guerra frla" e do expansionismo do capitalismo internacional; a criação de organismos financeiros ou a revitalização de outros (Banco Mundial, FMI, BIRD, 
etc.), a maior proeminència da CEPAL, reunindo técnicos de värios paises, inclusive sulamericanos, configurava novas perspectivas pạ ra o Brasil.

De mesmo passo, internamente buscava-se romper com o quase-absenteísmo estatal em situaçōes de planejamento, criando-se con d1çōes para uma nova reorlentaçāo do engajamento do governo federal nas questōes bãsicas de interesse nacional.

A burguesia ligada à indüstria (nacional e internacional) voltava-se mais ostensivamente para as definições de fundo e de for ma. A politização das classes urbanas, cindida na ldeologia do na cionalismo, refletla-se no debate público, aceso e notörio, sobre te mas atë entāo abordađos de maneira mais ou menos superficlas: a ques tão siderürgica, a do petröleo, a da energla, a dos financiamentos, a da valorização regional, a da tnflação e da sistemática salarial, etc., etc.

Importante passo fol dado pelo "Plano Nacional de Reapare Ihamento Econômico", em 1951, e pela criaçāo do Banco Nacional do Desenvolvimento Econömico (BNDE), em 1952.

0 BNDE era mutto mais que uma mera agência flnancelra, ca bendo-1he, em ültima instância um leque amplo de at1vidades de diag nóstico, planejamento e financiamento de projetos.

0 pröprlo governo assumta postçōes nacionalistas ao propugnar pela criação da PETROBRAs, da ELETROBRAs, da CACEx (Cartelra de Comércio Exterior), do fortalecimento da politica siderürgica en täo apolada na realidade de volta Redonda.

As agitações politicas que chegavan a um estado de efer vescência com os partidos majoritärios (UDN, PTB, PSD) não delxavam de influenciar as atividades do governo federal, que, ao mesmo tenpo que contemporizava, flrmava uma linha de ação nacionalista, para tanto fazendo apelo crescente aos örgãos de planejamento sob orientação direta da Presidência da Repüblica. 0 planejamento central corporificava-se, não obstante sofrer as indefintçōes de carāter po IItico.

Fato è que o periodo de 1951-1954, representou um marco para a intervenção estatal nas questōes magnas de interesse global, cortadas abruptamente pelo suicialo de vargas em 1954.

A mudança governamental do ponto-de-vista politico teve que contar com $\circ$ acervo dos planos e das novas orientacõos em ter mos de planejamento federal que iriam refletir no governo segulnte de Kubitscheck. 
A irreversibilidade de questōes de planejamento estava pos ta e serla aproveitada no "Plano de Metas", a partir de 1955.

0 Estado assumla o dever indeclinävel de propor planos in tegrados dal em diante. Os alversos örgāos de planiflcaçāo foram cordenados para o diagnóstico, o planejamento e a execucão dos planos integrados. A rigor, pode-se afimar que, pela primeira vez na h1stōria do planejamento governamental e a organização se configura va en termos de tecnologia plantficadora.

0 "Plano de Metas" do governo Kub1tschech fol publicado, em suas linhas gerals, como uma plataforma de governo, em 1955.

Apös as crises politicas internas que quase chegaram a comprometer a posse do candidato elelto, o "Plano" fol desdobrada a partix de 1956, em projetos especificos, cerca de trinta, girando a maior parte deles er torno do processo da industrialização.

As experiências do Plano SALTE, as atividades do BNDE, os estudos da CEPAL, a nova orientação da politica externa dos Estados Untcoos que jã provara sua eficiêncla na Europa e no Japão e voltava - se para outras āreas dependentes, foran canalizadas, aproveitadas pelo novo governo, ao definir-se em termos de política económica. As metas quantificavam os objetivos e previam as formas de captação de recursos, provententes do orçamento nacional e de investimentose emprēstimos estrangeiros.

Semelhante aos propósitos de Vargas no que tange ao desen volvimento via industrlalização, o plano de lietas dele diferia ao postular e a agir no sentido de que essa industrialização não podería ser alcançada senāo num slstema de 1nterdependência internacional.

A industrialização deixava de ser induzlda pelo estrangulamento do setor externo, notadamente levando-se em conta o final da guerra da coréla, levantavam-se as grandes carênclas nacionals, no que respeitava à Industrialização de substitulção das importaçōes (bens de consumo) e na criação e/ou diversificaçāo do setor de bens de equipamento.

A opinião püblica e os segmentos pollticos mals que nunca acreditavam que havia uma Intima correspondencla entre planejamento e desenvolvimento. 0 Conselho de Desenvolvimento, criado em 1956, tinha por tarefa bāsica acompanhar a implementaçāo dos projetos, es tando diretamente vinculada à Presidêncla da Repüblica.

Por via dos recursos financelros nactonais e dos internacionals, criaram-se a USIMINAS, no setor siderūrgico, ampllou-se a oferta de energia, tanto elētrica quanto petrolifera, montou-se o 
parque autamobilistico, deu-se infcio ao programa de construçäo naval, aumentou-se a rede rodoviärla, inclusive $\infty$ a abertura da Be lëm-Brasilia, fol projetada, construlca e Inaugurada a nova capital federal, criou-se a SUDENE, quando a situação polftico-econônica do Nordeste reclamava ação mais direta do governo federal.

A ênfase do "Plano de Metas" recalu no setor Industrial que se desenvolveu notadamente na "core-ärea" do pals.

Algumas metas industriais chegaram mesmo a ser ultrapassa das, o que não ocorreu no setor agricola e no de infra-estrutura so clal, particularmente no que se refere à educacão. Esta havia sido dimensionada com malor destaque no segmento de educação tëcnlca,aco plada à expansão industrial.

Pode-se afirmar que, ao final, o "plano de Metas" havia apresentado mals resultados palpáveis que os anteriores, näo obstan te ter-se configurado como uma forma de capitalismo dopendente, ou assoclado, do conträrio do que propugnava o segundo governo vargas.

A 1deologia desenvolvimentista estava finalmente implanta da e, mais importante, talvez, que a conscientização do fenómeno, era a criaçāo de una geraçāo de tēcnicos treinados em planejamento, não apenas na cüpula federal, mas nos sctores dos programas especificos e em alguns Estados da Federação.

Se o planejamento em $\mathbf{1}$ deve ser uma técnlca neutra, a rea lidade demonstra que a interferència de caräter polftico pode alterar sua substâncla e sua execução. Neste sentido, a fase de 19611964, no Brast1, è rica de ensinamentos.

o rápido período do governo Jânto Quadros não chegou sequer a realizar um balanço completo dos resultados próximos do "Plâ no de Metas".

As contradições internas se avolumaram, cindindo os interesses dos grupos ligados ao Executivo (prō-industrialızação) e dos grupos mals representativos no Legislativo (a força agräria do Paíd.

A divida externa que teve cie ser negociada e reescalonada a ma1or ènfase às exportaçōes de géneros primärios, a inflação cres cente, a falta de uma nitida definição de objetıvos governamentals, en sete meses de governo apenas evidenclaram as fortes contradições internas.

o governo Goulart que se seguiu, debateu-se, de Iniclo, en tre as questōes do parlamentarismo e do presidencialismo. Firmadoes te, a menos teorlcamente, permaneclam e avolumavam-se os grandes problemas de natureza estrutural. 
A economia de substitułção de 1mportaçōes esgotara seu velo; reduziu-se o Indice de Investimentos, decrescendo iguaimente - Ingresso de capttais externos; a 1nflação de custos era acompanha da de un reajuste salarial constante; os debates püblicos acirravam as Ideologlas da direita e as da esquerda; atingia-se quase a um pon to de ruptura ma1s que partidărıo econônico e social.

A defintção mals clara e objetiva fol buscada no "PLANo TRIENAI", elaborado por uma equipe supervisionada pelo econom1sta Celso Furtado. A Comissão de Planejamento Nacional (COPLAN) criada no governo de Jânio Quadros mal chegou a ser estruturada, quando em 1962, ainda sob o regime parlamentarista, crlou-se o Ministërlo Ex traordinärlo para o Planejamento. Ao ministro designado e confirma do no cargo, en 1963, coube a tarefa de fazer elaborar o plano Trie nal. En que pese o curto espaço de tempo no qual fol preparado, o Plano detinha-se no diagnöstico da problemätica nacional, propunha medidas drásticas para o perlodo 1963-1965 e representava um instru mento global e abrangente para a ação governamental.

Todavia não chegou sequer a ser implementado, mesmo sendo de caráter centralizante.

0 panorama da instabilidade politica nāo serviu de respal do para que fosse deslanchado. A queda do governo em 1964 iria mu dar radicalmente as estruturas politico-econômicas do Brasil.

o governo de Castelo Branco, entre as providenclas In clais, tratou de se armar de um plano governamental. Para tanto, em poucos meses, o Ministro Extraordinärio para o Planejamento e Coordenação Econômica cercou-se de uma equipe tēcnica e, tomando por ba se o Plano Trienal, apresentou o Programa de Ação Econômica do Governo (PAEG), em que se procurava conter, gracualisticamente, a $1 \underline{n}$ flação sem conduzir a estrutura econômica a uma desaceleração. A par pança 1nterna e os Investimentos estrangetros foram realçados no plą no; a absorção da mão-de-obra de baixa qualificação irla ser real1zada atravēs do Banco Nacional de Habltação (BNH); a reforma agrã ria que havia sido um dos pomos de discórdia no governo anterior $\mathrm{SU}$ PRA) fol redimensionada através do Instituto Brasileiro de Reforma Agrärla (IBRA); cuidou-se especialmente de eliminar os subsílios à Importaçāo e aumentar as exportaçōes; a polftica externa foi equa cionada en novas bases; o Executivo fol se fortalecendo an detrimen to do Legislativo. Os primeiros resultados, tanto no campo econōm co quanto no social, só aos poucos foram se evidenciando.

Em 1965 foi crlado o Conselho de Planejamento (CONSPLAN) de função consultiva, ao mesmo tempo en que o Escritór lo de planeją 
mento Econômico e Administrativo (EPEA, posteriormente IPEA) lançava-se na tarefa exaustiva de elaborar um planejamento mals amplo, o PLANO DECENAL 1967-1977, que fol posto de lado pelo governo seguinte.

Este, representado por costa e Silva, insistiu na "humani zaçäo da revoluçäo", formulando o PROGRAMA ESTRATEGICO DE DESENVOLVIMENTO. No fundo, porēm, a orientação básica do governo anterior continuava presente (1968-1970).

0 atual governo, através do Minłstério do Planejamento e Coordenação Geral, como que realizou um balanço dos planos anteriores, modificando alguns pontos e mantendo outros, no PRIMEIRO PLANO DE DESENVOLVIMENTO ECONÔMICO E SOCIAL. Deu-se destaque ao orçamento plurianual de investimentos, de forma a compatibllizar metas e re cursos financeiros.

Iqualmente cada Ministério cuidou de apresenter seu plano Setorial e a compatibilização dos mesmos com as metas do governo fe deral fol tarefa do Ministério do Planejamento.

A vigèncla deste Plano deverā ir atë 1974.

Ao longo de quase quarenta anos, o Brasil passou por uma sërie de planos governamentals.

Alnda hă algum tempo, argłla-se se o planejamento è cond1 ção "sıne qua non" para o desenvolvimento ou, em sentido Inverso, se - crescimento econômico e o desenvolvimento social podem processar-se independentemente de uma planificação.

Ao menos na atual conjuntura histörica, e nesse sentido o Brasil não è atípico, tudo $f a z$ crer que a planificação é altamente relevante para acelerar e coordenar as mültıplas atividades econôn 1 cas e sociais. A profundlade e a extensão de un plano, isso sim, variam em função dos contextos nacionais, mas a planificação constí tui uma das técnicas de governar, no sentldo de prever para atuar.

0 Brasil jä acumulou suficiente "know-how" em planejamento, seja global, seja setorial, seja no que se refere a microplanejamento.

A implementação dos planos e dos projetos, esta sim, ainda esbarra en vários obstáculos, certamente removíveis. Talvez o mais critico seja o referente aos recursos humanos da máquina administrativa. A burocracta brasileira está multo aquëm da delineada por Max Weber.

A reforma adminlstrativa não só se arrasta institucionalmente, como só alcançarā a sua plenıtude com a reformulação profunda da ineficiência registrada nos recursos humanos burocrăticos. 
Outro aspecto positivo para o planejamento no Brasil è que ele não representa mais un ponto-de-vista pessoal, senão um esforço interconjugado de tëcnicos. Mas aqui, vale ressaltar que hă um pri mado dos economistas, cujo enfoque termina por ser unilateral.

As equipes de planejamento alnda se ressentem de uma polí valêncla tēcnica em sua composição. A quase totalidade dos planos no Brasil gira en torno do problema econôntco, seja através do enfo que estruturalista, seja do monetarista. Crescimento econômico e desenvolvimento social são dados de uma mesma equação.

Un plano não é apenas um instrumento que valha à sobrevivèncla de um regime politico ou de um ministērto, ou de un örgão da administração püblica e privada. Ele deve ser un indicador da ação e como tal precisa ser respaldado por uma estabilidade politica e certa continuidade administrativa. Um plano central e uma fragmentação política são conflitantes. De igual modo, um plano e a ausên cia de um "staff" que o avalie e o reajuste, perlodicamente, não passa de um propōs1to.

Por ültimo, cabe assinalar que urn plano não é uma panacóia para males diagnosticados isoladamente. 0 seu sentido global e glo ballzante deve contar com o apoio, quando mals näo seja, da elite dirigente.

A allenação dos alrigentes e, por via de consequência, do povo, tornam um plano, no minimo uma vălvula de escape para as frug trações pessoats e grupais.

A conscientızação das metas e dos projetos de um plano po dem ser remédio eficaz inclustve para as variações da conjuntura in ternacional que, de uma ou de outra manelra, refletem-so na estraté gia para a execução dos projetos.

\section{7 - planejamento global e planejamento educacional}

Durante largos perlodos, o Brasil tal como muttos outros países, não dispunha de nada que se asserielhasse aos atuais planos de educação. 0 fenōmeno era quase espontâneo, geralmente tóptco, desvinculado de um contexto social e econômico, imediatista e arrumado para atender a uma que outra necessidade especifica ou a uma pressão social. Isso não significava, de forma absoluta, inexperiència no campo internacional (29). Desde a antigaldade clássica pla nejava-se a educação, quase sempre a serviço de objetivos sociaise/ ou politicos e não como um processo tendente a se integrar à dinâmi ca soctal, com vistas à acelerar sua mudança, eliminar os atritos e ellair os pontos de estrangulamento. 
A pröpria indefiniçāo do valor da educação agia como causa e efeito dessa posição subalterna ${ }^{(30)}$.

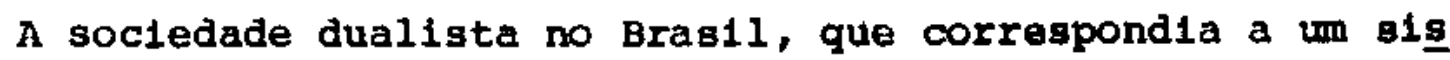
tema söcio-econōmico satëlite, realmente não pođía pensar en planejar a educação a não ser em termos de manter o "status quo".

A Intervenção estatal era reduzida ou nula e nisso fazia coro com as demais atividades no Estado ollgárquico, que elaborava programas a curto prazo para atender às necessidades da elite dirigente.

A partir da Repüblica; com o débil crescimento indus trial e com a urbanlzação; com o crescimento da classe médla; con - "efelto-demonstração"; por via de um contato mais amplo com ou tros palses; com a alteração dos comandos politicos; com o desenvol vimento das pesquisas clentificas; com os múltiplos efeitos da $2 a$. guerra munaial, só aos poucos o pals fol tomando consclêncla do gran de rombo educacional existente.

Sucederam-se, po1s, reformas, que eram mais legislativase administrativas que, na realidade, reformas de estrutura educacio nal. E assim não podla delxar de ser, quando a própria estrutura $\underline{\text { e }}$ conômica era só de leve tocada.

Os debates surgidos eram mals respeltantes a aspectos su perficlais da questão ou, quando multo, refletiam a bipolarização en tre "livre empresa e ação estatal". 0 resultado era a omissão do Estado e a propagação da "livre Iniclativa" no setor educacional. E como ela era altamente o fruto de iniciativas particulares, só coerentes quando se tratava de iniciativa de orientação religlosa, ore sultado era a descoordenação educacional.

o pröprio Ministérto da Educação era ambíguo e vacilante. Originariamente (14-02-1930) englobava assuntos da educação e da saúde; só en 1953 os temas desta ũltima passaram a ser do âmblto de atuação de örgão eepecifico.

A essa sobrecarga de tarefas (educação e saüdo), somavam-se: o peso da burocracia ineficlente e largamente pouco qualificada; os recursos orçamentärios pequenos; a instabllidade polftico-ad ministrativa; a hipertrofia funcional; a magnitude dos problemas; os próprios objetivos que norteavam a ação do Minlstērto, transformado en "agência cartorial" $e$, nem de longe, örgão planejador e coordena dor da educação.

o planejamento educaclonal a médlo e a longo prazos, esti mulado e reforçado por dotação orçamentärla (orçamento-programa) e 
por una tëcnica que val se tornando operacional, conta ainda, com uma série de entraves, para não ser apenas uma "carta de intençōest. Hoje, ao que tudo indica, posiclonou-se de forma correta a questão educacional no Brasil; ela constitul um subsistema inte grado ao sistema sōcio-polftico-econônico. Por 1sso mesmo, qualquer tentativa de equacionä-1o, deve levar em conta as outras grandes varláveis do sistena.

Planejar, modernamente, não tem mals o sentido mágico que antes permanecia, mas "a noção de planejamento não é outra se não a de aplicação de mëtodos cientificos ao trato dos fenòmenos naturals e socia1s, com o propōsito de aumentar a capacidade de prê visão humana e de ensejar intervençäo no processo de desenvolvimento social, acelerando-o ou modificando-on(32).

\section{8 - Conclusões parciais}

1. - Planejar $e$ atividade própria de grupos sociais mais coesos, mais determinados a alcançar objetivos.

2. - o planejanento no Brasil, a rigor, se iniciou depois de 1930.

3. - Os aiversos planos naciona1s, atẻ há ben pouco tempo, eram setorials e não atinglam os objetivos a que se propunham.

4. - No Brasıl, o plano ë um instrumento norteador da ação estatal, atravēs da atuação direta ou atravēs de indicadores para a empresa privada. 


\section{NOTAS REFERENTES AO CAPITULO 1}

(1) - LAJUGIE, Joseph - 0s s1stemas econômicos. Traduçāo de Geraldo Gerson de Souza - Sāo Paulo - Difusão Europēia do Livro - Co leção "Saber Atual" - 2a. edição - 1965.

A "introdução" é interessante para se reavivarem os conceltos bäsicos a respelto de s1stema, regime e estrutura. De la se retiram os trechos a seguir:

"Conceituaremos sistema econômico com un conjunto coerente de instituições jurílicas e socials no seto das quals são postos em ação, a fim de assegurar a realização do equilibrio econômico, certos melos tëcnicos organizados em função de cer tos möve1s dominantes".

"O regime econômico é apenas um elemento do sistema.

Defint-lo-emos como o conjunto de regras lega1s que, no se1o de um dado sistema econônico, regem as atividades econōmlcas dos homens, 1sto é, seus atos e ações em matérla de pro dução e de trocan".

"A noção de estrutura econömica, finalmente, está a melo caminho entre a de slstema e a de regime.

Designa, para empregarmos a definiçāo clässica de F. Pex roux, "as proporções e relações que caracterlzam um conjunto econômico locallzado "no espaço e no tempo", isto $\vec{e}$, as part1cularidades que infundem una fisionomia próprla a determinada unidade econômica". p. 7 - 12 .

(2) - LAROUSSE, Delta - Grande enc1clopédia - Rio de Janeiro - Ed1tora Delta S.A. - Vol. 9/10 - 1970.

"Planfficação, s.f. Ato ou ação de submeter algo a un plano,...". Planificação econôntca, conjunto de projetos orgânicos entre st, para obtenção, dentro de certo prazo, de determinados resultados econōmicos-sociais. O mesmo que planeja mento, vocäbulo preferente para os planos de micro-economia ou de organização setorial limitada". p. 5391.

"Planejamento s.m. Plano de trabalho detalhado. slatema de tēcnicas que têm por objeto a elaboraçāo de programas eo nômicos que comportam não somente a Indicaçāo dos objetivos a serem atıngidos, mas também a previsão das diversas etapas de execução, a provisão dos melos de financlamento, assim como a descrição da estrutura dos organismos especiais para sua ca bal reallzaçãon. p. 5390 . 
"Plano - Econ. pol. Conjunto de medidas governamentais ou intergovernamentals que tên por objetivo a solução de um problema econômlco ou flnanceiro, ou a expansäo econômica de uma regiăo, de um pals, etc." p. 5393.

"Progr amação - Econ. Planejamento menos rigido p=attcado em palses de conomia capitalista". p. 5553.

"Projeto s.m. Designio, intento, plano./ Primelra forma que se dä por escrito a uma ldểa ou a uma proposição qua quer". p. 554 .

(3) - Os conceitos de subdesenvolvimento, alëm de serem tomados "en relação a", encerram uma conotação de diverstdade e dinamlsmo. Normalmente enfocados en värias ciènclas Sociais, são mais fre qilentes en Economia, em Sociologia, em Geografia.

(4) - BeLtRAo, Pedro Calderan - Sociologia do Desenvolvimento - Pox to Alegre-RS - Editora Globo - 1965 p. 11 - 28.

(5) - MYRDAL, Gunnar - o Estado do Futuro. Traduçäo de Affonso Bla cheyre - Rlo de Janelro - Zahar Ed1tores - 1962. p. 24

Acrescenta, ma1s adiante, o autor: "A expressão "econonia planiflcada" contēm, è claro, uma tautología evidente, jă que a palavra "economia" en si mesma, Implica numa atributç̃̃o da melos disponiveis para se atingir um fim ou um objetivo. Acres centarmos "planificada" à mesma para indlcar que tal coordena fão de atividades ten um objetivo, não faz sentıdo e, pelo me nos, podemos afirmar que nāo é um bom emprego de palavras".

(6) - MYRDAL, Gunnar - op. c1t. p. 37 - 58 .

(7) - MYRDAL, Gunnar - op. c1t. p. 59 - 129.

(8) - GEORGE, Pierre - Geografia Econômica - Tradução de Ruth Magna nini - Rio de Janeiro - Editora Fundo de Cultura S. A. - la. ed1ção - 1961. p. $49-70$.

(9) - THOMSON, David - Pequena Histöria do Mundo Contemporâneo (1914-1961) - Tradução de J. C. Telxeira Rocha - Rio de Janel ro - Zahar Editores - 1967. p. 83 - 91.

(10)- GENET, L., et all11 - Le monde contemporatn - Classes Termina les - Collection D'Histoire Hatier - Paris - Iibrairie Hatler1962. p. $40-45$. 
(11)- GENET, L., et alli1 - Le monde contemporatn - op. cit.p.436 485.

"L'iniative revient à l'Etat: en espèce, l'organlsme compétent est le GOSPLAN. Jjepuls 1928, tout le développement èconomique est commandé par le plan qui englobe tou les secteurs d'activité. :

"Toute l'activité économique du pays est alnsi enserré dans un système untque et coordennë". p. 470 .

(12)- GEORGE, Plerre - Panorama do Mundo Atual. Tradução de Pedro de Alcântara Figueira - S. Paulo - Difusão Europēia do Livro-1966.

A segunda parte do livro (p. 85-211) analisa as diversas alteraçōes em profundidade dor que passou o mundo, no século $X X$, particularmente no periodo apös 1945 .

(13) - BeLtRão, Pedro Calderan - Sociologia do Desenvolvimento. on. cit.

"Todas essas tendênclas do pensamento econômico conflulam para uma retomada de consciêncla da problemática do desenvolvimento e, simultâneamente, de aspectos extra-econônicos do fenömeno". (p. 22).

"Durante a guerra multiplicaram-se tais escritos, começan do tambëm a 1nteressar as instâncias internacionals". (p.23).

"Neste aoós-guerra, a problemāt1ca do subdesenvolvimento tornou-se central nas relaçōes de influência ou de força poli tica na "guerra fria" entre Leste e Deste". (p. 24).

"Também quanto a outros pontos controvertidos os economis tas dos paises subdesenvolvidos foram conseguindo impor os próprios pontos de vista, nomeadamente com respeito ao comple xo problema inflação e desenvolvimento". (p. 26).

"O planejamento para o desenvolvimento, tornou-se, enfim, - traço característico das políticas econōnicas atuais, não somente na örbita soviētica e nos palses subdesenvolvidos fora dela, senão também nos pröprios palses que se desenvolveram en clima liberal". (p. 27).

(14) - MYRDAL, Gunnar - o Estado do Futuro - op. cit.

"Na segunda metade do sēculo o Estado, en todos os palses ricos do mundo ocidental, tornou-se um Estado do Bem-Estar de mocrätico, de compromissos bastante explicitos com relação às metas do desenvolvimento econöm1co..." p. 77. 
"Um aspecto interessante do aperfeiçoamento gradual do mo derno Estado do Bem-Estar é que nultas divisōes de opiniōes, antes de Importância vital, tenden hoje a desaparecer ou a mu dar de natureza e, assim, a se tornaram multo menos importantes: p. 86.

(15) - MYRDAL, Gunnar - O Egtado do Futuro - 0.9. c1t. p. 37.

(16) - ChAMBRE, Henri - A Economia plantflceda. Tradução de Pedro de Alcântara Figueira - São Paulo - Coleção "Saber Atlal" - D占 fusäo Européla do Livro - 1957.

"Numerosos economletas, plenificadores e especlalistas en

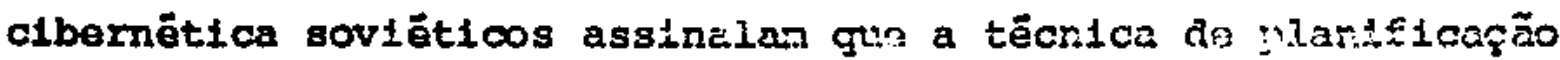
atual se tornará casa roz tals atficil, cada ver neis cispen -

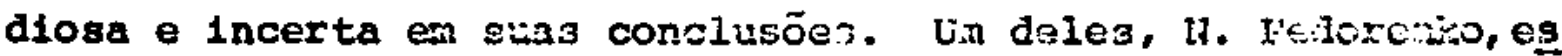
creve, no PRAVDA de 17.3.1965 gut, no Ittuo ex gio vĭo as co18as, em 1980, 100 milhões do pescoas empregezas no apcrolho da

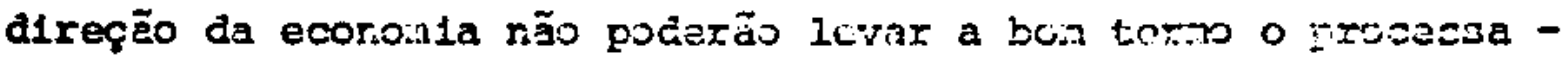

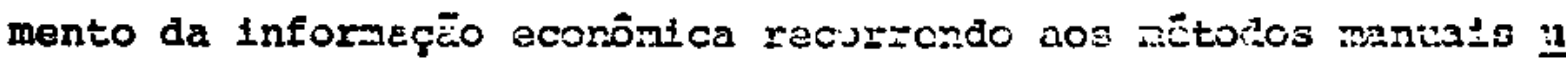
t1lizados hoje en cila". p. 110.

(17) - MYRDAL, Gunnar - Teorta Econontce e req1óes gubcesenvolvijaz Rio de Janeiro-ga - Editora 5aza - 1955. p. 125-15s.

(18) - SIMONSEN, Mär10 Venrique Brag12 2 Q02 - Elo cio Janelro-GB APEC Editora S.A. - 1969

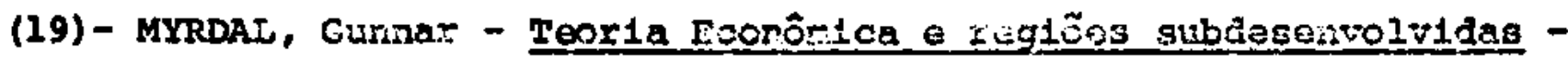
op. cit.

"Un plano nacional ceve ser o esquema du processo acumiativo de desenvolvimento econinico de urs pafs, a previeão do ero luir desse processo, quanio cef jagrado, masticio e conicolado por certas mudanças exögenas, induzldas no sistena social, mediante interferôncias estżals celiboradas. Esse esquena pres supöe, po1s, un estudo la causcgäo ciycular entre todos os fa tores relevantes do sistera sorja:. do Pãs, Glö sejan "cconômicos" ou "não-econônicos". p. 133-134.

(20) - FURTADo, Celso - Subdesenvolvimonto e estergneç̄o ra Arörlca La tina - Rio de Janeiro-GB - Eältora Cirilização Brasileira S.A. 1966. p. 155-127.

(21) - JAGUARIBE, Häl10 - Des onvolvirerto Ecorômico e Desoryo? vimento Politlco - Rlo Co Janelro-Gi - Editora Paz e Terra Ltda. 1969. 
(22) - LADA, Igor V. Bestuzhev. Evitemos entrar en el futuro a clegas. ¿Tiene porvenir la futurologia? Paris - El correo UNESCO - Año XXIV - 1971. p. 22- 27.

o autor assinala a existência das inümeras organlzaçōes voltadas para os problemas teóricos da investigação do futuro.

"Hay quienes plensan que la previsión es una disciplina c1 entifica nueva, una "clencia del futuro". ¿Esto es realmente clerto? Estamos aslstiendo, de hecho, al nacimlento de una nueva ciencia. Pero no se trata de una clencla del futuro en general, sino de la clencia de las leyes y los metodos del es tudio del futuro, de los problemas teöricos de la previsión proplamente dita. Para distinguirla de ēsta, se la llama a veces "prognósis". (p. 24).

Mostra, adema1s, o autor, que an 1970, na Europa 293 organ1zações se dedicavan ao trabalho de previsão social. Nos Eg tados Unidos, em 1967, havia 600 inst1tuigões do mesmo gênero.

Organismos estatals, nos paises socialistas a nos palses capitalistas tambën existem e em nümero não desprezivel.

(23) - KANH, Herman e Anthony J. Wiener - 0 Ano 2000 . Tradução de Raul de Polillo. São Paulo - Ediçöes Melhoramentos - 2a. edí ção - 1969 .

(24) - MASSE, Pierre - 0 plano, aventura calculada. Tradução de Alda Rosa e Alfredo de Souza - Lisboa - Portugal - Livrarla Mo ra1s Editora - 1967. p. 33.

(25) - IANNI, 0ctávio - Estado e Planejamento Econômico no Brasil Rio de Janeiro-GB - Editora Civilização Brasileira S.A. - 1971 p. 22 .

(26) - DALAND, Robert T. - Estratégia e Est1lo do Planejamento Brasi le1ro. Traduzido por Carlos kronauer - Rlo de Janeiro-GB Editora Lidador Ltda. - 1969 - p. 16.

(27) - IANNI, 0ctãvio - Estado e Planejamento Econōmico no Brasil op. cit. p. 17.

(28) - IANNI, Octávio - Estado e Planejamento Econōmlco no Brasıll op. ctt. p. 99.

Ver o Cap. III, p. 75 - 105. Igualmente, ver de DALAND, Robert T., op. cit. p. $27-33$ e p. $46-49$. 
(29)- CoOMBS, Phtlip H. Qu'est-ce que la planiflcation de l'educa tion? Traduite de l'anglais por l'ILPE - Louvain - BelgiqueUNESCO - 1970. p. 17 - 20 .

(30)- ARREU, Jayme - Educacão, Socledade e Desenvolvimento - R1o de MEC - INEP - CBPE - Sërle VI - Socledade e Educação - Vol. 81968. p. 79 - 104 .

"Na medida em que o conceito Ignorava a componente econônica da educação, na extensão em que negligenciava seu aspecto de investimentos em seres humanos, para pairar apenas na area de supertores direitos humanos, expressão de um concelto abstrato de humanidade, implicitamente homologava um cer to sentido latente de direlto a uma educação entendida, senão para o lazdr, para o refinamento pessoal ou como instrumento de dominação, desligando-a, nessa conceltuação onissiva, das formas concretas, "Inferiores", de preparação para o trabalho ou de instrumento para o incremento da produtividade, en suma, da realização do humano". p. 82 - 83 .

(31) - MELo, Oswaldo Ferrelra de - Teorla e Prätica do Planejamento Educacional - Porto Alegre-RS - Editora Globo S.A. - 1969.

Os obstäculos do planejamento educacional são analisados pelo autor nas päglnas 10 - 24. Ele os reune na sequência:po litica, sociolōgica, cultural, filosófica, inst1tucional, con celtual e operacional.

Cada uma dessas ordens forma uma tela, uma trama, de tal modo interligadas que, a rlgor, seria aleatörio atuar sobre uma apenas. 0 conjunto de variávels acaba por se conectar con a prōpria questão do cresctmento econômtco e do desenvolvimen to soctal.

(32) - ABREU, Jayme - Educacão, Socledade e Desenvolvimento - op.c1t. p. 44 . 
C A P I T U L 02

OS PLANOS SETORIAIS DE EDUCAÇAOO 


\section{2 - OS PLANOS SETORIAIS DE EDUCAÇÃo - ASPECTOS GLOBAIS -} ENTRAVES PARA SUA IMPLEMENTAÇĀO

\section{1- objetivos}

- Assinalar que a Inovação no planejamento setorial da edu cação corresponde a um novo concelto de planiflcação glo bal.

- Destacar o esforço que se vem desenvolvendo no país, no sent1do de estabelecer planos setorlais.

- Detectar as causas que determinam a dificuldade para a montagem dos planos de educação.

- Levantar os pontos que podem determinar a racionalização no planejamento setorial.

\section{2- Educação numa sociedade dualista}

Enquanto no Brasil, assim como em outros pafses em desenvolvimento, assinalax-se a existència de amplas camadas da população que estão à margem do desenvolvimento, a educação se restringe, do ponto de vista formal, a um reduzido grupo. No momento em que se toma consclèncta de que o crescimento econônico é inviävel sem o de senvolvimento social, passa-se a pensar em termos de educação de massa. Se as elites dirigentes não mals tendem a enfelxar 0 poder pelo poder, como nas oltgarquias e acreditam na democratização do ensino que visa a diminuir os desniveis soclais, a preparar mão-deobra qualificada, a romper a causação circular e, assim, aumentar os nivets de aspiração e a luta pelo aumento do poder aquisttivo, a eđucaçāo passa a ser repensada.

Repensar a educação numa socledade em desenvolvimento, não é tarefa apenas filosöfica, mas parte dela para estabelecer una poIItica educacional a curto e a longo prazos. Isto, naturalmente, en volve uma estratégia e uma tātica, que variam de acordo com as circunstânctas.

\section{3- O planejamento setor1al da educacão no Brası1}

A centralização excessiva que o Ministērio da Educação exercia sobre os subsistemas educacionais nos Estados, tirava muito da Iniciativa local. Pensava-se e decidia-se em termos federals. ora, o Brasil e por demais multiforme para admitir modelos centrais ünicos, execução única. A vastidão territorial, a que corresponde uma multiplicidade de realidades sociais, reclama diagnósticos locals, soluções locais. Evidentemente, não se trata de provincianismo estre1to, mesmo porque as autoridades federais podem garantir como de fato ocorre - ume grande dose de unidade e näo uniformidade 
A unidade pode ser garantıda atravēs dos mecanismos finanselros que não devem ser mais que a suplementação sólicitada, ou através da im plementação de programas especificos, de âmbito mais geral como os realizados pelo Instituto Nacional do Ltvro, pelo Programa de Expan são e Melhoria do Ensino, pelo Programa de Desenvolvimento do Ensino Méd10, pelo Programa Nactonal de Telecomunicações, pelo Instituto Nacional de Estudos Pedagógicos, pelo Programa Intens1vo de Preparação de Mão-de-Obra, pelo Movimento Brasileiro de Alfabetizaçāo, pela Campanha Nacional da Al1m entação Escolar e vár1os outros. A própria Lei n̊ 5.692 atravēs do nücleo-comum e diretrizes băsicas age como denominador, traço de 11gação, entre os subsistemas cstadụ als de educação. Acresce a 1 sso a assistëncia técnica que o diversos Departamentos do MEC prestan à Secretarias Estaduals de Educafão. Além disso a Inspetoria Geral de Finanças exerce controle cerrado sobre a aplicação de recursos federais alocados aos subsistemas e planos estaduais de educação.

Outro dado a considerar é a criąão das Delegaclas Regionats que devem ag1r como "mini-mecs", nos Estados.

Fica desta forma, e de outras mais, garantida a supervisāo do MEC e de sua politica educacional nos Estados e nos Territórios.

o sentido da urgência de planejar a educação para as necessidades e para as realidades estaduais è multo recente no Brasil Até o infcio da dẻcada de 1960, as leis de ensino aglam como uma ca misa de força, tornando as Secretarlas Estaduals quase que meras executoras das determinacões federa1s. A Lel de D1retrizes e Bases (1961), cono 1e1, deu mais poderes às Secretarias Estaduais, mas una série de fatores impediu que elas pudessem, a rıgor, executar suas novas atribuições:

- a tradição paternalista federal;

- a imcompreensão das Iinhas gerals da Lei;

- a carência de pessoal especializado para o planejamento e a implantação dos programas;

- a escassez dos recursos financeiros;

- o dualismo entre o püblico e o privado:

- a falsa dicotomia entre humanismo $x$ tecnicismo;

- ausência de uma reforma administrativa;

- as alteracöes constantes dos quadros superiores, que se refletiam numa constante alteração dos rumos propostos.

o Censo Escolar de 1964 e o diagnóstico educactonal reali zado pelo EPEA, com vistas à elaboraçäo do PLANO DECENAL, tiveram 
por efelto näo só apontar as lacunas existentes, como prever as estratëglas operacionais.

Ao lado desses fenòmenos de carater técnico, outros se Iam configurando, tais como a reforma administrativa do MEC (ainda não completada), a estabilidade do regime polftico, a destinação maior de recursos financeiros para a eđucação. o conceito de plantficaçāo deixou de ser conotado com o regime sociallsta, passando a ser um anselo, uma necessidade sentlda por parte de educadores alla dos a economistas. Estes, realmente, trouxeram uma contribulção vallosa para os subsistemas educacionals, seja através de metodologias, seja atravăs da ampliação do campo de abrangêncla do fenômeno.

E hecessärio convir que durante multo tempo as prioridades nos planejamentos se voltavam para o aspecto meramente econônco, multas vetes mals "fazendärio-financelro-monetarista" que proprlamente de alteraçāo de estrutura econômica e soclal. Não poucos olhavam a educação como gasto e não como investimento Infra-estrutụ ral, Investimento cujos frutos só podem sex colhldos en prazos ma1s ou menos longos. No momento em que o novo enfoque substituiu o anti go, os rumos se alteraram. E de registrar-se que a função da CEPAL e da UNESCO nesse sentido fol bastante apreciável. Publicaçōes, sim pósios, assistêncla técnica, encontros ministeriais, auxilio mater 1 al e financeiro, acabaram por agir como modificadores - num processo ou mals, ou menos lento - de pontos-de-vista crlstalizados por sucessivas atuações medíocres.

Hoje se tem como certo que o crescimento econôntco não é fruto exclusivo de variávels financeirns e fisicas, mas se apola e se multiplica pelos caminhos da educaçāo, quantitativa e qualitativa, mals abrangentes, mais racionals. Essa ractonalização, por seu turno, multifacetada, porquanto a educação formal è apenas ưn tema que adquire realidade, se matertaliza, à medida en que atende, ou procura atender, através dos sub-objetivos, selecionados e dirlgidos a:

- graus (primeiro, segundo, universitărio; pós-građuação; alfabetização e educação de base, preparaçāo intensiva de mão-deobra reclamada pelo mercado de trabalho (etc.);

- setores primário, secundärio e terciário da economia;

- setores carentes por via do desenprego e do subemprego

- melhorla do preexistente: atingindo a edú cação formal, transformando-a en educação permanente (1). 
A educação no Brasil, até há pouco tempo, previa una esco larização obrigatória dos 7 aos 14 anos, o que significava o perlodo relativo ao ensino primärio. Com a Le1 5.692, a faixa etäria abranglda continua a mesma, mas o ensino transformou-se em ensino de 18 grau, oito anos continuos, Integrados, que reunem o ant1go pry mārlo (4 anos) e o antigo secundārio, ginasial ou tēcnico (mais 4 a nos). Esse é o minimo de escolarızação desejável para todos os brasileiros eliminando as formas de ramos (profissionalizantes ou não). o prosseguimento se faz atravēs do ensino de 29 grau, em três ou quatro anos, nitidamente profissionalizante, que cria a figura do tëcnico de nivel médto, praticamente inexistente no Pafs. 0 ensino superior vem sendo objeto da Reforma universitāria, a partir de 1968.

Ao lado dessa reformulação quanto aos anos de escolarização, a Lei foi mais ao fundo do problema, transferindo malor respon sabilidade aos Conselhos Estaduals de Educação, às Secretarias de $\underline{E}$ ducação. Da mesma manelra, cabe às Secretarias de Educação gerir os recursos provenientes da quota arrecadada do salário-educaçāo,assim como destinar, aplicar, controlar os recursos advindos do Fundo Naclonal de Desenvolvimento da Educação, conjugadamente com órgãos do BEC.

o elenco de projetos prioritários do MEC se destina a suplementar o esforço de cada Estado(2).

\section{4- Os grandes problemas para a planificacāo setorial da educação}

o primeiro deles pode ser configurado como falta de prátí ca em planejar. As Secretarlas de Educação nāo contavam com equipes técnicas dedicadas à planificaçāo. Essas equipes quando se formavam faziam apelo a elementos de alta qualificação, multas vezes peđagógica, mas que careclan de metodologias aplicâveis à planificação educacional. Uma colsa é o planejamento escolar "per sen, de nature za administrativa ou didātica que se esgota na escola mesma, e outra, bem diferente, é o planejamento a nivel de Estado, em que as variāveis e os objetıvos são totalmente diferentes. A 1sso, acres cente-se que a estrutura Interna das Secretarias multas vezes não dava margem à constitułção de equipes flxas, porque estas se modıf $\underline{1}$ cavam ao ritmo das mudanças nas chefias de Departamentos ou da pröpria Secretaria.

Outro problema pode ser assinalado: a falta de pesquisas. Sem elas, sem os dados quantitativos que espelham uma realidade estadual, parte-se de pressupostos aleatóxios, mals ou menos baseados em estimativas que, em confronto com a realidade, podem se revelar 
altamente ineficazes. Enquanto não houver, a nivel estadual, um setor voltado para a pesquisa, que permita aos planejadores trabalhar sobre dados reals, grandes distorçöes continuaräo a se verificar.

Outro problema mais pode ser detectado à altura das metodologias que orlentem a montagem dos planos e dos projetos.Obviaman te nāo hä uma metodologia, como pretendem alguns, mas metodologias aplicãveis a cada situação ou grupo de situações.

vale acrescentar que, em muitos casos, as forças da reação que desejam perpetuar o "status quo", trabalham atıvamante para desacreditar a validade do planejamento, prendendo-se a tdéia (falsa, na realidade) de que a educação pode expandir-se sem os refinamentos de un plano.

Mais un problema se refere ao binômio quantidade $x$ qualidade. Um enfoque primärio crè que o problema central de educação no Brastl seja o de aumentar a oferta de vagas, não importando onde, como, com que recursos, de que forma, com que equipamentos e com quals recursos humanos. O crescimento vegetativo ou induzido das unidades escolares, por s1 só, seria solução para o problema educac1 cnal brasiletro. Ora, isto tem ocorrido com muita frequência e, lamentavelmente (embora fosse esperado) continua a ser uma modalidade de atuação, mascarada sob o nome de planejamento.

A expansão quantitativa não pode ser um fenômeno casual: envolve multas variävels, tais como: onde, quanto, de que espécie, destinado a que clientela, com que recursos financelros e humanos, etc, , etc.

- lado qualitativo do problema não è um dado a mals, toda via conjuga-se, ou deve ser conjugado, ao aspecto quantitat1vo. Qua lidade, no caso, se refere à estrutura, aos métodos, so material de ensino, ao nivel de habilıtação docente, às técntcas de direção e de avalıação de aprendizagem, à correção dos fluxos a fim de evitar as maclças repetências e evasōes ${ }^{(3)}$.

Os quadros no 24 e no 25 , baseados em dados de 1968, ass $\underline{1}$ nalam a desproporcionalidade entre pessoal habilitado e não hab1l1tado.

\section{Quadro ne 24}

QUALIFICAÇÃO DO CORPO DOCENTE, NO ENSINO PRIMARIO-BRASIL/1968

\begin{tabular}{|c|c|c|}
\hline \multicolumn{2}{|c|}{ CORPO DOCENTE } & \multirow{2}{*}{ TOTAL } \\
\hline NORMALISTAS & NAO NORMALISTAS & \\
\hline 283.882 & 148.478 & 382.360 \\
\hline
\end{tabular}

Fonte: SEEC 
Quadro no 25

QUALIFICAÇÃO DO CORPO DOCENTE NO ENSINO GINASIAL-BRASIL/1968

\begin{tabular}{|c|c|c|}
\hline & DOCENTE & TOTAI \\
\hline COM FILOSOFIA & SEM FILOSOFIA & \\
\hline 29.805 & 92.519 & 122.324 \\
\hline
\end{tabular}

Fonte: SEEC

- plano educacional näo pode estar desvínculado dos demais planos do Estado. A descoordenação dos planos entre s1 tem fre quentemente conduzido ao redondo fracasso de planos setoriais.o ser setorlal não quer dizer allenado, descompassado, desintegrado.

Outro problema para o planefamento setorlal de educação no Brasil, se refere à própria tomada de consciència de seu valor por parte de autoridades e do próprio povo. Planejar tecnicamente, no Bras1l, ainda é, para multos, uma sofist1cą̧a, um bizantınismo.

A própria reforma administrativa, que alnda nāo atingiu em sua plenitude as Sccretarias de Educacão, deveria prever uma equipe tecnicamente häbil, permanente, com dedicação exclusłva. Em caso contrārio, a cada mudança de superestrutura corresponderá uma alteração completa da infra-estrutura de planejamento. Isso signif ca, nada mais, nada menos, um eterno recomeçar. Muitos planos não são siquer completados ou, ao menos, implementados.

Outro grande problema na planificaçāo setorial e o respal do orçamentärio, o que se viabillza atravës do orçamento plurianual de investimentos, con recursos especificamente alocados. Planejar teoricamente sem esse particular tëcnico è ter a certeza do fracasso do planejamento.

\section{5- Planejamento setorial da educacäo e planejamento para o desenvolvimento}

A noção de desenvolvimento tem sido multo simplificada en tre planejadores de formaçāo precäria ou que, ao conträr1o, visual1 zam a educação e o desenvolvimento apenas do ângulo imediatista. Imediatista, no caso, se refere, quase que exclusivamente a pensar - educaçāo cono investimento para a qualificação da māo-de-obra.

Dimensionam-se os custos educacionals em termos excessiva mente pragmäticos, como è o caso do emprego da fórmula $\frac{y}{\mathrm{p} \mathrm{c}^{\prime}}$ onde $y=$ PNB/hab1tantes; $p=$ da população em ldade escolar em relação à população total; $c=$ relação entre os gastos com o ensino primärio e a população escolarizada neste nivel. Os indices encontrados, quando comparados diversos paises uns como os outros, e unas regi- 
ōes de um mesmo pais com outras, evidenc1an o esforço empregado para a escolarização total ${ }^{(4)}$. E de convir-se que este é um cálculo inicial para o diagnóstico do planejamento, cujo objetıvo primordial é "descrever e explicar a situação atual do ramo, a identifiar seus problemas, e a propor um programa de estudos,ao menos para as ações urgentes que devem ser executadas" (5).

A educaçāo e seu planejamento não säo fruto lou nāo devem sê-10) exclusivo de soluções matemáticas e estatisticas: se estas contribuem para a quantificação do fenômeno, para o estabelecimento de parâmetros segundo os quals deve-se aplicar o investimento, há multo mals variáveis entre a estatistica educacional e os objetivos para o desenvolvimento do que o resultado frio de uma equação.

E preciso levar-se em conta os prë-requisttos polfticos, a conjugação da educação ut1litária com a não-utilitāria, as prior 1 dades para o esforço educacional, que não deve visar apenas ao creg cimento econōmico mas, tambëm, ao desenvolvimento social ${ }^{(6)}$.

o planejamento setorial de educação, portanto, seja ele feito a nivel federal,estadual ou municipal deve ter seus objetivos e sua estratégia elaborados em decorrêncla de um planejamento mais amplo, global. Assim como una região só ē real em função das demals, tambēm o planejamento setorial só é validađo em relação sos outros. E outros, no caso, refere-se a um planejamento para a valorização dos recursos humanos.

Mesmo a educação que è muito mais trełnamento, ministrada em una empresa com vistas à räpida qualificação de mão-de-obra, não pode desvincular-se dos objetivos mais amplos de treifar näo para ter malor produtividade, mas educar via treinamento, para ajustar o individuo ao grupo e torná-lo capaz de assumir-se como pessoa.

\section{6- Planejamento setorial e implementacāo dos programas}

Muitas vezes - e isso ocorre com frequência nos paise e/ ou regiões subdesenvolvidas - acredita-se que um planejamento educa cional deva ser restrito aos técnicos de alto gabarito. Diagnóstica objetivos, programação, estabelecimento de metas, alocaçāo de recux sos, dispositivos institucionais, etc., etc., bastam (?) ser trabalhados a nivel de "estado-maior" da educação.

Os conceitos de eficācla no campo da educação, têm-se qua se que exclusivaraento restringido às noções "input" - "output", às análises de custo-beneficio, taxas de rentabilidade, capital mater al e capital humano, etc. ${ }^{(7)}$. Tem-se verificado que grande parte do fracasso, ou do sucesso parcial, de um plano setorial de educaçāo, deve-se ao fato de não haver uma conscientização ampla e plena por parte dos implementadores dos programas. A partir do momento em que 
um plano passa à fase de execução, torna-se necessärio um engajamen to grupal e Individual, sem o que ele, certamente, será desvirtuado ou, sirqlesmente, ignorado. A formação de pessoal, em diversos niveis com vistas à compreensão de um plano: seus objetivos, metas, recursos, tëcnicas, obstäculos, etc., è tndispensāvel. Cada vez mais torna-se necessäria a arregımentaçāo de todos para a execuçāo consciente dos programas. o professor que atua em contacto direto com os alunos e a pröpria comunidade devern ser sensibilizados e informadcs sobre o plano, sem o que a rejelção ao mesmo è o mínımo que se alcançará.

Preconiza-se hoje que a prónria formação dos professores, nos cursos regulares de licenclatura, não se restrinja a uma habilitação especfflca, mas contenha elementos esclarecedores sobre o planejamento educacional, não apenas teorētico mas revestido de prati cidade e respeitados os niveis de formação(8).

Se o plano setorial é conhecido por todos, evidentemente compatibllizado com os diversos nivels de compreensão dos grupos e dos individuos, ele passa a ser um quadro referencial e não uma pro posta fechada de solução māgica. E necessārio para a implementação do plano, que sua demarragem seja executada por mecantsmos operaclo nais capacitados, que precisam, por isso mesmo, ter seus recursos humanos treinados.

"Infelizmente, a tendèncla do planejador è cuidar com extremado carinho dos pormenores do próprio plano com instrumento de ação e, apōs o mesmo publicado e 1nstituclonalizado, despreocuparse com a sua plena execução" (9).

A execução deve ser acompanhada, 1sto è, pertodicamente verificados os resultados, as metas propostas. A avaliação dos projetos una atividade a ser inlciada a partir da execuçāo e deve fornecer os subsiaios para a reformulação e reajustamento das fases.

\section{7- Aspectos bäsicos dos planos setorials}

A tarefa de planejar a educação no Brasil, é, relativamen te recente, cm termos racionals. Por 1 sso mesmo, há falhas a corrigir em värıos planos setoriais. A grande ènfase que se observa è na proposição de objetivos gerals e operacionals que levam en conta ba sicamente a questão oferta-demanda de escolarização. Isto significa, nada mais, nada menos, a abordagem unilateral do fenômeno educa cional.

A consulta a vārios planos estaduais de educação, como os de Pernambuco, Bahia, Minas Gerals, Estado do Rio de Janeiro e Acre demonstra: 
18- que a filosofia norteadora dos planos nada tem a ver com a seleção dos objetivos operacionais propostos;

28- preocupação em quantificar as metas conslderando-se:

- expansão física da rede;

- aumento do número de docentes;

- crescimento das matrículas;

38- que a problemätica educacional do Estado é abordada do ponto de vista dos grandes conjuntos e näo das especificidades töpicas e microrregionais, estas sim, indicadoras das potencialidades e/ou debilidades sobre as quals devem incldir as medidas prioritárias.

Hä mesmo uma contradição flagrante em certos planos setorials, que fazem o diagnóstico a partir de unidades locais, mas que Indicam soluçōes de carāter global. O resultado, no mínımo, è que as disparidades entre as microrregiões se acentuam, de ano para ano mesmo porque as soluçōes globais terminam por beneficiar as äreas mals desenvolvidas.

Falta ainda aos planos setorials de educação, principalmente a nivel estadual, uma abordagem qualitativa e, mais que isso, uma seleção de projetos dirigidos especiflcamente para atender ao crescimento e ao desenvolvimento harmónico das diferentes subunidades regionais.

* possivel que o emprego de novas metodologias de planeja mento, apoladas na anälise de sistemas, e com o concurso de equipes multidisciplinares introduza mecanismos de correção nos planos seto rłais de educação.

\section{8- Conclusões parciais}

1. - Os planos setoriais de educação, no Brasil, são relativamente recentes.

2.- Qualquer planejamento deve envolver objetivos quantitativos e qualitativos.

3.- Os entraves para a 1 mplementação dos planos setorials são de diversas ordens, principalmente no que se refere à mäquina burocrática e ao engajamento consciente do pessoal, nos diversos níveis.

4.- A racionalızação dos planos setoriais ē muito mais uma questão de metodologia que propriamente de quantificação de metas.

5.- o diagnōsttco global deve ser o ponto de partida para a solução da problemática identificada nas diferentes äreas e mucrorregiöes. 
NOTAS REFERENTES AO CAPITULO 2

(1) PLATT, William J. Qlanification de l'ëducation - Notes sur les besoins nouveaux en matière de recherche - Paris - UNESCO -1970 p. 39-42

(2) MINISTÉRIO DA EDUCAÇÃo E CULTURA - Secretarla Geral - Plano Setorlal de Educacaäo e Cultura - 1972-1974 - Brasilia DF - 1971 p. $41-43$

(3) UNESCO - La planification de l'éducation. B1lan, problèmes et perspectives. Belgique - Maison d'Edition S.C. Marcinelle-UNESCO 1970 .

Este ë um livro que deve constituir um dos elementos refe rencials para os técnicos em planejamento. A planificação è abordada sob os mals diferentes ângulos, com 1ndicadores e suges tões de caräter bastante prätico.

(4) UNESCO - La planification de l'éducation. B1lan, problëmes et perspectives op. cit. p. 111.

(5) MINISTERIO DO PLANEJAMENTO E COORDENAÇĀO ECONOMICA - EPEA Plano Decenal de Desenvolvimento Econômico e Social - Diagnöstico pre liminar - Desenvolvimento Social - Educacão (I) - Rio de Janeiro.GB - EPEA - 1966 - p. 13,16.

(6) ALMEIDA, Rômuio de - Programação Educacional num País em proces so Inlcial de Desenvolvimento - Rio de Janeiro.GB - Revista Bra silelra de Estudos Pedagógícos - CBPE - INEP - 1968.

Todo o trabalho é bastante interessante, notadamente o ca pitulo sobre "Educação não utilităria" p.19-22, assim como a "Introdução" p.9-12.

(7) POIGNANT, Raymond - Curso de Planejamento de Educacão - Recife PE - Universidade Federal de Pernambuco - Faculdade de Educação 1970 .

Esta publicação, de enorme interesse para planejadores e educadores, è constituída por uma série de conferênclas do professor Raymond Poignant. Restringe-se aos aspectos de custos da educaçāo e de outras variáveis de carāter quantitativo.

(8) UNESCO - La planification de l'éducation. B1lan, problèmes et perspectives. op. c1t. p. 201-210.

"Les catégorles de "planificateurs" ētant diverses, 11 convient de considerer divers types et niveaux de formation" p. 201.

"Il y auratt peu d'espoir que la planification devienne une realitë si les executants, c'est-ä-dire les enseignants, ne 
comprenatent pas et n'acceptaient pas le plan". p.202.

"Il faut enfin souligner de nouveau l'importance des programmes d'information pour les homes politiques, les dirigeants des différents secteurs de la vie publique et de l'écono mie, les universitaires, les journalistes, etc." - p.205.

(9) MELo, Osvaldo Ferrelra de. - Teorta e Prätica do Planejamento Educacional - Porto Alegre.RS - Editora Globo S/A - 1969-Cap. 4 p. 45-62. 
IV - A gEOgRAFIA ATUANTE 
C A P I T U L 0 I

MUDANÇAS DE ENFOQUES NA APLICAÇAOO DOS CONHECIMENTOS GEOGRAFICOS 
1. MUDANCAS DE ENFOQUES NA APLICAÇ̊ DOS CONHECIMENTOS GEOGRAFICOS

\section{1 - objet1vos}

18 - Traçar um quadro evolutivo sumärio das aplicações dos conhecimentos geogräflcos.

29 - Assinalar as causas e os efeltos da confrontação da apllcablildade da Geografia, nos tempos atuais, no Brasil.

39 - Colocar a Geografla no quadro mals amplo das ciências e seu estágio de desenvolvimento no Brasil.

48 - Destacar a Importancia da Geografia em paises em processo de desenvolvimento.

\section{2 - $\Lambda$ aplicacão dos conhecimentos geográficos}

A Geografia, numa caracterização elementar, significando - conhecimento da paisagem, é 1nerente à curlosidade do homem, à sua necessidade de viver relacionado com os lugares e os grupos humanos. Já se tornou muito citada: "a Geografia tem um passado longo, mas uma histōria recente" (1) (2)..

De uma ou de outra forma, ao lango dos sëculos, sempre houve una preocupação constante em "fazer" Geografta com um sent1do utilltärto. Isso ocorreu, quando ela, embrionāria, não se distinguia da Astronomia, da Geodēsia, da Filosofia, da Histöria, da polftica.

Na Antlquidade, na Idade Média, nos Tempos Modornos, os conhecimentos geogräflcos apareciam a serviço do homem. Identificar, medir, localizar, comparar, indagar, descrever lugares, fenömenos, grupos humanos, de forma mals ou menos empirica, assistemática fol uma preocupação marcante.

A ordenação dos conhecimentos, o alargamento das pesquisas, a partir dos sēculos XVII e XVIII, por certo acabaram por se refletir na Geografla que começa a tomar corpo como clência. Em me ados do século XIX e Iníclo do século $X X, j a ̈$ se podía falar em Geo grafia - ciêncta ${ }^{(3)}$. 
Justamente quando se acelera a evolução da Geograf1a, tẹ minando por transformar-se em ciência, podendo, portanto, cooperar decisivamente para o progresso, a melhorla das condiçós existenci ais dos grupos humanos, a sua aplicabilidade fica aquém do seu po tencial cientifico ${ }^{(4)}$.

Destaque a se fazer é o relativo ao desenvolvimento da Geopolftica, cujas teorias foram lançadas por Rudolf Kjellēn, da Universidade de Upsala, em fins do sëculo XIX. Aos trabalhos de Kjellēn, seguiram-se outros värios, sendo os mals divulgados os de Karl Haushofer e Halford Mac Kinder. Os văr1os l1vros e artigos t1veram grande repercussão, justamente num momento histörico contur bado, qual seja o que antecedeu o o que precedeu a guerra de 1914/ 1918, ern que as questöes das nacionalidades (pan-germanismo, paneslavismo, mlnorlas étnicas) e as redefinlçōes dos poderes dos Estados, estavam em plano destacado. Deturpações das teorias de Kjellến foram mesmo utllizadas pela politica alemã, na dēcada de 30 conduzindo ao conceito de "espaço vital" e às decorrentes anexaçōes de territōrlos (Sudetos, Aüstria).

No Brasil, igualmente, os estudos de Geopolitica foram desenvolvidos por Mário Travassos, Everardo Backheuser e Lysias Ro drigues, chegando a ser ministrado curso formal de Geopolitica, na Pontificia Universidade Católıca ${ }^{(5)}$.

Os quarenta primeiros anos do sëculo XX foram de aprofun damento dos estudos geogräficos, fase de consolidação das teorias de Ratzel, La Blache e seus seguidores, na Europa, nos Estados Uni dos. Na URSS, princlpalmente depois de 1928, a Geografia é convocą da para cooperar nos estudos de acelerą̧äo econômf ca, de organiza ção regional, mas permanece muito presa às determinações de ordem politica administrativa e, por certo, aos postulados da economia(6)

E de justica, contudo, ressaltar o papel de multos traba lhos monogräficos regionais, na Europa e nos fistados unidos. A importâncla dessas monografias só não teve malor destaque e aprove1 tamento porque foram elaboradas numa fase em que o planejamento sócio-econômico, tal como hoje se apresenta, ainda näo despontara como orientador da ação politico-admintstrativa.

A rlgor, salvo algumas poucas exceçôes, como a Geografla colocando seu arsenal de tēentcas a serviço da reorganizaçāo dos espaços (T.V.A., nos Estados Unidos, "depressed areas", nas regiōes 
carboniferas Inglesas, a ação do Waterstaat, nos Países Ba1xos), a aplicação da Geografia é pouco expressiva, até depois de 1945 .

Os efeltos da 2a. Guerra Mundial, desorganizando espaços, deslocando populações, conturbando relaçōes econômicas, modificando fronteiras, fazendo surgir novos Estados ou sendo lmplantados novos rumos politicos e econômicos para outros, acabaram por susoltar no vas orientaçōes, em partıcular na clêncla Econômica, na sociologia, na Administração, ...

Os estudos das disparidades entre os palses desenvolvidos e os subdesenvolvidos se multiplicavam. A palavra de ordem era: reorganizar, organizar, planificar. Os conceltos de "aménagement du territolre" entraram em voga. Por outro lado, a ampliação das inovaçōes tecnológlcas, o acelerado avanço das pesquisas cientificas, não poderiam defxar de se refletir na Geografla. Esta revisava con ceitos, discutia métodos, começava a partir para uma nova fase ${ }^{(7)}$.

E forçooo convir, porém, que os novos enfoques da Geogra fia se bipolarizam no minimo, quanto à sua aplicabilidade: mediata ou imediata?

De um lađo, encontram-se os defensores da idēla: "a Geogra fia a serviço de ". De outro lado, os que acreditam ser essa orlen taçāo altamente danosa para a Geografia como clêncta, representanđo uma espécie de aviltamento de sua essência, de seus objetivos.

Não Importa que essa mesna questão seja muito antiga, até mesmo na Grëcia ela jä fora objeto de debates: a especulaçāo como fim em si mesma e a especulação para teorizar fatos concretos.

Não Importa que, ainda hoje, haja defensores da "clênclapura", da "pesquisa pura", antepondo-se aos que defendem a "pesquisa-aplicada" (ou aplicävel).

Os geōgrafos não constituem um mundo à parte, suas dúvt das e certezas, seus escrüpulos ou sua ânsia de criar, atingem a outros, clentistas ou meros expectadores da vida.

o fato porëm é inegävel e, de uma ou de outra forma, extrapola o campo do debate e se reflete na orientação metodológlca, na conceltuação dos objetivos e da essência da Geografla. 
Veja-se, a titulo de exemplo, o pensamento de representantes de um e do outro grupo:

"Duas razões forçavam a Geografla a conservar-se como ciêncla-pura. Por um lado, as condições econômico-sociais do conjunto, que não estimulavam 0 planejamento, logo não incttavam a estudar modifi cações conscientes da palsagem e da distribuição das gentes em larga escala. De outro lado, a Insu flclèncla de desenvolvimento teórico da própria Geografla e até o nāo se ter historlcizado tanto quanto seria necessärio para servir de instrumento, na modelação do porvir. (8)

"As aplicaçōes só são possiveis e fecundas a partir de una vigorosa investigação de base - de um poderoso florescimento teórico. Maurice Le Lannou chegou a apodar a Geografia-clêncla de passatempo, e a Geogzufia aplicada de engodo, para defender uma Geografla "tout court", preocupada tão só de compreender mais profundamente, para melhor colabo $\operatorname{rar}^{\prime \prime}{ }^{(8)}$

"Mas è só hā um quarto de sēculo que sistematicamen te se empreenderam investigações geogräflcas com fins präticos. As realizaçöes estrangeiras marcam neste dominio um avanço enorme sobre as realizações francesas. Este atraso è tanto mais lamentävel quanto o futuro da Geografia considerada como clêncla pura e disciplina de cultura parece subor dinada em grande parte ao progresso da Geografia, clência aplicada". (9)

"A oposição è fatal na medida em que o pesquisador se deseja livre de todo o preconcelto de destino preconcebıdo, de orientação prévia da pesquisa. A Geografta clentifica, que não cessou de progredir na anālise das relações entre fatos naturals e en tre estes e a evoluçāo histórica, entre patrimô nios e melos de produção ou necessidades atuals, tem segutdo um desenvolvimento contínuo, que se 
concretiza por um grande nümero de trabalhos cientificos, em primetro lugar teses tratando seja de balanços regionals, seja de questões de ordem geral.

Ao conträrio, as diversas formas de Goografia apli cada se revelaram na maior parte efêmeras, näo durando além do que duraram suas razöes de ser"(10).

"E notörio que o tempo no século $\mathrm{xx}$, que medela en tre a pesquisa clentifica e a sua aplicação tecno lóglca - prătica, foi tão encurtado que todos os pesquisadores adquiriram uma consciência nitida da aplicabllidade de sua pesquisa, a ponto de tornar praticamente inexistente a fronteira entre pesqui sa pura e aplicada. Toda a pesquisa hoje è aplica da e quase de imediato. Na Geografia esta tendên cia está tendo um efelto de procurar enquadrá-1a num contexto interdisciplinar - sem prejuizo de sua Individualtdade - con 0 objetivo de que ela traga a sua interpretação a um problema de trang cendental 1mportância nas sociedades modernas: a organização do espaço que constitui o próprio obje to das Investigaçöes geogräf1cas" (11).

E desnecessārio alongar as citaçōes. Observa-se em obras, ortentação dada a cursos, seminārios, etc., que as correntes estão definidas: Geografia pela Geografla X Geografla aplicada (ou apl1cável) .o que é danoso registrar: as posiçōes se radicallzam, em pre juizo da própria Geografia.

Parece que a rigor o fenômeno deve ser reduzldo à expreg são mals simples: a pureza da ciência não se avilta se os seus espe clalistas forom convocados para aplicar seus conhecimentos num determinado setor.

Pode-se fazer a pesquisa desvinculada de "encomendas", co mo pode-se fazer pesquisa "sob encomenda". Alıás, o tema é abertamente debatido em universidades estrangeiras, multas vezes chegando à efervescèncta. Ser ou não ser a pesquisa "encomendada" é outro da do da questão, entrando aqul a isenção do pesquisador, sua formação cientifica, os objetivos da pesquisa, etc.. 
Fato è que, de una ou de outra manelra, a aplicação dos conheclmentos geográficos em setores vārios ē incontestāvel. Se não o é por geögrafos ou por professores de Geografia, acaba sendo por outros especlalistas (agrónomos, urbanistas, economistas, sociólo gos) que não apenas usam tēcntcas geográficas como o acervo de conhecimentos da Geografia.

No fundo hă que considerar, mesmo de forma räpida, a existêncla de uma ligação multo estreita entre politica-planejamentorecursos financeiros-pesquisa-aplicação dos resultados da pesquisa. As relaçöes de dependência "centro-periferia" quando transpostas do plano meramente geográfico para o polftico, podem determinar o volume, a natureza e a direção da pesquisa. Em ültima instâncla é uma questão de importar "know-how" ou produzi-lo internamente.

Um pals como o Brasil necessita, obviamente, de maclças aplicações de tecnologia para solucionar problemas de natureza estrutural, como, por exemplo, o das dispariaades regionals, 0 do crescimento demogräfico e da PEA, os movimentos migratörios e a urban1zação desordenada, o uso total da sua força de trabalho, o au mento da produtividade econômica, a movimentação social e a renda "per-capita", o aumento da expectativa de vida, e tantos e tantos outros que seria fastidioso alongar a lista. O momento histórico para o Brasil a oportuno para a "decolagem" jä iniclada em algumas áreas. Por isso mesmo, planejar é mals que nunca organłzar as açöes de forma a operax com un mäximo de resultados e um minimo de desper dicios.

A Geografta não pode ficar numa torre de marfim, deba tendo questões que sö tendem a margiralizá-la na participação das clênclas no crescimento e no desenvolvimento do pals.

Em suma: quanto mais ciência geogräfica se fizer, com rl gor, com exatidāo, tanto maior poderá ser a aplicação dessas pesquisas à soluçāo de problemas nacionais.

Naturalmente, não basta dizer 1sso, como un corolärio de intenções. O problema è tanto mais complexo quanto envolve def1 nições e atuaçōes de natureza väria. Vejam-se, por exemplo, algumas delas:

18 - a existência, ou não, de geógrafos e/ou de profeg sores de Geografia am número e qualidade tals que 
possibilitassem sua contratação pora trabathos de planejamento;

28 - a natureza, a qual1dade de cursos de gradua ção e de pós-graduação em Geografia, notadamen te os ültimos, que pudessem preparar pessoal hab1l1tado para o pianejamento:

39 - a conscientização por parte de órgãos pübli$\cos$ e particulares da importância das contri bulções da Geografla para o planejamento,

48 - a alocação de recursos flnancelros aos depar tamentos de Geografla, possibilitando a pes quisa que multas vezes não é reallzada pela carêncta desses recursos;

58 - o estabelecimento, nos departamentos de Goografla, das divisões de tarefas, entre : :u corpo de professores, para aproveltar as ten dênclas especificas de uns para a docêncla,de outros para a pesquisa. Hoje é fato comprovado que não deve haver separação entre docência e pesquisa, mas observa-se, em multos casos, exemplos de total desvio operacional de excelentes pesquisadores que são absorvidos por tarefas exclusivamente docentes e, atẻ mesmo, administrativas.

\section{3 - A unidade e a fragmentaçäo da Geografia}

O malor risco que a Geografia corre, tanto no Bra811 como em outros paises, $e$ o da quebra da sua unidade. A questāo è velha de sēculos (Geografıa Geral x Geografia Regional) e vem se agravando aceleradamente.

O avanço das pesquissas cientificas leva, inexoravelmente, ao aprofundamento em determinados setores, à especiali zą̧ão. O fato ocorre com a Biologia, com a Física, corn a Química, com a Sociologia e a Geografia não estaria, como não está, em po sição diferente.

Mas hä una distorção nitida no caso: o aprofunda mento da pesquisa clentiflca não deve contribuir para fragmentar a Clência, mas para enriquecê-la como um tođo. Tome-se como exem plo a FIslca: multiplicam-se aceleradamente os trabalhos, as pes 
qu1sas, os campos de especializações são nitidos, mas a física como Clência è una.

A Geografia, ao contrário, vem correndo o perigo de perder sua unidade, sua individualidade e, assim prosseguindo, poderä vir a ser caudatäria de outras cièncias, absorvida por elas no todo ou em partes.

"La Géographie se trouve donc placée dans une situation triplement inconfortable. Une première ambigdité pèse sur la definition même de son contenu.

Une autre difficultë lul vient des specialisations diverses de ceux quil ont assuré ses premiers dẽveloppments modernes. Enfin, un troisième danger - et c'est peut-ētre le plus grave - est imputable à la nature de son domaine si varié et si complexe"(12).

Posto que hoje a bifrontação Geografia Geral X Geografia Regional foi à farta colocada em seus deviáos termos (13); quando a questão é mais um problema de enfogue, de método, ressurgem as f1ssuras na unidade da ciêncla.

Todo geógrafo e/ou professor de Geografia sabe que, a r1gor, não hä uma Geografia Industrial, ou uma Geografia Agrária, ou una Geografia climātica, ou uma reografia das M1graçōes e assim por diante. Há o estudo geográfico regional (o que resulta ser tautoló gico pois a região é o campo de trabalho da Geografia) de que se destaca, por intenção do autor o fenōmeno indüstrıa, o fenōmeno agrärio, o fenôneno climătico, o fenômeno migratörio. Evidencia-se um aspecto o que é diferente de imaginà-lo único, como por exemplo - fenômeno industrial desvinculado do agrärto, do climático, do migratório, pröxima ou remotamente. o concreto e o abstrato, o visivel e o não visivel de 1medlato, forman uma trama complexa no tempo e no espaço, na região e, muttas vezes, fora dela, explicando o que se observa.

Os mestres da Geografla vinham lutando para mostrar que à Geografia Fỉsıca não se opōe a Geografia Humana, que à Geografla Hu mana não se opōe a Geografta Econômica. Os laços, as correlaçōes, são amplos, se completam. 
"Pero se trata de Investigaciones dentro del marco general de la geografia econōmlca y de sus partes, $y$ no de ramas nuevas, más o menos independlentes. De otro modo se llegaria, en último extremo, a una particularización dañosa $y$ a una concepción unilateral, puesto que podria llegar-se en ultimo extremo a separar de la geografia de los ferrocarriles, unas nue vas geografias de los túneles y de los gâlibos"(14).

Mas a questão não ẽ paclfica. Assiste-se a um entrechoque de correntes, mals evidenciado nos ültimos quatro anos. Surgem as "novas geografias", tais como a "Teorética", a "Quantitativa", a "Ma temätica", a "Estatística".

De un lado, os adeptos da "velha Geografia", de raizes francesas, de outro, os defensores da "nova Geografia", abertamente declarando a falência de tudo que veio antes. São divergênclas que precisam ser colocadas nos devidos lugares, para não comprometer a Geografla mesma.

Ninguëm nega a importāncia da análise de sistemas, o mode lo teörico è um recurso excelente. Veja-se, por exemplo, o quadro ne 26 . 
Quadro no 26

MODELO DE LOCALIZAÇAO INOUSTRIAL

(Baseado ens Hamilton)

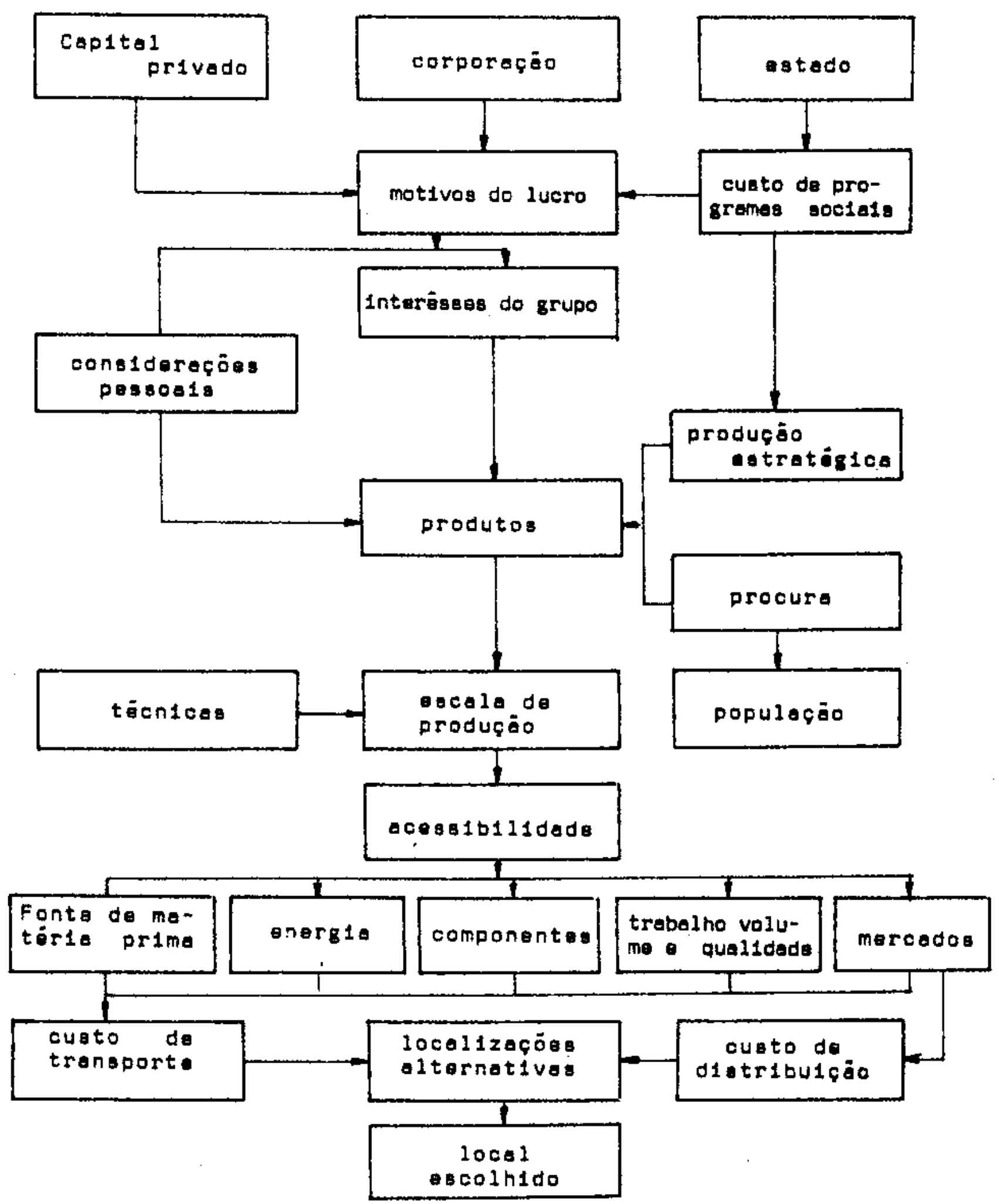

Fonte: Boletim de Geografia Teorälca - ne 2. 
Apresenta uma concepção abrangente, estruturando, relacionando os aspectos diversos que devem ser analisados a fundo, um por um (15).

Não se nega a importancia dos trabalhos de Von Thther. de W. Christaller, de A. Lobch: seus estudos de modelos das localldades centrais serviram de base para o desenvolvimento, a partir da década de 50 , de anälises geogräficas que conduziram às atuais concepçōes e metodologias, para as definlções de rede urbana, hierarqula das cldades, polarização.

Usar técnicas de quantiflcação è excelente, a Geo grafla não pode ser uma anälise do "mais ou menos", do "parece que!

Matematizar è enrlquecer as formulaçōes Geogräf1cas: "quand le gëographe s'engage sur la vole des explications et des comparalsons, son approche sera d'autant plus rigoreuse à la fols cumulative (se rëferut a des normes de comparaisons ob tenues a partir de résultats antérleurs) et communicables (com prëhensibles et utilisables par les autres) donc plus scientifiques et plus fécondes - s'11 s'exprime en langage mathẻmatique.(1)

A medida em que mais e mais a matemātıca for ut lizada como apolo aos trabalhos geográficos, tanto malor o rigo rismo, a exatidão, a precisão das análises, dos diagnósticos reg 1 onais se evidenciarão.

A Estatistica por certo, vem conferir maior preci são às anāllses geográficas.

E posição correta a de incluir a Estatistica nos currículos de graduação em Geografia. A familiaridade e o uso da Estatíntica são auxiliares vallosos para a interpretação, a comparação, a generalização, em certos casos, de fenômenos geogrāfi$\cos$.

As técnicas evoluem; a computação é valiosa auxlliar das pesquisas, geogräftcas ou não, para operar rapldamente com larga massa de dados; a metodologia se enrlquece à medida em que outras cièncias experimentals vão testando novos modelos. Será decretar a obsolescêncta da Geografla se, em 1972 ou 1975 , se trabalhar na anälise regional como Demangeon ou Christaller, há anos o faziam. 
O próprlo IBG, para não fazer referêncla apenas ao IBE, ambos componentes da Fundação Brasileira de Geografia e Estatistica, tem acelerado, nos últimos três anos vărios de seus trabą 1hos, principalmente os relativos à regional1zação, graças do empre go das tẻcnicas de computação.

o uso de matrizes geogrāficas pode possibllitar ao geó grafo uma visão sintética e interiłgada de fenômenos, talvez, à prî meira vista desligados uns dos outros ou de tênue relacionamento. A partir da anälise de matrizes, pode o geógrafo interpretar, expl1car com malor rigor e exatidão fenömenos e paisagens.

Mas a questão não ë apenas de usar novas técnicas. Vai mais fundo: hã um choque entre a "concepcão excepcionalista" , aquela que defende a 1dēia de ser cada ärea ún1ca, só idênt1da a si mesma e aquela que busca enquadrar as situaçöes especiais em leis de estruturação e de organização, modelos enfim.

E verdade que esse dualismo conceptual existe hã sêcun los, vindo sob as roupagens da Geografia Geral e/ou da Geografia Re gional. Atualmente chega-se à negação total do "excepcionalismo" e, do outro lado, à negação total da possibilidade de enquadrar fenô menos de natureza geogräfica, portanto sociais, humanos em modelos, formas.

A evolução da ciència nunca se fez harmonlcamente, mas espasmodicamente e, na malor parte das vezes com antagonismos vio lentus de pontos-de-vista.

A Geografia nāo è caso único e nem é a primeira vez que esse confronto se configura. Para não ir mutto longe, basta lem brar os antagonismos entre os deterministas e os possibilistas. Afinal de contas o processo dialético sempre é valioso para reali mentar e rejuvenescer a clència.

Constata-se isso sim, que estă havendo, em muitos casos, uma confusão entre objeto e mëtodo, entre método e técnicas.

Quanto mais complexo o objeto de uma ciência, mals abordagens ela possibilita para análise dos componentes desse objeto. Discutir uma tècnica ē vālido, testar uma metodologia, 1dem, confundir meio com $\underline{\text { fim }}$ è que pode levar os estudos geográficos a una distorçāo de seus objetivos. 
o choque nāo está em absoluto restrito a um grupo

pesquisadores geográficos: alcança - e altamente deturpado -

alunos universitäriog e de outros niveis. Allando-se ao fato a for fa dos qualificativos na socledade de consumo verifica-se a série de livros didáticos, ou não, ostentando os titulos: "Geografia Noderna", "Nova Geografia", "Geografia Atıva", "Geografia Dinânica".

o valor da Geografla como ciência e, ma1s que 1sso, a qualidade dos trabalhos, podem prescindir dessa objetivação. A rigor, não ocorreria a um autor a ldéia de intitular uma obra sua de "Geografie Estática", ou "Geografia Passiva" ou "Velha Geografia"...

Identifica-se em tudo isso um fato que merece ser con siderado: a Geografia,no Brasil, é uma calxa de ressonâncla das pes quisas geogräficas feitas $\in m$ outros países. Se não é uma geografia allenada é, ao menos, 1mportada. Isto é reflexo da carência, no Brạ s11, do pesquisa, tal como ocorre com a Fisica, a Matemätica, a Psi cologia, etc. Em termos de ciência, encontra-se o Brasil em fase inclpiente, a fase de tmportação de modelos estrange1ros, assim como se importa tecnologia. Só aos poucos se incentiva a pesquisa clentifica, com recursos financeiros mais alentados.

A Geografia $i$ grande demals, importante demais para ser diminuía não por elementos que não a conheçam, mas pelos pró prios geógrafos e/ou professores de Geografia que alnda não se deram conta do seguinte:

18 - a dialética não tem nada a ver com questiünculas pessoais e grupais;

29 - do atraso geogräfico em que se encontra o Brasil, sendo necessárı́, aqui tambēm, "quelmar etapas",o que vem sendo felto com esforço de alguns grupos;

38 - "a visão da ärvore está impedindo ver toda a flo resta" ;

48 - è impertoso somar esforços para desenvolver a pesquisa geogräfica no Brasil, atentando para as realidades e carências nacionals. Evitar que as disputas doutrinărias no estrangeıro venham à repercutir mais intensamente no Brasil. Isto não 
slgnifica xenofobla, alhelamento, mas uma tentati va de colher os resultados dos outros, é verdade, mas näo ficar apenas nisso.

Caso näo haja uma reversão de rumos, em poucos anos, nos centros universitárıos veremos, principalmonte:

- professores formando professores para ensinar Geografía (ou Bstudos Soclats?) a adolescentes;

- a Geografia como disciplina de "cultura geral" e com certo valor formativo - respeito pela opinião alhe1a, valorızação de recursos naturais do Pais, Geografia para a compreensão internacional...

- Brasil estā numa fase histōrica em que necessita se repensar, se reformular. Se os geögrafos e os professores de Geografia näo atentarem para isso, o planejamento territorlal, a orga nizaçāo regtonal, o planejamento urbano, tudo isso se fará com o esforço conjugado de economistas, engenheiros, arquitetos, sanitaristas, soclólogos, antropōlogos, demógrafos, ađministradores de sistemas, etc. Faltará, apenas, o geögrafoe, talvez, sua ausência nem siquer seja notada.

\section{4 - A Geografia atuante}

O Brastl na década de 70 , de uma ou de outra forma, de fintrá os rumos do seu modelo de cresctmento e de desenvolvimento, já esboçado e acionado.

Atē o presente, a contribuição da Geografia para o pla nejamento tem sido modesta. Basta verificar:

18 - existe a "carreira" de geógrafo, como no IBG, mas näo fol regulamentada, alnda, a profissão de geō grafo (17);

29 - a presença de geögrafos e/ou professores de Geografta ê muito pouco expresstva em órgãos como $\circ$ IPEA, O INCRA, o Ministér1o dos Transportes, O Mf nistērio do Interior, a SUDAM, a SUDENE, a SUDECO, 
- Ministërto de Minas e Energla, ouMinistério da Educação e Cultura, etc.;

30 - empresas particulares de planefamento, raramente contratam geógrafos e/ou professores de Geografia.

E preciso convir que se culpa existe, ela é mals dos órgãos que fazem pesquisa, ou pesquisa e ensino (Universidades), que apōs 30 anos de trabalhos, não conseguiram demonstrar efetivamente a Importância da Geografia no planejamento, a não ser em casoa excepciona1s, que por serem exceçäo confirmam a regra.

As Universidades com cursos de pós-graduação estão respon dendo ao problema: as monograflas regionais começam a servir de referencial para o planejamento. Alguns trabalhos mals recentes da Fundą̧āo IBGE, 1gualmente passam a ser buscados para a montagem de planos. Mas o esforço precisa ger, no minlmo, duplicado em pouco tempo e com alto padräo qualitativo.

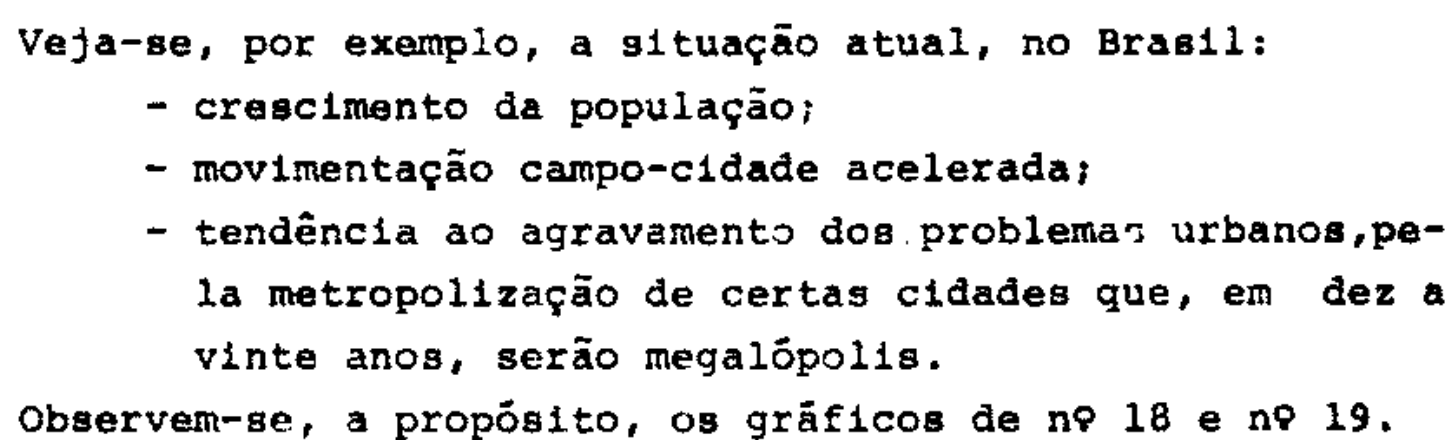

\section{Gräfico no 18}

DISTRIBUIÇAO DA POPULAÇÃO NO BRASIL: POPULAÇAO URBANA E RURAL

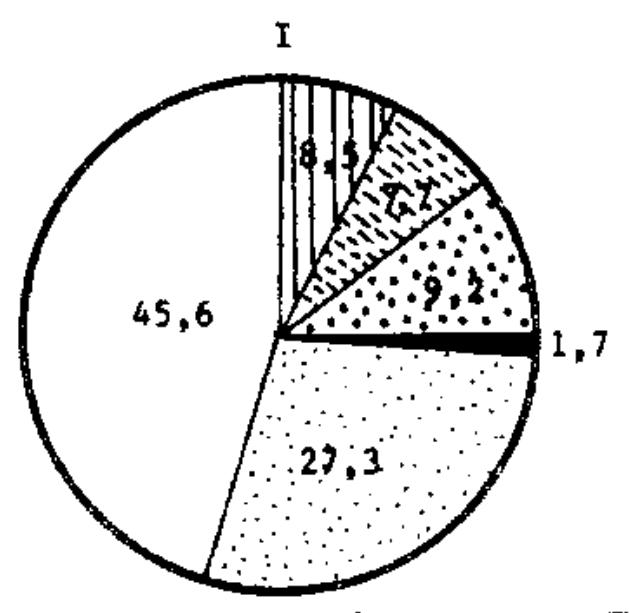

IIIII S.Paulo Eis Rio

$1-1970$

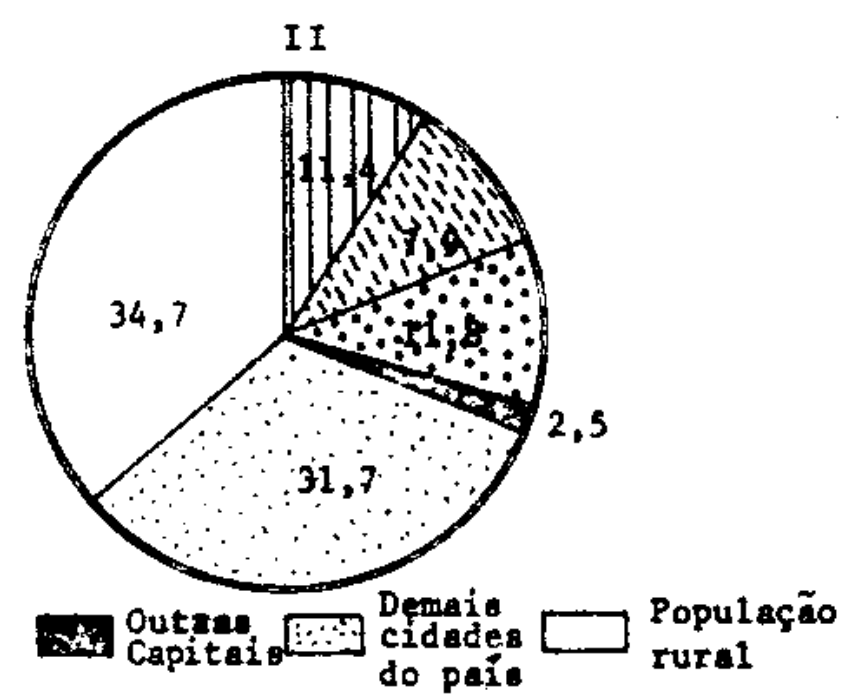

II - 1980 (previsão)

Fonte: "Jornal do Bras11" - 8/9/72 
Gräfico ne 19

EFEITOS DO CRESCIMENTO ECONOMICO SOBRE A CONCENTRAÇA DEMOGRAFICA NOS CENTROS URBANOS

(Comparação entre grau de urbanização e PNB "per capita")

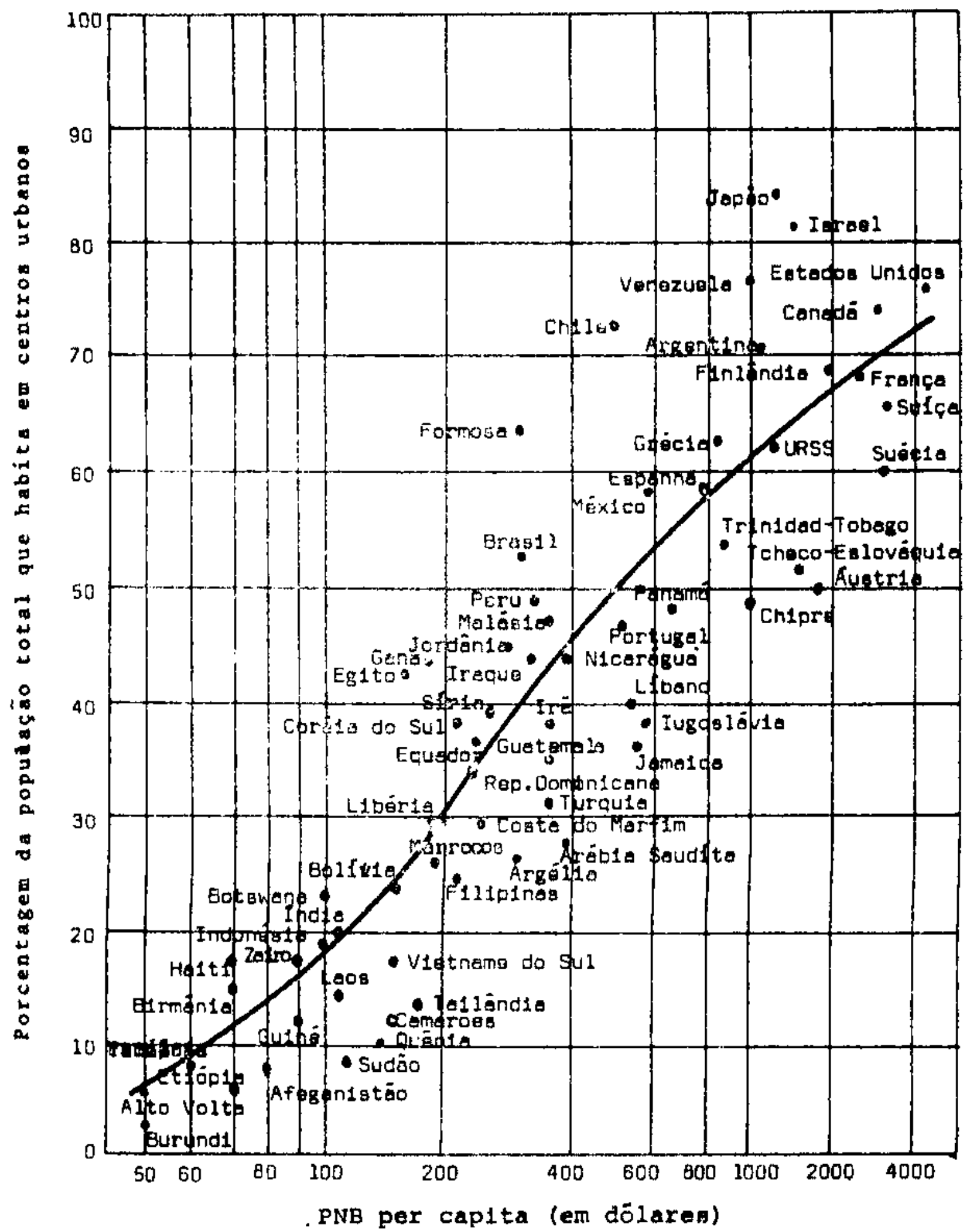

Fonte: "Jornal do Brasil" - 10/9/72. 
prevê:

O gráfıco no 18, baseado em estudos do BNH e do IPEA,

18 - o decrēscimo percentual da população rural, que de veré passar de $45,6 \%$ para $34,7 \%$;

28 - o conjunto integrado por Rio de Janeiro, são Paú lo e metrópoles deveră aumentar sua população na dëcada $70 / 90$, passando de 25,48 para 31,18 ;

38 - as outras capitais - cidades menos populosas deverão ter um aumento populacional de 0,88 ;

48 - as demais cidades - de $2 a ., 3 a \ldots .$. n... ordens,po derão ter acrescida sua população em $4,4 \%$.

O gráfico no 19 possibilita, nuna visão de conjunto, verificar que hã uma relação mutto próxima entre a renda "per-capita" e o grau de urbanização. A urbanização è mais acentuada nos Estados de mais elevada renda "per-capita", de forma geral.

Observe-se a posição do Brasil que aumenta mals de 508 da população nos centros urbanos, com uma renda "per-capita" em tox no de 300 aölares.

o que se constata, portanto, no Brasil, nos ültimos vinte anos é a alteração mais ou menos profunaa das relações cidade-campo. Com efeito, pode-se assinalar:

18 - a Implantação de áreas Industriais e de complexos industriais, em tomo dos maiores centros urbanos;

28 - a implantação de uma economia de escala, necesså ria a satisfazer parte da demanda interna e buscando abrir novos mercados no exterior;

38 - de par com a inđustrialização, amplia-se o setor terctärto;

49 - a implantação de uma infra-estrutura viăr1a, conectando regiōes atē então isoladas dos centros mais dinâmicos, ou frouxamente ligadas entre s1 
e aos referidos centros;

58 - o descompasso de investimentos infra-estruturalis

e socials entre:

- as malores cldades e as cldades de pequeno mé dio porte;

- as cluades e as zonas rurals;

68 - a deterioração de preços de produtos primários agro-pastoris;

78 - o decréscimo das taxas de mortalidade e a manú tenção das de natalidade nas zonas rurais;

$8 \%$ - a ampliação dos melos de comuntcação de massa, levando às populaçōes rurats e das pequenas clda des uma nova visão do mundo urbano, provocandopor isso mesmo, novos o mais varlados niveis de asp1 ração;

98 - as diferenças signiflcativas entre a renda "percapita" das populaçōes das grandes e médias cida des e a das populações das p:quenas cidades e das zonas rurais.

- resultado dessa conjugaçāo de fatores $\bar{e}$ a Intensif cação dos movimentos migratórlos que se fazem;

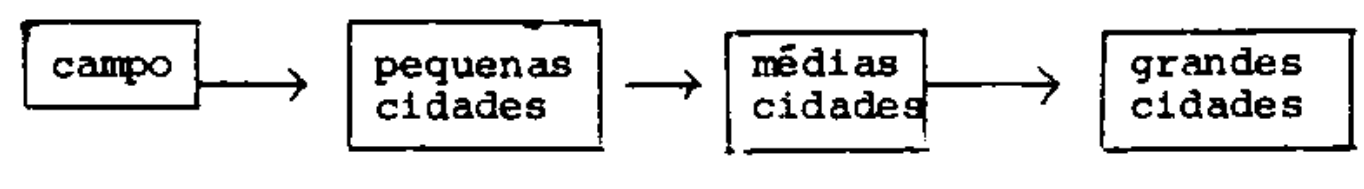

ou

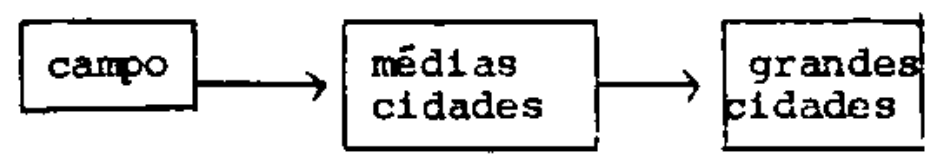

ou

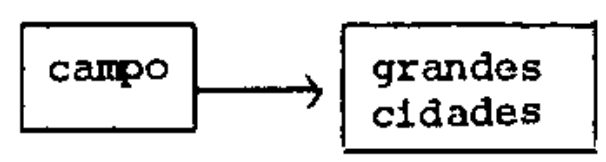


o fenômeno, todavia, não se restringe ao èxodo rural para as cidades. Os centros urbanos menos equfpados 1gualmente vão assistir à transferêncla de parte de sua população para centros de hlerarquila superior. $(18,19,20)$.

o problema, portanto, está posto: em dez, vinte anos, caso não haja reversão de expectativas, tudo leva a crer na hiper trofia das cidades, gerando o que se denomina de "crescimento sóclopātıo".

Mas determinacas medıdas conduzem à crença de uma cor reção, a tempo, no processo deslanchado. Entre elas podem ser c1ta dos:

19 - o Infcio da imelantação de polos Industriais fora das grandes metrópoles;

28 - a melhorla da infra-estrutura urbana, em cidades de médio porte: planos habitaclana1s, saneamento, apolo financelro às pequenas empresas industrials;

38 - abertura controlada de frentes ploneiras, ao longo dos eixos rodoviários;

49 - descongestionamento dos incentlvos flscais conđu zindo a aplicação de recursos em profetos agropecuärios e não exclusivamente em projetos 1ndus trials.

Todas eseas medidas e as que dela decorrem, necessi tam de profundos estudos de regionalização, a fim de possibilitar uma atuação racional e coordonada dos órgãos públicos e das empre sas particulares. Sem os dlagnósticos regionais, sem a anälise cor reta das formas e técnlcas de ocupaçāo dos espaços, as providências legislativas e executivas perderão sua eficlêncla. Em grande parte caberá aos goj̄grafos, participando de equipes interdisciplina res, a tarofa de atuar positivamente no equacionamento de formas de povoamento dos espaços vazios e de reorganização espaclal. Talvez seja essa a fase em que a contribuição da Goografia seja mais valiosa para indicar caminhos à politica global de crescimento eco nômico e desenvolvimento social menos distorcidos. 
Realmente agora o problema tem que ser enfrentado racionalmente, mesmo porque as conseqtências não são de ordem meramen te quant1tat1va. Isto slgniflca que não se buscaxá apenas. equilibrar os fluxos demogräficos, ou controlar a expansão urbana, ou cri ar novos polos de atração. A questão è de natureza mals funda, com amplos reflexos na mudança social. (21)

Até mesmo o ensino universitärio reclama nova orientą ção, para estar adequado à realldade brasileira.

"A necessidade de formação de equipes interdisciplinạ res de trabalho vem provocar, portanto, um debate que se torna 1nadiävel: a reformulação do ensino, em funçāo duma visão integrada, humana de nosso desenvolvimento e do tipo de homem que ele necessi ta.

Ass1m, nosso pals deverla preparar elementos capazes de abordar e dimensionar os problemas do próprio subdesenvolvimento. Atë hoje, nossas escolas, apesar da inegãvel contribuição conferida ao crescimento do pals, têm formado uma elite de proftssionais cujos conhectmentos, preparo e grau de informação tendem a criar un nücleo compacto, cujo nivel se aproxima bastante daquele que caracte riza profissionais educados em palses desenvolvidos. No entanto, $\dot{e}$ ai que o problema se torna mais sērto, esse pequeno nücleo de proflsalonals è levado, por força de clrcunstâncias, a atuar dentro de quadros e modelos que de manetra alguma podem ser os mesmos. A realldade de nossos problemas deve conferir, assim, aos aspectos da formaçäo profissional, uma escala ajustada e menos defasada de nossos conhecimentos. Dessa forma, todo "know-how" estrangeiro aisorvido deverá contribuir para o nosso desenvolvimento e cultura sem que com isso venhamos a perder nossas possibilidades de dec1 são e atuação política". (22)

Nesse contexto da problomática co Jebeavulvimento braslle1ro, no aspecto çue se refere à regionalização e ao planejamen to urbano, abrem-ge largas perspectivas para o trabalho do geógrafo e/ou professor de Geografla, nas equipes multidisciplinares, frise-se mais una vez.

Refira-se, por ültimo, que esse planejamento não pode se desvincular da questão eđucacional. A implantação e a ampliação da rede de escolas estä intimamente ligada aos aspectos de organ1za ção dos espaços. A rede escolar mal estruturada, em termos fístcos, 
em termos de oferta de vagas e de qualidade do ensino, pode ser un agente pernicloso no processo. O contrário: a rede escolar funcio nando integrada aos demais setores, não apenas poderá contribulr po sitivamente para o sucesso dos demais projetos, como acelerar as perspectivas de mudança social, elevar os padröes de vida, radicar os individuos ao seu ambiente, com possibilidades de conhecê-10 methor e atuar sobre ele.

\section{5 - Conclusöes parclals}

1a. - A Geografía aplicável ao planejamento não detur pa a pureza da Geografia-ciêncla. Aplicabilidade e pesquisa cientifica interagem uma sobre a outra, com beneficios reciprocos.

2a. - A unidade da Geografia deve ser uma meta dos geó grafos e dos professores de Geografia. As cisöes internas devem se orientar no sentido de um enriquecimento das pesquisas e, nāo, para tornar trreconciliáveis os pontos-de-vista defendidos.

3a. - A multiplicaşão de abordagens metodológ1cas e de tēcnlcas operaclonais ē väilda e garante a reno vação da Geografia, a sua atualização. O perigo estä em confundir objeto com método e com técnicas.

4a. - A contribuição da Geografia para os trabalhos de planif1cąão precisa ser incrementada. A Geogra fia não deve e não pode ficar à margem do proces so de desenvolvimento brasileiro.

5a. - Novas técnicas de pesquisa geogrăfica, ao lado de monografias regionals, têm sldo utilizadas pa ra cilagnostica. sócio-econômicos, para classif cação de cidades segundo suas funçōes e grau de polarizaçāo, para identiflcação de variados pro blemas, fornecendo jä subsidios para o planeja mento integrado. 


\section{NOTAS REFE RENTES NO CAP ITULO 1}

(1) MARTONNE, Emmanuel de - Traité de Gëographie Physique (I), in Panorama da Geografia - Livro Um. L1sboa-Portugal - Edıçöes Cosmos - 1953 -

Ver 1 - Evolução da Geografia - p. 1-20

"Diz-se muitas vezes que a Geografia è una ciência no va. Isso è verdadeiro se se quiser referis o conjunto de Investigações cientificas que hä mais de um século se agrupan sob esse nome. Mas considerada no seu sent1 do lato, como clência da Terra, é um dos mais antigos ramos do saber humanon. p. 2 .

(2) KRETSCHMER, Konrad. Histoória de la Geografia. Tercera edición revisada - 1942 - Barcelona - España - Editorial Labor, S. A. 1942 .

Ver, a respetto, "La Geografta en la Ant1gtedad". p.9-26.

(3) KRETSCHMER, Konrad. op. cit, p. 185-189.

(4) PHLIPPONNEAU, Michel. Geografia e Accão. Tradução de Judite Cor deiro Ferreira - Lisboa. Portugal - Edições Cosmos - 1964.

"Por outro lado, deve-se reconhecer que as condições gerals da ctvilização no fin do sēculo XIX e começo do sēculo XX não se prestavam nada a uma utilização prätí ca da Geografia de Vidal.

Que utilidade pode ter una disciplina que descreve e explica fenômenog espaciais numa época que é caracter 1 zada pela liberdade quase total delxada aos individurs para acomodar o espaço segundo a sua fantasia e o seu Interesse mais 1 mediato e mais tacanho?

Qual pode ser a utilidade prática de estudos de Geo grafla agricola quando se delxam os agricultores ado tar os métodos culturais mais devastadores, quando se 
não pensa em orientar a grodução em função das necessidades, esperando que a livre ação da oferta e da procura assegure o equilibrio? Qual pode ser a utilida de de estudos geogräficos sobre a indústria, quando to da a Itberdade é delxada aos industriais para escolhe rem a local1zação das suas fäbricas, segundo critērios puramente econôntcos? Para que podem servir investiga çōes de goografia urbana quando os construtores têm a latitude para edificar seja o que for, seja onde for?

Os estudos de Geografia regional não têm aplicaçăo quando se consente no agravar de desequilibrios regio nals perigosos e dispendiosos para a colettvidade.

Este liberalismo que preside à acomodação do espaço e não se preocupa nada com o bem comum, não favorece aplicações präticas das pesquisas geográficas. Aqueles que beneflciam de uma acomodação liberal, isto é, desordenada do espaço, o geogrāfo aparece muitas vezes como um importuno". p.40-4I.

(5) BACKHEUSER, Everardo - A Geopolítica Geral e do Brasil. R1o de Janelro - Biblioteca do Exército Editora - 1952 -

Possivelmente devido aos efeitos do uso deturpado da Geopolft ca, pela Alemanha na década de 30 e inf́lo da guerra de 1939/ 1945, pouco se escreveu, posteriormente sobre o assunto.

A respeito,lê-so. em Geografia e Folitica de A.E. Moodie Zahar Editores - Rio de Janeiro - 1965:

"Outrossim, as sociedades politicas exigem o direito de formular e operar seus próprios sistemas, contanto que não ponham em perigo a sobrevivēncla de outras socledades. Esse grau de tolerâncla deve preceder qualquex esforço para integrar os slstemas politicos, diversos a dispares do mundo; constitul requisito essen cial que é com demasia desprezado, e em grau jamais tão intenso do que pelos crentes na "Geopolitikn, que at1ngiu seu zêntte na Alemanha entre as duas guerras.

Cometeram o exro fatal de subordinar os meios aos fins da hegemonia alemã. Sua perspectiva e literatura eram 
Inteiramente subjetivas e representaram uma prostitu1 ção dos mëtodos e resultados da Geografía Polftica. Is so fol afnda mais funesto pelo fato de muitos professo res untversitär1os e pesquisadores alemães terem devo tado grande parcela de tempo e energla à tarefa de deg cobrirem provas em apolo das falsas doutrinas nazistas.

$E$ de esperar-se que esses mitos destituidos de base tenham sido destruldos, porém a "Geopolitik", na tentạ tiva de emprestar um colorido clentifico a teorlas es pürlas, prestou um desserviço ao pensamento politicogeogräfıco, o que ainda é mais de lamentar por ter s1do um alemão, Ratzel, o primeiro entre os escritores mo dernos a estudar a Geografia Polltica em normas clent $\underline{-}$ ficas". P. 18-19-

(6) CHAMBRE, Henr1. A economia planificada. Traduçăo de Pedro de Alcântara Figueira. São Paulo. SP. Difusão Europēia do Livro. Coleção "Saber Atual". 1967.

"Com exceção das experiencias de direção pelo Estą do das economias de guerra de alguns palses, notada mente na Alemanha, foi necessário que o mundo assis t1sse à rápida expansão da economia soviét1ca, no exato momento que em outros países se manlfestava uma paral1sta sem precedentes em decorrêncla da "grande depressão" de 1929, para que a questão da dirę̧a racional da economia fosse, finalmente, colocada com a devida serledade. Ora, em economia, "não existe ple na racionalidade senão num slstema perfeltamente cors clente de seus mecanlsmos. Esta consclêncla total con duz à concepção do plano". p. 12-13

(7) MONBEIG, Plerre - Novos Estudos de Geografia Humana Brastla1ra São Paulo. SP. Difusão Européia do Itvro - 1957.

"Matéria de ensino, a Geografia é também um lnstrumento que pode servir eficazmente às coletfvidades pü blicas ou grupos privados. A pesquisa geogräflca $\bar{e}$ suscetivel de aplicação e a oplntão dos geográfos me receria, muitas vezes, ser ouvida. Não se veja ntsso alguma estranha novidade. Assim como se admite a ne 
cessidađe de consultar um geölogo antes de se cong truir una barragem, un economista antes de se eesenvolver um ramo da produção, e até mesmo, um sociólo go antes de se legislar sobre a imigração, acabar-seá considerando normal a consulta ao geógrafo". p.20.

(8) CODINHO, Vitorino Magalhães. Geografia e Geografla Aplicada, In Geografia e Accão - Michel Phlipponneau - I1sboa - Portugal - Ealções Cosmos - 1964 - p. 11.

(9) PHLIPPONNEAU, Miche1. op. cit. p. 25

A obra de Phlipponneau ë bastante elucidativa, notadamente quan do inventaria os trabalhos que se desenvolvem em vărios países, tendo a Geografla-clência convivido em harmonta com a Geografla-aplicada.

(10) GEORGE, Plerre, et ali1. A Geografia Atıva. Tradução de G11 Toledo. Manuel Seabra. Nelson De La Corte - Vincenzo Bochicchio São Paulo - SP. Difusão Européta do Livro - Editora da un1ve王 sidade de são Paulo. 1966. p. 14 - 15.

A posição defendida por Picrre George, nesta obra e em outras, não deve ser confundida como uma posição de alholamento. Aliás, na obra citada, os autores colocam devidamente a questão da Geografia em estudos dos países subdesenvolvidos, das áreas mals industrializadas e as tarefas do geógrafo face à problemätica do desenvolvimento.

Parece preferivel atribuir a posição de Pierre George, a uma certa cautela, como uma advertêncla para quantos não fazem Geo grafia aplicada, mas se valem da Gecgrafia para fazerem traba Ihos encomendados, que nada têm a ver com Geografia.

(11) GALVÃo, Marilia Velloso e FAISSOL, Spertalão. A revolucão quan titativa na Geografia e seus reflexos no Brasil. Rto de Janei ro. GB - Revista Brasileira de Geografla. Ano 32 no 4 - Funda Ção IBGE-IBG - 1970 - p.6.

Talvez seja necessärio levantar duas pequenas observações a res peito do trecho citado:

la. - Nem toda a pesquisa é aplicada ou aplicável, o que não significa que seja lnütil. 


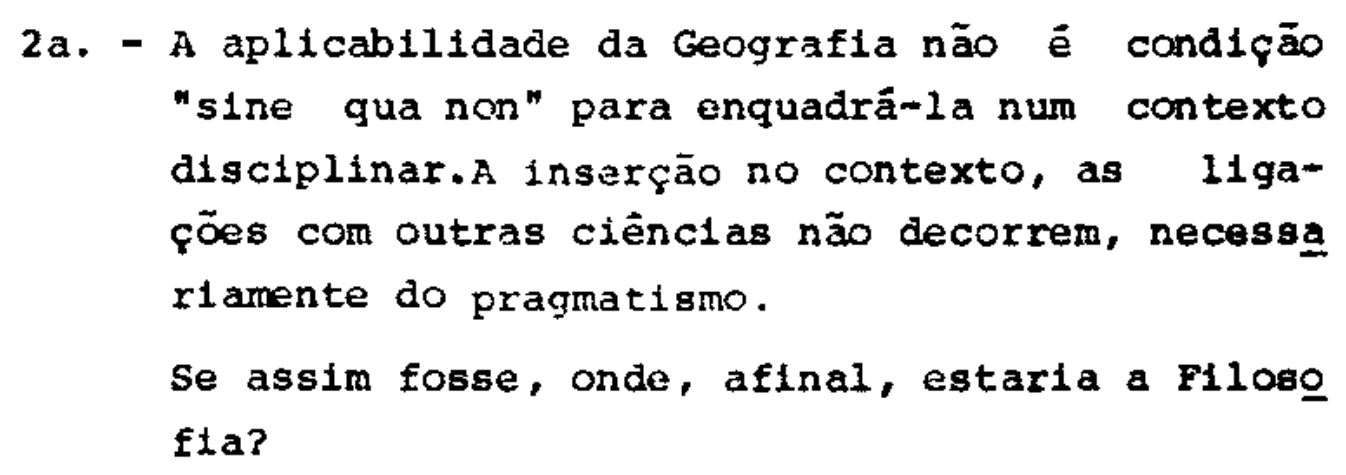

(12) GARNIER, Jacqueline Beaujeau - La Geographie: méthodes etpers pectives - Paris - France - Masson \& C1a. Editeurs - 1971. p. 7-12.

(13) HARTSHORNE, Richard. Questões sobre a natureza da GeografiaTradução de Thomaz Newlands Neto - R1o de Janelro - GB- Textos Bäsicos - 4 - Instituto Panamericano de Geografia e His törla - Com1ssāo de Geografía - 1969.

Ver, a respe1to, o capitulo 9: "Divide-se a Geografia en sis temātica e Regional?".

(14) LtTGENS, Rudolf - Los fundamentos geogräficos y los problemas de la vida econónica. - Traductón española por claud1o Matons Ross1. Barcelona - España. Ediclones Omega, S.A. 1954p. 7-8.

(15) DINIZ - Josē Alexandre Felizola - Modelos e Paradfqmas na Geo grafta, in Boletim de Geografla Teorét1ca, n8 2 - R1o . ClaroSP. Associaçäo de Geografia Teorética (AGETEO) - Editado com a colaboração da Faculdade de Filosofla, Ctências e Letras de Rlo Claro - 1971 .

(16) GARNER, Jacqueline Beaujeau - op. c1t. p. 49-50.

Deven-se ler os tóplcos "L 'explication et les modéles" e "La precistön: vers une nouvelle geographle?"

(17) DIARIO DO CONGRESSO NACIONAL - 20 de novembro de 1971

PROJETO No 447, de 1971 (DO SR. PAULO ALBERTO)

Disciplina a profissão de Geōgrafo, institul o Conselho Fede ral e os Conselhos Regionals de Geografos Profisstonals, e de termina outras providências.

(A Comissões de Constituição e Justį̧a, de Educação e Cultura e de Legislação Social) 


\section{- Congresso Nacional decreta:}

vat1vo de:

Art. 19 - O exercício da profissão de Geógrafo è prị

I - bacharel ou 11 cenciado em Geografia ou Geografia e História por Faculdade oficial ou oficial mente reconhecida;

II - bacharel ou licenciado em Geografla ou Geografta e História, diplomado no estrangeiro em curso re gular por universidade offctal ou reconhecida,des de que seus diplomas sejam revalidados no Brasil nos termos da lel.

Art. 28 - para o provimento e exercfclo de cargo téc nłco ou função de Geógrafo na administração centralızada, em autar quias, em empresas püblicas e socledades de economia mista, ou nas concessionärias de serviço públıco, é obrlgatörla a apresentação do diploma ou do titulo referidos no artigo precedente, respeitadas as vantagens dos atuais ocupantes efetivos do cargo de Geōgrafo, deven do ser readaptados os demais que não satisfaçam as condiçōes pre vistas nos inctsos I e II do art. 18.

parägrafo ünıco. A exibição do diploma ou do titulo não dispensa a prestação do respectivo concurso, quando esse for exigldo para o provimento do cargo.

Art. 38 - Consideran-se atividades profissionals do Geógrafo os reconhecimentos e estudos físico-geográficos pbiogeogräficos, antropogeográficos, e as procedidás nos campos gerałs e especiais da Geografia Humana que se fizerem necessárlas para:

I - a delimitação e caracterização de regiöes e subregiões geogrãficas naturals;

II - o zoneamento geo-humano com vistas ao planejamen to regional em geral, e, em particular para:

a) a elaboração e execução de planos atınentes à estrutura agräria a base da diversidade regio nal dos sistemas de uso da terra. 
b) a caracterização ecológica e etológica da palsagem gcogräfica e problemas pertinentes;

c) a polltica de povoamento, 1migração e colon 1 zação de regiöes novas ou da valorização de regiões de velho povoamento:

d) o estudo fisico-cultural dos setores primá_ rios, secundärios e terciários, em subsídio ao planejamento da produção;

e) avalıação e planifłcação da infra-estrutura;

f) o estudo das bases fístcas e geo-humanas dos núcleos urbanos e rurais;

g) o levantamento e mapeamento aerofotogeogräfico e geotopogräf1co necessário à interpretação de problemas regionals e especificos.

h) ao mapeamento cartogrāfico e temātico em esca las especificas, regionais ou gerais;

III - a proposição, em escala nactonal, regional ou lo cal, de problemas relativos aos recursos naturais do pals, como sejam:

a) seu aproveitamento pelo homem;

b) suas possibilidades de desenvolvimento;

c) sua preservação;

d) desequilibrios existentes entre esses recur sos naturałs e a utilização dos mesmos pelo homems

e) caracterização quantitativa e estrutural da população e das forças de trabalho;

f) proposição de obras püblicas visando corrigir -fettos de condições naturais; 
IV - a Interpretação morfológica e morfométrica da palsagem geogräfica, em espectal das bacias hidrográfıcas;

V - a divisão administrativa da União, dos Estados, dos Territörios a dos Municipios.

Art. 48 - As atividades proflssionais do Geógrafo, sejam as de Investıgaçäo puramente cientificas, sejam as destinadas a servir de apolo à polftica social-econômica ou as iniciativas de natureza privada, exercem-se atravës de:

I - örgãos e serviços permanentes de pesquisas e estudos integrantes de entidades clentificas: culturais, econōmicas ou administrativas;

II - prestação de serviço ajustado para a realização de determinado estudo ou pesquisas, do interes se de institulçōes püblicas ou part1culares;

III - prestação de serviço de carātex permanente soba forma de consultoria ou assessorta, a organtzaçes püblicas ou prtvadas.

Art. 58 - Para os fins de execução da presente lel são criados o Conselho Federal de Geógrafos Profissionais - CFGP, com sede na Capltal da República e os Conselhos Regionais de Geógra fos Profissionals - CRCPs.

Art. 69 - Constituir-se-á o CFGP de nove membros eleitos por representantes dos sindicatos dos geógrafos profissionais.

518 - O Presidente do CFGP, a quem caberá a adminis tração e a representação legal do conselho, serã escolhido entre os membros elettos.

S 29 - A substituição de qualquer membro serā felta por suplente, na ordem dos votos obtidos.

$\S 39$ - O mandato dos membros do CFGP será de três anos e a renovação do terço far-se-ã anualmente a partir do quarto ano da primeira gestão. 
Art. 78 - São atribulções do CFGP;

I - difundir as modernas técnicas de pesquisas e aplicação das clências geográflcas, e empenharse em favor de sua valorizaçāo em todos os seto res de atividades püblicas e privadas em que se mostrem necessärias ;

II - promover campanhas em prol da aplicaçāo dos conhecimentos geográficos nas tarefas de planejamento regional e urbano, para a solução de problemas de base geogräfıca;

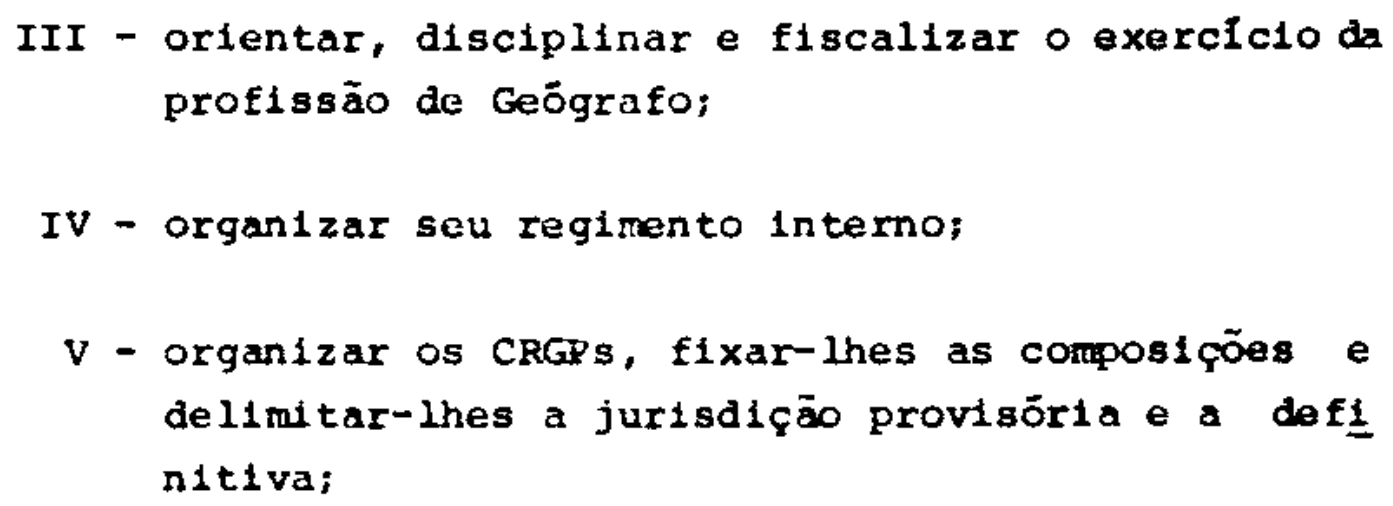
profissão de Geögrafo;

IV - organ1zar seu regimento interno;

V - organizar os CRGPs, fixar-lhes as composiçöes e delimitar-ihes a jurisdiçāo provisöria e a defi nitiva;

VI - tomar conhecimento de qualquer dúvida suscitada nos CRGPs e dirimi-la;

VII - examinar a aprovar os regimentos internos dos CRGPs, modiflcando o que for preclso para manter a unidade de ação dos Conselhos;

VIII - julgar, em ültima instäncia. os recursos de pena lidades Impostas pelos CRGPs;

IX - servir de órgãos consultivos dos poderes públi cos em assuntos pertinentes à proflssão de ceó grafo.

Art. 88 - Os membros de CRGP serão eleitos pela mes ma forma prevista para a eleição dos componentes do CFGP.

Parägrafo único. De cada CRGP deveräo participar, tan to quanto possível, representantes de todos os Estados que integra rem a área de sua jurisdição. 


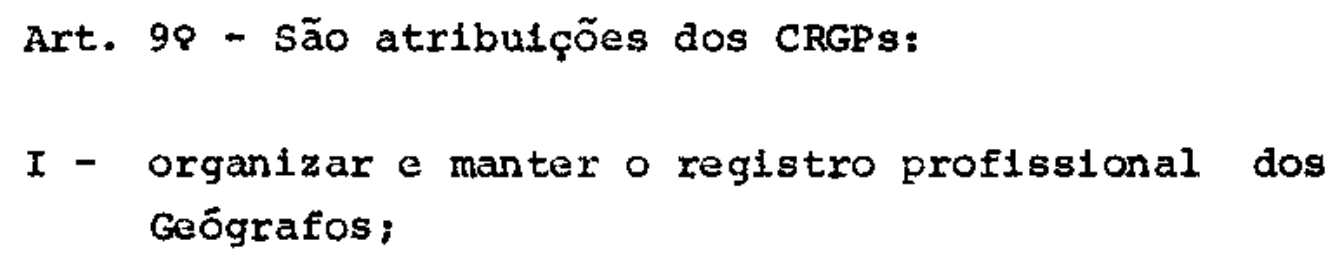

II - fiscalizar o exerclcio da proftssão de Geögrafo;

III - expedir as carteiras profissionais;

IV - auxiliar o CFGP no cumprimento das atribulções expressas nos incisos I e II do artigo anterior:

$\mathrm{V}$ - impor penalidades aos infratores de dispositivo da presente lei;

VI - elaborar seu regimento interno e submetê-10 à a provação do CFGP.

Art. 10. - Constitui renda do CFGP:

I - um quinto da renda bruta de cada CRGPs, excetua da a proveniente de legados e subvençöes;

II - doações e legados:

III - subvenções;

Art. 11. - Constitui renda dos CRGPs:

I - quatro quintos das multas aplicadas;

II - quatro quintos das anuidades recolhldas;

III - quatro quintos da taxa de registro facultativo de qualquer contrato, parecer ou documento pro fissional a ser flxada no regimento interno do CRGP ;

IV - doações e legados;

v - subvenções. 
Art. 12 - Somente poderā exercer a profissão de Geō grafo o profissional registrado no respectivo CRGP, e munido de Car te1ra Profissional.

Parägrafo ün1co - A Carteira Profissional conterá as seguintes indicaçöes:

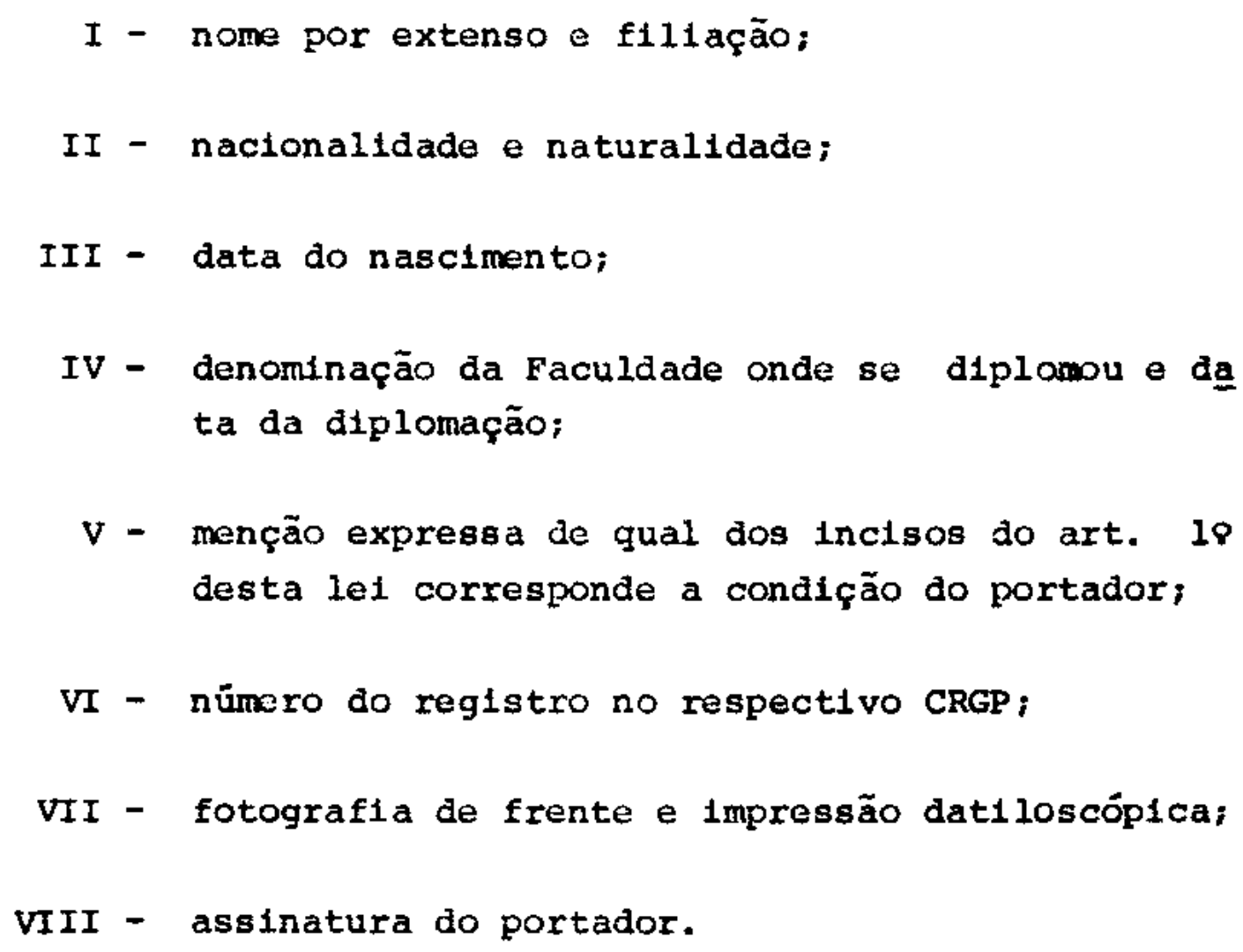

Art. 13 - A Carteira Profissional alëm de represen tar documento para fins do exercicto da profissão, servirá como Car teira de Identidade.

art. 14 - Cs profissionals, as empresas, as entida des e os escritórios referidos nesta lei estão sujeltos ao pagamen to de anuidades a serem flxadas pelo respectivo CRGP.

Art. 15 - A falta do competente registro torna 1le gal e punivel o exercícto da profissão de Geógrafo.

Art. 16 - Enquanto não instalados os CRGPs, suas atribulçōes serão exercidas pelo CFGP.

Art. 17 - o Poder Executivo regulamentarā a presente lei dentro de noventa dias contados da data de sua publicação.

Art. 18 - Esta lei entrará em vigor à data em que pu blicada. 
Sala das Sassões, 8 de novembro de 1971. - Paulo

Alberto.

\section{Justificação}

o presente projeto é inspirado em trabalho da comle são Nacional da Untão Geogräfica Internacional, com a valiosa colạ boraçāo de Geögrafos brasileiros.

Atende aos superiores interesses dessa laboriosa clas se, que aguarda, de hà muito, pelo disciplinamento legal da profissão, inesplicavelmente tão retardado, apesar de värias tentativas parlamentares.

A participaçäo hodiema do Geógrafo na luta contra o subdesenvolvimento fornece diferente retrato daquele que mantinhamos sobre o mesmo.

Tendo deixado de ser simples catălogo de nomes de lugares a dados estatísticos - cediço instrumento de tortura para os jovens estudantes - a Geografta não sendo mais simplesmente deg critiva, assumtu caráter eminentemente explicativo, a lhe conferir foros de clêncla, e a lhe permitir avaliar não somente as diferen gas entre paisagens da superficle terrestre, mas tambëm as razões dessa diversidade.

Consoante a moderna conceltuação, a Geografía es tuda a distribuiçāo dos fenômenos físicos, biológicos a humanos na superficle da terra, as causas dessa distribulção e as relações espectals entre esses fenômenos.

Constituem tarefas do Geögrafo dos tempos presentes: "conhecer e compreender a diferenclação regional; estudar a organização do espaço terrestre pelo homem; desvendar os fatores que facilitam ou dificultam o desenvolvimento social, cultural e econômico de äreas dıversas, de maneira a fornecer os fundamentos pa ra o intitulado "planejamento regional", em que ë essenclal alterarem-se as condições do melo físlco para possibilitar a modificação da flsionomia sōcio-econômica da ārea".

A Geografia dita "aplicada", dedica-se a colaborar na valorłzação da terra e do homem; e é sobretudo sob esse aspecto que a atividade do Geógrafo profissional vem sendo cada vez mais apre ciada e distingulda. 
Cumpre-nos ressaltar que hä 27 anos as Faculdades de Filosofja do Paf́s formam Geógrafos, e o exerciclo dessa profissão continua sem regulação em lei.

Dada a participação declsiva dos mesmos no desenvol vimento, e o inescondivel dilarçamento de sua importância não é aceltāvel se procrastine por mais tempo esse disciplinamento.

Convencidos dessa inadiabilidadc, estruturamos o pro jeto en justificação, pedindo para o mesmo a ajudada aperfelçoadora que o deixarā em condlções de merecer a aprovação das duas casas do congresso, e a sanção presidencial.

Sala das Sassäas, 8 de novembro de 1971. - Paulo

Alberto.

(18) Costa, Manoel Augusto, et alli1. Migracöes Internas no BraS11 - Rlo de Jane1ro. GB - IPEA - INPES - 1971.

"Relaçōes entre espaço geogräfico e processos migratórlos são estabelecldos através: (1) da quallfí cação das áreas geográficas segunđo a atuação de for cas de atração e de repulsão; (1i) do exame das con d1ções atuats de "complementarldade", "transferência", e "intervening opportunity" no processo de "transporte" ou interação espactal que as migrações representam, bem como sua variação no tempo; e (11i) do exame das consequências das $1 \mathrm{~m}$ tgrações sobre a estruturação, dinâmica e conexões das diferentes äreas geogräftcas.

Un quadro das unidades geogräficas brasileiras de atração distingue: (1) āreas dotadas de recursos ne turats ainda inexplorados, que atraem colonizado res, como as frentes pioneiras agricolas na periferia amazônica; (i1) regiões homogêneas ou functonais que mantendo uma economia dinâmica atraem novas popu laçöes, como as reglöes metropolitanas; (11i) focos de atividades centrais, particularmente cidades de posição hierārquica elevada, como as capitals esta duals, ou localtzadas sobre grandes eixos de trang porte; (iv) locais de Implantação de grandes empreendimentos industrials, ou mesmo do setor terctärio, 
onde os estabelecimentos se expandem continuadamente, ou conseguem imprimir efeitos multiplicadores. Brasilia è exemplo.

Brasilia nos lembra a necessidade de distinguir entre migraçōes Induzidas, organizadas, e espontâneas, pois apresenta todas elas. Na parte mais desenvolvida do Pais as formas induziaas e organizadas são mals frequentes. Compreendem inclusive migrações de quadro rural a rural, quando, por exemplo, se vinculam à organização de emprêsas agrícolas ou de coloni zação. Isto fol observado no Oeste do Paraná e Santa Catarina.

Brasilia recorda-nos alnda que a colonização e povoa mento não envolvem apenas populaçöes procedentes de äreas propriamente de repulsão. Mesmo que não tenha a maior expressão quantitativa, a salda dos elementos de elite, ou de certa qualificaçäo de centros maiores jä desenvolvidos e dinâmicos, para ativar centros menores, encerra grande signifłcação.

Talvez seja raro, por isso mesmo, qualificar as àreas como apenas de imigração. Importa, sim, reconhe cê-las segundo as värias formas do processo da substituição de populaçōes: em Jundlal vimos membros das familias dos antigos empresārios agricolas se transferirem para a cidade, sendo substituldos por trabalhadores de nivel cultural mais baixo, provenientes de regiões ma1s pobres de Minas Gerais; no Nordeste são bem caracterizados movimentos convergentes de po pulações rurats ou de pequenas localidades de baixo nivel cultural para as grandes cldades que, por sua vez, assistem a evasão de elementos de suas melhores camadas para as grandes metröpoles do "Su1"; jä entre o Rio de Janeiro e são Paulo estabelecem-se trocas que representam as tendências de integração num mercado de trabalho, embora en forma incipiente.

Mais frequentes são as āreas em que se pode dizer prevalece a repulsão ou a emigração. Muitas vezes é a repulsão a principal mola do movimento e nem sempre são os individuos mais bem dotados os que prime1 
ro partem. Nas áreas de seca do Nordeste o processo migratörio abrange principalmente os individuos menos enralzados. No entanto, mesmo no sul do Brasil, a ausêncta de transformações tecnolögicas na agricultura da chamada "economia colonial" gera pressões demogrăficas de repulsão.

A politica de transportes que repercute nas cond1çöes da acessibilidade às áreas de atração ou repul são influt no processo migratörto. Por outro lado,sur glndo novos polos de desenvolvimento, todo o slste ma migratörio é alterado pelas mudanças nas cond1çöes de complementarldade e "intervening opportunity".

são necessários estudos que conduzem a uma hierarquização dos processos migratōrios segundo seu conteüco quantitativo e qualitativo, bem como quanto à postção hterárquica regional das áreas envolvidas e do signiflcado que as migraçōes para elas representam.

Estuãos de percepcão da população teriam valla pa ra dofinir uma polftica de grvorno face às migrações.

Fora meu propósito sugerir a FIBGE que a Divisão de Pesquisas Reglona1s, que dirijo, Iniclasse em 1972 pesquisas sobre as migrações internas para $\circ$ melhor conhecimento dos mecanismos da regional1zação. A 1ntegração de pesquisas de órgãos d1versos pode ser cogitada. O Censo de 1970 constitui a fonte básica de estudos, devendo o trabalho ser complementado por estuöos de casos na base de amostragens e atividades de canpo.

Com vistas a definir uma politica de governo julgamos de interesse a realização de estudos de modelos de outros palses. O conceito de uma politica migra tōrla fundamenta-ge no fato de que induzir e organtzar migrações, atuar sobre a acesstbłlıdade às áreas, protbir certas formas de arreglmentação, assie tir e orlentar migrantes e informar à população em geral quanto ao problema não se choca com a liberda 
de democrätica de o inüividuo locomover-se livremen te.

Estruturação de arcabouço urbano, controle do processo regional, ascenção sócio-cultural da população, melhor aproveitamento dos recursos naturais, etc.,s 0 os objetivos visados pelos processos migratörios. Algumas metas podem ser sugeridas, como a fixação de empresários nas capttals nordestinas; a criação em cidades que são etapas 1mportantes de migração da ca pacidade de conservar maior quantidade de pessoas; - incremento da ocupação nucleada e organizada nas regiöes vazias, etc.

Propõe-se a organização de um sistema cuja função seria a de orientar a população a respeito da migra ção; preparar os migrantes; dar assistêncla nos pon tos de afluxo de migrantes, criando centros de recep ção e hospedagem; coordenar atıvidades com outros ör gãos de planejamento visando a ampliar o setor de migrações organizadas e influir no rttmo e controle de migração. Existem diversos instrumentos que podem atuar indiretamente nas migrações, como o planejamen to viärio, a legislação sobre loteamentos e constrú çöes, os requisitos de planejamento urbano e de recrutamento de pessoal nos grandes projetos economy cos, etc."

(19) BECKER, Bertha K. As Młgracões Internas no Bras11. Reflexos de una Organizacão do Espaco Desequilibrada, in Revista Brasileira do Gengrafia. Rio de Janeiro. GB. Ano 30 - no 2 Fundação IBGE-IBG - I968 - p.98-116 -

"Ora, pelo que se depreende da anălise das migrações internas, se elas constituem o reflexo de uma organ 1 zação do espaço desequilibrado, a ação consciente de transformaçăo do espaço deve encarar o pais como um todo, de forma global, e não considerar as regiöes problema, isoladamente, de vez que são partes de un conjunto. Por outro lado, se a indústria è, indiscú tivelmente, um fator de crescimento econômico, nem sempre $\vec{e}$, porém, um fator de desenvolvimento econômico sucial. O planejamento não deve visar exclus 1 
vamente o crescimento econômico, e sim o real desen volvimento, quer dizer, un crescimento econômico que seja acompanhado da redistribuição da riqueza produ zida regionalmente, de modo a que todos os habltan tes usufruan de seus benefícios. Trata-se de conferir à região capacidade econömica para se desenvol ver por si mesma, de modo autōnomo. A própría deli n1ção de região desenvolvida como "o resultado de uma massa de consumidores suflclentemente grande para garantir a rentabilidade dos serviços a serem consu midos,"1l denota a importâncla que tem para a regio nalização, ou seja, para o desenvolvimento a presen ̧̧a de uma população rural dotada de poder aquistttvo, que produza e usufrua da produção nos países subdesenvolvidos, onde somente parte dos habitantes das cldades gozam desse privilēgio. Assim sendo, a implantação de grandes fäbricas, dotadas da tecnologia mais moderna, tal como vem sendo feita no Nordeste, localizadas em sua periferia, próximo dos portos e às grandes vias de circulação, não parece ser a me thor forma de resolver a curto prazo, o problema do desenvolvimento regional. A absorção de māo-de-obra è pequena, enquanto se necessita de um "know-kow" a vançado que a região não pode oferecer. 0 estimulo excessivo a esse tipo de industrialização, parece, assım, mals benéfico às grandes empresas do sudeste, nacionals e estrangelias, que usufruem de matēria prima, espaço e mão-de-obra baratos, e de vias de circulação que facilitam o escoamento rápido da pro dução para mercados exterlores à regtäo. Näo nos parece que a renda assim produzlda seja retida e redis tribuida regionalmente; pelo contrário, tal implanta ção favorece a continuaçäo do processo de espoliação reglonal. E o exodo rural continua...

A dispersão de 1ndústrías de tipo mëdio e de equ1 pamentos nos centros menores, paralelamente a 1mplan tação da grande indūstria litorânea, seria frutife ra para o desenvolvimento regional. No entanto, o pa pel da Indústria e dos serviços ainda assim serla $1 \underline{1}$ mitado, refreado que é pelo balxo poder aquisitivo da população. Para que sejam rentāveis, hã que criar um

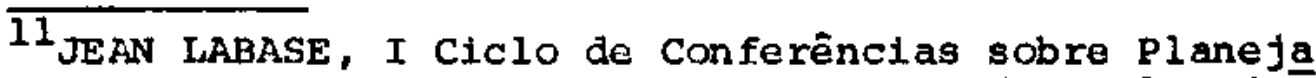
mento Urbano. Hin. do Interior, Min. do planeja" mento e Coordenação Geral, Embaixada da França. Agos to de 1967. 
mercado consumidor que inclua a massa de população rural. Tuđo leva a crer que em paises subdesenvolví dos, como è o nosso caso, o incentivo à industriali zação deve não só levar em conta o tipo de Indústria mals adequado a ser estabelecido, como, principalmen te, ser acompanhado por una reformulação da estrutū ra agräria. I tentativa aa Reforma Agrärla que vem sendo realizada por örgäos governamenta1s, näo tem desenvolvido o campo no ritmo desejāvel, nem tem arrefectdo o êxodo rural. Se è utópica uma reforma agrárla radical nas condições atuals do pals, pelo me nos uma atenção multo mator deve ser dada ao proble ma agrār1o. Nossa experiência indica que, no momento, uma das formas mais eflcazes de produção, capaz de romper as barreiras da falta de capital e de una conercializaçāo opressiva, é a cooperativa de produ tores. Nesse sentido deve se orientar a polftica agrärı, especialmente nas äreas de superfovoamento re lativo.

Atenção especiai, ainda aos problemas da terra, mere cem os espaços alnda não valorizados, que estäo sen do ocupados num processo de pioneirismo desordenado. - controle da posse da terra, a assistêncla técnica

e financeira à populaçāo agrícola, devem ser plane jados, paralelamente, à implantação de núcleos urbanos e industrials, para evitar que se repltam al as distorçōes tradicionals que caracterizam o setor agrárto no pals.

o ataque ao problema agrário, evidentemente, não ex clui nem o estimulo à industrialização, nem tampouco a renovaçäo do patrimônio urbano, visando torna-1o apto às novas necessidades da vida urbana. Nesse sen tido deve-se provar 3 adequaça do ritmo de cresct mento uxbano aos do fluxo migratório e do crescimento vegetativo, pela criação de novos empregos e, especialmente, no Sudeste, planejar o equilfbrio da rede urbana pela criação de novos polos de organ1zą ção da vida regional.

Somente através de um plenejamento integrado do ter ritörio nactonal, que vise eliminar as diferenças se 
torlais e regionais do crescimento econôm1 $\infty$, poderse-à consegulr un real desenvolvimento, ou seja, uma organização equilibrada do espaço, capaz de propor cionar condiçöes de vida dignas ao conteüdo humano do pals, e de valorizar o lmenso potencial que repre sentam os seus oitenta $c$ seis milhöes de habitantes."

(20) SANTOS, Milton - Crescimento Nacional e nova rede urbana: $\underline{0}$ Exemplo do Brastl, in Revista Brasilelra de Geografia - Rlo de Janeiro. G. Ano 29. nP I - Funđação IBGE-IBG - 1967-p.78 92.

"Quats são as lições que se deve tirar do atual estado da organização urbana do Brasil?

A primeira liçāo, é que a ruptura com o passado, revelada pela nova organizaçāo, representa também os esforços para a ruptura com o subdesenvolvimento e - imob1l1smo. Assim, as metrópoles do passado, depois de um períco de estagnação, transformaram a economda urbana, orientando-se para un processo de industrialização tanto mais penoso quanto é dificil num pais onde os desequilibrios regionais tiveram to do o tempo para se instalar e se afirmar. As novas metrópoles, com efeito, têm menos aificuldade para esta adaptação.

A segunda lição vem de que a vida das grandes cldades brasliefras depende cada vez menos do estrange ro, do mercado exterior; elas se nutrem do mercado interior. Um paradoxo pode ser aparente: na etapa atual do desenvolvimento industrial brasileiro é a cidade a mais importante que, sob certos aspectos, de pende do exterior. Entretanto no que concerne à organização urbana propriamente dita, as posições estāo jā defintdas, pois seu mercado interno estă em constante progressão.

A terceira 11ção, è qua esta evolução ocasionou, igualmente uma urbanlzação interior, que estä ligada aos progressos da industrialização e dos transportes terrestres e à elevação geral do nIvel de vida, no interior do pals. 
Tais resultados se prender às mesmas causas: o aumen to do consumo, tanto quantitativo e qualitativo quan to geográfico. O fator consumo - suas causas não nos importam mals - $\vec{e}$ o fato novo na geografla urbana brasileira após 1940. Daí a função 1mportante que de sempenha a população. Isto assegura a conservação do processo, bem que o subdesenvolvimento regional não seja imediatamente esmagado. Efetivamente a possi billdade de acumulação de cap1tals ten como resulta do uma aceleração do processo, seja esta acumulação espontânea, como originalmente, em São Paulo, seja uma acurnulação provocada, como è o caso, agora, no Nordeste.

Enfim, a quarta 11 ção, às diferentes tendências da economia reglonal e suas diferentes significaçöes es paciais, correspondem tendencias à elaboração ou a re elaboração das redes urbanas. As zonas pioneiras no vas criam claades em relação com a maior ou menor rí queza da produção. A distâncla entre estes centros ē um resultado das condições do transporte. o que ex plica, em antigas zonas pioneiras hoje estabilizadas, a seleção de aglomerações em detrimento de vuiras. Quando a revolução dos transportes se acompanha da concentração da propriedade fundiária, então a regressão é fatal. E o caso de algumas cidades da zona do cacau no Estado da Bahia, da velha zona do café e do tabaco no Estado da Bahıa, velhas cidades do ca fé no valo do paraíba, velhas ctdades do açúcar nos estados de Sergipe e Pernambuco.

Na sua região de influencia imediata, São Paulo 1mpôs uma nova organização no espaço regional. A presença de uma massa muito numerosa de assalariados constituía, ela sö, um apreciāvel motor de consumo, un acelerador da economia industrial a agricola.

Mas a economia industrial começou tambēm a exigir do mundo agricola umz produção mais racional, da qual se beneficiam 1gualmente os agrlcultores.

Uma estrutura favorável da propriedade, pois as pequenas propriedades formam grande nümero, contribulu 
para que a renda global seja menos injustamente dis tribulda. A procura de novos bens e servicos encon trava sua resposta na existência de recursos distr1 buíos na massa da população. Isto explica não somente o crescimento de numerosas cidades do interior do Estado, de são Paulo, mas tambēm a 1mplantação, nestas cldades, de indústrias bastante numerosas deg tinadas ao consumo regional. Um quadro das cldades paulistas as mais populosas, coincide, mals ou menos, com a lista das aglomerações sendo a produção industrial a mals importante.

Em outras regiões brastle1ras, mas sobretudo no Nor deste, no Norte e no Centro-Oeste, a forma de econo mia dominante opõe-se sempre à criação das cldades méđias. O sistema era tal que uma metröpole, grande ou näo, dominava todo o territoorio. Os elementos fun damentais desta economia são a agricultura comerclal orientada para a exportação, a predominância da gran de propriedade e dos sistemas sócloreconōmicos corres pondentes, a função absorvente de um setor terciärio representado essencialmente por um aparelho comerc1 al hipertrofiado. As raras ciciales médias são antes de tudo, o resultado da presença de três elementos: os serviços representativos do poder polftico da metrópole regional, a residência de agricultores abastados, e as sedes das empresas de exportação de produtos regionals. En poucas palavras: a região de Influência de cada um destes centros é o espaço de produção: cada un deles todavia, è o espaço de consú mo. E uma defintção muito simples, mas que define a situação e seră ainda mais compreensivel se levarmos em conta que aqueles que consomem, no interior da c1 dade são apenas uma minoria. Á revolução industrial veio modificar substancialmente a situação, por intermédio do jogo de diferentes fatores:

a) a produção industrial reclamou a produção de diversos produtos agrícolas e contribul para a che gada de uma massa considerável de dinheiro liquido nos campos; 
b) o aumento da população urbana e de seu poder de compra agiu como un estimulante da produçäo de produtos alimentares a uma escala cada vez menos autārquica e cada vez mais comercial;

c) O efeito demonstrativo, representado por contatos mantidos, graças aos caminhöes e automóvis e os diferentes meios de divulgação, fez nascer um grande número do necessidades que era necessärio sa tisfazer.

Certos pontos do território, certas cidades bem s1tuadas em função de novos transportes beneficiaram se da presença destes fatores, porque eles tornaramse o centro de escoamento da produção rural e o cen tro da distribuição dos produtos recentemente reclą mados. Sua função intermediāria afirmo-se, às vezes de forma radical.

A manutenção de um sistema agrārio ou a parte do ganho que pertence ao agricultor é mínimo, reduz as possibilidades de extensão, a campanha de beneficlos da cłvilização industrial na qual, ironicamente, ele estä direta ou indiretamente ligado. Sua particlpa cäo no consumo è pequena. Esta margem de participação è diretamente proporcional à parte que o agricul tor recebe do produto do seu trabalho.

Muito nitida é a oposição entre os nivels de vida e a massa de consuno nas regiöes como a do cacau no Es tado da Bahia ou como a região de Itabalana, no Esta do de sergipe, onde os pequenos agricultores produ zem, sobre suas próprias terras, produtos destina dos à alimentação; è, por exemplo, o que acontece nas ăreas de criação extensiva ou da cultura de cana-de-açücar, onde o latifúndio ê rei. Em compensação, o nümero $e$ a importância das cidades nas regiöes do cacau ou do sisal são bem mais eloquentes que nas regiōes de criação ou da cana-de-açúcar.

A nova organização brasilelra apoiou-se pois, funda mentalmente, sobre a industrialização do pais, mas 


\begin{abstract}
suas nuances são devidas, ao peso da histöria, ao desempenho persistente da função polftico-adrinistra tiva, às diferentes estruturas agrärtas، $E$ o que ex plica as diferenças reglonals do processo e dos re sultadoo, com tantas outras variantes intra-regiona is."
\end{abstract}

(21) LOPES, Juarez Rubens Brandäo - Desenvolvimento e Mudança Soclal. São Paulo. SP. Companhia Edttora Nactonal -2a. Edıção 1971.

- trabalho do autor é de grande Interesse para os geógrafos e professores de ceografia. Ele permite ir ao fundo da ques tāo referente aos 1mpactos que o processo de industrializaçäo e de urbanizaçāo provocam na estrutura social brasileira.

(22) LOEB, Roberto - Aspectos do Planejamento Territorlal Urbano no BrastI, in Planejamento no Brasil. LAFER, Betty Mindi1n, et alli1. São Paulo - SP. Editora Perspectiva - 1970-p,142. 
CAPITULO 2

GEOGRAFIA E EOUCAÇAO 
2 - geografia e educacho

\section{1 - Objet1vos}

19 - Assinalar a existência de estreltas ligações entre Geografia e educação.

29 - Analisar as causas de un nāo-interrelactonamento mais fecundo e produtivo entre Geografia e educaçāo, princlpalmente no Brasil.

38 - Sugerir modelos de planejamento educacional que se a poiem em contribuiçöes da Geografia.

\section{2 - Introducão}

o tema è vasto, complexo, alnda nāo explorado em profundidade por planejadores educaclona1s e por geögrafos e/ou professores de Geografia. Mas ressalta que se o planefamento educacional deve

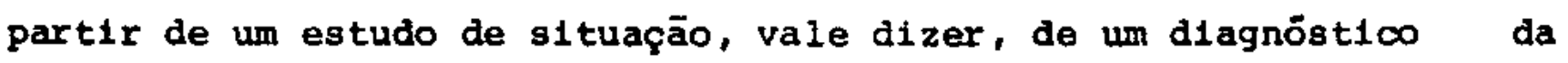
educação, este diagnöstico tem que ser completo, isto é, jogar com todas as variävels do subsigtema. Algumas dessas variäveis são:

- o espaco fisico onde se implanta o sistema educacional;

- a populaçāo como um todo, anal1sada de diversos ângulos: estatist1co, demogrăf1co, cultural, soclolögico, histōr co:

- a economia: caracterizaçāo, perfil, potencialldades.

Enquanto os diagnósticos educacionals insistirem em trabalhar com un nümero reduzido de varıäve1s, chegando à stmplificação (mals no sentido de eliminaçāo, alhelamento que de síntese) de cons1 derar como centro do diagnóstico a relação população escolarizável: populaçāo escolarizada, eles resultarão falhos, alienados.

Ao conträrio, quando se parte para o concelto de sistema e de subsistemas, estabelecendo-se as mültiplas 11gaçōes, que há en tre eles e das variãveis umas com as outras, o dtagnóstico do subsia tema educacional na realldade se complexifica, mas torna-se mais ver dadeiro, mats integral.

A partir de então, as prioridades podem ser estabelecir, as estratēgtas para implementaçäo dos projetos e programas são mals bem montadas. A educação não const1tui um "sistema fechado", mas è um "sletena aberto" ou mais precisamente um subsistema aberto, 1sto ë, aquele que atravēs de trocas, ações e interaçōes se expande, se enriquece, se amplia, se dinamiza. 
Deve ficar claro que nāo se busca demonstrar que a educacäo liga-se direta e unicamente à Geografla, lato seria una prova de insensatez. Pretende-se, $18 s 0 \mathrm{sim}$, assinalar as ligaçöes estreي tas entre ambos e que a Geografla pode cooperar com o planejamento educactonal.

\section{3 - Babitat - homem - desenvolvimento}

Preston James, o geögrafo norte-americano a quem mu1to de vem a Geografla con um todo e, em particular, a Geografla na Amërica do Sul e no Brasil, apresenta una sërle de conceltos interesiantes sobre a questão em causa: Habitat-homem-desenvolvimento ${ }^{(1)}$.

Parte o autor dos conceltos de região para en seguida caracterizar: ecoss1stemas, habitat e req1öes cultura1s.

"A reg1ão, ...., é um segmento da superficle da Terra, de finido como homogèneo porque dentro dele existe certa enpócie de interconexão entre coisas e acontecimentos de origemdferen te."

"Os ecossistemas sāo o resultado das associaçōes sonais dos processos flslcos e blöticos, sem a intervenção humana."

"O habitat è um ecossistern mais ou menos modificado pela presença do homem."

As regiōes cultura1s: "... zonas dentro das quais são algo homogèneos os respectivos objetivos e a habilidade tẻcnica da socledade humana."

\section{REGIF̃O}

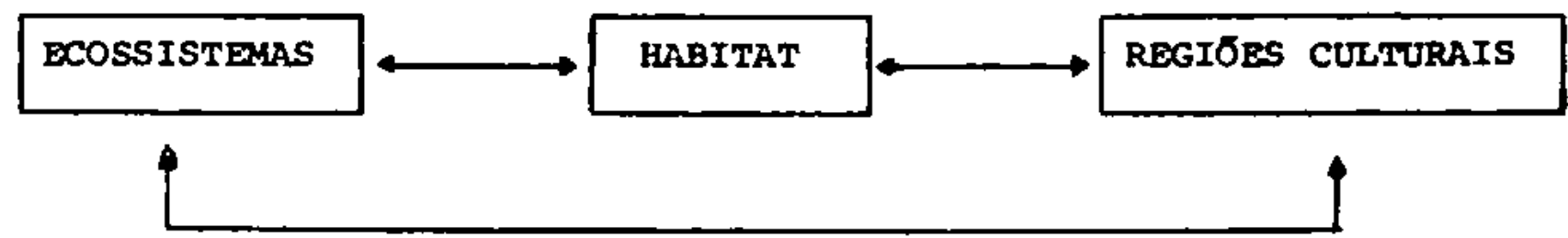

- autor cltado estabelece uma sërle de interrelaçōes en tre os três subsistemas, deixando evidenciado que no estágio atual dos conhecimentos, a questão do desenvolvimento $(\theta$, obviamente da eđucação) depende de "uma melhor compreensão das 1nterconexöes do homem e de seu amblente natural", "... o significado, para o homem das caracteristicas fisicas e biōticas do seu habłtat, ë uma fun çāo das atıtudes, objetivos e habilidades téenicas do pröprio hameñ. 
Por 1sso mesmo, um concelto de natureza geogräfica, deve (ou deveria) ser un dos indicadores preliminares para o planejamento educacional, considerando o homem a quem se busca educar cmo par te do ecosststema e da reglão cultural. A partir dessa prenissa ele mentar, que, em absoluto não è de natureza determinista, educar sig nifica posstbilitar ao homem a atuação esclarecida sobre essa moldu ra, esse pano de fundo.

Un grupo humano pode agif mals racionalmente ou menos $r \underline{a}$ clonalmente sobre o seu hab1tat, dependendo esta atuação, em boa me dida, do grau de evoluçāo dos conhectmentos desse grupo.

os exemplos negativos do relactonamento grupo humano - ha bitat são variados e de repercussões multas vezes danosas, quando não se leva em conta a ocupação ordenada dos espaços. Organtzar a ocupação do habitat è uma das tarefas da educaçāo.

Observe-se, por exemplo, o caso de reglöes metropolitanas cuja problemätica gerada pelo crescimento desordenado exige hoje so luções drásticas, custosas. Töquio, Nova Iorque, são Paulo, Rec1fe são exemplos típicos ${ }^{(2)}$.

Ao contrărio, a ocupação racional dos espaços: cldades pla nejadas, colonização tecnicamente projetada, abrem novas possibil1dades, se não houver desvirtuamento dos objetivos, o que sempre pode ocorrer. Brasilia, colonização no norte do Paranã, novos elxos rodoviärlos na Amazônia, são tentativas de ocupą̧äo planejada do es paço físico.

A primelra sugestão para o planejamento educacional:

Levar en conta o Interrelacionamento primário: habitat-homem-desenvoivimento-educaçäo.

\section{4 - Regtão e planejamento educacional}

Ds conceitos de região

Dentre os multos remas da Geografia que são objeto de debates, congressos, monografias, etc., estä o relativo ao concel to de REGI§̃O.

Alguns uxemplos:

18 - "Porção de espaço terrestre, qualquer que seja o mo do pelo qual for considerada ou a utilidade que the for atrtburda, a regläo è de qualquer forma um fenömeno geogräficon"(3). 
28 - "En seu estudo, Ricchter1 admitla a existēncia três tipos de reglōes, a saber:

a) a região elementar, baseada en ư gó fenōmeno, po dendo ser geológlca, morfolöglca, hidrogräf 1 ca clț mätica ou botānica;

b) a reg1ão geogräflca complexa, compreendendo äreas sobre as quals se superpunham virias regiōes ele mentares. Como tal, $\dot{e}$ tipo de região que ele qualifica expressamente como geogräflca;

c) a reg1ão integral, formada por un conjunto de re glões complexas" (4).

30 - "Textualmente, afirma o professor Cholley: "A Idëla de região implica un principlo de organtzação. Deve-se em consequência, reservar esta expressäo exclusí vamente às organizaçöes realizadas pelo homem na su perficie do planeta". Continua afirmando ser "o ter mo dominio ma1s conveniente que região para designar as unldades fisicas, estruturals, climátlcas e morfo löglcas". E também o termo que deveria ser empregado a propósito dos fenómenos ligados à attvidade humana, quando se quer considerar apenas sua extensāo: domínio do trigo, dominio da visha, etc." (4).

49 - "La region est l'a1re extension d'un paysage géographique (Max Sorre) ${ }^{n(5)}$.

Pode-se buscar na literatura geogräfica un sem número de conceltos a respelto de REGIÃo. Mas nāo é esse o propöaito do tra balho. Vale, $1850 \mathrm{sim}$, recordar que os conceltos de reglão não sāo dispares só recentemente.

"La introducción y uso generalizado de este tërmino por los fundadores de la Geografia Moderna, en el siglo XIX (P. Bua che, J. Ch. Gatterar, H. G. Hommeyer, A. Zeune, J. R. Y G. Fos ters) $y$ en la primera mitad del siglo XVIII (A. Humboldt $y$ K. R1tter), representaron un largo paso hacla adelante en la evo luctón metódica de los estudios geogräficos, expresada por la substitución de las unidades zonales, polftica y administrat1vas, definidas "a prlort", por otras unidades establectdas so bre la base de caracteristicas naturales comunes y definidas em piricamente por un estudio atento de la realidad"(6).

Variaram, igualmente, em função de certos dados, como por exemplo: 
18 - o próprio estágio de evoluçāo dos conhecimentos geogräficos ;

28 - a ligaçāo mais ou menos estrelta, em certos momentos e en certos palses, da Geografia corn a Histöria (re giōes baseadas na evolução histōrica); da Geografia com a Geologia (regióes apoiadas no embasamento geo lógi(o); da Geografia com a Antropologia (regiōes al tura1s) e, mals recentemente, com a Economia tregiöes econòm1cas).

Isto não representa, em absoluto, uma falta de per. sonalidade da Geografia, mas resulta de tentativas va rladas de se buscar a melhor caracterizaçāo para una determinada ărea da superfícle terrestre;

38 - o pröprio sistema econômico-polftico-social, enfat1zando a regiäo econônica, por exemplo, na uRss ${ }^{(6)}$; ou as regiöes objeto de intervenção ertatal para reorga nização do espaço, como na Grä-Bretanha, na Itãlla, no Brasil, os exemplos da SUDENE, SUDAM, PROVALE, RE GIÕES METROPOLITANAS, etc.

Evoluem os conceltos e parece correta a posição de BERARD KAYSER; quancio afirma: "Nos dias de hoje,o geögrafo se dispōe sem complexos, a reconhecer que o desenho dos limites regionals jä não é mais o objeto princlpal de sua pesquisa: ele tende a con stderar a região com o campo de ações concomitantes de intensi dades variãvels, mals do que como a inscrição espaclal precisa de equilibrios fundamentais. Mas isso não o dispensa de def1nir com precisão aquilo que ele quer tratar, de pesquisar cri teriosamente o 1mpacto espacial exato dos fenómenos que ele ana 11sa. Os limites regionais são múltiplos, dinâmicos, agindo tanto como fretos, quanto como forças, eles contëm en si mesmos sua própria superação.

os conceltos de regtāo sāo diversos, aplicados efetivamen te a diferentes de desenvolvimento econömico" (7).

Por 1sso, buscam-se levantar os dados e os fatos que carac terizer uma determinada ärea da superficle terrestre, em função de objetivos prë-fixados ${ }^{(8)}$ : 


\begin{tabular}{|c|c|}
\hline ripo & objet1vo \\
\hline Area de programação & $\begin{array}{l}\text { Coordenação das atıvidades de pla } \\
\text { nıflcação em escala menor co que } \\
\text { a Nação como um todo. }\end{array}$ \\
\hline Regıão de planifıcação & 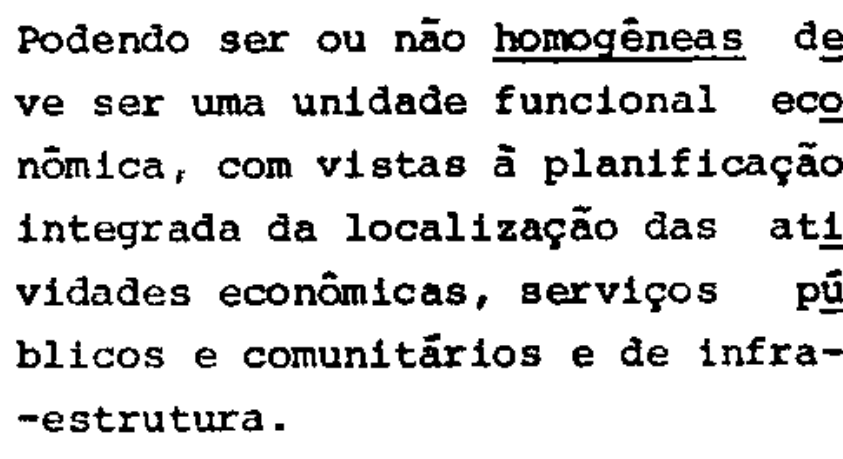 \\
\hline Sub-regtão de planificação & 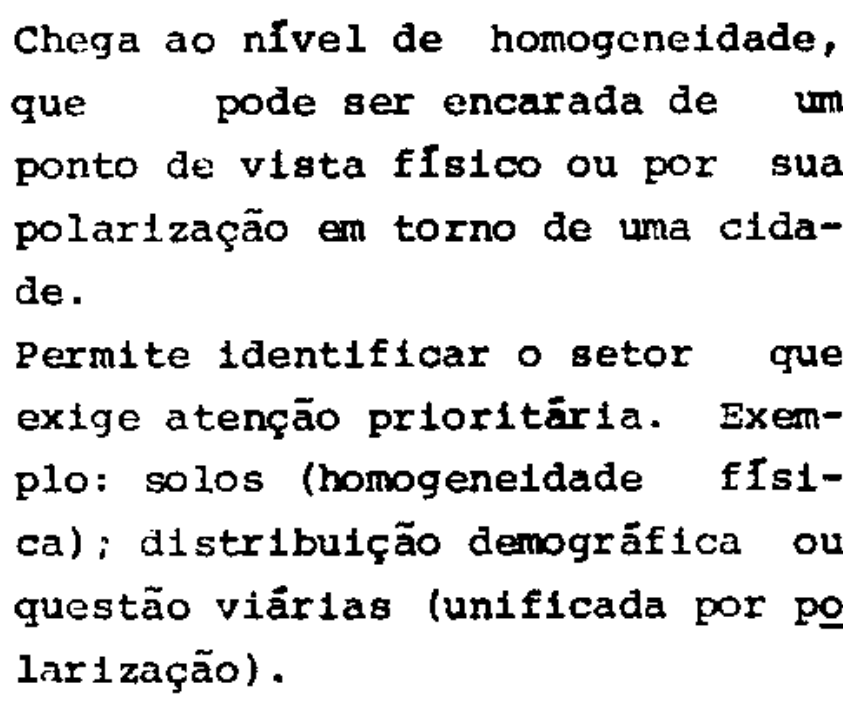 \\
\hline
\end{tabular}

o quadro-sintese esboçado $\bar{e}$ um resumo de debates ocorr1 dos no "Primeiro Seminário Interamertcano sobre a definição de regiöes para a planificação do desenvolvimenton, em 1967.

0 tema "planificação para o desenvolvimento", desde então vem preocupando mais a mais os clentistas soclais, os politicos, a administrą̧ão, o prōprlo sistema econômico (capitalista e socia l1sta, nas suas diversas modalldades). Só alnda não preocupou, na devida medida das necessidades, os planejadores educacionals.

De uma ou de outra forma, pode-se afirmar contudo:

18 - o concelto de região precisa ser desmltificado ${ }^{(9)}$, aco tando-se critêrios básicos para sua caracterização e tipologia; 
28 - depende da ötla do pesquisador, ou do pranejador, o concelto de regiäo, assim cono sua estrutura, 11m1 tes, objetivos do estudo ou do programa a ser implan tado;

39 - a Geografla tende a caracterizar a regiäo a partir do concelto de centralidade, polarização(10);

49 - o acervo de pesquisas geogrä́ficas é bastante pondené vel sobre o tema, en värios pafses e, mesmo no Bra s11, de forma que as abordagens metodológicas para o estudo da regiäo possibilitam o aproveltamento desse. "know-how" para aplicá-lo ao planejamento educacio nal.

\section{Os estudos sobre regionalizaçäo no Brastl}

Como é sabido pelos geógrafos e professores de Geografia, os estudos sobre regionalização no Brasil são recentes, bastante re centes, embora sejam muito mais antigas as proposições sobre divisão reglonal do Brasil.

No sēculo passado e no iníc1o do atual foran feltas pro postas de divisão regional do Brasil, sob um enfoque geográfico e não mais político e administrativo.

A rigor pode-se alzer que a alteração do concelto estático que envolvia as divisões regionais do Brasil só passou a ter uma conotação dinâmica - a regiāo como um campo de forças - mais proximamente, quando o planejamento econômico necessitou de novos enfo ques regionais ${ }^{(11)}$.

Igualmente, o desenvolvimento dos conceltos de relacionamento nos espaços polarizados em sentido estrito e dos conceltos de relação "centro-periferia", impulsionaram os estudos de regionaliza ção no Brasil (12).

oficialmente, muito contribuiram para a nova abordagem do tema regionalização os värios trabalhos publicados pelo IBG. Den tre eles, destacam-se "Subsidios à Regionalização" (1968), Dlvisão do Brasil em Mtcro-Regtöes Homogêneas (1968) e D1v1são do Bras1l em Regiöes Funcionais Urbanas (1972).

Do ültımo, vale transcrever: "Deste modo, as cldades e as regiōes funcionais urbanas (base para os estudos de polariza ção) poden se tornar ao mesmo tempo, objeto e elemento Impor tante do desenvolvimento regional.

A divisão do Brasil ora apresentada define un sistema hie rarquizado de divisões territoriats e de cldades que pode ser 
vir de modelo tonto para una polftica reglonalizada do deservol vimento, como para orientar a racionalização no suprimento dos serviços de infra-estrutura urbana atravēs da distribuição espa cial mals adequada" (p. 9).

No estägio atual, temos no Brasil a seguinte hierarquiza çào regional:

\section{Macrorregiāo \\ Regiāo \\ Sub-reg1ões \\ Microrregiōes (eventualmente com os municiplos formando sto -setores).}

Esta hlerarquização só adquire significado en função da sua anălise dināmica, com vistas a periōdicas reformulaçōes e com um sentido prospectivo que só o estudo das estruturas en constante mov 1 mento e Interação possibilita.

"La régionalization est donc l'aménagement de l'espace brut par l'houme, aménagement etant pris au sens d'action comme au sens de rēsultat. Une rëgion de plantflcation, une région d'in fluence urbaine, ne peuvent naturellement pas ètre ignorées des gëographes sous pretexte que les actions impliqués n'ont pas, ou pas encore, modtflë le paysage risible, mals elles ne sont, au maximum, que des rëglons gëographiques potentielles" (13).

Considere-se mals que reglonalização não è o estudo d1le. tante ou especulativo dos espaços regionais. Ao contrário - e este è o caso do Brasil - ela envolve un aspecto politico que visa à execução de programas de organlzação e reorganização espaclai ${ }^{(14)}$.

A segunda sugestāo para o planejamento educacional:

Considerar que a base fornecida pela Geografia, no que diz respeito aos estudos de regionalização, até agora tem ser vido ma1s ds questōes pertinentes ao crescimento econômico, à "organização do espaço!

Hä un "know-how" aprectävel no Brasil à disposição dos planejadores educaclonais, no momento en que se valham das me todologias para o estudo reglonal, a firm de diagnosticar de fato a educação inserlda, I1gada, dependente e aceleradora chs modificaçōes nas estruturas espaciais. Não è compreensivel que o planejamento educacional pouco ou nada tenha a ver com a regionalização. 
Na anālise de una regiāo, o cue pode interessar ao planeja mento educacional

Já se assinalou anteriormente que no Brasil e, especialmen te nos Estados, o planejamento educacional:

18 - toca de leve nas microrregiōes, faz referência vaga a "polos de crescimento", sem precisar se se trata de polos de crescimento ou de äreas subdesenvolvidas (po los en que a "drenagem" de recursos > "irrigação" oue vitalize a ärea polarizada).

- Razão: a mlcrorreglão vale, alnda, só como um referenclal estatistico; os conceltos, estrutura, fun clonalidade, evolução dos polos, não são dominados pelos planejadores educaciona1s, a1nda não esclarecidos sobre a importāncia dos mesmos para o crescimento o desenvolvimento:

28 - mesmo usada a microrregião só como unidade que permite quantificar a população: crescimento, distribulỡo espaclal (às vezes), relação "escolarizävel-escolar1zada", ela è destacada do contexto reglonal, o que des figura a anălise. A nicrorregião não ẽ um espaço ho mogêneo sem mültiplas ligações com as demais e com 0 centro polarizador, no minimo;

38 - não parte para um diagnōstico amplo, abrangente da re giāo, considerando todos os aspectos relevantes, para integrar a eđucação aos demals setores, como por exem plo: cultura, estrutura etäria e ocupacional, mobil1dade derroxräfica, setores econömicos (primärto, secundärio e terciärio), infra-estrutura viāria, impactos de origem diversa: comunicação, tecnologia, etc., ou o inverso: imoblitsmo, freios, isolamento, etc.

Terceira sugestão para o planejamento educacional:

Partir da análise global da microrregião, que è (ou deve ser) tarefa de equipes multidisciplinares.

Considerar a microrregião como parte integrante de una unidade de ordem imediatamente sunerior: a sub-reglão, onde se localizará um polo (cldade), que deveră merecer anălise es pecifica e aprofundada, vez que esse polo age e sofre as açő 
da ărea que polartza, inclusive as cldades das microrregiões sob sua influência.

Considerar a sub-reg1äo cmo articulada fou necessitando articular-se) com a regiāo, onde se 1dentificarão outros centros reglonats (polos) que devem ser analisados em função da hierarquia urbana.

Ter presente que a região é parcela da macrorregião, on de a trama de fenômenos sócio-político-econômicos se complexifica, fornecendo indicadores mais diversificados para o pla nejamento global, onde deve inserir-se o planejamento do sub sistema educacional.

Não imaginar que a macrorregião é o ponto final do planejamento integrado: ela compöe con as demais o territörlo na clonal que, por seu turno, relaciona-se com outras naçōes, o que mais ou menos fortemente, influencla o planejamento na cional.

Ter consclêncla de que a planificação regional, com v1s tas a acelerar o crescimento e o desenvolvimento, E feita pá ra perfodos mals ou menos curtos: $3,4,5$ anos e que essa pla nificação é uma etapa para a "organização do territōrio", tạ refa de uma ou ma1s gerações (15) (16).

As regiões, qualquer seja o seu tipo (micro-, sub- ou ma crorregião), estão sempre Interligadas, e suas relações aprẹ sentam-se, freqtentemente, do tipo "centro-periferia". 0 pla nejamento, em particular o planejamento educaclonal, pode vir a ser um instrumento para a correção de tendências e pro cessos que criam ou acentuam os desequilibrios interregto nats.

Fettas essas consideraçōes preliminares, à guisa de sugestōes para o planejamento educacional, cabe buscar as respostas à per gunta: "na anālise de uma regiāo, o que pode interessar ao planeja mento educacional?"

Hã vārias respostas:

la. - tudo o que for significativo para caracterizar a re gião, do ponto de vista do seu dinamismo. De quanto mats elementos caracterlzadores disponham os planeja dores educactonais, mator será a possibilidade de es tabelecer prioridades; 
2a. - depende do nivel do planejamento: munictpal, urbano-rural, mlcrorregional,....., estadual, federal,...

3a. - a globalizacāo dos aspectos setorla1s, que respondam a uma evolução, estāglo atual e projecōes próximas e ma1s afastadas:

4a. - en vista do que fol assinalado nas très primelras res postas, é conveniente delxar claro, que a anälise da região é tarefa de que particlpam idealmente värıos especialistas, dentre eles os geögrafos e os planeja dores educacionais; ainda mais: não hă uma metodologila padrão para o estudo regional, as metodologias ve rlan em função, no minimo, de:

- tipo de regtão: micro? polarizada? urbana? rural? ...?

- superficie da região;

- quantitativo demogrä́fico;

- embasamento econômico;

- orlentaçāo polftica dada à pesquisa, pelos órgãos governamentais, se for o caso;

- recursos humanos e técnicos disponivels para a ta refa ;

- recursos financeiros para a execucão do trabalho;

- prazos; ...

A geografia pode sugerir algumas abordagens metodológicas.

"- Levantamento dos equipamentos urbanos existentes: secun dărios e terciärios;

- levantamento dos fluxos para os centros urbanos relat1vamente bem equipados;

- porcentagem da população urbana na população total do município;

- relação entre o valor da produção agricola e industrial de cada municlpio;

- equipamentos industriais quanto ao nümero de estabelec1 mentos, nümero de empregados, valor da produção indus trial, tipos de indústrias:

- equipamentos comercials: atacadistas, varejistas, armazēns e silos;

- equipamentos bancärios: bancos, cooperativas;

- equipamentos administrativos;

- equipanentos de educação: [ensino de 19 grau], [ensino de $2 s$ gra:d], ensino superior; 
- equipamentos de saūde: nümero de hospita1s, nümero de leitos;

- equipamentos de cultura e lazer: teatros, clnemas, clụ bes:

- nümeros e tipos de profissionais [universitärtos] en ca da centro urbano: advogados, mëdicos, agrōnamos, enge nhelros, veterinär 1os, dentistas, farmacêuticos;

- equipamentos de transporte;

- fluxo entre polos;

- fluxo no interior dos polos;

- fluxo entre um polo e sua região;

- Fluxo entre a região polarizada e seu polo;

- fluxo entre as regiōes dependentes de polos diferentes:

- fluxo no Interior de uma região polarizada;

- fluxo de ura polo pira a região de outro polo.

A área de Influêncla é medida atravēs de pesquisas que es clareçam e quantifiquem a Intensidade de fluxos que podem ser agrupa dos em várlos 1tens, a saber:

- transportes e comunicações: aēreos, maritimos, fluvials, ferroviārlos, rodoviārlos, comunicaçōes;

- ärea de 1nfluência de suas indūstrias: fluxo de matēriag -primas, fluxo de capitais, fluxo de mäo-de-obra, fluxo de energia, destıno da produção Industrial;

- Influência do comércio: atacadista, varej1sta;

- Influência dos seus serviços: ârea de influêncla das es tações rädı-emissoras, jornais, estaçōes de televisão, chamadas telefönicas;

- ārea de influência de seus estabelecimentos de ensino superfor, [de 28 e de 18 graus];

- ärea de influêncla de suas igrejas;

- ärea de influência de seus profissiona1s liberais: médicos, dentistas, advogados, agrōnomos, veterinärios, pro fessores, etc.:

- ärea de influência de seus clubes e casas de diversōes;

- ărea de Influência de seus estabelecimentos de crédito: bancos e cooperativas;

- ärea de furisdição das repartiçōes püblicas: federais, es taduals (municipais);

- ärea de influência de suas casas de saüde: hospltais, ma ternidades, etc." (17).

Quanto ao estudo das relações entre a cldade e as zonas rura1s, podem ser sintetizadas: 
" a origen da população urbana;

- as causas do movimento emigratório;

- as formas e etapas da enigração:

- as consequências da atração urbana nas zonas de emigração:

- as atividades dos imigrantes na cidade;

- lugar de origem dos migrantes;

- a época da migração e suas relações com as atividades locais;

- as consequências da migração temporár1a ${ }^{(18)}$.

Outras sugestōes:

"Analisar os fatores naturais e históricos; 1dem, a polari zação; as comunfcações; a administração; a 1nfluẻncia das transforma çöes tëcnicas; a Influência dos fatores humanos; o destino da reglãa

Analisar:

- a população, en seus aspectos demográficos e sociats;

- os recursos e sua utilização;

- o consuno:

- as relações exteriores;

- a estrutura geoogräfican (10)

Como sintese temos o quadro no 27. 
QUADRO NO 27

O ESTUDO REGIONAL

\begin{tabular}{|c|c|c|c|c|}
\hline \multirow{2}{*}{ RAMOS DE ESTUDO } & \multicolumn{4}{|c|}{ PARTICIPANTES } \\
\hline & GEOGRAFO & DEMOGRAFO & SOCIOLOGO & ECONOMISTA \\
\hline POPULACĀO & $\begin{array}{l}\text { 1. Localização } \\
\text { 2. Mobllidade }\end{array}$ & $\begin{array}{l}\text { 1. Fecundidade } \\
\text { 1. Estrutura de 1da } \\
\text { de } \\
\text { 3. Perspectiva mão- } \\
\text {-de-obra }\end{array}$ & $\begin{array}{l}\text { 2. Classes } \\
\text { 2. Atitudes } \\
\text { 2. Niveis söcio-cul } \\
\text { turais }\end{array}$ & \\
\hline RECURSOS & $\begin{array}{l}\text { 1. Inventärio } \\
\text { 1. Equipamento }\end{array}$ & & & $\begin{array}{l}\text { 2.3. Capitais } \\
\text { 1.3. Produção } \\
\text { 1. Equipamento }\end{array}$ \\
\hline CONSUNo & 1.3. Repartição & & $\begin{array}{l}\text { 2. Häbłtos e apti- } \\
\text { dões às mudanças }\end{array}$ & $\begin{array}{l}\text { 1. Niveis } \\
\text { 1. Equipamentos e } \\
\text { rendas individunis }\end{array}$ \\
\hline TROCAS EXTERIORES & 3. Migrações & & & $\begin{array}{l}\text { 1.3. Transporte de } \\
\text { mercadortas }\end{array}$ \\
\hline $\begin{array}{l}\text { ESTRUTURA GEOGRA- } \\
\text { FICA }\end{array}$ & $\begin{array}{l}\text { 1.2. Zonas homogè- } \\
\text { neas } \\
\text { 1.2. Transportes } \\
\text { 1.2. Rede urbana }\end{array}$ & $\begin{array}{l}\text { 1. População attiva } \\
\text { das cidades }\end{array}$ & & $\begin{array}{l}\text { 1.2. Zonas homogè- } \\
\text { neas }\end{array}$ \\
\hline
\end{tabular}

FONTES PRINCIPAIS DO ESTUDO: 1. EstatIst1cas; 2. Inquër1tos; 3. Est1mattvas.

(FONTE: A Geografia Ativa - Pierre George, et all11. Ed. da USP - 1966). 
Observanão. o autor não se preocupou, en aksoluto, en pro por mocielos metodológicos para o estuco reglonal. Apenas alinhou to mando a liberdade de fazer sinteses, alguns exerplos. 0 objetivo: mostrar rue as netodologias são varladas e, cada vez ma1s o serãa na medida en ruc evoluam as técnicas de nesculsa geogräfica, soc10lögica, econômica, agronômlca, sanitarista, gerencial, educacional, ct.

\section{5 - Geografia, regionalizacão, planejamento educaclonal}

Una vez carzcterizada a rogıão objeto de estudo, noderá cą ror a um segundo ascalão de planiflcadores educacionais montar os pla nos, programas, nrojetos.

Esse segundo escalão, atē o presente, a rigor não exlste no MIEC e nas Secreterlas do Educacão. Por motivos vãrios, çue torna ran crônica a carêncla de possoal hakilitado nara a planificação edü caclonal, seja a nivol feccral, seja cstadual, soja municipal, mu1 tas vezes os olanos setoriais são fruto do trabalho de clementos ató mesmo cstranhos aos ruadros dos órgãos ofıciais, convocados estes e outros dos örgãos püblicos mara montar o plano, tão somente.

os resultados são facilmonte identificāve1s:

19 - não atendon às necullaridades e necessidades reglo na1s, contribuindo dc una ou outra forme, para agravar as disparidades entre as muttas ároas do pais e lou Estado;

39 - são fortenente influenciados por algumas variáveis,das ruais destacam as estatisticas educacionals e os re cursos financelros: deixanco de lado o tue seria de importêncta primordial: a realidade regionicl en seus nültiplos asncctos:

39 - não são compatibilizados com os planos de outros $M \underline{1}$ nistírios e/ou Secretarias, a não ser soh a forma de compatih1lizacão orcamontäria:

49 - esgotam-se em si mosmos, não constituindo etapa que se liguc a una etapa subsentente, com vistas à "organização dos espraçor". (0eixe-sc claro quo isto não significa sugerir is elaboração de um plano cm 1972 nara ter val1dace atō. d1ga-se, 1900).

Conclul-se, nortanto, cue nlanos con tais caracteristicas dificilnente orientam ume ação eflcaz tue objntive solucionar os pro blemas educacioneis $e$, atravís da nducação, venham a auxtllar a supe racão de graves dispcridades regionais. 
A partir de 1972 à cuc o !tEC csté culdando de preparar eculpes têcnicas de planejamento educacional con as seguintes caractê rfsticas:

1. - essas ecrulpes deven sor troiradas especificamente pa ra o plancjanento educacional

2 ? - devem former un corno permanente de assessorta, con ronuneraç̃o condigna o tcnpo integral:

3. - deverão sex capazos de nlanojar com un sontido mais abrangente, mals profundo, dada a sue prónria forma c.̃o.

@̣uando houvor a ligacão entro:

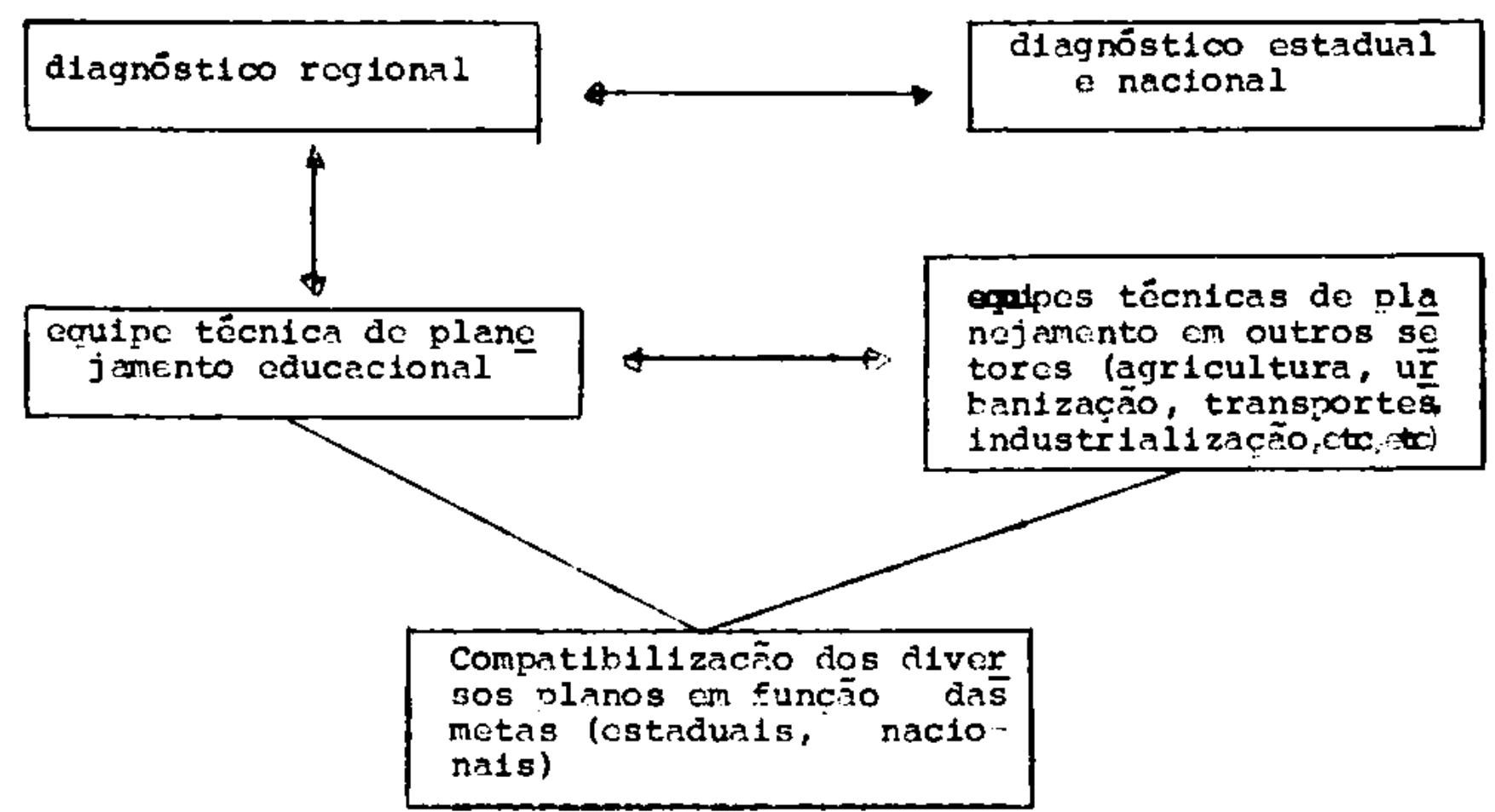

então, se poderä ter razoñvel margem de seguranç de planificação in tegral e Integrada aapaz de acelerar o crescimento econômico e o desenvolvimento social.

Por ïltimo cabe Indagar: rual a função do geógrafo e/ou do nrofessor de Geografle, nesse conjunto de proposiçöes?

Algumas respostas:

1. - particinar do diagnöstico regional com outros tëcn1 cos: 
23. - ser un dos elementos rue comnonham assessoria de olanejamonto, ruer fcderal, cuer estadual, ceuer municinal (Guando o municiplo tiver condiçōes de manter essar equine):

3. - mrcstar, assistenaticamente, serviços de consultoria às reforidas couloes

4. - em nivel mis singclo - o nivel escola - o profossor de Gcografir se näo podc tudo pode multo, isto é:

- coonerar: culçä, coordonar os estudos de anảllse e diagnóstico microrregional, ou municipal, nara fornccer ao corpo cocente. \& täcnico de sua escola ou conjunto de escolas, una nrimaira eproximaçăo da rcalladar sohrc a rual a escola deve agir:

- oricntar o estudo da matëria (Estudos Socinis) ou di disciplina (Gcografia) de tal forme cui possiblI1te aos scus alunos un conhccinento neis conrente do cuadro regional ar ruc so situa a cscola.

\section{6 - Conclusõos parcinis}

$1:$ - 0 olmejemento ceucacional scrímais realistico se atrntar pera as realledes regionais, a fin do atuar mi1s produtivamente.

2. - Os conceltos dr PECIño tôn virlado en função de multas causas, nis hojr, no Bras11, os trabalhos do re gionalizacão nossibllitam seu aprovcltamento pera com-or a nlenificargão global e e educacional.

3? - Os dlagnösticos rcqiona1s integrados constituem exceIento subsicio para a intrgracão dos planos, clucacio nâs ou não.

4. - 0 geórrafo c o nrofessor de Gengrafia noden (e devem) atuar decisivamentc nos clagnósticos rcglonals, oue scrão, dr. una ou de outra forma, vallosos pera a educação. 


\section{NOTAS REFERENTES AO CAPITULO 2}

(1) - JAMES, Prcston E. A estrutura concettual de Gcografia. Tradução de Joacuín I. da Silveira Mota. Rio do Janeiro - GB - Bole tim Geogrăfico n8 199 - Fundaçäo IBGE - IBG - 1967 - p. 3-18.

(1) - op. c1t. - p. 9 .

(2) GEORGE, Pierre - A acão do homen. Tradução de octavio :Ionces Ca Jado - São Paulo - SP - DIfusão Euronēia do Livro - 1971.

"A arrumação ou a organização do espaço começam com o desenho do primeiro campo, a construção do primeiro muro e o tra çado do primeiro cantnho. A diferenca essencial entre esse tipo de organizaçāo $e$ as intervencōes complexas nara orcenar a vià econômica e social das soctedades modornas ē uma diferenfa de escala e de estrutura. Por escala, cumpre entender não só a dimensão dos fenômcnos o dos espaços am tela, mas também a sua nluralidade. Im consectência desse salto qualitativo e dessa pluralidade, a iniciativa escapa ao erpresārio, ainda we o emnreendimento seja cada vez mais concentrado, porque näo sc confunde concentraçāo com sintesc.

A sintese portence à colrtivieade, ao Estado. E arul se s1tua a mudança de cstrutura. A organdzação, a arrumação pas sar para a cscala do Fstado ou da organização internacional..." $(n .7)$.

Estas Idelas de Picrre Grorg̣ vêm corroborar a necossidade da planificação pelo ou sob o controle do Estado. Nesse partí cular, estã a quostão da planificação orucacional.

(3) - KAYSER, Bernard - A região como objeto de estudo da Geografia, in Gcografia ntiva - Pierre Gcorge, et all11. Tradução de G1l Toledo, ilanuel Seabra, lịelson DC La Côrte e Vincenzo Bochié ch1o. São Paulo - SP - Difusäo Euronōla do Livro - Editora da Untvorstcadc de São Paulo - $1966-$ p.281.

(4) - ANDRAde, Manuel Corrcla de - Fspaco, Polar1zacão e Desenvolvimento. São Paulo - SP - Editora Brrsiliense - 1970 - o. 39.

(4) - on. cit. p. 4?.

(5) - GARNIER, Jacơucline Boaujeu - La Géographic: mëthodes ot perspectives. Paris - France - Masson \& C1a. Editeurs - 1971 - p. 99. 
(6) - DZIEKONSKI, R., ct ali11. Exanc de conceptos y teortas do la regionalización económica, in Centralidade - poglonalizacão Textos Bäsicos-1 - Instituto panamcricano de Geografla o H1stō r1a - Rio äc Jane1ro - GB - 1068 - n. 79.

(6) op. c1t. p. 79-91. Ver, om csnccial, a respelto, n. 82-83;8788.

(7) - KAYSER, Bcrnard - op. cit. p. 281-282.

(8) - INSTITUTO PAIAMERICANO DE GEOGRAFIX E HISTÓRIA. Comisiö́n do Geografia - Documcntactōn dc1 I Seminario sobre REGIOInLIZACro Rio de Janitro - GB - APEC Edttora S.R. - 1969.

Ver princlpalmente: p. 12-36:273-300.

(9) - GARNIER, Jacquelins Bcaujeu - op. cit. p. 107.

(10). Clnval, Paul - La Tcoria de los lugares centralcs, in Centrali dade - Regionalização - Toxtos Bāstcos-1 - Rlo de Janelro - eB Instituto Panamericano de Gografia e Histōrir? - 1968 - 0.19 .35

ANDRADE, ianuel Correla do - Centralldade .. Definição de una Mctocologia para o estudo da Contralidado. R1o de Janniro - GB 1. Conforência lactonal do G:ografla e Cartografia - Fundaçēo $I B G E-I B G-1968$.

CORPEN, Roborto Lnbato - Estudos sobfe Contralidaco no Erasil. Rio dc Janciro - GB. 1. Conforc̄ncla Nacional de Gcografla e Cartografin - Fundaçäo ITrge - IBG - 1968.

COREEA, Rohorto Lobato - Estudos das Rcilecõos cntre Reg1ão C $C$ Cidade - R10 de Janciro-G3 - 1 : Conferôncia Nacional de Gco grafla c Cartograf1a - Fundagãn IBGF-IBG - 1968.

K.YSER, Bornarc. A regiño como onjetn de cstudn. op. cit.

MOLLER, N1ce Lccoce - Urbantzaçãn e organizacão do cspaco no vale dn perafha, Estado de são Paulo, in S1mpös1o do Gcografia Urbana - Rio de Janciro - Gr. Conisión de Geografla - Institụ to Panamcricano do Goonraflè e Histöria - 1968.

BERHARDES, Lys1a M.C. Hicrarcula Urbana c Polar1zacão no Bra sil, in Simpósio de Geografia Jrbana - Pio de Janeiro - GB. Co misión c.e Googrifia -. Instituto panamericano de Gcografia e Hig tōri. - 1068 . 
(11) - GEIGER, Pedro Pinchas - Divisão Regional e Probloma Rogional. Rio de Janeiro - GB - 1. Conferêncie lacional de Goografia Certografia. Fundação IBrn - IBG - 1963.

"Quanto à Gcografia, ou se ocupava cm estudar formas do es paço brasile1ro, cono no campo da geomorfologia ou dos siste mas agricolas, ou ralizava monografias descritivas de deterni nados espaços do pals, san maior sentido prospectivo". p. 2.

"Compreonce-se, pols, quo a rogionalizarão expressc o de senvolvimonto e que o desenvclvimento nacional se faz através do desonvolvimento regional" n. 7.

"n divisão on regiöes adrinistrativas que vem sendo observada en diversos Estados implice na escolha de cidades para a centrallzação de estabelecimentos ou repartlções pübllcas, e na delimitação do ralo de acão destes estabelccimentos. Tal polftica, na medida en oue accntua a centralidade do algumas cldades, se integra aos oroblemas gerais do planejamento e de senvolvimonte regional" n. 17.

(12)- GEIGER, Pedro Pinchas " lodelnca Estrutura Espacial do Bras11, in Curso Dara Professoros de Grografia - no 16 - Rio de Jane1rC - GB - Funtação IBGS - IBG - 1370 .

"o descnvolvimento do plinejamonto, ou seja, a implentação de diretrizes de: governos no sontido de orlentar de forma cons denada as atividaçes econôm1cas do sistcma, inclusive quanto à localização das emprosas, tem se acentuado nos ültimos anos e ó outra aspecto do sistema. seu carätor centraltzado roflote a existência do núcleo, bon como a necessidade de integrar nücleo o periferia, sua neccssicade se vincula aos impasses ca racteristions que se criam nos modelos nücleo-porlforla, inclu sive para evitar a atomizacão dos recursos numa dispersão pela periforla. Sendo o planejamento um fato politico rofletira na turalmonte as caracteristicas do núclco, da periferia o seu re lacionamento" p. 13.

(13) - DEMAGgoT, Jcan - Milicu Naturel et Regtonalization de l'ospace au Brēsil, in La Rëglonalization do l'ospace au Brësil - Pa ris - France - Edition du centre National de la acchorche scientifigue" - 1071 . . 31...e.

(14) - DOLLFUS, Olivier - Rapnort de Synthòse, in op. cit. supra - p. 185-188. 
(15) - ANDRADE, Manucl Correla de - Geograf1a, Região e Desenvolvimen to - São paulo - SP - 2a. edição - Editora Brasiliense - 1971D. $35 \sim 48$ 。

"O "amënagement du territoire", por exemplo, éfelto a lon go termo, resulta de una visão a longo prazo e as linhas gerais desses flanos contrastan com o curto prazo e com a previsão de okjetivos as planos ctinctenals e cuadrienals de desen volvimento.

ìssim, o "amënagonont तu territoire" dä uma visão a longo prazo e com objetivos gerals, encuanto a plantficação regional E feita a curto prazo e con objetivos definidos especificos; donde se deve partir de um nlann de "aménagement du territcire" para os planos de descnvolvimente regional, quadrienals, trienais o gulnatienais.

D "amēnagoment du territntre", a contrárlo da planificação não olha o homem como um produtcr, mas como habitante: o homem habitante é ume escala mais amnla do homem-produtor, isto é, apenas um aspccto do homen-habitante. Assim, interessam ao "amënagement du torritolre" os problomas do habitat, os problemas polfticos, soctais, an lado dos problenas econômicos que são especificos da planificaç̃o regional" $ๆ$. 38-39.

(16) - MONOD, Jörôme - CASTELRAJAC, Philippe de. L'Aménagement du territoire. Paris - France - Prosses universitaires de France "nue saig-je?" - 1971 .

"L'amönagement du territnire n'est donc pas une polltique facile. Ellc oscile ontre doux extromes, celul de nier toute contralnte göngraphique et de rechercher un développement abso lument ecuilibri disponsant la population de toute rigration et colui au contraire de constituer un moyon pour les techniciens de jouer avec lo sort de chacun en disposant sulvant des modèles abstraits de la croissance de chaque village, de cha rue ville, do chaque rëgion.

Les controverses oul eclatent parfois sur tells ou telle action d'amōnagoment du territoire trouvent lä - au delä des constdérations particuliòres qui peuvent lcs motiver - lour ex plication. Le rôle d'une administration consciente, lorsme de tels conflicts se produisent ontre la recherche dr l'opt1 mum sconomioue et les considerations sociales, est de fournir exactoment les connēs du problems au pouvoir polttiạo aut seul pout trancher. 
L'anënagement cu territolre n'est donc pas, en dëfinitive, I'apanage des géographes, ou des economistes, ou des sociolo ques, ou do telle ou tellc autre catëgorte d'experts. c'est a la limite une affalre de comnromis, donc prescrue toujours un problème nolitique" p. 17-18.

(17)- AldDADE, Manuel Corrola de.. Centralirade - Definicão de una metodologia para o estuco da centralldade. Rlo de Janelro - GR 1. Conferôncla Nacional de Geografia e Cartografia - Fundação IBG: - IBG - 1968 - n. 8-13.

(10)- CORREA, Rober to Lcbato - Estudo das Relações entre Reglão e Ci

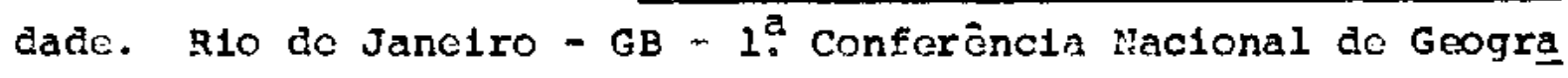
fia e Cartografia - Fundação IBGE - IBC - 1968.

(19) - KMYGER: Bernard - op. c1t. 
C A P I T U L 03

GEOGRAFIA E CARTA ESCOLAR 


\section{1- Objetivos}

1 - Assinalar o estäglo atual dos trabalhos e as perspectivas que serão abertas pela "CARTA ESCOLAR", como subsidio valioso para o planejamento educacional.

2 - Destacar as funções que poderão caber a geögrafos e/ou professores de Geografia, na elaboração continuada das "CARTAS escolares".

3 - Sugerir o engajamento dos Departamentos de Geografia das Universidades, no projeto "CARTA ESCOLAR" (PROCARTA).

\section{2- Introdução}

O Plano Setorial do MEC - $1972 / 74^{(1)}$, na parte referente aos Projetos Prioritários, apresenta o Projeto de no 29 gue diz res peito à Carta Escolar. O Projeto nq 29 é inédito no Bras11, razão porque ainda não fol devidamente considerado por geógrafos, professores de Geografia, planejadores e administradores dos sistemas escolares.

o primeiro documento a respeito do assunto foi elaborado pelo Centro Nacional de Recursos Humanos (CNRH), do Instituto de Pesquisas Econömicas Aplicadas (IPEA) (2). Esse documento apresenta considerações gerais e ensaia uma metodologla para o desenvolvimento do projeto. Embora sofrendo restrições por parte de alguns tēcni cos em educação, teve o grande mérito de levantar as varıáveis do problema. colar 1971 .

o Estado de Goiás dedicou-se à elaboração de sua Carta Es

Notando a relativa timidez com que outras unidades da Federação se lançavam ao projeto e, ainda mais, considerando que as experiênclas desenvolvidas por Goiás e pela Bahı́a deixavam bastante a desejar, a Secretaria Geral do MEC avocou a si, em malo de 1972, a tarefa de implementar o Projeto, para 1sso constituindo um grupo de trabalho que deverä apresentar seus primeiros resultados no f1nal do ano de 1972 . 


\section{3- A politica educacional e a distribuicão geogräfica dos elementos que compöem seus objetivos.}

Pode-se dizer que até o presente momento (1972) a politica educacional tanto a nivel federal, como de estado e de municlpio luta por quantificar e por qualificar suas metas.

Hâ carència de diagnósticos sistêmicos abrangendo todas as variāveis que Interessam ao subsistema educacional e aos subsistemas por ele influenciados como: o subsistema demográfico, $\circ$ subsistema econônico, o subsistema da mão-de-obra "latu sensu", o subsistema polftico, etc.

Atẻ mesmo o diagnóstico do subsistema educacional é elabo rado a partir de grandes IInhas que não revelam as necessidades pr 1 oritárias. Assim por exemplo pode-se ter una idéla da populajão escolartzāvel - população escolarizada, o que permite vārias ilaçōes, como necessidade do aumento da rede escolar, do nümero de professores a injetar no subsistema, de recursos financeiros para a expansão flisica, etc., etc. Mas tuđo se faz em termos globals, quando as necessldades educaclonals, os pontos de estrangulamento, as äreas carentes de melhoria qualitativa, por exemplo, são microrregionals ou municipais.

Em decorrència, os Investimentos não são aplicados em ãreas prioritárlas, eleitas por análise do sistema global, mas multas vezes para atender a determinadas pressões de carāter social, polltico ou mesmo pessoal.

Os Planos Estaduals de Educação são coerentes com as necessidades söcio-econômico-polittcas. Pode-se mesmo afirmar que hä Planos, mas não há projetos. Isto ocorre por muitas razões, dentre as quais sobreleva ressaltar: estrutura organizacional das Secretarias de Educação, das prefelturas, carêncla de recursos humanos ha bilitados, falta de diagnōsticos e projetos eepeciflcos montados tecnicamente.

Hă uma fllosofla que norteia os rumos da politica educacional: a de conceder mator autonomia aos Estados e aos Municipios que devem assumir a responsabilidade de gerir a educação que neles se implanta. Evidentemente o Estado ou o Municlpio è que devem sentir suas necessidades, suas possibilidades, suas realidades, enfim. Caberá ao Governo Federal, atravēs do MEC, traçar diretrizes gerais, prestar assistência técnica e financeira aos Estados e, esses, aos Municipios. 
A municipalização do ensino é meta última do $\mathrm{MEC}$, no que tange a descentral1zação administrativa e financelra por que vem l또 tando nos ültimos très anos.

Os gräflcos a seguir llustram essa tendèncla que é uma preocupaçäo constante por exemplo na SEC/R1o Grande do Sul (4).

\section{Gráf1co no 20}

LINHAS GERAIS DA REFORMA DO SISTEMA EDUCACIONAL DO RIO GRANDE DO SUL
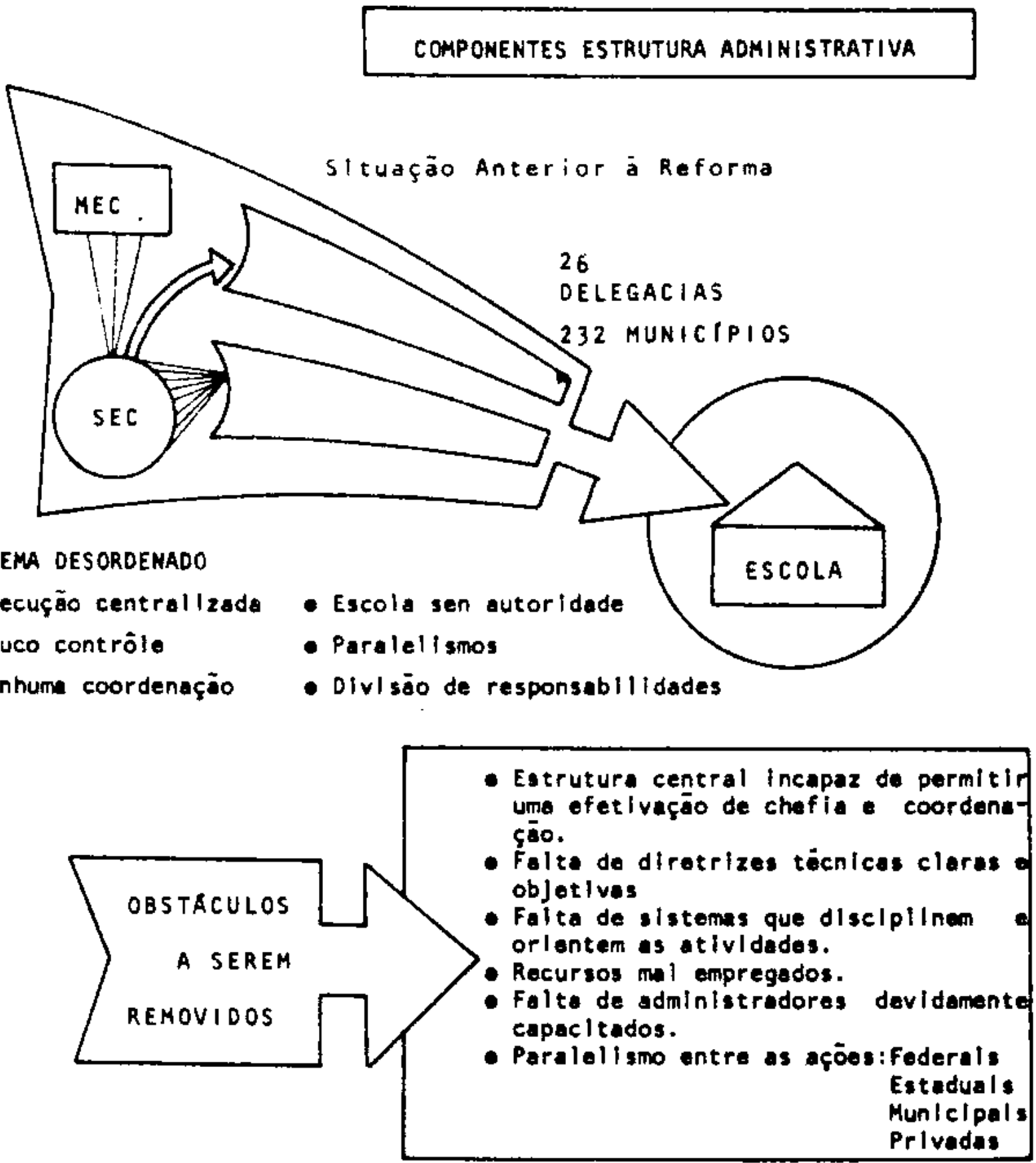

Fonte: Introduçāo à Reforma do S1stema Educactonal do R1o Grande do Sul - Documento Preliminar - SEC - 1971. 
Gráfico no 21

COMPONENTES DO SISTEMA

EDUCACIONAL DO RIO GRANDE DO SUL

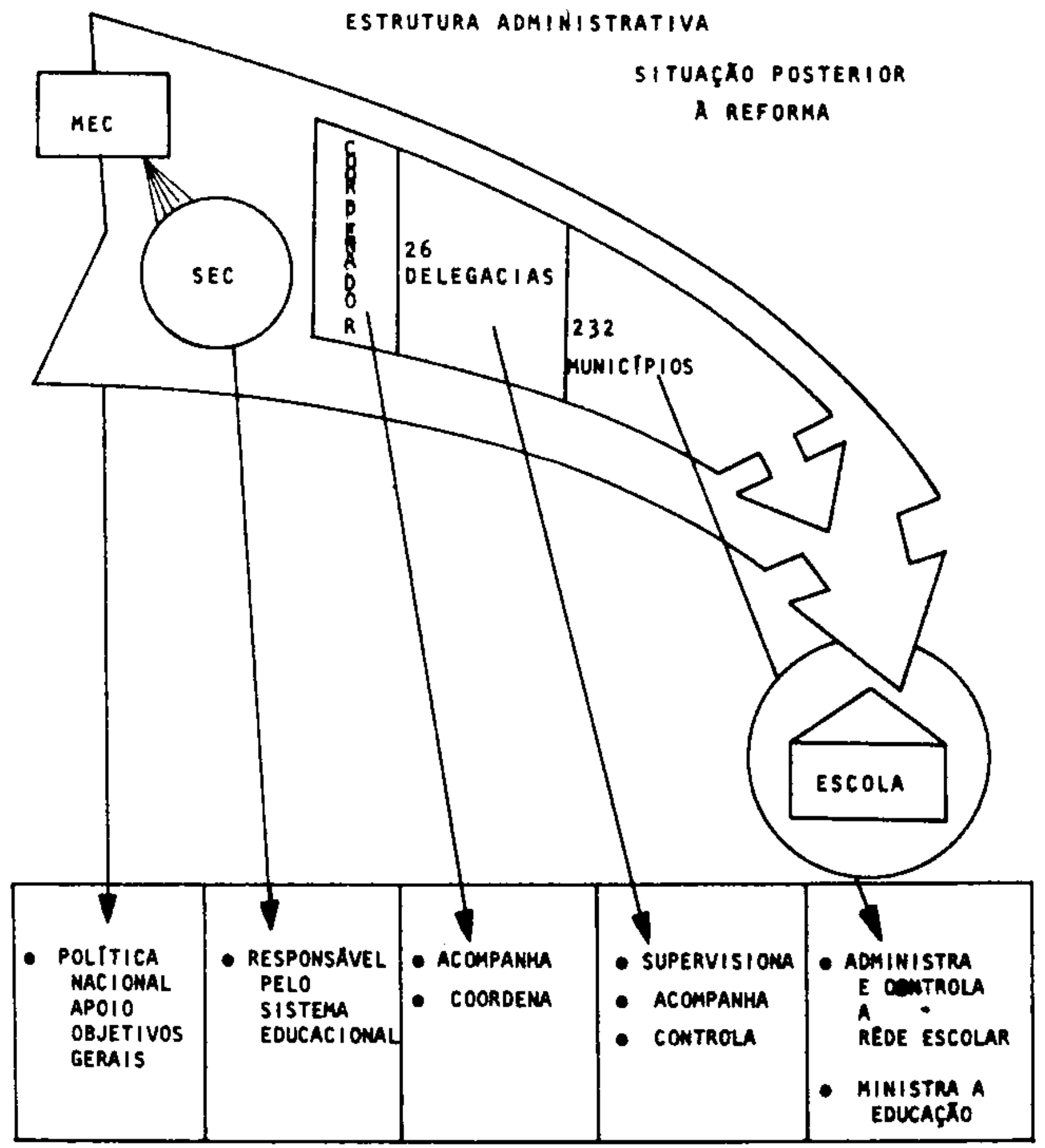

Fonte: Introdução à Reforma do Sistema Educacional do Rlo Grande do Sul - Documento Preilminar - SEC - 1971.

Como se pode observar, caberá aos Municlpiog efetivamente, e à comuntdades, desejavelmente, a ministração direta do ensino de 18 e de 28 graus. 
E a esse nível que se torna necessäria a elaboração da Carta Escolar, que possibilitarã una primetra qualificação e quant ficação do fenômeno ensino, através da anălise da distribulção esp̣a cial:

- da rede escolar;

- do fluxo dos alunos pelas diferentes séries e estabelecimentos de ensino.

A parttr desses dois dados básicos, de carāter quantitatị vo, outras variăveis poderão e deverão ser introduzidas na Carta Escolar, como, por exemplo:

- intercomplementaridade das escolas:

- caracterização dos tipos de escolas;

- caracterização do pessoal docente e tëcnico-administrativo:

- possibilidades e necessidades da expansão física da rede escolar:

- caracterização demogräfica e social do muntcipto:

- perfil económico do municlpio:

- rede de transportes básicos:

- pulsação sazonal das atividades econômicas:

- Identificação co(s) polo(s) municipal, microrregional e regional, de crescimento e de desenvolvimento;

- estudos de centralidade e fluxos de prestação de servicos e de população.

Quando houver uma sērie de cartas "radiografando" o municipio, a microrregião e o Estado, al, sim, se poderão fazer diagnós ticos do subsistema educacional com maior precısāo. Esses diagnóstí cos mais seguros serão a base para a montagem de projetos guatendam ao subsistema educacional, com a maximização de resultados.

Nesse instante, tanto a polftica educacional federal,cono a estadual e a municipal poderão ser equacionadas realisticamente.

Esse é o caminho para "organizar concretamente a oferta de educação de acordo com os objetivos do plano. Isto supöe uma politica de implantação dos estabelecimentos de ensino em todo o territörio, isto é, a organização de uma "carta escolar" que va_ trans por os objetivos globais do plano ao nivel regional e local". (5) 


\section{4- A Carta Escolar : pressupostos bás1cos}

o documento do CNRH - IPEA, citado anteriormente, sugere, na página 13:

"A Carta Escolar" deverã:

- compreender um suporte flsico, que possibilite situar:

- os elementos geográficos que influem na escolariza ção;

- os elementos mais expressivos do sistema escolar;

- os elementos externos ao sistema escolar que exercem Influência sobre êle;

- ter dimensōes que permitam fãcil manuseio;

- ser construlda numa escala que permita leitura fácll;

- ter un caräter permanente;

- ser atualizada anualmente;

- ser capaz de conter o aumento progressivo dos dados;

- ser prevista a um nivel de utilização que a torne, real mente, um instrumento operacional."

Ma1s adiante, lembra (p. 15):

"A Carta Escolar compreenderá um municlp1o, alguns municiplos vizinhos ou somente parte de um muni cipio, e uma falxa cuja largura deverä representar, no máximo, $4 \mathrm{~km}$ do território dos municípios vizinhos, a fim de permitir a visualizaçāo da intercomplementaridade entre os municipios".

A partir da Carta Escolar será possivel, pela caracteriza ção dos seus elementos em fichas aproprladas, contar-se com as seguintes indicaçöes (päginas 16 e 17):

"- a dependēncia administrativa dos estabelecimentos;

- as escolas do ensino primário do sistema ainda em vigor:

- as escolas do ensino ginasial do sistema ainda em vigor:

- as escolas de ensino fundamental;

- o número de alunos por anos de estudo;

- o nümero de professores:

- o número de turnos;

- a relação professor-aluno;

- o núnero de salas de aula;

- a capaciade da escola: 
- o número de vagas, por anos de estudo;

- o número de laboratörios:

- o nümero de oflcinas:

- a zona de recrutamento da escola;

- a população escolarizāvel da zona de recrutamento da escola;

- a intercomplementaridade dos estabelecimentos:

- a intercomplementaridade entre os municlpios;

- a Impossibilidade de intercomplementaridade (grande distância, ausêncla de vias de comuntcação, obs táculos naturais: rios, serras, etc.);

- as zonas carentes de escolas;

- fatores que determinem a necessidade de criação de novos estabelecimentos escolares (densidade de população, vias de comunicação, etc.):

- situações que reclamam providências urgentes (esco las que precisam ser construidas, falta de professores, etc.)".

A medida em que se desejarem - e eles são indispensáveisoutros pormenores, de natureza demogräfica e econômica, sugere o dọ cumento citado (página 57):

"- o censo anual das crianças que alcancem a idade es colar, por zona de atendimento de cada escola;

- censo anual das crłanças escolarizadas da mesma falxa etārıa, dessa mesma zona;

- a diferença eritre a população escolarłzāvel e esco larizada, dessa fałxa etăria, dessa mesma zona;

- censo anual das crianças que alcancem a idade esco lar das zonas desprovidas de escola;

- os censos dos anos anteriores e o do ano em curso permitirão determinar cada ano, com uma certa precisão, a população a ser atendida dentro dos pröxí mos 3 anos.

As informaçöes bäsicas para determinar as preví sões, que aparecem acima, devem ser completadas, na medida do possivel, com informações que permitam determinar essas previsões com maior segurança: a evolução demogräfica, a concentração urbana, o desenvol vimento econômico (projetos de criação de zona indug trial), remoção da população de uma favela, deslocamento de una população, etc. 
No caso da implantação de uma escola em zonas onde a população emigra por não poder manter-se trabalhando durante muitos anos (fronteiras agricolas, regiões de terra pobre, etc.) será interessante prever escolas facilmente removivels, como as do tipo vagão, prē-construídas, etc.".

Uma das grandes dificuldades que se levará em conta é que poucos Estados ou poucas regiões estão mapeadas em escala suficientemente grande: 1:100.000, 1:50.000, 1:10.000, de forma a facilitar - trabalho dos técnicos que elaborarão a Carta Escolar.

Todavia, por outro lado, grande parte das Prefelturas dis põe de cartas ao menos da sede municipal, por onde se iniciară, cer tamente, a tarefa de localizar espacialmente os elementos minimos.

A base será, tanto quanto possível, a Carta topográfica.

Outras formas de superar a carência de cartas:

- lançar mão do SERFHAU, ou de órgãos como a SUDENE, SUDAM, INCRA, Batalhões de Engenharla e Construção, empresas partlculares de construção de méd1o e grande portes;

- mobilizar os serviços estaduals de cartografia;

- Idem, 1dem, das prefeituras, quando os houver;

- recorrer a uma fonte ainda pouquissimo explorada: Un1versidades e Escolas Superiores Isoladas;

- valer-se de recurso humano treinado ou rapldamente trei nável para trabalhos cartogräficos mats singelos: os professores de Geografia.

Isto posto, ou seja, dispondo-se de una carta do municipio e, nos centros urbanos, de plantas das cidades, é necessārio contar-se com elementos previamente treinados para localizar na car ta (ou planta) os dados considerados băsicos.

Numa primelra fase, um răpldo treinamento de recursos humanos encontrados no município, ou para lá deslocados pela secretaria de Educação e/ou pelas Escolas Superiores (principalmente dos cursos de Geografia e de Pedagogla), possibilitará a execuçāo desse trabalho.

Evidentemente, a médio e a longo prazos, num processo con tinuado, ano a ano, essa primeira Carta Escolar serā enriquecida de elementos, assim como outras cartas deverão ser levantadas para com plementar a carta básica. 
A essa altura en que o refinamento das informaçōes das cartas for atinglndo niveis crescentes de especialização, duas hipọ teses podem ser antevistas:

Iㅁ - reformulação dos cursos básicos de Cartografia e de Geografia, a nivel de Graduação universitäria, de forma a ca pacitar professores de Geografla e geógrafos para a tarefa;

2a - habilitaçāo especifica, a nivel de $28 \mathrm{grau}$, de técnicos em topografia e cartografia, com 2.900 horas de curso e cujo curriculo esteja fortemente concentrado em Matemāt1ca, Estatistica, Geografia Física, Humana e Economica, So ciologia, e, obviamente, Topografia e Cartografia.

De qualquer forma, tudo Indica que essa è uma responsabtlidade dos cursos de formação universitäria em Geografia, quer preparando professores de Geografia - inclusive para atuarem no ensino de $29 \mathrm{grau,} \mathrm{habilitação} \mathrm{especifica} \mathrm{levantada} \mathrm{na} 2$ â hipótese - guer preparando geögrafos.

Mats ainda: na medida em que os Departamentos de Geografla das Universidades e Escolas Superiores Isoladas forem sensib1Iizados para o problema, rápidos e intensivos cursos de rectclagem poderāo habilitar professores de Geografia licenciados em anos ante rlores e que deven constituir o primeiro escaläo de recursos humanos com que contariam as Prefeituras e as Delegacias de Ensino, ou Distritos Educacionais. 


\section{5- Conclusōes parctale}

Ia - o Projeto da Carta Eucolar evidentemente nāo é o remöd1o ün1co reclamado pelo aubsistema educacional, mas conetitul val10so elemento para o diagnóstico e a montagem de projetos educacionais;

2E - as Ilnhas diretrizes para deslanchar o Projeto, a nivel de Eatado e de Municiplo somente estarão liberadas pela secretaria Geral do MEC em fins de 1972 ou iniclo de 1973;

$3^{2}$ - deve caber aos Departamentos de Geografia proparar ou reciclar docentes e geögrafos que posearn eer convocados para a tarefa de Implemontaçāo e prosseguimento do Projeto, a nivel de Mun1clplos, aos qual cabera a atrlbulģa de comandar a sua politt ca educactonal, tal como we observa no gräflco abalxo:

\section{Gräf1co no 22}

\section{RELACIONAMENTO}

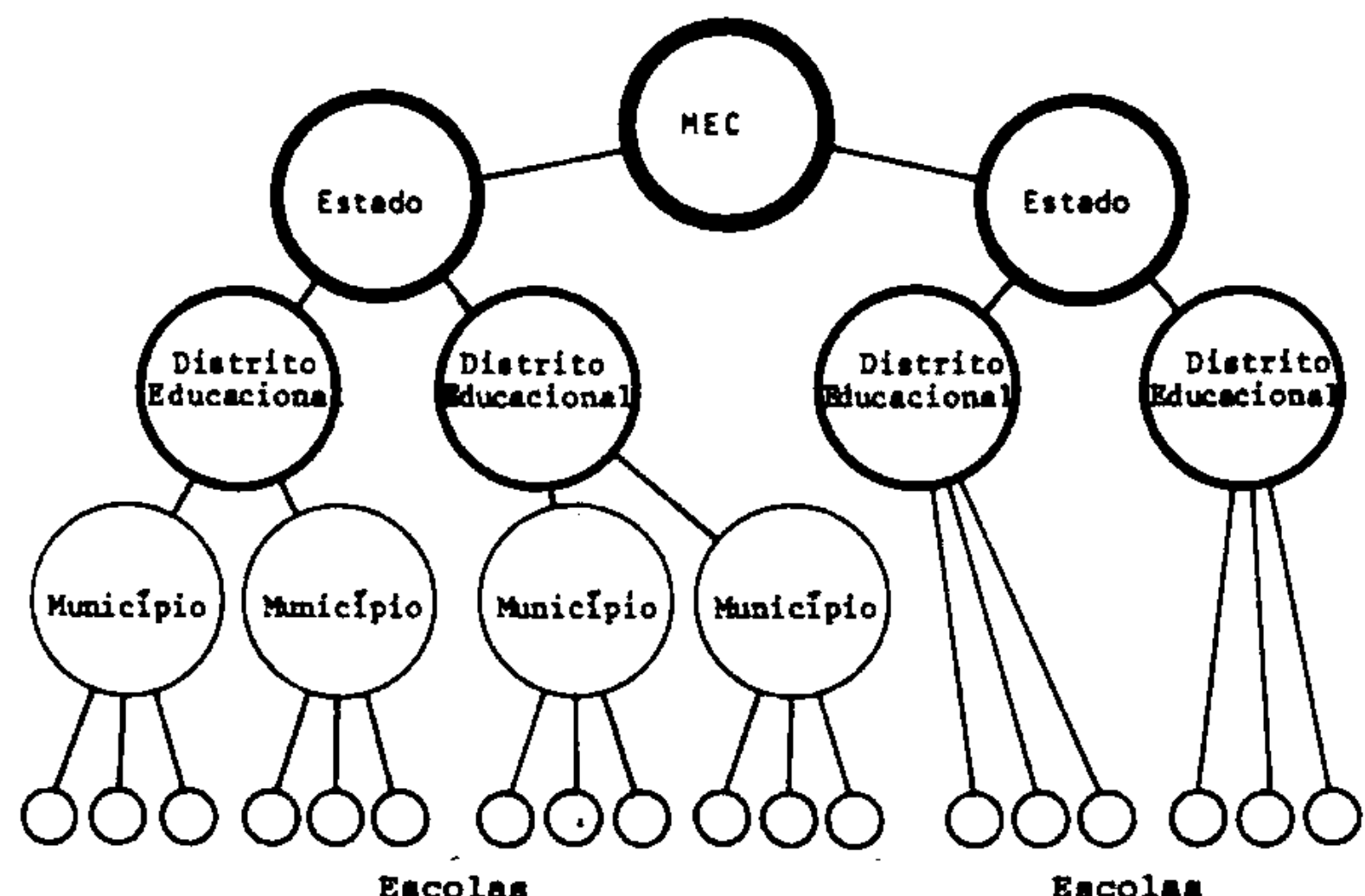

(Fonte: Carta Escolar, op. c1t.)

$4^{a}$ - Oe geógrafos e/ou professores de Geografia, atuando a nivel de Secretaria de Educação, ou a nivel de Municlpio, deverāo manter a Carta Eacolar atualizada, ano ano.

Se a Carta contiver poucos elemento esclarecedores, a elen igualmente, deverá caber a tarefa de upervisionar aeelaboração de cartas suplementares que, superpostas ou comparadas umas às outras, posalbilitem ter uma visão integrada de fatos e fenône nos que representem a "radiograf1a" bóclo-ecand -educacional das diferentes áreas cartografadas. 


\section{NOTAS REFERENTES AO CAPITULO 3}

(1) MINISTERIO DA EDUCAÇAO E CULTURA - Secretaria Geral - plano Setorial de Educacão e Cultura - 1972/74 - Brasilia -DF- 1971. o Projeto 29 - Carta Escolar - desenvolve-se da página 211 à 217. Estā dividido en dois subprojetos: o co Ensino Fundamental e o do Ensino Méd1o, a que hoje denominarlamos de 18 grau e Ensino de 28 grau.

Observa-se que, inexplicaveimente, os itens referentes aos recursos humanos para a implantação de ambos os subprojetos não envolvem, prioritarlamente ou não, pessoal das universidades, en particular dos Departamentos de Geografia.

Parece que, ao menos como consultores, poderiam ter sido envol vidos nos trabalhos preliminares, para juntar o seu "know how" ao dos demals especlalistas.

Não serã isso sintomático do absentelsmo da universidade no Brasil, nos projetos educacionais que interessam ao $\mathrm{MEC}$, às Se cretarias de Educação, aos Municipios ?

(2) MINISTERIO dO PLANEJAMENTO E COORDENAÇÃo GERAL - Instituto de Planejamento - Centro Nacional de Recursos Humanos - CNRH Documentos IPLAN - n8 1 - Carta Escolar - P10 de Janeiro - GB1971.

o documento é referido como primetro, embora o assunto tivesse sido objeto de uma conferência do professor Raymond Polgnant, em curso ministrado no Brasil, por convennio UFPE/Faculdade de Educaçāo/UNESCO/SUDENE.

(3) SECRETARIA DE EDUCAC̣AO E CULTURA - GOIAS - Carta Escolar -Goiâ nia - GO - 1971 .

(4) SECRETARIA DA EDUCAÇÃ $E$ CULTURA - Rio Grande do Sul - Introducão à Reforma do Sistema Educacional do Rio Grande do Sul Documento Preliminar - Porto Alegre - RS - 1971.

o documento é bastante interessante porque aborda a reforma em 1mplantaçāo na SEC/RS.

Nele se lê o Projeto 6 - Carta Escolar de que, a seguir, se transcreve 0 texto:

"PROJETO 6

Carta Escolar 


\section{1 - ot etivos}

Obter-se através de "carta um Instrumento que perm1ta :

Subprojeto 1 - Visualização da distribuição espacial:

- da fopulação escolarizável;

- da população escolarizada;

- das escolas segundo o tipo (isoladas,reun1das, grú pos escolares, Ginăsios);

- capactdade e matricula (matricula efetiva, número de salas); situação nos aglomerados populactonais.

Suborojeto 2 - Utilização ótima da capacidade dispo nivel atravēs de:

- redução de subutilização ou superutilização das capacidades existentes:

- determinação da intercomplementaridade das capacidades digponfiveis nas unidades escolares.

Subprojeto 3 - o planejamento racional da expansão da rede escolar mediante:

- ampliações

- construções."

(5) POIGNANT, Raymond. Curso de Planejamento da Eaucacäo - Universldade Federal de Pernambuco - Faculdade de Educaçäo - Convênio UFPE/FAE/UNESCO/SUDENE - Recife - Pe. 1971. p. 155/170.

Da conferênc1a do autor sobre o tema, notadamente no que se refere ao ensino de 28 grau, parece interessante destacar seu ponto de vista que se encalxa nos propósttos da Reforma do Ensino no Brasil - Lei no 5.692.

"Organizar un dispositivo de orientação visando, simultaneamente, a permitir o conhecimento das aptidōes individuais e a realizar a melhor compatibilização possivel entre a "demanda soclal" (isto é, as aspirações das famillas) e a oferta planejada de educação concretizada na carta escolar.

Estas duas tarefas estäo estritamente 11gadas.

Em larga escala, a existência de uma oferta de educação ("carta-escolar") quantitativamente suficiente e diversificada nos seus diferentes graus constitul-se em condição prévia a to da politica de orlentação e pode ser considerada em $s 1$ mesma, como fator determinante da adaptação da demanda espontânea dos individuos aos objetivos do plano; entretanto, è pouco provä- 
vel que a coincidencla perfetta entre a oferta e a demanda pos sa ser alcançada por 91 mesma, notadamente quando os objetivos do plano implicam em uma modificaçāo do comportamento atual das familias': (p. 256).

"Pode ocorrer, aparentemente, um conflito quanto à escoIha das familias, que desejariam poder determina-la apenas nelas aptidōes de seus filhos, e as exigēnclas do planejamento e conômico, que conduzem a un sistema de regularizaçāo do "fluxo" dos alunos, relativamente "voluntarista".

Em teorta, êsse cofl1to existe, mas não é preciso dramat1 zä-10. A expertêncla prova, com efeito que as familias, cada vez mals dificilmente informadas sobre a multiplicidade das carretras escolares e profissionais, desejan, ao contrár1o, re ceber conselhos que permitam conciliar os interesses e aptidōes individuals de seus filhos $e$ as necessidades da socleda-

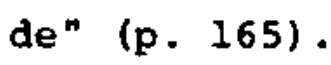


CAPITULO 4

GEOGRAFIA E CURRICULO 


\section{4 - geOgRAFIA E CURRICULO}

\section{1- objetivos}

18 - Colocar proposiçōes básılcas sobre o conceito de currícu10, notadamente para 0 ensino de 18 e 28 graus.

28 - Assinalar as causas das distorções que têm ocorrido com a estruturação dos planos curriculares das escolas.

38 - Evidenciar que a montagem do currículo pleno nāo deve prescindir do diagnöstıco regional, que caberä ao geögrafo e/ou professor de Geografia elaborar, conjugando esfor ços com outros especialistas.

\section{2- Alguns conce1tos sobre curriculo}

Pelo contato próximo e continuado com professores,alunos, técnicos en educação, não é diffcll perceber que os conceltos de multos deles, a respeito de curriculo, são vagos, difusos, contradí tórios.

Não è Incomum ouvir-se, por exemplo, que:

- o curriculo é stnôntimo de programas;

- o currículo (de Geografia) é a sequência de conteúdos programäticos, desenvolvidos ano após ano;

- o currículo é pré-ftxado pelo Conselho Federal de Educação e/ou pelo Conselho Estadual de Educação;

- o currículo, uma vez estabelecido, é Invariävel;

- o curriculo (de Geografia) pode ser detectado (!) pelos Indices dos livros didáticos.

Tudo 1sso, lamentāvel como ê, se deve em grande parte à desinformação e ao laicato docente.

As noções emanadas de Parecer do Conselho Federal de Edu-
caçäo (1) são claras, colocam nos devidos termos os conceltos de cur rículo, matēria, disciplina, atividade e áreas de estudo.

Nada obstante, as incertezas foram pouco removidas por di versas razöes, dentre as quals destacam-se:

1 a - as Informaçōes insuficlentes, multas vezes, não são de molde a levar os professores a conceltuar diferentemente curriculo;

2 a - a persistência de conceitos antigos (e errados) continua, parecendo que curriculo como sinônimo de programas é uma 
"camisa-de-força" que amarra e Inibe a flexibilidade e a criatividade do professor;

$3^{a}$ - o nivel de preparação profissional de muitos docentes, embora, ē lōgico variem as estatísticas de um istado para outro e, mesmo, de una microrregião para outra. E fato so bejamente provado que parte considerável dos docentes no Brasil (notadamente no ensino de 18 grau) è composta de leigos, cujo autodidatismo node ser mals ou menos eflcien te. o lełgo, conhecedor de suas limitaçöes profissionais, prende-se a formas estereotipadas, a "receitas programät 1 cas", ao texto de livros didáticos.

Considere-se, mais ainda, que a formação universităria de professores é quase sempre, unidirecionada, vale dizer, prepara o futuro docente para "ensinar" uma (ou mats disciplinas), mas enfoca pouco a estrutura globalizante do currículo e, por via de consequên cia, da posição de sua disciolina no conjunto do curriculo.

Acrescente-se małs que até a Leł de Diretrizes e Bases de 1961 - tão pouco conhecida e menos ainda aplicada - a centralização educacional no Brasil atingia o absurdo de se terem estabelecido programas únicos para todo o pals.

A pobreza de publicaçôes didäticas no Brasil è ma1s constatada quando se buscam obras a respeito de curriculo. A rigor quase Inexistem e é preciso valer-se de obras estrangeiras (2) e nacio nais quase sempre restritas ao ensino das sëries iniciais ${ }^{(3)}$.

\section{3- Escola e educação}

Imaginar que a educação se processe por via exclustva da escola è desconhecer a realidade. Os agentes soctałs (familia, grupos de relacionamento, a própria socledade - mais aberta ou mais fechada em termos de alteração dos padrões prë-estabelecidos e ace 1 tos, consciente ou inconscientemente -, os melos de comunicação de massa, o trabalho, a 1greja, as doutrinas nacionats, a planetarização do mundo que divulga novos padrões éticos, estéttcos,políticos, etc.) são małs, inulto ma1s atuantes que a ação esporádica e nem sem pre inteligente da escola.

A escola, hoje, cabe preparar, sistematicamente, a crianca e o adolescente para pensar crlativamente, resolver problemas, or denar o pensamento para saber escolher dentre a multiplicidade de Informações com que conv1ve, adaptar-se às mudanças socia1s, a saber dispor da tecnologia, a raclocinar integradamente, a respeltar 
outros valores que não os seus, a agir sobre a sociedade para acele rar sua evolução, a explorar inteligentemente os recursos materiais e humanos que são dilapldados ou postos de lado.

A escola pode ser uma experiência vitalizadora, conquanto não seja a ünlca e, talvez nem a ma1s importante para criança ou pa ra $\circ$ adolescente. Mas pode, por 1gual, ser frustradora,frenadora em termos de experiêncla, consciêncla, vivência e clência.

Um dos recursos de que pode dispor a escola ( notadamente de 19 de 28 graus) para a educação das crianças e dos adolescentes, è a concepção dinâmica do currículo.

o curriculo deve ser entendido como o conjunto de ativida des inteligentemente propostas pela escola para a educação do aluno como inalviduo e como ser social.

Por uma tēcnica de eliminação, pode-se dizor que o curriculo não è:

- um agregado de conteúdos programātlcos, escalonados série por sërle;

- mensurável a curto prazo;

- estático, rígido, uniforme para todas as escolas;

- fruto de uma ordenação lögica de informaçōes;

- determinado aprioristicamente, sem se levar en conta a população-alvo, o(s) grupo(s) soc1al(1s) de onde provém a população-alvo, as conđilçōes ambientats (físlcas, humanas, econômicas) onde se insere a escola.

Ao contrăr10, o currículo en sentido amplo:

- pode ou deve ter suas linhas-mestras propostas a nivel federal e estadual, para se garantir un mintmo de unida de educacional em ambos os niveis. Veja-se, contudo,que linhas-mestras näo significa propor programas, nem metodologias:

- deve ser completado, interpretado, trabalhado, a partir das linhas-mestras, pelo corpo docente de cada escola;

- deve levar em conta os dados da psicologia de aprendizagem, no que tange aos níveis de maturação da intel1gência: prātica, simbölica, intuitiva, operações concretas, operações abstratas ${ }^{(4)}$;

- precisa, forçosamente, ter um quadro referenclal da estrutura e dos fluxos socials, politicos e econônicos que caracterızam a ārea que influencia e é Influenciada pela escola. Essa ärea não deve restrıngir-se ao bairro 
ou à cidade, mas dilatar-se para o municiọio, a microrregiāo, o Estado e, até mesmo, o País;

- deve ser integrado e não, atomizado pelas diferentes disciplinas, äreas de estudo e atividades;

- deve estar conectado com os fins e os objetivos educaciona1s;

- deve oferecer variadas oportunidades para que 0 aluno aprenda a conviver com seus semelhantes;

- deve preparar o aluno não para o "ontem" e para o "agora", mas para o "amanhãn, quando o adolescente de hoje serä adulto num mundo em acelerada transformaçāo ${ }^{(5)}$.

Estas são apenas algumas Idēias bäslcas que devem nortear a elaboração do curriculo pleno de cada escola.

\section{4- O papel da Geografia na elaboracão dos curriculos}

Não se pretende aqu1 abrir questão sobre a colocação da Geografia no curriculo das escolas de 10 e 29 graus, o que vem provocando celeuma e algumas impropriedades, apös o advento da Lei no 5.692 .

0 propósito é mostrar o papel que os professores de Geografia, os geōgrafos, as universidades podem desempenhar, juntamen te com outros elementos, na elaboração dos curriculos.

Em primeiro lugar, tome-se como ponto de partida que um curriculo elaborado para una escola qualquer, deve levar em considerą̧ão:

- o perfil sōcio-etário-econônico da população-alvo;

- as características sōc1o-politico-econômicas da região (Yunicipio, microrreqião, Estado, Pals, conforme fol anteriormente assinalado):

- mais detalhadamente, as expectativas sociais, os objet 1 vos nacionals permanentes e os conjuntura1s, as caracterlsticas do mercado-de-trabalho;

- os traços culturals da socledade cu dos grupos soclais de onde provén a população-alvo;

- as necessidades de acelerar os movimentos sociais, vertical e horizontalmente.

Em segundo lugar, deve-se considerar, no campo restrito da Geografia, os progressos assinalados em termos de novas descober tas, novas metodologias, novos enfoques, pesquisas mais recentes. 
Quanto ao primelro caso, ressalta a importância do profeg sor de Geografia ou do geógrafo para, atuando interdiscipitnarmente, elaborar o quadro referencial sobre que se desenvolverä um plano curricular e, a seguir, os 11neamentos programáticos.

Ignorados os pré-requisitos acima apontados é possivel que - currículo seja didaticamente aceltável, mas não o será do pontode-vista educacional e social. Isto significa que o currículo será um simples exercicio didătico, mutilando a educação e tornando a es cola un ambiente que não atua efetivamente para o desenvolvimento soclal e para a maturação dos seus alunos.

Uma hıpötese é perfeltamente viävel para atingir os objetivos de elaboração de um currículo pleno, com a participação do professor de Geografia e/ou do geögrafo:

- o(s) professor (es) de Geografia de uma escola e, eventualmente, um geógrafo que possa ser consultado pela equipe docente da escola, tratariam de fornecer os dados de carăter geogräfico 1dentificadores da regiāo, sua população analisada dos diversos ângulos, o quadro econōmico, aproximadamente na sequência proposta anteriormente.

A partir dessa moldura referencial os denals professores da escola estariam melhor orlentados para elaborar o plano curricular.

Essa sugegtäo que parece e é simples, na malor parte dos casos não tem sido posta em prätica porque:

- realmente uma parcela ponderāvel dos docentes desconhece o que seja currículo;

- muitos legisladores educacionais, nāo obstante a clareza do texto da Lel no 5.692 e de Pareceres a ela referentes, insistem erradamente, em propor programas un1cos para toda a rede oficial de ensino;

- o peso da tradição ainda se faz sentir, traduzido na es pera de programas nacionais e/ou estaduals, por parte de multos professores;

- de fato, a preparação de muitos professores de Geografla é insatisfatória, não os habilitando a fazer esse tipo de trabalho que, en ültima instância, è Geografia aplicada. 
As soluções, se não se apresentam simples, são viäveis;

- consclentizar os professores a respeito do que seja cur rículo e dar-lhes informações sobre a técnica de sua elaboração;

- tornar cursos de formação de professores de Geografia mais voltados para a aplicação prätica dos conhecimentos teóricos, sendo-Ihes ensinada a tēcnica de levantar o perfil geogrāfico de uma ārea. Entender-se-á, aqui, - perfil geogräfico, como o levantamento das felções de mográficas, sociais, econômicas, culturais, que se inserem em um determinado quadro físico. Esse perfil è sempre fruto de uma evolução histórica que, muitas vezes, è a raiz para explicar o "porquê" desse arranjo, aqui e agora. Como a ärea não é um mundo fechado em $\mathbf{s}$ mesmo, hă que buscar relacionä-la com outras para obter-se um perfil mais coerente, mais realistico.

Esse trabalho, mesmo esboçado em traços gerals, pode permitir a elaboração de um diagnóstico regional. Sobre esse diagnóstico é que se deve montar o curriculo. Se o treinamento do professor de Geografia, ou do geögrafo, for mais cuidado, ele estarā habilitado a, partindo do diagnóstico, levantar os prognósticos, as perspectivas, as projeçōes a curto e médio prazos. Dispondo dessas variāveis analiticas e prospectivas, o grupo de professores de uma escola estarä multo mais esclarecido para propor o currículo pleno da mesma.

Não se pense que esta tarefa do professor de Geografia e/ ou do geógrafo são altamente requintadas, deles exigindo uma preparação muito sofłsticada. Parece, mesmo, que um razoăvel curso untversitärio de graduação é bastante e suficiente, para capacitá-1os a desempenhar esse trabalho. Naturalmente, o que se requer desses cursos è que sejam orientados por um moderno enfoque da Geografia, vale dizer, simplesmente, a teorta servindo de base para a aplicabllidade prática dos concettos fundamentais.

Outra hipótese para elaboração do currículo pleno deverã tomar o perftl demogräfico, social, econômico da área em que se insere a escola, como ponto de partida:

- solicitar o concurso de professores de Geografia da un 1 versidade e/ou de Escola Superior Isolada, com curso de Geografia, cujo raio de ação atinja a escola. Uma equipe, não multo numerosa de professores de Geografia, com relativa facilidade pode orlentar os professores da es- 
cola no que tange à 1dentificação, diagnóstico e projeção do quadro flisico-soclal em questão. Impossivel ? $\mathrm{D} \underline{\underline{1}}$ flcil ? Parece apenas que tanto uma como outra hipótese não foram, como sistema e processo, acionadas.

Trata-se de recursos humanos sobre os quals se investiu e que nāo são, ou não têm sido, aproveitados. Educação, criatividade, conjugação de esforços, sāo dados de uma mesma equação.

Há que se levar em conta que a universidade é - ou deve ser - o centro pesquisador, Inovador, de onde deven fluir novas des cobertas, novas tëcnicas operacionals, novas metodologias.

A dicotomia Universidade-sistema formal e Informal de ensino, até o presente, tem sldo uma constante, ressalvados poucos ca sos.

E preciso que os órgãos que estabelecem os conceitos gerals, as linhas mestras sobre elaboração do curriculo (dado que o curriculo pleno è tarefa da escola) sejam assessorados por una consultorla técnica, onde se faça presente a figura do professor de Geografia e/ou de geógrafo.

"Cada geraçāo dá nova forma às aspiraçōes que podelam a educação em seu tempo. O que talvez esteja sur gindo, como marca da nossa, è um amplo renovar da preocupação com a qualıdade e os objetivos intelectuals da educação - sem que abandonemos porém, o ideal de que ela deve ser um meio de preparar homens bem equilibrados para a democracla. (6)

Tem havido una participaçāo sem precedentes, no desenvolvimento de curriculos por parte de estudiosos e clentistas das universidades, homens eminentes pelo trabalho no campo de suas respectivas disciplinas. Têm-se eles dedicado à preparação de cursos para a escola primárla e secundäria, não apenas refletindo os progressos na clência e no saber, mas também incorporando ldélas arrojadas sobre a natureza da experiência escolar". (6)

\section{5- Projeto nacional Dara o ensino de Geografia}

O ensino da Geografia no Brasil, notadamente no antigo nI vel médio (ginasial e $29 \mathrm{clclo}$ ) fol fortemente lnfluenclado pelo en foque da Geografia, na França. 
A "escola francesa" e seus manuais didáticos marcaram a $e$ laboração de programas, adoção de mētodos e conceitos da Geografia nesse nivel de ensino.

Recentemente, alguns setores da Geografla nos Estados Un1 dos, começam a Influenciar geögrafos e professores de Geografia, no Brasil.

Resulta de toda essa influência - muito benéfica, diga-se de passagem - que, até o presente não há ensaios ou definições sobre o ensino da Geografia calcado em modelos nitidamente brasileiros.

E convenlente delxar claro que não hä geografias tão distintas conforme as escolas, ou em função das tendências momentâneas de um pals. Como ciència, a Geografia é uma só. O que varia, no tem po e consoante as escolas, è a sua metodologia, as técnlcas operacionais, até mesmo os objetivos da pesqu1sa geogräfica.

No caso particular do Brasil, por värias razöes,ainda não se pesquisou profundamente o estudo da Geografia que, partindo de una filosofta, dos seus princlpios, se adequasse às realidades e às necessidades brasileiras, com reflexos positivos e imediatos no seu ensino no 19 e 29 araus.

Diferentemente tem-se o exemplo de Clências Fisicas, Químicas e Biolögicas. Durante certo tempo, a orientação bãsica emanava de textos norte-americanos, conhecidos, sinteticamente, como BSSC, PSSC, etc. Multo recentemente, a Secretarla Geral do MEC crlou un grupo de trabalho cujo objetivo bástco é proceder ao estudo de programas integrados nos ofto anos do ensino de $18 \mathrm{grau}$, programas esses pesquisados pelos Centros de Ciências, visando a atender às peculiarldades e às necessidades braslleiras. O Projeto de Cièncias, como è conhecido, se desenvolveră durante três anos e deverá apresentar como resultados básicos:

- sugestões de programas;

- manuais didätıcos;

- sugestões metodolögicas;

- protōtipos de materials didáticos, para posterior prodú ção em larga escala.

Com 1sso, obviamente, não val crlar-se uma Clêncla brasilelra - o que seria absurdo - mas oferecer sugestōes para o ensino de Clèncias no Brastl. 
No que se refere à Geografia e a sua:

- posição no curriculo pleno;

- orlentação segundo nossas necessidades;

- produção de textos e materiais didāticos;

nada fol alnda proposto. Parece que esta atividade precisa urgentemente ser montada, a exemplo do que vem ocorrendo com ciências.

Esta tarefa, naturalmente, deve caber a un grupo de traba lho que envolva värios Departamentos de Geografia de Universidades dispostos a cooperar.

Dessa forma, en alguns anos, terlamos o ensino da Geografla não padronizado, evidentemente, mas um ensino que respondesse às necessidades e pecullaridades do Brasil.

\section{6- Conclusões parclais}

19 - A educação será mais eficaz na medida em que os currículos atinjam a um grau mais elevado de conceltuação, estrú turação, ap̣licação.

29 - A escola não é ur. "mundo fechado em s1 mesmo". Assim, seu plano curricular deve refletir as caracterlaticas do quadro regional em que a escola se situa.

39 - Um plano curricular é tarefa de que devem participar todos os professores da escola. Aos de Geografia (e eventualmente aos geógrafos), caberá fornecer indlcadores básicos para a montagem do curriculo pleno. Esses indicadores se referem à anālıse e à prospectiva da regiāo servida pela escola e que dela se beneficia.

48 - Os Departamentos de Geografia de Escolas Superiores deverão voltar-se mais e mals para cooperar com o ensino nas escolas de 19 e 28 graus, através de:

- preparação de seus alunos de forma a capacitá-los nos trabalhos de diagnóstico reglonal;

- estudo de viabilidade para montar un projeto nacional para o ensino da Geografia. 


\section{NOTAS REFERENTES AO CAPITULO 4}

(1) CONSELHO FEDERAI DE EDUCAÇÃo - Parecer no 853/71, de 12/11/1971 Assunto: Núcleo comum para os curriculos de 10 e 28 graus. A doutrina do currículo na Let no 5.692. Brasilia - DF - 1971.

(2) RAGAN, Wllliam B. - Curriculo Primärio Moderno - Traduçäo de Ruth Cabral - Porto Alegre - R.S. - Editora Globo S.A. - 1964Ver, notadamente, a Qutnta Parte - p. 435 a 474.

Este trabalho tem sido um vade-mecum para muitos professo res. Desnecessärio comentar que é ultrapassado (edição de 1964) e representa uma experiència estrangeira.

(3) SPERB, Dalila C. - Problemas Gerais de Curriculos - Porto Alegre - RS - Editora Globo S.A. - 1966.

Ver,principalmente, da pág. 11 a 72.

(4) LIMA, Lauro de Oliveira - A Escola Secundäria Moderna - Petröpolis - RJ - Editora Vozes L1mıtada - 9a. edição - 1971 - p. 53 a 76.

(5) LIMA, Lauro de oliveira - Mutações em Educação segundo Mc Luhan Petrópolis - RJ - Editora Vozes Limitada *2 2a. Edição - 1971 -

- livro em questão é un brado de alerta para professores e administradores educacionais. Deixa claro o autor, a partir de textos de Mc Luhan, que a escola se tornará obsoleta caso não busque acompanhar, ou mesmo antecipar-se às räpidas transformações por que vêm passando as sociedades, por força da tec nologia, da urbanização, dos meios de comunicação de massa, do crescimento demográfı́co.

(6) BRUNER, Jerome - oprocesso da educação - Tradução de Lélio Lourenço de olivelra - São Paulo - SP - Companhia Fdıtora Nacional - 1968.

Introdução - p. 1-2.

- autor procura evidenciar que ã Universidade deverá caber, em última instância, a orlentação mais moderna, informar sobre o avanço da clência geográfica, para servir de base à adequação desse evolutr no currfculo das escolas de 18 e de 29 graus. 
CAPITULO 5

GEOGRAFIA E COMUNIDADE 


\section{- geografia e comunidade}

\section{1- Objetivos}

18- Levantar questões a respeito das jiversas tdélas sobre co munidade.

28- Caracterizar a responsabilidade dos grupos comunttärios en co-participar do processo educacional.

30- Destacar o papel que o professor de Geografia e/ou geógra fo podem desempenhar para a ligação escola-comunidade.

\section{2- Introducão}

o título em questão parece ser redundante ou pleonástico, ou mesmo amplo. Is to porque:

18- os geógrafos e os professores que acreditam na unidade da Geografia encaram-na uma ciência cujo objetivo central é o estudo dos grupos humanos no seu relacionamento com o quadro fístco.

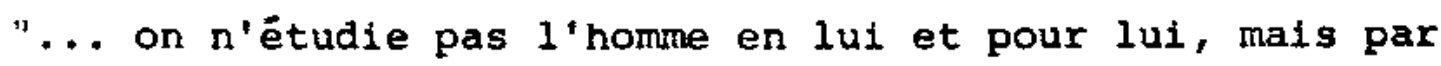
rapport a son milileu et en relation avec ses formes de groupements et ses manifestations d'activités. La quasi unanimité des vrais géographes ont bien cette optique, mais ce que bien peu possedent, c'est une tdëe précise de la mëthode propre quil leur permettra cette approche originale" (l).

Em outras palavras, a Geografia tem por objettvo "o estudo da Terra como habitat do homem"; ou o "estudo global das palsagens". De qualquer fcrma, variando ligeiramente as diferentes colocaçōes dos geógrafos, a Geografia busca estudar os homens, nas suas diversas formas de grupamento, em relação a um espaco físico. Mais alnda, preocupa-se com a evolução desses grupamentos e dos espaços; com as atividades e os interralacionamentos dos grupos entre si e com o espaço físico.

Ora, grupos humanos e comunidades, à primeira vista parecem ser sinônimos donde a redundância de se falar em Geografia e co munidade, porque a Geografia encerra en seu bojo a preocupação com a comunidade;

28- o concelto de comunidade muitas vezes não é empregado con forme a abordagem soclológica, mas apresenta-se deformado, alterado, quando se refere à "comunidade nacional", à "comunidade interna cional".

Ainda mals se poderã argtilr se o estudo e a ação dessas 
comunidades não ë objeto mals da Histöria (diacronia), ou sociologia, (anālise sincrônica). Acrescente-se a essa argạição que a atú ação sobre a comuniaade è mals de outras äreas (ação social), de certos poderes (poder püblico) ou, mesmo, das atividades particulares (comërcio, pubilcidade, comunicação de massa, etc) ou de entida des rellgiosas.

Tudo isso é real, vez que os grupos humanos sāo trabalhados, conduzidos, torcidos ou orientados, por un conjunto de forças - eles pröprios, grupos humanos, sendo em $\mathbf{s 1}$ mesmos forças aceleradoras ou frenadoras.

Seria por demais pretensioso, colocar a Geografia como clência única a orientar o estudo da comunidade. Pretensioso e unilateral, na abordagem de um fenômeno que è complexo por sua próprıa natureza.

o que se busca é levantar algumas questōes e sugestöes no que se refere ao papel da Geografia, interdisciplinarmente atuando, para compor un diagnöstico e propor soluções alternativas para. a educação comunitāria.

\section{3- Comunidade e educacão}

Algumas defintções bástcas: comunidade.

"Empregamos o têrmo "comunidade" no sentido de "grupo 10cal altamente integrado, en que predominam contactos primärlos, sen do a cultura tradicional homogènea, segundo uma das definıçōes apresentadas por Emillo WILLENS, Dicionärio de Soclolog1a, p.29. Em oposição, a "sociedade" seria têrmo mais amplo que a englobaria".

"Definimos "cultura urbana" no sentido da cultura de uma comunidade onde a diferenclaçāo de funções teve como resultado uma solidarledade decorrente da complementaridade das mesmas, em oposição à cultura de comunidades, cuja solidariedade decorre, seja da vizinhança, seja do parentesco, etc. Como o conceito de cultura urbana é lato, devido aos vários tipos que apresenta, apelamos para o qualificativo "ocldental" com o fim de delimitä-1o, pols é esse 0 tipo de cultura urbana para o qual tendemos". (2)

Evidentemente, a transinssão da cultura de um grupo mals velho ãs crianças e adolescentes, existe como condição "sine qua non" da sobrevivëncia desse grupo. O fenômeno se constatou e se constata entre as comunidades ditas primitivas e nas comunidades ur banas mals tecniflcadas, do momento atual. Toda a socledade, de uma ou de outra forma, intervēm, participa nun sistema de dupla tro ca do processo educacional. 
"Qualquer sociedade, seja qual for o seu grau de evolução técnica, possui uma cultura e una história que impregnam a criança desde o seu nascimento. Qualquer sociedade possul o seu próprio s1s tema educativo cuja função băsica consiste em fazer com que o individuo salba viver em sociedade, en vez de lhes transmitir apenas conhecimentos. Pode, em certa medida, arrastar consigo outro sistema de ensino, mas a ação deste só dura se estiver de acordo com o melo global, porque senão este recupera a superioridade, a não ser que o prōprio individuo delxe o meio". (3)

Ora, torna-se claro que a educação como processo conducen te à conscientização, profissionalızação, desenvolvimento, crescimento econôm1co, ascensão social, aumento do poder aquisitivo, realização pessoal, cooperação, fruição do lazer, etc., etc., é hoje priorităria, notadamente em paises como o Brasil.

A causação circular da pobreza, Ignorância, subdesenvolv $\underline{\underline{1}}$ mento, pode ser rompida a médio prazo, pela difusão da educação. Um dos seus agentes - a escola - tal como a entendemos via de regra, é apenas uma das instituições que podem ser acopladas ao processo sis temătico e continuado da educação em sentido mais abrangente, ou se ja, o conjunto de atividades planejadas visando à alteração do "status quo" socio-econōmico.

A alfabetização de adultos, a qualificação da mão-de-obra semi ou desqualificada, o treinamento de mão-de-obra para que adqu1 ra nivels crescentes de oportunização profissional, a educação de base (famlitar, santtäria), a preparação de comunidades para que se rompan as barreiras ao progresso (material, individual, social), a educação permanente a partir da demarragem instrucional em qualquer nivel de habilitação e aculturação representam formas de edu car que podem prescindir do concurso da escola, tal como è, atualmente, caracterizada.

A educação da comunidade è um caso típico de ação intence onal, planejada, programada, que pode ou näo valer-se da instituição escola. A medida em que a escolarłzação normal absorve todo o contigente escolarizável; à medida em que a Instituição escola (de 18, 29 ou 39 graus) adicione à sua função tradicional, a de atuar mais ampla e profundamente na comunidade, os recursos financelros e humanos poderão ser dirigldos e aplicados em outras formas de edu cação para una sociedade - que se pretende - em constante mutậ̃ão qualitativa. 


\section{4- Projetos comunitärlos no Bras1l}

Historicamente, os projetos comunitärios, visando à educa ção dos grupos, são antigos de sēculos. Isto desde que se desvincule o concelto moderno e corrente de profeto que tem uma conotação oriunda da Economia, dos conceltos mais difusos, menos tecnificados Nesse caso, o projeto pode ser encarado como um conjunto de ativida des propostas para se atingir um determinado objetivo.

Nessa ótica, teríamos como exemplos, entre centenas, o projeto de ação evangellzadora das missões religiosas no Brasil co lonial; os projetos de aculturação forçada e 1mposta aos grupos de escravos negros trazidos para o trabalho nas propriedades latifundiārlas do "Brastl - açucarelro"; os projetos de colonização, no Brasil meridional, especialmente no século XIX, quando se implantavam comunidades européias (1talianas, alemãs, polonesas, etc.) e buscava-se integrá-las à "sol-disant" sociedade brasiletra; projetos de colonização, por elementos nacionais, de äreas plone1ras pelo então Inst1tuto Nacional de Imigraçāo e Colonização - INIC -, etc. (4) (5) (6)

A essa fase - denomine-se herólca - seguiu-se uma nova, mals recente, representada pelo impacto das migraçōes internas que determinaram novas formas de acomodação, aculturação, assimilação dos grupos humanos que se deslocavarn das äreas rurals para os centros urbanos.

O processo acelerou-se a partir da década de 1940, quando o complexo "crescimento demogrăfico - industrialização - transportes" conduziu, por fim, à quebra do equilibrio campo-cidade. Os resultados foram, são e possivelmente serão, traduzidos pela evasão rural e pela "inchação urbana".

o problema deve passar a ser repensado de forma diversa. E toda una polftica global que visa a ajustar os dâdos da equação: reforma agrária (como e a que preço?); expansão das oportuntaades , nos melos urbanos de absorção da mão- de-obra desqualificada que chega das äreas rurals; abertura de frentes plonetras, não mals ao sabor do expansionismo natural, mas controladamente, como temos os exemplos do planejamento previsto em PROTERRA, PRODOESTE, TRANSAMAZONICA, esta muito ma1s que un elxo rodoviārio, envolve toda uma política global, dirigida à ocupação dos "espaços vazios".

A toda esta ebulição demogrāfica, sociolögica portanto, econömica, polftica, deveria corresponder uma polftica educacional que não se estruturasse a reboque do fato consumado, mas agisse con comitantemente. 
Como se assinalou anteriormente, educar as comunidades - ou pretender educā-las - é fato histörico de sēculos. Hoje, educá las è imperativo de uma polftica global que pretende:

- não ser 1mediatista;

- la çar, estruturar, orçanizar as bases de uma nação que saiba como superar o subdesenvolvimento, a curto e mëdio prazos;

- equalizar - a longo prazo - a distribuição de renda e os benefictos soclais e individuats decorrentes de una educação prevista, com um minimo de escolarização para todos.

Disto resulta que uma nova orientaçäo se impöe para "educar as comunidades", sistematicamente ou por melo de processos que visem a integrä-las no sēculo xx. Esta ūltima afirmação não è irôni ca, mas reflete uma realidade brasilelra, onde se constata a existência de comunidades totalmente à margem de um minimo de usufruto dos chamados bens de uma civilização material e de uma cultura que thes permita viver mais que sobreviver.

A histōria da colonização do Bras1l está por demals reple ta de exemplos de sucessos e fracassos, uns e outros representando de certa forma, a diferença entre planejamento e espontaneismo.

o estudo mais aprofundado da colonização agräria e da urbanização, em que se confrontassem os exermplos numa amostragem bastante significativa, levantando-se para cada caso as determinantes do sucesso e/ou do insucesso do empreendimento, alnda está por ser feito em nosso pais. A bibliografta existente sobre o assunto é ampla, mas o tern aparece diluído no contexto que é a pröpria meta do trabalho.

rome-se, cono referencial, un dos mais alentados estudos de que se dispõe: "A Rodovia Belēm- Braslila", de orlando valverde e Catharina vergolino Dias. (7) A seleção do trabalho, no caso, se deve a que:

- è um estudo de Geografia Regional, portanto analisando todo o processo de ocupação humana, sob as mais diferen tes situaçōes, aqui entendidas como variedade de quadros fisicos, atividades economicas, diversidade dos grupos humanos, quanto à origem e niveis de desenvolvi. mento, Impulsōes demográficas e econônucas, espontaneí mos e dixigismo quanto às formas de colonização; 
- trata-se de uma anälise que abrange uma ärea bastante extensa, cujo elxo coletor è a rodovia Belém-Brasilia;

- estuda um processo deslanchado mais ou menos recentemen te. O mos se refere à área de Influêncta de Belém; o mais, às áreas que passaram a ser ocupadas após a aber-

- tura da rodovia.

A leitura da obra possibilita uma sērie de constataçōes - oque é óbvio - mas ressaltando o seguinte:

- as formas, os processos, as tēcnicas de ocupação da tex ra, revelando-se aqui ou all atravës de um habitat disperso e/ou concentrado, se fizeram a rigor completamente desvinculadas:

18- de um planejamento prévio, salvo algumas poucas exceçöes;

29- de uma relaçāo equillibrada "homem-espaço";

38- de um infra-estrutura educacional que minimizasse os desperdicios, os fracassos, a improvisão.

Dir-se-à, contudo, que bem ou mal, a área fol ocupada, no vas atividades econōmicas se desenvolveram, vitalizou-se, en suma, uma hinterlândia. Isto è inegävel. Por outro lado, cabe a indagação: os quadros espacial, humano, econômico não apresentariam hoje fistonomias multo mals dinâmicas e racionalizadas, se essa colonização fosse conduzida, dirigłda, planejada, acompanhada? Mułtas das comuntdades rurais e urbanas que se localizam na ărea estudada pelos autores, não estarlam hoje em grau mais avançado de desenvolv1mento, se seu trabalho resultasse de una coordenação, uma educação, uma assistência (não confundir com paternalismo colonizador)?

Um país como o Brasil não pode permitir-se mais o desperdicio e a improvisação. A relação custo-benefício tem que estar ot mizada, sob pena de se continuar a assisttr à ailutção de recursos flsicos, humanos, técnicos e de capltais, de que o país é carente.

Se se pretende agora reconstituir, recolonizar, reurbanizar, reestruturar as atividades econömlcas, oferecer às populações que se flxaram na área novos e melhores padrões de vida, qual o cus to do empreendimento?

Outra è a técnica de colonização que se está propondo para a Transamazônica. Do complexo de providências, ressalta uma - co nectar osupação com educação: qualificação da mão-de-obra, ensino 
formal, alfabetização de adultos, educação comunitāria.

Os resultados, evidentemente, só poderão comę̧ar a ser avaliados daqui a três, cinco, dez anos, mas é de crer-se que sejan muito superiores aos constatados na área da Belém-Brasilia.

Muitas outras experièncias de educação comunitária tèm-se registrado no Brasil, notadamente nos centros urbanos. E nesses, em particular nas áreas que recebem o itipacto de um cresciniento demogrăfico acelerado resultante da mi yração campo-cidade. nessas zonas favelizadas, aqui ou ali, reorganizar a comunidade, quer do ponto-de-vista físico, quer do humano. As soluçöes tên vari ado ao extremo, o que, en tese, pode parecer correto, pois "cada ca so é um caso" e serla absurdo equacionar-se a solução a partir de um modelo teorëtico. Mas não se trata disso, as soluções via de regra têm sido pouco satisfatōrlas, porque a questão é aboraada de uma angulação muito setorial: urbanizar (sic) as favelas; pura e simplesmente remover a favela e seus moradores para outros locais; levar aos favelaios assisténcia soctal, criar escolas que sirvan à comuntdade e oucras providências de teor diverso são acionadas.

Desnecessärio assinālar o fracasso das soluções. (8) (9) "Es se fracasso é; por certo, uma advertêncla (mūito dispenúiosa, digase de passagem) de que a questão não pode ser abordada unilateralmente por urban1stas, sociólogos, assistentes sociais, econonistas, arquitetos e mesino pelas autoridades policiats...

Ao que conta, nos casos brastleiros, ao menos dessa culpa escapam os geögrafos porque tên sido eles os que menos são requisitados para dar a sua cooperação para o estudo do problema.

E de Erisar-se, por outro lado, que as tentativas de solu cão para questões urbanas abordam o fenömeno através de inümeras va riávels das quais a mais frequentemente ausente é a referente à edụ cação comunttāria.

\section{5- Novas e ncessärias conceituaçöes de comunidade}

Constata-se que muitos educadores e planejadores de educa ção no Brasil se preocupan com o tena comuntdade.

E sabido iqualmente o fracasso das tentativas de tigar o binomio naturalmente indissolüvel escola-comunidade. Pura e sinples mente ambas se desconhecem, quando não se atritam. Os jä famosos Circulos de Pais e Frofessores, que deverian representar una das formas de integração da escola na comunidade, até aqui têm sido de atuação mininina, para não dizer-se nula. 
As causas, logicamente são muitas, formam um complexo, mas algumas delas podem ser apontadas:

18- a escola não corresponde aos anseios da commidade;

28- a escola não age sobre e com a comunidade, 1imdtando-se a penas à oferta de matriculas para membros da comunidade;

38- a inexistência da Carta Escolar 1mpossibilita ou dificulta locar escolas onde elas são realmente necessárias, para atender a una comunicade pröxima;

48- a formação docente tem-se 1imitado a preparar professores e tëcnicos educacłonals para um trabalho intraescolar e não, também, extraescolar;

50- os conceltos correntes de comunidade são estereotipados e quase sempre, nos maiores centros urbanos, assemelhados a tipos de comunidade de outros palses, notadamente os Estados Unidos onde 0 interrelacionamento escola-comunicade é efetivo.

E necessárla una nova conceituação de comuntaada para o caso brasileiro, levando-se em conta as características geogräficas, histöricas, culturais, sociolöglcas, econômicas. Somente a par tir dessa concettuação é que se poderá ldentıfıcar cada comunıdade no que ela tenha de típico, para poder atuar sobre ela.

\section{6 - Projetos integrados}

o desenvolvimento não é fruto apenas do crescimento econô mtco. Este è una das variäveis e, em determinadas circunstâncias histörico-politicas, a de malor peso, que possibilita a demarragem do desenvolvimento social.

Todavia parece ponto pacífico que não hã mais lugar para as teses ditas antecipacionistas: primelro é preciso crescer economicamente para depols pensar-se no desenvolvimento; em sentldo opos to: o desenvolvimento social è prë-requisito para o crescimento eco nômico acelerado. De nada, ou de pouco vale investir recursos sobre grupos sociais incapacitados para reproduzi-los, conforme afirman certas correntes econôntcas ${ }^{(10)}$.

Väo tomando corpo, não apenas as ldēias, mas tarabën os projetos integrados que visam concomitantemente a abordar as duas faces da questão: o crescimento e o desenvolvimento. Deixando de la do outros exemplos de projetos dessa natureza, destaque-se aqui o chamado "PRoJeTo piaul" (1i). 
A Idála Inicial partiu do Miniatério da Educação e Cultura, atravée de convite ao antropölogo João Rlbelro de Souza para elaborar um profeto que viaasse co desenvolvimento do Estado, toman do por base o s18tema soc1al da Educação.

Posterlormente, outron órgäod federale foram envolvidoa nas negociaçōes, terminando o modelo proposto por se const1tuir em un dos pontos-chave do programa entadual.

Uma intese do projeto indica que:

18- Parte-se da anäl1se do Un1verso Soc1al, que a composto de onze siatemas social. (conforme a conceltuação do autor) tal como se observa no gráflco no 23 .

GRAFICO NQ 23

\section{Sietemae sociale}

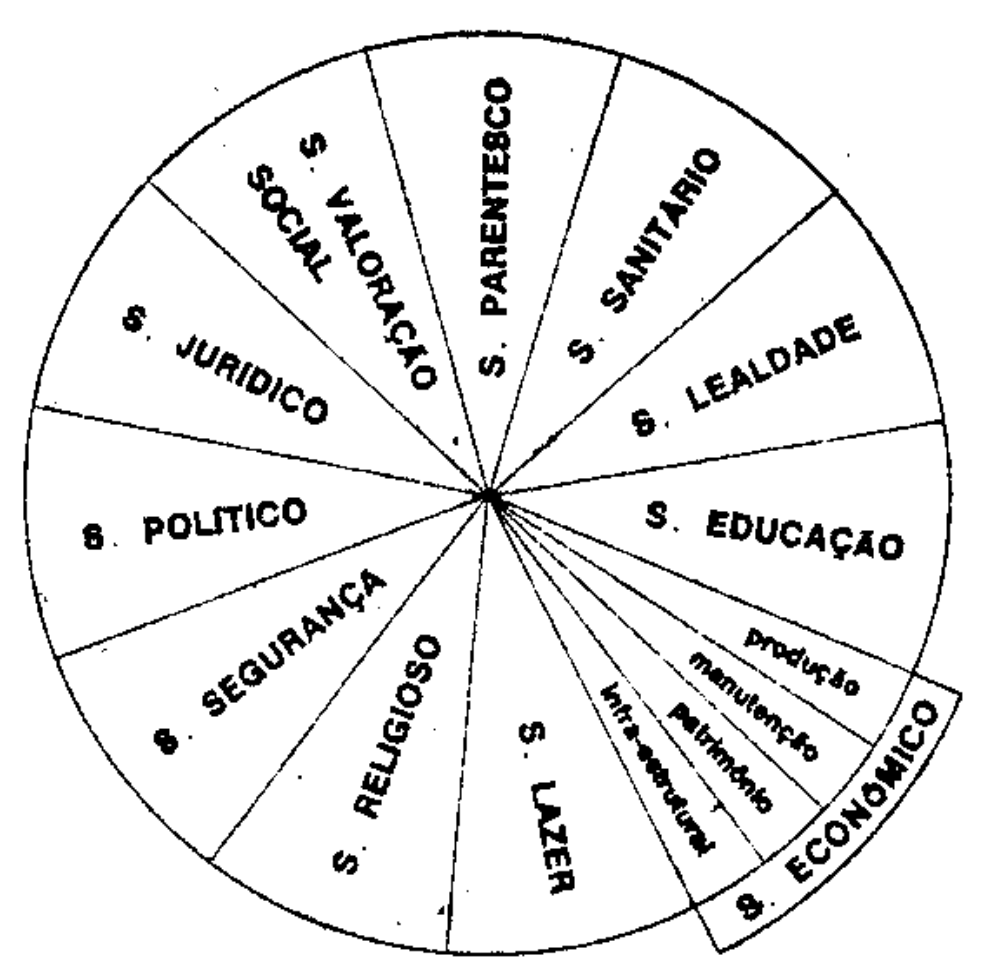

Fonte: "Projeto Plauiz".

20- Cada sistema a desdobrado para efelto de uma abordagem que possibilite un alagnōstico mals real. E o que se vó no gráfico no 24. 
GRAFICO NQ 24

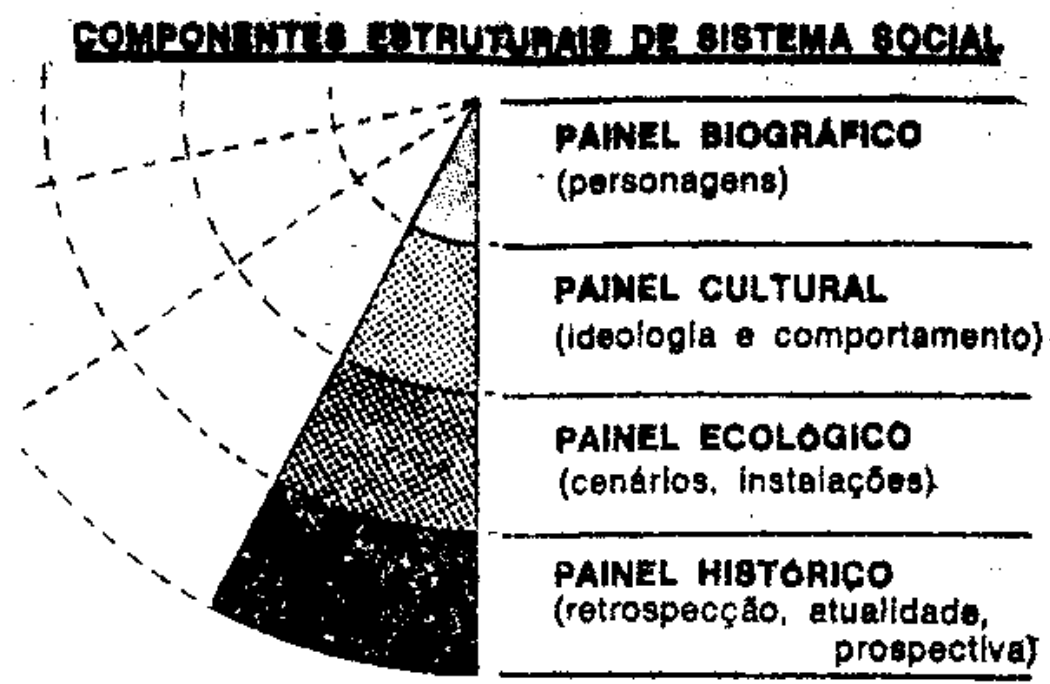

Fonte: "Projeto Plaui".

39- A estrutura organizacional tem como modelo o que se vê no gráf1co no 25 , partindo da enfera estadual até atingir cada esfera nuclear, que, por seu turno, compóe con outras a esfera munletpal e estas, se reünem nas esferas microreglonals.

GRAFICO NQ 25

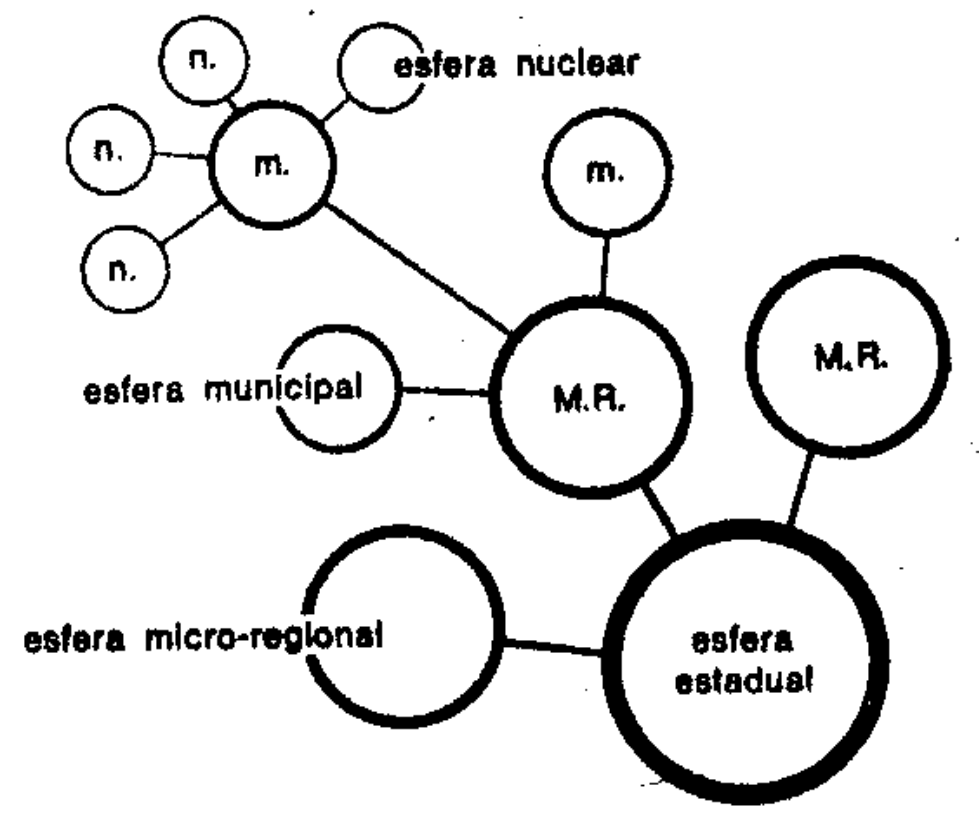

Fonte: "Projeto Piaur".

40- A sequêncta operacional do projeto é apresentada, om suas 11nhas gerals, denominadas Etapas, no documento citado (Projeto P1auI) :

- V1são Intelal

- Convênios 
- Corauntcaçäo social ampla

- Seleção e capacitação da equipe técnica interdisciplinar microrregional e/ou de técnicos de desenvolvimento de municipio

- Levantamento e seleção das lideranças de nível superior e médio

- Capacitação de l1deranças de nível superior e mëdio

- Pesquisa e levantamento integral (em todos os sistemas sociais) do universo social abordado

- Divisão do universo social en núcleos urbanos e rurals

- Anällse dos dados

- Diagnóstico tēcnico global

- Definição de metas

- Levantamento e seleção de lideranças por núcleos

- Capacitação de lideranças de nücleos

- Pesquisas e levantamentos nucleares

- Análise dos dados das pesquisas e levantamentos nucleares

- Diagnósticos nucleares

- Definição de Metas Nucleares

- Confrontação das Metas

- Definição, discussão e aprovação das Metas Nucleares e Municipals para cada sistema Social

- Compatibllização das lietas aprovadas con os integrantes do Plano do Estado e das esferas Regional e Nacional

- Ordenação das Metas por sua prioridade e viabilldade

- Crlaçāo dos Centros de Desenvolvimento Integral Partic1 pativo de Núcleos, do Municiplo Polo de Desenvolvimento, dos demals Municipios integrantes da Microrregião enquanto Universo Social

- Grupamentos das Metas em Profetos por Sistema Social

- Elaboração dos Projetos e seu grupanento em Programas e subprogramas do Sistema, ordenados de acordo com sua priorldade e viabilıdade

- Elaboração dos Planos de Desenvolvimento Integral Part1 cipativo Nucleares e Muntcłpal

- Compatibilização dos Planos de Desenvolvirento Integral Participativo dos Municiplos entre si, compondo o plano de Desenvolvimento Integral Participativo Microrregional

- Implantação dos Planos de Desenvolvimento Integral Partlcipativo dos Nücleos, dos Muntciplos e Microrregional 
- Compatib1lização dos Planos de Desenvolvimento Integral Participativo Microrregionats entre si, gerando o plano de Desenvolvimento Integral Participativo do Estado

- contrôle

- Avaliação e ajustamentos do Plano de Desenvolvimento In tegral Parcicipativo.

o Projeto Piaul, conforme pode ser constatado, encontra-se em plena fase de execução. Evidentemente os obstáculos para sua implementação se diversificam, apresentammse de naturea especifica dependendo, é claro, de um conjunto de variáveis, desde a tiplcidade comunităria, até à sustentação financeira e polltica.

Todavia é inegävel que o modelo - que não partiu de uma abstração para ser comprovada a "posteriori"e "a fortiori" - resultou do conhecimento das realidades estaduals, microrregionals, muni cipals; levou em consideração experiēncias de ação comunitária rea11 zadas no Brasil; englobou todo o Universo Soc1al, dando margem a uma anälise global de que devem participar värios campos de conheci mento: Antropologła, Soclologia, Economia, Hıstörıa, Adminłstração, Geografia, etc.

As bases para o sucesso do Projeto foram lançadas; dando-se continuidade à tarefa, a médio e a longo prazos se podertoavali ar, efetivanente, seus resultados.

\section{7- O papel da Geografia nos projetos comunitärios de caräter amplo}

Ressalta que à Geografia cabe una tarefa ponderãvel em projetos comunitários integrados, como o anteriormente focalizado. A pröpria distribulção espacial - do Estado à microrregião, desta ao muntcípio-polo, deste aos nücleos urbanos e rurais lesfera nuclear) - confere Importância à Geografia, no que tange à questão das anālises regionais.

Acresce que deve caber ao geógrafo e/ou ao professor de Geografia, com formação profissional satisfatōria, uma tarefa impor tante nos diagnósticos físicos, humanos (em particular, demográf1cos) econónicos, que possibilitem e fecilitem o trabalho dos tëcnicos de outros setores. Esta afırmação não atribul, em absoluto, um papel subalterno à Geografla, ao servir de "limpa-trilho" para o restante da composição(12). Ao conträrıo, reafirmando o objeto de scus estudos, ela deve participar integralmente da análise global dos espaços, realizando a sintese geogräfica que the possibilite 
afirmar e confirmar sua posiçāo ímpar em estudos dessa natureza.

Por isso mesmo, realizado esse diagnóstico geogräfico, não deve o geógrafo e/ou o professor de Geografia afastar-se do projeto. O acompanhamento de sua implementação 1mporta para retro-alimen tar seus estudos preliminares, com vistas a estudos posteriores.

Outro dado de não pequena importância: poderá caber à Geo grafia atuar como elemento corretor em determinados projetos de edu cação comunitária que, nas suas origens conceptuais tragan o germe do futuro insucesso. Explica-se: trata-se dos projetos setorializados, atomizados, unidirecionados.

A comunidade não è uma ilha isolada, desligada de outras e de outras variáveis. A esse respeito é altamente llustrativo o trabalho de Charles Wagley - "Uma comunidade amazônı́ca" (13).

Abaixo transcrevent-se dois trechos do citado artigo.

Apenas uma nova técnică, entretanto, não será suficiente. Fatores humanos terão que ser levados em con sideração na "conquista"da Anazônia e outras regiōes similares do mundo. Esses fatores humanos estão presentes na sociedade $e$ na cultura dos povos gue habitam essas areas, ben como na natureza de suas relaf̧öes com os recém-chegados. O desenvolvimento do vale amazōnico significară a transformação da sociedade local e da cultura tradicional. o conhecimento dessa sociedade e dessa cultura será tão vital aos programas de assistēncia tēcnlca como os potencials do ambiente físıco e a presença de uma tëcnica apropriada. O sentido da transformação social de uma sociedade e o efeito das inovaçōes devem ser previstos dentro dos limites de nossa capacidade para assim proceder, pois existem porigos na assistêncta tëcnica. Uma transformação rápida imposta a um povo poderá desorganizar seus sistemas soclais e sua cultura tradicional a ponto de se perder mals do que se ganha. São muitos os exemplos que nos ofereco o mundo Ae grupos primitivos camponeses transformados $\mathrm{cm} m$ sorāveis trabalhadores agrícolas, mineiros e operários de fäbricas - em pussoas despojadas da seus valores e instituições tradicionais, sem qualquer possibll1dade de participar da nova socledade". (p.524) 
"A transformação soctal deverá ser empreendida em várias frentes ao mesmo tempo. Em virtude dessas rea çöes em cadeia, o desequilíbrio e a desorganização poderão facilmente ser causados pelas rápldas transformaçöes em una ünica esfera da vida. Sem modificaçöes equivalentes en toda uma extensa frente, os pro gramas especificos, orientados en uma só direção, são frequentemente fadados ao fracasso. Enquanto näo se dispuser de meios de educação e enquanto o sistema econômico não experimentar melhoria programa do SESP em Itā, destinado a melhorar as con d1ções sanitárlas do lugar, obterá apenas resultados limltados. Sem una educação melhor, que facilite a compreensão das causas das moléstias, sem melhores regimes allmentares, a melhoria permanente das condi ções sanitárias de Itā è 1mpossfvel" (p.525).

E facilmente constatável que o exemplo de Itá não é o üni co no Brasil, assim como as tentativas de educação coraunitäria são, de Igual modo, encaradas de forma semelhante.

Poderã a Geografia alterar essa ótıca, na medida em que forneça os elementos de seu objeto de estudo - as caracteristicas, os relacionamentos, os equilibrios e os desequilibrios regionais para que se enfoque a comunidade como parcela de um conjunto mais amplo.

Desenvolver è atuar sobre as comunidades ou instrumentālas, esclarecê-las para a atuação, 1sto ē, para que elas saibar e possam absorver, multiplicar e benefictar-se do crescimento econônu co.

A propösito da contribuição nais signıficatıva da Geografia para este objetivo, veja-se o que escreve Pierre George ${ }^{(14)}$ :

"Les problèmes se posent aujourd'hut à une autre ōchelle, celle de l'introspection de chaque Etat et celle de l'actualité de l'inégal développement. Les politiques d'amenagement du territoire, de coopération technlque et d'aide aux pays sous-développés font appel à. un nouveau cortège decconnàissances qut n'ont de signification pratique qu'au niveau des vues synthētiques et de la prospection globale. L'expé rience a appris que 1 'on ne pouvait reussir une entreprise spēclalisēe qu'a condition de connaltre les effets en chaine et les contradictions 
qu'entraine toute action novatrice: nouvelle justif $\underline{\underline{1}}$ cation de la nécessité de l'enquête et des bllans gëographiques. Mais les problèmes. se posent diffërem ment suivant le degrë de développement, et sulvant l'importance des connaissances prëalablement acqu1ses, et, sans exagérer dangereusement les corrēlations conjonturelles, on peut poser conme préalable à une interprētation de la diversité des préocupations des écoles géographiques, la diversité des besoins de connalssances rēsultant de l'inégal développe ment et de la variēté de la conjonture."

En ültıma 1nstância, quando se lmagina um projeto de edu cação comunitária com vistas ao desenvolvimento e ao crescimento econômico, o trabalho de natureza global, profunda e continuada no tempo e no espaço, nada mais é que o próprio desenvolvimento regional integrado. 0 "l'aménagement du territolre", com objetivo de corrigir as disparidades regionats.

Num país cono o Brasil, en que essas disparidades regionais são flagrantes, jā hā expertênclas à farta mostrando que as abordagens unilaterais para a valorizaçäo regional são ou inōcuas ou geram distorçōes sērias no futuro. A criaçäo de uma ärea industrial, desacompanhada de outras implantações colaterais, pode aumentar O PIB da reg1ão, mas não necessartamente, un crescimento eco nômico equilibrado e nem sempre, o desenvolvimento. o exemplo mais nitıdo è representado pela atuação da sUDENE que centrou muito enfa tıcamente sua atuação na polftica de industrialização do Nordeste. As disparidades regionais se acentuaram porque se a Indüstria $\bar{e}$ o motor do crescimento econômico, ela por si só não basta para o cres clmento global e para o desenvolvimento.

A atuação, na ārea xural, da SUPRA, do IBRA, do INDA, de xou por igual, un saldo pouco favorävel em termos de desenvolvimento.

- INCRA está enfocando a questão diferentemente. Os proje tos deolonização (Transamazônica) ou de reforma agräria (como a re centemente iniciada em áreas do Nordeste) estão equacionados com ma lor profundidade, senđo a educação comunitariła uma das tônicas dos projetos.

Na medida em que se conscientizar essa verdade meridiana, qual seja a de que só se promove a mudança regional em sentido posí tivo, atravès do planejamento global e da participação da(s) comuni dade (s) ai, sim, pode-se falar em "queimar etapas". 
Igualmente na medida em que se considerar o planejamento regional como tarefa de equipes interdisciplinares (outra verdade acaclana), e não mais trabalho pröprlo só dos economistas, ou só dos urbanistas, ou só dos agrônomos, etc, caberă o concurso polivalente de outros profissionals, entre eles o geögrafo.

\section{8- O papel da Geografia nos projetos comunitärios de caräter restrito}

Afirmou-se anteriormente que se fazia necessārio conceitụ ar comunldade segundo a realidade brastleira.

o estereötipo europeu norte-ocidental e norte-amerteano de comunidade restrita (a vila, a pequena cidade, o bairro, o distrito das cldades médlas e grandes, a comunidade agrärla) tem sido, perigosa o danosaminte,transplantado por educadores brasileiros para o nosso meio.Assim, quando se armam nas escolas esquemas de atuaçāo comunităria a partir das experiênctas estrangelras, o proje to traz ern si o germe do pröprio fracasso.

- fenómeno tem que ser revisto à luz das realidades loca is brasileiras, 1 sso não é lmpeditivo para a atuação da escola na comunidade. Alıás, o verdadeiro papel da escola formal, só é ating do quando ela consegue entrosar-se com a comunidade, exercendo sobre e com ela uma atuação que transcenda o simplório "regime cartotial" a que se referla com insistência o professor Anis1o Teixeira, "regime cartorial" significando a agêncla de diplomação do estudante ${ }^{(15)}$.

Os projetos comunitários de âmbito restrito, vale dizer, os que envolvom uma escola e sua comunidade ( uma agrovila, uma c1dade de 5000 habitantes, um bairro de uma cldade maior, que forneça os alunos para aquela escola) não devem se encarados como atividade esporádica, emergencial. Ao conträrio, podem ser, ao menos de duas naturezas:

1.:- projetos de atuaçäo comunitäria integrando o currícụ lo pleno da escola;

2.- projetos de atuação comunttāria não integrando o cur r1culo pleno da escola, mas constando da programação geral das atividades escolares.

Quanto ao primeiro tipo podem ser citados alguns exemplos:

- "estudo do melo", cono una das formas mais eficlentes para revelar aos alunos a sua "ambièncla" fisica-humana-politica-eo nômtca. o "estudo do melo" pode ser programado para se desenvolver 
en etapas, quer sob a forma de atividades, áreas de estudo ou de disciplinas, conforme preceitua a Lel no 5 692;

- atuação na comunidade, por parte dos alunos, sob forma de prestação de serviços, tais como campanhas sanitărias; alimentares; de esclarecimento sobre as funções da escola; arborização; pequenos reparos (jardins, calçamento de vias püblicas, pinturas de prédios escolares e, a nível de ensino de $29 \mathrm{grau}$, pequenos reparos que exigem malor treinamento, como o de viaturas das prefeituras em cidades pequenas, o de revisão de instalaçōes elétricas e hidráulicas de prédios püblicos, etc. Os exemplos podem ser multiplicados dependendo do engajamento da escola na comunidade e do grau de trei namento dos alunos, notadamente nas últimas séries do ensino de 18 grau e no ensino de $28 \mathrm{grau}$, conforme as habilitações profissionals conferidas pela escola.

Quanto ao segundo tipo, o que integra a programaçäo geral das atividades escolares, podem ser citados como exemplos:

- a educação de adultos (alfabetização e prosseguimento do ensinol;

- melhoria do padrão profissional de pais de alunos e de outros elementos da comunidade, semt ou pouco qualificados;

- cursos para atualização de elementos da comunidade, visando a melhorar seu enfoque vivencial, esta atividade que admite un sem-nümero de variações, facilitará a ambientação do aluno ao lar.

Essas três modalidades assinñladas são de vital importância para, no minimo, garantir, ou factlitar, o exito das atividades formais de ensino.

A defasagem entre o mundo que deve ser revelado ao aluno na escola e suas condições existenclais no lar, muitas vezes, è uma das causas do desajustamento do adolescente. De igual forma muito da aprendizagem do aluno via currículo, perde-se, desacelera-se, entrechoca-se quando o desnivelamento entre aluno-pais atinge graus muito elevados. Numa sociedade como a brasileira, encarada como um todo, è importante que a escola vise, em primeira aboraagem, à reeducação das mães. Quando a mão é esclarecida sobre as funçōes esco lares, preparada para aceitar as modificações a que a escola se pro pöe, ela é um clemento-chave para facilitar o ensino-aprendizagem. Na socledade brasileira, a mãe è o elemento conservador por excelên c1a, repositörio de tradições culturais o que, muitas vezes, pode representar um frelo à mudança social.

Hă, em desenvolvimento no Brasil, a implantação dos "Centros Comunitärios", ligados diretamente ou não a escolas formais. 
Tałs Centros, em sua concepção original, devem possibilicar:

- cursos de alfabetização (MOBRAL);

- cursos de qualificação profissional (PIPMO);

- oportunidades de recreação (piscina, quadras de esporte, jogos de salão) até aqui privativas quase somente de parcelas das classes médias e altas, para puro lazer;

- assistência médica-sanitärı-odontológica;

- acesso à leitura: blblioteca comunitária.

Rosulta muito evidente que quaisquer dos projetos assinalados anteriormente, dependem basicamente de planejamento. Esse pla nejamento deve partir do diagnóstico da comunidade. Esse diagnostico não pode ser meramente quantitativo, ou referente a níveis de as piração, ou relativo a tentativas aleatórias de mudança social. o diagnöstico tem que ser global e nessa altura dos acontecimentos,de ve e pode entrar o trabalho do geógrafo e/ou do professor de Geogra fia - o que será o caso mais frequente.

Esse trabalho, sempre de natureza intergrupal, deve ser coordenado pelo professor de Geografia. Explica-se: ele è o elemento- por formação universitäria- que estā, ou deverä estar capacitado para propor as linhas gerais para a montagem do diagnóstico comu nitärio. Esse diagnöstico é mutto małs que sociológico, ou demogräflco, ou econômico. Ele deve naturalmente abordar enfaticamente esses aspectos mas é un dłagnóstico mais abrangente, em suna, uma anā lise do quadro regional (ou mais ou menos extenso) que é objeto da Geografia.

Poder-se-á levantar a questão de que os professores de Geografla näo se encontram capacitados para tal tipo de tarefa. E essa è una verdade para multos deles. Mas, o que terá falhado: a orientação teörico-prätica de seu curso de građuação ou de pós-graduação, ou ele mesmo ?

Não serã o caso de se repensar, reformular, alguns cursos de graduação geogräfica, tornando-os nais prátıcos ? E não se pense que um curso dessa natureza deve "preparar o futuro geögrafo e/ou professor de Geografia para coordenar diagnösticos comunitäriog". Isto seria deformar a natureza, os objettvos de um curso, não atentaria contra a Geografia en si mesma, que visa a interpretação das paisagens.

\section{9- O papel de Geografia nos projetos comunitarios de un "cam- pus" avancado de Universidade.}

Há pouco mais de cinco anos, fol idealizado o PROJETO RON DON que tinha por objetivos: 
- selecionar alunos universitários para se deslocarem de suas āreas de estudo para outras, geralmente apresentando fortes fenômenos de subdesenvolvimento;

- Fazer com que esses grupos universitários permaneces ser cerca de trinta dias nessas áreas, orestando assistêncla às co munidades locais, tais como: médica, veterināria, odontolögica, educacional, administrativa, etc;

- revelar aos universitärios uma outra face da realidade brasileira;

- incentivar os futuros profissionals a se fixarem no in terior do país, quando formados.

Após as primeiras expertênctas o PROJETO RONDON evoluiu. Jā não se tratava de deslocar esporadicamente os grupos para esta ou aquela localidade, por um perfodo restrito. o aspecto social-f1 lantrópico da assistēncia, que tinha seu lado positivo, era interrompido, não havia continuidade no trabalho que se pretendia mais orientador que propriamente paternaista. A evolução fol traduzida pela Instalação dos "campl" avançados das untversıdades, em áreas determinadas pelo Ministërio do Interior.

Cada "campus" avançado deve ter:

- um nücleo fístco que abrigue as equipes universitárias;

- um rato de atuação que ultrapasse o do núcleo fís1co;

- equipes multidisciplinares que permaneçam no campus avançado por um periodo de 30 a 40 dias, sendo subst1tuldas por outras equipes de forma a manter a continul dade das operações.

Mais ainda: o "campus" avançado deve constttuir uma opor tunidade de estágio prătico para os seus alunos, alēm de promover a interiorização da assistência às comunidades.

Em 1972, hä vărios "campi" en funcionamento e outros prọ jetados .

Inegavelmente a experiëncia parece ütil e deve continuar. As falhas - muito naturats em atividades ploneiras dessa natureza- por certo serão corrigidas.

- autor visitou os "campi" avançados de duas universidades, na Amazônia. Observou, todavia, que a ambos faltava um embasa mento preliminar que possibilitasse uma atuação mais coordenada de educação comunitária. Faltava o diagnostico regional, a caracterização do espaço fístco, humano e econômico, uma visão correta das comunldades a serem trabalhadas. Não conseguiu localizar siquer 
uma carta das regiōes, em escala grande. Faltava, em suma, uma interpretação, singela que fosse da paisagem. Careciam ambos os "cam pi" de um trabalho preliminar felto por uma equipe interdiscipilnar sob a coordenação dos Departamentos de Geografía de ambas as $\underline{U}$ niversidades.

Outro exemplo; um "campus" avançado 1naugurado no mês de malo de 1972, no Pará, levava a primetra equipe cam elementos de medicina, assistência social, pedagogia, administração, nenhum elemento do Instituto de Geociênclas.

Está visto que as primeiras fases do trabalho serão mera mente de carăter assistencial-paternallsta, até que se introduzam correções no planejamento.

Indispensavel, principalmente em se tratando de espaços e de comunidades a organizar, o trabalho preliminar a que estä afeito o geōgrafo: estudo do melo, preparação de cartas geográficas, diagnóstico das atıvidades econômicas, caracterização demogra fica, etc., etc. Muito se pouparia de esforço sincero mas que fatalmente serä dispersivo, quando não, contraproducente, se o plano estivesse montado sobre um quadro geral preparado por geógrafos e professores de Geografia. Mais uma vez trata-se da "organlzação do territörio" que possibilita uma atuação das diversas equipes nos pontos de resistência ao desenvolvimento.

\subsection{0- Conclusöes parclais}

$1^{a}$. Os conceltos vigentes sobre comunidade devem ser revistos, principalmente à luz da realidade histörico-cultural-politico-econōmica brasileira.

$2^{a}$. Os projetos de educação comunitäria, no Brasil, de forma geral, tẽm apresentado resultados pouco alentadores. O fato se deve, em parte por serem fragmentários, na conceltuaçāo, no plạ nejamento e na execução.

$3^{a}$. Os projetos de desenvolvimento (vale dizer educaçāo) comunitäria devem ser integrals e integrados, contando com a parti c1pação da comunldade. os projetos impostos tendem ao fracasso.

$4^{a}$. A Geografla, atravês de professores e/ou geögrafos, não pode estar ausente dos projetos de educação comunitäria. Deve somar seus esforços aos de outros profissionals.

$5^{a}$. A Geografia cabe um papel destacado na elaboração participativa de projetos de educação comunitäria, quer os de mais ampla perspectiva, quer nos projetos mais restritos, como os que envolvem o binömio "escola-comunidade" . 


\section{NOTAS REFERENTES AO CAPITULO 5}

(1) GARNIER, J. BEAUJAU- La Géographte: méthodes et persperctives. Par1s- France- Masson \& Cie, Editeurs. 1971

A citação no texto é da păgina 11 . o sub-capitulo L'UNITE DE LA GEOGRAPHIE (p. 7-12) è um modelo de concisão e de afirmação doutrinăria da unidade da Geografia. Importa muito ler e meditar sobre o tema, justo numa fase en que a Geografia corre o risco de fragmentar-se, alluir-se, delxar-se absorver por outras clénctas. As causas do fenômeno, evidentemente são vārias, mas não será despropositado afirmar que uma das forças corrosıvas dessa unidade é, como assinala a autora, "la nëgligence des géographes pour toute recherche approfondie d'une mëtholologie systëmatique et globale, tenant compte des progrés généraux de la connalssance et de l'orientation conterporaine de la philosophie des sciences'. (p.10) o problema da fragmentação, aqui vista como subdivisão da Geografia, não deve ser considerado necessariamente um mal. Ele ocorre por uma necessidade de aprofundamento nas pesquisas. Se rá contudo um mal se a fragmentação conduzir a uma perda da es sência que confere unidade à Geografia.

(2) QUEIRoz, Maria Isaura Pereixa de. O povoado de Santa Brigida, in Comunidade e Socledade no Brasil. Florestan Fernandes, et all11. São Paulo-SP. - Companhia Fditora Nacional- Editora de são Paulo - 1972 - Notas às p. 61 e 65.

(3) KHOI, Lê Thãnh. A Indūstria do Ensino. Tradução de Maria Fernanda Margarida Correla - Porto - Portugal Livraria Civilização - Editora - 1970 - p. 35

(4) PETRONE, Pasquale. Povoamento e colondzacão, in, Brasil, a ter ra e o homem. Aroldo de Azevedo, et allii. Säo Paulo-sp. Compa nhia Editora Nacional - Editora da Universidade de são Paulo vol. II- A vida humana - 1970

Ver, do zutor citado, o capitulo III, p. 127-153, onde se faz a sintese do povoamento e da colonização no Brasil. Ao lado da apresentação histörica (âiacronia) do fenómeno, vê-se o proble ma do àngulo geográflco: ocupação de espaços, fixação dos grupos colonizadores, resultados dessa ocupação, no habltat, na economia, na cultura, etc.

Mas está presente, em todo o capltuio, a preocupação do trabatho de integrar os grupos colonizadores no substrato social preexistente. 
(5) SERVIÇO SOCIAI DA INDOSTRIA - Migracões interna, Imigração, Co lonizacão - Conferências - Rio de Janeiro - 1956.

A sérle de conferênclas, versando sobre o fenômeno migratörio no Bras11, deixa clara a preocupação com o processo de integra ção, aculturação dos grupos migrantes.

(6) NEIVA, Axthur Hehl. A Imlgracãc na politica brasileira de povo amento - Rio de Janeiro,- Separata do no 6 - Ano II da "Revista Brasileira dos Municipios" - Serviço Grä́lco do IBGE- 1950. o autor revela grande preocupaçäo com os aspectos tendentes à assim1lação dos grupos 1migrantes. O tema é abordado (p. 237) 239) de forma rápida, como se depreende do texto a segulx transcr1to: "Esta è a própría essência de toda a técnica de assimtlação. Não se deve extirpar a fórceps a cultura do allenigera, e nunca obrigä-lo a substitui-la pela nossa, mas sobre por a brasileira à que trouxe incorporada à sua personalidade. Alläs, sō assim poderemos efetivamente aproveitar tudo quanto - 1migrante possul em benefíclo do Pals, pela criação de um sincretismo cultural muito mais rico de experiêncla do que qualquer das cultu. as isoladamente" (p. 238).

(7) VALVERDE, Orlando e DIAS, Catharina Vergolino. A Rodovia Belëm -Brasilia. Rio de Janeiro-GB- Fundação IBGE- Instituto Bras1leiro de Gecgrafia - 1967.

(8) ABRAMS, Charles - Habłtacão, Desenvolvimento e Urbanizacão-Rio de Janelro-GB - Tradução de Alexandre Lissovsky - Edlções 0 Cruzeiro - 1967.

- livro trata do tema com bastante objetividade e abrangência, pois parte das constatações do fenômeno em värios países. Aliàs estão incluídos não apenas os chamados subdesenvolvidos mas, também, os de civiliz ção industrial que apresentam muitas áre as urbanas com problenas - diferentes é certo - igualmente sérios de reorganização do espaço urbano.

(9) DAvis, Kingsley, et alli1 - cldades - A Urbanızacão da Humani-

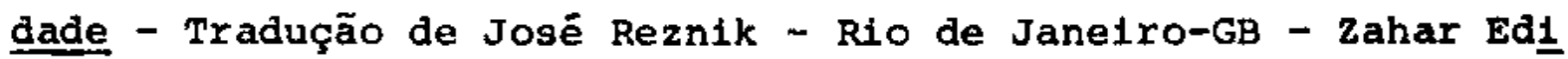
tores - 1970 .

são particularmente interessantes os seguintes capitulos: "O $\underline{\mathrm{U}}$ so da Terra nas Cidades", de Charles Abrams; "O Metabolismo das Cidades" de äbel wolman; "ì Renovação das Cldades, de Nathan Glazer.

(10) BLAUNT, James M. A Geografia e o Desenvolvimento da Agricultura Camponesa, in Geografia Humana nos Estados Unidos - Preston E. James, et allii - Tradução de Luiz cläudio de Castro e Costa 
- Rio de Janeiro -GB - Forum Editora - 1970.

o capitulo XIV - p. 203/223 è o referido na indicação acima. E particularmente interessante pela análise do papel que a Geografia pode e deve desempenhar no desenvolvimento agrärio de $\underline{u}$ ma região.

"A partir dêsses dados surgiu una série de postulados que oferecem uma explicação ou outra do fracasso dos programas desenvolvimentistas. A esses dados acrescenta-se uma ünica teoria de fundamento que converte qualquer postulado que explique 0 Insucesso passado em um postulado que afirme a certeza de fracasso futuro. Chamamos a isso - com multa pretensão - a "misteriosa teoria da doença tropical", porque postula, em sua mals pura e extremada forma, o fato de que a agricultura campo nesa ten dentro de si mesma certo fator tóxico, desconhecido e incurăvel, que deve inevitavelmente atacar qualquer programa de desenvolvimento camponès e vir a derrotā-lo por fim.

Um dos postulados que se escondem por trās dessa teoria, de certa forma antropológico, emioora desautorizado pelos antropölogos, afirma a existência de barreiras culturais : impeneträ veis - ja que as culturas camponesas erguem barreiras, ao contrăric de outras, que não o fazem, e jã que os programas deseñ volvimentistas se destinam a falhar mesmo quando facetas nãoeconômicas de cultura são levadas em conta devidamente. Outro postulado afirma que os agricultores camponeses são motivados por valores sociais e não econômicos, não sendo, portanto, sen siveis aos atrativos econômlcos do desenvolvimento - enquanto os valores socials sempre podem ser, en qualquer cultura, sepa rados dos valores econômicos; e já quer a demanda de gêneros alimenticios é un valor econôntco en uma cultura, e um valor so cial, em outra. Outro postulado ainda quer o que se chama una curva de suprimento de mão-de-obra descendente para os agricul tores camponeses, com isso indicando, efetivamente, que esses agricultores trabalham mais quando os incentivos são menores e vicc-versa. Isto não ë verdade. E assim acontece com outras crenças acerca da falta de motivação de realızação, da imobi lização de terras por força de propriedades conjugadas, supres são do espirtto empresarial em numerosas famílias camponesas e coisas desse gênero.

Nem todas essas proposições afirmam a impossibłlıdade de um ge nuino desenvolvimento camponês; em sua maior parte, com efelto, indicam apenas que o desenvolvimento serä uma tarefa diffcil e custosa. Convertê-las porém em uma teoria de não- desenvolvimento é tarefa simples: trata-se apenas de projetar o pas 
sado no futuro. E è exatamente o que fizeram värıos örgãos na cionals. O resultado é fracasso alnda mafor; uma teoria derro tista tende a pör em prática as suas próprias profeclas derrotistas" (p.208/209).

(11) GRUPO TAREFA INTERMINISTERIAL - Projeto PlauI - Teresina- Pi: aur - 1971 .

(12) GARNIER, J. Beaujau. op. cit.

"Tout d'abord il est nëcessaire de definir des positions"pour "preparer 1'analyse des espaces èconomiques considērés comme bien distincts des espaces gëographlques" (Perroux,1954, 330). Et la reciproque est vraie! Mais dans 1'approche de F.Perroux, prëcisëment - et $11 \mathrm{n}$ 'est pas le seul - l'espace gëographique est très souvent restreint a ses purs aspects physlques: "L'espace gëographique concu comme un ensemble de distances et d'obstacles physiques" (1d.343). Or, c'est une définttion à laquelle, bien entendu, aucun géographe ne peut souscrire. puisque bien loin d'être confiné plus ou moins dans une pure étude des conditions du millieu physique, ou même dans un inventaire des socletës humaines aux prises avec ce millieu phy słque, de qu'ıl revendlque, c'est la globalité des inter-rela tions entre le milieu et l'organization due à l'home et, en cela, ses préoccupations rejoignent un certain aspect de celles des économistes." (p.64)

(13) WAGLEY, Charles-"Uma comunldade amazônlca," reproduzido o cap. VIII, pp. 369-370 e 387-398, sob o título: "O desenvolvi mento comunitárło como dilema nacional" - In Comunidade e Soci edade no Brasil- Florestan Fernandes, et allii- São PauloSP. Companhia Editora Naclonal- Editora da Unlversidade de São Paulo- 1972- p. 519-527.

(14) GEORGE, Plerre- Les Méthodes de la Géographle - Paris-FrancePresses Universitaires de France- "Que sals-je?" No 1398-1970

(15) TEIXEIRA, AnIsio- Educacão näo é privilëgio - Rio de Jane1roLivrarta José Olimpio Editora - 1957-

"A reglonalização da escola que, entre nōs, se terā de caracterizar pela municipalização da escola, com administração local, programa local e professor local, embora formado pelo Es tado, concorreră em muito para dissipar os aspectos abstratos e Irreais da escola imposta pelo centro, com programas determinados por autoridades remotas e alstantes e servida por pro fessores impacientes e estranhos ao melo, sonhando perpetuamente com redentoras remoções. 
Tal escola, com horários amplos, integrada no seu melo e cam ele 1dentificada, reglda por professores provindos das suas mais verdadelras camadas popularos, recebendo os salários desse melo, serā uma escola reconciliada com a comunidade e já sem o carăter ora donlnante de escola propedéutica aos estudos ulteriores ao primärio. Esta será a escola fundamental de educação comum do brasileiro, regionalmente diversificada, comum não pela uniformidade; mas pela sua equivalēncia cultural" (p. 51).

-. "Por outras palavras, o diploma escolar è uma presunção de preparo e não um atestado de preparo" (p.112). 
CAPITULO 6

GEOGRAFIA E MERCADO-DE-TRABALHO 


\section{1- objet1vos}

18- Relactonar os problemas do cresclmentoeconöntco e do der senvolvimento social com os mültiplos aspectos do mercado-de-traba1ho.

28- Caracterizar o estág1o atual dos planejamentos, projetos, estudos e pesquisas referentes a mercado-de-trabalho, no Brasil.

38- Destacar a 1mportância da contribulção da Geografla para a anālise do mercado-de-trabaiho, tendo em vista o binômio "educa ção - qualificação da mäo-de-obra".

\section{2- Introdução}

o crescimento económico de un pals e/ou de uma região é

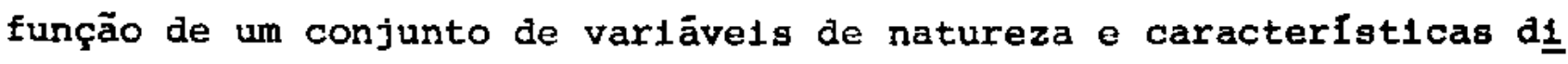
versas. São exemplos, dentre outros:

- a superficle real, ocupada efetivamente e ocupäve1, a curto, médio e longo prazos ${ }^{(1)}$; äreas $^{(1)}$;

- a localização ou situação relativa a outros centros ou

- a transformação dos "bens naturats" em "recursos econômicos", quando os "recursos naturais" passam à fase de exploração 1ndustrial ${ }^{(2)}$;

- o quantitatıvo demogräfico e a qualificação dessa população; acrescenta-se o aspecto da distribuição espacial da população (3):

- evolução, caracterIsticas, tipologia, distribulção espacial das atıvidades relativas aos setor?s prımárıo, secundärıo e terctär1o;

- produção, produtividade, comērcio interno e externo,pou pança, balanço de pagamentos;

- quadro geral da conjuntura munaial, do ponto-de- vista polftı.co-econômico;

- regime politico vigente;

- planejamento e implementação dos projetos de crescimento e de desenvolvimento;

- mobilização popular para o esforço tendente a elevar os nivels de produtividade (crescimento) e os de bem-estar (desenvolvi mento);

- etc. 
o etc. acima fol colocado com a 1ntenção de de1xar

bern claro que o conjunto de variáveis que pesam mais, ou pesam menos, no crescimento econōmico de um pais, microrregião, muntclpıo, não se esgota com a listagen anterior. Esse conjunto é mais abrangente. vale acrescentar, ainda, que o slstema global de crescimento e os diversos subststemas, dependem da conjugação dessas varláveis. Essa conjugação nāo è um ato de fó, mas depende das opções polítıcas e do momento histórico.

Objetiva-se, em particular, neste capitulo, destacar, para breve anālise, a questão pertinente aos recursos humanos para 0 cresclmento econömico. Evidentemente se o considerarmos um subsiste ma, ele não è o mais importante, mas constitui o ponto de partida e - ponto de chegada de toda uma ação politica. Cresce-se para o desenvolvimento e desenvolve-se para crescer, tendo como meta bástca o homen, em particular e os grupos sociais como un todo ${ }^{(4)}$.

Os recursos humanos referidos, serão enfocados do ângulo do binômio mão-de-obra/educação.

\section{3- Consideracōes gerais sobre a mäo-de-obra}

Conceltuaçöes preliminares.

o concelto genérico de mäo-de-obra, numa sociedade cono a brasile1ra, vem carregacio de conotaçōes pejorativas, Identificando-se entre pessoas mal informadas, como sinonimo de trabalho serv11. o processo da evolução histórica, en boa parte, explica esta distor ção.

Mão-de-obra, capital humano, força-de-trabalho, populaçäo economicamente ativa são outras expressōes muitas vezes confund1-

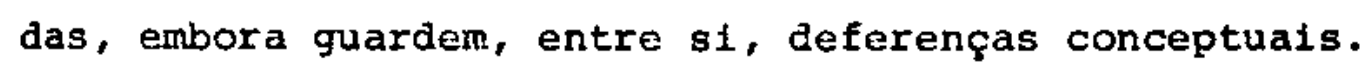

Numa distinçäo Inicial se deve propor:

- a população economicamente ativa (PEA) corresponde ao total de elementos, estat1sticamente quantificados no circulto da produção;

- a força-de-trabalho "se define como a energla, a potêncla disponfvel para o desempenho de atividades, e pode estar sendo aplicada ou não. Neste segundo caso, se incluem aqueles individuos que possuen as condições para o trajalho, mas nāo estão em atividade, seja por motivos alheios a sua vontade, seja voluntariamente. Por fim, existe un grupo que representa a força-de-trabalho potenc1 al, e que no futuro estarā em condiçōes de desempenhar atıvidades, mas presentemente ainda não o faz. Entra aqui principalnente o fator idade" (5); 
- "e expressão "formação de capital humano", que se utili za neste trabalho, significa o processo de formação e incremento do nümero de pessoas que possuem as habilidades, a educação e a expert ència Indispensávels para o desenvolvimento político e econômico de um pals. $\Lambda$ criaçäo de capltal humano se assimila, desse modo, a uma inversão em beneficlo do homem e de seu desenvolvimento como um recurso criador e produtivo" ${ }^{(6)}$;

- mão-de-obra, será uma expressão usada no texto como sig nificativa de trabalhador, seja do setor primärio, secundärio, terciärio, seja de nivel superior, mëdio, ou tnferior, quanto à habili tação.

Por ūltimo, considere-se a expressão "mercado-de-trabalho' como o complexo de setores que pode oferecer (ou não) emprego para a mão-de-obra.

Mão-de-obra, desenvolvimento e educação.

São três componentes de um processo, muito interligados uns con os outros. A varłação de um dos componentes afeta, de uma ou de outra mancira, os demais, podendo-se notar que há um relaclonamento de "natureza clrcular".

Jà é fato comprovado que o crescimento econômico è função de certas varıáve1s, ta1s como:

- acumulação flsica de capttal:

- aumento do estoque de mão -de-obra;

- educação;

- melhoria da produtividado dos fatores.

Historicamente, em multos paises, no Bras1l inclusive, o crescimento econômtco não dependeu de uma melhoria da produt1vidade dos fatores, muito menos da educação. Capital + estoque de mão - de obra e, em certos casos, abundâncla e acesso aos recursos naturais compunham a equação do crescimento econômico.

Vejan-se dols exemplos distintos, quanto à natureza e ao momento histórico.

18- O Bras1l durante o "ciclo" de cana-de-açücar. 0 - ctpttal físico era representado pelo latifündio e pelos financiamentos estrangetros. A mão-de-obra era escrava e os dirigentes da produção, eles mesmos, prescindiam da educação. Para ambos, a tradıção, o ensato e erro fazlam as vezes da educação.

Apesar disso, a econonta colonial como um todo cresceu.

28- A Inglaterra à ćpoca da Revolução Industrial. o capttal fisico era fruto do mercantilismo, de uma precāria urbantzação, da 
sua frota. A mēo-de-obra era abundante nos focos industriajs nascen tes, principalmente devido ao exodo rural. A tecnologia era incipiente, mas a grande massa de trabalhadores cra analfabeta e desqual 1 ficada do ponto-de-vista habilitação. Apenas uma minoria tinha uma tradição artesanal.

No século XIX, principalmente na Europa Octdental, em par te da Rüssia, nos Estados unidos, a educação bäsica, primāria se ex pandia, melhorando as condiçōes de produção. De igual maneira, a ni noxta intelectual fazia avançar as pesquisas clentificas transforma das, mais adiante, em aplicaçōes tecnológicas. Fenômeno idêntico ocorreu no Japão, en fins do sēculo XIX o inf́clo do século XX. I medida que o crescimento econôntco se acelerava, que a produção se diversificava $e$, por consequência, amplitava-se o leque do consumo, a educação passou a ser mals valorizada, mals requerida para allmen tar o próprio crescimento econōmlco e, em contra-partida, dele bene fictar-se.

Uma esquematização gräfica simplificada, como a que segue busca dar una 1dēia do interrelacionamento dos fatores.

QUADRO NO 28

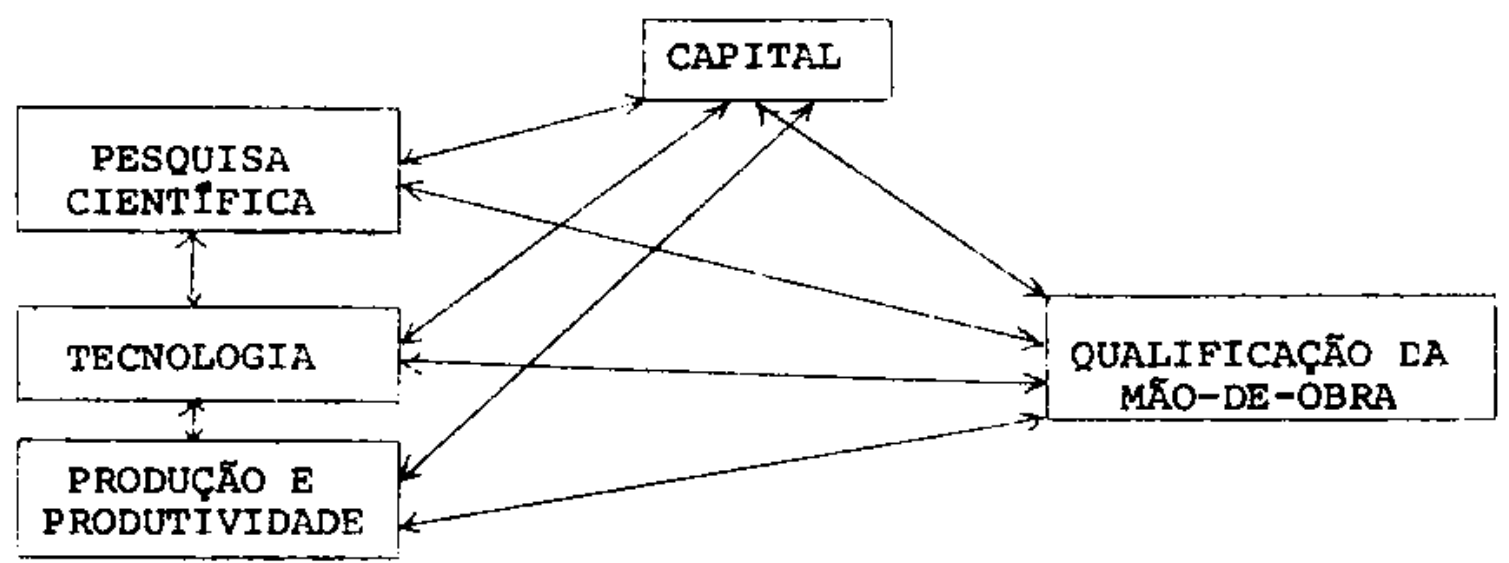

o processo è universal, variando de país para pafs, conforme seu regime politico e seu cstágio de crescimento e desenvolvi mento.

Hoje, contudo, todos buscam, por um ou por outro caminho, incrementar os componentes do s1stema. Nuns, o esforço se centra prioritariamente na pesquisa clentifica e sua aplicação na tecnologla (Estados Unidos, Japão, Mlemanha Ocldental, União Soviētica, por exemplo); noutros na alfabetização de adultos (Argélia, NIgērł. a, Bras11, etc); noutros, na implantação e ampliação da escolaridade Inicial (Brasil, Peru, Mëxico, etc).

Os palses de cconomia inaustrial e pós-1ndustrial exportam tecnologia e capital (União Soviética, Japão, Palses Baixos, Es 
tados Unidos, etc); outros, embora 1mportando ambos, buscam desenvolver a pesquisa cientifica e tecnológica, assim como aumentar a poupança para geração de um estoque de capital nacional (Brasil por exemplo).

Como regra geral, a educação è considerada priorttärıasem - qua sarescatrato n económico é pequeno e o desenvolvimento social re duzido, agravando a concentraçāo da renda $e$ as disparidades regionais e internacionais.

A manutenção do rltmo de crescimento de um pals e/ou regi ão fica fortemente na dependência do quantitativo e da qualidade de "capital humano".

Cabe, a esta altura, uma consideração a respe1to da rela ção entre educação e capital humano.

Enquanto educar nada tinha a ver com a questão do cresc1mento econônico, nem com a viabilızaçăo do acesso do indivíư às oportunidades de uma ascenção socłal, o problema apenas interessava a uma minoria e o "pedagogismo" pontificava.

Quando,em sociedädes como a brasileira, educar passou a ter outro slginificado, pela pressão demogräfica, pela democratização do ensino, pela necessidade de co-particlpar no crescimento eco nônico, as reações e as incompreensöes subıram à tona e borbulharam. A prova mais concludente: estigmatıza-se a educação que se pro pöe para a sociedade brasileira como "alienada do humanismo", "prag mätica", "massificadora", "veículo de preparação de näo-de-obra" , "educação a serviço đas empresas", e outras alegações do mesmo cali bre. A rigor, nenhuma delas resiste a um debate frio e equilibrado.

Particularmente no que diz respelto à educação como "velculo de preparação de mão-de-obra" é preciso levar en conta:

18- um sistema educacional que não prepare o homem para o exerciclo, próximo ou remoto, de una profissão, è alienado e tem levado milhões de brasileiros a uma frustação pessoal e profissional;

28- o trabalho é um dos componentes da atividade humana e quanto mais ajustado o Individuo à sua profissão, mais ele se reali za como pessoa e como ser social;

30- um sistema educacional sobre o qual se façam investimentos de diversas ordens e fontes, sem apresentar, ao fim de 4 ou mais anos de escolarização, Indivíduos mais ajustados, criativos, produtivos, não tem justificativa para se manter.

Visto que o sistema educacional brasileiro, vigente no bé culo atual, a despelto das reformas por que passou, não respondia 
às necessidades nacionais, notadamente no que tange ao crescimento econômico, entrarara en cena os economistas, para planejar a educação.

Reagiram, evidentemente, os educadores que julgavam Indëbita a "invasão dos economistas", com suas técnicas, sua linguagem especifica, seus objetivos. Fato é que, grande parte dos educadores, na realidade, não estava preparada para 1mprimir malor dinamís mo e novos rumos à educação. A "invasão do campo" acabou por resultar vantajosa para a educação:

- muitos educadores se atualizaram e passaram a ter uma linha de horlzonte mals ampla;

- os economistas se beneficlaram do diálogo, do trabalho com os educadores, abrandando os rigores da econometrla que joga, matematicamente com insumos (inputs) e produtos finais (output).

Ora,basicamente o que interessa ao economista é um produto final (aluno trelnado, habilitado) de mäxima rentabilidade con um mintmo de investimentos.

Ten-se agora a perspectiva de um sistema educacional mals flexivel, małs democratizante, małs operacional que começa a crer em planejamento Integrado e integral, em descentralização executiva, em não mais opor humanismo ao tecniclsmo, uma falácia residual a re mover.

Crescimento, desenvolvimento, mercado-de-trabalho, mão-de Fobra (7)

A relação entre nercado-de-trabalho e mão-de-obra estä na dependencia de muitos fatores que, om ültima Instâncta, confluem pa ra o biñomio crescimento econômi co-desenvolvimento.

o problema da escassez ou do excesso de mão-de-obra, ou o equilibrlo entre oferta e demanda tem que ser analisado ̀̀ luz de multos 1ndicadores, de que são exemplos:

19- diagnóstico das tendências cconômicas do país e/ou região somo un todo;

28- estudo detalhado da composição demogrăfıca, consıderandose:

- faixas estärias;

- distribulção por sexos;

- população economicamente atıva (setores de atıvidade, nú mero de dependentes);

- escolarizaçãon qualiflcação da força-de-trabalho;

- oferta de salärios:

- movimentos migratórios; 
- relação entre população rural e urbana, expansão urbana;

- higidez da população.

39- caracterızação do mercado-de-trabalho, considerando-se;

- nümero, tipos, produção e produtividade das empresas aquil englobadas as oficials e as particulares;

- possibilidade de expansão das empresas;

- relação entre produção $x$ mão-de-obra, segundo os nivels de qualificação.

Escapa ao objetivo deste trabalho entrar nos pormenores dos diagnóstticos e das tendências do mercado-de-trabalho e da mãode-obra, no Brastl.

E.contudo, necessärio e oportuno assinalar determinados aspectos, não obstante de forma superfictal.

19- A população economicamente ativa, no Bras1l, não estã suflcientemente estudada, apesar das melhorias nitidas observadas entre os trabalhos dos censos de 1960 e 1970. värios örgãos procedem aos levantamentos periódicos da situação da mão-de-obra no país, mas carece-se de estudos mais aprofundados, como Mercado-de-Traba1ho em são Paulo - Marisa de Assis, et alli1.

28- o setor primárto tende a absorver cada vez menos a força-de-trabalho, seja pelas migraçōes campo-cidade, seja pela introduçäo da tecnologia na produçäo rural.

38- o setor secundärio apresenta uma fase de expansão e diver sifłcação, nas dëcadas de $1950 / 60$ e 1960/70. Prevê-se que na década 1970/80 sua capacidade de absorção de mão-de-obra decresça proporci onalmente às dēcadas anteriores. O motivo básico se prende ao fenōmeno da automação industrial, isto $\vec{e}$, as indústrias modernas são do tipo capital-intensivo, que emprega menor nümero de operários, subs tituindo, em grande parte, a mão-de-obra pelas mäquinas mais sofisticadas.

48- O setor terciärio, após ser responsāvel pela oferta de em prego percentualmente ma1s significativa na década $1950 / 60$ que na 1960/70, deverá tender a retomar o ritmo mais acelerado na década 1970/80. Aliás, o fenômeno do aumento de empregados no setor tercia rlo é tiplco de paises industrializados ou em marcha para a industriallzação.

Os quadros nis. 29 e 30 , confirmam as observações e indicam as perspectivas. 


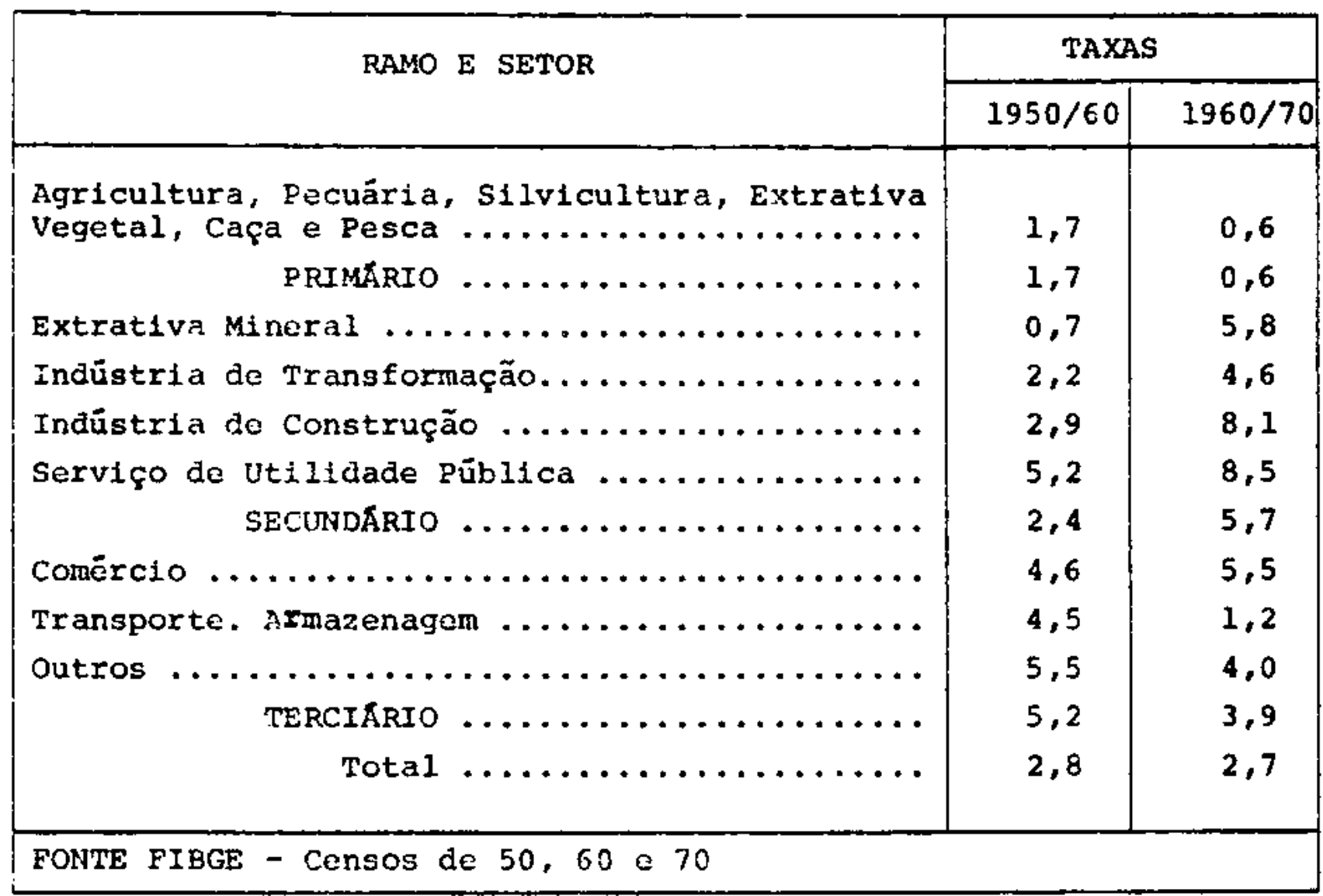

Observação: 0 quadro no 29 foi reproduzido integraimente da fonte c1tada. Cabe observar duas oolocações que não são usuais:

1. - a inclusão das atividades extrativas minerais no setor secundário o, năo, no setor primário:

2. - 1qualmente o item servico de utilidade püblica, no setor secundärio $\mathrm{e}$, não, no setor terclärio.

\section{QUADRO NQ 30}

\begin{tabular}{|c|c|}
\hline \multicolumn{2}{|c|}{ Evoluçäo do emprego por setores, no periodo } \\
\hline (Previsão) & 1970/1974: \\
\hline & $\begin{array}{c}\text { Cresctmento } \\
\text { Anual ( } 8)\end{array}$ \\
\hline Sctor Primário & 1,2 \\
\hline Setor Secundärto & 4,1 \\
\hline Indūstria de Transformação & 3,5 \\
\hline Construção & 4,6 \\
\hline Setor Terciärio & 4,7 \\
\hline $\operatorname{TOThL} \ldots \ldots \ldots \ldots \ldots \ldots$ & 3,1 \\
\hline
\end{tabular}

FONTE: Projeto do I PIANO NACIONAL DE DESENVOL VIMENTO ECONOMICO E SOCIAL - Ministério do Plä nejamonto e Coordenação Geral. 
Face a essas previsöes oflclais, a PEA, em 1974 E est1mada om $32.980 .000^{(B)}$.

50 - Caber a sistema educacional responder positiva e rapida mente aos reclamos de um morcado-de-trabalho que se diveraffica se soflstica em termos de recrutamento de mão-de-obra com nivels crescentes de qualificação.

O gräfico no 26 , relativo à apuracão da Lel $2 / 3$, refere-se a 5,5 milhōes de trabalhadores urbanos, regidos pela CLT ${ }^{(9)}$.

Gráf1co ne 26

DISTRIBUIÇAO DE EMPREGADOS

SEGUNDO GRAU DE INSTRUÇAO

BEASIL - 1969

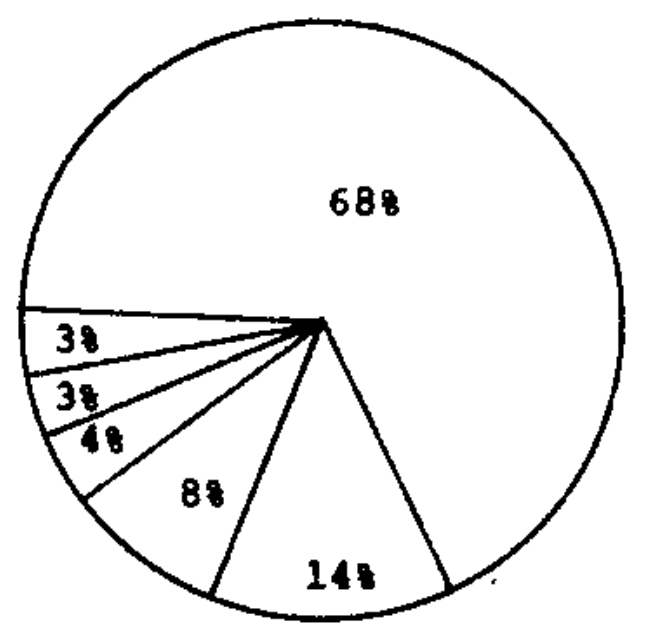

PRIMARIO $68 \%$

GINASIAL $\quad 148$

COLEGIAL 88

UNIVERSITARIO

ANALFABETOS 38

NÃO DECLARADO 39

Fonte: Boletim Täcnico do SBPr - no 21 - Dez. 1970

Pela anklise do gráfico, verifica-se que os trabalhadores englobados como portadores de habllitação conferida pelo ensino pr 1 märio e pelo ginasial, compreendem 828 do . total.

Deve-se, certamente, lovar en conta que o grafico registra os graus de instruçāo de forma globalizada. Naturalmente hả que se considerar que ha trabalhadores com curso primärlo completo e com curso primário incomploto; com gtnaglal completo e com ginastal incompleto e assim por diante. 
O problema da qualificação da força-de-trabalho não interessa apenas pelo que essa qualifłcação venha a representar na modernização do słstema produtivo. Interessa igualmente a, pelo menos dols outros setores:

- o relativo ao trabalhador e sua renda mensal;

- o referente à concentração de renda e capacıdade de poú pança, sabidamente un dos pontos nevrālglcos do crescimento econômico do país, como um todo e de cada região de "per se".

QUADRO NQ 31

\begin{tabular}{|l|c|c|c|c|c|}
\hline \multicolumn{6}{|c|}{ BRASIL - Educação e concentração de renda } \\
\hline \multicolumn{7}{|c|}{ Renda mensal em Cr\$ de 1970} \\
\hline Idades & Analfabeto & PrImärio & Ginäsio & Colegial & Super1or \\
\hline $20 / 24$ & 80 & 160 & 300 & 450 & 700 \\
$25 / 29$ & 100 & 240 & 460 & 700 & 1300 \\
$30 / 39$ & 120 & 280 & 640 & 1040 & 2040 \\
$40 / 49$ & 140 & 320 & 900 & 1450 & 2600 \\
$50 / 59$ & 140 & 320 & 1040 & 1600 & 2648 \\
$60 / 69$ & 130 & 290 & 1040 & 1500 & 2580 \\
\hline
\end{tabular}

FONTE: Censo de 1970 - Fundação IBGE-

\section{4- Mão-de-obra e educação}

A Lei ne 5692/71, como já se viu à farta, nāo foi promulgada para "preparar trabalhadores", exclusivamente, conforme se depreende da leltura do texto que segue:

"LEI No 5692, DE 11 DE AGOSTO DE 1971"

F1xa Diretrizes e Bases para o ensino de 18 e 28 graus.

O Presidente da República,

Faço saber que o Congresso Nacional decreta e eu sanciono a seguinte Lei:

\section{CAPITULO I}

Do Ensino de 18 e 29 graus

Arto 18 - O ensino de 18 e 28 graus tem por objetivo geral proporc 1 onar ao educando a formação necessāria ao desenvolvimento de suas potenctalidades como elemento de auto-realização, qualificaçāo para - trabalho e preparo para o exercicto consciente da cldadanian(10).

A par da formação geral do educando, buscar-se-á prë-qua- 
Ifflcä-lo (ensino de 18 grau) ou habilitá-lo para o desempenho de a tividades produtivas (ensino de $28 \mathrm{grau}$ ). Ao ensino de 39 grau, cabe espectficarnente a qualıficação para o trabalho de nivel superior.

Cabe referêncta tambëm ao ensino supletıvo, objeto de Parecer do Conselho Federal de Educação (Parecer no 699/72).

o antigo Supletivo foi reformulado pelo texto legal, apre sentando-se agora mais abrangente, porque se diversifica em quatro modalidades:

18- "A Suplèncla, como função de "suprir a escolarização regu lar para os adolescentes e adultos que não a tenham seguido ou concluido na ldade próprıa"(11).

28- "O Suprimento, é a função de "proporcionar, medtante repe tida volta à escola, estudos de aperfeiçoamento ou atualização para os que tenham seguido o ensino regular no todo ou em parten(11).

39- " $\Lambda$ Aprendizagem è a "formaçâo metódica no trabalho" a car go das empresas ou das instituiçöes por estas criadas e mantidast(il).

48- "A Qualificação é de certc modo o oposto da madureza tradicional: basela-se obrigatoriamente ern cursos, e não apenas em exa mes, e visa elotivamente à profissionalização, sem preocupaçōes de educação geral" (11).

Os diplomas legals (Lei e Pareceres) estão, pois, com suas atenções voltadas, inclusive para ajustar a educação ao cresc1mento económico e ao desenvolvimento social.

Nesta fase inicial de ajustanentos e reformulações de objetivos educacionals, nota-se em setores ligados ao ensino, em seto res da opiniäo püblica e, mesmo, entre os empresărios (públicos e privados) certo grau de expectativa e de incerteza. Isto é natural, pois as reformas visando a alterar situações vigentes, não se processam sem opostções, conscientes ou sub-conscientes.

Fato è que, de uma ou de outra forma:

- busca-se ampliar a escolarização para um mínimo de olto anos;

- procura-se formar um quadro de tēcnicos de nível médio, de que o Brasil è carente;

- ajusta-se o ensino supletivo, agora com outras direções, às necessidades de uma população que não pōde se escolarizar em época nornal, assim como precisa qualif car-se profissionalmente e atualizar-se perlodicamente- educação permanente;

- realiza-se um esforço no sentido de dimtnuir o nümero 
absoluto de analfabetos, prosseguindo a sua qualificação em cursos pōs-alfabetização.

Componente importante nesse panorama geral esboçado è o relattvo à tecnologia.

\section{5- A tecnolog1a}

Em estudos sobre mercado-de-trabalho e mão-de-obra, è interessante e necessärio comentar a respeito da tecnologia e seus re flexos no relacionamento oferta-demanda.

"O conhecimento cientifico se refere à compreensão dos fa tos da natureza e suas inter-relações, conduzindo à interpretação de tals relações como um todo (teorla cientifica).

o conhecimento tecnológico compreende o campo das tëcn1cas criadas pelo honem no desenvolvimento de sua atividade econômica.

A tēcnica pode ser entendida como um conjunto de instru çöes para a atividade produttva.

Assim, podemos entender a ciência como o saber no campo da tecnologia, e a tecnologia como o fazer no campo da ciência"(12).

Evidentemente, a tecnologia admite vărias formas e estägios. Quanto às formas, pode-se fazer referências às tëcnicas instrumentais no campo da produção, no campo da organização e, até, no campo das tecnologias intelectuats ${ }^{(13)}$.

Quanto aos estägios, isto é,quanto ao acervo tecnológico de um pals, ou mesmo, de uma empresa, a distinção mais singela que se pode fazer é a seguinte:

- tecnologia dos países desenvolvidos;

- tecnologia dos países em desenvolvimento;

Para os países em desenvolvimento, o dominio das tecnologias pode ser un fator de grande relevância para a aceleração do progresso, e se faz de uma ou outra forma, conforme o esquema a seguir:

\footnotetext{
"Fase de imitação passiva"

"Fase de ađaptação"

"Fase de criaçāo" (13).
}

Nesses países, "o mecantsmo de mercado leva as empresas a optarem sempre pela importação de P-D (Pesquisa e Desenvolvimento), ao invēs de produzi-1o internamente'." 


\begin{abstract}
"No Brasil, não se desenvolve a pesquisa. E isto por razões que vão desde inadequadas condtỗos de produção de conhecimentos científicos e tecnolöglcos (sobretudo no que diz respeito à desarticulação dos órgãos responsáveis e à pulverização dos recursos disponive1s), atē à insuflctência de uma demanđa efet1va de P-D destinado a inovações, capaz de dinamizar e racionalizar o próprio funcionamento das institui ções produtoras e/ou flnanciadoras" (15).
\end{abstract}

Localizar-se-à melhor o estäglo em que se encontra o Brasil, assinalando que em alguns setores ainda predomina a fase da imitação passiva (exemplos: informātica, indūstria químico-farmacêu tica, metalurgia leve, etc); en outros setores, jā se entrou na fase da adaptação (organização de empresas, tecnologla rodoviärla, tec nologia educacional, etc); em outros setores, a fase de criação é embrionäria (a agricultura no cerrado, industrialização de concentrados de frutos troplcais, etc). Fato è que, no momento atual, coe xistem as diversas fases, o que tem provocado una sērle de consequências. Algumas delas referentes exclusiva e especificamente ao mercado-de-trabalho e à mão-de-obra:

- pequena absorção de mão-de-obra pelas indüstrias;

- baixa produtividade no setor agrārio, onde se pode cons tatar:

* pleno emprego

- subemprego

- emprego sazonal

- setores tradicionals que, sofrendo reformulação tecnoló gica, demandam novo tipo de qualificação de mão-de-obra ocasionando, por outro lado, o desemprego.

São exemolos, dentre outros: a modernização de indústrias têxteis; a racionalização dos serviços bancários; a mecanização da lavoura ${ }^{(16)}$.

A medida em que o subststema econômico sofre alterações estruturais e conjunturais, graças a uma sērie de variáveis, sendo a tecnologta uma delas, observa-se uma flutuação grande na estrutura de empregos. O resultado preliminar: en certos setores há escassez de mão-de-obra e, em outros, nota-se o excedente. Assinale - se que estes conceitos de escassez e excedente, não se limitam ao aspecto quantitativo. 
mäo-de-obra.

Cabe ao subsistema de ensino, em ültima instância, flexibllizar-se e atualizar-se de maneira tal que possa responder, näo apenas aos seus objetivos mais altos quanto à auto-realização do in dividuo, mas tambēm às solicitaçōes do subsistema econômico, cada vez mais penetrado pela tecnologia.

\section{6- A Geografia, o mercado-de-trabalho e a mão-de-obra}

Pesquisa sobre mercado-de-trabalho.

Observa-se que de hä multo existem no Brasil organizações que realizam pesquisas sobre mercado-de-trabalho e a decorrente questão da demanda-oferta de mão-de-obra. O Ministērio do Trabalho, atravës de setores especificos (delegactas) e do Departamento Nacio nal de Mão-de-Obra; O SENAI, O SESI e O SFNAC; a Federação das Indústrias; o inintstērlo da Agricultura; órgãos particulares, como a Fundação Getūlio Vargas e a Fundação João Plnheiro: o Instituto Bra stlelro de Estatistica da Fundação IBGE e outros mais atuam neste setor contratados por empresas particulares e governamentais.

Mas hă una observação que se faz necessāria: avultam as estatisticas, as pesquisas, mas conhece-se pouco, pouquíssimo a res peito do assunto. As causas podem ser de värias ordens:

- desentrosamento entre os órgãos de pesquisa;

- emprego de metodologias pouco compativeis oom os objetí vos;

- evolução rápida do fenōmeno e descompasso com a lentidão da coleta e tabulação dos dados, etc.

Outra observação: determinadas pesquisas são

setorials, abrangendo pequenas äreas (uma cidade, um municipio, um Estado); ou determinados ramos de atividade: indüstria petroquinica, medicina e enfermagem, marcenaria, magistērio, etc.; ou são imediatistas, isto é, buscam analisar o fenômeno para atender a problemas emergenciais. Acrescente-se, ainda: têm una conotação fortemente económica, vale dizer, culdam de estudar a relação demanda-oferta e a questão dos custos da mão-de-obra.

o pais necessita de um esforço grande no sentido de conhe cer os seus recursos humanos, a sua população economicamente ativa, a sua força-de-trabalho, para:

- aperfelçoar, constantemente, o seu dlagnóstico sócio-po lit tico-econômico:

- estabelecer metas globais e setoriats; 
- corrigir as disparidades de renda e os desniveis regionais :

- Impulsionar o sistema educacional a fim de que ele co-participe, no tempo e no espaço, do processo de crescl mento e de desenvolvimento;

Para tanto, a anälise do mercado-de-trabalho e da mão-de-obra não pode ter un direcionamento puramente econônico. Esta hipertrofia levou e levarä a distorçōes graves que se tornarão mais agudas na medida em que novos contingentes humanos cheguem à idade de entrar no mercado-de-trabalho.

Das crianças nascidas em 1972, grande parte 12 milhões ? 3 milhões?...) daqui a 14, 15, 18 anos necessitarā de novas, diversiftcadas e mültiplas oportuntdades de emprego.

Uma nova visão das pesquisas sobre mercado de trabalho.

Tome-se como ponto de partida, apenas por uma questão metodolögica, a obra de Pierre George - Sociologta e Geografia ${ }^{(17)}$. 0 capítulo I - o Trabalho - realmente coloca o problema de um ângulo de abordagem muito equilibrado. Resumindo $\circ$ pensamento expresso (p.94):

Tema: trabalho diversas facetas enfoques específicos

$\frac{\text { Faceta tecnologlca }}{\downarrow} \quad \begin{gathered}\text { (parcialmente assimilada pela análise geo } \\ \text { gräfica) }\end{gathered}$
Responde à questão: como, com que, quando ?

$\frac{\text { Faceta soclológica }}{\downarrow}$

Responde à questão: por quem, para quem ?

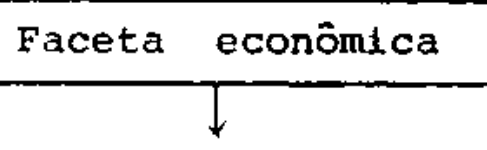

Responde às questōes: posse dos meios de produção? Investimentos? modos de comercialização e mercados ? conjuntura?

quantidade e qualificação do emprego ? polos de desenvolvimento e fluxos económicos?

Faceta geogräfica

Responde à questão: onde ? $\rightarrow$ necesstta reagrupar e sintetizar os dados refletidos pelas 3 outras face tas. 
A seguir o autor tece valiosas conslderaqöes sobre duas grandes unidades: o trabalho rural $\in$ o trabalho industrial e urbano.

Se a anälise do mercado-de-trabalho e da estrutura de emprego se fizesse, num pals como o Brasil, a partir das sugestões apresentadas por Plerre George, jä se teria dado um largo passo nessa questäo. Seria conclusivo, no minimo:

18- o fenômeno tem que ser estudado interdisciplinarmente;

29- cada ărea objeto de análise apresenta um especificidade. Embora seja possivel partir, em certos casos de modelog, a pesquisa local è indispensăvel para detectar as nuances, as caracteristicas, o potenctal, as perspectivas;

38- a dinânica regional exige a atualização mais ou menos constante das pesquisas inicials;

48- os resultados obtidos serão muito mais fidedignos, respondendo às necessıdades da área de estudo, justamente porque anali sam o fenōmeno interdisciplinarmente, jogando mals con duas variáveis de peso: tempo e espaço.

Outra sugestão de valor, que deve ser levada em conta ao se proceder a una análise regional, com vistas e ressaltar o binômio mercado-de-trabalho/mão-de-obra, a dada por Yves Lacoste ${ }^{(18)}$. In teressa notar que a partir do estudo do desemprego, en uma área (mi crorregião, Estado, macrorregião, País), no caso subdesenvolvida , pode-se, atravês da Geografia:

- levantax as características gerafs da ärea, do ponto de vista físico, ressaltando os traços que interessem à or ganização espacial;

- proceder à identificação do perfil demográfico e de con posição da força-de-trabalho;

- estudar a evolução históxica e seus reflexos presentes, nos dados que se identiflquem como frelos e/ou aceleradores do progresso;

- caracterizar o subsistema econönico, detectando os pontos de estrangulamento e suas repercussões na geração do fenômeno do subemprego, desemprego crónico e cíclica

- estudar soluçóes alternativas para a implantação de uma polftica e organização do investimento-trabalho.

No caso especifico de zonas rurais com acentuado grau de pauperismo e, consegtientemente, con agudas formas de desemprego, propõe Yves Lracoste dois tipos de intervenção de poder central:

1.- "ações permanontes administrativas e políticas; 
2. - intervenções materiais destinadas a permitir o inicio do desenvolvimento na região" (18).

Uma vez deslanchado o processo de organização, intensificando e diversificando a produção agrícola, a continuidade do crescimento dependerä menos da intervenção incial, ou dela poderá prescindir.

Todavia, na fase incial, são relevantes os trabalhos dos agrônomos e dos geógrafos, assinala o mesmo autor.

Ao geögrafo, notadamente; caberiam tarefas relacionadas com o estudo da região, principalmente do ponto-de-vista climático, de modo a permitir:

- "avaliar o grau de segurança de una cultura considerada, numa região e um ambiente tëcnico dados (portanto e vitar aos planejadores graves erros de previsão em matéria de crescimento da produção ou da rentabilidade de investimentos);

- propor enriquecimentos do capttal cultural por adoção de culturas novas;

- intervir na produção, estabelecendo stnais de alarme pa Fa prever a aproximação de uma ameaça climática e permI tir aos técnicos da agricultura tentar enfrentä-la ou aos da economia preparar coberturas para uma queda da produção" (18).

Em sintese, conclut-se que o problema do desemprego e,por via reflexa, do emprego, em zonas agrărias, não é fruto exclusivo de uni feromeno e, nem sempre a economia, ou a sociologia, 1solada mente podem diagnosticar as causas e propor soluçöes.

vals una vez se evidencia a imperiosidade dos trabalhos interdisciplinares, com lugar de destaque para a Geografia.

Ainda para o estudo integral e integrado da questão merca do-de-trabalho/mão-de-obra, conta a Geografia com un arsenal de tec nicas $€$ de metodologias, que tanto podem interessar a uma zona agrạ ria, como a um núcleo urbano (qualquer que seja sua dimensão popula cional), ou, o que è mais completo, à anälise de tipos de regiões e e processos de polarização.

"Algunos utilizaron datos para las ciudades, solamen te, omitiendo las industrias rurales; otros usaron datos rurales $y$ urbanos, lo que planteaba el problema de la diferenciación de los tipos de fabricación 
que solo satisfacia las necesstdades locales $y$ los que sirven a mercados más amplios, obteniendo asi in gresos de la región en estudio. R. Hartshorne (1936) abordó el problema suponiendo que diez por ciento de la. población total de una ciudad particlpaba en las actividades industriales locales.

Asi, se consiguieron progresos notables en cuanto a la diferenciación de los componentes băsicos y no bä sicos de la masa de empleados, entendendiändose por "báslcas las actıvidades que producen mercanclas para allende de las necesidades locales, de modo que se ponen a la disposiciōn del intercamblo interregio nal y de la compra de productos o servicios de otras regiones" (19).

Nos estudos das funçōes urbanas, os conceltos de "bāslco" e "näo básico", ainda pouco explorados na literatura geográfica pro duzida no Brasil, podem ser elementos de grande utilidade na caracterização dos mercados-de-trabalho/mão-de-obra.

"Los estudios tradicionales de comunidades, basados en datos de categorias profestonales, publicados en el censo o proporcionados por órganos de empleo, generalmentc son seriamente deficientes en un aspecto: no dan la medida de las actividades bästcas, porque tales datos de categorias profesionales no permiten una claslficación segura de las actividades en térmi nos de las äreas geogräficas en que son vendidas las mercancías y productos de la cludad. El componente local no se puede distinguir del componente mäs fundamental (básico), que sostlene a la cludad. As1, el metodo convencional de medir las "estracturas de medios de vida-aunque estas sean muy informativas- posee una deficiencia clara"(20).

Outra orientação valiosa pode ser encontrada ao se estudar o "método das necessidades minimas".

"El mētodo de las necesidades minimas es un procedimiento substitutivo destinado a la comprensión de la estructura del empleo urbano" ${ }^{(21)}$. 
fica, no gue diz respeito ao problema da caracterização do mercado-de-trabaiho ${ }^{(22)}$.

Resulta dessa breve aprcciação que se fez, a propósito do papel da Geografia na caracterizaçäo sócio-econômica de uma ărea, con vistas a um melhor conheclmento da relação demanda-oferta de mão-de-obra, que é välldo insistir sobre o tema:

18- o crescimento acelerado da cconomia brasiletra, que ainda se realiza sob a forma da relação "centro-periferial, necessita de um suporte diagnosticador quanto à PEA e à força-de-trabalho, inclu sive do ponto de vista qualitativo;

28- o aumento demográfico e a mobilldade da população requerem estudos amplos, Integrados, no que respelta ao mercado-de-traba lho, quanto às demandas atuais e futuras. Esses estudos, no estágio atual, são fragmentários, dispersos, não possibilitando uma perfelta "transparência do mercado", isto é, conhecimento real da demanda e da oferta por parte de empregadores e da mão-de-obra;

38- a "transparência do mercado" não $\bar{e}$, nāo pode ser tarefa de especialistas de uma só ãrea: necessita-se da formação de equipes tecnicarnente preparadas para esses trabalhos. Tudo faz crer que a marginalização dos geōgrafos dessas equipes se traduzirá por una abordagem ou deformada, ou incompleta, ou imediatista, do quadro que diagnostique e que possibilite projeções de demanda-oferta a curto e mëdio prazos;

49- o estudo da "transparencia do mercado" Interessa de perto ao subsisteina de ensino, para que ele possa.

- alterar, quando necessārio, seus planos curriculares,pa ra atender ã formação de técnicos c especialistas, seja a nivel de 18 , de 28 e de 38 graus (este $\bar{c}$ un dos objetivos da educação);

- preparar alunos con formação de base geral e, em parte, com direçöes, habilitações profissionalizantes, treinäveis rapidamente nas empresas;

- não apenas atender às solicitações do mercado, mas provocar o aparecimento de novas demandas.

Cabe relevar que os estudos sobre mercado-de-trabalho/mão -de-obra devem conjugar os esforços dos órgãos governamentais especificos e das escolas.

"Em primeixo lugar, não parece recomendävel que cada
Universidade, isoladamente, se lance à realização de
pesquisas de mercado-de-trabalho, a nivel local ou 
microrregional. Como jä deve estar claro, essas pesquisas têm sërlas limitaçōes. Nos casos em que existe um mexcado geograflcamente bem definido, de dimen sōes razoäveis e para o qual está voltada a maior parte da oferta de mão-de-obra produzida pelos estabelecimentos da região, serta admissfvel que o conjunto das untversidades e Escolas al situadas patrocinasse uma tal pesquisa.

"Outra linha de atuação da ma1or 1mportância seria o incentivo aos Departamentos ou Institutos na área das Clèncias Sociais, como Economia, Sociologia, Psí cologia e de Educação para a realização de estudos e pesquisas sobre a economia regional, a problemātica social e econômica do emprego (o que é distinto de pesquisa de mercado), ......."

"O que se estä pretendendo sugerir é que a universidade não pode e não deve esperar que os órgãos gover namentals lhes digam o que se está passando no seu pröprio mundo. Ao conträr1o, cabe a elas dizer-1hes" (23).

Por último, para delxar bem clara a posição dos estudos geogräflcos, associados aos de outros especialistas, vale apresentar o quadro no 32 , a seguir.

Verifica-se a necessidade do suporte geogräfico quer nas diferentes fases do diagnōstico como na elaboração do plano, ambos enquadrados no "Estudos e Plantfl cação dos Recursos Humanos" (24). 
Conte 192

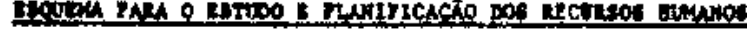
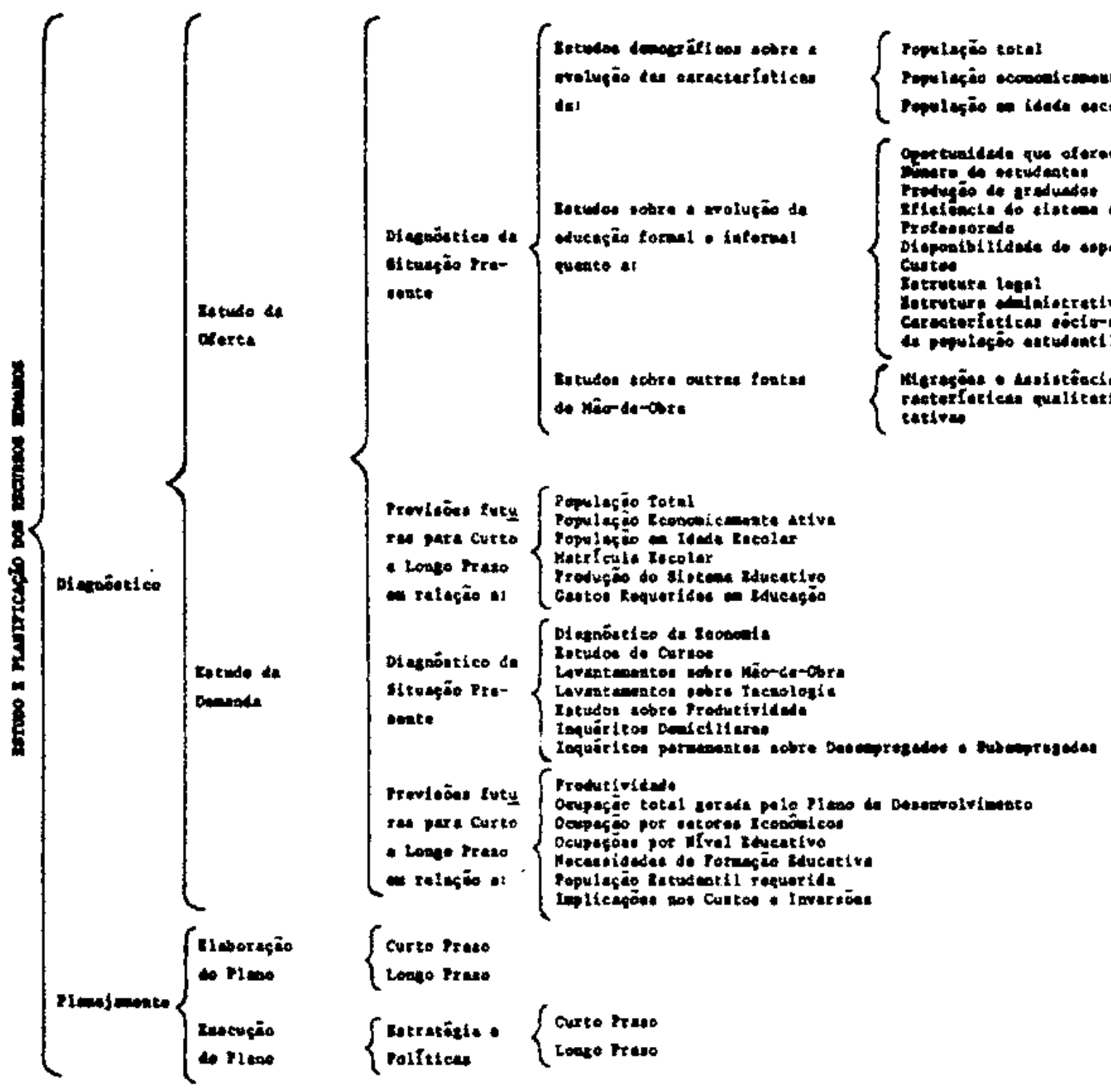


\section{7- Conclusōes Parciats}

18 - o crescimento econômico e o desenvolvimento socilal estão intimamente relacionados com o binômio mercado-de-trabalho/mão-de-obra.

28 - No Brasil os estudos sobre esse binômio ainda se encontram em fase embrionária, não em termos de tempo, mas em termos de metodologia, coordenação, informação, anālise e prospectıva.

39 - A expansão econômica, o crescimento da PEA, a tecnologia, nāo podem prescindir de estudos mals integrados sobre o mercado-de -trabalho e a mão-de-obra.

48 - O sistema de ensino se defasa em relação às necessidades do mercado-de-trabalho por vârias razões, inclustve porque a Esco la se mantém alheta à realidade que deveria procurar configurar.

59 - A Geografla deve e pode contribulr, juntamente com outras āre as de pesquisa, para o estudo mais aprofundado das relações de manda-oferta de mão-de-obra.

69 - A Geografia dispõe de un suporte metodolögico específico para trabalhos dessa natureza.

79 - Para o conhecimento da "transparêncła do mercado", devem somar esforços as autorldades governarentals e as escolas, ressaltan do-se, neste particular, o papel que as Universidades podem de sempenhar na ärea de sua influência. 
NOTAS REFERENTES AO CAPITULO 6

(1) CASE, Earl C. e BERGSMARK, Dantel R. - Geografia General.Regi onal Y Económica - Traducción española de la tercera edición inglesa (1950) por Luis Jordā. Barcelona - España - Ediclones Omega S.A. 1952.

Ver capitulo Primeiro: "El slgnificado geográfico de las rela clones espaciales" - p. 23/38.

(2) OLIVEIRA, Dëcio Rufino de. Recursos Naturais. Fatores Determi nantes na Ocupacão do Territōrlo Brasileiro. Rio de Janeiro -GB - Editora Gondwana Ltda. 1971 - p. 29/37.

(3) DERRUAU, Max- Tratado de Geografia Humana - Traducido por Ra1 mundo Griñó - Barcelona - España - Editorial Vicens - Vives - 1964 .

Ver, particularmente: p. 35/46; p. 107/118; p. $165 / 173$.

(4) MINISTERIO DO PLANEJAMENTO E COORDENAÇÃO GERAL - Projeto do 1 Plano Naclonal do Desenvolvimento Econômico e Social- 1972/74

- Brasilia - DF -Composto e impresso no Serviço Gráfico da Fundação IBGE - 1971.

"O modo brasilelro de organizar o Estado e moldar as institulçōes para, no período de uma geração, transformar o Brasil em naçāo desenvolvida, constitul o modelo brasiletro de desenvolvimento". p. 4

'A Polftica de Integração Social opera no sentido de:

I - Assegurar a partıclpação do trabalhador na expansão da renda nacional.

II - Democratizar o cap1tal das empresas.

III - Impedtr os abusos do poder econōmico.

IV - Expandir os programas de desenvolvimento social,

V - Valorizar as categorias vitais para o desenvolvimento.

VI - Apoiar as categorias de renda minima.

VII - Recuperar as populaçöes marginalizadas"p.2930

(5) ASSIS, Marisa de, et all11. Mercado de trabalho em São Paulo. São Paulo-SP - Cia. Editôra Nacional. Instituto de Pesquisas Econōmlcas - 1972 - p.36

Esse trabalho recente è básico para a consulta de professores, administradores educacionais, planejadores... e geógrafos.

A Parte I: Introdução: Aspectos metodológlcos é valiosa. Igualmente a Parte II; A Força de Trabalho, vale muito como análise do problema. 
(6) HARBISON, Frederick H - Mão-de-obra e desenvolvimento econômico: problemas e estratēg1a. Tradução de Lu1z Pereira, in Desen volvimento, Trabalho e Educacão - Josē Medina Echevarria, et al111. Rio de Jane1ro-GB - Zahar Editores - 1967- p.153

(7) RIBEIRO, Paulo de Assis - Estrutura do Sistema Educacional Bra sileiro - in "A Educacão gue nos convëm" - Rio de Janeiro- GB. APEC Editora S.A. - 1969

o trabalho do professor Paulo Assis Ribeiro é tmportante para se ter uma noção das mültiplas ligações entre sistemas educaç ona1s e mercado-de-trabalho. o artıgo é acompanhado por inúmeras tabelas e gräficos, não apenas relativos ao Brasil, mas referentes a outros paises.

(8) MINISTERIO DO PLANEJAMENTO E COORDENAÇÃO GERAL - op. cit. p.54

(9) MINISTERIO DO TRABALHO E PRTVIDENCIA SOCIAL - Boletim Técnico do SEPT - Rio de Janeiro-GB - Serviço de Estatistica de Previdêncla e Trabalho. IBGE no 21 - Dezembro-1970.

(10) LEI N8 5692/71 - Presidência da Repüblica

(11) MINISTERIO DA EDUCAÇÃO E CULTURA - CONSELHO FEDERAL DE EDUCA ÇÃO - Ensino Supletivo - (Parecer ne 699/72)

Funçöes do Ensino Supletivo - p. $7 / 11$.

(12) LOBO, Thomaz Theaim - Tecnologia e Desenvolvimento, in Brasil Potência - diversos autores - São Paulo-SP. Editora Unitas Ltda. 1971 - p. 333.

(13) CASTRo, Alberto Pereira de - Tecnologia para um país em desenvolvimento, in Brasil Potência. São Paulo-SP. Editora Unttas Ltda. 1971 - p. $319 / 320$.

(13) CASTRO, Alberto Pereira de - op. cit. p. 321/323

(14) LOBO, Thomaz Thedim - op. cit. p. 340.

(15) LOBO, Thomaz Thedim - Transferencia de Tecnologia, in op. c1t. p. $342 / 951$.

(16) UNEsco - El Correo - La espiral del desempleo - Paris- Francia - Año XXIII Febrero - 1970 - p. 28/30

"Tanto el desempleo como el subempleo son resultado de una incapacidad para absorver el grán incremento en la fuerza de trabajo que resulta de la gran acele ración del crecimiento demográfico". 
"En los sectores no agrícolas de los paises de ingre sos bajos uno de los motivos de que las medidas mas amplias de desarrollo no hayan logrado crear oportunidades adecuadas de empleo ha sido, indudablemente, el excessivo estimulo acordado, por una deformación oficial de los costos de los factores, a la adopción de técnicas que exigen muchas maquinas y poca mano de obra. Como ya se dispone de este tipo de tëcnicas en los paises industrializados, los organismos que proporcionan ayuda y los contratistas extranjeros han tendido a transferirla a los demăs países sin so meterla a las necesarlas modificaciones". p. 28

(17) GEORGE, Plerre - Sociologia e Geografla - Tradução de Sërglo M1celi - Rio de Janeiro-GB. Companhla Editora Forense - 1969.

(18) LACOSTE, Yves - Perspectivas da Geograf1a em País Subdesenvolvido - In Geografia Ativa - Pierre George, et allii - São Pau10-SP. - Difusão Europēia do Livro - Editora da Universidade de São Paulo - 1966 - p. $47 / 158$.

(18) ILACOSTE, Yves - op. cit. p. 151/152

(18) LACOSTE, Yves - op. cit. p. 155

(19) HARRIS, Chauncy D. - Mĕtodos de 1nvestigaclón en regionaliza.= ción econōmica, in Centralidade - Reglonalização - Textos Bās cos-1- Rio de Janeiro-GB. Instituto Panamericano de Geografia e Histórja - 1968.

o autor apresenta multas outras valiosas contribuições para es boço de metodologias que visem à anālise do problena em foco. Ver, em especial: p. 56 - "zonas - problema" e item II - "Reg $\underline{i}$ ones de organizaciōn" - p. 56/61.

(20) ALEXANDER, John w. - El concepto bäsico - no bäsico de las fun ciones econömicas urbanas, in Classificacão Functonal das cida des - Textos Básicos-2- Rio de Janeiro-GB. Instituto Panamericano de Geografia e História - 1969.

(21) ULLMFN, Edwara L. e DACEY, M1chael F. - El método de las necesidades minimas en el estudio de la base economica urbana, in Classificacão Funcional das Cidades. Textos Básicos-2- Rio de Janeiro-GB. Instituto Panamericano de Geografia e História - 1969.

(22) CARRIERE, F. P PINCHEMEL, P. - Funcõos banais e específicas, in Classlficação Funcional das cliades - Textos Básicos-2- Rio de 
Janeiro-GB. Instituto Panamericano de Geografia e Historia - 1969.

- trabalho dos dois aut res esclarece a respeito dos métodos econômicos e dos métodos demográficos, empregados pelos geógra fos, para a anāise das funçōes banais e especificas.

os métodos demográficos tèm sido preferidos por permitirem ands facilmente estabelecer-se, inclusive, análises comparativas en tre vărias cidades.

(23) SOUzA, Edson Machado de - Expansão do Enstno Superior e Necessidades do Mercado de Trabalho. Brasilia-DF. - Ministërio da Educação e cultura - 1972 - p.32/37.

(24) CORREA, Arlindo Lopes - Reflexões sobre uma politica de recursos humanos para o Brasil. - Rio de Janeiro-GB. - Ministërio. do Planejamento e Coordenação Geral - IPEA/CNRH - 1971 - p.6. 
$V$ - A FORMACAO DOS GEOGRAFOS E DOS PROFESSORES DE GEOGRAFIA. 
C A P I T U L O

OS CURSOS DE GRADUAÇOO E DE POS-GRADUAÇAO 
1. OS CURSOS DE GRADUACXO E DE POS-GRADUACAO

\section{1 - Objet1ros}

10 - Eroceder à anál1se da colocação dos cursos de Geg grafia, na universidade e nas escolas superiores 1Bo ladas.

28 - Discutir as tendências atuais dos cursos de graduação em Geografia.

39 - Examinar a situação dos cursos de pós-graduação em Geografia.

48 - Veriflcar as possibllidades de formação de professo res de Geografla e de geógrafos que se possam dedi car ao planejamento educacional.

\section{2 - Introdução}

Analisar a problemática de cursos de graduação e de pósgraduação em Geografia é tarefa que deve ser precedida de um estudo sintetizado sobre a universidade. Obviamente se os referidos cursos são parte do conjunto de atividades que se desenvolvem no "sistema" universitārio, deve-se partir da estrutura mais ampla, suas caracte risticas, suas finalidades, sua essêncta, para se chegar à anălise de una parte componente desse "sistema". Justifica-se essa abordagem:

18 - Os conceitos de universidade, no mundo, são variados e, mesmo, contraditörios,

28 - o "fenômeno universtdade", no Brasıl, é recente, debate-se em busca de uma caracterização ampla: a pró pria Reforma Universitäria (li) ainđa não se concre tizou integralmente no Pafs;

39 - os cursos de graduação e os de pós-graduação - como os de Geografia - devem ser analisados à luz de un contexto mats amplo, 1Bto $\dot{e}$, da escola superior. Cer tos autores preferem enfocar o ensino superior como un slstema, tal como o são o ensino de 28 grau $\theta 0$ ensino de 18 grau. O confunto integrarla um siste ma de ordem superior ou "meta-sistema" (2). 
No presente trabalho - a a própria conceituaçāo de sistemas o permite - tem-se considerado todo o ensino como um subsistema, que se liga ao sistema sóclo-polittico-econômico. Alnda a partir da conceituação mesma de sistema, os subsistemas podem ser divididos em partes, que sãó os sub-subsistemas. Em qualquer ângulo que se coloque - analista cabe reconhecer que um sistema è 1ntegrado por unladades IIgadas umas às outras, em constante ação e interação.

o "sistema" universitärio, ou o ensino superior, simplesmente, como parte integrante do subisistema educacional, deve ser o ponto de partida para se descer ao levantamento das caracteristicas dos cursos de graduação e de pós-graduação em Geografta.

\section{3 - A Reforma Univers1tärta}

A Lel no 5540, de 1968, fixou normas de organização e fun clonamento do ensino superior no Brastl. Decorridos quatro anos, ob serva-se que a implantação da reforma atinge graus variados de intensidade e de qualidade, o que não constituł surpresa, por muitas razões dentre as quals podem ser ressaltadas:

18 - o que se convenctonou denominar "crise da untvers1dade" é un fenômeno muito generalizado, ocorrendo na malorla dos palses;

29 - os conceltos vigentes e debatidos sobre a essència, as funções e a estrutura untversitárla, de Igual modo são dispares, não sendo vãlido lmaginar-se "a universidade" como sinônimo de modelo üntco, mas "universidades", que variam extremamente entre s1;

38 - o Brasil carece de tradição universttārla: a rigor a universidade no pals está sendo criada e não récriada, como ocorre em outros centros,

48 - os cursos de nivel superlor, correspondiam a modelos estrangeiros transplantados para a nossa realidade. Aspecto a assinalar: a autononta de gestão desses cursos reflete-se, ainda hofe, numa diflculdade de integração entre os diversos núcleos que devem cọmpor a unfversidade;

58 - os estudos a respelto da organ1zação un1versidade são relativamente recentes no Brasil, já não do ponto de vista axiológico ou teleulög1co, mas operacional. 


\section{A crlse da universidade}

Por certo essa crise nāo è um fenômeno 1solado de um con texto mais anmlo, ou seja, a crlse sóclo-politico-econōmica que ocox re, a rigor, em quase todos os paises. O momento histórlco (1945/dêcada de 70) é de profundas reformulações, reajustamentos, busca de novos caminhos e a universidade, de uma ou de outra forma, reflete sas al teraçōes em gestação ou em processo desencadeado.

A esse fato, por si só capaz de provocar reflexões sobre natureza, essêncta e finalıdades do ensino universitário, acrescente-se o da "explosāo cultural" causado principalmente:

- pelo crescimento demográfico acelerado em värios paises;

- pela multiplicaçāo de novos inventos que transformam os padröes vivenclats e os niveis de aspiração individual e social;

- pelo aumento da escolarização băsica que val conduzir à busca de novos niveis de escolarizaçāo, considerandose o universitärio como meta ültima a atingir;

- pelo aumento dos meios de comunicação de massa.

Os fatos assinalados - e são apenas alguns dentre uma constelação, levam ao questionamento do papel da educação como um todo e do ensino unlversităr1o, como parte do subsistema.

Problemas de natureza vāria são debatidos, tals como:

- qual o limite critico de absorçäo da massa estudantil pe 10 ensino superior?

- dado que "o conhecimento é poder", quais as vinculações da universidade com a estrutura politica? quals os $1 \underline{1}$ mites ldeals de relacionamento universidade-empresa?

- a universidade deve cobrir, abranger todos os ramos do conhecimento, ou deve haver una repartição de especia l1zaçöes entre o complexo universitärio de um pals?

- qual a função da untversidade no que se refere à pes- 
quisa clentifica?

- deve a untversidado apenas responder aos reclamos soc1 als ou, mals quo 1sso, deve ser um "radar soctaln(3) cạ paz do antever as mudanças e trabalhar no sentido de re formular-se, reajustar-se, para comandar as alteraqoos do processo social?

- a universidade tal como hoje é concebla é um modelo ul trapassado, devendo abrir caminho para a multiversidade?

Estas e outras indagaçōes refletem um estäglo de profundo repensar a universidade. parece claro que não haverã uma resposta, mas soluçōes varladas, até mesmo nos estreitos $11 \mathrm{mites}$ de um pafs. Começa, igualmente, a tomar corpo a noção de flexibilldade da estru tura organizacional da universidade, capaz de refazer-se e reajus tar-se e, não mals, constituir uma entidade de tal maneira 1solada e pesada que tenda à desintegração de todo "sistema fechado": morte por entropia, 1sto è, falta de alimentação que resulta do Intercâmbio com outros organismos sociais, no caso.

\section{Os paradoxos da universidade}

As organizações complexas, por certo, engendram paradoxos, conflitos, debates quanto a sua estrutura e finalidades. 0 ens no universitärto é exemplo típlco.

Fugirla ao propósito deste trabalho aprofundar a análise dessas contradiçōes, por isso se buscará uma sintese dos pontos crụ clals, a partir de recente trabalho do professor Newton Sucup1ra(4).

a) o crescimento da universidade, em termos físicos e qualitativos, è uma das causas de sua desagregaçăo, "... a universidade é uma vítima de seu próprio êxito, de seu gigantesco crescimento".

b) A acusação de tradicionalismo, acrescenta-se a acusação de pragmatismo, que delxa em plano secundário a valorização da "alta cultura".

c) Deplora-se a massificaçāo do ensino supertor, ao mes mo tempo em que se luta pela democratização do acesso à universidade. 
d) Dicotonizam-se as correntes que propugnam pela "unida de do saber" (untversidade como repositórto do conhe cimento) e, ao Inverso, pela necessidade de desenvol ver a especialıząão cientifica.

e) A universidade ou deve ser um organismo integrado,co eso ou deve-se partır para a criação de escolas proflssionais, institutos especializados, que não guar dam entre si unidade de propósitos.

f) Enfase maior ao ensino ou à pesquisa?

qual o ponto de equilibrio e de entrosamento entre am bas as atividades que devem ser de natureza 1ntercom plementar?

g) A universidade ou é acusada de conservadorismo ou é atacada por estimular a inovação social e a crítica de valores.

h) A autonomia universitäria debate-se entre:

- controle pübilico ou não;

- Iiberdade acadêmica ou ensino integrado;

- demanda social ou demanda econômica;

- especialização ou polivalência.

i) Preparação de grande massa de estudantes para a vida profissional ou criaçäo de novos conhectmentos.

j) Entrechoque: tensão entre suas 11m.taçöes inst1tucio nais e novas tarefas reclamadas pela clvilizaçāo tec nolögica.

1) De uma ou de outra forma, a massifficação no "ensino untversitärto (ascenção social, profisstonâlizaçao) eg barra com obstāculos:

- Insuficiêncla de pessoal docente habilitado;

- classes muito numerosas;

- relacionamento pedagógico-vivencial (alunos-professores) prejudicado;

- infra-estrutura incapaz de atender à crescente demanda;

- recursos financelros insuficientes. 
m) Democratização = heterogeneldade social do alunado em Institulçōes que se crlaram (e não se reajustaram) pa ra atender à educação de uma "sol-d1sant" el1te.

n) Universidade estätica $x$ universidade que deve acompa nhar, ou estimular, ou provocar:

- novas tecnologias educacionals;

- a organização da pesquisa.

o) O Intelectual solitärio, pesquisando só ou quase só, tem que ser substituido pelo trabalho de equipe, dis pondo de recursos e ambientes especiflcos e de custosa manutençäo.

p) A "universidade-claustro", fechada para o mundo exte rior, deve ser substituida pela universidade que apre sente alto grau de integração e cooperação com a soct edade.

q) Pressão social para molhor atendimento as suas exigèncias ut1litārias. Unl versidade Pressão da juventude que a acu sa de se:vidāo ordem estabelecida.

r) A universidade deve realizar a sintese dialëtica en tre a "orlentação tecnocrát1ca" e a "mag1stratura do espirito". 


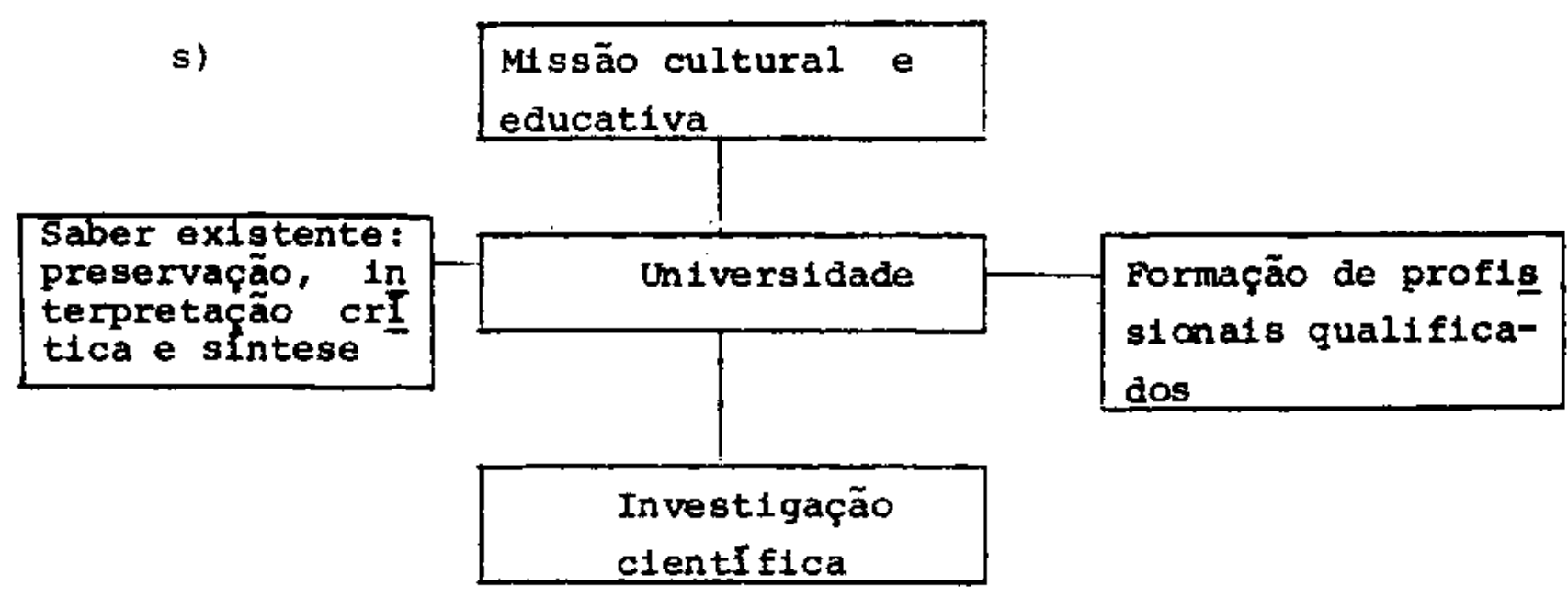

A questão é compatibilizar essas atividades que não se devem antagonizar, mas completar-se.

t) A universidade não è capaz de se pensar (?) diferentemen te da forma por que fol concebida, mas nāo pode sobreviver sem se repensar, face às mudanças sociais.

u) I universidade deve:

- responder a uma demanda social;

- dispor de autonomia no emprego de seus meios e quanto a sua própría organ1 zação;

- constituir um conjunto social onde se organizem relações sociats especificas.

v) Imperioso que a universidade se considere uma empresa cuja finalidade è produzir:

- ciência

- tecnologia

- cultura em geral

Como empresa "sui-generis" não pode fugir aos principlos bäsicos de racionallzação de suas atividades.

x) A "unfversidade-conglomerado" deve ceder lugar à "univer sidade-sistema".

Essa sintese delxa antever que as contradiçōes, as ten sões e os paradoxos que envolvem a universidade, extgem estudos acurados para repensar, reorganizar o ensino superior capacitando-o a não se fossilizar. 
- problema não ẽ típico de paises em desenvolvimento, a questão, muitas vezes, é mais dramätica nos paises de longa tradiধão universitāria (Grã-Bretanha, França, Estados unidos, Alemanha, etc.) necessitam romper com o peso do tradicional1smo, removendo as barrelras que estrangulam o renascimento da universidade.

\section{A universidade no Brasil}

A rigor pode-se dizer que a universidade no Brasil é um "devir" isto ë, apresenta-se en estado de formação, debatendo-se à busca dos modelos que melhor correspondan as nossas realidades e necessidades.

Não hã no Brasil tradição universităria, como na Alemanha (centro de pesquisa); na Grä-Bretanha (preparação aristocrătica das elites); nos Estados unidos (sintese entre a formação de técni $\cos$ e a pesquisa, o culltivo do saber); na França, de que importa mos o mokelo (preparação dos "quadros dirigentes superlores" para a administração nacional).

Originalmente, tiramos a criação de cursos superiores isolados, cuidando basicamente da preparação dos bacharēis ( em direito, primordialmente $e$, em plano secundärio, em medicina e em engenharia). A socledade agrária, latifundiária, nitidamente dual, necessitava de juristas ou simplesmente advogados que culdassem do interesses agrärios e exportadores; em plano mais modesto, de médu cos e de engenheiros que atendessem à classe dirigente, nas clda des a despontar ${ }^{(5)}$.

As transformaçöes no panorama mundial, após 1918, tive ram algum reflexo no Brastl, traduzido por tentativas de novas or entaçöes econômicas. O ensino igualmente passou a ser questionado, mas o de nivel superior permaneceu reflexo do modelo napoleônico: a escola para as elites dixigentes se consolidou.

E conveniente, mals uma vez, deixar claro que a organ 1 zação do ensino superior é uma repercussão da prōpria estrutura so cial, politica e econômica, esta no brasil só comę̧a a sofrer as primeiras alteraçöes mats profundas a partir de $1945^{(6)}$ (7).

Entre a década de 30 e a de 60 , assiste-se à prollfe ração de faculdades isoladas, concentrando maciçamente alunos nos cursos de Filosofia (formação de professores) e de Direlto. 
Quando o Bras1l parte para a reorganização econômica,int ciando a politica de industrlalização que visava a substituir a 1프 portação de bens de consumo, è que se veriflca o crescimento das matriculas nos cursos de engenharla, de economia, de quimica, de geologia, de medicina. O modelo faculdade persistiu. Somente próforma podia-se denominar untversidade ao aglomerado de faculdades a tônomas, com tênues I1gações en torno de uma Re1toria ${ }^{(8)}$.

Mais recentemente, na década de 60 , è que se buscou pas sar do modelo da "universidade paleotfpica" (cátedras e sistema p1 ramidal de administração) para a"universidade neotipica" (organizacão departamental integrada e interligada) (9).

As barreiras a ultrapassar estão identificadas, hoje há un consenso de necessidade de se recriar ou melhor dizendo, criar a untversidade brasileira. Esta não pode ser mals un modelo reflexo d universldades estrangel ras que servem a especificos contextos.

"Os dados estatisticos confirmarão, certamente, que as universtdades produzem essenclalmente os profissionals, os homens de ctêncla e de cultura que são exigidos pela socledade a que pertencem" 10$)$.

A origem dos cursos supertores no Bras11: problemas atuals.

Fol assinalada anteriormente, de forma sintëtica, a or $\underline{1}$ gem, a atomização e a allenação dos cursos de nlvel superior no Brä sil.

A criação de "universidade-prestíg1o", não obstante a Lei no 5540, ainda è um fato no pais(11).

A cristalização de un falso sentido de autonomia pedagọ gica e administrativa, de que a figura do catedrätico (a cátedra fol extinta pela Lei no 5540) era o simbolo máximo, obstaculizou de forma ponderável o esforço da criação da "unıversidade-sistema" que d1fere, no concelto e na organtzação da "universtdade-aglomeração de-escolas".

O ano de 1968 representa um marco importante para a un 1 versidade brasileira, tomada em sentido geral: o anacronismo, a rigidez estrutural, a sua não-correspondēncia às expectativas socials e econômlcas, conduziram-ra a um impasse que se traduziu por uma sérle de estudos, cujo objetivo era propor soluções para a proble mätıca malg que evidenclada. 
- Relatório Melra Matos, as conclusões do Grupo de Traba tho da Reforma Universitárla e a Lei no 5540 abriram caminhos, apon taram deflclênclas, levantaram alternativas para um repensar e um recriar (ou criar, seria mals exato) a universidade no Brasil. Entenda-se o singular "a universidade" não como sinôntmo de modelo único, mas como indicattvo de pressupostos básicos que deveriam or entar as proposiçōes para os diversos modelos de universidade.

E de justica assinalar o pionelrismo da universidade de Brasilia que lançou os germes da Reforma Intversitäria, embora ela pröpria, por motivos conjunturais, tenha sofrido processos de reajustamentos.

Os principlos bäsicos que hoje orlentam as novas modalt dades de estruturas organizactonais, podem ser sintetizadas como segue $^{(12)}$ :

" - Integração estrutural e funcional da universidade ten do por base o principlo de não duplicação dos melos para fins ldênticos ou equivalentes, de modo a assegurar a plena utilização dos recursos empregados em sua manutençāo e funcionamento.

- Concentração dos estudos bäsicos, cientificos e humanisticos, num sistema integrado de unidades, para servir a toda a universtdade.

- Institulção do sistema departamental, concentrandose, em cada departamento todo o pessoal docente e recursos materlais relativos à mesma ärea de conhe cimentos proplciando, assim, as condiçōes para que as atividades didăticas e de pesquisa se realizem no sistema de cooperação.

- Inst1tucionalização das atıvidades interescolares com a crlação de örgãos de coordenação responsáveis pelas atividades de cada curso ou projeto, compreenden do professores de diferentes departamentos $e$ unidades que participam do curso.

- Supervisão dessas atividades ao nIvel da administra ção superior da universidade por melo de órgãos de coordenação central com poderes deliberativos.

- Possibilidade de criação de örgãos setoriais com fun çöes deliberatıvas e execut1vas destinadas a coorde 
nar unidades afins para a integração de suas ativ1dades."

A unidade băsica na estrutura universttária é $\circ$ Departą mento que reunirá professores, 1nstalações e recursos para ministrar cursos que sirvam a vários outros órgãos, sejam eles Institutos ou Faculdades.

Os modelos propostos säo värios e caberä a cada un1vers dade a adoção do que melhor corresponda à sua realidade.

Observe-se a seguir a sērie de modelos, que não se esgotam, mas possibllitam combinaçöes variadas.

GRAFICO NQ 27

ORGATOS BASICOS DA UNTVERSIDADE DE ESTPUTURA TRIPARTIDA

INSTITUTOS CENTRAIS

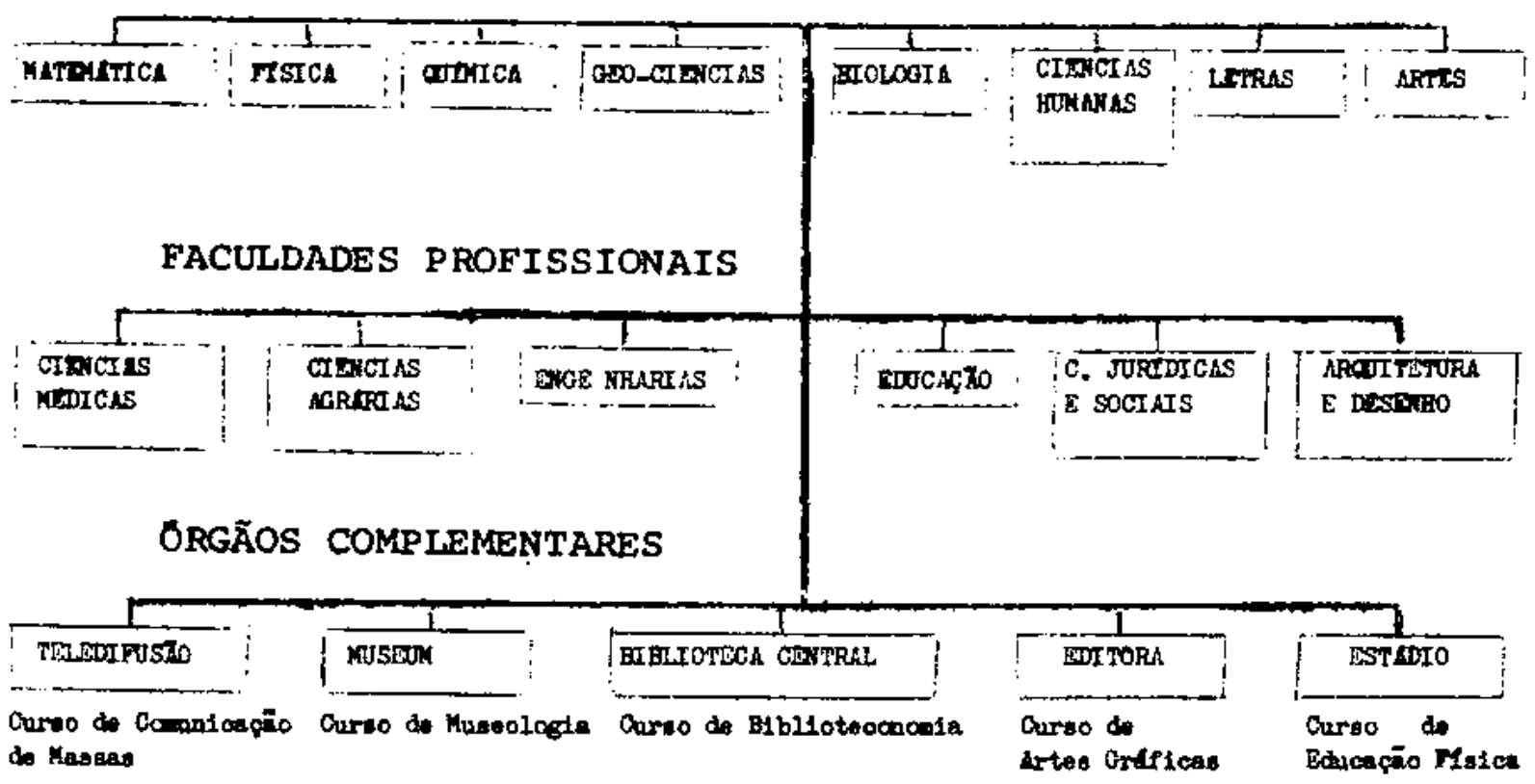

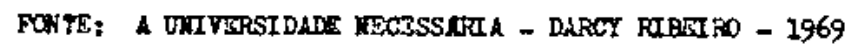


Gráfico no 28

ESQUEMA 1 - FACULdDADS e departamentos

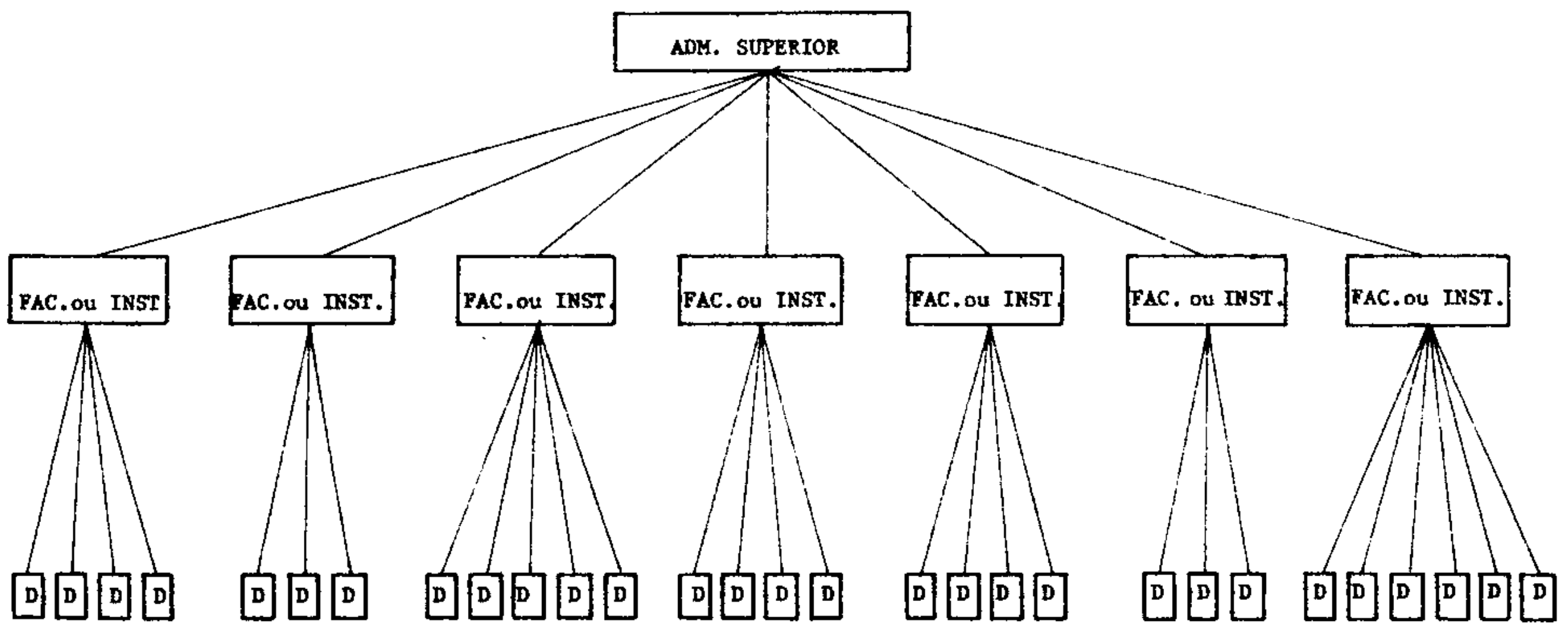

Fonte: A Condiçäo Atual da Universtdade o a Reforma Universitäria Brasılletra -

MEC - Newton Sucup1ra - 1972 
ESQUEMA 11 - ORGAOOS SETORIAIS, FACULDADES E DEPARTAMENTOS

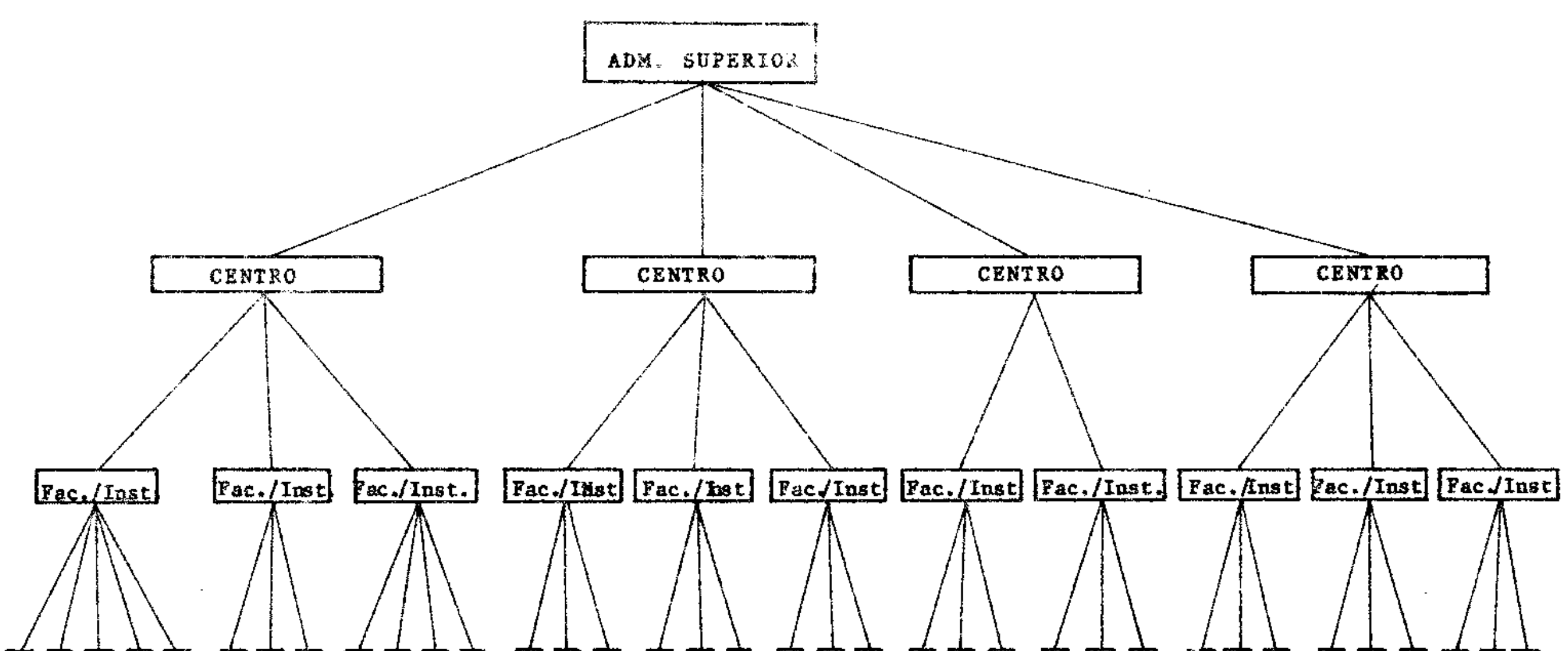

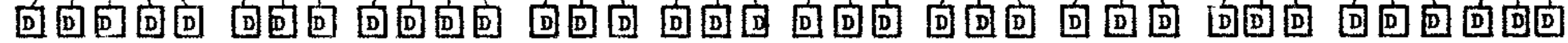

Fonte: A Condicão Atual da Univergidade e a Reforma Univeraitäria Brastleira

MEC - Newton Sucupira - 1972 
Gräfico no 30

ESQUEMA TII - CENTROS E DEPARTAMENTOS

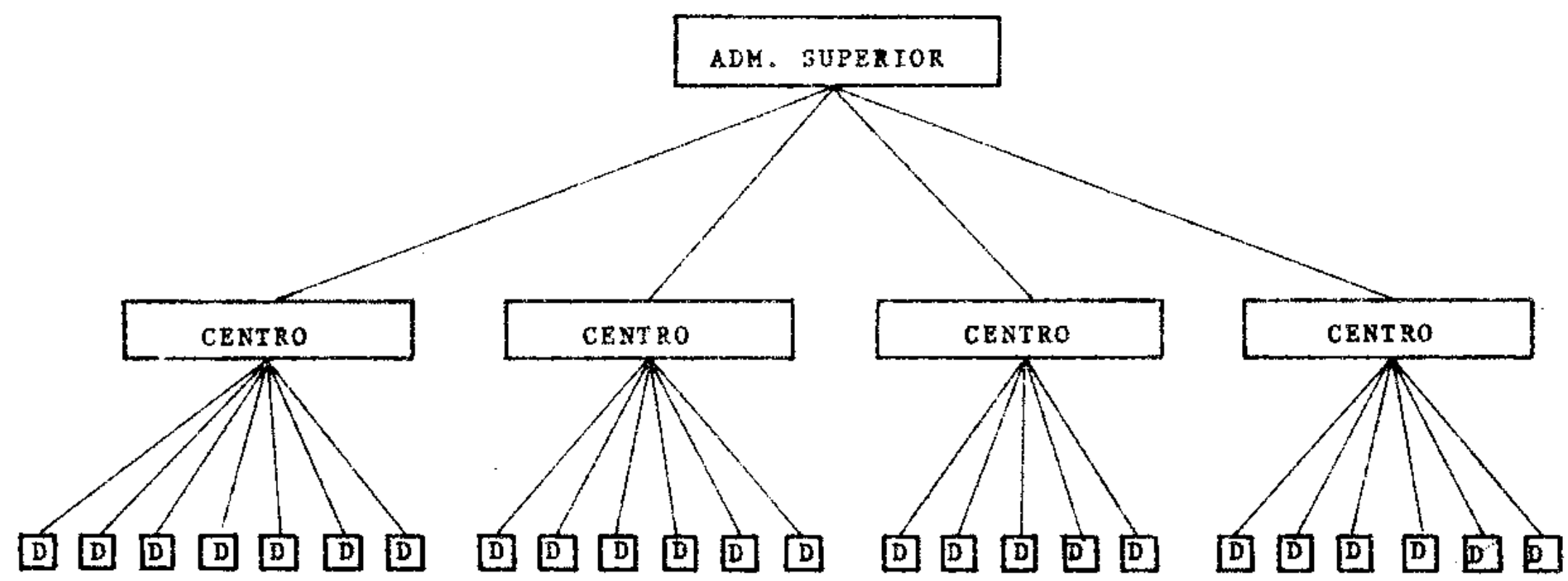

Fonte: A Condicão Atual da Universidade e a Reforma Univergitäría Brastletra

MEC - Newton Sucuptra - 1972 
Gräflco no 31

\section{ESQUEMA IV - DEPARTAMENTOS}

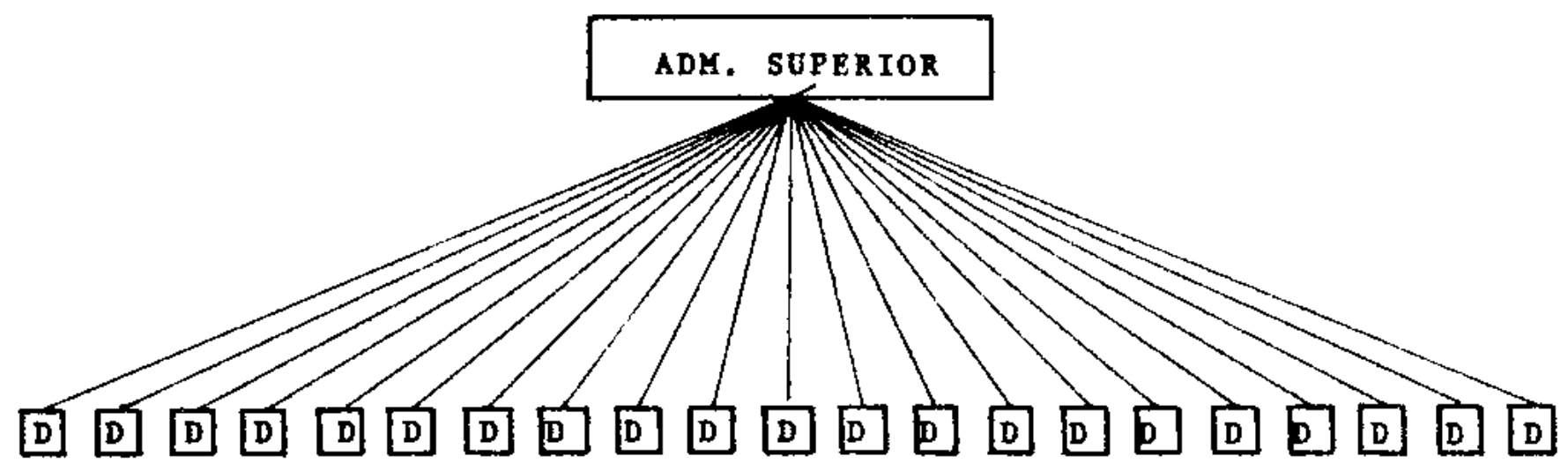

Fonte: A Condicão Atual da Untversidade e a Reforma Univergitäria Brasileira MEC - Newton Sucupira - 1972 
Gräflco ng 32

ESQUEMA $V-M I S T O$

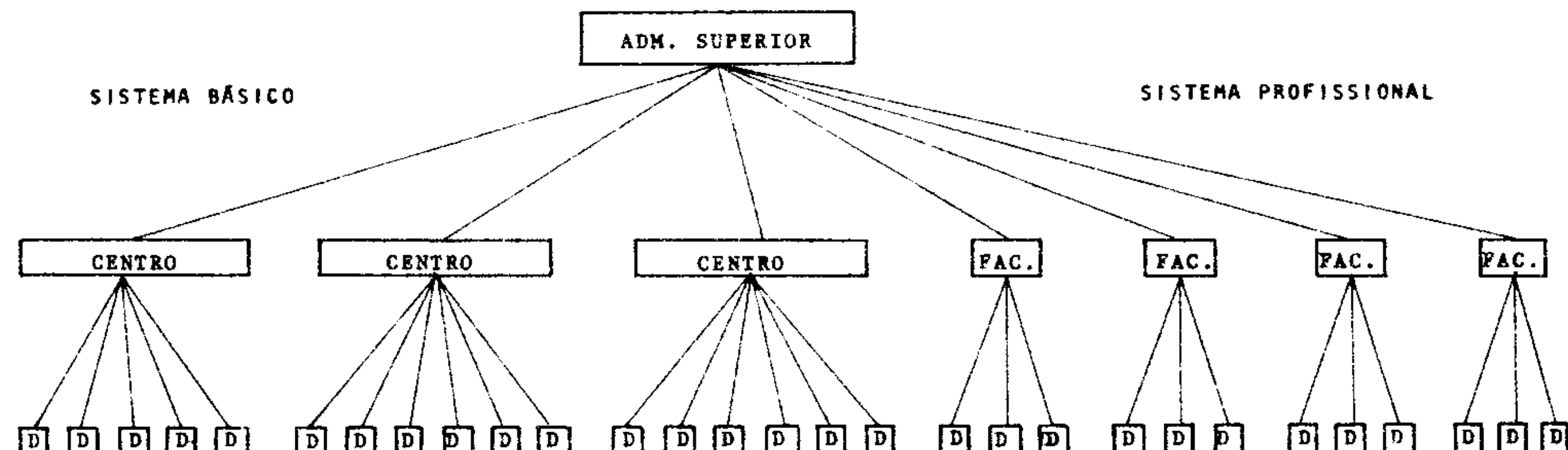

Fonte: A Condicäo Atual da Universidade e a Reforma Untversitäria Brasileira MEC - Newton Sucupira - 1972 
Observam-se nos gráficos de nümeros 27 a 32 , diversas pro posições para a organização geral das universidades. Eviduencia-se que há uma série de formas pelas quais a estrutura organizacional das universidades pode ser delineada. Isto vale para confirmar a idéia de que nöj hă un modelo para a universidade, mas cada umabus carả definlr-se em função de múltıplos variāvels, tals como:

- dimensão da matricula;

- ärea de atuação da untversidade;

- composição de áreas, como por exemplo, tecnológica, bio médica, formação de professores, etc.;

- flexibilidade que possibilite alterações no tempo.

Os grăficos de nümeros 28 a 32 , alëm de demonstrarem 0 que fol assinalado, evidenciam a existência nuclear do Departamento como célula bäsica de todo o conjunto.

\section{Organizacão universttäria: os conceitos de produtividade.}

Foi demonstrado en várias passagens deste trabalho, que são relativamente recentes, no subsistama educacional brasileiro, os conceltos de investimentos, rentabilidade, qualidade do produto fl nal, eficăcia dc processo educativo, relação entre ensino e desenvolvimento, relação entre educação e "renda per-capłta", l1gações entre ensino e mercado-de-trabalho, etc. As causas desse alhe1 amento da educação com relação a outras variāveis, em parte, foram assinaladas e podem ser redutiveis a duas causas bäsicas: falta de conhecimento e prätica das tēcnicas de planejamento e a ilusão de considerar a educação vālida em si mesma, quando ela è un subsiste ma de un sistema aberto.

Só aos poucos começa o subsistema educacional a ser compa rado com uma empresa de natureza e finalidades especificas, é óbvio, mas que deve buscar orlentar-se pelas técnicas de gestão e de opera ção empresarials, a flim de atingir mais rapidamente, mais eficien temente, seus objetivos visando ao clássico e batido: "a maximiza ção de resultados e a minimização de custos".

A Reforma universttäria, entre outros objetivos, tem em mut ra racionalizar as atividades do ensino superior, vez que $\vec{e}$ poss vel considerar o protótipo da universidade brasileira um residuo histörico, nunca um modelo a partir do qual possam ser ajustados oㄴ tros modelos. 
A produtividade em uma "universidade-sistema", tem que le var em conta uma série de fatores que, à primeira vista, sāo repudiados por certos grupos de educadores, sob alegação de que se tra ta de tecnoburocratizar uma atividade por sua própria natureza des vinculada de modelos, parâmetros, instrumentos de avaliação, anâl1se de custos, etc. Evidentemente deve-se levar essa atitude à con ta da desinformação, pois o planejamento universitărlo visa justa mente possibilitar o mäximo de rendimento nas atividades que são inerentes à pröpria universidade:

- formar profissionais qualificados e demandados pelo mex cado-de-trabalho, a fim de evitar o "excedente profissio nal" que conduz aos desvios ocupacionals;

- realizar pesquisas e divulgar os resultados dessas pesquisas que, em parte, devem enriquecer o "know-how" tecnológı́co do pars ;

- conservar, propagar, aumentar o acervo cultural do pais;

- promover a mudança social, através de inúmeras ativida des, das quais a consciêncla crítlca é, tão somente, uma delas.

- "planejamento" universitário, quando realizado na forma empirica, fatalmente conduz a graves e pesadas disfunçōes e perdas, que não são apenas de ordem financelra.

o estudo de situação deve proceder ao trabalho de planeją mento e ressalta, nessa fase, a coleta de informacões que posstb1litem planiflcar sobre dados e não sobre hipóteses.

Helio Pontes ${ }^{(13)}$ alinha como indicadores bäsicos para o diagnóstico os seguintes:

"-corpo docente (lotação, titulação, regime de trabalho, nivel hierārquico, campo de trabalho-área ou disciplina, etc.):

- corpo discente (origem geográfica, caracterização sōcioeconôntca) ;

- corpo técnico e administra+1vo (lotação, funçäo, regime de trabalho, escolaridade, etc.)

- vida acadêmica (disciplinas oferecldas, crëditos, matrí culas por curso, unidades e departamentos, nümero de tur mas, evasão, repetência, candidatos a vestibular, etc.); 
- finanças (recelta: orçamentária, própria, de convênios e despesa: por atividades e projetos, por setores, unida des e departamentos);

- sttuação flsica (prēdios, terrenos, ärea ütil distribuf da em termos de ārea para a administração, laboratōrios de pesquisa e ensino, salas de aula e anfiteatros, gab1netes de professores e alunos, blbliotecas, recreação);

- equipanentos e blbliotecas (relação de equipamentos prin cipais, em termos de preço, sofisticação volume, acervo bibliogräfico: livros e periōdicog);

- região (caracteristicas educacionais, demogräficas e sócio-econômicas)."

A coleta de dados deve constituir atıvidade periódica da universidade ou de cada um dos seus setores, formando um "banco de dacos" que fornecerá os indicadores bäsicos para o planejamento $\odot$ replanejamento.

A partir da anălise da situação devem ser considerados os outros dados do problema que conduzam a um tipo de planefamento vi sando à mäxima produtividade.

Em sintese, no sub-subsistema devem ser levados em conta:

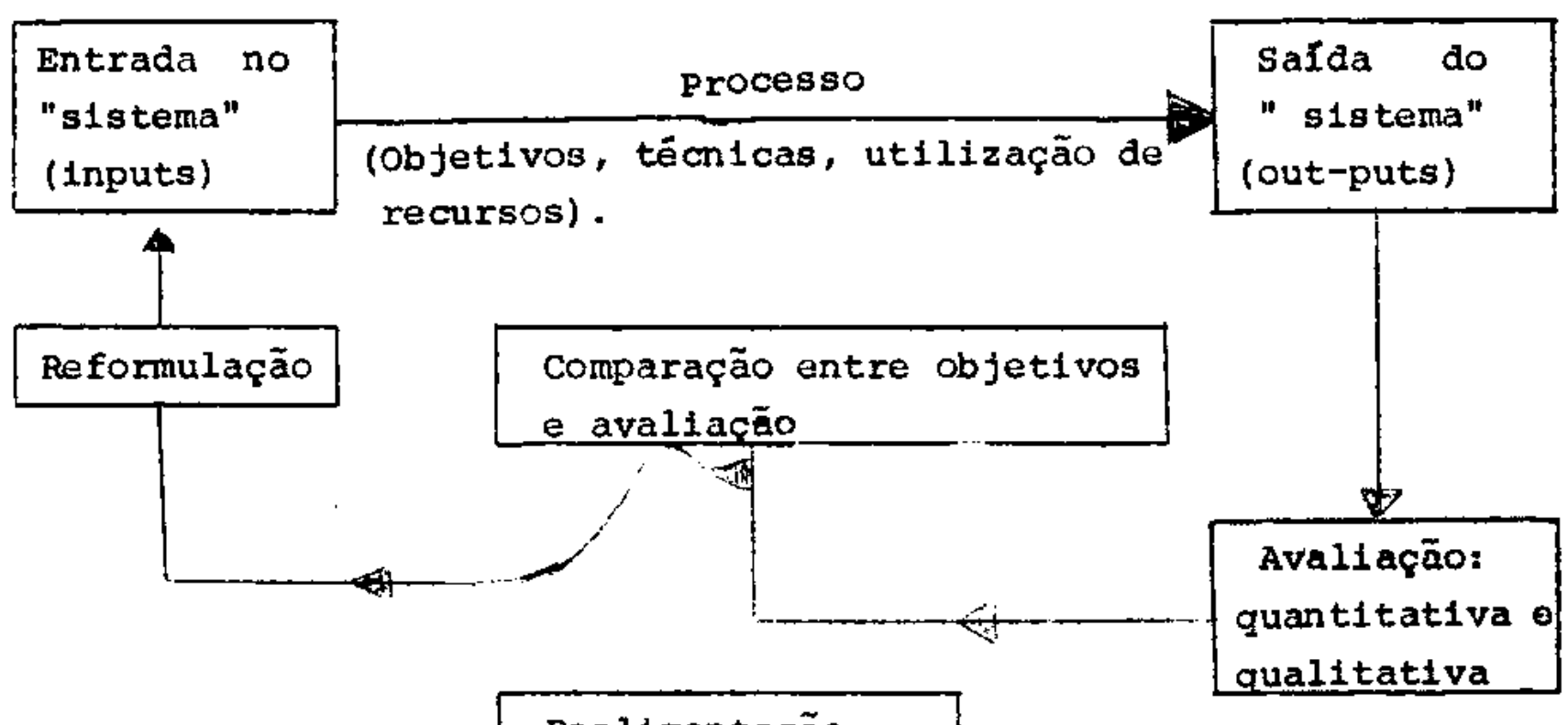

Realimentação

A entrada pode ser descomposta no seguinte: 
- população a escolarizar:

quantidade

gualldade

- recursos

financelros

humanos

fisicos

- processo, que è a transformação dos "inputs", è a fâ se na qual operam diretamente os professores, os alunos, os admi nistradores, de tal forma idealmente identificados quanto à natu reza e as restrições do trabalho a realizar que possam aumentar a produtividade, seja na seleção dos objetivos, na tecnologia em pregada, na utilização dos recursos.

Nesta fase devem incldir todos os esforços docente-disoen tes porque é ela, de forma geral, a que apresenta maiores perdas. As perdas ou subutilização, no caso, se referem a:

- qualidade e quantidade do ensino e da pesquisa;

- reprovaçōes, evasões;

- malbaratamento de recursos;

- formas diversas de ociosidade (de prëdios, equipamentos. tempo, potencial intelectual, etc.)

A saida pode ser compreendida como:

- quantidade e qualidade de profissionais; sua relação com o mercado-de-trabalho;

- quantidade e qualidade das pesquisas e sua utilizaçāo para o crescimento econômico e o desenvolvimento soc1al;

- ação sobre a comunidade.

Esses três elementos: entrada, processo e salda para serem constantemente reformulados e reajustados (sem o que a univer sidade se fossiliza) devem ser submetidos a um constante proces so de avaliaçäo (o que usualmente não se faz) cujos resultados possibilitarão, através de um confronto com expectativas e objetivos alcancados una reformulacão do planejamento.

Sem esse circulto contínuo de alimentacão e realimenta६ão, o sub-subsistema universitário torna-se fechado e tem o destino dos sistemas não-abertos: morte por entropla. 
Em conclusão, sendo a universidade complexa en sua estrutü ra, essêncla e responsabilidade soctal, não pode ser conduzida ama doristicamente ou allenada de seu papel no desenvolvimento social e no crescimento econôntco.

Para tanto não basta a reforma universitäria em termos de estrutura organizacional. E imprescindivel que haja uma conscienti zação por parte de adrinistradores, professores e alunos, sobre a vida un1vers1tär1a como uma etapa da educação permanente - que se pretende atingir - que necessita ser racionalizada, para fac1litar a aprendizagem tendo como base a amorização (14).

\section{4 - A colocacão da Geografia na estrutura universitäria.}

- ensino da Geografla no Bras1l è bastante ant1go, cons1 derando-se, apenas, o ensino formal. Em 1850, o Imperial Colégio de Pedro Segundo previa a inclusão da Geografia, no curso de sete anos, a partır da $2 a$. sērie atē a última (15).

Como não havia cursos especificos de formação de professo res, durante multas dẻcadas o auto-didatismo era a forma de prepa raçăo docente na ärea de Geografia e nas demals.

Sö a partir da Reforma Francisco Campos (1931) começa a se esboçar a criação das Faculdades de Filosofia, Clênclas e Letras, como a de são Paulo e a Faculdade Nacional de Fllosofia (RIo de Jane1ro) (16).

o período de 1939/1946 assistiu a uma prollferaçäo de Faculdades de Filosofia, com o agravante de terem os curriculos e programas Idênticos aos da Nacional.

Lentamente, essas Faculdades acabaram por flcar aquém dos propósttos para os quals haviam sido criadas, reduzindo-se à forma ção exclusivamente de professores.

Com a Reforma Untversitärıa (1968) as orıginals Faculdades de Filosofla, Clênclas e Letras perđeram sua razão de ser: infclou a sua transformação agora que se proporm novos modelos para a orga nização estrutural das universidades.

Nas Faculdades de Filosofia inserlam-se os cursos de Geo grafla e Histōria, com duração de 4 anos para a Licenciatura e de 3 anos para o Bacharelado. Esses cursos que formaram oficlalmente no 
Brasil as primeiras turmas de professores para o ensino médio (gina sial, colegial) guardavam uma sërie de amblgüıdades e deficiências. são exemplos, dentre outros:

- teorl camente eram estruturados para formar professores e pesquisadores que, no caso particular da Geografia, seriam os geōgrafos;

- visavam a licenciar para o magistērio os professores de Histöria e de Geografia, concomitantemente;

- debat1am-se com problemas de carência de pessoal docente de nivel superior, em número suficlente, para atender as suas próprias necessidades.

Já no final da década de 50, e inficio da de 60 , os cursos de Geografia e Histōrla foram desdobrados em dois:

Bacharelado e Licenciatura em História
Bacharelado e Licenclatura em Geografia.

Essa divisão visava a possibilitar aos futuros professores e pesquisadores, um aprofundamento maior nos estudos de graduação, o que não ocorreria anteriormente, quando ambos os cursos estavam fundidos num só.

Para a Geografla não se pode dizer que a situação não tenha aberto novas perspectivas. A partir de então dols aspectos foram positivos:

- alunos e professores podiam dedicar mals tempo aos trabalhos geográficos, porquanto tiveram as horas aumenta das pela supressão das diversas "cadelras" de Histōria;

- cada curso pod a elaborar un plano curricular submetido à apreciação do Conselho Federal de Educação, mas sem as amarras anterlores de reproduzir os programas da Facul dade Nacional de Filosofia.

Dols aspectos, contudo, continuaram entravando melhor desemenho dos cursos de Geografia:

10 - a indefinlção quanto aos objettvos: formar professores e especialistas (geógrafos). No fundo, procuravase uma sintese entre as duas orlentações, mas prevale cla mesmo o encaminhamento dos estudos para a forma ção de professores; 
28 - a qualificação docente. Por un desses paradoxos do ansino no Brasil, havia instituições especlficas para a habilitação dos professores de ensino primärio (Ing t1tutos de Educação, Escolas Norma1s), outros para a habilitação de pessoal para o ensino mëdio (as Facul dades de Filosofia) e nenhuma, ou mesmo nenhum curso especifico de pós-graduação, para habilitar os docen tes das escolas superiores. (Esse assunto será trata do com malor detalhe no capftulo seguinte). Se se acrescentar a esse problema que era solucionado pelo auto-didatismo da maioria (com multos resultados brilhantes, é de assinalar), o outro decorrente da proliferação dos cursos de Geografia, para atender a uma crescente e explosiva demanda de professores nas escolas de nível médio (a década de 60 assistiu a uma verdadelra saturação da capacidade instalada em termos de oferta de vagas), ter-se-à un quadro real, mas pouco positivo, quanto à qualidade dos cursos de gra duação em Geografia.

Por mais esforços que tenham sido fettos, as deficiênclas não eram apenas confunturais, elas eram um reflexo da prōprla estru tura da universidade que, a partir de 1968, se vat alterando.

Na medida em que a "universidade-sistema" seja um fato $e$, mais que 1sso, un fato que revele renovação, melhorla do todo, as partes componentes do conjunto universitário desejavelmente serão beneflciadas.

No ano de 1972 , encontram-se ainda cursos de Geografia colo cados nas Faculdades de Filosofia, Ciências e Letras de algumas un 1 versidades, em outras, a Geografia está nos Institutos de Geocièncí as, na área Tecnológlca; em outras, nos Institutos de Ciências Eu manas e Filosofia.

Nos do1s ültimos casos, tem-se veriflcado divergência profunda de oplniōes quanto à colocação da Geografla na Area de ciências Exatas ou na Area de Ciēncias Humanas.

Como costuma ocorrer, são välidos os argumentos de ambas as correntes e não parece que este seja o problema central a ser resolvido, já que tanto numa como na outra área, o importante é a existênc1a do Departamento de Geografia. Sobre este devem concentrar-se as preocupaçöes. Da estrutura, da organ1zação interna, dos 
currículos, da metodologia, da qualificação do corpo docente, dos re cursos materials e flnancelros, dependerá o Departamento de Geografla para cumprir suas funçãas no âmbito da universidade. A célula: báslca ë o Departamento e sabre ele drvem convergir os cuidados pa ra aumentar sua efictèncta, sua produtividade.

\section{5 - Os cursos de graduacão em Geografia}

o estudo comparativo de curriculos de diversas universidades, na ärea de Geografia (17), revela grande identidade, ao menos no que se refere à seleção das disciplinas, quer as do ciclo bäs 1 $c o$, quer as do ciclo profissionalizante.

Dos planos curriculares consultados, apenas um era mals explicito, mals analitico, indicando de cada disciplina quals os te mas principals, as atıvidades präticas, a orlentação błbllogräfıca. E evidente que a simples análise de uma listagem de disciplinas não possibllita a małs leve 1dentiflcaça da qualidade do curso. possibllitou, 1sso $81 \mathrm{~m}$, concluir que:

18 - o clclo básico foge às características que se the pretendem imprimir, vale dizer, uma fase de identifi cação pelos alunos das possibilldades profissional $\underline{1}$ zantes oferectias pela universidade, ao lado de estu dos băsicos que:

- homogene1zassem uma clientela multo diversificada quanto aos niveis de conheclmento, não obstante a seleção para o ingresso (ela em si mesma discutivel e sob continuadas reformulaçöes nos ültimos três anos);

- oferecessem aos alunos uma v1são panorântca da ärea em que se situan.

o clclo băsico, de forma geral, estä constituido por dís ciplinas que são prë-requisitos umas das outras e prërequisto para o ciclo profissional.

29 - O ciclo profissional ainda não estã suficientemente definido, 1sto é, se visa à formação de professores ou à formação de geógrafos.

Em värios planos curriculares analısados, hã menção ao bacharelado e à licenciatura, sem contudo definir exatamente o que se busca com um e com outro titulo: 
magistério ou atıvidades de gaógrafos. Em outros, a dí ferença de disciplinas que devem levar à docêncla a de disciplinas que procuram preparar o futuro geögrafo é multo tênue, a rigor são praticamente quase as mesmas. Registre-se, mais uma vez, que a analise é prejudicada porquanto se clnglu à comparação dos planos cur riculares e, não, das metodologias, po1s estas, em úl timo caso, è que definirão a qualidade e a orientação dada a um curso.

Tudo faz crer que boa parte dessa indefinłção se deve ao fato de não haver sldo reconheclaa a proflssão de geógrafo, devida mente regulada por le1. O assunto é dabatido há muttos anos e cong titui uma aspiração de multos. Ein capitulo anterior fol feita re ferencla ao fato de existir a "carrelra" de geógrafo e, paradoxalmente à primelra vista, nada haver de definição legal quanto à pro f1ssão a não ser un anteprojeto de lei que tramita na Câmara Fede ral.

Parece que se chegou àquele impasse do "não se faz porque não está regulamentada e não se regulamenta porque não se fez". Será bom que haja definição legal da profissāo, bom mas não imprescin dível. Institucionalızar profissōes, para alguns, è aleatórto, è estar preso a velhos preconceltos de orlgem medieval, quando vigora vam as corporações de oflc1o.

- grande regulador do exercício de uma atividade é o merca do-de-trabalho de par com a qualidade dos recursos humanos.

Vejam-se dois exemplos extremos:

19 - a profissão de economista é regulada legalmente, toda via é mats que evidente a saturação do mercado-de-tra balho. Edson Machado de Souza, compatibllizando estu dos feitos pela Fundação Getúlio Vargas com os resul tados do Censo de 1970 , estima que 48,58 dos economistas não estão no exercício da profissäo ${ }^{(18)}$;

28 - a profissão de sociólogo não é regulamentada por le1 especifica. Não obstante os Cursos de Ciências so ciais não desaparecem, ao conträrio vêm acusando cres cimento de matrículas. E aos egressos de cursos de bom padrão, abre-se o mercado-de-trabalho com relat 1 va facilldade ${ }^{(19)}$. 
QDADRO NQ 33

ENSINOS S D P E R I OR

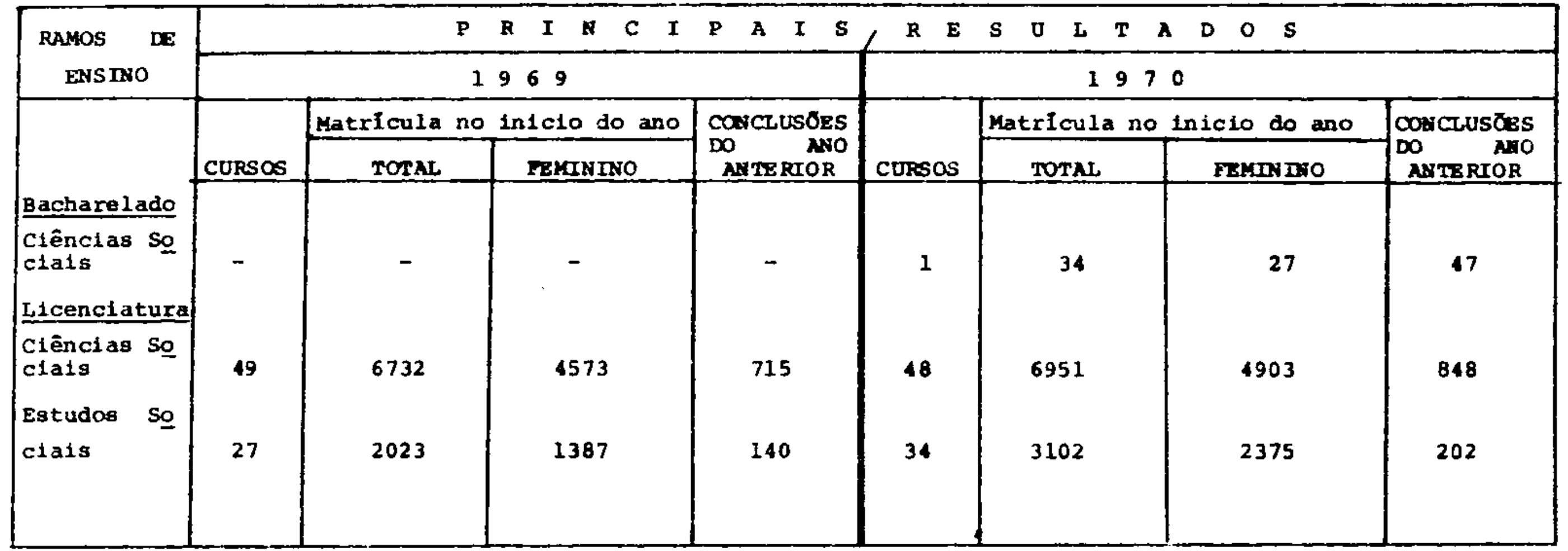

FONTE: Anuārio Estatístico do Brasil - 1971 - Furdação IBGF - IBG 
Assim, parece que os cursos de graduação em Geografia não se definem abertamente pela formação tambēn do geógrafo por un excesso de cautela de não provocar desvios ocupacionals futuros. E fato 1gualmente notörio que o apelo de órgãos governamentais e empresas particulares ao trabalho do geögrafo, até squi tem sido muit to pequeno.

Mas è o caso de uma indagação: o recrutamento é reduzido porque não hä geōgrafos em nünero suflclente, sendo suas funções exercidas, de uma ou de outra forma, por profisstonals como os eco nomistas, os geölogos, os engenheiros, ou é reduzido porque as prô prias untversidades relutam em formar geögrafos, fornecendo ao mer cado-de-trabalho uma 1mpressão pouco lisongelra da 1mportância dos geögrafos para o planejamento?

A unlversidade não pode reagir, com anos de retardamento, às solicitaçöes do mercado-de-trabalio, ela deve, tambēm, prē-agir, forçando o surgimento de novas demandas ${ }^{(20)}$.

No momento em que o ciclo profissional dos cursos de Geografia se definir claramente pela 11cenciatura e pelo bacharelado, não apenas poderão reorlentar-se o plano curricular e as decorren tes metodologias, como estará forçando o mercado-de-trabalho a ace tar a evidêncla da necessidade do geógrafo para as tarefas de plane jamento. O momento parece oportuno para essas definiçōes, não só porque a Reforma Universitáría está em fase de implantação como,por outro lado, o Brasil necessita do concurso de geógrafos.

Os Quadros de n\& 33 e no 34 permitem algumas observações (ver päginas seguintes).

Quanto ao Quadro n8 33 , temos:

18 - Ainda se registra, em 1970, a presença de curso de $1 \underline{\underline{1}}$ cenclatura em Geografla e Histöria;

28 - As matrículas cresceram razoavelmente:

\begin{tabular}{|l|l|l|}
\hline Ano & $\begin{array}{l}\text { Matricula em } \\
\text { cursos } \\
\text { Geografia }\end{array}$ & $\begin{array}{l}\text { Matrícula no } \\
\text { ansino superi } \\
\text { or (*) }\end{array}$ \\
\hline 1968 & 4633 & 276259 \\
1969 & 5537 & 346818 \\
1970 & 6302 & 426081 \\
\hline
\end{tabular}

(*) Fonte: SEEC - MEC - 
Quadro ne 33

CURSOS - GEOGRAFIA - ENSTNO SUPERIOR

\begin{tabular}{|c|c|c|c|c|c|}
\hline \multirow{2}{*}{\multicolumn{2}{|c|}{ ESPECIFICACุÃO }} & \multicolumn{4}{|c|}{1968} \\
\hline & & \multirow{2}{*}{$\begin{array}{c}\text { NQ } \\
\text { Curso }\end{array}$} & \multicolumn{2}{|c|}{ Matr.inicto ano } & \multirow{2}{*}{$\begin{array}{l}\text { Concl. ano } \\
\text { anterior }\end{array}$} \\
\hline & & & Total & Fem. & \\
\hline Parä & (L) & 1 & 12 & 11 & 6 \\
\hline Maranhäo & (L) & 1 & 26 & 17 & 7 \\
\hline Piaui & (L) & 1 & 12 & 11 & 8 \\
\hline Cearä & (L) & 3 & 151 & 89 & 21 \\
\hline R10 G. Norte & $\begin{array}{l}\text { (L) } \\
/ \mathrm{H})\end{array}$ & 1 & 69 & 43 & 9 \\
\hline Paraíba & (L) & 2 & 91 & 83 & 31 \\
\hline Per nambuco & (L) & 2 & 103 & 67 & 11 \\
\hline Alagoas & (L) & 2 & 71 & 41 & 2 \\
\hline Sergipe & (L) & 1 & 18 & 15 & 1 \\
\hline Bahla & (L) & 2 & 144 & 111 & 7 \\
\hline Minas & (L) & 7 & 380 & $24: ?$ & 39 \\
\hline Esp. Santo & (L) & 2 & 189 & 119 & 9 \\
\hline Rio de Janeiro & (L) & 3 & 286 & 164 & 33 \\
\hline Guanabara & (L) & 6 & 430 & 286 & 56 \\
\hline & (B) & & & & \\
\hline são Paulo & (L) & 16 & $1 . .72$ & 991 & 1e? \\
\hline Prraná & (L) & 8 & 603 & 376 & 30 \\
\hline Sta. Catarina & (I) & 3 & 114 & 56 & 4 \\
\hline RIo G. Sul & (L) & 5 & 297 & 270 & 18 \\
\hline Mato Grosso & (L) & 2 & 74 & 54 & 29 \\
\hline Gotăs & (L) & 2 & 91 & 66 & 5 \\
\hline & $/ \mathrm{H})$ & 1 & 101 & 67 & \\
\hline D1str. Fed. & (L) & & & & \\
\hline BRASIL & (B) & & & & \\
\hline & (L) & 70 & 4.633 & 3.112 & 399 \\
\hline & $/ \mathrm{H})$ & 1 & 101 & 67 & \\
\hline
\end{tabular}

FONIE: SEEC-MEC (L) Licenclatura (B) Bacharelato

(G/H) Geografta e Histörıa

(continua) 
(continuaçāo)

Quadro no 33

\begin{tabular}{|c|c|c|c|c|c|}
\hline \multirow{3}{*}{ ESPECIF ICAÇAO } & & \multicolumn{4}{|c|}{$\begin{array}{llll}1 & 9 & 6 & 9\end{array}$} \\
\hline & & \multirow{2}{*}{$\begin{array}{c}\text { No } \\
\text { CURSO }\end{array}$} & \multicolumn{2}{|c|}{ Matr. Inicio ano } & \multirow{2}{*}{$\begin{array}{l}\text { Concl. ano } \\
\text { anterior }\end{array}$} \\
\hline & & & Total & Fen. & \\
\hline Pará & (L) & 2 & 54 & 37 & 20 \\
\hline Maranhão & (L) & 1 & 31 & 19 & 4 \\
\hline Plauf & (L) & 1 & 9 & 8 & 3 \\
\hline Ceará & (L) & 4 & 198 & 125 & 17 \\
\hline \multirow[t]{2}{*}{ R1o G. Norte } & (L) & & & & \\
\hline & $(G / H)$ & 1 & 141 & 110 & \\
\hline Paralba & (L) & 1 & 61 & 56 & \\
\hline Pernambuco & (L) & 2 & 145 & 91 & 12 \\
\hline Alagoas & (L) & 2 & 70 & 46 & 6 \\
\hline Serglpe & (L) & 1 & 24 & 4 & 2 \\
\hline Bahia & (L) & 2 & 212 & 161 & 22 \\
\hline M1nas & (L) & 7 & 459 & 319 & 38 \\
\hline Esp. Santo & (L) & 2 & 230 & 153 & 24 \\
\hline Rio de Janeiro & (L) & 3 & 281 & 181 & 35 \\
\hline \multirow[t]{2}{*}{ Guanabara } & (L) & 4 & 375 & 263 & 65 \\
\hline & (B) & 1 & 115 & 95 & 22 \\
\hline São Paulo & (L) & 16 & 1.827 & 1.257 & 183 \\
\hline Paraná & (L) & 9 & 859 & 543 & 52 \\
\hline Sta. Catarina & (L) & 3 & 137 & 75 & 6 \\
\hline R1o G. do Sul & (L) & 4 & 260 & 234 & $\therefore 0$ \\
\hline Mato Grosso & (L) & 2 & 102 & 24 & \\
\hline Goirs & (L) & 3 & 203 & 143 & 14 \\
\hline & $(G / H)$ & 1 & 11 & 2 & \\
\hline Dist. Federal & (L) & & & & \\
\hline \multirow[t]{3}{*}{ BRASIL } & (B) & 1 & 115 & 95 & 22 \\
\hline & (L) & 69 & 5.537 & 3.739 & 543 \\
\hline & $(G / H)$ & 2 & 152 & 112 & \\
\hline
\end{tabular}

(continua) 
(continuação)

Quadro no 33

\begin{tabular}{|c|c|c|c|c|c|}
\hline \multirow{3}{*}{ ESPECIFICAÇÃO } & & \multicolumn{4}{|c|}{$\begin{array}{llll}1 & 9 & 7 & 0\end{array}$} \\
\hline & & \multirow{2}{*}{$\begin{array}{c}\text { No } \\
\text { CuRSO }\end{array}$} & \multicolumn{2}{|c|}{ Matr. Infclo ano } & \multirow{2}{*}{$\begin{array}{c}\text { Concl. ano } \\
\text { anter tor }\end{array}$} \\
\hline & & & Total & Fem. & \\
\hline Pará & (L) & 2 & 83 & 45 & 6 \\
\hline Maranhão & (L) & 1 & 16 & 14 & 12 \\
\hline Piaui & (L) & 1 & 17 & 8 & 4 \\
\hline Cearā & (L) & 4 & 177 & 105 & 89 \\
\hline Rio G. Norte & $\begin{array}{r}(\mathrm{L}) \\
(\mathrm{G} / \mathrm{H})\end{array}$ & 1 & 43 & 32 & 21 \\
\hline Paraíba & (L) & 1 & 49 & 42 & \\
\hline Pernambuco & (L) & 2 & 158 & 103 & 21 \\
\hline Alagoas & (L) & 2 & 77 & 49 & 36 \\
\hline Serglpe & (L) & 1 & 37 & 29 & 1 \\
\hline Bahia & (L) & 2 & 290 & 249 & 26 \\
\hline Minas & (L) & 7 & 771 & 542 & 59 \\
\hline Esp. Santo & (L) & 2 & 269 & 195 & 21 \\
\hline Rio de Janeiro & (L) & 1 & 102 & 64 & \\
\hline Guanabara & $\begin{array}{l}\text { (L) } \\
\text { (B) }\end{array}$ & 5 & 630 & 475 & 95 \\
\hline säo Paulo & (L) & 16 & 1.937 & 1.394 & 205 \\
\hline Paranã & (L) & 8 & 852 & 577 & 71 \\
\hline Sta. Catarina & (L) & 3 & 132 & 84 & 16 \\
\hline Rio G. do Sul & (L) & 4 & 297 & 271 & 45 \\
\hline Mato Grosso & (L) & 3 & 95 & 52 & 18 \\
\hline Goiās & (I) & 3 & 268 & 212 & 17 \\
\hline & $(G / H)$ & 1 & 27 & 5 & 3 \\
\hline Dist. Federal & (L) & 1 & 10 & 2 & \\
\hline BRASIL & (B) & & & & \\
\hline & (L) & 70 & 6.302 & 4.543 & 763 \\
\hline & $(G / H)$ & 1 & 27 & 5 & 3 \\
\hline
\end{tabular}


Quadro ne 34

CURSOS DE GEOGRAFIA SEGUNDO A DEPENDENCIA

ADMINISTRATIVA POR ESTADOS - 1971

\begin{tabular}{|c|c|c|c|c|c|c|c|}
\hline \multirow{3}{*}{\multicolumn{2}{|c|}{ ESPECIFICACุÃO }} & \multicolumn{3}{|c|}{ TOTAL } & \multicolumn{3}{|c|}{ FEDERAL } \\
\hline & & \multirow{2}{*}{$\begin{array}{c}\text { N9 } \\
\text { Cursos }\end{array}$} & \multicolumn{2}{|c|}{ Corpo Docente } & \multirow{2}{*}{$\begin{array}{c}\text { No } \\
\text { cursos }\end{array}$} & \multicolumn{2}{|c|}{ Corpo Docente } \\
\hline & & & Total & Fem. & & Total & Fem. \\
\hline Pară & $(L)$ & 1 & 12 & 8 & 1 & 12 & $\theta$ \\
\hline Maranhão & $(I)$ & 1 & 4 & 3 & 1 & 4 & 3 \\
\hline Piaul & (I) & 1 & 11. & 3 & 1 & 11 & 3 \\
\hline Ceará & (L) & 4 & 17 & 17 & 1 & 15 & 7 \\
\hline R1o G. Norte & (I) & 2 & 41 & 17 & 2 & 41 & 17 \\
\hline Paraíba & (I) & 2 & 21 & 1.2 & 1 & 16 & 8 \\
\hline Pernambuco & $(L)$ & 2 & 28 & 7 & 1 & 15 & 3 \\
\hline Alagoas & (I) & 3 & 13 & 4 & 3 & 13 & 4 \\
\hline Sergipe & (L) & 1 & 8 & 3 & 1 & 8 & 3 \\
\hline Bahia & (L) & 2 & 62 & 26 & 1 & 50 & 19 \\
\hline Minas Gerais & $(L)$ & 7 & 89 & 31 & 2 & 41 & 9 \\
\hline Esp. Santo & $(\tau)$ & 2 & 31 & 16 & 2 & 16 & 10 \\
\hline Rio de Jan. & (L) & 3 & 38 & 9 & 1 & 20 & 6 \\
\hline Guanabara & (B) & 1 & 24 & 16 & 1 & 24 & 16 \\
\hline Guanahara & (L) & 5 & 67 & 16 & 1 & & \\
\hline são Paulo & (I) & 21 & 253 & 94 & & & \\
\hline Paranä & (L) & 9 & 107 & 33 & 1 & 6 & 3 \\
\hline Sta. Catar. & (L) & 3 & 37 & 16 & 1 & 16 & 12 \\
\hline Rio G. SuI & (n) & 5 & 49 & $3:$ & 2 & 26 & 20 \\
\hline Mato Grosso & $(L)$ & 3 & 19 & 12 & & & \\
\hline Goiās & (I) & 3 & 29 & 9 & 1 & 7 & 1 \\
\hline Dist.Federal & (L) & 2 & 14 & 5 & 1 & 4 & 2 \\
\hline \multirow[t]{2}{*}{ BRASIL } & (B) & 1 & 24 & 6 & 1 & 24 & 6 \\
\hline & (L) & 82 & 980 & 371 & 24 & 321 & 134 \\
\hline
\end{tabular}

FONTE: SEEC MEC

Obs. (L) Licentlatura

(B) Bacharelato 
(continuaçäo)

Quadro no 34

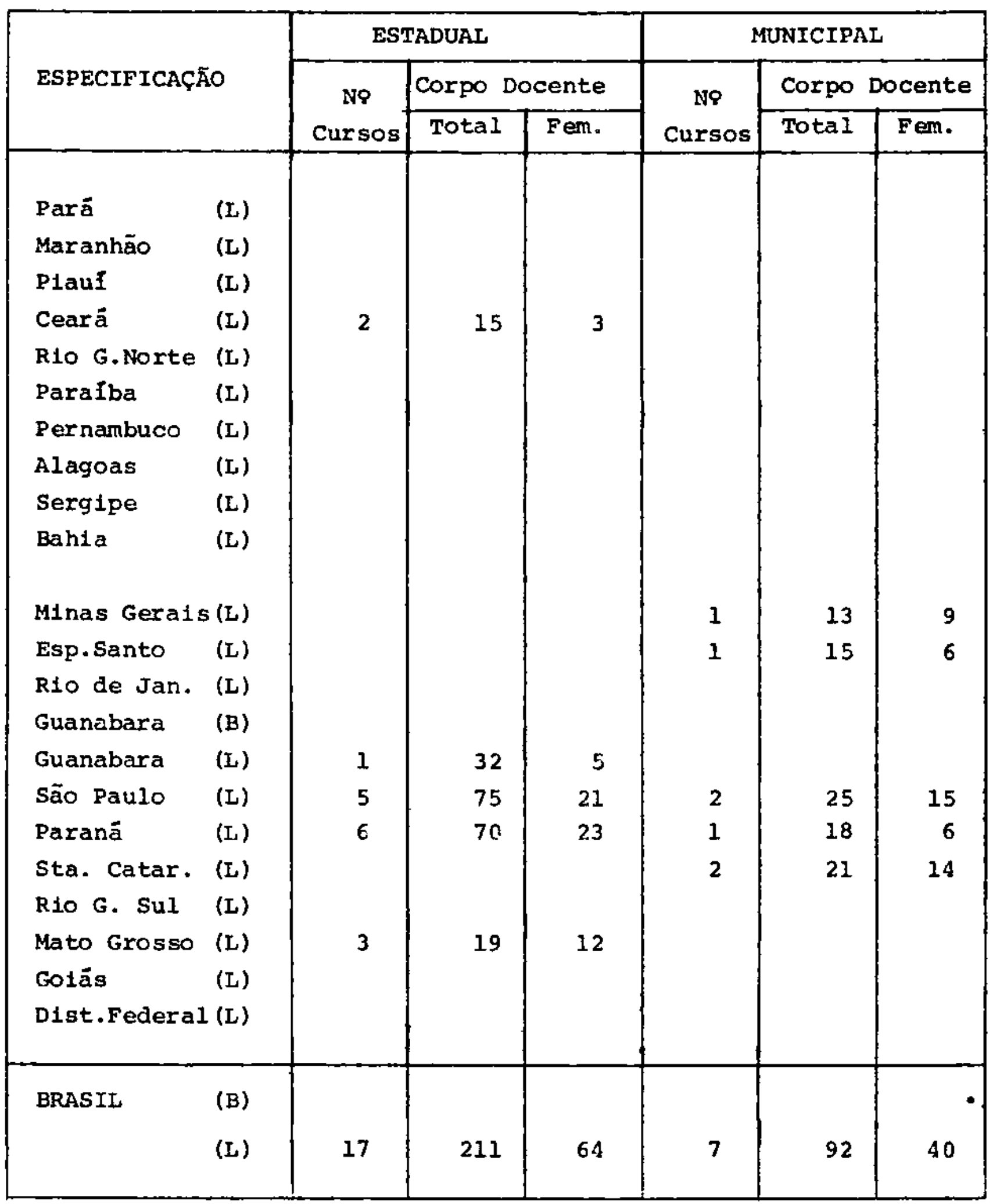

(continua) 
(continuação) Quadro no 34

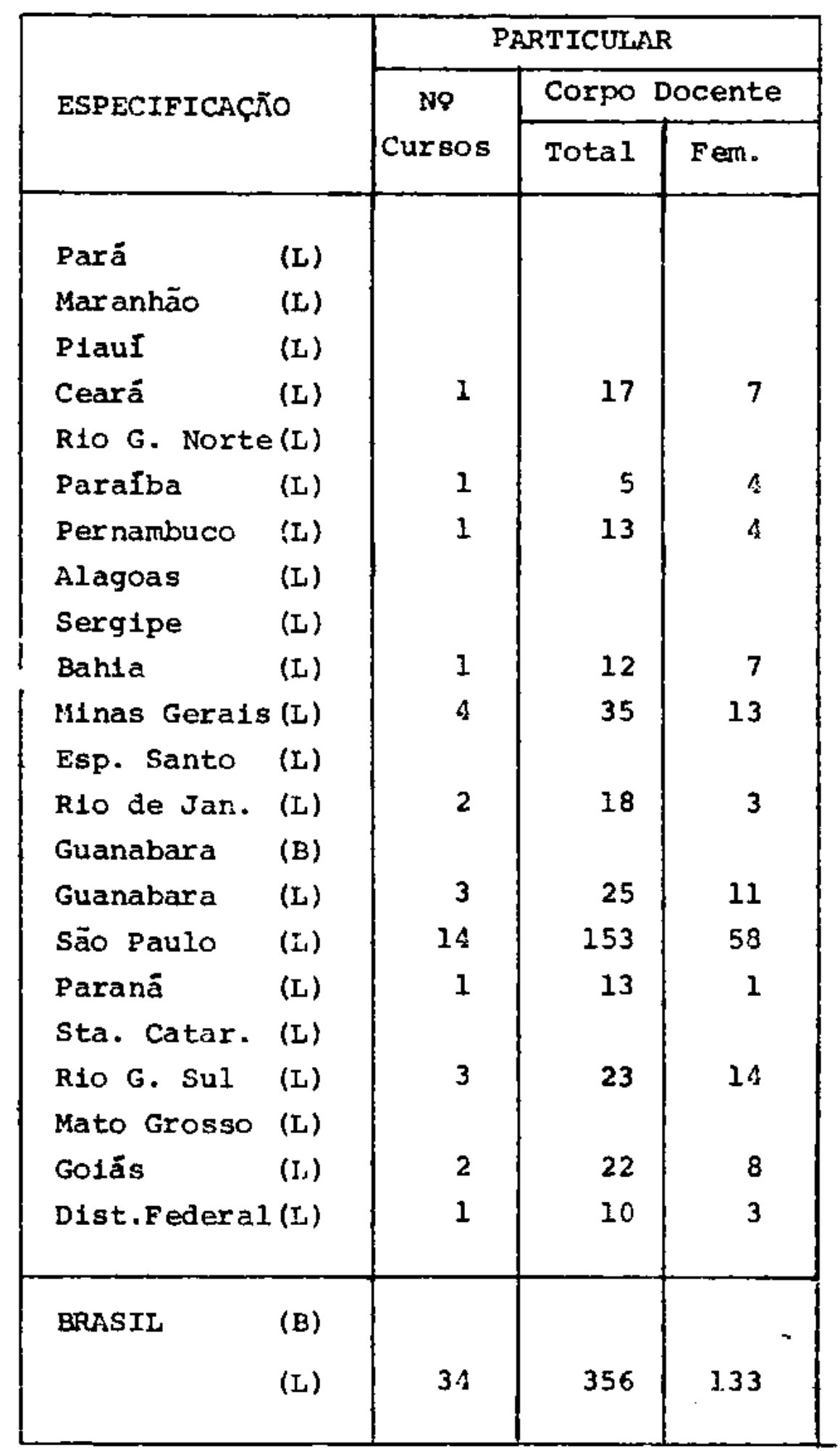


Comparando a matricula nos cursos de Geografia com a matr cula total no ensino superior, constata-se que a porcentagem para a Geografia é de cêrca de $2 \%$, decrescendo percentualmente entre 1968 e 1970;

39 - a presença do elemento feminino, na composição do cox po discente é maxcante, sendo de aproximadamente 708 no ano de 1970;

48 - as conclusões de curso são maciçamente em l1cenclatü ra. Se se entender a licenciatura como a habilitaçāo exclusiva para o exercicio do magistério, constatase a Insigniflcância conferida à formação de geōgra fos;

5 \% - os Estados que acusam matrícula maior são, por ordem decrescente: São Paulo, Paranā, Minas Gerals e Guana bara.

Quanto ao Quadro no 34 sintetizando:

18 - Os cursos de graduação em Geografta são mais numerosos nas Escolas Superiores Particulares -34 que nas Federais - 24, nas Estaduais - 17 e nas Mun1cipais 7 ;

28 - o corpo docente não atinge a 1000 professores: cerca de $33 \%$ são de Escolas Federa1s e cerca de 358 de Escolas Particulares.

Possivelmente o nümero total de docentes em exerciclo não corresponde à realldade, porquanto pode ter ocorrido que o levantamento apresente duplicação de atividades segundo a dependèncla administrativa da $\mathbf{E} \underline{\mathbf{S}}$ cola, vale dizer, professores que lecionam em Escola Federal e Estadual, em Escola Federal e Particular,etc.

38 - os Estados com maior número de cursos de Geografin são, por ordem docrescente: são Paulo, Paranä, Mlnas Gerais e Guanabara;

48 - o corpo docente feminino representa 388 do total.

1.6 - Nova perspectiva para os cursos de graduacão em Geografia

A Lei no 5692/71 provocará a curto e a médlo prazos, alte 
raçōes nos cursos de graduaçäo em Geografia, vez que Pareceres do CFE em complementação ao texto legal, se referem à matéria ESTUDos SOCIAIS para o ensino de 18 grau e à GEOGRAFIA COMO disciplina para o ensino de 28 grau. (Paxecer no 853/71).

- Parecer e Resolução do Conselho Federal de Educação (Resolução 1/72) (20), Indicam a necessidade da formação do professor polivalente em Estudos Soclais para o ensino de 19 Grau. Tal professor não seră um especialista em Geografia, ou em História ou em ciências Sociais, mas deverá tex uma visão globalizada das três ãreas, fundindo-as nos Estudos socials. Anteriormente, em 11cencla tura de curta duração, já se fazia, embora timidamente, a prepara ção do professor polivalente em Estudos Soclais, tal como, por exem plo, na Untversidade de Passo Fundo (RS) e na Unlversidade Federal do pará.

Agora, face ao parecer e à Resolução cltados, mais cedo ou mais tarde, as Unfversidades deverão cuidar dessa habilitação que prevê:

18 - minimo de 1200 horas para a Licenciatura de Curta Dú ração em Estudos Socials;

28 - minimo de 2200 horas para a Licenciatura Plena em Geo grafia, em História, em ciênclas sociais.

Buscando equilibrar as tendênclas e a realldade da Le1, o autor propôs ao Reitor da Universidade Federal Fluminense a forma ção de um Grupo de Trabalho que redefiniră a orlentação dos cursos de Geografia.

As tdêias básıcas são as que seguem:

19 - o ciclo básico deverá ter cerca de 1500 horas, prepa rando o professor polivalente em Estudos Socials, para exercício do magistërio nas escolas de $18 \mathrm{grau}$. Aproxlmadamente 500 horas seriam dedicadas ao estudo da Geografia, 300 horas para a formação pedagógica e 700 horas para os estudos de Histōria e outras ciên clas Sociais. As 1500 horas poderão ser 1ntegraliza das num periodo de um ano e melo a dols anos, quando - aluno terá fetto o curso bäsłco, podendo, legalmen te, ingressar no mercado-de-trabalho: 
28 - apōs esse ciclo básico que è igualmente profissionali zante, os alunos poderão obter a licenciatura plena, que terä a duração de mals 1300 a 1400 horas. Ao término do ciclo básłco, os alunos deveräo estar em con dlçōes de optar pela licenclatura plena ou em Geogra fia, ou em História, ou em Ciências Socials.

No caso especifico de Geografia, prevê-se que cerca de 508 das horas destinadas à complementação da licenciatura sejam destina das ao aprofundamento dos estudos em disclplinas especificas da area da Geografia, constituindo-se num segundo suporte de conhecimentos comuns a todos os alunos. Para os restantes 508, os alunos poderão optar pela profissionallzação no magistërio de 29 grau ou pelo ramo que os habilite ao exerclclo das funções de geögrafo. Nes ta ultima parte do curso, portanto, as disciplinas e as respect五 vas metodologlas serão diversas, conforme se destinem à preparação do futuro professor de 28 grau ou do futuro geōgrafo.

A Idéia graficamente aparece a seguir.

\section{GRAFICO NO 33}

Reestruturação proposta para os cursos de građuação, na Universldade Federal Fluminense, nas áreas de Geografia, Histōrla e cienclas Sociais.

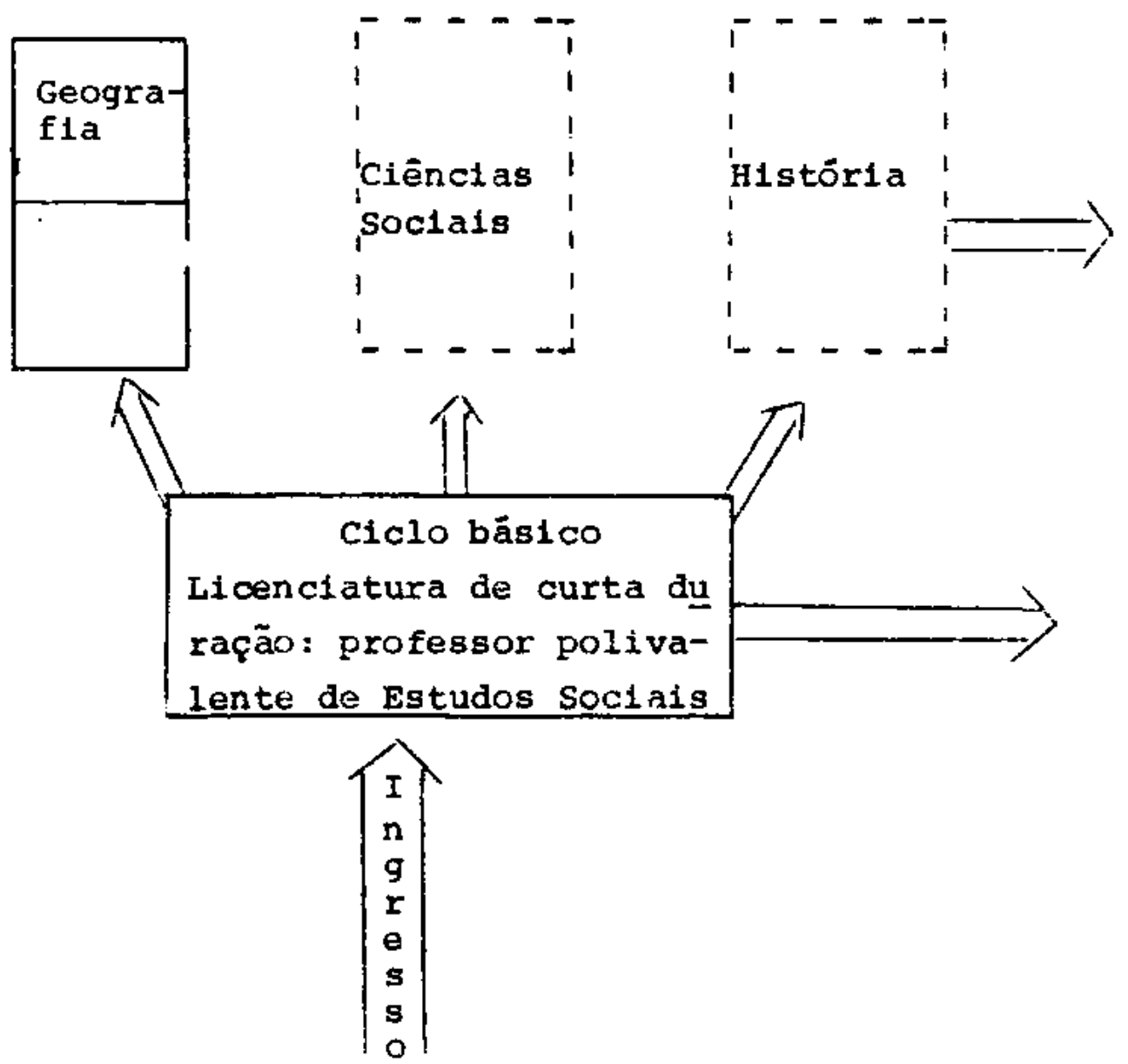

2a. etapa $1300 / 1400$ horas. Licencia tura plena, ou bacharelado

1a. etapa 1500 horas 
Destacando do conjunto representado no Gräfico no 34 a par te relativa à Geografla, teriamos a seguinte representação.

\section{GRAFICO NO 34}

2a. etapa: Curso de graduação em Geografia:

650 a 700 horas. Habıl1t tação: Pro fessor de Geogra fia: 28 grau.

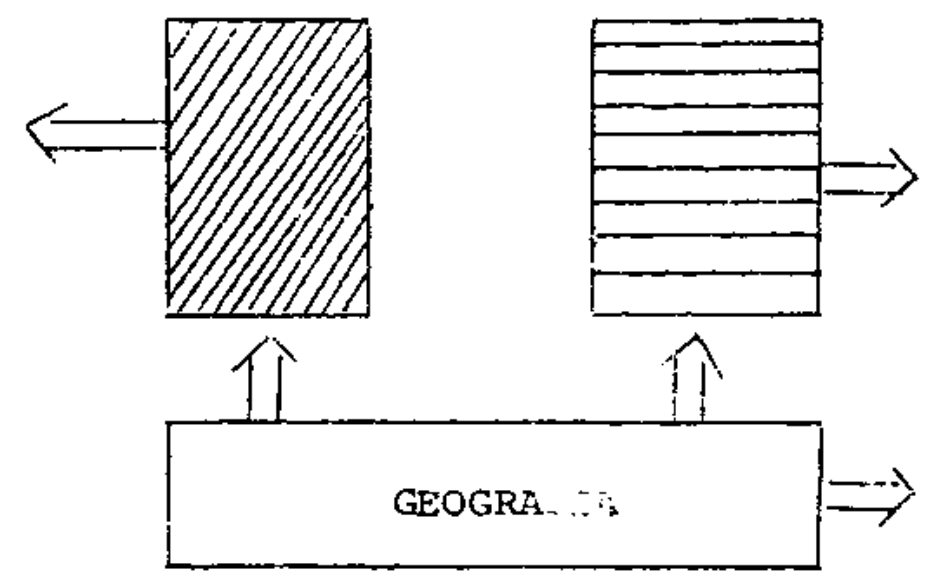

650 a 700 ho ras. Habilita ção: Geógrafō

650 a 700 horas. Bástco da $2 \mathrm{a}$. etapa

Essa proposição parece apresentar as seguintes vantagens:

1a. - profissionaliza nais rapidamente os alunos que ingressain ra universidade, abrindo-lhes a perspectiva de um mercedo-de-trabalho en continuada expansão: 0 magistério de 18 grau;

2a. - na fase inicial (1500 horas) oferece ao aluno uma visão integrada e tnterligada da Geografla, de rilstö ria, de Ciências Sociais e de Pedagogia, que serão indispensáveis para o seu trabalho no ensino de 19 grau. Igualmente essa formação básica poderá vir a ser altamente valiosa para o aprofundamento nos est느 dos geogrä́icos que contarão com urn suporte minimo de outras ciênclas socłais;

3a. - possiblitia aos alunos uma 2 a. etapa de estudos co muns, antes que eles façam a opção pelo magistērio de 29 grau ou pela habilitação como geógrafo. Essa 2a. etapa de estudos comuns poderá permitir ao aluno que jä esteja lecionando autovaltar-se em relação ao seu desempenho e aptidão para o magistēr1o, assim como ter uma visão do mercado-de-trabalho quanto ao ensino de 28 grau ou quanto à demanda de geógrafos. Feita a opção, se oferecerã aos alunos o aprofunda mento de estudos necessários para alcançar razoável 
cflciência, seja como professor de 29 grau, seja co mo geögrafo;

4a. - em qualquer tempo, apōs conclulda a l1cenclatura ple na, se o entäo proflssional se achar deslocado em suas at1vidades e desejar mudar de profissão, como se observa na representaçäo gräflca a segulr,

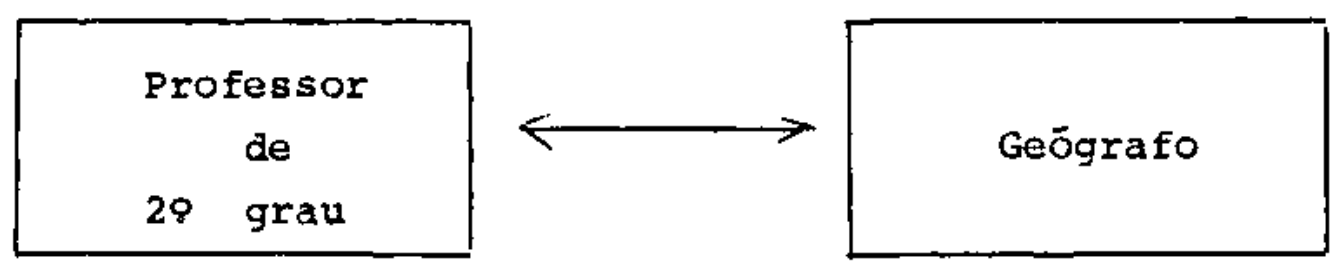

bastará que ele cumpra os créditos necessärios para obter nova habilitação, ou seja, complete con mais 650 ou 700 horas, na undversidade, a parte que the falta para a outra habilitação (ou geógrafo ou professor de 28 grau).

Se essas podem ser algumas vantagens, a reformulação esque maticamente representada demandará uma completa e necessária) reor ganização curricular e, principalmente, metodológica.

\section{7 - os cursos de graduacão e o planejamento educacional apot- ado na Geografta.}

A Lese procura demonstrar que o planejamento educacional no Brasil deve apolar-se nas contribulções da Geografia, o que até agora multo raramente tem ocorrido. Parece evidente que não se graduará alunos em Geografia para atuarem futuramente no planojamento educacional, assim como seria absurdo habilitar o futuro professor já esperando que ele fosse um especialista (?) em Geografla do Brasil ou em Geografia Humana, por exemplo. De igual mane1ra, o curso de građuação para geögrafos deve procurax fornecer aos futuros pro fissionals un embasamento multivalente, cuja tônica fosse represen tada pela técnica de trabalho de campo, trabalhos de gabinete, tra balhos em equipes interdisciplinares.

A organização, o currículo, a metodologia de um curso de Geografia que: 
- ensine os alunos a estudar:

- capac1te os alunos a "ponsar geograficamente";

- habilite os alunos a realizar trabalhos práticos de cam po e trabalhos teórico-práticos em sala;

- habilite os alunos ao trabalho com alunos de outras areas (H1störla, Sociologia, Economia, por exemplo);

- prepare os alunos para fazer estudos regionals e elaborar monografias;

- Inicie os alunos nos trabalhos com modelos e análises de sistemas,

estará preparando futuros profissionals de razoável gabarito.

Um professor de ensino de 18 ou de 28 graus assim formado, possívelmente será capaz, atuando em sua escola:

18 - de elaborar diagnósticos regionais (c1dade, microrrcgião, por exemplo) que forneçam subsidios para:

- montagem do plano curricular da escola,

- estabelecimento de estratēgias operativas em relação à comunidade;

- anälise do mercado-de-trabalho;

29 - de atualizar periodicamente a Carta Escolar do Distrí to Educacional.

- geögrafo, se formado com orientação aproxtmadamente 1dên tica à do professor, sendo mals treinado para os trabalhos de pesquisa de campo e de gabinete, igualmente poderá cooperar no planejamento educacional, seja a nivel de Escola, ou de Municipio, ou de Secretarla de Educação.

Evidentemente se desejar o aprofundamento nos estudos de Geografla aplicada ao planejamento educaional, o geógrafo deverá buscar essa especiallzação em cursos do pōs-graduação.

Em conclusão: na medida em que os cursos de graduação em Geografia aumentem sua eficiência, que se traduzirá na habilitação de profissionais mals capacitados a pensar e a atuar com "espirito geó gráfico", o planejamento educacional muito poderá se valer do trabọ lho desses profissionals, o que tem ocorrido, até o presente, é o mütuo desconhecimento do potenclal e das necessidades do ambos: 0 professor de Geografia e o geógrafo ainda não alertados para o pa pel que poderão desempenhar no planejamento educacional; por outro 
lado, os planificadores da educação pouco suspettaram da possibil dade de se aliarem aos professores de Geografia e aos geográfos pa ra produzirem planos e projetos mais realistlcos.

\section{8 - os cursos de pós-graduação}

Os cursos de pós-graduaçäo pođen ser enquadrados em dols grandes sub-tipos:

18 - pós-graduação de sentido geral, que compreende tc do tipo de curso de especialização, atualização e/ou aperfelçoamento, ministrado por escola superior ou ent1dade de reconhecida capacidade (Fundaçäo Getülio Vargas, Instituto Brasileiro de Geografia, por exemplo). As caracteristicas, a duração, os temas aborda dos, são de natureza văria, dependendo dos propósí tos do örgão que ministra o curso. Após a Lei no 5540 é que foram definidos os diversos tipos de cursos de pós-graduação "latu sensu" ;

28 - pös-graduação em sentido estrito, que compreende os cursos de Mestrado e Doutorado. Esses foram apreciados pelo Conselho Federal de Educação, em 1965, que lhes definiu a armlitude, natureza, fixando normas para sua organização e funcionamento. (Antes de 1965 ao que consta, somente a iniversidade de são paulo mantinha cursos dessa natureza, na ärea de Geografia).

Os primeiros têm sido ministrados no Brasil de forma mals ou menos constante por alguns örgäos (ver caso dos "cursos de férias" do IBG), ou ocasionalmente, quando se revelam necessidades prementes de retrelnamento de professores (cursos patrocinados por Secretarlas de Educação, de ma1s recente ocorrência) Atnda cabem ressa categoria, os cursos de especialização oferecidos por uma ou outra universidade, quase sempre de duração curta.

Os cursos de pós-graduação "stricto sensu" se impuseram co mo uma necessidade para formar pesquisadores e docentes que já não podlam ser apenas auto-didatas ou aperfeiçoar-se en cursos răpidos. o desenvolvimento da pesquisa a das tecnologias educacionals esta rla gravemente afetado se não fossem abertos os cursos de Mestrado e Doutorado. E de justiça ressaltar o trabalho desenvolvido nas dẹ cadas de 30 e de 40 , pela Universidade de são paulo e pela Faculda 
de Nacional de Filosofia quando trouxeram värios professores estran geiros para ministração de cursos na área da Geografia. Fol uma so lução adequada para a época e que produziu resultados satisfatórios e, em certos casos, altamente satisfatórios.

A sua Inexistêncla no Brasil conduz a duas consequências:

1a. - o fosso tecnológico entre o Brasil e outros palses se aprofundava mats e mals;

2a. - o graduado que desejasse especiallzar-se, buscava cursos no exterior. Esses cursos podem apresentar duas faces:

- a posttiva, porquanto suprem uma deficiencia em nọ sa estrutura untversıtária;

- a negativa, na medida em que se constituem no pri meiro passo para a "evasão de cérebros", 18to ē, o pös-graduado que näo volta ao Brasil, ou volta por um breve periodo, radicando-se depols no exterlor.

Face a essas evidênclas, não só foram regulamentados os cur sos de pós-graduação, como, pouco depols, foram criados os centros Regiona1s de Pós-graduação ${ }^{(21)}$.

Para fazer face ao problema da manutenção dos candidatos acs cursos de pós-graduação, cuidaram os órgãos educacionais de prever recursos para a concessão de bolsas-de-estudo.

Os Quadros de nos. 35. 36 e 37 posslb1litam veriflcar 0 número de beneficlados pelo CNPQ, pela FAPESP, pela CAPES. (Ver päginas seguintes).

Do Quadro no 35 é interessante observar o crescimento do nümero de pös-graduados no Bxasil (84, em 1966 - 601 em 1971) e o crescimento menos acentuado de bolsas para pós-graduação no exter1 or (77, em 1966 - 133, em 1971), pelo CNPQ.

Do Quadro no 36 vale ressaltar:

18 - o aumento verificado em concessão de bolsas pela FAPESP para Mestrado e Doutorado, entre os anos de 1966 e 1971).

29 - que a concessão de bolsas para pesquisa no Brasil fol bastante maior que a concessão de bolsas para o exterior. 
Do quadro no 37, veriflca-se, no caso especifico de bolsas concedidas pela CAPES para Ciências humanas, Econômicas e Soclais (onde possivelmente estariam enquadrados os da ärea de Geografia) , que a oscilação fol grande de ano para ano, representando em 1970 cerca de $1 / 3$ do total computado em 1966.

E conveniente ressaltar que os três exemplos anal isados nö constituem as unicas fontes de concessäo de bolsas para estudos da pós-graduação. Ainda mals: hă professores e pesquisadores que fazem cursos de pôs-graduação, sem recorrer a bolsas.

Mais do que o número de beneficlados pelas bolsas de estụ do, importa considerar o valor da bolsa. Como, de forma geral, para cursos no Brasil, o valor mensal oscila em torno de Cr $\$ 1.000,00$, is to tem constituldo um fator limitante para que muitos possan fre qtentar os cursos de Mestrado e Doutorado.

A explicação é fácil, no caso de Geografia, conforme pode ser constatado: o professor que jä se graduou hā $3,4,5$ ou mala anos, assumiu uma sêrie de compromissos profissionals, socials e financelros que o impedem de abandonar por um ou dois anos parte de suas at1vidades para se dedicar ao kestrado ou ao Doutorado.

o valor da bolsa, muito frequentemente, não cobre o seu "deficit" salarial.

Este fato tem impedido que muitos profissionals da ärea de Goografia se aperfelçoem como desejartam, e como seria, em vários casos, impertoso que o fizossem para melhorar sua eficlencia no ensino ou na posquisa. Escapan a essa contigencia poucos que tên tempo integral em universidade, e dedicando parte desse tempo para as ativiciades do Mestrado su do Doutoradn.

Caso näo haja um mecanismo corretor na concessão e no vaIor da bolsa de estudo, corre-se o risco de o Mostrado, em primeira fase, ser apanägio de alguns recēm-egressos do curso de graduação an Geografia. 
Quadro no 35

CONSELHO NACIONAL DE PESQUISAS

(CNPq)

CONCESSÃO DE BOLSAS DE ESTUDO E PESQUISA

PERIODO $1966-1971$

\begin{tabular}{|c|c|c|c|c|c|c|c|}
\hline MODALIDADES & 1966 & 1967 & 1968 & 1969 & 1970 & $1971^{\star}$ & TOTAL \\
\hline Iniciação Cientifica & 619 & 751 & 704 & 655 & 666 & 537 & 3.932 \\
\hline Aperfeicoamento & 175 & 227 & 330 & 572 & 572 & 183 & 2.059 \\
\hline Pōs-Graduação no País & 84 & 117 & 172 & 275 & 564 & 601 & 1.806 \\
\hline Pós-Graduação no Exterıor & 77 & 97 & 110 & 154 & 153 & 133 & 724 \\
\hline Pesquisador Assistente & 125 & 125 & 152 & 239 & 371 & 219 & 1.231 \\
\hline Pesquisador & 53 & 63 & 67 & 97 & 145 & 91 & 516 \\
\hline Chefe de Pesquisa & 27 & 33 & 37 & 60 & 63 & 62 & 282 \\
\hline Pesquisador Conferenclsta & - & - & 164 & 90 & 166 & 188 & 608 \\
\hline TOTAL & 1.160 & 1.406 & 1.736 & 2.143 & 2.700 & 2.014 & 11.158 \\
\hline
\end{tabular}

FONTE: Relatór108 anuais do CNPq - in Desenvolvimento da Educacão no Brasil - MEC - 1971.

- (até o mês de setembro). 
Quadro n? 36

FUNDAÇÃo DE AMPARO A PESQUISA DO ESTIDO DE SÃo PAULO

(FAPESP)

CONCESST̃O DE BOLSAS DE PESQUISA

NO PERIODO DE 1966-1971

\begin{tabular}{|c|c|c|c|c|c|c|c|}
\hline MODALIDÄDES & 1966 & 1967 & 1968 & 1969 & 1970 & $1971 *$ & TOTAL \\
\hline Inicłação Cientifica & 121 & 155 & 183 & 233 & 262 & 249 & 1.203 \\
\hline Aperfeicoamento ou Mestrado & 66 & 104 & 155 & 209 & 276 & 385 & 1.195 \\
\hline Doutoramento & 29 & 38 & 46 & 41 & $\Delta 1$ & 65 & 260 \\
\hline Pesquisa & 17 & 17 & 23 & 33 & 16 & 13 & 119 \\
\hline Pesquisador-Chefe & 6 & 1 & $\dot{s}$ & 1 & - & - & 12 \\
\hline Complementą̧ão & 13 & 28 & 14 & 4 & - & - & 59 \\
\hline Espectal & - & - & - & - & - & - & - \\
\hline Bolsas no Exterior & 15 & 29 & 91 & 110 & 104 & 79 & 428 \\
\hline TOTAL & 245 & 361 & 482 & 604 & 699 & 791 & 3.276 \\
\hline
\end{tabular}

FONTE: Relatórıos anuais da FAPESP, In Desenvolvımento da Educação no Brasil - MEC - 1971.

- (até o mês de setembro) 


\section{Quadro No 37}

CAPES

BOLSAS DE ESTUDO CONCEDIDAS NO PERIODO DE 1966-1970

(Inclusive auxilios individuals)

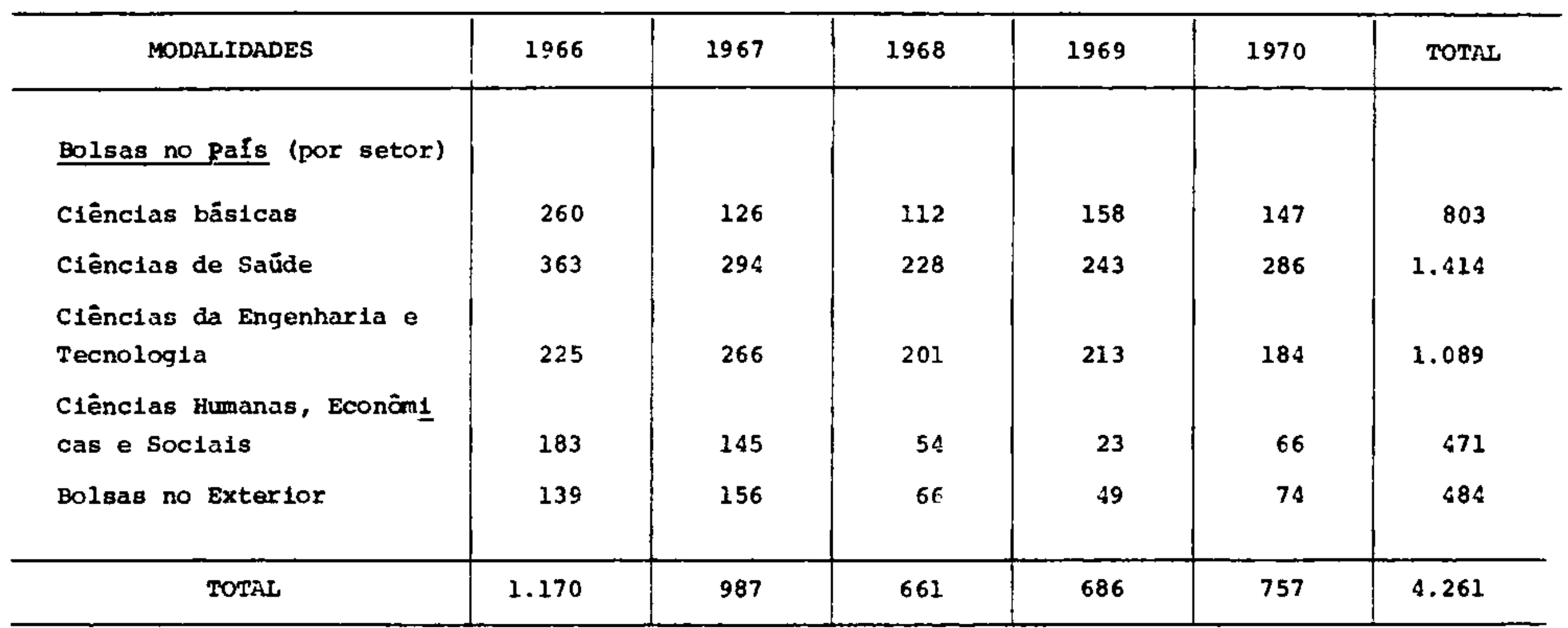

FONre: Relatór 1os anuals da CAPES, in Degenvolvimento da Educacāo no Brasıl - MEC - 1971. 
Ora, è sabido ser a pōs-graduação um tipo de curso de alto custo e que deve se destinar a uma parcela apenas dos soaciacos que justifiquem $\circ$ investimento atravēs de un efeito-reprodutivo, se ja na docência, seja na pesquisa ou en ambos, como é desejável.

Uma das mültiplas exigências para o t.ngresco nos cursos de Mestrado deverla ser o tempo de vivência profissional efetiva, cono por exemplo, de três a cinco anos, no minimo. Esse tipo de canaidato se beneficiara de umi curso de Mestrado porque aliare a cutras gra IIficações exigidas, a sua expertēncia profissional.

Se o Mestrado se restringir aos gue poden dispor de tenpo e de recursos, vale dizer, aos que ainda não estão no exercício pleno de suas atividades profissionais, terminari por se constituir num simples prolongamento do curso de graduaç̃o. Se ssco ocorrer, ata a qualidade mesma dos cursos de graduação pode baixzx, pois re tera a certeza do prossegutriento le estudos no iestrado. 0 ex siplo jo aue ocorreu nos Estados Unidos deveria ser considerado para incorrer no erro lá constatado(22).

E de esperar-se que, uma vez organizacios os centros $\mathrm{R}$ aglonais de Pós-graduação, a ārea de Geografia possa regisirar un aumento de vagas nos cirsos de Mestrado e Doutorado. Caso 1sto não oco:ra, juntamente com as providências para seieção da çindidatos ance riormente sugeridas, o ensino e a pesquisa en Gcogratia estarão ca plano modesto comparativamente às demais disciplinas.

\section{9 - Os cursos de pös - graduação e o planejanento educacional apoiado na Geografia}

Procurou-se mostrar que é factível, nos cursos inesmos de graduação formar profissionals (professores e geögrafos) que, não obstante certas linitaçōes, podem cooperar pira os trabalhos de plą nejamento educacional, em nível mais simples.

Ao conträrio, desełando se professores e/ou geögratos que possam trabalhar na ärea do planejamento educacional mais complexo, a sua formação deverä operar-se a nivel de Mestrado e Doutorado.

Cabe observar que, nesse caso, ambos os tipus cie pós-gra duação deveriam estar na área da Educação. Essa, ern se tratando de Planejamento Educacional, não deve restringir o acesso eos portado res de diplomas de graduaçăo em Pedagogia, exclusivame te. Contra rianente, ao lado desses, seria valioso que fossen aceitos graduados em Economia, en Sociologia, em Geografia, em Matemätica, em Medicina, etc. I planificação educacional a nível de Estaco, ou de macrorre gião, ou federal, não è tarefa para sex enfrentara exclusivamente por 
pedagogos. Ela necessita do concurso de profissionals de qualifica ção varlada, de equipes multiaisciplinares.

A planificação educacional não deve e não pode ter um sen tido estritamente pedagógico, vez que ela tem envolvimentos sanitários, econômicos, estatisticos, demogräficos, geográficos, sociolōgicos, politicos, administrativos, etc. O macroplanejarento educacional sem o concurso de especialistas diversos tem conduztdo a gra ves distorções no equacionamento e na proposição de estratégtas ten dentes a superar um dos pontos de estrangulamento da economia e do desenvolvimento social no Brasil: a questão educacional.

\subsection{0 - Conclusōes parciais}

1. - Os cursos de graduação e de pös-graduação en Geografla não apresentam problemas solucionăvets por s1 mesmos: inserem -se na questão mais ampla e profunda da Reforma Universitäria.

2. - A "crise da untversidade" não é especifica do Brasil, ela ocorre em värlos outros países. As soluçōes buscadas para a problemātıca universitārta brasileira, se não são atipicas, devem orlentar-se pelo quadro das necessidades brastleiras.

3. - A Reforma Universitärıa visa a Implantar efetivamente no país, a "universıdade-sistema", cuja cēlula bäsıca è o De partamento.

4. - 0 aumento da produtividade no ensino superior ē uma das metas a se alcançar a curto prazo.

5. - Os cursos de graduação en Geografia só começaram a ser mais eficientes a partir do momento que se desmembra ram dos antigos cursos que englobavam a Geografia e a Hig tória.

6: - Os cursos de Geografia, atē o presente, salvo poucas exce ções, tem se voltado mais para a habilıtação de docentes que de pesquisadores (geögrafos).

7?. - A Lei no 5.692 repercutirā, a curto e a mëd1o prazos, na organizaçäo dos cursos de Geografia, na Universidade.

8. - Os cursos de pös-graduação, jā reformulados oftcialmente, precisam ser reajustados en certos aspectos e ampliados, no que se refere à Geografia.

9. - Tanto nos cursos de graduação, como nos de pós-graduação, é possivel habilitar profissionais (professores e geógrafos) que possam se aplicar inclusive nos trabalhos de pla nejamento educacional. 


\section{NOTAS REFERENTES NO CAPITULO 1}

(1) - A Lei que define a Reforma Universitár1a data de 1968 (Lei no $5.530)$.

(2) - GUIMnRÃES, Magda Soares - Produtividade do Ensino Superior Brasilia-DF. Ministērio da Educação e Cultura - I Encontro de Reitores das Untversidades püblicas - 1972 - p. 8-18.

(3) - PEURSEN, C.A. van - O Futuro da Universidade - Traduçāo de Cristiano 01ticica, in PAZ e TERRA, no 2 - Rio de Janeiro-GB. p. 7-43.

0 estudo do autor è interessante pelas colocações teleoló gicas e pelas Indagaçōes pragmäticas que faz.

A leitura do artigo deve ser completada pelo estudo sobre o mesmo, felto por Pierre Furter, na mesma Revista, p.45-50.

Furter, na anālise do artıgo, delxa como 1nđagações:

18 - atē onde a confusão entre caräter operacional do conhecí mento não estā se convortendo en "operacionalismon, como alnôntro de prarmatismo estrelto?

28 - quando se tomarā consciència de que "a educação è un modo de aprender a organizar dados e tambén a $\mathbf{s} 1$ próprio?" Essa posição levará fatalmente a dar malor 1mportâncla à pedagogla e não ao currículo, aos métodos didáticos e não às disclplinas;

38 - como transformar a universidade em agêncla de educação permanente, reduzindo-se o estägio iniclal de aprendizagem básica?

48 - mais que una responsabilidade moral, atë onde pode se con figurar a responsabilidade politica da universidade?

(4) - SUCUPIRA, Newton - A Condicão Atual da Universidade e a Refor ma Universttäria Brasileira-Brasflia-DF. Ministërio da Educa ção e Cultura - I Encontro de Reitores das Universidades Pü blicas - 1972 - p. 4-34.

(5) - MORAIS, Pessoa de - Soclologia da Revolucão Brasileira - Rio de Janeiro-GB. Editora Leitura S.A. - 1965.

Ver a respeito o capitulo "o Bacharel, o professor e a Re volução" - p. 81-95. 
(6) - Gonçalves, Suzana - Estrutura da Universidade, in A Educacão que nos convém - Rio de Janeiro-GB. APEC Editora S.A. - 1969 p. 83-92.

"O desenvolvimento è, em grande parte, o produto da trans formação da vida soclal pela presença de um nivel sufictente de capacidade cientifica e tecnológlca. A grande revolução contemporânea è a revolução pela ciència. Assim sendo, as so cledades prë-cientificas são destltuidas de vigor e da capac1 dade de orlentar o seu processo de desenvolvimenton. p. 83.

(7) - RIBEIRo, Darcy - A Univer sidade Necessär1a - R10 de JaneiroGB. Editora Paz e Terra - 1969.

"Todas as grandes estruturas untversitärlas do mundo moderno poder ser definidas como produtos residuals da vida de seus povos, scmente inteligiveis coro resultantes de seguên clas histöricas singulares. Elas são, na verdade, subprodu tos reflexos de un desenvolvimento social global que não se fez a partir da universidade e para o qual ela contribulu se cundärlamente. Pelo conträr1o, este desenvolvimento, uma vez alcançado, atuou sobre as universidades, provendo-as de recur sos e sxigindo-lhes novos serviços.

As nações abdesenvolvidas cabe enfrentar a tarefa total mente distinta de criar uma universidade que seja capaz de a tuar como motor do desenvolvimento". p. 31.

(8) - SUCUPIRA, Newton - op. c1t. p. 34.

(9) - Gonçalves, Suzana - op. cit. p. 90.

(10)- LOPES, J. Leite - Ciêncla e Libertacão - Rio de Janeiro-GB. $\underline{E}$ ditora Paz e Terra S.A. - 1969 - p. 90.

(11)- SIMONSEN, Măr1o Henrique - Brasil 2001 - Rio de Jane1ro - GB. APEC Editora S.A. - 1969.

"En vărlas regiöes montar faculdades e, se possivel, con gregar cinco delas numa universidade, è un instrumento de po der para os politicos locals. Dada a escassez de recursos ma terlais e humanos, e a motivação central de distribulr diplomas, a seleção das faculdades nāo se faz pela avallação das necessidades do mercado, mas pela lei do menor esforço: crlam -se as faculdades que podem ser instaladas com mela düzia de salas de aula, giz e quadro-negro e un corpo improvisado de professores, como as de Economia, Filosof1a, D1re1to, etc"p 231. 
(12) - SUCUPIRA, Newton - op. cit. p. 45-46.

(13)- PONTES, Hēlio - Planejamento Univers1tärio - Brasilia - DF. Ministērio da Educação a Cultura - I Encontro de Reitores das Untversidades püblicas - 1972 - p. 9-12.

(14)- LIMA, Lauro de Oliveira - A Escola Secundärta Moderna - Petró polis-RJ - Editora Vozes Itda. - 8a. edição - 1970.

"Neste mundo novo que vem despontando, não hã ma1s lugar para os que temem a alegria de viver e se apavoram com o poder da crlação da Inteligèncla. Parece que, finalmente, o ho mem começou a acreditar en $\mathrm{sl}$ prōprio, afugentando os pavores atāvicos, a morbidez do pecado, o masoguismo da nortificação e o sadismo da dominação. Parece, finalmente, preparado para a amorizaçäo untversaln. p. 193.

(15)- FONSECA; James Braga Vieira de - O Ensino da Geografia no Bra s1l - Rio de Janeiro - Instituto Panamericano de Geografla e H1störıa - Conissão de Geografla - Publicação no 211 - 1956.

E sumamente interessante o trabalho citado, que apresenta relações de programas de Geografla desde 1850 até à época da publicaçăo, quando estavan em vigēncla os programas elabora dos pela Reforma Capanema, en 1942.

Flca evidenclada, atravēs da anälise dos diversos programas, a sua pequena flexibilidade e o grau restrito de inova ções.

A cada Reforma correspondia novo programa, que quase inte gralmente repetia o anterior, variando o nümero de anos - mul tas vezes diminuido - o que acarretava uma sobrecarga programätıca para determinadas séries.

Anda è de se observar que o peso da tradição só multo re centemente começou a ser rompldo. A Lei de Diretrizes e Bases (1961) conferiu aos professores maior autonomia para a elaboração de programas e lentamente começou a surtir efeftos

E de esperar que após um melhor conhecimento da Lel no $5.692 / 71$, os professores de Geografia atuando na matëria Estụ dos Soc1ais, possam elaborar programas realisticos, adaptados às prescrições da psicologia da aprendizagem, da realidade só clo-econômica de seus alunos e da comunidade e, além disso, Fon gramas que sejam "atividades-meio" para atingir os objetivos do plano curricular da Escola. 
(16) - SILVA, Geraldo Bastos - A Educação Secundäria - São Paulo -SP. Companhia Editora Nacional - 1969 - p. 392-416.

0 autor oferece uma visão sintética objetiva das condiçöes que prestâiram a criação das primeiras Faculdades de F1losofia, no Brasil.

(17)- Foram anal1sados e comparados, para o presente trabalho, currfculos de Geografia das seguintes universidades:
a) Federa1s
- Fluminense
- Rio de Janelro
- Bahia
- Rlo Grande do Sul
- Espirito Santo
- Paranä
- Para
- Pernambuco
- Minas Gerals
- Juiz de Fora

b) Estadual:

Universidade de São Paulo

c) Particular:

Universidade Gama Filho

d) Fundação:

Universidade de Brasilia

(18) - SOU2A, Edson Machado de - Expansão do Ensino Superior e Neces sldades do Mercado de Trabalho - Brasflia-DF. Ministërlo da Educação e Cultura - I Encontro de Reitores das Universidades Pübl1cas - 1972 - p. 16-23.

(19)- PASTORE, José - o Ensino Superior en São Paulo - São Paulo-sP. Companhia Editora Nacional - Instituto de Pesquisas Econōnl cas - 1972 .

A opinião do autor é contundente quanto à qualidade dos Cursos de clências Socials, no Estado de são Paulo. Como re sultado da pesquisa realizada, chegou ele às conclusōes seguintes:

19 - o crescimento das matrículas nos referidos cursos ë bastante expressivo. 
Tabela $5-13$

Expansão das matrículas na 1a. sërie do Curso de ciências sociais

\begin{tabular}{l|r|r|r|r|r|r|l}
\hline Anos & 1940 & 1945 & 1950 & 1955 & 1960 & 1965 & 1968 \\
\hline $\begin{array}{c}\text { Matricu- } \\
\text { las }\end{array}$ & 6 & 42 & 26 & 71 & 121 & 473 & 1.028 \\
\hline
\end{tabular}

28 - São cursos de caráter "livrescon".

38 - são cursos que apresentam grandes 1rregularidades crô:.icas, tanto no que se refere aos aspectos docentes como nos discentes.

49 - A un professorado com pouca preparacāo e superocupado, responde um alunado que o autor designa de "allenado".

58 - O mercado de trabalho senđo reduzidamente elástico, só è aberto para us poucos profissionals que conseguiram un treinamento sistemático e mais apurado.

ver p. $108-110$.

(20) - CONSELHO FEDERAL DE EDUCACÃo - Resolucão_ni 1/72 - Brasil1a DF. Ministërio da Educação e Cultura - 1972.

"Ministério da Educação e Cultura

CONSELHO FEDERAL DE EDUCAÇÃO

RESOLUÇÃO NO 1, de 17 de janeiro de 1972

ALTERA A DURAÇÃO MINIMA DOS CURSOS DE LI CENCIATURA QUE INDICA.

O PRESIDENTE DO CONSELHO FEDERAL DE EDUCAÇÃO, no uso de suas atribuições legais e na forma do que dispōe o artigo 26 da Lei no 5.540, de 28 de novembro de 1968; de acordo ain da com o que estabelece o artigo 30, alinea b e c, da Lei no 5.692, de 11 de agosto de 1971; e tendo en vista os ter mos da Indicação no $07 / 71$, aprovada pelo Plenário e homologada pelo Exmo. Sx. Ministro de Estado da Educação e Cultu$\mathbf{r a}$,

RESOLVE:

Art. 19 - Os cursos superlores de graduação abałxo indi cados, sem alteração dos respectivos curriculos míntmos fá estabelecidos, passam a ter a seguinte duração mínima: 
a) Iicenciaturas plenas em Física, Química, Cièncias Biológicas e Economia Domëstica - 2.500 horas de atí vidades, com integralização a fazer-se no minimo de três e no máximo de seis anos letivos;

b) Licenciaturas plenas em Matemätica, Geografia, Histō ria, Ciēncias Sociais, Pedagogla, Letras, Música, De senho e plástica e Filosofia - 2.200 horas de atividades, com integralização a fazer-se no minimo de très e no máximo de sete anos letivos.

c) Licenciatura de 18 grau em Ciências - 1.500 horas de atividades, com integralização a fazer-se no mint mo de um ano e meto e no máximo de quatro anos let1vos;

d) Licenclatura de 18 grau en Estudos Soclais, Letras - Pedagogia - 1.200 horas de atividades, com integra lização a fazer-se no minimo de um e melo e no māximo de quatro anos letivos.

Art. 29 - Os critërios de duração fixados nesta Resolução poderão ser estendidos a cursos já iniciados, mediante as necessärias adaptações, desde que não seja omitida qualquer disciplina resultante dos curriculos minimos estabelecldos para os cursos considerados.

Art. 38 - As instituições de ensino que mantenham cursos dentre os mencionados no artigo 18 farão as necessärias modificações de seus regimentos, as quals se terão como aro vadas quando sejam observados os mintmos de duração estabelecidos nesta Resolução e os de conteúdo fixados nos respec tivos atos deste Conselho.

Art. 48 - A presente Resoluçāo entrará em vigor na data de sua publicação, revogadas as disposiçōes em conträrio.

Conselho Federal de Educação, em Brasīila, 17 de jane1ro de 1972 .

\section{Roberto Figueira Santos \\ Presidente"}

(21) - MINISTERIO DA EDUCAÇÃo E CULTURA - Desenvolvimento da Educa ção no Bras1l - Brasilia-DF - 1971 - p. 73-74.

"Por outro lado, considerando que a pós-graduação ē essen clal à expansão e aprimoramento do ensino superior e às neces 
sidades da pesquisa cientifica, fol instituida a polftica na ctonal de pōs-graduação atravēs dos Centros Reglonals de pós -Graduação (Decreto no 63.343, de 1/10/68).

A razäo de ser dos Centros está en que as Un1versłdades, por Iniclativa próprla e com recursos hunanos e materiais, nāo poderiam implantar, pelo menos a curto prazo, a póa-graduação nas diferentes äreas de conhecimento, ao nivel correspondente à natureza e objetivos de tals cursos. Dal a necessidade de uma política que coordene esforços e mobilize recursos, concentrando-os em centros devidamente selecionados.

Com o objetivo de efetivar a polftica nacional de pös-gra duação, O Decreto no 67.350, de outubro de 1970 definiu e crlou cinco centros regionais. Entende-se por Centro Regio nal de Pōs-Graduação o conjunto de cursos de Mestrado e Douto rado, credenciados pelo Conselho Federal de Educaçāo, funcionando coordenada e organicamente, e correspondendo a determinada reglão do País.

Para cada Centro haverá uma Universidade-sede. Todo centro terä uma comłssão constitufda por um representante de cada instituição que o integra e um coordenador indicado pela Universidade-sede. Fara a implantação do Programa de centros Regionais de Pōs-Graduação, fol crlada uma Comissão Nacional funclonando no àmblto do Departamento de nssuntos Universitarlos, órgão encarregado da coordenação do Programa no plano na clonal".

(22) - PASTORE, Josẽ - op. cit.

O trabalho do professor Pastore, embora publicado en 1972, refere-se a pesquisas feitas nos anos de 1967-1968, no ensino superior en São Paulo.

A época, a sua análise quanto aos cursos de pōs-graduação no Estado (anterior portanto à Lei da Reforma do Ensino superior e à implantação dos centros $R$ jionais de pōs-Graduação). leva a conclusōes desalentadoras.

Refere-se o autor ao baixo nivel de muitos dos cursos, que ele denomina de "Apōs-Graduação", não escapanđo a sua anälıse - fenômeno da pressão soclal sobre multas Escolas Superfores. Diz, textualmente: "... mas o jovem que se forma nos cursos unlversitărios de baixa qualidade e disfuncionals para a econo mia e para a sociedade, enfrenta o mesmo problema, pols, como economista, advogado, adninistrador, hacharel en clênclas so- 
cials, etc. não è absorvido pelo mercado de trabalho. E uma nova alternativa vem sendo vislumbrada por essa legião de de sempregados-formados, ou seja, continuar na untversidade ao nível de pōs-graduação". p. 159 
C A P I T U L 02

A FORMACAO DO PROFESSOR UNIVERSITARIO

DE GEOGRAFIA 
2 - A FORMAC̨ÃO DO PROFESSOR UNIVERSITARIO DE GEOGRAFIA

\section{$2.1-$ objetivos}

18 - Trą̧ar breve histórico relativo à formação do professor universitārio de Geografia, no Brasil.

28 - Relacionar o complexo de causas que repercutem na formação e no aperfelçoamento do professor de Geografla, na universidade.

38 - Assinalar algumas soluções para o aperfetçoamento do professor universitărio de Geografia.

\section{2- Introducão}

Antes de comentar a respeito da formação do professor un 1 versitärio de Geografia, no Bras1l, talvez fosse conveniente indagar qual a origem desse professor.

Historicamente, sabe-se que è muito recente no Brasil a crlação de escolas superiores. As primeiras eram poucas, afastadas uma das outras, elitizantes, escolas dependentes da cultura exterior, primeiro passo para a futura unlversidade - reflexa de que fala DARCY RIBEIRO ${ }^{(1)}$.

o professor, no sëculo XIX, era representado pela flgura tpica do bacharel, o protōtipo do individuo que buscava ascender soclalmente, 11gando-se à classe patriarcal, mas contestando muitas vezes seu poder de fato, bacharel que defendia posiçōes liberais por un lado e se identificava com a burguesia, por outro, de onde provinham as raizes de multos deles.

o bacharelismo fol não um fim on si mesmo, fol una forma de ascençäo social, ao qual a posição no magistério supertor conferia "status". Os primelros representantes do magistërio superior marcaram sua presença atẻ hoje, aqui e alı com fragmentos de sobrevivēncla cultural. "Guardava, no entanto, os traços básicos de sua mentalidade de bacharel, consolidad e, talvez, ató aprimorada pelo tempo, o mesmo sentido de ornamentação de suas origens, presente em tudo: no gosto que quase não mudou pelo eruditismo estrangeiro;pela citação de terminologia melo gongörica; pela preleçäo oral solene e pomposa; pelo verbo fácil e suntuoso; multas vezes pelo próprio trá je bem arrumado; pelo sapato lustroso e pelo anel de grau faiscando no dedo. 
Sobretudo, não raro, pela alienação quase completa de sua formação intelectual, reluzante de teorias de fora, mas com pouca ou quase nenhuma Integração na realidade do seu país ou do mundo de hoje" (2).

As escolas superiores aumentaram de nümero até 1930, guar dando muitas das caracteristicas das suas origens e o professorado, era autodidata por excelência e por carêncla de escolas de formação. Pontilhava nessas escolas, o bacharel-burguês, cuja aspiração mäxí ma era a cátedra.

As primeiras Faculdades de F1losofia surgem na década da 30 e só proliferam de fato, a partir da década de 50 . Elas formaram os primeiros professores para o enstno médio de então, muttos desses professores, chegando a ocupar, eles mesmos, posiçc̃es dontnantes nas novas Faculdades que se abriam. E era fenomeno de certa constāncla: quase todas as novas faculdades abrtam o curso de crografla e História, posteriormente desmembrado no de Geografia $e$ no de Histöria.

Com o fenômeno do crecimento quantitativo das Faculadades de Filosofia, abriu-se o mercado-de-trabalho para professores de es colas superiores. Mas fol aberto sem os cuidados imprescindiveis pela seleção, pela qualificaçäo profissional. o concurso para in gresso serla a forma de acesso dos melhores. O peso da tradição era multo forte e mais forte a posição do catedrático e, assin, durante multo tempo, o catedrático indicava seus auxiliares. Por outro lado, as Faculdades menores, vártas localizadas em pequenas e médias cldades do intertor, não podiam se dar ao luxo de selecionar muito o seu professorado.

Só muito recentemente as Escolas Superłores Federais e ES tađuais começaram a cuidar da seleção docente, mediante os concursos de ingresso. As Escolas superiores Particulares, muitas delas, não apresentam essa exigência minima: o ingresso na docêncta é regụ lado pela oferta-procura ou pela indicação de algum elemento que trabalha na Escola.

llas um fato è incontestăvel: as mudanças operadas no país, a mobilidade social, acabaram por se refletir no professorado de es colas superiores. "Os resquicios do bacharelismo professoral serão então tragados na voragem dessa tendèncta em ascenção. o professor tenderä a perder completamente os artificialismos de sua formação. Sua cultura intelectual perderá os ültimos vestigios do exibicionig mo postiço, para ser mais objetiva e mals prätica"(2). 


\section{3- A formacão e o aperfelcoamento do professor universitärio de Geografia.}

Essa não difere multo das condições dos demais professores. Hoje, a maioria esmagadora em quase todas as Escolas Superiores tem formação universitärıa especifica: são os antıgos alunos das Faculdades de Filosofia, Ciênclas e Letras ou os novos que vão saindo dos cursos de Geografia, com a licenciatura plena ${ }^{(3)}$.

A rigor não se pode avaliar a qualidade seja dos cursos que os formaram, seja do desempenho profissional dos docentes em Geografia. As medidas da eficãcla são aleatórias:

18 - ainda não se fez no Bras1l uma avaliação tecnicamente mon tada para testar a eficlêncla dos cursos de graduação e do seu produto: os professores em exerclcio. o ünico ins trumento de aferiçāo é o estudo da relaçāo "matrícula in clal: conclusão de curso" o que pouco ou nada revela;

28 - a volta dos alunos diplomados às escolas superiores, para cursos de pós-graduação (em sentido amplo e em sentido restrito), com regularidade, poderia representar a possibilidade de avalıar a qualidade do curso de graduação e o desempenho profissional do professor de Geografia e do geögrafo.

Esse ideal de educação permanente esţá atnda em fase embrionária, mas será o fator de realimentação do sistema, que possibilite o reajustamento dos objettvos, da metodologia, do curriculo.

o Gräfıco no 35 procura esquematizar o fenômeno.

GRAFICO NQ 35

PEFORMULAÇÃO PERIODICA DOS CURSOS DE GRADUAC̣̃̃O EM GEOGRAFIA.

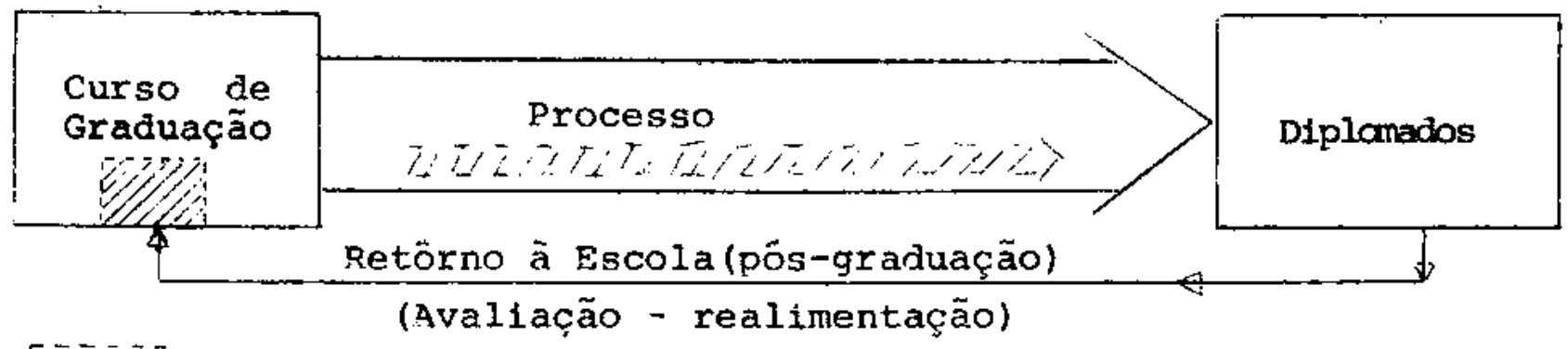

/ $/ / / / /, \rightarrow$ reformulação do curso, graças a realımentação: 
blema:

Essa é uma das maneiras de atender a dois aspectos do pro

19 - retorno periód1co do professor à untversiảade = aperfelçoamento;

28 - aperfeiçoanento = poss1b1lidade de autoavaliaçāo da eficá cla do curso de graduação.

Quanto ao segundo aspecto, deve-se levar em conta a mobilidade geográfica do professor que o levaria a pós-graduar-se em uma escola, que não a sua de origem. Isso poderă ser altamente positivo, na medida em que possibilite a avaliação e comparação de đI ferentes cursos, através de seus diplomados, con o curso que ministra a pós-graduação.

Os entraves ao aperfelçoamento do professor de Geografia e do Geögrafo.

Säo de natureza multo varlada, mas de forma geral podem ser enquadrados no que segue:

18 - relação "carga horāria semanal: salāxio";

28 - carèncla quantitativa e qualitativa de cursos de aperfeiçoamento;

39 - incentivos que acelerem a conscientização da necessidade do aperfeiçcamento perłödico.

Quanto ao primeiro, é sabido que parcela conslderável dos professores de Geografia e, mesmo de geōgrafos, não trabalham em re gime de tempo integral na untversidade, ou órgão empregador, para o caso dos geögrafos. O fato conduz ambos os tipos a multiplicar suas atividades, docentes ou não, para compor um salärio apenas razoạ vel.

O MEC pretende ampliar o nümero de professores em regime de tempo integral ( 40 horas) ou parclal (24 horas) nas Universidades federais. A medida seră valiosa para posslbilitar a montagem de cursos de aperfeiçoamento na pröpria untversidade, podendo o pro fessor dedicar parte de sua carga horárla para essas atıvidades.

Igual providência estă sendo tomada por algumas universidades estaduais e particulares.

E necessärio, contudo, que a correspondêncla salarial ao trabalho docente não force o professor a buscar atividades para com plementação de salärio. 
En determinados Estados, o sistema oflcial remunera melhor o professor do ex-ensino médio que as pröprias universidades ou escolas superiores 1 soladas.

Quanto ao segundo: o nümero de cursos de aperfeiçoamento é alnda muito restrito. Constituen para multas universidades fatos eplsöd1cos, quando deveriam ser periödicos e estar integrados na programaçäo oficlal da universtdade, ou, ao menos, na do Departamen to de Geografia.

En certos casos, a natureza e a qualidade do curso oferecldo podem agir como fatores repulsivos e não de atração de docentes e geögrafos.

Quanto ao tercelro: professores e geógrafos devem ser consclentizados da necessidade de frequientarem cursos de aperfel ̧oa mento. Não basta, contudo, provocar o desejo se não são oferecidos melos e incentivos. Um dos incentivos poderá v1r do pröprto Estatu to do Magistério ao vincular o acesso a nivels superiores de docêncla (aqui entendida como docêncla e pesquisa) e a melhorla salarial, à conclusão de cursos de pós-graduação, em ambos os sentidos: pōsgraduação em sentido amplo e Mestrado e Doutorado.

\section{Os cursos de aperfeicoamento a seus reflexos na eficácia docente.}

De maneira geral, os cursos de aperfeiçoamento, de Megtra do e de Doutorado em Geografia têm-se voltado mais para aspectos es pecificos da Geografia, delxando de lado, parclal ou totalmente, as questōes referentes à tecnologia do ensino. E fato que poucos cursos de građuação e de pōs-graduação estão montados de forma a habilitar o futuro professor ou o professor que se pós-gradua, para so$\operatorname{mar}$

conhecimentos + metodologias + tecnologia

A respeito, escreve a professora NELLY ALEOTTI MAIA, da Universidade Federal de são Carlos - Sp ${ }^{(4)}$ :

"... até há poucos anos, o nosso professorado era constituido, em sua quase totalldade, de profissionals de outros campos. Acrescente-se a isso a convicção de que o conhecimento do conteúdo automaticamente confere a seu possuidor o "carisma" didatico. 
As Faculdades de Filosofia, constituindo louvävel esforço e tentativa de nova mentalidade, não conseguiram sanar totalmente a situação e induziram a outro erro de conseqtências igualmente funes tas: a falsa "tecnicalização" do professor. O professor não serła mais o "defroquë" das outras profissōes, mas o "tēentco". Por "téc nico" entendeu-se errônea e ingenuamente aquele que podia oonhecer pouco, mal, ou desconhecer o conteúdo, mas mediante certa "montagem" de aula, seria capaz de transmitir. De renegado profisstonal a mágico, assim procedeu a manetra de se encarar o professor".

o fenōmeno, atualmente, parece ter sofrido alteração, a partir da Reforma Universitäria.

Explica-se: o ciclo bästco e grande parte do profissionalizante culdam especificamente do ensino da Geografla, cabendo às Faculdades de Educação fornecer os créditos na ärea pedagógica para os futuros l1cenciados. A porcentagem do tempo destinado à formação pedagóglca raramente atınge a 208 do nümero de horas da licenclatura plena. Se alguns reparos cabem a essa parte, eles se relacionam ao excesso de teorias educacionais em detrimento de una efetiva e realistica prética de ensino, embasada obviamente na fundamentação teórica do processo de aprendizagem.

A falta absoluta de avallação da eficãcla dos cursos de graduação en Geografia, pode-se apenas constatar, através do contato com professores recëm-egressos da universidade, que seu verdade 1 ro aprendłzado de docência val ser realizado no dia-a-dia do seu trabalho.

Mas 1 sso não è estranhävel, outros profissionais univers 1 tārios ao ingressar no mercado-de-trabalho è que vão vivenciar a sua formação, multas vezes atravẻs do ensaio-e-erro. Mesmo que meIhorem substancialmente os cursos de formação pedagógica, eles não poderão jamals preparar "otimamente" o futuro professor. Por 1sso mesmo, torna-se necessārlo que os cursos de aperfelçoamento, de Mes trado e de Doutorado, incluam uma parte destinada a atualizar o pro fessor com a tecnologia educacional. Se assim ocorrer, de par com - aprofundamento dos estudos cn äreas especificas da Geografla, o docente estará em melhores condições de exercer trabalho mais ef1clente no seu Departamento. Não basta que após um curso de aperfeí çoamento, ou de Mestrado, ou de Doutorado ele domine mais os conhecimentos especificos $\in$ a metodologia geogräficos, ele deve estar atualizado con a tecnologia educactonal para ser mais eficiente nos cursos que iră młnistrar. 


\section{4- A estrutura organizacional do Departamento de Geografia e o aprefe1coamento do professor.}

E verdade que multos Departamentos de Geografia, nessa fa se de implantação da Reforma untversitária, não puderam ainda organizar-se de maneira a apresentar uma estrutura que eficientize $\circ$ trabalho docente.

Essa eficientização poderã ser conseguida atravēs de duas formas, no minimo:

18 - oferta regular de cursos răpidos de aperfeiçoamento, apro veitando parte da disponibłlıdade horárla dos professores;

28 - criação de um centro ou núcleo de Tẻcnica de Ensino e de Pesquisa.

Quanto ao primeiro caso, os cursos tanto podem ser orlentados para os aspectos didátıcos, como para os de Geografia propria mente dita (conteúdos e metodologias).

Os referentes aos aspectos didăticos são importantes,pois não é dificil constatar-se que se registram lacunas mais ou menos sërias nas seguintes āreas:

- seleção de objetivos operacionals (5) (6);

- modos operacionais (7).

- avalıação da aprendizagem (8).

Os referentes aos conteūdos, são em multos casos, menos graves. Mas seria valloso insistir na questão das metodologlas, que, afinal, darão funcionalidade ao acervo de conhecimentos geogrā ficos.

Constata-se que bons alunos, aqueles que conseguem ter ra zoável bagagem de conhecimentos, em situação de aplicá-los, em trá balhos prátıcos, de campo ou de sala de aula, perdem-se, confundemse, possivelmente por não terem a compreensão da estrutura ${ }^{(9)}$ ou por não dominarem metodologlas e técnicas de operações geogrä́ficas. Nes se sentido, será interessante tecer alguns comentários. Em vários cursos de graduação geogrāfica a lônica é o conteúdo, carecendo de instrumentar os alunos con os métodos e as técnicas que dên operaclonalidade a esses conteúdos. 
São exemplos dentre multos outros:

- o aluno estuda cartografia e muttas vezes:

- não sabe orientar a carta em trabalho de campo;

- não está capacitado a selecionar cartas em função de determinados assuntos a estudar;

- desconhece técnlcas de trabalhos cartográficos que poderá propor a seus futuros alunos;

- não domina técnicas de levantamentos topogrä́ficos simples;

- não é capaz de elaborar esboços cartográficos, capazes de exprimir suas observaçōes feltas na palsagem (10) (11).

- os estudos regionais se desenvolvem, seja na Geografia do Brasil, seja na Geografia dos Continentes, seja em trabalhos especificos de Geografia Humana, etc. Mas, sentese, em multas oportunidades, que falta a esses estudos um embasamento de métodos de trabalho regional. Esse embasa mento é que poderá possibilitar ao aluno a aplicação dos conhecimentos nas tarefas de camno, para realizar estudos da palsagom, diagnösticos regionais (12) (13).

- as excursōes geográficas, ainda timidamente feitas em muí tos cursos, constituem paxte obrigatória na programação de certos Departamentos.

Talvez haja necessidade, em alguns casos, de repensar esse tıpo de atıvidade de suma importância na graduação e na pös-graduação.

As excursöes geográficas deverian, por exemplo:

- ser mais freqtentes,

- merecer culdadosa preparação. Em alguns casos, antes do trabalho de campo (aqui entendico em seu significado mals abrangente), há de se fazer uma sérłe de estudos preliminares: cartográficos, estatisticos, pesquisas bibliogräfí cas, elaboração de ume sintese preliminar sobre a ärea ou fenômeno a ser observado. A excursão val completar as Informaçōes, tornar real o que fol analisado por "documen tação incireta", posslbilltar aos alunos uma comparação entre a teorização e o quadro real, dotado de dinamismo. Em outros casos, a excursão visa a outros objetivos, dispensando pois essa preparação. 
Os alunos vão ao campo de observação, colhem as Informações, visualızam a palsagem em bloco e, posteriormente, trabalham sobre esses dados, complementando-os em sala, com material bibliográfico, estatistico, fotogrāfico, car togräfico;

- visar mals a habilitar os alunos no trabalho de campo que, propriamente, comprovar teorias analisadas em sala de aula;

- ser planejadas e orientadas por um grupo de professores, a fim de se produzir um roteiro de trabalho que abarcasse fatos da Geomorfologia, da Biogeografla, da Geografia Agräria, etc. etc. Multas excursões são unilaterais, no sentido em que, orientadas por un professor, a ènfase recai, naturalmente, na especialidade do referido professor. Isso não sō $\vec{e}$ un desperdicio de oportunidade, como pode levar a uma distorção dos propösitos da Geografıa, que ví sa à anälise da palsagem, integradamente, relaclonando os diversos fenōmenos entre si;

- evoluir para a excursão de que participem alunos de outros Departamentos, formando pequenos grupos interdisciplinares. Uma excursão que reúna alunos de Geografia, de História, de Sociologia, de Economia, de Engenharia estară mais próxima de una realidade futura, quando o professor de Geografia e/ou o geögrafo trabalharão em equipes interdisciplinares. Os óbices a esse tipo de excursōes săo de natureza administrativa, mas os seus possiveis resultados positivos devem prevalecer sobre as dificuldades de ajustar os programas de atfvidades dos diversos Departamentos (14) (15).

Quanto à segunda sugestão, de se criar um Centro lou núcleo) de Tëcnica de Ecnsino e de Pesquisa, ela decorre da necessida de de se dotar o Departamento de uma infra-estrutura de apoio ao trabalho docente, seja no que se refere ao ensino, seja no que diz respeito à pesquisa.

No âmbito das escolas de 18 e 28 graus, aos poucos vão impondo-se a importância e a vallaade de um Serviço de supervisão Escolar, ao qual estariam afetas as questōes da ārea "enstno-aprendi zagem" .

Embora variem de Estado para Estado, o enfoque da Supervi são e a aceleração do processo de implantação do Serviço, fato è que ele hoje é considerado peq̧a-chave na estrutura técnica da escola ${ }^{(16)}$. 
Se isso ocorre em escolas de 18 e 28 graus, por necessida de de manter os estabelecimentos atualizados quanto a tecnologia educacional inclusive coordenando o trabalho docente, è estranhävel que a universidade não mantenha setores anălogos, evidentemente adaptados a um tipo de estrutura diversa e com objetivos igualmente diferentes. Estranhâvel mas explicável: decorre da autonomia da cá tedra que era auto-suficiente e operava, quase sempre, isoladamente.

A "universidade-sistema" deve corresponder por igual 0 "Departamento-sistena", aqui entendido como unidade celular que fun cione integrando, coordenando, reajustando suas mültiplas atividades, basicamente redutiveis a duas: ensino e pesquisa.

$\mathrm{Na}$ atual organtzação departamental em algumas universidades, cabe ao coleglado do Departamento opinar sobre os planos de trabalho. Mas isso é pouco e funclona frouxamente porque:

- as reuniões do colegiado são en nümero reduzido;

- o Colegiado não è órgão técnico, mas normativo.

o que pode ocorrer, pela inexistência de um örgão que res ponda pela coordenação do ensino e da pesquisa, a nível departamental, è a diminuição de eficłēncia, o rebalxamento da produtividade do Departamento.

A um Centro de Técnica de Ensino e de Pesquisa podem corresponder as seguintes funções, como exemplo:

\footnotetext{
- coordenar o plano curricular, entrosando os diferentes planos de curso:

- acompanhar tecnicamente o desenvolvimento do plano curricular, para sugerir alterações quando necessärio;

- incentivar a adoção de novas tecnologias educacionats que mal penetraram en algumas universidades: o ensino não-diretivo, a dinâmica de grupo, o microensino, a ins trução programada, o emprego de meios auxłliares, crian do alguns, orlentando a criação de outros pelos professores e alunos, habilitando os professores a utillzarem corretamente os materiais de ensino: Ifvros, projetores, fllmes e "slides", aparelhos para demonstração de experiências e para trabalho de campo, etc;
} 
- coordenar o processo de avaliação da aprendizagem, não no sentido tradicional de impor as nefastas "provas ún cas", mas, ao contrário, auxillando os professores na busca de adequados instrumentos de avaliação; tabular dados relatıvos à aprendızagem passivel de afertçāo, com o objetivo de cooperar com os professores no diagnöst1co do conjunto "objetivos operacionais-avaliação";

- manter um sistema de informaçōes educacionals, visando a trazer o professor a par de publicações na sua área de trabalho.

Observações preliminares:

1. - a pesquisa, no exemplo que seguirä, não se refere à pesquisa educacional, esta flcaria afeta à àrea de ensino anteriormente mencionada;

2. - trata-se aqui da pesquisa no sentido de busca de novas tëcnicas, modelos experimentais, anālise de paisagens, estudo de fenômenos de natureza fisica, huma na e econōnica;

3. - fazer pesquisa não é tarefa făcil, exige o dominio de técnicas especificas bäsicas. A partir dal, o resto corre por conta do pesquisador e de sua equipe, contando muito para o extto do trabalho: a crlatividade, a adoção de métodos e técnicas geogrä́ficas, a persistēncta, o interesse, o engajamento pessoal e grupal no trabalho, etc.,

4. - observa-se, em alguns casos, que os "planos de pesquisa" apresentados por professores ao Departamento de Geografia, visam mais a satisfazer exigências burocrăticas que justifiquem o PETIDE (Regime de Tempo Integral e Dedicação Exclustva), que propriamente a desenvolver um trabalho de carater clentifico e, pos sivelmente, aplicável, como é o caso das monografias regionais. Entenda-se a expressão "monografia regło nal" como significativa de:

- estudo de uma microrregião:

- estudo de um setor de una microrregião;

- trabalho sobre um aspecto relevante, como por exem plo, młgraçōes regionats, urbanização, evolução de um bairro, equipamento terciārio de uma cidade e 


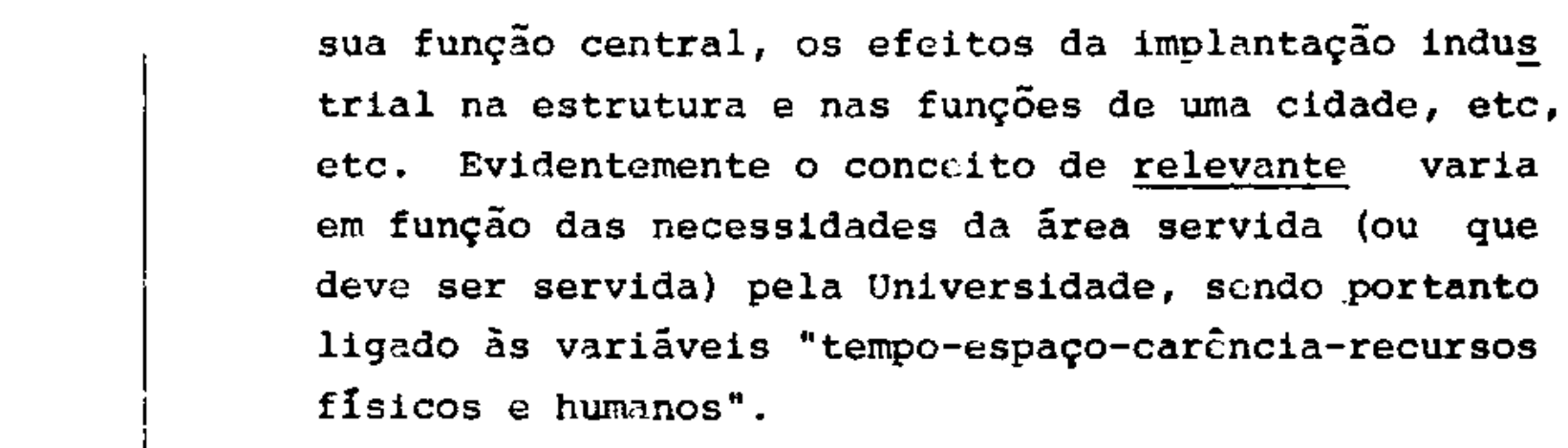

Seria sempre valioso que professores para serem adm1 tidos em regime de tempo integral e dedicação excluslva (RDIDP - Regime de Dedicação Integral à Docêncla e à Pesquisa, na USP) apresentassem planos de pesquisa para fim de estäglo probatório.

Feitas essa observaçōes, pode-se 1maginar que o setor de resquisa do Departamento de Geograf1a, dever1a ter como atribuiçōes básicas :

- coordenar os planos de trabalho que devem ser desenvolvidos, de forma a:

- considerar as priorldades e os recursos fistcos e humanos;

- compatibilizar pesquisas a fim de evitar redundâncias:

- grupar professores e alunos em torno de pesquisa, somando esforços;

- orientar professorcs pouco experientes, transmitindolhes 0 "know - how" básico para as pesquisas;

- providenciar os recursos materials e flnanceiros para o desenvolvimento dos trabalhos;

- fazer a avalıação das pesquisas, em função dos objeti vos propostos:

- divulgar o resultado dos trabalhos.

As sugestões feitas quanto ao Centro de Tëcnica de Ensino e de Pesquisa, podem ser reduztdas a un modelo teörtco. A partir desse modelo è que se buscarā adaptā-lo às condições especificas de cada Departamento de Geografia. Em qualquer hipötese, é välido con slderar que a existência desse Centro tenderä a racionalizar as ati vidades do Departamento, aumentando a sua eficiēnc1a. Na medida em que atue, de uma ou de outra forma, estará contribuindo decisivamen te para o aperfeiçoamento docente. 


\section{5 - A formação do professor universttärio de Geografia e sua possivel contribuicão ao planejamento educactonal.}

A Idëlas desenvolvidas anteriormente visavam a levantar a questão da formaçāo e do aperfelçoamento do professor universitärio de Geografla. Em nenhum trecho houve insistência em cprreł̣actonar a formação e o aperfeiçoamento com a planificação educacional, mes:mo porque era absolutamente desnecessärio. Explica-se: na medida em que o Departamento de Geografia conte com uma equipe docente capaz de enslnar e de fazer pesquisas eficlentemente, ele estarä apto a cooperar com os planejadores educacionais, seja da próprla univer sidade, seja de um Municlpio, seja da Secretaria de Educação, seja, mesmo, do Ministērio da Educação e cultura.

Essa aptiaão poderá ser 1dent1ficada atravēs do trabalho que se desenvolver, nas equipes interdisciplinares, pelo:

- diagnōstico regional (cidade, microrregiāo, Estado), em sentido amplo, sintëtico e abrangente, como devem ser os estudos geogräficos para guardarem coerència com os objetivos e a essência da Geografia;

- estudo de tendência evolutiva ou involutiva do quadro regional analisado, fazendo projeçōes para curto e mëdios prazos.

A questão, portanto, não se prende especificamente a um Departamento de Geografia, ela depende:

18 - do papel que a universidade deve assumir de prestar serv $\underline{1}$ ços à comunidade;

29 - da conscientização dos órgãos de planejamento educacional, até o presente pouco ou nada sensibilizados para a importāncia da Geografia para esta atividade.

No momento em que se ohservar uma reversão de enfoque da Universldade e dos örgãos de planejamento educacional, os Departamentos de Geografta que sejam eficientes, poderäo cooperar, assesso rar, trabalhar com as equipes de planłficação da eđucação.

\section{6 - Conclusões parciais}

1. - A evolução da educação no Brasil fez passar do "docentebacharel" ao licenclado en Geografia. Subsistem todavia professores leigos. 
2. - A qualidade dos cursos de graduação em Geografia é aferida de maneira multo precăria. o "sistema" não è real1mentado, o que poderia ser feito através da Institulçāo permanente dos cursos de retreinamento, nas escolas superiores.

3. - o levantamento dos entraves ao aperfelçoamento dos profes sores de Geografla e un passo para as possivels soluçöes do problema.

4. - Os cursos de aperfelçoamento deveriam enfocar com mais destaque os temas relativos às metodologias e à tecnologia de ensino.

5: - A estrutura organizactonal dos Departamentos de Geografla deveria prever a oferta de cursos de aperfeiçoamento para seus professores.

6. - A criação de un Centro de Técntca de Ensino e de Pesquisa, nos Departamentos de Geografia, poderà apresentar resulta dos altamentc compensadores, pela racionalização dos trabalhos de docência e de pesquisa. Essa racionalização po derá contribuir para o aperfeiçoamento docente.

7. - Na medida em que se torne mais eficiente o trabalho de en sino-aprendizagem, nos Departamentos de Geografia, docentes do Departamento e futuros professores e geógrafos poderão contribulr positivamente para a planificação educacional. 


\section{NOTAS REFERENTES AO CAPITULO 2}

(1) RIBEIRO, Darcy - A Universidade llecessāria.Rio de Janeiro. GB. Editora Paz e Terra S.A. 1969. p. $9-13$.

(2) MORAIS, Pessoa de - Soclologia da Revolução Brasile1ra. Rio de Janeiro - GB. Eaitora Leitura S.A. p. 82-95-. op. cit. p. 94

(3) CONSELHO FEDERAL DE EDUCAÇÃO - Pareceres nis. 912/69.255/70 e $74 / 70$

Esses Pareceres oficializam a Licenclatura de Curta Duração, em 1600 horas.

Do Parecer no 912/69 retira-se o texto a segulr:

"Das 88 faculdades de filosofia existentes em 1964, 52 se achavam localizadas em apenas sels Estados: Guanabara, São Paulo, Estado do Rio, Minas Gerals, Paraná e Rio Gran de do Sul, perfazendo o total de 808 da matricula nac1onal. Estas proporções continuam praticamente inalteradas. No que se refere à distribuição da matrícula pelos diferentes cursos das faculdades de filosofia, as estatisticas de 1966 acusavam os seguintes percentuals: 10.330 alunos nos cursos de Letras, ou 23,18; 9.094 em Pedagogia, em 20,38; 4.446 em Histörta, ou 9,98: 3.647 en Clênclas Soclats, ou 8,$18 ; 3.157$ em Filosofia, ou $78 ; 2.686$ em Geo grafia, ou 68; 2.618 em Matemätıca, ou 5,$88 ; 2.212$ em His töria Natural, ou 4,$98 ; 1.322$ em Biologia, ou 38; 1.157 em FIsica, ou 2,68; 857 em Qufmica, ou 1,98".

Do Parecer no 255/70, retira-se o que segue:

"Em todas as Licenciaturas, a parte de Formação Pedagógica ocuparä um total de 640 horas alstribuldas:

\section{Disciplinas}

Psicologia da Educação

Estrutura e Fucionamento

do Ensino de 20 Grau

Didătica e Prätıca de Ensino

Estudos Brasileiros
No de horas 80

360

Total $\frac{80}{640 \text { horas }}$ 
Licenctatura em Geografia

Geografta Física

Geografia Humana e Econômica

80 horas

Geografia Regional (Continentes)

120 horas

Ceografia do Brasil

250 horas

Complementos de Português

450 horas

60 horas

Total

960 horas".

A partir de 1972, a Licenclatura ce Curta Duração formarā nāo mais o professor monovalente em Geografia, mas o professor polivalente em Estudos Soc1ais (Resolução 1/72 - CFE).

Os professores licenclados em Curta Duração destinam-se ao magistērio no ensino de 18 grau, oflclalmente. E possivel contudo que alguns dentre eles venham a leclonar em cursos superiores de Geografia, nas Escolas Isoladas cria das precarlamente, em centros urbanos de pequeno porte, onde a falta de professores com titulação universitāia é quase total. El esperar, contudo, que o fenômeno seja contido palo CFE.

(4) MAIA, Nelly Aleotti - Produtividade da Universidade. Brasilia - DF. Ministério da Educação e Cultura - I Encontro de Reitores das Universidades Püblicas - 1972. p. 17-18.

En outro trecho do trabalho, a autora busca enfatizar 2 "qualidade docente" como essenclal para que a Untversidade atinja seus objetivos bäsicos.

"Saber e prof1ssão, pesquisa e tre1namento. Da compatib1 lização desses objetivos nasce a unłversidade cuja univer salidade è, historicamente, teleolögica.

Somos integralmente favorăvels à manutenção desse en tendimento da untversidade. Cabe-lhe, como entidade proftssional, produzir, mas, cabe-lhe, também, pesqutsar, in clustve pesquisar formas melhores de produção.

Em resumo: a nrodutividade de universidade está na pesquisa.

E que pesquisarā prioritariamente a Universidade? formas avançadas de produtividade. E o ciclo se rompe no sentido da evolução pelo concelto de produtividade - instrumento.

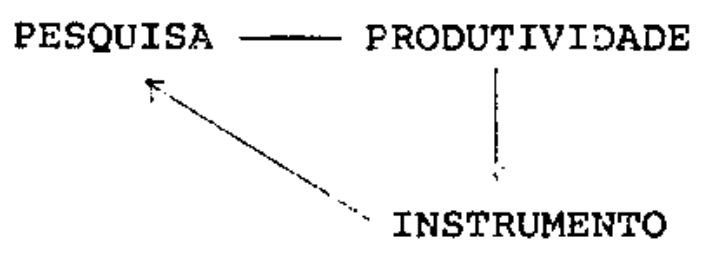


Operacionalizando, transformando em metas, terfamos:

- formação de profissionais

- desenvolvimento da pesquisa

Mas cabe à Universidade a difícil e antinômica tarefa de fornecer seu pröprio "feedback".

E a esse aspecto crítico que será dedicada a malor atenção de nosso modêlo. Com efeito, só se pođe entender a Produtividade - Instrumento se se torna explicito e individualizado o fator-agente đa realimentação. Por sua ex 1 gência de comunicação interna ele é, por excelência, um elemento humano - o professor.

Claro è que não è função exclusiva da universidade a formação de professores. No entanto, è esse o elemento critico. Do momento en que há falhas na sua produção, hã colapso no sistema. E, talvez, num pré-colapso ou colapsos em subcircuitos ou en subsistemas esteja o fulcro da chamada crise da Univeraidade". p. 13-14.

(5) MAGER, Robert F. Objetivos para o Ensino Efetivo. Rio de Jane 1 ro, GB. Traduzido e adaptado para o português, da versão em espanhol, pela Divisão de Ensino do Departamento Nacional do SENAI - Serviço de Aprendizagem Industrial. 1971.

Esta obra, baseada na Psicologia Behaviorista e apresentada sob forma de Instrução Programada, pode ser considerada de grande utilidade para professores de ensino universitärio que, porventura, não dominem as técnicas de seleção de objetivos operacionais.

(6) BLOOM, Benjamin S., et alli1. Taxionomia de Objetivos Educacio nais. Tradução de Flävia Maria Sant'Anna. Porto Alegre, RS. Editora Globo, Co-edições URGS. 1972.

o trabalho em questão è outro de importância para os professores universitărios.

o estudo das idëias desenvolvidas por BLOOM e por MAGER, possí velmente será de grande utilidade para os professores de Geografta, na medida em que os capacite a orientar seus cursos a partir de objetıvos operacionais. Esta técnica normalmente tem apresentado resultados bastante positivos em diversos cursos. 
(7) ROGERS, Carl R. Liberdade para Aprender. Tradução de Edgar Godói da Mata Machado e Márcio Paulo de Andrade. Belo Hor1zonte - MG. Interlivros de Minas Gerais - 1971.

As teorias rogerlanas de aprendlzagem são revoluclonärlas, pode-se dizer. Exigem do professor não apenas o conhecimento das idéias do autor, como também un alto propósito de despojax se do ensino tradicionalista, que conduz a uma aprendizagem coercitiva o que, em ültima instância, não è aprendizagem. Mas parece inegãvel que a adoção de värias sugestões de ROGERS poderá conduzir a um relacionamento menos tensionado, portanto mais afetivo, entre alunos e professores. Outro dado relevan te: as teorias rogerianas quando bem aplicadas levam a um trabalho de co-partictpação dos alunos e dos professores, na montagem e no desenvolvimento de um curso de Geografia.

Operar rogerianamente no ensino universitārio é un desafto que merece ser testado.

(8) GOULART, Iris Barbosa MAFRA, Edith Soares. Avaliaçäo na Esco la. Belo Horizonte - MG - Indüstrias Gräficas vera Cruz. 1969. A avaliação da aprendizagem constitul um dos pontos nevrälgicos no processo educacional, principalmente quando se realiza desligada dos objetivos do curso e sem estar apolada em técnicas especificas.

o trabalho das autoras possivelmente fornecerá aos professores de Geografia uma visão mals funcional da avalıação da aprendızagem.

(9) BRUNER, Jerome S. O processo da Educação. Tradução de Lóllo Lourenço de Oliveira. São Paulo - SP - Companhia Editora Nacional. 1963.

"Recapitulando: o tema principal deste capitulo foi o de que o curriculo de una dada matérta deve ser determinado pela compreensão mais fundanental que se possa atingir, a respeito dos principios bäsicos que aão estrutura a essa matërił. Ensınar töpicos ou habilidades especificas, sem tornar claro seu contexto na estrutura fundamental mals ampla de un dado campo de conhecimento, $\vec{e}$ anti-econômico em vários e profundos sentidos. Em primeiro lugar, esse ensino torna excesstvamente dfficll ao aluno generalizar, a partir do que aprendeu, para o que val encontrar depois. Em segundo lugar, a anrendizagem que não consegue captar os principios gerais e mal recompensada em termos de est $\underline{1}$ mulo intelectual. 
o melhor melo de despertar interesse por um assunto é tor nar valioso o seu conhecimento, lsto é, tornar o conhecimento adquirido utilizăvel na mente de quem 0 adquiriu, en situações após aquela en que a aprendizagem ocorreu. Terceiro, o conhecimento adquirido por alguẻm, sem suficlente estrutura a que se ligue, è un conhecimento fadado ao esquecimento. Um confunto desconexo de fatos não tem senão uma vida extremamente curta em nossa memöria. orga nizar os fatos en termos de principlos e ldēias, a partir dos quals possam ser inferidos, é o único melo conhectdo de reduzir a alta proporção de perda da memórla humana.

Planefar curriculos, de modo a refletir a estrutura bāsica de um dado campo de conhecimento, exige a mais pro funda compreensão desse campo.E tarefa que não pode ser le vada a cabo sem a particlpação ativa dos estudiosos e cientistas ma1s capazes". p. 28

(10) WOOLDRIDGE, S. W \& LAST, W . Gordon - Espirito e propōsitos da Geografla. Tradução de Thomaz Newlands Neto. R1o de Jane ro - GB. Zahar Editores - 1967.

Ver capitulo IV - A Geografia e os Mapas - p. 66-83.

(11) BROE.R, Jan O.M. Iniciação ao Estudo da Geografia. Tradução de Waltensir Dutra. 2a edıção. Rio de Janeiro. GB. Zahar Edi tores. 1972 .

" O geógrafo não tem o monopölio da Cartografia, nem estā necessartamente habilitado nas técnicas cartográficas usa das, por exemplo, em Geodẻsia, Levantamentos Topogräficos e Fotogrametria. Não obstante, hã um amplo âmb1to de con ceitos, técntcas e recursos para o preparo de mapas que estão intimamente associados à Geografia. Certos geógrafos desenvolvem esse campo como um ramo especial, a carto grafia Geogrăfica. Para a maloria de seus colegas, porēm, - mapa serve como instrumento, certamente o mais destacado instrumento da profissão. Todo geógrafo deve ter algum conhecimento da apresentação cartográfica, não só para ler mapas, mas também para fazê-los.

Os mapas têm duas funçōes na pesquisa. Em primeiro lugar, servem como base para o reglstro dos dados geográftcos, quer recolhidos no campo ou na bibltoteca. Segundo, a Inspeção dos pađrões de distribułção en dols ou ma1s ma pas podem revelar possiveis relações. Todos os alunos po dem, e devem, aprender os rudimentos do registro cartogra fico e a sua comparação". p. 89. 
(12) CRIBIER, F., et allii. Inttiation aux exercices de Géographie Régionale. Paris, France - Societé D'Education D'Enseignement Supērieur. 1967. Publicações do gênero dessa deveriam circular nos cursos de graduação e nos de aperfeiçoamento. Publicações do gênero, mas feltas por autores brasileiros, refletindo nossa realidade, exemplificando com paisagens brasileiras.

(13) BRourLLETTE, Benott, et al1i1. Mêtodo para la enseñanza de la Geografla. Barcelona - España. Telde/Unesco. 1969.

Essa è outra obra que apresenta uma série de sugestöes metolögicas para os professores de Geografia. \$ primeira vista pode ria ser interpretada como trabalho primär1o para uso em cursos de graduação, vez que os exemplos dos exerciclos, dos estudos, se dirigem para aplição a alunos cujas faixas etārias estão en tre os 12 es 16 anos. Não è o caso, contudo. A simplicidade dos enfoques, a objetividade das proposiçöes de pesquisas, podem perfeitamente ser um ponto-de-partida para orientar meto dologicamente os professores de cursos de graduação em Geografla. Em certos casos, bastará adequar ao nỉvel mental dos alu nos universitärios muitos dos exercicios sugeridos, que visam, primordialmente, a "metodizar" os estudos regionats.

(14) WOOLDRIDGE, S. W EAST, W. Gordon - op. cit. cap. IX - Os trabalhos de campo em Geografia.

"Assim, certas Escolas de Geografia, de nível universitą rio, têm revelado tendência para encarar os trabalhos de campo como sendo, na realidade, levantamentos topogräficos, ou seja, a elaboração de mapas no sentido literal e básico da expressão. Encontraremos outros grupos a visitar granjas e fäbricas, realizando estudos em primeira mão na esfera da economia rural ou urbana. Depararemos, ainda, o que se poderia denominar o método dos recenseamentos, aplicado, por assim dizer, à "investigação de vilas", o qual 1mplica a visita de casa em casa a fim de co ligir informações sobre os tipos de trabalho exercido, a extensão dos deslocamentos ou viagens feltos, etc.

Todas essas atividades poderão ser evidentemente classificadas entre os trabalhos de campo, na acepção mais ampla do termo. No entanto, mesmo se conjugadas de $\underline{i}$ xarão multo a desejar quanto à formação e preparo dos geögrafos. E como tambën, alëm disso, possuem valor positivo e são relativamente făceis de organizar-se, tendem, 
quer nas escolas, quer nas universidades, a substituir os verdadelros trabalhos de campo, segundo nos propomos considerá-los:0 mtnucioso exame e a anălise atenta de un tre cho de terra, procedidos no campo, os quais revelem um ou małs aspectos de diferenciação entre äreas". p. 171-172.

(15) STERNBERG, Hłlgard O'Re1lly. Contribuicão ao Estudo da Geogra fia. Rio de Janelro - Ministērio da Educação e Saúde - Serviço de Documentação. 1946.

A obra em pauta apresenta boas sugestōes para o trabalho de campo. Merece destaque o capitulo III - Realização do Traba1ho de Campo - Seus Mëtodos. p. 26-59.

(16) Programa de Expansão e Melhoria do Enstno (Premen). Manual de Recursos Humanos da Escola Polivalente - O Servico de Coordenação Pedagóg1ca - Rio de Jane1ro - GB. Ministério da Educação e Cultura - 1971

Em ambos os documentos enfatiza-se a posição do serviço de Supervisão Escolar (Coordenação Pedagögica). Cabe ao Serviço, em sintese:

- propor o currículo pleno da Escola, alterando-o face à experimentação, às realldades da população - alvo e à configuração soctal do melo em que se insere a Escola;

- promover reuniões semanats com os coordenadores de matéría, para debater:

- planejamento integrado e sua execução:

- questões ligadas aos procedimentos didát1cos;

- aspectos ligados à avaliação da aprendizagem;

- estabelecer normas didäticas que possam identificar a orlentação da Escola nesse aspecto. As normas fluem do consenso grupal (supervisor escolar e coordenadores de matéria):

- cuidar do setor de recursos audjovisuais, buscando sua uttli zação racional pelos professores;

- propor e programar cursos, debates, seminärios que visem à reciclagem do corpo docente;

- divulgar noticias e material bibliogräfico, entre os professores, mantendo-os atualizados quanto ao conteúdo de sua matéria e quanto à tecnologia do ensino. 
$V I-C O N C L U S O E S$ 


\section{I - INTRODUÇÃO}

1 - A tese se baseou em dols pontos de apolo que se constitulam, por assim dizer, na entrada e na salda do sistema, vez que procurou analisar o fenômeno educacional no Brasil sob o en foque sistèmico.

2 - Realmente, partiu-se do concelto mals amplo do sistema sōclo-politico-econômico para se chegar à caracterlzação do subsistema educacional. Neste, o conjunto das principals va riāvels fol identificado, dissecado, fazendo-se a necessāria Interligação das mesmas. Os objetivos eram:

18 - assinalar a coerēncia e interdependència das variāvełs do subsistema educacional;

28 - colocar o subsistema educacional na estrutura mais ampla do sistema sōclo-polltico-econômico, que è extrema mente variável no tempo e no espaço, por se tratar de um sistema aberto, em constante processo de alimentacão e realimentação.

3 - Em ültima instância, visou-se dissecar os mecanismos de con trole do subsistema educacional, vale dizer, o planejamento da educação como elemento que proplcte o malor entrosamento das variāveis, com o objetivo de atingir a determinadas metas racionalmente.

4 - Por ülttmo, na apreciação do planejamento educacional,houve a nitida preocupação de assinalar as possiveis contribuições da Geografla para tornar o referido planejamento ma1s realistico.

\section{II - DESENVOLVIMENTO}

1 - A educação é atividade inerente a todos os grunos sociałs. Ela vat sendo mals sofisticada, ma1s refinada, mals complexiflcada à medida em que os grupos sociais evoluem material mente.

2 - Hä, portanto, uma relacão Intima entre crescimento econôm1co e desenvolvimento soctal. A educação pode constitu1r-se num ponto de apoio, para evitar a defasagem decorrente entre o crescimento (aspecto material) e o desenvolvimento (aspecto social). 
3 - Por $₫ s s o$ mesmo, a educação se coloca num "campo-de-forças", muitas vezes conflitantes umas com as outras. O êxito de suas proposiçōes depende, em grande parte, das suas mültıplas ligações inteligentes com as variäveis que atuam, ou ma1s, ou menos dinamicamente, nesse "campo-de-forças", cujos limites constituem o próprio sistema sócio-politico-econômi co.

4 - Durante multo tempo, a educação entendida como ensino formal, pouco pesava na estrutura soctal. Era un "mal menor" , reservada a uma parcela restrita do estrato superior das sociedades.

5 - A "aceleração histórica", observada no sëculo xx e, principalmente depois de 1945, descobriu na educação formal uma das maneiras de aumentar o crescimento económico e promover o desenvolvimento social.

6 - A questão não ficou restrita ao pequeno grupo de Estados de civilização industrial. Ela passou a interessar, multo de perto, aos inúmeros Estados em processo de desenvolvimento.

7 - A valorização dos recursos humanos por via da educação formal assumiu posição prioritäria, praticamente em todos os Estados.

8 - Não bastava, poröm conferir-1he prioridade, tornava-se necessärio:

- estudar sua essência;

- dimensionar seus efeltos multiplicadores;

- analisar sua estrutura;

- considerá-la como investimento e, não como absorvedora de recursos financelros, muitas vezes escas sos.

9 - Passa-se a configurar a educação como atividade planificável, a exemplo de outras atividades.

10 - o planejamento educacional deveria, pols, contar com metodo logias especificas e ser o resultado de:

- uma intenção politica;

- conjugação do trabalho de equipes interdisciplinares, a fim de evitar o seu enfoque unidirecional. 
11 - Do planejamento educacional à sua efetiva concretização, hã um longo caminho a ser percorrido. Um somatórlo de pré-requisttos são necessários para garantir a implementação dos planos educactonals.

12 - No caso particular do Brasil, uma série de fatos de natureza econônica, demográfica, soctal, politica conduztu à necessidade de se repensar profundamente a educação. Não bastavam as reformas legals e os propósitos. Era 1mperioso pla nificar a educação segundo novos modelos, vez que os proble mas socials se agudizavam sem que o subsistema educacional respondesse eficazmente para a sua solução.

13 - O novo modelo educacional que busca ter características altamente dinânicas para não se tornax obsoleto em pouco tempo, encontra vários pontos de estrangulamento. Um, dentre esses muitos pontos de estrangulamento, è representado pela carência de recursos humanos capazes de planejar a educação de forma integral e integrada. Outro, se refere à debilidade no que tange à implementação dos projetos que compōem un plano de educaçäo.

14 - Falha observāvel em muitos planos educacionais: o diagnóstico que fornece os indicadores bāstcos para o equactonamen to das linhas mestras do plano, ainda se ressente de malor realismo. Esse realismo, en boa parte, è o representado oe10 diagnöstico regional completo, envolvendo multo mais que - simples levantamento estatistico da população escolarizävel e da população a escolarızar.

A educação é uma das variáveis de um sistema, portanto ela deve ser analisada à luz de suas relações espácio-temporałs com todas as outras variáveis signtficatıvas.

15 - Parece faltar ao planejamento educacional o estudo das realidades regionais integradamente. Parece faltar, pois, a con tribuição dos estudos geogrä́ficos, a nivel de regiāo, soman do sua apreclação às das demais ciênclas e tēcnicas que devem atuar em conjunto para a elaboração dos planos educacio na1s.

16 - Até o presente, a contribuição da Geografia à planif1cação educacional tem sido modesta, multo aquém do que ela, através dos professores e dos geögrafos, pode oferecer. 
17 - A Geografla, no Brasil, vem sofrendo profundas modificações, graças ao trabalho que se desenvolve en alquns centros espe cificos, tais como as Universidades e a Fundação IBGE.

Mesmo nessa fase de reformulações - fase que atinge a outras ciênclas, igualmente - a Geografia fá dispõe de um arsenal de metodologias e técnicas capazes de cooperar nas atıvidades de planificação educacional.

18 - Os estudos regionais do ângulo de abordagem da Geografia são valiosos como subsidios para o planejamento da educação. Em sentido ma1s restrito, sua contribuição pode ser aprove1 tada para os trabalhos indispensáveis da carta escolar,para auxiliar a montagem de planos curriculares, para possibilitar uma atuação mals eficiente da escola sobre a comunidade, para os estudos relativos ao mercado-de-trabalho.

19 - E de esperar-se que a contribulção da Geografia para o planejamento educacional se torne mais efetiva, vez que a qualidade dos docentes e dos geögrafos vem apresentando melhoria räplda e profunda.

A Reforma universitārıa em hoa parte possibilita o refinamento da qualidade dos profissionais da Geografia.

III - FINAL

1 - o planejamento educacional que jä è um fato irreversivel no Brasil deverá recorrer, mais e mais, ao trabalho das equipes interdisciplinares. Nessas equipes hà perfeitamente lugar de destaque para professores de Geografia e geógrafos.

2 - o objetivo central da tese fol o de procurar sensibilizar os planejadores educacionals para a valiosa contribulção da Geografia para a montagem dos planos de educação. Igualmente buscou-se mostrar aos professores de Geografia e aos geó grafos o papel que lhes cabe nas tarefas de cooperar para a plantficação eđucacional. 
VII-BI BLIOG RAF I A 


\section{BIBLIOGRAFIA CITADA NA TESE}


ABRAMS, Charles - Habitação, Desenvolvimento e Urbanização - Rlo de Janeiro - GB - Tradução de Alexandre Lissosky - Edições 0 Cruzeiro - 1967.

ABREU, Jayme - Educação, Sociedade e Desenvolvimento - Rio de Janei ro - MEC - INEP - CBPE - Sērie VI - Sociedade e EducaçãoVolume $8-1968$.

AB'SABER, Aziz Nacib - Geografia e Planejamento, in Revista de H1störia. NQ 80 - Ano XX - São Paulo - SP - 1969.

ALEXANDER, John W. - El concepto bäsico - no bāsico de las functones econónlcas urbanas, in Classificação Funcional das Cidades - Textos Bästcos - 2 - Rio de Janeiro - GB - Instituto Panamericano de Geografia e Histör1a - 1969.

ALMEIDA, Rômulo de - Programacão Educacional num País em Processo Iniclal de Desenvolvimento - Rio de Janeiro - GB - Revista Brasileira de Estudos Pedagögicos - CBPE - INEP - 1968.

ANDRADE, Manuel Correla de - Centralidade - Definição de uma Metodologia para o estudo da Centralldade. Rio de Janeiro-GB1. Conferência Nacional de Geografla e Cartografia - Fundação IBGE - IBG - 1968.

- Espaço, Polarização e Desenvolvimento. São Paulo - SPEditora Brasiliense - 1970 .

- Geografia Região e Desenvolvimento. São Paulo - SP 2a edição - Editora Brasillense - 1971.

ASSIS, Marisa de, et all11. - Mercado de trabalho em São Paulo. são Paulo-SP - Companhia Editora Nacional. Instituto de Pesquisas Econômicas - 1972 .

BAADE, Fritz. - A corrida para o ano 2000 - Tradução de Macêdo Neto - Rio de Janeiro - Editora Nova Fronteira S/A - 1966.

BEEBY, C.E. - Educação e Desenvolvimento Econônico - Tradução de Edmond Jorge - Rio de Janeiro - Zahar Editores - 1967.

BECKER, Bertha K. - As Migrações Internas no Brasil. Reflexos de uma Organização do Espaço Deseguilibrada, in Revista Brasileira de Geografia - Rio de Janeiro - GB. Ano 30 - no 2 Fundą̧ão IBGE - IBG - 1968 - 
BELTRAO, Pedro Calderan - Sociologia do Desenvolvimento - Porto Ale gre - RS - Editora Globo - 1965.

BERNARDES, Lysia M. C. - H1erarquia Urbana e Polarizacão no Bras11, in Simpösio de Geografia Urbana - Rio de Janeiro - GB Comisión de Geografia - Instituto Panamericano de Geografia e Histörta - 1968 .

BERRY, Brian J. L. - PYLE, Gerald - Grandes regiōes e tipos de agricultura no Brasil, in Revista Brasileira de Geografia, Ano 32, no 4 - Rio de Janeiro - GB - Fundação IBGE - 1970.

BLAUNT, James $K$. - A Geografia e o Desenvolvimento da Agricultura Camponesa, in Geografla Humana nos Estados Unidos -Preston E. James, et allii - Tradução de Luiz clăudio de Castro e Costa - Rio de Janeiro - GB - Forum Ed1tora - 1970.

BLOOM, Benjamin S., et alli1. - Taxionomia de Objetivos Educacionałs - Tradução de Flăvia Maria Sant'Anna. Porto Alegre, RS - Editora Globo, Co-edições URGS - 1972.

BONILLA, Frank. - A Educacão e o Desenvolvimento Politico no Brasil. A Evolucão do Nacionalismo - Tradução de Amélla Maria Noronha - Rlo de Janeiro - CBPE - 1962.

BROEK, Jan O.M. - Inic1ação ao Estudo da Geografia - Tradução de Waltensir Dutra - 2 a edição - Rio de Janeiro - GB - zahar Editores - 1972 .

BROUILLETTE, Benoft, et allii. - Mëtodo para la enseñanza de la Geografía. Barcelona - España - Telde/Unesco - 1969.

BRUNER, Jerome. - Oprocesso da educação - Tradução de Lëlio Louren ço de oliveira - São Paulo - SP - Companhia Editora Nacio nal - 1968 .

CARRIERE, F. e PINCHEMEL, P. - Funcões banais e especificas, in Classificacão Funcional las cidades - Textos Bäsicos - 2 Rio de Janelio - GB - Instituto Panamericano de Geografia e História - 1969 .

CASE, Earl C. e BERGSMARK, Daniel R. - Geografia General - Reglonal YEconómica - Traducctón española de la tercera edición inglesa (1950) por Luls Jordâ. Barcelona - España - Eđictones Omega S.A. - 1952. 
CASTRO, Alberto Pereira de - Tecnologia para um pais en desenvolvimento, In Brasil potênc1a - São Paulo - SP - Editora Unttas Ltda - 1971 .

CHAMBRE, Henri - A Economia Planiflcada - Tradução de Pedro de Alcântara Figueira - São Paulo -Coleção "Saber Atual" - Difusão Europēıa do Livro - 1967.

ClaVAL, Paul - La Teorla de los lugares centrales, in CentralidadeRegionalizacão - Textos Băsicos - 1 - Rlo de Janeiro -GBInstituto Panamericano de Geografia e Histöria - 1968.

COMISION DE GEOGRAFIA - Inst1tuto Panamericano de Geografla e n1stó ria - Regionalización - Rio de Janeiro - GB - Apec Ed1tora -1969 .

COOMBS, Ph1lip H. - Qu'est-ce que la planification de 'l'education? Traduite de I'anglais por I'ILPE - Louvain - BëlgiqueUNESCO - 1970 .

CORREA, Arlindo Lopes - Reflexões sobre una polftica de recursos humanos para o Brasil - Rlo de Janeiro - GB - Ministērlo do Planejamento e Coordenação Geral - IPEA/CNRH - 1971.

CORREA, Roberto Lobato - Estudos das Relacões entre Região e Cldade

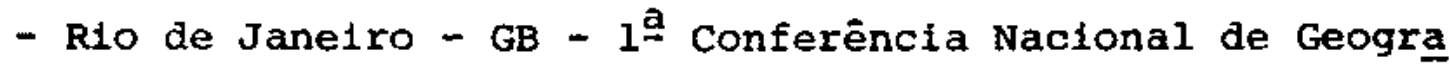
fla e Cartografla - Fundação IBGE - IBG - 1968.

- Estudos sobre Centralidade no Brasil. - Rlo de Janeiro - GB - 1a Conferência Nacional de Geografla e Cartogra fia - Fundação IBGE - IBG - 1968.

CRIBIER, F., et allii. - Initlation aux exercices de Gëographte Réglonale. Paris, France - Societé D'Education D'Enseignement Supërieur - 1967.

CROUZET, Maurıce - Histörı́a Geral da Civilização - Tomo VII - A Epo ca Contemporānea - 29 volume - o Mundo Dividido - Tradu̧ão de Paulo zingg e J. Guinsburg - são Paúlo - Difusão Européia do Livro - 1958.

CuNIL, Pedro - A Amërıca Andina - Tradução de Octavio Mendes Cajado - São Paulo - Difusão Européla do Livro - 1968.

CURLE, Adam - L'ident1té professionnelle du planificateur de l'education - Louva1n - Bélglque - UNEsco - 1970. 
DAIAND, Robert T. - Estratégia e Estilo do Planejamento BrasileiroTraduzido por Carlos kronauer - Rio de Janeiro - GB - Edí tora Lidador Ltda - 1969.

DAVIS, Kingsley, et allii - Cidades - A Urbanização da Humanidade Tradução de José Rezn1k - Rio de Janeiro - GB - zahar Ed1 tores - 1970 .

DEMANGEOT, Jean - Milieu Naturel et Régionalization de l'espace au Brëstl, in La Rëglonalization đe l'espace au Brésil - Paris - France - Eaitions du Centre National de la Recherche Scientifique - 1971 .

DERRUAU, Max - Tratado de Geografia Humana - Traducido por Raimundo Griño - Barcelona - España - Editorial Vicens - Vtves 1964.

DIARIO DO CONGRESSO NACIONAL - 20 de novembro de 1971.

DINIZ, Alexandre Felizola, et allit - Geografia Teorética, in Boletim de Geografia Teorëtica - nP 2 - Rio claro - SP 1971 .

- Modelos e Paradigmas na Geografia, in Boletim de Geografla Teorétlca, no 2 - Rio claro - SP - 1971

DoLlFus, Ol1vier - Rapport de Synthèse, in La Regionalization de l'espace au Brēsil - Paris - France. Editions du Centre National de la Recherche Scientifique - 1971.

DZIEWONSKI, K., et alli1 - Examen de conceptos y teorias de la regionalización econömica, in Centrallaade - Reglonalizacão - Textos Bäsicos - 1 - Instituto Panamericano de Geografia e Histöria - Rio de Janeiro - GB - 1968.

ECHEVARRIA, Josē Medina, et allii - A Agricultura Subdesenvolvida Tradução de Dorothy Nebel - Petrópolis - RJ - Editôra Vozes Linttada - 1968.

- Desenvolvimento, mrabalho e Educação - organizaçāo e Introdução de Luiz Pereira - Rio de Janeiro - zahar Edito res -1967.

FAISSOL, Speridião -. Métodos Quantitativos na Geografıa, in Curso para Professores de Geografia - Rio de Jane1ro - GB - Fun đação IBGE - no 16 - 1970 . 
FONSECA, James Braga Vieira da - OEnsino da Geografia no Bragil Rio de Janeiro - Instituto Panamericano de Geografia e História - Comissão de Geografia - Publicação no211-1956.

FOURASTIE, Jean - As 40.000 horas - Tradução de Paulo Moreira da Silva - Rio de Janeiro - Coleção Prospectiva - Companhia Editora Forense - 1967.

FRANK, Andrew Gunder, et al111 - Urbanização e Subdesenvolvimento organização e Introdução de Luiz Pereira - Rio de Janeiro - Zahar Editores - 1969.

FREYRE, Gilberto - Casa Grande \& Senzala - Rio de Janeiro - 4a edição, definitiva - Livraria José olympio Editora - 1943.

- Sobrados e Mocambos - São Paulo - Companhia Ed1tora Na cional - 1936.

FURTADO, Celso - Subdesenvolvimento e Estagnacão na Amërica LatinaRio de Janeiro - GB - Editora Civilização Brasileira S.A. - 1966.

FURTER, Pierre - Juventude e Tempo Presente - Tradução de Luis Lourdes de orlandi - Rio de Janeiro - Editôra Paz e Terra Ltda. - 1967.

GALBRAITH, John Kenneth - O Nôvo Estado Industrial - Tradução de Alvaro Cabral - Rio de Janetro - Editora Civilızação Brastletra S.A. - 1968.

GALVAO, Marilia Velloso e FAISSOL, Speridiāo - A revolução quantitativa na Geografia e seus reflexos no Brasil - Rio de Janeiro - GB - in Revista Brasileira de Geografia -Ano 32 - no 4 - Fundação IBGE - IBG - 1970.

GARCES, Wilson - Resumen General de las Necessidades de Planificaciōn en Amërica Latina - Regionalización - Instituto Pana mertcano de Geografia e Histöria - Comisión de GeografiaRio de Janetro - Apec Editôra 5.A. - 1969.

GARNIER, Jacqueline Beaujeu - La Géographie: méthodes et perspectiven - Par1s - France - Masson \& Cia. Editeurs - 1971.

GEIGER, Pedro Pinchas - Divisão Regional e Problema Regional - Rio de Janeiro - GB - I Conferencia Nacional de Geografia e Cartografla - Fundação IBGE - IBG - 1968. 
- Modelo da Estrutura Espacial do Brasil, in Curso para Professores de Geografia - no 16 - Rio de Janeiro - GB Fundação IBGE - IBG - 1970 .

GENET, L. et allil - Le Monde Contemporain - classes Terminales Collection D'Histoire Hatier - Paris - France - Librairie Hatier - 1962.

GEORGE, Pierre - A acão do homem - Tradução de octavio Mendes Cajado - São Paulo - SP - Difusão Europēia do I1vro - 1971.

- A Geografla Ativa - Tradução de Gil Toledo. Manuel sea bra. Nelson De La Côrte. Vincenzo Bochicchio - São PauloSP - Difusão Europëla do Livro - Editora da universidade de São Paulo - 1966.

- Geografia Econômica - Txadução de Ruth Magnanin1 - Rio de Janeiro - Editoora Fundo de Cultura S.A. - $1 \stackrel{\text { a }}{\text { edição }}$ - 1961.

- Les Méthodes de la Géographie - Paris - France - Presses Universitaires de France - "Que sais-je?" No1398-1970.

- Panorama do Mundo Atual - Tradução de Pedro de Alcanta ra Figueira - São Paulo - Difusão Européia do Livro-1966.

- Sociologia e Geografia - Tradução de Sérglo Miceli-Rlo de Janeiro - GB - Companhia Editora Forense - 1969.

GODINHo, Vitorino Magalhães - Geografla e Geografia Aplicada, In Geografta e Accão - Michel Ph1ipponneau - Lisboa - Portugal - Edições Cosmos - 1964.

GONÇALVEs, Suzana - Estrutura da Universidade, in A Educacão gue nos convém - Rio de Janeiro - GB - APEC Eaitora S.A. 1969.

GOULART, Ir1s Barbosa \& MAFRA, Ed1th Soares - Avallacão na Escola Belo Horizonte - MG - Indústrias Grāficas Vera Cruz -1969. GUIMARÃES, Magda Soares - Produtividade do Ensino Superior - Brasilia - DF - Ministério da Educação e Cultura - I Encontro de Reitores das Universidades Pübllicas - 1972.

GRUPO TAREFA INTERMINISTERIAL - Projeto PiauI - Teresina - RiauI - 1971. 
HARBISON, Frederick H - Mäo-de-obra e desenvolvimento econömico: problemas e estratégia - Tradução de Luiz Pereira, in Desenvolvimento, Trabalho e Educacão - Josē Medina Echevarria, et allii - Rio de Jane1ro - GB - Zahar Ed1tores-1967.

IIARRIS, Chauncy D. - Mëtodos de investigaciön en regionalización econörica, in Centralidade - Regionallzacaão - Textos Bāsi cos - 1 - Rio de Janeiro - GB - Instituto Panamericano de Geografia e Histöria -- 1968.

HARTSHORNE, Richard - Questöes sobre a natureza da Geografia - Tradução de Thomaz Newlands Neto - Rlo de Janeiro - GB - Textos Bästcos - 4 - Instituto Panamericano de Geografia e História - Comissão de Geografia - 1969.

IANNI, Octävio - Estado e Planejamento Econômico no Bras1l - Rio de Janeiro - GB - Editôra Civilização Brasileira S.A.- 1971.

INSTITUTO PANAMERICANO DE GEOGRAFIA E HISTORIA - Comisión de Geogra fia - Documentación del I Seminario sobre REGIONALIZACION. Rio de Jane1ro - GB - Apec Editōra S.A. - 1969.

JAGUARIBE, Hēlio - Desenvolvimento Econōmico e Desenvolvimento Politico - Rio de Janeiro - GB - Editôra Paz e Terra Ltda 1969.

JAMES, Preston E. - A estrutura conceitual da Geografia - Tradução de Joaquim I. da Silveira Mota. - Rio de Janeiro - GB - Bo letim Geogrä́fico n̊ 199 - Fundação IBGE - IBG - 1967.

JUNGK, Robert - El futuxo ha comenzado. ¿ Tiene porvenir la futurologia ? EL CORREO - UNESCO - Paris - France - Año XXIV 1971.

JR, Datus C. Smith - Educação e Comunicacão: duas verdades. S/d Artigo condensado de Foreigh Affairs - 1968.

KAHN, Herman e WIENER, Anthony J.- o Ano 2000 - Tradução de Raul de Polillo - São Paulo - Edições Melhoramentos - 2 a ed1ção 1969.

KAYSER, Bernard - A região como objeto de estudo da Geografia, in Geografla Ativa - Pierre George, et all1i.- Tradução de Gil Toledo, Manuel Seabra, Nelson de La Côrte e Vincenzo Bochicchto. - São Paulo - SP - Difusão Europëla do Iivro - Editôra da Universidade de São Paulo - 1966. 
KHOI, Lề Thành - I Indüstrta do Ensino - Tradução de Maria Fernanda Margarida Correia - Porto - Portugal - Livraria Civilização Editora - 1970 .

KRETSCHMER, Ronrad - Histōria de la Geografia - Tercera edictón revisada - 1942 - Barcelona - España - Editorlal Labor, S.A. - 1942.

LACOSTE, Yves - Geografia do Subdesenvolvimento - Tradução de T. Santos - São Paulo - Difusão Europēia do L1vro - Editora da Universidade de São Paulo - 1966.

- Perspectivas da Geografia em Pais Subdesenvolvido, in Geografla At1va - Pierre George, et alli1 - São Paulo-sP. - Difusão Européia do Livro - Editora da Universidade de São Paulo - 1966.

LADA, Igor V. Bestuzhev - Evitemos entrar en el futuro a clegas. 2 Tlene porvenir la futurologia? - Paris - France - El Correo - UNESCO - Año XXIV - 1971.

LAJUGIE, Joseph - Os Sistemas Econômicos - Tradução de Geraldo Gerson de Souza - 2a edição - Coleção Saber Atual - são Pau10 - Difusão Européia do L1veo - 1965.

LAMBERT, Jacques - Amër1ca Latina - Tradução de Lélio Lourenço de oliveira - São Paulo - Companhia Editôra Nacional - Editô ra da Universidade de são Paulo - 1969.

LAROUSSE, Delta - Grande enciclopëdia - Rio de Janelro - Editôra Delta S.A. - Vol. $9 / 10$ - 1970 .

LEITE, Antonio Dias - Caminhos do Desenvolvimento, Contribuicão para um Projeto Brasileiro - Rio de Janeiro - Zahar Editores - 1966.

LIMA, Lauro de Oliveira - A Escola Secundárla Moderna - Petrópolis - RJ - Editora Vozes LIm1tada - 9a ed1ção - 1971.

- Mutações em Educação segundo Mc Luhan - Petrōpolis RJ - Editora Vozes Limitada - $2^{a}$ edição - 1971.

- Treinamento en Dinâmica de Grupo, no Lar, na Emprêsa, na Escola - Petrópolis - RJ - Editora Vozes Limitada 2ầ edição - 1970 . 
LIONNAIS, Françols Le $-\varepsilon$ Tiene porvenir la futurolog1a? Los pros y los contras - EL CORREO - UNESCO - Paris - France - Año $\underline{\text { XXIV }-1971 .}$

LOBO, Thomaz Thedim - Tecnologia e Desenvolvimento, in Bras1l Potência - dıversos autores - São Paulo - SP - Editōra Unitas Ltada. - 1971.

- Transferência de Tecnologia, in Brastl potêncla - diversos autores - são Paulo - SP - Editôra Unitas Ltáa -1971 .

LOPES, J. Leite - Ciência e Libertação - Rio de Jane1ro - GB - Ed1tôra Paz e Terra S.A. - 1969.

LOPES, Juarez Rubens Brandão - Desenvolvimento e Mudanca Social-são Paulo - Sp - Companhia Editora Nacional - 2a ediçāo-1971.

LOEB, Roberto - Aspectos do Planejamento Territorial Urbano no Brasil, in Planejamento no Brasil - LAFER, Betty Mindlin, et alli1 - São Paulo - SP - Editōra Perspectiva - 1970.

LUTGENS, Rudole - Los fundanentos geogräficos y los problemas de la vida econômlca - Tradución española por Claudio Matons Rossi. - Barcelona - España - Ediciones Omega, S.A.-1954.

MAGER, Robert F. - Objet1vos para o Enstno Efettvo - Rio de Janeiro - GB - Traduzido e adaptado para o português, da versão em espanhol, pela Divisão de Ensino do Departamento Nac1o nal do SENAI - Serviço de Aprendizagem Industrial - 1971.

MAIA, Nelly Aleott1 - Produtividade da Untversidade - Brasilia - DF - Ministërio da Educação e Cultura - I Encontro de Re1tores das Untversidades püblicas - 1972 .

MARTONNE, Emmanuel de - Traité de Gëographic Physique, in panorama da Geografta - (Tomos I e II) - Lisboa - Portugal - Ediçōes Cosmos - 1953.

MASSE, Plerre - o plano, aventura calculada - Trađução de Alda Rosa e Alfredo de Souza - Lisboa - Portugal - Livraria Morais Editora - 1967.

MELo, Osvaldo Ferreira de. - Teorla e Prätica do Planejamento Educacional - Porto Alegre - RS - Editora Globo S.A. - 1969. 
MINISTERIO DA EDUCAÇÃo E CULTURA - Desenvolvimento da Educação no Brasil - Brasilia - DF - 1971.

MINISTERIO DA EDUCAÇÃo E CULTURA - Eđucacão no Brasil - (Subsídio para a Conferência Internacional de Educação) - Brasilia - DF - 1971.

MINISTERIO DA EDUCAÇAO E CULTURA - Secretaria Geral - plano Setorlal de Educacão e Cultura - 1972-1974 - Brasil1a-DF-1971.

MINISTERIO DA EDUCAÇAO E CULTURA - CONSELHO FEDERAL DE EDUCAÇAO-Ensino Supletivo - (Parecer no 699/72) - Brasilia - DF-1972

MINISTERIO DA EDUCAÇÃO E CULTURA - CONSELHO FEDERAL DE EDUCAÇĂO-Parecer no 853/71 de 12/11/1971 - Assunto: Nücleo comum para os currículos de 18 e 28 graus. F doutrina do curriculo na Lei no 5.692 - Brasilia - DF - 1971.

MINISTERIO DA EDUCAÇÃO E CULTURA - CONSELHO FEDERAL DE EDUCAÇÃO-Pareceres nis 912/69.255/70 e 74/70 - Brasilia - DF . 1970.

MINISTERIO DA EDUCAÇÃ̈O E CULTURA - CONSELHO FEDERAL DE EDUCACĂO-RQsolução no 1/72 - Brasilia - DF - 1972.

MINISTERIO DO PLANEJAMENTO E COORDENACAOO ECONOMICA - ESCRITORIO DE PESQUISA ECONOMICA APLICADA - EPEA - Educacão (I) (II) Diagnóstico preliminar - Plano Decenal de Desenvolvimento Econônico e Social - Rio de Janeiro - Departamento de Imprensa Nacional - 1966.

MINISTERIO DO PLANEJAMENTO E COORDENAÇAO GERAL - Pxojeto do I Plano Nacional do Desenvolvimento Econômico e Soc1al - 1972/74Brasilia - DF - Compos to e impresso no Serviço Gráfico da Fundação IBGE - 1971.

MINISTERIO DO PLANEJAMENTO E COORDENAÇÁ GERAL - Inst1tuto de Plane jamento - Centro Nactonal de Recursos Humanos - CNRH - DO cumentos IPLAN - no 1 - Carta Escolar - Rto de Jane1ro 1971 .

MINISTERIO DO TRABALHO E PREVIDENCIA SOCIFL - Bolet1m Técnico do SEPT - RIo de Janeiro - GB - Serviço de Estatistica de Previdêncta e Trabalho - IBGE ne 21 - Dezembro - 1970.

MONBEIG, Plerre - Novos Estudos de Geografla Humana Brastletra -Säo Paulo - SP - Difusão Européia do Livro - 1957. 
MONOD, Jërôme - CASTELBAJAC, Philippe de. - L'Amënagement du terr1toire - Paris - France - Presses Universitaires de France - "Que sals-je ?" - 1971.

MORAIS, Pessoa de. - Sociologia da Revolucão Brastleira - Rio de Ja neiro - GB - Editôra Leitura S.A. - 1965."

MULLER, Nice Lecocq - Urbanizacão e organização do espaco no vale de Paraíba, Estado de São Paulo, in S1mpósio de Geografia Urbana - Rlo de Janetro - GB - Comisión de Geografia -Ing tituto Panamericano de Geografia e Histöria - 1968.

MYRDAL, Gunnar - O Estado do Futuro - Tradução de Affonso Blacheyre - Rio de Janeiro - Zahar Editores - 1962.

- Subdesenvolvimento - mradução e adaptação de Rosinethe Monte1ro Soares - Bras111a - DF - Coordenadora - Editôra de Brasilia Ltda - 1970 .

- Teoria Económica e regiōes subdesenvolvidas - Rio de Janeiro - GB - Edıtôra Saga - 1965.

NEIVA, Irthur Hehl - A imlgracaão na politica brasileira de povoamento - Rio de Janeiro - Separata do no 6 - Ano II da "Revista Brasileira dos Municipios" - Serviço Gräfico do IBGE - 1950 .

OLIVEIRA, Dëcio Rufino de. - Recursos Naturais. Fatores Determinantes na Ocupação do Territórto Brasileiro - Rio de Jane1ro - GB - Editôra Gondwana Ltda. - 1971.

PASSARINHO, Jarbas Gonçalves - A educação no Brasil: esbōco de uma politica naclonal - Rio de Janeiro - 1970.

- Educacão Planificada - Brasilia - DF - Ministërio da Educação e Cultura - 1971.

PASTORE, Josē - O Engino Superior em São Paulo - São Paulo - SP Companhia Ed1tôra Nacional - Inst1tuto de Pesquisas Econō micas - 1972 .

PERROUX, François - A economia do sēculo XX - Tradução de José Lebre de Freitas - Lisboa - Portugal - Livraria Morais Ed1tôra - 1967 . 
PETRONE, Pasquale - Povoamento e colonizacão, in Brasil, a terra e o homem - Aroldo de Azevedo, et allii - São Paulo - SP Companhia Editôra Nacional - Editôra da Universidade de são Paulo - Vol. II - A vida humana - 1970 .

PEURSEN, C... van - o Futuro da Universidade - Traduçäo de Cristiano Otticica, in PAZ e TERRA, ne 2 - Rio de Janeiro-GB-1970

PFEIFFER, John - Uma visão nova da educação - Tradução de Leonidas H. B. Hegenberg e Octanny Silveira da Mota, revista por AnÍsio Teixeira - são Paulo - SP - Companhia Editôra Nacional - Editôra da Universidade de São Paulo - 1971.

PINTO, L.A.Costa - Desenvolvimento Econōmico e Transicão Social Rio de Janeiro - 2 à edição - Editōra Civilização Brasile ra S.A. - 1970.

PHLIPPONNEAU, Michel - Geografia e Accão - Tradução de Judite Cordeiro Ferrelra - L1sboa - Portugal - Ediçöes Cosmos-1964.

PLATT, William J. - Planification de l'ëducation - Notes sur les besoins nouveaux en matlère de recherche - Paris - France - UNESCO - 1970.

POIGNANT, Raymond - Curso de Planejamento da Educação - Universidade Federal de Pernambuco - Faculdade de Educação - Convênio UFPE/FAE/UNESCO/SUDENE - Recife - PE - 1971.

PONTES, Hélio - Planejamento universitärio - Brasilia - DF - Ministério da Educação e Cultura - I Encontro de Reitores das Universidades Püblicas - 1972 .

RRESIDENCIA DA REPOBLICA - LEI nO 5692/71.

PRESIDENCIA DA REPOBLICA - Metas e Bases para a ação do govêrno Brasilia - Composto e impresso no Serviço Gräfico da Fundação IBGE - 1970.

PROGRAMA DE EXPANSAOO E MELHORIA DO ENSINO (PREMEN) - Manual de Recursos Humanos da Escola polivalente - O Serviço de Coordenacão Pedagógica - Río de Janeiro - GB - Ministério da Educação e Cultura - 1971.

QUEIROZ, Maria Isaura Pereira de. - O povoado de Santa Brigida, in Comunldade e Sociedade no Brasil - Florestan Fernandes, et alli1 - São Paulo - SP - Companhia Editôna Nacional - Ed1 tôra da Universidade de são paulo - 1972. 
RACINE, Jean - Bernard - Nova Fronteira para a Pesquisa Geogräfica, in Boletim Geogrăfico - no 221 - Rio de Janeiro - GB Fundação IBGE - 1971 .

RAGAN, william B. - Curriculo Primärio Moderno - Traduçāo de Ruth Cabral - Porto Alegra - RS - Editôra Globo S.A. - 1964.

RIBEIRo, Darcy - A Universtdade Necessárla - Rio de Janeiro - Editô ra Paz e Terra S. A. - 1969.

ROGERS, Carl R. - L1berłade para Aprender - Tradução de Edgar Godō1 da Mata Machado e Márcio Paulo de Andrade - Belo Horizonte - MG - Interlivros de Minas Gerais - 1971.

SANTOS, Milton - Crescimento Nacional e nova rede urbana: O Exemplo do Brasil, in Revista Brasileira de Geografia - Rto de Janetro - GB - Ano 29. no 1 - Fundação IBGE-IBG - 1967.

- Le Métier de Géographe en Pays sous - Développé. Paris - France - Editions OPHRYS - 1968.

SCHRAMM, Wilbur, et allit - Tëcnlcas modernas y planeamento de la educaciōn - Amsterdarn - Palses Bajos - Unesco -ILPE-1967.

SCHREIBER, Jean Jacques Servan - O Desafio hmericano - Tradução de Alvaro Cabral - Rio de Janeiro - Editôra Expressão e Cultura - 1968 .

SECRETARIA DA EDUCAÇÃo E CULTURN - Estado de Goläs - Carta Escolar - Goiânia - Go - 1971.

SECRETARIA DA EDUCAÇÃO E CULTURA - RIo Grande do SuL. - Introdução a Reforma do Sistema Educacional do Rto Grande do Sul - Documento Preliminar - Porto Alegre - RS - 1971.

SERVIÇO SOCIAL DA INDÓSTRIA - Migracões internas, Imigração, Colonizacão - Conferênctas - Rio de Janeiro 1956.

SILVA, Geraldo Bastos - A educacão secundãria (Prospectiva histórica e teoria) - são Paulo - Companhła Editôra Nacıonal-1969

SIMONSEN - Mârio Henrique - Brasil 2001 - Rio de Janeiro - GB Apec Editôra S.A. - 1969.

SouzA, Edson Machado de. - Expansão do Ensino Superior e Necessidades do Mercado de Trabalho - Rrasilia - DF -Ministério da Educação e Cultura - I Encontro de Reitores das Universidades Públicas - 1972. 
SPERB, Dalila C. - Problemas Gerais do Curriculos - Porto Alegre-RS - Editôra Glubo S.A. - 1966.

STERNBERG, Hilgard $0^{\prime} R e 1 l l y$ - Contribulcaão ao Estudo da Geografla Rlo de Janeiro - Ministērio da Educação e Saúde - Serviço de Documentação - 1946 .

SUCUPIRA, Newton - A Condicão ntual da universidade e a Reforma Universităria Brasileira "- Brasilia - DF - Ministérıo da Educąão e Cultura - I Encontro de Reitores das Univers1dades Püblicas - 1972.

TEIXEIRA, Anís1o - Educação e o Mundo Moderno - São Paulo - Companhia Editôra Nacional - 1969.

- Educacão não é Privilég1o - São Paulo - Companhta Editôra Nacional - 2a edição - 1968 -

THOMSON, David - Pequena Histöria do Mundo Contemporâneo (19141961) - Tradução de J.C. Teixeira Rocha - Rło de Janeiro - Zahar Editores - 1967.

ULLMAN, Edwarda L. e DiCEY, Michael F. - El mëtodo de las necesidades minimas en el estudio de la base económica urbana, in Classificação Funcional das Cidades - Textos Básicos - 2Rio de Jane1ro - GB - Instituto Panamericano de Geografia e Histöría - 1969 .

UNESCO - Educación y Desarrollo en América Latina - Bases para una politica educativa - Buenos Ayres - B1blioteca "Dimensión Americana" - Ealciones Solar S.A. y Libreria Hachette S.A. $1^{\text {a }}$ edición - 1967 .

UNESCO - EL Correo - La espiral del desempleo - Paris - França -Ano XXIII Febrero - 1970.

UNESCO - La plantfication de 1'education: B1lan, problèmes et perspectives - Imprimé par Maison d'Edition S.C. - Marcinelle - 1970. (Bëlgique)

UNESCO - Situaciōn Demogräfica, Econônica, Social Y Educativa de Amërica Latina - Buenos Ayres - Argentina - Ediciones Solar Y Libreria Hachette S.A. - 1966.

VALVERDE, Orlando e DIAS, Catharina Vergolino - A Rodovia BelèmBrasfl1a - Rlo de Jane1ro - GB - Fundação IBGE - Instituto Brastleiro de Geografia - 1967. 
HAGLEY, Charles - Uma comunidade amzônica, in Comuntdade e Socieda- de no Bras1l - Florestan Fernandes, et alli1 - são Paulo - SP - Companhia Editôra Nacional - Editôra da Universida de de São Paulo - 1972.

WOOLDRIDGE, S. W e IMST, W. Gordon - Egplrito e Propósitos da Geografia - Tradução de Thomaz Newlands Neto. - Rio de Janei ro - GB - Zahar Editores - 1967. 
A digitalização deste documento foi possível graças ao investimento do Programa de Pós-graduação em Geografia Humana (PPGH-FFLCH-USP) e realizada com recursos da Coordenação de Aperfeiçoamento de Pessoal de Nível Superior - Brasil (CAPES) - Código de Financiamento 001. Essa ação integra as atividades de comemoração dos 50 anos do PPGH no ano de 2021. Para mais informações sobre o PPGH e sua história, visite a página do programa: http://ppgh.fflch.usp.br/.

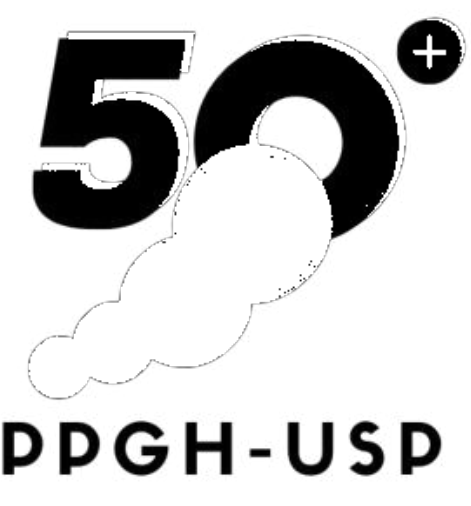

1971.2028 